\title{
La ayuda militar alemana a España 1939-1945
}

Autor: Lucas Molina Franco

Dirigida por: Dr. Ricardo Martín de la Guardia

Departamento de Historia Moderna, Contemporánea, de América, Periodismo, Comunicación Audiovisual y Publicidad

Facultad de Filosofía y Letras

Universidad de Valladolid 


\section{INDICE}

-INTRODUCCIÓN

-CAPÍTULO I. LAS ADQUISICIONES DE ARMAMENTO Y MATERIAL DE LOS MINISTERIOS MILITARES EN ALEMANIA ENTRE 1939 Y 1944

\section{I.1.- El Ejército del Aire}

I.1.1.- Los veleros

I.1.2.- Los aviones de escuela

I.1.3.- Los aviones de transporte

I.1.4.- Los aviones de bombardeo

I.1.5.- Los aviones de caza

I.1.6.- Los hidroaviones Heinkel He 114 y Dornier Do 24 T-3

I.1.7.- Los aviones de enlace

I.1.8.- Los Heinkel He 111 meteorológicos

I.1.9.- Los aviones internados

\section{I.2.- La Marina española}

I.2.1.- La Comisión "Suances” en Alemania

I.2.2.- Licencias de construcción de buques

I.2.3.- Las adquisiciones de julio de 1942

I.2.4.- Los "Rahmenverträge" posteriores a julio de 1942

I.2.5.- Adquisiciones atípicas de material naval

I.2.5.1.- Operación "Isabella"

I.2.5.2.- U-Boote en España. Los U-573 y U-760

I.2.5.3.- Las lanchas de salvamento alemanas FL.S y FL.B de la Luftwaffe 


\section{I.3.- EI Ejército de Tierra}

I.3.1.- Contratos con la empresa "Waffenwerke Brünn A.G."

I.3.2.- Contratos con la empresa "Krupp"

I.3.3.- Contratos con la empresa "Rheinmetall Borsig A.G."

I.3.4.- Contratos con la empresa "Demag G.m.b.H."

I.3.5.- Contratos con la empresa "Siemens Schuckertwerke"

I.3.6.- Contratos con la empresa "Hans Scheibert"

I.3.7.- Contratos con la empresa "Ringsdorf A.G."

I.3.8.- Contratos con la empresa "Polte"

I.3.9.- Contratos con la empresa "AGEKA"

I.3.10.- Otros contratos

I.3.11.- Una visión general de los contratos negociados por la Dirección General de Industria y Material del Ministerio del Ejército

-CAPÍtulo 2. EL CONVENIO COMERCIAL CON ALEMANIA DE DICIEMBRE DE 1942

\section{II.1.- Introducción}

II.2.- La firma del Convenio

-CAPÍtUlO 3. EL PROGRAMA BÁR. GÉNESIS, NEGOCIACIONES POLÍTICAS Y MILITARES

III.1.- Génesis del Programa

III.2.- La Comisión Interministerial para la Adquisición de Material de Guerra

III.3.- El informe "Krahmer" 
III.4.- El primer viaje de Martínez de Campos a Alemania

III.5.- Informe y reunión de Martínez de Campos el 29 de abril de 1943

III.6.- Los problemas de la entrega de materiales

III.7.- Martínez de Campos se vuelve a reunir el 3 de mayo de 1943

III.8.- 11 de mayo. La última reunión de Martínez de Campos

III.9.- Gestiones con AGEKA para adquirir fonos fuera del "Programa Bär"

-CAPÍtULO 4. EL PROGRAMA BÄR. NEGOCIACIONES ECONÓMICAS

IV.1.- Reuniones en Madrid

IV.2.- Reuniones sobre los precios del material de guerra

IV.3.- Crédito extraordinario. Las Cortes se mojan

IV.4.- Los envíos de material

IV.5.- Nuevo acuerdo sobre minerales no férricos

-CAPÍtUlO 5. EL PROGRAMA BÄR. DESARROLLO E IMPLICACIONES MILITARES. MATERIAL PARA EL EJÉRCITO DE TIERRA

V.1. Material acorazado

V.1.1.- Los carros de combate

V.1.2.- Los cañones de asalto StuG III

V.2.- Material automóvil. Motocicletas

V.2.1.- La motorización de la postguerra

V.2.2.- Las motos medianas

V.2.3.- Motocicletas pesadas: Las BMW R-75 
V.3.- Material de artillería de campaña. La artillería soviética del "Programa Bär"

V.4.- Material de artillería antiaérea

V.4.1.- Materiales negociados con Alemania

V.4.3.- La Comisión antiaérea española en Alemania

V.5.- Material de artillería contracarro

V.5.1.- La artillería contracarro del "Programa Bär"

V.6.- Otro material contracarro. Minas, granadas, fusiles y brocales

V.6.1.- Las minas terrestres

V.6.1.1.- Las minas T-42 y ligeras

V.6.1.2.- Las minas magnéticas Hafthohlladung (HHL)

V.6.2.- Las granadas de mano fumígenas

V.6.3.- Fusiles lanzagranadas y brocales

\section{V.7.- Material de transmisiones}

V.7.1.- Pedidos recibidos en su totalidad

V.7.2.- Pedidos recibidos parcialmente

V.7.3.- Pedidos no recibidos

\section{V.8.- Material de radiolocalización. Los radares}

V.8.1 Los orígenes del radar

V.8.2.- El primer empleo operativo del radar

V.8.3.- Los primeros radares alemanes de defensa aérea

V.8.4.- Radares para España

V.8.5.- Las recepciones de material

V.8.6.- Tierra versus Aire. El destino de los radares 
-CAPÍtUlO 6. EL PROGRAMA BÄR. DESARROLLO E IMPLICACIONES MILITARES. MATERIAL PARA LA ARMADA Y EL EJÉRCITO DEL AIRE

\section{VI.1.- Material alemán para la Armada}

VI.1.1.- El material para la Armada en las negociaciones previas al "Programa Bär”. La Comisión Antón.

VI.1.2.- Los suministros de material

VI.1.3.- Negociaciones en España. Los precios a debate

VI.1.4.- Material recibido en el "Restprogramm"

VI.1.4.1.- Las lanchas torpederas

VI.1.4.2.- Artillería para la Marina española

VIA.4.3.- Otros materiales

\section{VI.2.- Material para el Ejército del Aire}

VI.2.1.- Comisión de compras en Berlín

VI.2.2.- Llegan a España los materiales

VI.2.3.- Material de vuelo y munición para el mismo

VI.2.4.- Equipos de radio y localización

VI.2.5.- Material para la protección de vuelo y otros equipos

\section{•CAPÍTULO 7. LAS CUENTAS GENERALES DEL "PROGRAMA BÄR"}

VII.1.- Las cuentas del Ejército de Tierra

VII.2.- Las cuentas de la Armada

VII.3.- Las cuentas del Ejército del Aire

VII.4.- Cuentas generales en mayo de 1945 
-CAPÍtulo 8. EL CANTO DEL CiSne. LOS PROGRAMAS

"ANKARA" Y "ELTZE" DE 1944 Y LAS EXPEDICIONES DE MATERIAL MILITAR ALEMÁN POR VÍA AÉREA"

VIII.1.- Los Programas “Ankara" y "Eltze"

VIII.2.- Expediciones a España por vía aérea

\section{-CONCLUSIONES}

\section{-ANEXOS}

-Anexo I.- Acuerdo comercial entre España y Alemania (16-12-1942)

-Anexo II.- Plan de suministros alemanes desde 1-12-42 al 30-11-43

-Anexo III.- Listados completos de peticiones españolas negociadas por el general Martínez de Campos en Berlín el 15 de abril de 1943

-Anexo IV.- Resumen general de necesidades del Ejército de Tierra. Diciembre de 1942

-Anexo V.- Material solicitado, ofrecido y aceptado en las conversaciones previas al "Programa Bär"

•Anexo VI.- "Programa Bär” Aviación

- Anexo VII.- "Programa Bär”. Marina de Guerra

•Anexo VIII.- "Programa Bär”. Ejército de Tierra

•Anexo IX.- “Programa Bär”. Maquinaria.

-Anexo X.- "Programa Bär". Marina. Material solicitado por la Comisión "Martínez de Campos"

-Anexo Xbis.- "Programa Bär". Marina. Material aprobado para su entrega a España

•Anexo XI "Programa Bär”. Aire. Material aprobado para su entrega a España •Anexo XII.- Claves para el desarrollo del "Programa Bär" 
-Anexo XIII.- Programa Inmediato (“Sofortprogramm”). Partidas que lo componían, detalle de los trenes del "Sofortprogramm", resumen, trenes ajenos que transportaron los fonos Tepas y coste de las partidas del "Sofortprogramm".

-Anexo XIV.- Programa Restante ("Restprogramm"). Partidas que lo componían, detalle de los trenes del "Restprogramm" y resumen.

•Anexo XV.- "Restprogramm" del Ejército de Tierra.

•Anexo XVI.- "Restprogramm” del Ejército del Aire.

•Anexo XVII.- "Restprogramm” de la Armada

•Anexo XVIII.- Pagos de transporte de material del "programa Bär".

-Anexo XIX.- Desglose de todo el material del Ejército de Tierra recibido en el "Programa Bär" con su precio unitario.

-Anexo XX.- Desglose de todo el material de la Armada Española recibido en el "Programa Bär" con su precio unitario.

-Anexo XXI.- Desglose de todo el material del Ejército del Aire recibido en el "Programa Bär" con su precio unitario.

•Anexo XXII.- Presupuestos españoles 1940-1945 


\section{GUÍA DE SIGLAS Y ABREVIATURAS}

AAA: Artillería antiaérea o bien ametralladora antiáerea.

AEG: Allgemeine Elektricitäts Gesellschaft (Empresa alemana de material eléctrico)

AGK o AGEKA: Ausfuhrgemeinschaft für Kriegsgerät (Empresa oficial alemana para la venta de armamentos, dependiente del OKW)

AISA: Aeronáutica Industrial Sociedad Anónima.

AS/88: Aufklärungsstaffel See /88 (Escuadrilla de hidroaviones de la Legión Cóndor)

Ausf: Asführung (Modelo en alemán)

BMW: Bayerische Motorische Werke. (Fábrica de vehículos)

BOE: Boletín Oficial del Estado

C: Cañón (Abreviatura)

CASA: Construcciones Aeronáuticas Sociedad Anónima

CENEMESA: Constructora Nacional de Maquinaria Eléctrica Sociedad Anónima

CETME: Centro de Estudios Técnicos de Materiales Especiales (Fabricante español de armamento)

Cm: centímetros

COMEIM: Consejo Ordenador de Minerales Especiales de Interés Militar

CSR: Cañón sin retroceso

CTV: Corpo Truppe Volontarie. (Unidad expedicionaria italiana en la Guerra Civil española)

DCINM: Dirección de Construcciones e Industrias Navales Militares

DFS: Deutsches Forschungsanstalt für Segelflug (Instituto alemán para la investigación del vuelo sin motor)

DGIM: Dirección General de Industria y Material

DKW: Dampf-Kraftwagen (Marca alemana de coches y motocicletas)

DO: Diario Oficial

EATA: Escuela de Aplicación y Tiro de Artillería 
EE.UU.: Estados Unidos de Norteamérica

EM: Estado Mayor

EMA: Estado Mayor de la Armada / Estado Mayor del Aire

EMC: modelo de mina naval de origen alemán

EMCE: Estado Mayor Central del Ejército

EMD: modelo de mina naval de origen alemán

ENMASA: Empresa Nacional de Motores de Aviación Sociedad Anónima

FACE-ELT: Tratados multilaterales para reducir el nivel de fuerzas convencionales desplegables por los estados firmantes.

FFM: Vagón ferroviario especial alemán para transportar carros de combate

FL.B y FL.S: Modelos de lanchas alemanas de salvamento de náufragos

Flak: Flugzeugeabwehrkanone (Cañón antiaéreo)

FuG: Funkgerät (Aparato de radio)

FT: Fábrica de Trubia

FAO: Fábrica de Armas de Oviedo

G: Gramos (Abreviatura, unidad de peso)

HA: Hispano Aviación

HASA: Hispano Aviación Sociedad Anónima

HISMA: Hispano Marroquí de Transportes (Empresa creada en España durante la Guerra Civil para llevar a cabo los acuerdos de clearing)

HMS: His/Her Majesty Service (Al servicio de Su Majestad. Lo llevan delante del nombre todos los buques de guerra británicos)

HP: Caballos de vapor (Abreviatura, medida de potencia)

HS: Hispano-Suiza (Fabricante de material móvil y armamento)

IEME: Instituto Español de Moneda Extranjera

IFF: Identificador amigo-enemigo (Lo llevan los aviones modernos)

INI: Instituto Nacional de Industria 
INTA: Instituto de Técnica Aerospacial

Jasta: abreviatura de Jagdstaffell (Escuadrilla de caza en alemán)

Kg: Kilogramos (Abreviatura, unidad de peso)

Km: Kilómetros (Abreviatura, unidad de longitud)

Kw: Kilovatios (Abreviatura, unidad de potencia eléctrica)

LOBA: Lista Oficial de Buques de la Armada

LT: Lancha torpedera

M: metros (Abreviatura, unidad de longitud)

MB: motores de lanchas torpederas fabricados por Daimler-Benz

MG: Ametralladora

MHz: Megahertzios (Abreviatura; unidades de frecuencia)

Mm: milímetros (Abreviatura, unidad de longitud)

Mod.: Modelo (Abreviatura)

MP: Subfusil o pistola ametralladora alemana

NSDAP: Nationalsozialistische Deutsche Arbeite Partei (Partido Nazi)

NSU: Neckarsulmer Fahrzeugwerke $A G$ (Fabricante alemán de coches y motocicletas)

OKH: Oberkommando der Heer (Mando supremo del Ejército alemán)

OKL: Oberkommando der Luftwaffe (Mando supremo de la Aviación alemana)

OKM: Oberkommando der Kriegsmarine (Mando supremo de la Marina de guerra alemana)

OKW: Oberkommando der Wehrmacht (Mando supremo de las Fuerzas Armadas alemanas).

ONU: Organización de las Naciones Unidas

OTO: Odero-Terni-Orlando (Fábrica italiana de material de artillería)

Pak: Panzerabwehrkanone (Cañón antitanque)

PmK: Phosphor mit Kern (Tipo de munición alemana: perforante incendiaria con núcleo de acero) 
Ptas: Pesetas (Abreviatura. Moneda española hasta el año 2000)

RA: Regimiento de Artillería. También acrónimo de Rohr Aufbau (Tubo de cañón)

RACE: Regimiento de Artillería para Cuerpo de Ejército

RADAR: Radio Detecting and Ranging

RAF: Royal Air Force: (Aviación británica)

RB: Rheinmetall -Borsig (Empresa alemana fabricante de armamento)

RDF: Radio Direction and Finding

RLM: Reichsluftministerium (Ministerio del Aire alemán)

ROWAK: Rohstoff-Waren Kompensation Handelgesselschaft G. m. B. H. (Empresa creada en Alemania para llevar a cabo los acuerdos de clearing)

RRH: Ringtrichterrichtungshoerer. (Fonolocalizador alemán fabricado por la empresa Elektroacustic).

S.A.M.: Siemensapparatenmaschinen (Sistema de recepción y transmisión de datos para cañones antiaéreos)

S.E.: Tratamiento. "Su Excelencia"

SAPA: Sociedad Anónima Placencia de las Armas

SAR: Servicio Aéreo de Rescate

SECN: Sociedad Española de Construcción Naval

SmK: Spitz mit Kern (tipo de munición alemana: perforante con núcleo de acero))

SOM: modelo alemán de telémetro

sS: Schweres Spitzgeschoss (Tipo de munición alemana: proyectil pesado)

StuG: Sturmgeschütz (Cañón de asalto)

Tm: Toneladas (Abreviatura)

U.T.G: Ubertragunsgerät (Sistema de recepción y transmisión de datos para cañones antiaéreos)

UNED: Universidad Nacional de Educación a Distancia

V.E. : Tratamiento. "Vuestra Excelencia" 
VDM: Vereingite Deutsche Metallwerke. (Empresa alemana fabricante de hélices para aeroplanos)

W: vatios (Abreviatura; medida de potencia)

WBF: Wasser Bombe Ausf. F. (Modelo alemán de cargas de profundidad para los buques de la Armada)

Z.B.: Zbrojovká Brno (Fábrica de armamento checa, incautada por Alemania) 


\section{INTRODUCCIÓN}

Los últimos veinte años del régimen de Franco la gran mayoría de los sistemas de armas de los tres ejércitos españoles se recibieron a través de convenios con los Estados Unidos de América. La "ayuda americana", que no era sino una contraprestación por las facilidades ofrecidas a Estados Unidos, no fue exclusivamente militar sino que parte de ella consistió en el abastecimiento de materias primas, productos agrícolas, asistencia técnica o financiación de los más diversos proyectos, desde forestales o agrícolas hasta turísticos.

Pues bien, si el 26 de septiembre de 1953 Franco firmaba con Eisenhower los “Acuerdos de Amistad y Cooperación”, solo diez años antes, se había convenido con la Alemania nazi un "Acuerdo" por el que ambos países se comprometían a profundizar en sus relaciones comerciales de todo tipo. Aunque parezca mentira, el Tercer Reich necesitaba a España para mantener su economía de guerra, pues nuestro país figuraba entre sus mejores proveedores de materias primas.

El día 27 de septiembre de 1943, el ministro del Ejército español, Carlos Asensio Cabanillas, solicitaba al Consejo de Ministros, reunido en Madrid, autorización para contratar la adquisición de determinado armamento que una comisión nombrada al efecto había pactado en Berlín, la capital del Reich alemán, unos meses antes. Esta curiosa situación se producía porque el proyecto de modelo de contrato no se ceñía estrictamente a las disposiciones legales que regulaban la contratación en el Ministerio del Ejército.

Al mismo tiempo Asensio pidió al Consejo que los trámites de la firma de los diferentes contratos con las casas suministradoras se llevaran a cabo en Berlín y fuera el agregado militar español quien los efectuara, con el objetivo de eximir las formalidades de escritura pública, pago de derechos reales, así como el resto de impuestos que gravaban aquel tipo de acuerdos, por haberlo exigido el citado organismo alemán. El pago del suministro de material militar debería efectuarse, en cualquier caso, con cargo al suplemento de crédito de 506.000.000 de pesetas que había sido habilitado para tal fin, y que había aprobado el Jefe del Estado, Francisco Franco, el 4 de septiembre de ese mismo año. 
Este acuerdo fue tratado con la máxima reserva, no se dio conocimiento más que a los considerados "indispensables" -siempre con la nota de "Secreto"-, no se publicó nunca, ni en el Boletín Oficial del Estado ni en el Diario Oficial, y siempre que se habló del asunto se trató confidencialmente como "material adquirido con destino al Ejército".

Fuera del ámbito militar y diplomático, en España nunca se supo de la existencia del denominado "Programa Bär", un concienzudo y trabajado programa para la adquisición de armamento de última generación -el primero llevado a cabo tras la Guerra Civil española-, que llevó a España -procedentes del Tercer Reich-, más de mil vagones de ferrocarril cargados de material bélico con destino a las tres ramas de las fuerzas armadas.

Si bien es cierto que programas similares se llevaron a cabo en países tales como Hungría, Rumanía, Bulgaria o la propia Italia, no es menos cierto que los citados países eran aliados de Alemania y sus tropas luchaban codo con codo con la Wehrmacht en diversos frentes. Por contra, España era un país no beligerante ${ }^{1}$, pese a los innumerables lazos que le unían con Alemania desde el final de la Guerra Civil, y el esfuerzo de reconstrucción de un país absolutamente roto tras los tres años de conflicto civil no dejó de ser una opción aducida en múltiples ocasiones por los representantes políticos y diplomáticos en sus relaciones con las autoridades germanas, desde el propio Franco y los ministros de Asuntos Exteriores, hasta el último consejero de legación. Una opción y una alternativa que Alemania utilizó en su propio beneficio a lo largo de toda la guerra mundial: España como aliado bélico podía ser una rémora -lo fueron los italianos- y como enemigo podía ser una pesadilla en la retaguardia.

\footnotetext{
${ }^{1}$ Otros países europeos neutrales o no beligerantes, como Portugal o Turquía, dispusieron también de programas de armamento similares al aquí expuesto, aunque en mucha menor cantidad. Por ejemplo, Portugal vendió a Alemania wolframio y recibió vía terrestre, a través de España, entre otro material militar, piezas antiaéreas ligeras de $20 \mathrm{~mm}$ y armas automáticas. Turquía vendió a Alemania diferentes minerales -el más importante el cromo- y adquirió diverso armamento, como carros de combate Panzer III y IV así como aviones de caza Focke Wulf Fw 190. Existen numerosos testimonios de estas relaciones en los US National Archives, de los que entresacamos unos ejemplos. (Report 12575 -listado de empresas portuguesas controladas Alemania, 12 páginas, julio 1945-; Report 13044 -comercio de wolframio con Portugal por la empresa Gesellschaft fur Elektrometallurgie- Report 14867 -Acuerdos entre la empresa Krupp y el gobierno portugués y entre Krupp y empresas turcas-; Repport 15759 - Empresas portuguesas que recibieron ayuda financiera alemana durante la guerra y actividades clandestinas alemanas en Portugal. Listados de personas y empresas relacionadas). Fuente: Records of the research and analysis Branch. RG 226. Interallied and Interservice Military Agencies Records. National Archives. (http://www.archives.gov/research/holocaust/finding-aid/military/rg-226-3g.html). Phelps, Will; Schoeters, Rudi, Panzer IV survivors: A-J, Autoedición de los autores, Sacramento (California), 2005, pág. 7.
} 
Además de la evidente y abultada deuda económica, el régimen de Franco tenía una deuda de gratitud con Alemania por la ayuda militar prestada en la pasada Guerra Civil; precisamente había sido en el transcurso del conflicto español cuando se habían puesto en práctica los inevitables "acuerdos de compensación" -clearing- entre ambos países para regular los intercambios y canalizar el apoyo militar teutón a los sublevados. En efecto, dos años después del inicio de la gran reestructuración económica alemana impulsada por el ministro de Economía del Reich, Hjalmar Schacht, se creaban sendas empresas, HISMA $\operatorname{Ltda}^{3}$ y ROWAK ${ }^{4}$, que actuarían durante toda la contienda española como verdaderas cámaras de compensación para facilitar el comercio exterior entre el Tercer Reich y la España "nacional”. Acuerdos bilaterales que en 1936 concedieron a

\footnotetext{
${ }^{2}$ Los acuerdos de clearing se generalizaron en Alemania tras la reestructuración de la política comercial exterior impulsada por Hjalmar Schacht a partir de 1934, con su denominado "Neuer Plan". En dicho Plan se daban al Ministerio de Economía amplios poderes para controlar y regular el comercio exterior mediante acuerdos bilaterales con otros países, organizando los intercambios sobre la base de un comercio de "trueque" o "canje" y compensación de mercancías. Estos acuerdos de clearing estaban pensados para que existiera una compensación entre las importaciones y las exportaciones sin que hubiera una transferencia real de monedas entre dichos países. Para ello funcionaba una cámara de compensación en cada uno de los países, que realizaba los pagos en moneda nacional a los exportadores del citado país gracias al dinero recibido de los importadores nacionales. En este tipo de acuerdos, un elemento fundamental era el tipo de cambio entre las monedas de ambos países, verdadero regulador de los intercambios. El tipo de cambio entre la peseta y el marco alemán en el período que nos ocupa permaneció estable, siendo 1 marco = 4,34 pesetas. García Pérez, Rafael, "El proyecto continental del Tercer Reich". Revista de Estudios Políticos nº 87, enero-marzo 1995, pág. 275.

${ }^{3}$ La Hispano-Marroquí de Transportes Limitada (HISMA Ltda) fue creada el 31 de julio de 1936 por un español, Fernando Carranza y Fernández-Reguera, y un alemán, Johhannes Eberhard Bernhardt, con el objeto social de fomentar y explotar el negocio de los transportes. Existe abundante bibliografía sobre esta empresa fundamental y sus vicisitudes a lo largo de la Guerra Civil española y años posteriores, convertida en el holding SOFINDUS. Whealey, Robert H. Hitler and Spain. The nazi role in the Spanish Civil War. 1936-1939. Kentucky. The University Press of Kentucky, 1989, pag. 73. García Pérez, Rafael. Franquismo y Tercer Reich. Las relaciones económicas hispano-alemanas durante la Segunda Guerra Mundial, Centro de Estudios Constitucionales, Madrid, 1994, pág. 65. Rühl Klaus-Jörg. Franco, Falange y III Reich. España durante la Segunda Guerra Mundial, AKAL, Madrid, 1986, pp. 35 y siguientes. Molina Franco, Lucas, El legado de Sigfrido. La ayuda militar alemana al Ejército y la Marina nacional en la Guerra Civil española. (1936-1939), AF Editores, Valladolid, 2005, págs. 37-45.
}

4 Acrónimo de "Rohstoff-Waren Kompensation Handelgesselschaft m. B. H.", empresa "espejo" de HISMA, creada en Berlín en octubre de 1938 con capital netamente alemán. Al mando de la misma fue colocado Eberhard von Jagwitz, hombre ligado a la organización exterior del partido nacional-socialista (Auslandorganisation-AO) y con experiencia en negocios en Hispanoamérica. ROWAK financiaba las exportaciones alemanas con destino a España con el producto de las ventas de las mercancías españolas cuyos importadores alemanes pagaban en marcos al contado. García Pérez relaciona el nacimiento de ROWAK con el Plan Cuatrienal de Goering y los resortes exteriores del NSDAP. García Pérez, Rafael. Franquismo y Tercer Reich. Op. cit., pp. 62-63. La ROWAK también realizó actividades comerciales con Portugal, Irán, Afganistán, Eslovaquia y el lejano oriente. En concreto, con Portugal fue la encargada del comercio de wolframio y del clearing germano-portugués. Ver: Record 12533. Records of the research and analysis Branch. RG 226. Interallied and Interservice Military Agencies Records. National Archives (http://www.archives.gov/research/holocaust/finding-aid/military/rg-226-3g.html) 
Alemania el papel preponderante en la negociación, ya que los sublevados no estaban en condiciones de marcar distancias ni de endurecer posturas.

Pero en cualquier caso, las pautas marcadas por Schacht en su plan, cuyos objetivos pasaban por adaptar las importaciones germanas a la escasa disponibilidad real de divisas, por potenciar la obtención de materias primas indispensables y por captar socios en el ámbito internacional para asegurar los suministros, se vieron cumplidos de forma casi perfecta con la participación teutona en el conflicto español.

De hecho, el año 1936 marcó un giro importante en la concepción estratégica de la política comercial exterior germana. Ese año, además de coincidir con el inicio de la Guerra Civil española, dio comienzo la carrera por la consecución de una:

“...economía de guerra autosuficiente que asegurara la mayor independencia posible respecto al exterior, tanto en materias primas como en mercados (...)

El objetivo era conseguir en un determinado ámbito territorial una corona de socios comerciales amigos, o cuando menos neutrales. Un cordón comercial que ofreciera una independencia económica lo más alta posible buscando además una fórmula de relación con esos países para que en caso de conflicto permanecieran en el ámbito de sus armas...",

Los evidentes motivos ideológicos que movieron a Hitler y las autoridades del partido nazi a intervenir en la guerra española, fueron dando paso a otro tipo de condicionantes -básicamente económicos-, que determinaron el acontecer de las relaciones que sucederían tras el desenlace del conflicto y que por algunos autores

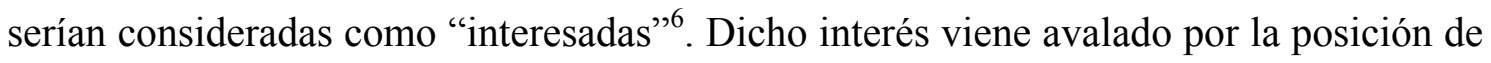
privilegio obtenida por el Tercer Reich frente a las autoridades franquistas para participar en inversiones en diferentes empresas españolas -sobre todo del sector minero- ${ }^{7}$; por convertirse en el principal socio comercial español en cuanto a

\footnotetext{
${ }^{5}$ García Pérez, Rafael. “El proyecto continental del Tercer Reich”, op. cit., págs. 278 y 279.

${ }^{6}$ Viñas, Angel, Guerra, dinero, dictadura: ayuda fascista y autarquía en la España de Franco. Barcelona. Crítica, 1984, pag. 178.

${ }^{7}$ La coincidencia en el tiempo entre el inicio del conflicto español y la puesta en práctica del Plan Cuatrienal alemán, amén de la efectividad de las medidas aplicadas dos años antes por el entonces ministro de Economía teutón, el Dr. Hjalmar Schacht, con su "Neuer Plan", explican el interés alemán en establecer una "influencia" creciente -transformada a mediados de 1937 en "participación" efectiva- en la base productiva mineral española. Dicha participación, con la sociedad HISMA Ltda. -y su subsidiaria Montaña SA- como principal accionista en diversas explotaciones mineras, se fue transformando en franca "penetración", como asegura el profesor García Pérez, gracias, precisamente, a la evolución de
} 
operaciones import-export ${ }^{8}$ y por el manejo por parte de las autoridades teutonas de la denominada "deuda de guerra", un comodín que utilizarían en los años venideros como arma arrojadiza para intentar forzar la entrega de mercancías y materias primas españolas, cuando la enorme desproporción del clearing entre ambos países -a favor de España-, comenzaba a estrangular las relaciones comerciales bilaterales y amenazaba con paralizar la entrega de vitales suministros.

Finalizada la guerra en España con la victoria de Franco, y tras las dificultades y dilaciones de éste para entrar en la guerra mundial al lado de Alemania, todos los esfuerzos germanos se centraron a mantener un statu quo para que los suministros españoles de materias primas fundamentales para la economía de guerra del Reich, siguieran fluyendo en cantidad suficiente para paliar la carencia de muchos alimentos, minerales, y algunos productos manufacturados, de los que Alemania era deficitaria neta.

En el verano de 1939 se producía la primera negociación económica con Alemania en la que se sentaron alrededor de una mesa comisiones de ambos países para intentar normalizar las relaciones comerciales hispano-germanas tras el período de excepcionalidad de la guerra española ${ }^{9}$. Los alemanes aseguraban que el sistema de compensaciones HISMA-ROWAK sólo podría ser sustituido por un tratado general de comercio entre Alemania y España. Los negociadores españoles, mucho más a la defensiva, querían ganar tiempo para ponerse al día en todo lo referente al comercio exterior, pues la guerra recién finalizada había marcado los tiempos, y las necesidades perentorias de España en el conflicto habían imposibilitado la necesaria homogeneización de procedimientos burocráticos que ofrecieran, entonces, luz sobre la

HISMA Ltda hacia una empresa holding con un amplio abanico de inversiones en diversos campos: Sofindus. García Pérez, Rafael. Franquismo y Tercer Reich. Las relaciones económicas hispanoalemanas durante la Segunda Guerra Mundial, op. cit., págs. 59-82.

\footnotetext{
${ }^{8}$ Las exportaciones a Alemania, que en 1935 suponían un 13,1 \% del total de exportaciones españolas, tres años más tarde, en 1938, superaban ya el 40 \%. García Pérez, Rafael. Franquismo y Tercer Reich, op. cit., pág. 60.

9 La comisión germana estaba compuesta por Helmuth Wohlthat, consejero de estado y director ministerial del Plan Cuatrienal -figura clave en la política económica del Tercer Reich-; Hermann Sabath, consejero jefe de la Sección III del Departamento de Política Comercial del Auswärtiges Amt; Friedrich Bethke, segundo de von Jagwitz y director in pectore de ROWAK; y el doctor Könning, consejero vinculado a la misma ROWAK. Por parte de la embajada alemana en España participaron el secretario Stille y el agregado comercial Enge. AMAE Leg. R 1895/6, citado por García Pérez, Rafael, Franquismo y Tercer Reich, op. cit. pág. 100.
} 
situación real de la economía y estadísticas fiables sobre las que organizar un marco comercial bilateral ajustado a las necesidades españolas.

Pero hasta diciembre de ese año de 1939 no se alcanzaría un acuerdo, forzado por la circunstancia de estar Alemania en guerra con el Reino Unido y Francia. Se firmaron sendos documentos confidenciales: un Protocolo y un Acuerdo sobre tráfico de mercancías, y quizás lo más sobresaliente fue el final del sistema HISMA-ROWAK y el compromiso de equilibrar la balanza comercial exterior, que hasta entonces había sido favorable a Alemania. La satisfacción de la deuda española con el Reich, resultante de la Guerra Civil, valorada en más de 372 millones de marcos, fue aplazada para fechas posteriores no determinadas ${ }^{10}$.

Entre 1940 y 1944 Alemania fue el principal destino de las ventas de productos españoles ${ }^{11}$, desbancando el tradicional liderazgo británico de nuestras exportaciones, con la mirada puesta en el saldo definitivo de las deudas de guerra vigentes todavía. Prácticamente en el ecuador del lustro que abarca el período antes citado, a mediados de 1942, se produciría un hecho que marcaría las relaciones económicas entre los dos países en los años venideros: el incesante incremento de las importaciones de productos españoles por parte de Alemania -el 700\% en 1941 con respecto a 1940- no era compensado en absoluto por el aumento de las exportaciones de productos alemanes, que en ese mismo período -1941 - solo aumentaron un $150 \%$ con respecto al año anterior. Tras la invasión de la URSS por parte de la Wehrmacht, estas cifras se acentuaron, observando a finales de 1942 un desfase en la balanza comercial entre España y Alemania de cerca de 200 millones de $\operatorname{marcos}^{12}$.

Pese a que la expresión pueda parecer algo exagerada, e incluso descarnada, Rühl llega a afirmar que Alemania había tratado a España durante años, como "su colonia de materias primas", añadiendo a continuación que:

\footnotetext{
${ }^{10}$ Rühl Klaus-Jörg. Franco, Falange y III Reich, op. cit., pág. 36.

${ }^{11}$ El 24,74\% de las exportaciones españolas durante el lustro citado lo fueron al Tercer Reich frente al 20,53\% que irían a la Gran Bretaña. Martínez Ruiz, Elena. El sector exterior durante la autarquía. Una reconstrucción de las balanzas de pagos de España (1940-1958) Edición revisada. Servicio de Estudios del Banco de España. Estudio nº 43, Madrid, 2003, pág. 76.

12 Ruhl ofrece unas cifras de 152.800.000 marcos a finales de 1941 y 198.300.000 marcos un año después. "Las relaciones hispano-germanas, que habían mejorado considerablemente por la colaboración de España en la guerra germano-soviética, habían entrado en un compás de espera, a raíz de la larga duración de la guerra en el Este y de la entrada de los EEUU.” Rühl Klaus-Jörg. Franco, Falange y III Reich, op. cit., págs. 37 y 43.
} 
“...(España) ascendió a la categoría de igualdad comercial con la aparición de los Aliados en el área del Mar Mediterráneo. Ciertamente que el gobierno español estaba dispuesto a entregar a Alemania cualquier cantidad de materias primas, exigiendo por otra parte compensaciones en forma de armas y apoyo tecnológico, para la modernización de la industria española..."13

Era necesario y urgente reglamentar el comercio bilateral y alcanzar un acuerdo que mejorara y afianzara las posturas. España se estaba convirtiendo en suministrador neto de todo lo que Alemania necesitaba y las autoridades españolas, sobre todo tras la llegada del general Jordana al Ministerio de Exteriores no estaba dispuesta a mantener ese estatus. De esta manera, por la pura necesidad de mantener un intercambio comercial suficiente con España, uno de los pocos socios internacionales que le quedaban a la Alemania de Hitler, las Fuerzas Armadas españolas fueron depositarias de un legado armamentístico que, de otra manera, hubiera sido impensable alcanzar en aquellos turbulentos años centrales de la Segunda Guerra Mundial.

Así, tras la firma de un Acuerdo de Comercio entre España y Alemania, llevado a efecto tras arduas e intensas negociaciones en diciembre de 1942, la situación deficitaria del comercio exterior teutón en la cuenta de clearing con nuestro país, llevó a los negociadores españoles a plantear la posibilidad de que el Reich entregara diverso armamento para compensar ese desfase, ciertamente preocupante, que lastraba el comercio bilateral hispano-germano. El armamento sería la válvula de escape que utilizarían ambos países para mantener controlado el déficit máximo aceptado en el Tratado Comercial de 1942.

En efecto, el planteamiento hispano a las autoridades germanas llegó a buen puerto, no sin dificultades, y para rehabilitar el marchito clearing, Alemania accedió a suministrar armas a los tres ejércitos españoles; unas armas que deberían servir, sin duda, para oponerse a una hipotética invasión aliada -mera cuestión estética- aunque para el Ejército de Tierra, la Armada y el Ejército del Aire servirían para intentar modernizar su anticuado y mastodóntico parque armamentístico, proveniente todo él de la Guerra Civil, la mayoría obsoleto y sin repuestos, usado hasta la saciedad y de dudosa eficacia ante cualquier amenaza, Aliada o del Eje. Y en el otoño de 1942 los rumores de que se preparaba un desembarco aliado en el norte de África eran bien conocidos en el gobierno español, al que preocupaba de manera evidente la situación de las islas

\footnotetext{
${ }^{13}$ Rühl Klaus-Jörg. Franco, Falange y III Reich, op. cit., pág. 225.
} 
Canarias y del Protectorado. "Aquel octubre de 1942 fue para nosotros uno de los momentos de mayor tensión de la guerra" diría el diplomático José María Doussinague, refiriéndose, precisamente, a la "Operación Torch" ${ }^{14}$.

La ocasión era inmejorable y pese a que las cantidades de armas que podían llegar de Alemania no iban a cubrir las necesidades básicas de los ejércitos españoles, sí podían servir para no perder el pulso de las nuevas tecnologías desarrolladas en la Guerra Mundial -léase rádar, carros de combate modernos, aviones de caza y bombardeo, artillería eficaz, material de transmisiones de última generación, etc...-, abundando así en la idea de los militares españoles de no quedarse atrás en todos los conceptos de la guerra moderna que se estaba produciendo en Europa por esos años.

Numerosas comisiones españolas de la rama técnica de los tres ministerios militares visitaron Alemania durante la guerra para ver, analizar y estudiar nuevas tecnologías en materia de desarrollos militares. Otras fueron invitadas por sus homónimos germanos para visitar los frentes de batalla y sacar conclusiones de tácticas y estrategias desarrolladas por el considerado mejor ejército del momento. Algunas comisiones asistieron a cursos en Alemania para aprender a utilizar el material que se adquiría de manera habitual desde 1939, denominado en todos los documentos de la época, "Suministros Especiales". Enmarcadas en el denominado "Programa de Armamentos" - cuyo nombre clave era "Programa Bär" (“Oso" en alemán)-, otras muchas comisiones militares acudirían a Alemania para poner al día y sacar el máximo aprovechamiento al material que se iba a negociar.

El "Programa Bär" entendido como asunto económico, fue, como acabamos de ver, el producto necesario para salvar un desequilibrio monetario entre España y Alemania fruto de los desfases del comercio entre ambos países. Una forma más o menos sencilla para Alemania, que producía armamento en cantidades ingentes, de

\footnotetext{
${ }^{14}$ Analizando la cantidad de armas pactadas en el "Programa Bär" y la preparación y dimensión del Ejército español de la época, consideramos que éste no estaba en disposición de hacer frente al "rodillo" Aliado en el caso de que se hubiese producido una invasión en territorio español o del Protectorado. Es más, el propio ministro de Exteriores, general Jordana, en un amplio informe que presentó al Consejo de Ministros el 19 de septiembre de 1942, señaló la urgente necesidad de que España concentrara sus esfuerzos en mejorar al máximo sus industrias de guerra, en obtener en otros países el material bélico más moderno, en movilizar efectivos y fomentar el voluntariado y en la preparación de cuadros de mando. En resumen: España debía hacer todo lo posible para alcanzar "un ejército tan poderoso como sea posible con vistas a las complicaciones exteriores. (...) España tiene que ser fuerte, tiene que adquirir un rango militar muy superior al que en la actualidad le corresponde." Doussinague Teixidor, José María, España tenía razón. (1939-1945), Espasa-Calpe SA, Madrid, 1949, págs. 68 y ss.
} 
aminorar el déficit bilateral de balanza exterior. Pero dicho "Programa" tuvo otra visión mucho menos conocida o, quizás menos divulgada por la historiografía, que lo hizo excepcional en su época: fue la única vía para que las Fuerzas Armadas españolas adquirieran, renovaran, mejoraran e implementaran su ya vetusto parque armamentístico; fue la ocasión de situarse a la altura de los tiempos que transcurrían en su entorno geográfico - una guerra mundial de proporciones nunca antes vistas- y una buena forma de entrenar y cualificar a una pequeña parte sus miembros en las más modernas técnicas de combate del momento, junto a los que, sin duda, eran los mejores y más fogueados soldados de la época. A este segundo aspecto, tan importante -casicomo poseer armamento moderno, no solo colaboró el envío de equipos humanos y comisiones de oficiales y suboficiales a Alemania o a los frentes de batalla para instruirse, sino también el hecho de que España participara en el conflicto bélico contra la URSS por medio de una división de infantería, la llamada División Española de Voluntarios, la "División Azul"15.

Esta división, por la que en dos años y medio pasaron más de 45.000 españoles de todos los orígenes geográficos y de todos los estratos de la sociedad de la época, y que combatió en unas condiciones climatológicas extremas contra un enemigo duro, valiente y preparado, fue una verdadera escuela militar para los oficiales, suboficiales y tropa que sirvieron en ella. Es factible pensar que esta unidad española fue una anécdota entre las más de 350 divisiones alemanas del frente ruso, pero su valor militar y su comportamiento en el lugar del frente que le fue asignado, es suficiente para justificar su presencia en la Segunda Guerra Mundial.

Para los militares españoles de entonces fue todo un reto y una ilusión poder contar con armamento de "tecnología punta", armamento que se estaba empleando, con

\footnotetext{
${ }^{15}$ Existen numerosísimos estudios, bien sean globales o bien monográficos, que versan sobre la participación de la División Azul en el frente ruso, en el transcurso de la Segunda Guerra Mundial. Quizás el más académico, de carácter global, y escrito con la necesaria distancia geográfica y perspectiva temporal, sea el debido a los profesores norteamericanos Kleinfeld, Gerald R. y Tambs, Lewis A., La división española de Hitler. La División Azul en Rusia, Editorial San Martín, Madrid, 1983. Más cercano en el tiempo, con un estilo académico, serio y desapasionado, se ha publicado otro trabajo, Moreno Juliá, Xavier, La División Azul. Sangre española en Rusia (1941-1945), Crítica, Barcelona, 2004. Entre la multitud de estudios monográficos sobre la División Azul, nos decantamos por la obra de Caballero Jurado, Carlos. Morir en Rusia. La batalla de Krasny Bor, Quirón Ediciones, Valladolid, 2003. El estudio de la División Azul desde el punto de vista político y diplomático, es muy importante la obra de Rühl, Klaus-Jörg. Franco, Falange y III Reich, op. cit., pp. 22-30 y 98-102. Por último, el mejor estudio económico sobre los costes de la División Azul, lo realiza García Pérez, Rafael. Franquismo y Tercer Reich, op. cit., págs. 263-270.
} 
éxito, en todos los frentes de combate de la Segunda Guerra Mundial y que pasaba por ser el más eficiente y el más contrastado de todo el utilizado por los distintos contendientes en el conflicto.

Es una constante en la historiografía española mantener en segundo plano los temas que toquen de lleno a los ejércitos, sus técnicas, sus tácticas o sus estrategias, dejando para su estudio en las academias militares o en los servicios históricos de los ministerios de defensa, todas las cuestiones relacionadas con estos asuntos. Y así ha ocurrido, desgraciadamente en el tema que nos atañe: el "Programa Bär" ha sido analizado desde el punto de vista económico, desde el político e, incluso, desde el diplomático, dejando huérfano el prisma militar, ciertamente importante si tenemos en cuenta los acontecimientos que se estaban produciendo en nuestro entorno en esos momentos.

En todos los textos publicados, el asunto de las importaciones de material bélico alemán por parte del gobierno español en los años de la Segunda Guerra Mundial, es tratado de manera tangencial y circunstancial, siempre como un aspecto secundario, supeditado a los avatares de la política internacional o de las relaciones económicas bilaterales, pero nunca se ha puesto en valor en su justa medida, analizando el porqué del armamento solicitado, estudiando el que realmente llegó a España, su efectividad real en el contexto de la época en la que se adquiere y su encuadramiento en el ejército español de entonces.

Nuestro planteamiento en el momento de abordar el estudio de las adquisiciones de material militar en Alemania por parte de los ministerios militares españoles, tiene dos vertientes que, aunque complementarias en sus fines, están claramente diferenciadas a la hora de plasmar nuestras investigaciones.

Por una parte se ha intentado sistematizar, consolidar y profundizar de manera documental -minuciosa y prolija-, todos los hitos de la colaboración hispano-germana en materia militar desde el 2 de abril de 1939 -fecha en la que comenzó la "Paz", tras el fin de la Guerra Civil española- hasta la firma del Acuerdo de Comercio el 16 de diciembre de 1942, verdadero punto de inflexión en las relaciones entre ambos países y fecha que marcaría una nueva era en la adquisición de armamento y tecnología militar en el Tercer Reich. El Capítulo I responde, precisamente, a estos objetivos, dando 
cuenta de la mayoría de los "negocios" militares llevados a cabo de manera independiente, por cada uno de los tres ministerios castrenses, e incluso por las diversas fábricas y maestranzas militares de los respectivos ejércitos españoles hasta esa fecha.

La segunda vertiente del trabajo -la más amplia y documentada- se centra, precisamente, en el cambio de las estrategias germana y española a la hora de planificar, cuantificar y materializar la entrega de armamentos a la España franquista, planteadas tras la firma del Acuerdo citado. Una vez expuesto de manera sintética el análisis histórico del propio Acuerdo -desarrollado en el Capítulo 2- y de las negociaciones políticas, militares y económicas que dieron origen al envío masivo de armamento a los ejércitos españoles -Capítulos 3 y 4-, llegamos, por fin, al estudio en profundidad del material bélico entregado a España en el marco del "Programa Bär" -nombre clave dado por los alemanes al envío planificado de armas de guerra, producido al margen de las negociaciones normales llevadas a cabo hasta la fecha del Acuerdo anteriormente citado-.

El análisis detallado del armamento entregado al Ejército de Tierra -Capítulo 5y a la Armada y al Ejército del Aire -Capítulo 6-, teniendo siempre en cuenta sus características técnicas, su calidad real, su novedad en el momento de la exportación, su adecuación al campo de batalla de la época, así como su encuadramiento orgánico en las diferentes unidades militares españolas existentes, -sin olvidar las cantidades recibidas de cada uno de ellos- nos va a permitir elaborar un completo informe que servirá para pulsar el valor -siempre en términos militares relativos- de las entregas de armas a España llevadas a cabo por el Tercer Reich hitleriano.

A la par del estudio estrictamente militar, marco de innegable validez empírica para desarrollar una tésis certera sobre la importancia de las aportaciones germanas de equipo bélico, es inevitable un estudio paralelo que tenga en cuenta la valoración económica de las citadas aportaciones -desarrollado en el Capítulo 7-, siempre con la vista puesta en las negociaciones que sobre los precios del material llevaron a cabo los técnicos españoles con sus contrapartes alemanes -revisado en profundidad en el Capítulo 4-. El monto económico conjunto que supuso el "Programa Bär", teniendo en cuenta también el malogrado programa de maquinaria, es el reflejo numérico de la lucha teutona por la financiación en la segunda mitad de la Guerra Mundial.

La remisión de pequeñas cantidades de material bélico por vía aérea -una vez cerrada la terrestre, tras la liberación de Francia por los Aliados- y las "entelequias 
imposibles plasmadas sobre el papel", que supusieron los Programas "Ankara" y "Eltze" - estudiados ambos asuntos en el capítulo 8-, no fueron más que el reflejo de la impotencia y las dificultades insalvables del Reich por seguir obteniendo de España -al igual que ocurrió con otros países- las materias primas ineludiblemente necesarias para mantener activa su economía de guerra.

Nuestro objetivo no es otro que la puesta en valor de la entrega de armamento a España, en época tan difícil y compleja para adquirir ese tipo de materiales; puesta en valor a la que anteriormente nos referimos y en la que nadie, hasta ahora, ha profundizado desde su vertiente específicamente militar. Un estudio que no ha de ser pasado por alto si se quiere hacer un análisis riguroso del papel de España en el marco de la Segunda Guerra Mundial.

Por último, se hace necesaria una aclaración respecto al título del trabajo. Se ha elegido "La ayuda militar alemana a España" frente a otros posibles y más evidentes, pese a que el mismo pueda resultar chocante, ya que todo el material del que vamos a hablar tuvo su reflejo económico y contable y se pagó religiosamente en la cuenta de clearing hispano-alemana. La palabra "ayuda" está aquí referida más bien a la predisposición germana, desde los tiempos de la Guerra Civil española, a enviar armamento e instruir a los militares españoles en las técnicas de combate más modernas, algo que se quiere enlazar -de alguna manera y salvando las distancias- con la conocida "Ayuda Americana" de los años cincuenta. Se trata, simplemente, a fuer de ser sinceros, de un uso forzado o exagerado de esta palabra. Una "ayuda" interesada, no cabe duda.

Klaus Jörg Ruhl en su trabajo, Franco, Falange y III Reich, fue quizás el primero que estudió y analizó las relaciones políticas, económicas y diplomáticas entre España y Alemania en el transcurso de la Segunda Guerra Mundial. Precisamente al asunto del armamento dedica dos interesantes epígrafes, titulados "Materias Primas a cambio de armas" y "La pérdida de la posición alemana en el mar Mediterráneo. Negociaciones hispano-germanas sobre armas y suministros españoles”.

El primero de ellos está dedicado al estudio de las negociaciones económicas que dieron origen al Convenio Comercial de diciembre de 1942, poniendo de manifiesto la necesidad española de contar con material de guerra alemán: 
“...a fin de poder fortalecerse -aunque sólo fuera ópticamentefrente a los aliados (y frente Alemania), modernizando el ejército español..."16

Al margen de consideraciones de otro orden, las afirmaciones de Rühl respecto al material militar que conformaba en esa época el ejército español no dejan de ser algo sesgadas, basadas -probablemente- en informes alemanes de la época, en los que pesaba, sin duda, cierto afán de protagonismo. Como ejemplo valga la siguiente afirmación que recoge en su tesis:

“...Los pocos cañones de gran calibre, situados en las Islas Canarias, las Baleares y el paso de Gibraltar -en su mayoría procedentes de suministros de la marina alemana- se utilizaban de forma limitada a causa de la escasa munición..."

Como tendremos ocasión de comprobar más adelante, los únicos cañones de costa suministrados por la marina alemana fueron una docena de vetustas piezas navales procedentes de buques de la Primera Guerra Mundial, de calibres medios (150-170 mm) que artillaron cuatro puntos concretos de las islas de Tenerife y Gran Canaria en 1940. Todas las piezas de gran calibre presentes en la costa española eran Vickers, de fabricación inglesa, bien de $381 \mathrm{~mm}$, bien de $305 \mathrm{~mm}$. La mayoría de las de calibre medio eran de fabricación española, aunque de patente inglesa Vickers.

Con una ligera mención, fragmentaria e incompleta, a las listas de peticiones de material de guerra alemán por parte de las autoridades militares españolas, Rühl da por finalizado el asunto militar en este epígrafe.

El segundo de los epígrafes citados se limita a hacer una exposición sintética de las vicisitudes de las comisiones españolas que negociaron la entrega de armamento, desde enero hasta mayo de 1943, aportando, de nuevo, datos muy incompletos de las peticiones de armas presentadas por el general Martínez de Campos cuando se hizo cargo de la delegación española, así como de la contraoferta germana consecuencia de dichas peticiones.

Lo referente al desarrollo del "Programa Bär" lo despacha Rühl en poco más de dos párrafos, haciendo hincapié, únicamente, en el denominado "Programa de entrega inmediata" -Sofortprogramm - aportando, como en los casos anteriores, datos muy generales y con poco rigor, llamémosle, militar.

\footnotetext{
${ }^{16}$ Rühl Klaus-Jörg. Franco, Falange y III Reich, op. cit., pág. 159.

${ }^{17}$ Rühl Klaus-Jörg. Franco, Falange y III Reich, op. cit., pág. 163.
} 
Pese a ello, y con todas las limitaciones a la investigación que existían en la época, a Rühl le cabe el honor de ser el primer historiador que habló de la existencia del "Programa Bär" en su dimensión militar, realizando una aproximación muy poco definida y bastante lejos de la realidad de lo que verdaderamente significó este programa, pero es cierto que su Tesis no iba en ese camino.

El más importante de los estudios realizados hasta la actualidad sobre la adquisición española de armamento alemán, fue el de Rafael García Pérez en su ya citado Franquismo y Tercer Reich, al que se le concedió el premio "Nicolás Pérez Serrano" el año 1992 y fue publicado por el Centro de Estudios Constitucionales dos años más tarde.

Pese a tratarse de un estudio histórico-económico, basado en las relaciones bilaterales entre España y Alemania desde 1936 hasta el final de la Segunda Guerra Mundial, no ceja en la ardua tarea de desentrañar los materiales que formaron parte de las adquisiciones de material militar alemán entre 1936 y 1944. Asuntos como los Rahmenwerträge (acuerdos marco) firmados con los ministerios de Marina, Ejército y Aire y los suministros especiales de diversa naturaleza para las fuerzas armadas, son citados por el autor a lo largo del trabajo, poniendo de manifiesto afirmaciones como la siguiente, que confirma de manera explícita la dificultad que entraña investigar estos $\operatorname{asuntos}^{18}$ :

“...Lamentablemente, no puedo ofrecer un catálogo completo de todas estas compras "complementarias" de armamento, dada su dispersión administrativa con que fueron gestionadas. Su volumen fue, sin duda, muy elevado..."

Pese a ello, detalla algunos de los negocios militares llevados a cabo hasta finales de 1942 enmarcados en los citados Rahmenverträge y su inclusión posterior -en algunos casos- en el "Programa Bär".

Dedica dos epígrafes completos (los 4.1 y 4.2 del capítulo V) al citado "Programa Bär" y a las negociaciones económicas sobre el armamento, y en ellos, de manera sintética, desarrolla las negociaciones finales del general Martínez de Campos en Berlín para asegurar las armas seleccionadas por los militares españoles y describe el programa escalonado diseñado por los alemanes para el suministro del armamento.

\footnotetext{
${ }^{18}$ García Pérez, Rafael. Franquismo y Tercer Reich, op. cit., pág. 395.
} 
"Se trataba de un volumen enorme de armamento, por lo que hubo que habilitar cuatro pasos ferroviarios en los Pirineos..."

Pese a esta consideración, García Pérez afirma que este armamento no variaba significativamente la capacidad militar española pues la guerra mundial había multiplicado la capacidad destructiva de los contendientes y era evidente que España no podría competir. Coincidimos, en el fondo de la cuestión: España no podría llegar al nivel de ninguno de los contendientes del conflicto, pues no estaba en guerra; pero ese volumen enorme de armas importado de Alemania, le daría la posibilidad de mejorar su capacidad combativa, en caso de ataque o invasión por parte de alguno de los mismos. De cualquier manera, no deja de ser mera especulación lo que hubiera podido hacer o no, con el mismo, ya que afortunadamente, no hubo posibilidad de comprobarlo.

García Pérez es el único investigador que ha cuantificado y valorado el armamento del "Programa Bär" (cuadro sinóptico de la página 401), aunque la realidad de la ejecución del citado programa se aleje bastante de los datos aportados en ese estudio, elaborado con la información recogida en diversos certificados de valoración de material del programa, fechados en septiembre de 1943 y conservados en el archivo del Ministerio de Asuntos Exteriores ${ }^{20}$. Diversos errores de transcripción a la hora de nombrar algunos materiales ${ }^{21}$ y la heterogénea y distorsionada agrupación de las diferentes partidas $^{22}$ que propone García Pérez, así como el diferente grado de

${ }^{19}$ García Pérez, Rafael. Franquismo y Tercer Reich, op. cit., pag. 394. Pese a que es cierto el aserto de García Pérez de que se habilitaron cuatro pasos fronterizos en los Pirineos, poco antes de dar comienzo el envío de trenes cargados con material desde Alemania, las autoridades españolas decidieron prescindir de uno de ellos -Puigcerdá-, manteniendo únicamente Irún, Canfranc y Port-Bou. Mediado ya el denominado "Restprogramm", también se prescindió de Canfranc, quedando únicamente los otros dos.

${ }^{20}$ En dichos certificados, estudiados con detenimiento para esta investigación, se han detectado diversos errores, como considerar 24 los carros de combate contratados, cuando en realidad fueron sólo 22 (20 de línea y dos de mando), o únicamente seis los cañones de asalto solicitados y recibidos, cuando fueron realmente diez. También la cifra referente a las ametralladoras ligeras y pesadas está muy sobreelevada (se citan 1.150 ejemplares), ya que en realidad solo se habían solicitado 750, llegando únicamente la mitad, 375. Y hay que tener en cuenta que esta adquisición se produjo conjuntamente con las motocicletas pesadas BMW R-75, pues se trataba de ametralladoras para montar sobre los "side cars" de las motos. En el material correspondiente a Marina hay también diversos errores en la cuantificación y descripción de la artillería, así como en todo el material destinado a submarinos y motorización de diversos buques, que nunca se llegó a recibir.

${ }^{21}$ Se produce cierta confusión en el cuadro al citar la palabra "baterías" en el mismo plano que "cañones" (vid. “268 baterías y cañones antiaéreos"). En el lenguaje artillero una "batería” está formada por varios cañones. Pueden ser dos, si éstos son de gran calibre; cuatro si son de mediano calibre; e incluso seis si son de pequeño calibre. Por lo tanto, en el caso anterior, o bien se trata de 268 baterías o bien de 268 cañones, pero ambos conceptos no se deberían mezclar, y mucho menos si estamos hablando de diferentes modelos de piezas artilleras y de variados calibres.

${ }^{22}$ Es, quizás, lo más llamativo del cuadro construido por García Pérez. Pese a que el objeto de la agrupación en una tabla o cuadro sea simplificar la lectura e interpretación de los datos, consideramos que 
cumplimiento del "Restprogramm" debido a la imposibilidad real de los transportes terrestres por Francia a partir de julio-agosto de 1944, perjudican la validez del citado cuadro sinóptico, que no deja de ser un resumen muy generalista, simplista y sintético de una realidad militar mucho más amplia y compleja, una realidad llena de matices y dificultades como la que supuso el "Programa Bär".

El más que meritorio y profundo estudio de las relaciones económicas hispanoalemanas durante la Segunda Guerra Mundial realizado por García Pérez, ha marcado un verdadero punto de inflexión en la comprensión de las razones reales de dicha ayuda, incorporando elementos de juicio para valorar en su justa medida todos los condicionantes que llevaron al Tercer Reich a plantearse la citada colaboración en los términos en los que sucedió.

En otros trabajos de naturaleza económica, como en el caso de la tesis doctoral del profesor Jordi Catalán, titulada La economía española y la Segunda Guerra Mundial, se asume la cuestión de las divisas gastadas en importaciones de algunos artículos, como el armamento, y aunque le dedica unas pocas líneas, reconoce que ${ }^{23}$ :

“...son normalmente difíciles de localizar entre las partidas de las estadísticas de comercio exterior, puesto que están casi siempre descritas con categorías difíciles de identificar. No obstante, hay evidencias que muestran que las importaciones españolas de material de guerra alemán fueron muy importantes en algunos años del conflicto, como en 1944. Según los datos que figuran en los registros de caja del IEME, en dicho año la partida mayor de divisas cedidas

agrupar en una única partida elementos que no son comparables lleva, normalmente, a errores de apreciación y de concepto, tanto más evidentes cuanto mayor diferencia exista entre los mismos. Veamos un ejemplo, aplicable al resto de partidas agrupadas. El autor cita " 456 cañones de campaña, antitanque y de asalto, de diversos calibres". Aquí se incluyen los siguientes tipos de piezas artilleras: cañones de campaña rusos de 122/46 mm; cañones antitanque alemanes de 75/46 mm; cañones antitanque franceses de 25/72 mm y piezas de asalto sobre chasis de carro de combate Panzer III denominadas StuG III, dotadas de cañón largo de 75/48 mm. En el "Programa Bär" se incluyeron 150 ejemplares de cada una de los tres primeros modelos citados y diez de las piezas de asalto (que harían 460 y no 456). Un somero análisis de las características de estos cañones nos hará convenir que no son comparables, por ejemplo, un cañón de campaña ruso de $122 \mathrm{~mm}$ de calibre, con siete toneladas de peso en posición de tiro, que podía colocar un proyectil de 22 kilos (con tres de explosivo) a 20 kilómetros de distancia, con un cañón antitanque francés "Puteaux" de $25 \mathrm{~mm}$ de calibre, con un peso de 300 kilos, que colocaba sus pequeños proyectiles de 320 gramos a 1.800 metros de distancia. Tampoco es muy ortodoxo agrupar con las citadas piezas, los cañones de asalto, que eran autopropulsados al ir montados sobre la barcaza del carro de combate Panzer III y disponer de un cañón de $75 \mathrm{~mm}$, propio de los más modernos carros alemanes de la Segunda Guerra Mundial. La excesiva agrupación de conceptos lleva irremediablemente a una homogeneización imposible y a una pérdida de la perspectiva de realidades diferentes.

${ }^{23}$ Catalán Vidal, Jordi. La economía española y la Segunda Guerra Mundial. Barcelona, Ariel, 1995, págs. 240 y 241 . 
para financiar las importaciones españolas correspondió al equipo bélico. En ese año, las compras de material de guerra absorbieron cerca de un quinto de las importaciones registradas por el IEME..."

Por su parte Christian Leitz, en el libro colectivo Spain in an International Context, 1936-1959, publicado con las aportaciones de reputados historiadores a un congreso celebrado con motivo del sesenta aniversario del inicio de la Guerra Civil española, dedica un capítulo completo (el noveno) al asunto del suministro de armamento alemán a la España franquista entre 1943 y 1944, titulando el citado capítulo, precisamente, "Programa Bär"24.

Afirma Leitz al iniciar el capítulo:

"En el transcurso de la Segunda Guerra Mundial las relaciones germano-españolas experimentaron diversas transformaciones las cuales, como se mostrará a continuación, se pueden ilustrar mediante un examen del rol de las exportaciones de material de guerra germano a España, y en este contexto, el más ambicioso de los programas de suministro: el Programa Bär".

Tras una parte introductoria en la que se sitúa al lector anglosajón en disposición de entender la política militar española de postguerra, se analiza brevemente la situación de las adquisiciones de este tipo de material de guerra desde 1939, recién finalizada la guerra civil, y los acuerdos llevados a cabo por los ministerios militares con empresas germanas a través de la omnipresente AGEKA (agencia estatal alemana de venta de armamento en el exterior), también denominados "Rahmenvertrage".

Tras la entrevista entre Franco y Hitler, que tuvo lugar de Hendaya el 23 de octubre de 1940, y los esfuerzos alemanes para que España entrara en la Segunda Guerra Mundial, se analizan los cambios ocurridos en las relaciones económicas entre ambos países, pasando España de ser un país con bajo nivel de interés para el III Reich en los primeros compases del conflicto, a necesitar sus productos básicos -ya en 1942para mantener los esfuerzos de guerra; el déficit en la cuenta de clearing hispanogermano fue decisivo, definitorio y, de alguna manera obsesivo para el Reich hitleriano.

Hasta finales de 1942, los suministros de material bélico y de patentes y licencias de fabricación llegaron con cuentagotas, pese a que había en esa época muchos negocios en curso de negociación. Los acuerdos oficiales y las conversaciones menos

\footnotetext{
${ }^{24}$ Leitz, Christian y Durnthorn, David J., Spain in an International Context, 1936-1959, Berghahn Books, New York, 1999, págs. 171-190.
} 
formales entre oficiales españoles y alemanes entre 1942 y 1944 aumentaron considerablemente, sobre todo a raíz de la firma del citado Acuerdo Comercial del 16 de diciembre de 1942. A partir de este momento, Leitz desgrana de forma rápida las negociaciones de las comisiones españolas en Berlín para llegar al meollo de la cuestión, que es el programa de adquisición de armamentos, llegando, por fin, al Acuerdo Económico del 18 de agosto de 1943, una extensión del firmado en diciembre del año anterior.

La aportación de Leitz al estudio del "Programa Bär" es importante y sin duda suficiente para el lector anglosajón, pero deja las mismas incógnitas que en su día no pudo resolver la obra de García Pérez. No detalla ni profundiza en los "Rahmenvertrage" de los tres ministerios militares, ni en el material adquirido en el seno del Programa, ni en su asignación y empleo en las fuerzas armadas españolas y por ende, en todo el proceso de adquisición del mismo.

En 2001 se publicó un voluminoso libro debido a la pluma de Miguel Platón, titulado Hablan los militares ${ }^{25}$, en él se recogen testimonios de diversos militares españoles constituyendo un ambicioso estudio desde el punto de vista militar, de la España franquista, de la Transición y de los primeros veinte años de democracia.

Uno de los epígrafes del primer capítulo está dedicado al "Programa Bär", justificando de forma somera su planteamiento en un momento de debilidad alemana y en la necesidad de los suministros de materias primas españolas para la economía de guerra del Tercer Reich.

Tomando como eje del estudio los recuerdos de algunos militares destinados en aquellos años en el Estado Mayor Central del Ejército (EMCE), reconstruye de "forma aproximada" -como el mismo autor reconoce- los suministros bélicos servidos por los alemanes en el marco del citado programa de adquisiciones, negando validez real (otorgándosela únicamente como documento burocrático) a la tabla publicada por el profesor García Pérez en su ya citado "Franquismo y Tercer Reich”.

Pese a que Platón intenta detallar los suministros de material bélico para el Ejército de Tierra, la Armada y el Ejército del Aire, contenidos en el "Programa Bär", sólo traza un somero esbozo de los mismos, con la presencia evidente del material más

\footnotetext{
${ }^{25}$ Platón Carnicero, Miguel, Hablan los militares. Testimonios para la historia (1939-1996), Planeta, Madrid, 2001.
} 
importante y notorio (carros de combate, artillería de asalto, artillería de campaña, antiaérea y algo de contracarro, aviones y torpederas), pero con notables ausencias (radares, material de transmisiones, minas, piezas y fusiles antitanque, cargas de profundidad, artillería naval de 10,5 cm, goniómetros, grupos electrógenos, cineteodolitos, etc...) y con una evidente mezcla de conceptos a la que, desgraciadamente, estamos acostumbrados: introduce en su relación diverso material militar que pese a ser de origen germano y llegar a España entre 1940 y 1944, nunca formó parte del denominado "Programa Bär".

Como veremos en el desarrollo de nuestro trabajo, ni las ametralladoras de origen checo ZB-26 y ZB-30, ni el submarino U-573, ni los aviones Heinkel He 111 "meteorológicos", ni los hidros Dornier Do 24 que se citan, formaron parte jamás del citado programa de adquisiciones.

Una obra publicada por Gabriel Cardona en 2003, que lleva por título El gigante descalzo. El ejército de Franco ${ }^{26}$, analiza el papel del ejército español durante la era franquista y despacha en poco más de tres párrafos de un epígrafe todo el esfuerzo español para adquirir armamento en Alemania. Además de plasmar una obviedad: el estado calamitoso del material militar español en los años posteriores a la guerra civil, relata Cardona la necesidad de adquirirlo en Alemania. Tras citar de manera genérica algunas de las armas enviadas y las patentes adquiridas, afirma ${ }^{27}$ :

"El armamento comprado era insignificante ante las necesidades. De modo que la pomposa División Acorazada Brunete quedó reducida a apenas un nombre, porque solo pudo contar con dos batallones blindados, uno con los magníficos carros alemanes PzKpfw IV Tiger, recién comprados, y otro dotado de anticuados rusos T-26 capturados a los republicanos durante la guerra civil..."

Pese a no acertar con el modelo de carros de combate adquiridos -no eran Tiger-, algo nada superfluo si tenemos en cuenta la condición de militar de carrera de Cardona, echamos de menos un análisis más profundo del armamento recibido e incorporado a los ejércitos españoles, precisamente por su condición de miembro de las Fuerzas Armadas.

\footnotetext{
${ }^{26}$ Cardona Escanero, Gabriel. El gigante descalzo. El ejército de Franco, Santillana Ediciones Generales S.L., Madrid, 2003

${ }^{27}$ Cardona Escanero, Gabriel. Op. cit., pág. 118.
} 
En 2008 el hispanista, Stanley Payne, publicó un trabajo titulado Franco y Hitler. España, Alemania, la Segunda Guerra Mundial y el holocausto ${ }^{28}$, donde traza los orígenes del régimen de Franco y su ligazón con el Tercer Reich, así como la evolución de las relaciones entre ambos países y sus mandatarios durante la Segunda Guerra Mundial. Un único epígrafe del capítulo XI, con sólo cuatro páginas de texto, dedica Payne al asunto que aquí trataremos, sin aportar nada nuevo a lo ya estudiado por otros autores anteriormente.

Queremos reseñar, por último, un libro publicado en 2009, titulado "Entre la antorcha y la esvástica”, tesis doctoral de su autor, Emilio Sanz-Francés ${ }^{29}$, donde se trazan de manera profunda y exhaustiva las difíciles relaciones políticas entre la España de Franco y ambos contendientes en la Segunda Guerra Mundial: el Eje y los Aliados. En este trabajo existe una leve referencia al asunto que nos ocupa, que aunque sólo tiene la categoría de nota de pie de página, demuestra, por su redacción y descripción de fuentes, la dificultad y complicación que supone adentrarse en el terreno prolijo de los materiales militares.

La mayor parte de la documentación de carácter político, económico y diplomático referente a las relaciones entre España y Alemania entre 1939 y 1945 se conserva, como no podía ser de otra manera, en el archivo Renovado (R) del Archivo del Ministerio de Asuntos Exteriores (AMAE), sito en el Palacio de Santa Cruz. Entre toda esa documentación figura una parte referida, de alguna manera, a los programas de adquisición de armamento en general y a los denominados "Programa Bär", "Programa Ankara” y "Programa Eltze" en particular, y sus implicaciones de carácter militar, como listas de armamento solicitado por diferentes comisiones y en distintos momentos de las negociaciones; asuntos tratados por la llamada Comisión Extraordinaria para Material de Guerra y alguna correspondencia de su presidente, el general de división Carlos Martínez de Campos, con el entonces ministro de Exteriores español, conde de Jordana; actas de las diferentes reuniones celebradas en Madrid para valorar el armamento contratado en el seno de las negociaciones; telegramas cruzados desde la Embajada en

\footnotetext{
${ }^{28}$ Payne, Stanley. Franco y Hitler. España, Alemania, la Segunda Guerra Mundial y el holocausto, La esfera de los libros, 2008.

${ }^{29}$ Sanz-Francés San Baldomero, Emilio, Entre la antorcha y la esvástica. Franco ante la encrucijada de la Segunda Guerra Mundial, Editorial Actas, Madrid, 2009.
} 
Berlín y el Ministerio de Exteriores español, referidos a las diferentes fases de las negociaciones del Acuerdo económico de diciembre de 1942 y su extensión de agosto de 1943, así como otros importantes documentos para entender y desentrañar los aspectos de carácter económico ligados de manera profunda a los diferentes programas de armamento que nos van a ocupar.

Pero como era de esperar, el Archivo del Ministerio de Asuntos Exteriores no dispone de documentación específica generada por los ministerios directamente implicados en el desarrollo del programa de armamentos más ambicioso desarrollado por España hasta las negociaciones con los Estados Unidos de Norteamérica en 1953. Esta documentación, de carácter estrictamente militar, se encuentra depositada en cuatro diferentes archivos pertenecientes, respectivamente, al Ejército de Tierra -Archivo General Militar de Ávila (AGMAV)-; al Ejército del Aire -Archivo Histórico del Ejército del Aire (AHEA) - sito en Villaviciosa de Odón (Madrid); a la Marina Española -Sección de Marina del Archivo General de la Administración Civil del Estado (AGA)sito en Alcalá de Henares (Madrid) y a la Dirección General de Adquisiciones de Presidencia del Gobierno, cuya documentación obra en el Archivo Histórico Nacional (Madrid). En el caso de la Marina, y debido a cuestiones de volumen de la documentación y a la capacidad reducida del Archivo General de la Armada del Viso del Marqués (Ciudad Real), los fondos generados desde la Guerra Civil española están depositados en el Archivo General de la Administración.

Quizás el más importante de los tres para la investigación llevada a cabo -por la cantidad de información localizada, no solo del Ejército de Tierra, sino también correspondiente a la Marina y al Ejército del Aire- haya sido el archivo abulense, donde se custodian una serie de cajas procedentes del Archivo del Cuartel General del Ejército (Fondo procedente del antiguo Ministerio del Ejército), en las que se conserva la documentación generada por los programas de adquisición de armamento llevados a cabo entre 1939 y 1944 entre España y Alemania.

Informes, facturas, telegramas, cartas y diversa documentación procedente de la Comisión Extraordinaria para Material de Guerra, la Agregaduría Militar en la Embajada española en Berlín, la $5^{\mathrm{a}}$ Sección del Estado Mayor Central del Ejército y otros organismos relacionados con la adquisición de material militar en Alemania, constan en estas cajas guardadas en el Archivo General Militar de Ávila, con una particularidad que ha marcado la investigación: la poca organización -en muchos casos, 
nula- con la que está archivada toda esta documentación, fruto, posiblemente de los convulsos tiempos en los que fue generada y guardada. Desde aquellas fechas hasta que estos documentos han sido puestos a disposición de los investigadores -mediados de los años 90 del pasado siglo- éstos han permanecido, suponemos, almacenados en el Ministerio del Ejército (Cuartel General del Ejército), sin recibir consulta alguna ni merecer la atención de los técnicos, algo de todo punto lógico dadas las circunstancias ulteriores: Alemania había perdido la guerra y sería imposible solicitar más materiales, ni siquiera repuestos, ni nada relacionado con todo lo allí recogido.

El Archivo Histórico del Ejército del Aire de Villaviciosa de Odón (Madrid) custodia la documentación específica generada por el Agregado Aeronáutico en la Embajada española en Berlín, fuente importante a la hora de estudiar los materiales recibidos con destino al Ejército del Aire desde el final de la Guerra Civil, incluyendo todo lo relacionado con las adquisiciones de patentes de fabricación de diversos modelos de aviones con los que la industria española iba a dotar al citado Ejército los siguientes veinte años.

La Sección de Marina del Archivo General de la Administración Civil del Estado (Alcalá de Henares-Madrid), contiene una buena parte de la documentación generada por la Armada Española desde la Guerra Civil hasta la actualidad. Existen varias cajas referentes al armamento adquirido en Alemania y los contactos con empresas germanas desde los tiempos del conflicto civil, además de las comisiones de compras españolas llevadas a cabo en ese país desde 1939. Para investigar en este archivo los fondos de la Armada hay que solicitar autorización expresa en el Cuartel General de la Armada (Instituto de Historia y Cultura Naval).

El Archivo Histórico Nacional (AHN) conserva la documentación de la denominada Dirección General de Adquisiciones de Material de Guerra en el Extranjero, organismo dependiente de Presidencia del Gobierno, encargado desde febrero de 1938 -en plena Guerra Civil- hasta mayo de 1950 de la realización de pedidos de material militar en el exterior. Dicha Dirección General de Adquisiciones mantuvo estrechas relaciones con diferentes organismos de la administración civil como la Dirección General de Comercio, el Instituto Español de Moneda Extranjera (IEME) o la Dirección General de Aduanas, así como con los tres ministerios militares y sus estados mayores, directamente relacionados con las adquisiciones. 
Otros archivos importantes en la investigación han sido los relacionados a continuación: el Archivo General Militar de Segovia, donde se han consultado diferentes hojas de servicio de los personajes militares más importantes de los participantes en las negociaciones de adquisición de material; el Archivo General Militar de Madrid, en el que se custodian los historiales de las unidades militares del Ejército de Tierra, algunos de los cuales se han consultado para esta investigación; el conservado en la Fundación Nacional "Francisco Franco", que mantiene diversos documentos remitidos por los Agregados Naval y Aeronáutico en Berlín, relativos a material de su jurisdicción y a diferentes negociaciones con los militares germanos; el Archivo Intermedio del Cuartel General del Ejército del Aire, donde se encuentra diversa documentación sobre hidroaviones Dornier Do 24 adquiridos en Alemania en 1944 para la Comisión de Salvamento de Náufragos; el Archivo privado de la familia Espinosa (del que fuera Agregado Naval español en Berlín durante todo el conflicto mundial, capitán de fragata Manuel Espinosa Rodríguez), con una importantísima colección de telegramas cruzados entre el Estado Mayor de la Armada y el Agregado Naval en Berlín, referentes a adquisiciones de todo tipo de materiales de guerra y diversas vicisitudes de carácter económico generadas por dichas adquisiciones; el conservado en el Servicio Histórico del Estado Mayor de la Armada, para diversas comisiones de oficiales de la Marina Española en Alemania; el Archivo del Polígono de Experiencias de Carabanchel, donde se consultaron diversos informes referentes a pruebas balísticas de material de Artillería así como a pruebas de otro tipo de armamento como fusiles y cañones contracarro, brocales, etc... procedentes de Alemania; el Archivo del general José Varela Iglesias, conservado en la ciudad de Cádiz, que dispone de numerosa documentación relacionada con las vicisitudes del Ejército de Tierra español entre 1939 y 1942, años en los que Varela ejerció el cargo de ministro del Ejército; el Archivo Linz, de la Transición española, para obtener notas biográficas de ciertos personajes y el Archivo de la Fábrica de Artillería de Trubia, donde se han consultado diversas órdenes de fabricación de piezas de $122 \mathrm{~mm}$, copia de las soviéticas adquiridas en el "Programa Bär".

Amén de los trabajos del alemán Rühl y del español García Pérez, ya citados anteriormente y que versan en detalle sobre las relaciones económicas, políticas y diplomáticas entre España y Alemania entre 1936 y 1945, se han consultado diversos 
libros divulgativos publicados sobre armamento y material del ejército alemán objeto de las negociaciones, así como manuales técnicos, resúmenes de las comisiones de armamento en Alemania y monografías sobre unidades militares del Ejército Español que engloban la época objeto de consulta.

Mención especial merecen dos profundos trabajos de investigación publicados hace ya unos años. El primero de ellos se debe al infatigable investigador naval Juan Luis Coello Lillo, y se titula Buques de la Armada Española. Los años de la postguerra. Narra con detalle las vicisitudes de la Marina Española en los años inmediatos al final de la guerra civil y los programas de construcción naval desarrollados en la década de los 40, detallando pormenorizadamente aspectos fundamentales que atañen al material alemán objeto de este estudio: buques en servicio, artillería, torpedos, submarinos, etc....

El segundo se lo debemos al general ingeniero aeronáutico Jesús Salas Larrazábal, cuyo título tan expresivo De la tela al titanio. El ayer y el hoy de la actividad aeronáutica en España, detalla la evolución de las aeronaves en servicio en la Aviación Española desde los lejanos años de la segunda década del siglo XX hasta los inicios del siglo XXI, así como los avatares de su diseño y fabricación. Al igual que en el caso anterior, Salas nos pone sobre la pista de todos los aviones adquiridos y fabricados en los años cuarenta del siglo XX con patente alemana, así como las vicisitudes de la política militar seguida por las autoridades del Ejército del Aire desde su creación en 1939 -bajo la égida del general Yagüe- y durante los complejos años cuarenta.

También hemos de tener en cuenta los meritorios estudios realizados por Javier de Mazarrasa Coll desde los años setenta del pasado siglo para lograr desentrañar los aspectos más recónditos de la adquisición por el Ejército Español de material acorazado y blindado desde los tiempos de la guerra de Marruecos, con mención especial al titulado Blindados en España. La difícil posguerra. 1939-1960 así como los 1levados a cabo por José María Manrique García y Artemio Mortera Pérez -Historia de la artillería antiaérea española, ( $1^{a}$ parte), La fábrica de Trubia, etc...- en cuestiones referentes a material de artillería, ametralladoras y armas largas, un terreno difícil y complejo por el que han transitado muy pocos investigadores. Mención especial merecen los estudios aeronáuticos de José Luís González Serrano, minucioso analista de los aviones que han pertenecido al Ejército del Aire y cronista de la vida y el destino de los mismos desde aquel lejano año de 1939 hasta la actualidad. 
Otros trabajos monográficos de autores españoles como Carlos Caballero Jurado, Alfonso Escuadra, Alejandro Pazó, José María Doussinague, Carlos Martínez de Campos, José María González Llanos, Jorge García Parreño, o Carlos San Emeterio, completaron aspectos concretos y puntuales de la investigación. 


\section{Capítulo 1}

\section{LAS ADQUISICIONES DE ARMAMENTO Y MATERIAL DE LOS MINISTERIOS MILITARES EN ALEMANIA ENTRE 1939 y 1944}

Desde que en julio de 1936 Hitler decidiera intervenir a favor de los alzados en España, en lo que a la postre devendría en conflicto civil español, las relaciones entre los Ejércitos de ambos países fueron a partir de entonces fluidas y más que amistosas, llegando a convertirse en algo habitual entre 1936 y 1945 las visitas, comisiones e intercambios entre militares españoles y alemanes. Tanto el Ejército de Tierra como Armada y, a partir de agosto de 1939, el Ejército del Aire, enviarían al país teutón numerosas comisiones de oficiales, suboficiales y especialistas para observar, analizar, aprender e intentar adquirir material militar y licencias de fabricación para ponerse al día en cuestión de armamentos. Alemania era en 1939 la potencia militar más importante de Europa.

En 1940, casi un año después de finalizada la Guerra Civil española, las tres ramas del Ejército español firmaban con sus homónimos alemanes unos contratosmarco (Rahmenverträge) de cooperación militar, contratos que se vieron afectados por las negociaciones fallidas entre ambos países en torno a la no beligerancia española y que tuvieron un seguimiento muy irregular, cayendo muy pronto en el olvido y perdiendo su vigencia, precisamente por la falta de acuerdos finales en torno al espinoso asunto de la participación española en la guerra ${ }^{30}$.

En cualquier caso, tanto el Ejército del Aire, como la Armada y el Ejército de Tierra -este último en menor medida-, tuvieron serias y amplias relaciones económicomilitares entre 1940 y 1942, previas a la negociación del Convenio Comercial y a la del "Programa Bär", de tal manera que una gran parte de los suministros de material bélico e industrial procedían de Alemania.

Comenzaremos este capítulo estudiando los Acuerdos Marco del Ejército del Aire, para analizar después los de la Armada y el Ejército de Tierra.

\footnotetext{
${ }^{30}$ García Pérez, Rafael. Franquismo y Tercer Reich, op. cit., pág. 287.
} 


\section{I.1.- EL EJÉRCITO DEL AIRE}

Tras el final de la contienda civil se produjo la reorganización del Ejército vencedor, siendo una de las más importantes realizaciones, la creación el 7 de octubre de 1939 del llamado Ejército del Aire, que recogía todos los cometidos que había llevado durante el conflicto la llamada Aviación Nacional. Al igual que la Luftwaffe germana o la Regia Aeronáutica italiana, el nuevo Ejército del Aire español nacía como arma independiente de sus hermanos de tierra y $\operatorname{mar}^{31}$.

Pero lo más curioso, lo que dejó completamente desconcertados a todos los aviadores militares españoles, fue la decisión de Franco de nombrar para el cargo de Ministro del Aire a un general que nada había tenido que ver nunca ni con la Aviación Militar ni con la Aeronáutica Naval; un general africanista, de su misma promoción de la Academia de Infantería de Toledo, y que, con sus más y sus menos, era de su total confianza: Juan Yagüe Blanco.

El inquilino natural de ese ministerio, por su formación y por su trayectoria, era -sin lugar a dudas- el general Alfredo Kindelán Duany, máximo artífice de la Aeronáutica militar española desde su creación, allá por 1911, y hasta el final de la Guerra Civil, General Jefe del Aire del Ejército Nacional. Es posible que su filiación monárquica alfonsina fuera un impedimento para su nombramiento, pasando a desempeñar el cargo de Capitán General de Baleares. El falangismo indisimulado de Yagüe, cuando sus principales interlocutores iban a ser alemanes e italianos, puede ser que fuera una baza para que el soriano alcanzara ese ministerio.

En cualquier caso, el general Yagüe, como apunta Pérez San Emeterio:

“... se lanzaba en tromba al terreno de las ensoñaciones. En medio de la lógica euforia que siguió al final victorioso del conflicto civil, los más utópicos proyectos llenaron carpetas. Para la Marina del almirante Moreno, y así, de un plumazo, cuatro acorazados, varios cruceros y un sinfín de escoltas y submarinos. Para el nuevo Ejército del Aire, cinco mil aviones. Plazo: cinco años. Como era de esperar, el soporte tecnológico de tan colosal plan de rearme habrían de proporcionarlo Alemania e Italia (...) Se entregó con decidida eficacia, tanto a la tarea legislativa como a apuntalar lo que había en vuelo, e

\footnotetext{
31 Pérez San Emeterio, Carlos y otros. Enciclopedia de la Aviación Militar España. Vol.I. Quirón Ediciones, Valladolid, 2000, págs. 209 y ss.
} 
impulsó los primeros programas de fabricación aeronáutica que tenían lugar en España tras la guerra"32.

Todo el plan de fabricación aeronáutica ideado por Yagüe ponía de relieve la capacitación de la industria nacional - la que ya existía antes de la guerra, complementada con las nuevas factorías- para la tarea de fabricar una serie de modelos estándar con los que dotar al Ejército del Aire. Tras un estudio profundo de los múltiples aparatos supervivientes de la contienda recién finalizada $\mathrm{y}$, dando por sentado sería imposible conseguir apoyo industrial para fabricar material de origen soviético, francés, inglés e incluso norteamericano, se establecieron los parámetros básicos que deberían reunir los aviones en servicio para cada especialidad.

Afirma Pérez San Emeterio que se trataba de:

“... un programa realista y bien elaborado - exceptuando aquella idílica cifra de cinco mil aviones-, al que el desencadenamiento, en septiembre de 1939, de la Segunda Guerra Mundial no tardaría en convertir en papel mojado..."33

Ya durante la guerra se habían desplazado a Alemania José Ortiz Echagüe y el teniente coronel Felipe Lafita Babío, este último, jefe de los servicios técnicos de la Jefatura del Aire, con el fin de firmar contratos con las casas "Bücker", "Heinkel” y "Junkers"34. En junio de 1938 el Consejo de Administración de "Construcciones Aeronáuticas S.A”. (“CASA”) amplió capital para financiar así la ampliación y reconstrucción de las factorías de Cádiz y Getafe y la construcción de una nueva en Sevilla -anexa al aeródromo de Tablada-. La idea era construir en Cádiz las avionetas de escuela elemental Bücker Bü 131 y Bü 133, en Getafe, las de transformación Gotha Go 145 y en Sevilla, los bombarderos Heinkel He 111, modelos elegidos para la producción en serie por los Servicios Técnicos del Aire junto al caza Messerschmitt Bf 109 y al transporte Junkers $\mathrm{Ju} 52 / 3 \mathrm{~m}$, modelos todos ellos probados y experimentados durante la Guerra Civil ${ }^{35}$.

\footnotetext{
${ }^{32}$ Pérez San Emeterio, Carlos, op. cit, pág. 214.

${ }^{33}$ Pérez San Emeterio, Carlos, op. cit, pág. 216.

${ }^{34}$ Ambos ingenieros aeronáuticos se reunieron en Berlín, en noviembre de 1937, con varios constructores alemanes, entre ellos Ernst Heinkel, con el fin de estudiar aspectos relativos de la adquisición de licencias de fabricación de diferentes aviones. Salas Larrazábal, Jesús. De la tela al titanio. El ayer y el hoy de la creatividad aeronáutica en España. Espasa Calpe SA, Madrid, 1983, pag. 135.

${ }^{35}$ Salas Larrazábal, Jesús. De la tela al titanio, op. cit., pag. 137.
} 
De hecho, en agosto 1938 se había contratado con Alemania la fabricación de 25 avionetas Gotha Go 145 y 75 Bücker Bü 131 y Bü 133, cuya producción comenzó en marzo de 1940 en los talleres de "CASA" de Getafe.

Sin embargo no sería hasta 1940 cuando se obtuvo la concesión definitiva de la licencia de fabricación para los aviones Heinkel He 111, así como autorizaciones de compra de diversos motores y utillaje, cuya adquisición se cubría -en parte- con los 4.000.000 de marcos concedidos en forma de ayuda por la Luftwaffe a principios de ese mismo año ${ }^{36}$.

Precisamente, a principios de 1940 existían en España 1.148 aviones militares de 95 tipos diferentes, fabricados en siete países, aunque los repuestos para los mismos eran tan escasos que la eficacia del arma aérea no era proporcional a la cifra de material existente. Además, la logística para mantener en estado de servicio a esos 95 tipos de aviones era tan grande que no resultaba operativa ${ }^{37}$. A lo largo de 1940 se realizaron pedidos ordinarios de aviones, motores, repuestos y licencias de material alemán para los aviones en servicio en el Ejército del Aire de esta nacionalidad por valor de 18.000.000 de marcos. Los pedidos urgentes alcanzaban la cifra de otros 5.000.000 de marcos.

Las cantidades más importantes en cuanto a repuestos eran para "Heinkel" (3.500.000 marcos), "Daimler-Benz" (2.000.000 marcos), “Jumo" (872.000 marcos) o "Messerschmitt" (500.000 marcos) y en cuanto a aviones, motores o licencias, podemos destacar la adquisición prevista de 30 Junkers Ju 52/3m (7.368.000 marcos), 30 motores Jumo $211 \mathrm{Da}$ (1.314.000 marcos), la licencia del motor DB 601 (1.000.000 marcos) o la compra de 40 Bücker Bü 131 (680.000 marcos). De hecho, hasta el 31 de marzo de 1940 habían llegado a España 37 partidas de material aeronáutico de todo tipo, con un peso total de $338^{\prime} 95$ toneladas $^{38}$

\footnotetext{
${ }^{36}$ García Pérez, Rafael. Franquismo y Tercer Reich, op. cit., pág. 288.

${ }^{37}$ Nota reservada del Ministro del Aire español al Jefe del Estado. Ref n ${ }^{\circ} 22$ de 20 de febrero de 1940. AHEA A-13024.

${ }^{38}$ Se trataba de material enviado por las casas "Heinkel", "Autoflug" (bujías y micómetros), "Elektron", "Bücker", "Focke-Wulf", "M.A.N.”, "Gotha”, "Henschel”, "Pittler", "Hirth”, "Alfred Shutte”, "Lange und Geilen", "Propellerwerk Schwarz", "B.M.W.", "Junkers", "Schaefer" y "Auto-Union". Todo este material fue enviado por vía marítima, bien en el minador "Júpiter" de la Armada Española en un viaje
} 
En julio de 1942, previo a la firma del Acuerdo Comercial Hispano-Alemán de diciembre de ese mismo año, se había llegado a un acuerdo entre el Ministerio del Aire español y el alemán, a autorizar mediante compensación, los suministros a librar hasta mediados de 1943 por la industria aeronáutica alemana.

\section{TABLA I-A.}

\section{“RAHMENVERTRAGE" ENTRE LOS MINISTERIOS DEL AIRE ESPAÑOL Y ALEMÁN}

\begin{tabular}{|c|c|c|c|c|}
\hline Material & $\begin{array}{l}\text { Precio unitario } \\
\text { (Marcos) }\end{array}$ & $\begin{array}{c}\text { Precio unitario } \\
\text { (Pesetas) }\end{array}$ & $\begin{array}{c}\text { Precio total } \\
\text { (Marcos) }\end{array}$ & $\begin{array}{c}\text { Precio total } \\
\text { (Pesetas) }\end{array}$ \\
\hline He $111 \mathrm{H}-6$ con motor Jumo 211-F & $500.000,00$ & $2.170 .000,00$ & $500.000,00$ & $2.170 .000,00$ \\
\hline Material para $10 \mathrm{He} 111 \mathrm{H}-6$ & $200.000,00$ & $868.000,00$ & $2.000 .000,00$ & $8.680 .000,00$ \\
\hline Planos y utillaje He $111 \mathrm{H}-6$ & & & $20.000,00$ & $86.800,00$ \\
\hline $\begin{array}{l}\text { Un juego completo Ju } 52 \text { G-10 para } \\
\text { comprobación de útiles }\end{array}$ & $173.000,00$ & $750.820,00$ & $173.000,00$ & $750.820,00$ \\
\hline Material para 6 aviones Ju 52 G-10 & $110.000,00$ & $477.400,00$ & $660.000,00$ & $2.864 .400,00$ \\
\hline Prensa para ondular chapa Ju 52 & $35.100,00$ & $152.377,40$ & $35.100,00$ & $152.377,40$ \\
\hline 60 motores Jumo 211-F & $43.800,00$ & $190.092,00$ & $2.628 .000,00$ & $11.405 .520,00$ \\
\hline Una célula Me 109 Ga-2 & $137.000,00$ & $594.580,00$ & $137.000,00$ & $594.580,00$ \\
\hline 500 toneladas de aluminio & $2.000,00$ & $8.680,00$ & $1.000 .000,00$ & $4.340 .000,00$ \\
\hline Banco de pruebas para motores & $1.444 .000,00$ & $6.266 .960,00$ & $1.444 .000,00$ & $6.266 .960,00$ \\
\hline 80 motores Hirth 504 & $6.985,00$ & $30.314,90$ & $558.800,00$ & $2.425 .192,00$ \\
\hline 30 veleros Grunau Baby II B & $3.868,93$ & $16.791,116$ & $116.068,00$ & $503.735,12$ \\
\hline 20 veleros Kranich & $10.739,00$ & $46.607,26$ & $214.780,00$ & $932.145,20$ \\
\hline 10 veleros Weiche & $9.910,00$ & $43.009,40$ & $99.100,00$ & $430.094,00$ \\
\hline 100 juegos de instrumentos "Autoflug" & 628,00 & $2.725,52$ & $62.800,00$ & $272.552,00$ \\
\hline Aparatos de prueba Askania & $40.000,00$ & $173.600,00$ & $40.000,00$ & $173.600,00$ \\
\hline 2 cabinas “Link Trainer" Askania & $40.000,00$ & $173.600,00$ & $80.000,00$ & $347.200,00$ \\
\hline TOTAL & 2.757.040,93 & 11.965.557,64 & $9.768 .658,00$ & 42.395.975,72 \\
\hline
\end{tabular}

Fuente: AMAE. AR. Sig. R-2066-2

El coste total de este Rahmenvertrage era de 9.768.658,00 marcos, que venía a suponer, en pesetas de la época, 42.395.975,72, pagadero en los tres años siguientes a la 
firma. Como veremos, nunca se llegó a suministrar todo el material contenido en el acuerdo, aunque sí una buena parte de él ${ }^{39}$.

En estas mismas fechas (julio de 1942), independientemente del Convenio al que nos estamos refiriendo, se habían solicitado elementos y repuestos por parte del Ministerio del Aire y de CASA por un importe de 4.889.348,6 marcos, de los cuales se habían pagado 3.055.375,33 marcos y otros 309.343,94 marcos se habían compensado con un sobrante en ROWAK a favor del Ministerio del Aire procedente de pedidos anteriores anulados, quedando pendiente la cantidad de $1.833 .973,34 \operatorname{marcos}^{40}$. Se trataba de repuestos para motores Jumo $210 \mathrm{D} / \mathrm{Ha}$ y $211 \mathrm{~A}$, herramientas para los citados motores, repuestos para Heinkel He 111 y Messerschmitt Bf 109 así como cuatro emisoras Bake de onda ultracorta de 500 watios.

\section{TABLA I-B}

\section{SOLICITUD DE MATERIAL PARA EL EJÉRCITO DEL AIRE Y CASA. (JULIO 1942)}

\begin{tabular}{|l|l|l|l|l|}
\hline Concepto & $\begin{array}{l}\text { Pagado } \\
\text { (Marcos) }\end{array}$ & $\begin{array}{l}\text { Pagado } \\
\text { (Pesetas) }\end{array}$ & $\begin{array}{l}\text { Pendiente } \\
\text { (Marcos) }\end{array}$ & $\begin{array}{l}\text { Pendiente } \\
\text { (Pesetas) }\end{array}$ \\
\hline Elementos solicitados por CASA & $29.760,00$ & $129.158,40$ & $322.989,64$ & $1.401 .775,03$ \\
\hline Elementos solicitados por el MdA & $3.025 .615,33$ & $13.131 .170,55$ & $1.510 .983,70$ & $6.557 .669,25$ \\
\hline $\begin{array}{l}\text { Sobrante en Rowak por pedidos } \\
\text { anulados }\end{array}$ & $309.343,94$ & $1.342 .552,70$ & & \\
\hline Total & $3.364 .719,27$ & $14.602 .881,65$ & $1.833 .973,34$ & $7.959 .444,28$ \\
\hline
\end{tabular}

Fuente: AMAE. AR. Sig. R-2066-2 (CASA: Construcciones Aeronáuticas S.A.)

Por último, las licencias de adquisición de diverso material aeronáutico contratadas con Alemania en esas mismas fechas ascendían a 6.648.000 marcos, de los cuales se habían pagado hasta ese momento 2.327.000 marcos, quedando pendiente la diferencia, que se difirió hasta $1945^{41}$. Incluso en dos de las licencias, la de ampliación sobre los instrumentos de "Askania", y la de hélices de paso variable, con "V.D.M.”, no estaba previsto hacer pagos hasta después de 1945.

\footnotetext{
39 Esta cantidad tenía que hacerse efectiva en el transcurso del año 1943. "Concepto $\mathrm{n}^{\circ}$ 2. Suministros especiales. A/Convenio especial. MDA-RLM”. AMAE. AR. Sig. R-2066-2.

40 "Concepto $\mathrm{n}^{\mathrm{o}}$ 2. Suministros especiales. B/Elementos y repuestos solicitados independientes del Convenio". AMAE. AR. Sig. R-2066-2.

41 “Concepto $\mathrm{n}^{\circ}$ 2. Suministros especiales. C/Licencias”. AMAE. AR. Sig. R-2066-2.
} 
TABLA I-C

\section{LICENCIAS DE FABRICACIÓN.}

\begin{tabular}{|c|c|c|c|c|c|c|c|}
\hline Licencias. Material & Total & $\mathbf{1 9 4 0}$ & $\mathbf{1 9 4 1}$ & $\mathbf{1 9 4 2}$ & $\mathbf{1 9 4 3}$ & $\mathbf{1 9 4 4}$ & $\mathbf{1 9 4 5}$ \\
\hline He 111 H-6 & 1.585 .000 & 317.000 & 507.000 & 190.200 & 190.200 & 190.200 & 190.200 \\
\hline Me 109 Ga-2 & 1.500 .000 & & 780.000 & 180.000 & 180.000 & 180.000 & 180.000 \\
\hline Jumo 211 F & 1.270 .000 & 260.000 & 410.000 & 150.000 & 150.000 & 150.000 & 150.000 \\
\hline Ju 52 G-10 & 1.500 .000 & & & 150.000 & 850.000 & 250.000 & 250.000 \\
\hline $\begin{array}{c}\text { Instrumentos Askania } \\
\text { instrumentos Askania }\end{array}$ & 93.000 & 43.000 & 10.000 & 10.000 & 10.000 & 10.000 & 10.000 \\
\hline $\begin{array}{c}\text { Ampliación } \\
\text { Hélices paso variable } \\
\text { VDM }\end{array}$ & 600.000 & & & & & & \\
\hline TOTAL & $\mathbf{6 . 6 4 8 . 0 0 0}$ & $\mathbf{6 2 0 . 0 0 0}$ & $\mathbf{1 . 7 0 7 . 0 0 0}$ & $\mathbf{6 8 2 . 0 0 0}$ & $\mathbf{1 . 3 8 2 . 0 0 0}$ & $\mathbf{7 8 2 . 0 0 0}$ & $\mathbf{7 8 2 . 0 0 0}$ \\
\hline
\end{tabular}

Fuente: AMAE. AR. Sig. R-2066-2. (Todas las cantidades en marcos)

Los suministros españoles para compensar los pedidos de material aeronáutico del Convenio, en cumplimiento del Acuerdo de restitución de metales no férricos ${ }^{42}$ se establecieron en 70 toneladas de wolframio, 20 de vanadio, 500 de plomo y unas 5.000 de blenda de zinc, cuyo valor estaba estimado en unos 10.000.000 de marcos. El acuerdo fue firmado en Berlín el 21 de julio de 1942 por el entonces coronel Vicente Roa Miranda ${ }^{43}$ y el general Erhard Milch ${ }^{44}$.

Cuando se firmaba este acuerdo, a mediados de 1943, se había estructurado completamente el primer plan industrial aeronáutico. Como afirma Jesús Salas ${ }^{45}$ :

\footnotetext{
${ }^{42}$ Los países compradores de mercancías germanas que incorporasen en su proceso productivo ciertos minerales, estaban obligados a restituir a Alemania una cantidad concreta de estos minerales antes de la entrega de la citada mercancía e independientemente de su precio. Lo habitual era que la cantidad a entregar estuviera en función a la utilizada en su fabricación, aunque había excepciones. Todos los contratos de "Suministros especiales" firmados entre los ministerios militares y las empresas alemanas contemplaban una cláusula de estas características, aunque su aplicación efectiva se regularía en el Acuerdo Comercial de diciembre de 1942. García Pérez, Rafael. Franquismo y Tercer Reich, op. cit., pág. 281.

${ }^{43}$ Vicente Roa Miranda era coronel del Cuerpo de Ingenieros Aeronáuticos del Ejército del Aire. Había sido nombrado Director General de Industria y Material del Ministerio del Aire y a la vez ejercía como presidente de la Junta Económica Central de dicha Dirección General. Pocos meses más tarde ascendería al empleo de general de brigada, siendo confirmado en su cargo.

${ }^{44}$ Resultado de las conferencias entre la Comisión del Ministerio del Aire español (coronel Roa y teniente coronel Núñez) y el R. D. L. U Ob. D. L. (Generalmajor v Gablenz. Min. Dirigent Müller, Generalmajor Krahmer) el 9 y 18 de julio de 1942. AHEA. A-2792.

${ }^{45}$ Salas Larrazábal, Jesús. De la tela al titanio, op. cit., pag. 156.
} 
“...El plan era ambicioso y bien pensado. Tenía por objeto dar de baja al numeroso y heterogéneo parque aéreo de la postguerra (...) y sustituirlo por un modelo puntero de cada especialidad. De ahí la contratación de 200 Messerschmitt Me 109 G de caza, 200 Heinkel He 111 de bombardeo, 100 Junkers Ju 52 de transporte y 175 avionetas Bücker (75 en 1938, 50 en 1940 y 50 en julio de 1943)..."

Es cierto. En los años previos - concretamente a finales de 1941- se había firmado un contrato con "CASA" para fabricar una serie de 200 bimotores Heinkel He 111, que anulaba el pedido realizado en 1938 -en plena guerra civil- por 36 aviones de este tipo, y otra serie de 100 trimotores de transporte Junkers Ju 52. La contratación de la serie de cazas Messerschmitt Me 109 a "La Hispano-Suiza" estaba a la espera de comprobaciones para la motorización del mismo, que serían llevadas a cabo en $1943^{46}$.

Analicemos, pues, el desarrollo de cada uno de los tipos de aeronave que se adquirieron en Alemania y/o se fabricaron en España merced a los citados acuerdos llevados a cabo entre el recién creado Ministerio del Aire hispano y el Tercer Reich, en los que tuvieron un papel fundamental, tanto la industria aeronáutica germana como las empresas aeronáuticas españolas, que intentaban alcanzar una posición preminente en el mercado tras el final del conflicto civil español.

\section{I.1.1- Los veleros}

Como acabamos de ver, en el Rahmenverträge de julio de 1942 se contemplaba la adquisición por parte española de aparatos de vuelo sin motor, denominados en el argot aeronáutico "veleros". Ya en abril, el general jefe del Estado Mayor del Aire había gestionado en Berlín, vía Agregado Aeronáutico, la adquisición de seis veleros de doble mando Kranich II, pedido que sería ampliado $^{47}$ el 19 de junio de ese mismo año y se concretaría a 20 de estos veleros Kranich II, otros 30 Grunau Baby II B y 10 Weihe, como ya hemos visto que se plasmó en el documento citado anteriormente entre el coronel Roa y el general Milch ${ }^{48}$. La urgencia en la adquisición de este material por parte del Ministerio del Aire venía forzada por la necesidad de disponer de veleros para

\footnotetext{
${ }^{46}$ El motor previsto era el Hispano-Suiza 12Z-89. Las pruebas se celebraron en Barcelona en 1942, supervisadas por el consejero de la empresa, Marcos Birkigt, de su hijo Luis y de los ingenieros Hermann y Chevasier. Se utilizó un Messerschmitt Bf 109 E, superviviente de la guerra (6-119) y piloto Lacour, que realizó los ensayos, alcanzó en dichas pruebas una velocidad máxima superior a la del aparato original. Salas Larrazábal, Jesús. De la tela al titanio, op. cit., pag. 153.

${ }^{47}$ Pedido del Agregado Aéreo en Berlín. AHEA. M-1004.

${ }^{48}$ AHEA. Legajo M-8350.
} 
las Escuelas de Vuelo sin motor en el tiempo que mediara entre la orden de fabricación por la industria española de los tres tipos citados y la disponibilidad de los mismos una vez fabricados. Fue por ello que el Agregado Aeronáutico en Berlín, teniente coronel Pazó, incluyó estas partidas en el contrato de julio de $1942^{49}$.

El Kranich II fue el primer planeador biplaza que se fabricó en serie. Desde los primeros vuelos del prototipo que realizó Hanna Reitsch ${ }^{50}$ en 1937 hasta el final de la Segunda Guerra Mundial, se fabricaron unas 2.500 unidades, la mayoría de ellas en Alemania, aunque también, bajo licencia, en otros países, entre ellos, España. Los veleros Weihe eran igualmente, monocasco de madera, cuya ala, de 18 metros de envergadura, estaba dotada de freno aerodinámico. Eran más propios de pilotos entrenados o profesores de vuelo sin motor. Por otra parte, también se adquirió la licencia para otro planeador más básico: el Schneider DFS 108-14, denominado también Schulgleiter Sg 38, diseñado en 1938 como aparato de iniciación al vuelo sin motor.

La empresa "AISA" fue la encargada de fabricar en España los veleros Schulgleiter Sg 38, Kranich II y los Weihe, de los cuales, al menos, llegó a construir medio centenar del primero $^{51}, 60$ del del segundo ${ }^{52}$ y ocho del tercero ${ }^{53}$.

\footnotetext{
${ }^{49}$ El coste de estos veleros fue el siguiente: los 30 Grunau Baby, 116.068 marcos; los 20 Kranich, 214.780 marcos y los 10 Weiche, 99.100 . marcos. "Concepto $\mathrm{n}^{\mathrm{o}} 2$ 2. Suministros especiales. A/Convenio especial. MDA-RLM”. AMAE. AR. Sig. R-2066-2.

${ }^{50}$ Hanna Reitsch fue una de las más importantes mujeres piloto de todos los tiempos. Actuó como probadora de la mayoría de los veleros del DFS (Deutsches Forschungsanstalt für Segelflug) y su fama y valor le hizo acreedora de la Cruz de Hierro de $2^{\mathrm{a}}$ y $1^{\mathrm{a}}$ clase durante el segundo conflicto mundial. En los últimos días del III Reich acudió al Berlín sitiado por los soviéticos acompañando al general de aviación Robert Ritter von Greim, pudiendo salir de las ruinas de la capital alemana pilotando una avioneta Fieseler Fi 152 "Storch". Reitsch, Hanna. Volar fue mi vida. Memorias de la piloto de pruebas de la Luftwaffe. Niseos, Buenos Aires, 2008, págs. 234-245.

${ }^{51}$ VV.AA. Aviones militares españoles. Ministerio de Defensa. Secretaría General Técnica, Madrid, 1986, pag. 387.

${ }^{52}$ Eran aeronaves biplazas, de fabricación monocasco en madera, con ala media y tren lanzable, que pesaba $185 \mathrm{~kg}$ en vacío. Estos veleros estuvieron destinados a las escuelas de vuelo sin motor. $\mathrm{Su}$ matrícula civil era EC 2-1, EC 2-2 etc.... Salas Larrazábal, Jesús. De la tela al titanio. op. cit., págs. 161 y 162.

${ }^{53}$ Según Salas Larrazábal, sólo se construyeron ocho ejemplares, dedicados a profesores y alumnos aventajados de las escuelas de vuelo sin motor. Su matrícula civil era EC 3-0, EC 3-1 etc... Salas Larrazábal, Jesús. De la tela al titanio, op. cit., pag. 162. Pese a ello, las investigaciones de mi buen amigo José Luis González Serrano en cuanto a matrículas de aeronaves españolas, apuntan a que se llegaron a construir once aparatos de este tipo, pues ha localizado matrículas que van desde la EC 3-0 hasta la EC 3-10. La investigación está abierta.
} 
Los Grunau Baby II entraron en servicio en Alemania en 1933 y entrenaron a toda una generación de pilotos, siendo construidos en grandes cantidades entre $1931 \mathrm{y}$ 1945. En España los fabricó el "Taller Experimental n 1", del "INTA", en Jerez de la Frontera, llegando a salir de dicho establecimiento un número próximo a los 90 , continuando la producción hasta principios de los años cincuenta ${ }^{54}$.

Todos los planeadores de los que estamos hablando fueron desarrollados en Alemania por la "D.F.S”. (Deutsches Forschungsanstalt für Segelflug), instituto alemán para la investigación sobre vuelo a vela, del que saldrían excelentes aparatos que fueron empleados con mucho éxito en distintas operaciones aerotransportadas durante la Segunda Guerra Mundial. Los Kranich II fueron fabricados en Alemania por "Karl Schweyer AG”, en Manheim; los Weihe, por “Jacobs-Schweyer” y los Grunau-Baby II y los Schulgleiter Sg 38, por "Edmund Schneider".

\section{I.1.2- Los aviones de escuela}

La decisión de adoptar como avionetas de escuela las Bücker Bu 131 y 133 y las Gotha Go 145 se tomó en el transcurso de la Guerra Civil española. De hecho, el primer contrato para la fabricación de 75 avionetas Bücker y 25 Gotha se firmó en agosto de 1938, aunque las primeras entregas de estos aeroplanos datan de fechas posteriores a abril de $1939^{55}$.

La Bücker Bü 131 "Jungmann” fue una de las avionetas biplanas de escuela de más éxito en los años 30 y 40 del siglo XX. Fue diseñada por el aviador naval Carl Clemens Bücker, quien fundó su propia empresa en Alemania en 1933, y su destino era servir de entrenador elemental en las escuelas a los futuros pilotos militares. A España llegaron con motivo de la sublevación de julio de 1936, recibiendo la Aviación nacional un total de 55 aparatos, los dos primeros en noviembre de 1936, otros 28 en el transcurso de 1937 y los 25 restantes, en $1938^{56}$. Fueron asignadas a la Escuela de

\footnotetext{
${ }^{54}$ En el modelo "II b" además de un morro rediseñado, se añadió un tren de aterrizaje que se lanzaba tras del despegue. Fue ser la versión más popular del velero y uno de los más construidos en Alemania. Salas Larrazábal, Jesús. De la tela al titanio, op. cit., pag. 197.

${ }^{55}$ Salas Larrazábal, Jesús. De la tela al titanio, op. cit., pag. 137.

${ }^{56}$ Las dos primeras, llegadas en noviembre de 1936 las trajo la casa fabricante para probarlas en el conflicto español y eran del modelo A-2, dotadas de un motor Hirth HM 60R de 80 Cv. De las 28 recibidas en 1937 cinco fueron del modelo A-2 y 23 del modelo B, que montaban un motor más potente Hirth 504A-1 de 105 Cv. Las 25 recibidas en 1938 fueron de los modelos B-1 y D-1, dotadas de motor
} 
Pilotos de Tablada (Sevilla), que formó en el transcurso de la guerra unos 350 pilotos elementales de la Aviación nacional.

Entre los meses de mayo y diciembre de 1940 se recibieron otras 40 Bü 131 D-2, dotadas de motor Hirth 504 A-2 que había solicitado la Jefatura del Aire, con lo que se completaron así las 95 solicitadas al constructor alemán durante el conflicto. Y también durante el conflicto, como ya he afirmado antes, se celebró un contrato entre la Aviación Nacional y "CASA" - que había adquirido la licencia de fabricación de estas avionetas a la "Bücker-Flugzeugbau GmbH" germana en 1937-, para fabricar 50 aparatos de este modelo. De hecho, la producción dio comienzo en la factoría de Puntales (Cádiz) a finales de 1939 y los aparatos -de la variante D-2- fueron entregados al Ministerio del Aire entre mayo de 1940 y agosto de $1941^{57}$.

A este primer lote seguiría un segundo, contratado con "CASA" en diciembre de 1940, formado por otros 50 ejemplares que fueron entregados entre abril y diciembre de 1943. En julio de este mismo año, se contrataría un tercer lote, constituido por cincuenta ejemplares más, que causarían alta en el Ejército del Aire entre octubre de 1945 y febrero de 1946. El cuarto lote -que sería ya el último fabricado en España- fue contratado con "CASA" en junio de 1945 y entregado a la Aviación española entre noviembre de 1946 y noviembre de 1947. Esta primera serie de 200 ejemplares, motorizados con los Hirth alemanes de $105 \mathrm{cv}$., fue denominada CASA C-1.131H. ${ }^{58}$

A partir de 1948 se encargaron cinco lotes más de estas $\operatorname{avionetas}^{59}$ y en 1963, otro -que sería el último- de 30 aparatos. Todos ellos, los 330 ejemplares, fueron dotados de un motor fabricado en España por la compañía "Elizalde" -"ENMASA" (Empresa Nacional de Motores de Aviación SA) a partir de 1951- denominado

Hirth HM-504A-2. Estas avionetas se recibieron por mediación de la sociedad ROWAK y del traficante de armas Veltjens. Salas Larrazabal. Jesús y González Serrano, José Luis. "Bücker Bü 131 Jungmann". Enciclopedia de la Aviación Militar española. Quirón Ediciones, Valladolid, 2000, págs. 1.543, 1.544, 1.552 y 1.553 .

${ }^{57}$ La Aviación nacional entregaría a CASA los motores, los aparatos de a bordo y otros elementos cuya fabricación no pudiera realizarse en aquel momento en España. Salas Larrazabal. Jesús y González Serrano, José Luis. “Bücker Bü 131 Jungmann”, op. cit., págs. 1.554, 1.558 y 1.559.

${ }^{58} \mathrm{La}$ "C" correspondía al constructor, en este caso Construcciones Aeronáuticas SA. El primer dígito "1" por el número de motores que llevaba el avión. El segundo grupo de dígitos "131" se refería a la denominación original del avión en su país de origen.

${ }^{59}$ Los dos primeros (1948 y 1950), de 100 ejemplares cada uno, los dos siguiente (1955 y 1959), de 50 ejemplares cada uno. 
"Tigre" ${ }^{60}$. Esta segunda serie de avionetas Bücker fue denominada C-1.131E en España, por la empresa constructora "CASA" España fue el Ala 78 de Granada, en cuyo 781 Escuadrón sirvieron hasta que les llegó la hora de la baja definitiva en el Ejército del Aire ${ }^{62}$.

La Bücker Bü 133 “Jungmeister” fue un desarrollo de la Bü 131 en versión monoplaza, con menor envergadura y longitud y un motor más potente, el Siemens Sh $14 \mathrm{~A}$ de siete cilindros y $160 \mathrm{cv}$ de potencia ${ }^{63}$.

Al igual que las “Jungmann”, las Bücker Bü 133 “Jungmeister” llegaron a España con motivo del conflicto civil de 1936-39, enviando el Tercer Reich un total de 21 aparatos en 1937 con destino a la Escuela de Transformación de la Aviación nacional, con base en El Copero (Sevilla). Por esta escuela pasarían los 350 alumnos elementales formados en España así como los 128 formados en Italia y Alemania ${ }^{64}$. Un total de 16 aparatos sobrevivieron a la guerra y se integraron en el Ejército del Aire en 1939.

En el mismo contrato que ya hemos citado para la "Jungmann", "CASA" fue encargada de fabricar 25 aparatos "Jungmeister" en España, tras haber adquirido la correspondiente licencia en 1937. Hay que decir que los fabricados en España no dispusieron del mismo motor que los importados de Alemania, sino que a estos 25 ejemplares se les dotó de un Hirth HM 506A-1, pese a lo firmado en el contrato. Los ejemplares fabricados en Cádiz no estuvieron listos hasta finales de 1940, siendo

\footnotetext{
${ }^{60}$ Este motor tenía cuatro cilindros en línea y una potencia máxima de $125 \mathrm{Cv}$., y estaba basado en un Walter J-4 de origen checoslovaco. Su denominación oficial era: ENMASA G-IVA. González Serrano, José Luis. “Bücker Bü 131 Jungmann”, op. cit., págs. 1.560-1565.

${ }^{61}$ Una treintena de las avionetas fabricadas en las primeras series, dotadas con motor Hirth, serían remotorizadas con el "Tigre" en los años cincuenta. Salas Larrazabal. Jesús y González Serrano, José Luis. “Bücker Bü 131 Jungmann”, op. cit., págs. 1.560-1565.

${ }^{62}$ La última avioneta Bücker del Ejército del Aire fue dada de baja el 7 de junio de 1988.

${ }^{63} \mathrm{Su}$ presentación pública tuvo lugar en Berlín, con motivo de los Juegos Olímpicos de 1936, y su consagración le llegó un año más tarde, cuando ganó el certámen acrobático de Zurich (Suiza), alcanzando las tres primeras posiciones. Salas Larrazabal, Jesús. "Bücker Bü 133C Jungmeister". Enciclopedia de la Aviación Militar española. Quirón Ediciones, Valladolid, 2000, págs. 1.577.

${ }^{64}$ Salas Larrazabal, Jesús. Bücker Bü 133C Jungmeister, op. cit., págs. 1.578.
} 
entregados al Ejército del Aire hasta junio de 1942, que se recibió el n ${ }^{\circ} 25^{65}$. Se trataba de un entrenador acrobático para Escuelas de Transformación y en España fue denominado como CASA C-1133L ${ }^{66}$.

Por último, las 25 avionetas Gotha Go 145 contratadas también durante la Guerra Civil, fueron fabricadas por "CASA" en Cádiz y Sevilla, y se entregaron al Ejército del Aire entre 1942 y 1943. En España fueron denominadas CASA C-1145L ${ }^{67}$. Se trataba de un entrenador biplaza, dotado de motor de origen alemán Argus AS 10C refrigerado por aire de $240 \mathrm{Cv}$, empleado en las Escuelas de Transformación. Sólo se fabricaron los citados ejemplares y la última de estas Go 145 en servicio en el Ejército del Aire español fue dada de baja en abril de $1953^{68}$.

\section{I.1.3- Los aviones de transporte}

Durante la Guerra Civil, el avión de transporte por excelencia fue el Junkers Ju $52 / 3 \mathrm{~m}$, aportado por Alemania al bando nacional desde los primeros momentos de la lucha. Sus buenas prestaciones, su fiabilidad y sus magníficos servicios durante la contienda, incluso como bombardero, hicieron pensar en él a partir de 1939 como avión estándar de transporte del nuevo Ejército del Aire español. El Junkers Ju 52/3m era el sucesor del Junkers G 24, aunque con mayor superficie alar, y mantenía la típica estructura metálica Junkers, con revestimiento de chapa ondulada. Entró en servicio en 1934 con Lufthansa y su bautismo de fuego lo obtuvo en la guerra del Chaco, que enfrentó a Bolivia contra Perú, encuadrado en la Fuerza Aérea Boliviana.

Al constituirse la Luftwaffe en 1935, ésta adoptó enseguida la versión militar de este avión para ser empleado como bombardero, aunque pronto fue desbancado en esta

\footnotetext{
${ }^{65}$ La última de estas avionetas que sirvió en el Ejército del Aire fue dada de baja el 9 de octubre de 1969. González Serrano, José Luis. “Bücker Bü 133C Jungmeister”, op. cit., págs. 1.579-1.595.

${ }^{66} \mathrm{La}$ "C" correspondía al constructor, en este caso Construcciones Aeronáuticas SA. El primer dígito "1" por el número de motores que llevaba el avión. El segundo grupo de dígitos "133" se refería a la denominación original del avión en su país de origen.

${ }^{67} \mathrm{La}$ "C", como en los casos anteriores, correspondía Construcciones Aeronáuticas. Igualmente, el primer dígito "1" era el número de motores que llevaba el avión. El segundo grupo de dígitos "145" era la denominación original del avión en su país de origen.

${ }^{68}$ Durante la Guerra Civil ya se habían adquirido en Alemania 21 ejemplares de esta avioneta. VV.AA. Aviones militares españoles, op. cit., pag. 250.
} 
misión por otras aeronaves más veloces y preparadas específicamente para este cometido. Pese a ello, al iniciarse la Guerra Civil española, Alemania envió un total de 67 aviones de este modelo, que combatieron durante todo el conflicto, bien en la Legión Cóndor, bien integrados en la Aviación nacional; al finalizar la guerra un total de 60 de estos aparatos habían sido entregados a los españoles. En marzo de 1940 todavía prestaban servicio 24 Junkers $\mathrm{Ju} 52 / 3 \mathrm{~m}^{69}$. A finales de 1941 el Ministerio del Aire español firmaba con la empresa "Construcciones Aeronáuticas SA" un contrato para fabricar en España un centenar de estos trimotores, concretamente la variante $\mathrm{Ju} 52 / 3 \mathrm{~m}$ $\mathrm{G} 7 \mathrm{e}^{70}$.

Sería la factoría de "CASA" en Getafe, tras finalizar las 25 avionetas Gotha Go 145 en febrero de 1942, la que comenzaría la fabricación de estos aparatos. De los suministros que debían haber llegado de Alemania en los primeros momentos, llegaron sólo unos pocos, pues como afirma Salas Larrazábal ${ }^{71}$ :

“...pues a medida que se deterioraba la posición de Alemania respecto a la de sus enemigos en la Segunda Guerra Mundial, las entregas comenzaron a fallar y resultó necesaria la nacionalización sucesiva de primeras materias, fundiciones a base de aluminio y magnesio, piezas forjadas en acero y de los remaches, incluso. Esto exigió una puesta a punto simultánea de procesos de control de materiales, de fabricación de piezas, de soldaduras, tratamientos térmicos y superficiales, etc..., todo ello sin ayuda técnica de la casa licenciataria ni de nadie del exterior."

En efecto, el material contratado con la casa era el recogido en el acuerdo firmado en Berlín el 21 de julio de 1942 por Vicente Roa y el general Milch, que hemos citado anteriormente, y que preveía la entrega de material para fabricar seis aviones completos, además de diverso utillaje, como una prensa para ondular chapa. Lo cierto es que el primero de estos trimotores de fabricación española realizó su primer vuelo el 6 de julio de 1944, llegándose a producir un total de 170 aparatos en los siguientes 10 años, terminando dicha producción en 1954. Fueron en total tres series, la primera, como hemos visto, de 100 ejemplares, contratada en 1942; la segunda, de 30 aviones,

\footnotetext{
${ }^{69}$ VV.AA. Aviones militares españoles, op. cit., págs. 279-282.

${ }^{70}$ Salas Larrazábal, Jesús. De la tela al titanio, op. cit., pag. 152.

${ }^{71}$ Salas Larrazábal, Jesús. De la tela al titanio, op. cit., pag. 157.
} 
contratada a finales de la década; y la tercera, de 40 aparatos, cuyo encargo se recibió en 1952.

Los motores para los Junkers eran los BMW 132, algunos de los cuales fueron adquiridos en Alemania y, tras la guerra, en Francia, de una partida que allí quedó al finalizar el conflicto ${ }^{72}$.

En España estos aviones fueron denominados CASA C- $352^{73}$, y hubo en servicio tres versiones diferentes: la de transporte de carga o de paracaidistas, conocida como CASA C-352A-1; la de transporte de personas, CASA C-352A-3, habilitada con butacas para transportar un total de 14-18 personas; y la de escuela, CASA C-352C.

\section{I.1.4- Los aviones de bombardeo}

El bombardero por excelencia del bando nacional durante la Guerra Civil española fue el bimotor Heinkel He 111, del cual Alemania aportó en el transcurso del conflicto un total de 97 aparatos, destacando dos modelos: en febrero de 1937 se recibían aviones de la versión $\mathrm{B}$, que montaban sendos motores Daimler Benz DB 600C, de $880 \mathrm{cv}$. A partir de marzo de 1938 se recibirían aviones de la versión E, en concreto de las variantes E-1 y E-3, que montaban motores Jumo 211, de $1.000 \mathrm{cv}$ la primera y de $1.100 \mathrm{cv}$ la segunda ${ }^{74}$. Al partir la Legión Cóndor hacia Alemania, en mayo de 1939, quedaron en España 58 Heinkel He 111, 22 aparatos de la versión B y 36 de la $\mathrm{E}^{75}$.

Ya durante el conflicto civil español, mandos de la Aviación Nacional realizaron contactos en Alemania con la casa Heinkel, con la idea de adquirir los derechos de

\footnotetext{
72 En los años cincuenta, la industria nacional fabricaría los denominados ENMASA E.9C. "Beta", que equiparon a los Junkers Ju 52/3m hasta bien entrados los años setenta del siglo XX. El último Junkers español se daría de baja en el Ejército del Aire el 4 de octubre de 1978. Salas Larrazábal, Jesús. De la tela al titanio, op. cit., págs. 165 y 193.

${ }^{73} \mathrm{La}$ "C" era por ser Construcciones Aeronáuticas el fabricante. El primer dígito "3" por el número de motores que llevaba el avión, en este caso, tres. El segundo grupo de dígitos " 52 " se refería a la numeración del tipo de avión en su país de origen, en este caso Ju 52.

${ }^{74}$ Molina Franco, Lucas; Manrique García, José María. Legión Cóndor. La historia olvidada. Quirón Ediciones, Valladolid, 2000, pag. 41.

${ }^{75}$ Salas aporta esta cifra como total de aviones supervivientes en 1940. En mayo de 1939 la Legión Cóndor entregó un total de 45 aviones, 9 del modelo B y 36 del modelo E. En 1939, antes de finalizar la guerra, se habían entregado varios aparatos del modelo B a la Aviación española, con los que se dotaron los grupos 10G25 y 11G25. Ver: VV.AA. Aviones militares españoles, op. cit, pag. 273 y Molina Franco, Lucas; Manrique García, José María. Legión Cóndor. La historia olvidada, op. cit, pag. 29.
} 
fabricación de estos aviones en España. De esta manera, en 1938 el gobierno de Burgos firmó un contrato con la casa "Heinkel" para fabricar 36 aparatos de la variante H-3, por lo que finalizada la guerra se montó una nueva factoría de "CASA" en Tablada (Sevilla).

Debido al tiempo transcurrido entre la adquisición de la licencia y la puesta en marcha de la factoría, cuando se tomó la decisión de fabricación se cambió de parecer en cuanto al modelo a fabricar, pasando a considerarse, entonces, la versión H-16 para lo que se solicitó a Alemania un avión completo de este modelo como muestra de la serie $^{76}$, material para fabricar otros diez más así como planos y utillaje necesario para cambiar la licencia a la H-16. También se solicitaron 60 motores Jumo $211 \mathrm{~F}^{77}$.

La cuestión de la motorización de estos aviones fue uno de los aspectos más complejos a la hora de acometer la producción en serie de los mismos en nuestro país, debido a la lógica de la guerra: el cedente de la patente había sido derrotado en el conflicto y era muy complicado obtener en el mercado internacional una planta propulsora de las mismas características ${ }^{78}$, y España no estaba en condiciones de fabricarla. Este problema se solucionaría a principios de la década siguiente, cuando lo cierto era que los aviones estaban totalmente superados ${ }^{79}$. El último CASA C-2.111 en vuelo fue dado de baja definitiva en el Ejército del Aire el 14 de febrero de $1975^{80}$.

\footnotetext{
${ }^{76}$ Este aparato se recibió en febrero de 1943, llegando al aeródromo de Barajas (Madrid), vía ParísBurdeos. Se trataba del Heinkel He 111 H-16 dotado de motores Jumo 211F-1 con matrícula alemana DAXVU, cuya tripulación la componían el piloto Siegfried Sulzbacher, el radiotelegrafista Günther Schrahm y el mecánico Willy Schmidt. El vuelo fue aprovechado por dos comerciantes alemanes que viajaron en el avión hasta Madrid. AHEA. A-13177.

${ }^{77}$ El valor aproximado del avión de muestra de la serie fue de 500.000 marcos y el del material para fabricar otros diez más, 2.000.000 de marcos. Los planos y utillaje importaron 20.000 marcos. Los 60 motores tenían un coste de 2.628.000 marcos, siendo la partida con un importe mayor de todo el contrato. Datos obtenidos en: "Resultado de las conferencias entre la Comisión del Ministerio del Aire español (coronel Roa y teniente coronel Núñez) y el R. D. L. U Ob. D. L. (Generalmajor v Gablenz. Min. Dirigent Müller, Generalmajor Krahmer) el 9 y 18 de julio de 1942”. AHEA. A-2792. También se puede seguir el desarrollo económico de estas adquisiciones en "Concepto $\mathrm{n}^{\circ}$ 2. Suministros especiales. A/Convenio especial. MDA-RLM”. AMAE. AR. Sig. R-2066-2.

${ }^{78}$ A partir de 1945 se obtuvieron un total de 354 motores Jumo $211 \mathrm{~F}$ y J en Francia, más de la mitad de ellos con averías importantes, fruto de sabotajes al material, procedentes de excedentes de la Segunda Guerra Mundial. Así mismo se importaron de Francia 100 hélices para estos aviones. En 1947, se intentó adquirir en Polonia un lote de 500 motores originales Jumo 211F que habían quedado en Stettin tras el fin de la $2^{\text {a }}$ Guerra Mundial. Tras unas rocambolescas negociaciones - con intermediario sueco incluido-, el asunto salió a relucir en la ONU, y se frustró. Datos facilitados por el investigador aeronáutico José Luis González Serrano y Salas Larrazábal, Jesús. De la tela al titanio, op. cit., pag. 162.

${ }^{79}$ En el Salón Aeronáutico de Farnborough de 1948 se produjeron contactos entre personal de "CASA" y de la Rolls-Royce, para interesarse los españoles en el motor "Merlin", que había propulsado a tantas
} 


\section{I.1.5- Los aviones de caza}

Quizás el mejor avión de caza de la Guerra Civil española fuera el Messerschmitt Bf 109, del que los alemanes enviaron, en total, 139 aparatos. Además de tres prototipos remitidos por la casa fabricante en los últimos meses de 1936, la Legión Cóndor comenzó a disponer de aviones de la serie B en marzo de 1937. Sucesivos envíos con aparatos de las series $\mathrm{B}$ y $\mathrm{E}^{81}$, culminaron con la cifras antes citada, que resultó la más elevada de cuantos aviones fueron enviados por Alemania en el transcurso del conflicto ${ }^{82}$.

A principios de 1939, poco antes de dar comienzo la ofensiva sobre Cataluña, se entregaron a los españoles una decena de aviones Bf 109 B, con los que se organizó una escuadrilla de caza española -la 1-E-6- a las órdenes del capitán Murcia, que combatió hasta el final del conflicto. Al terminar éste, la Legión Cóndor entregó 10 Bf 109B y 21

aeronaves aliadas durante la pasada contienda mundial. En 1951, Londres daba luz verde a la venta a España de dichos motores Roll Royce 500 "Merlin", con lo que a partir de ese momento, los Heinkel 111 españoles pudieron motorizarse con esa nueva planta motriz. Para los Heinkel 111 españoles se adquirieron 300 motores "Merlin", de los cuales 270 motorizaron los 135 aparatos acabados con esta planta motriz. Los 30 restantes sirvieron como repuestos para los aviones en vuelo. Inicialmente estaba previsto que 70 de los He 111 fueran terminados con esta motorización, aunque al final fueron 83, a los que tenemos que sumar otros 52 que habían sido dotados de motor Jumo 211, y que serían modificados por su mal rendimiento. En la tabla siguiente se recogen los avatares de producción de estos 200 aviones.

\begin{tabular}{|l|l|l|l|l|}
\hline He 111 H-16 & Previstos & Entregados & Transformados & Total \\
\hline Motor Jumo 211 & 130 & 117 & -52 & 65 \\
\hline Motor "Merlin" & 70 & $70+13$ & 52 & 135 \\
\hline Total & 200 & 200 & & 200 \\
\hline
\end{tabular}

Fuente: Salas Larrazábal, Jesús. De la tela al titanio, op. cit., pp. 164 y 165.

${ }^{80}$ En total se llegarían a fabricar los 200 ejemplares de Heinkel He $111 \mathrm{H}-16$ previstos en el contrato, que en España se denominó CASA C-2.111. Hubo un total de ocho variantes: bombardeo CASA C-2.111 A y B (La versión de bombardeo dotada de motores Jumo 211 se denominó "A" y la dotada de motores "Merlin" se denominó "B".); reconocimiento CASA C-2.111 C y D (De la misma manera que en la versión anteriormente citada, en la de reconocimiento, los Heinkel dotados de motor Jumo 211 recibieron la denominación "C" y los motorizados con "Merlin", la "D"); escuela CASA C-2.111F y G, y transporte CASA C-2.111E y H, que estuvieron en servicio en el Ejército del Aire hasta los años setenta del siglo XX. La fabricación de los He 111 españoles finalizó en diciembre de 1960. Al igual que hemos visto en los casos anteriores, la "C" correspondía al constructor, Construcciones Aeronáuticas SA. El primer dígito, "2", era el número de motores que llevaba el avión. El segundo grupo de dígitos, "111", se refería a la numeración original del avión en su país de origen: He 111. A partir de 1949 se entregaron al Ejército del Aire 117 aviones dotados de motores Jumo 211F pese a que, como afirma Salas Larrazábal: “...dieron un tiempo medio entre fallos realmente bajo, lo que obligó a utilizar estos aviones con extremadas precauciones...” Salas Larrazábal, Jesús. De la tela al titanio, op. cit., págs. 158 y 159.

${ }^{81}$ Aunque diversos autores han afirmado que se recibieron Bf 109 de las series C y D, no está confirmado tal extremo. Ver: Laureau, Patrick. Condor. The Luftwaffe in Spain. 1936-1939. Hikoki Publications, Ottringham-East Yorkside (Great Britain), 2000, pp. 96,97. Riess, Karl; Ring, Hans. Legion Condor. 1936-1939. Eine illustrierte Dokumentation. Dieter Hoffmann Verlag, Mainz, 1980, pág. 262.

${ }^{82}$ Tras ella, con 97 aparatos, estaban los He 111 y con 93, los Heinkel He 51. Más lejos, con 67 aviones, los Junkers Ju 52 de transporte y bombardeo. Molina Franco, Lucas; Manrique García, José María. Legión Cóndor. La historia olvidada, op. cit., pág. 28. 
Bf 109 E3, con lo que los aparatos de este modelo existentes al finalizar 1939 eran 41: 14 de la variante B y 27 de las versiones E-1 y E-3 $3^{83}$.

A finales de 1942, el Ejército del Aire adquirió la licencia de fabricación del Messerschmitt Bf 109 G, para lo cual contrató con "La Hispano Aviación SA" su fabricación en serie como caza estándar ${ }^{84}$. En octubre de ese año, el Ejército del Aire había enviado a Alemania una comisión a las órdenes del teniente coronel Gonzalo Taboada Sangro, en la que también tomaron parte los capitanes Kindelán y Bonet, para examinar el montaje de los Messerschmitt Bf 109 Ga-2 alemanes "in situ" 85 .

Era importante aquella visita pues iban a ser dos centenares de aviones los fabricados por "La Hispano", para los que una buena parte del material se iba a importar de Alemania -por un montante global de unos 40 millones de pesetas-, aunque debido a los motivos ya citados del curso de la guerra mundial, sólo pudo llegar a España el correspondiente a los primeros 25 aviones de la serie.

Pero el verdadero problema que iba a dilatar todos los plazos de construcción de los Messerschmitt españoles, fue la selección del motor que se iba a emplear en estos aparatos fabricados en nuestro país. Precisamente por este motivo, y por la imposibilidad de la casa "Messerschmitt AG" de llevar a cabo el estudio para acoplar otro motor diferente al que montaba la versión G, el Ministerio del Aire solicitó en 1942 a su homólogo alemán una célula de esta variante, para estudiar la construcción y el acople del motor que, posteriormente, se seleccionaría. El contrato final por el que se iban a encargar esos 200 aviones se firmó el 22 de julio de 1943 con la empresa "Hispano Aviación SA" - cerca de dos años más tarde si tenemos en cuenta la fecha en la que se contrataron los Junkers y los Heinkel-, y la variante a fabricar sería la Ga-2, con motor Hispano HS $8912 Z^{86}$.

En 1944 se recibían de Alemania 25 células $^{87}$ con las que "La Hispano" comenzaría a trabajar. Seis de ellas fueron motorizadas con una planta motriz Hispano-

\footnotetext{
${ }^{83}$ VV.AA. Aviones militares españoles. Op. cit, pag. 305. También en: Molina Franco, Lucas; Manrique García, José María. Legión Cóndor. La historia olvidada, op. cit., pág. 29.

${ }^{84}$ Ese mismo año una comisión de ingenieros de "La Hispano Aviación" visitaron la casa "Messerschmitt AG” en Ausburg para familiarizarse con el modelo que iban a producir. AHEA. A-2764.

${ }^{85}$ La documentación de esta comisión se encuentra en AHEA. A-11035.

${ }^{86}$ Salas Larrazábal, Jesús. De la tela al titanio, op. cit., pág. 160.

${ }^{87}$ Se entiende por célula de un avión al conjunto de fuselaje, empenaje de cola, planos y estabilizadores del mismo. De hecho, la primera de ellas se había negociado en julio de 1942, ascenciendo su coste a
} 
Suiza HS 89 12-Z, un motor-cañón de $1.300 \mathrm{CV}$ que dio origen a la primera versión española del famoso Messerschmitt: el HA-1109JL ${ }^{88}$. El primer prototipo volaría en Tablada el 2 de marzo de $1945^{89}$.

Las deficiencias observadas en este motor en las pruebas realizadas en los prototipos originaron la suspensión de todos los vuelos en 1947. Entonces se decidió sustituir la planta motriz por otra Hispano-Suiza similar en potencia, pero construida por la filial francesa de la compañía: era el motor denominado HS 89 12Z-17 ${ }^{90}$.

137.000 marcos. "Concepto $\mathrm{n}^{\mathrm{o}}$ 2. Suministros especiales. A/Convenio especial. MDA-RLM". AMAE. AR. Sig. R-2066-2.

88 VV.AA. Aviones militares españoles. Op. cit, pág. 382. Como ya hemos comentado en los aviones anteriormente citados, la "HA" correspondía al constructor, Hispano-Aviación. El primer dígito "1" se correspondía con número de motores que llevaba el avión. El segundo grupo de dígitos "109" se refería a la numeración del avión en su país de origen: Me 109.

${ }^{89}$ Salas Larrazábal, Jesús. De la tela al titanio, op. cit., pág. 160.

${ }^{90}$ VV.AA. Aviones militares españoles. Op. cit, pag. 390. En 1952 se iniciaron los trabajos de ajuste de seis de estos motores a otras tantas células (tres de las enviadas por Alemania y otras tres de las construidas ya en España), dando origen al nuevo modelo, ahora denominado HA-1109K1L. El 15 de julio de ese mismo año se firmaba un segundo contrato con "La Hispano" para fabricar otros 100 aviones del mismo modelo, dotados de este motor. Por esas fechas, ya se habían terminado algunos aviones monoplazas, así como dos en configuración biplaza. En 1954, en la oficina de proyectos de "La Hispano Aviación" se realizaron diversos estudios con variopinto armamento para este modelo: ametralladoras CETME y cohetes de $80 \mathrm{~mm}$ (versión HA-1109.K2L); sólo con cohetes de $80 \mathrm{~mm}$ (versión HA1109.K3L); con cañones HS-404 en góndolas (sin denominación, fue pronto desechada); con cañones HS-404 dentro de las alas y cohetes debajo de las mismas (versión HA-1112.K1L). Esta última sería la definitivamente aprobada para este segunda versión española del Messerschmitt Me 109G. Salas Larrazábal, Jesús. De la tela al titanio, op. cit., pág. 199.

Parecía que todos los inconvenientes de la motorización ya se habían solucionado. Pero no era así. En 1954, la oficina de proyectos de "La Hispano Aviación" estudiaba la adaptación del motor Rolls-Royce 500-45 "Merlin" y de la hélice Rotol a un monoplaza desarmado: era el denominado proyecto HA1109M1L, del cual saldrá la última adaptación hispana de los famosos cazas de Messerschmitt. En efecto, con la adquisición en el Reino Unido de 205 motores "Merlin" (172 de ellos empleados en otros tantos aviones y 33, como repuestos) en 1951, se había solucionado el problema de la motorización de los aviones producidos por la industria española en aquellas fechas, en concreto los bombarderos y los cazas estándar del Ejército del Aire. El primer Messerschmitt español que voló con motor británico "Merlin" lo hizo el 29 de diciembre de 1954, más de diez años después de iniciado el proyecto y cuando estaba ya negociado el acuerdo de cooperación y defensa mutua de España con los estados Unidos de Norteamérica, por el que se empezaba a recibir todo tipo de armamento de una generación muy posterior al que se estaba fabricando en España. Pero en cualquier caso, esta unión "contra natura" de la célula alemana y el motor inglés, fue un éxito indiscutible de los ingenieros españoles, forzados por las circunstancias, si se quiere, pero éxito al fin y al cabo. El rediseño del morro del Messerschmitt para recibir el voluminoso motor "Merlin" hizo que, ya en la factoría de Sevilla, se le conociera con el mote de "Buchón", apodo que pasó a la historia de esta curiosa y única aeronave construida en España. La denominación definitiva de este aparato fue la de HA-1112 M1L, y en 1956 se entregaban al Ejército del Aire los dos primeros aviones. Los dos contratos firmados con "La Hispano Aviación" - el primero de 200 aeronaves y el segundo por otras 100 más- fueron refundidos en uno el 30 de octubre de 1956 por el que se encargaban 170 cazas Messerschmitt monoplazas dotados de motor "Merlin", dos biplazas motorizados de la misma forma y otros 35 -ya construidos- dotados de motor Hispano-Suiza. En total fueron 207 aviones los que llegaron a volar. La producción de HA-1112 se prolongó hasta 1961 y el último avión de este modelo que se dio de baja en el Ejército del Aire lo fue en enero de 1966. El resumen final de ambos contratos, podemos decir que fue el siguiente tras la refundición de 1956: del primer 


\section{I.1.6- Los hidroaviones: Heinkel He 114 y Dornier Do 24 T3}

En pleno proceso de negociación del "Programa Bär", el 30 de abril de 1943 se recibía en el Ministerio del Aire una oferta de "Ernst Heinkel Ausfürung GmbH” para adquirir hidroaviones Heinkel He $114^{91}$. Dicha oferta, archivada con el $n^{0} 1063$, estaba basada en un presupuesto de la citada firma $\left(n^{\circ} 1055\right)$ en el que se valoraba la posible venta a España de tres hidroaviones de reconocimiento He 114 A. Sin embargo Madrid no consideró válido este presupuesto, pues las necesidades del Ejército del Aire cuadriplicarían la citada cantidad ofrecida por los alemanes. En cualquier caso, Berlín aceptó la variación al alza y el pedido oficial del Ejército del Aire se materializó el 12 de mayo de ese mismo año, suponiendo la citada adquisición un precio total de 2.376.000 marcos. Se trataba de aparatos usados dotados de una ametralladora MG 17, otra MG 15 y dos lanzabombas de $50 \mathrm{Kg}$. La forma de pago se consideró que debía ser a través del "clearing” hispano-alemán.

El He 114 era un hidroavión biplano de reconocimiento producido en la década de los años treinta en Alemania para sustituir en los buques de la Kriegsmarine a los ya anticuados Heinkel He 60, aunque pronto quedó obsoleto y fue, a su vez, sustituido por los más modernos Arado Ar 196 en esa misión de reconocimiento en los grandes buques de la Marina de Guerra germana.

El representante de "Heinkel" en España, Juan F. Sturm, remitía el 5 de julio de 1943 al jefe de fabricación de la Dirección General de Industria y Material del Ministerio del Aire español un escrito por el que le comunicaba que ya existía la autorización escrita del Ministerio del Aire alemán para la exportación de los 12 hidros y los correspondientes repuestos ${ }^{92}$. A partir de ese momento, todos los aparatos estaban disponibles en la ciudad germana de Rostock, cargados en una treintena de vagones de ferrocarril. La cifra antes expresada aumentó, pues los repuestos importaron 534.000

contrato, se hicieron 35 aparatos monoplazas con motor Hispano-Suiza HS-12Z-17; 133 aparatos monoplazas con motor Rolls-Royce "Merlin"; dos aparatos biplazas con motor HS-12Z-17 (luego modificados a "Merlin") y el resto de lo fabricado, se utilizó como despiece para repuestos. Del segundo contrato de 100 aviones, solo se llegaron a producir 37 monoplazas en versión Rolls-Royce "Merlin" y los 63 restantes fueron anulados y no se fabricaron. Salas Larrazábal, Jesús. De la tela al titanio, op. cit., pág. 200.

${ }^{91}$ Todo lo relacionado con la adquisición de los hidroaviones de reconocimiento Heinkel He 114 A, en AHEA. M-8350/2.

${ }^{92}$ Por esas mismas fechas viajó a Alemania una comisión presidida por el coronel Felipe Lafita Babío, para estudiar algunos tipos de hidros en servicio en la Luftwaffe. Integraban la citada comisión, además de su presidente, los tenientes coroneles Federico Noreña, Pedro Huarte, Luis Servet e Isidoro López de Haro, así como los comandantes Carlos Pombo e Ignacio Ansaldo. AHEA. A-13177. 
marcos y los gastos de embalaje, transporte y montaje y prestación de personal sumó la cifra de $180.000 \operatorname{marcos}^{93}$. El envío se realizó a la estación de Port-Bou en un tren especial y urgente, al ser mercancía para el Ejército, y fue acompañado de un soldado de la Comandancia de Transportes del Parque Aéreo de Swinemunde y un montador especialista de la casa Heinkel.

Los aparatos fueron recibidos en España en octubre de 1943 y su destino inicial fue el denominado 52 Grupo de Hidros, con base en Los Alcázares (Murcia). Sería éste el único hidroavión del Ejército del Aire que iría embarcado -en ocasiones- en un buque de la Armada, en concreto, en el crucero de la clase Cervera "Miguel de Cervantes" 94 . En 1951 se trasladaron al 51 Regimiento de Hidros, con base en Pollensa, permaneciendo allí sólo dos años. En 1955 fueron dados de baja.

De la misma manera que ocurriera con la adquisición de los Heinkel He 114 A, aunque con distinto enfoque orgánico y táctico, un año más tarde, en mayo y junio de 1944, varias comisiones del Ejército del Aire acudían a Marsella (Francia) para recoger los primeros ejemplares de Dornier Do 24 T-3, y a realizar allí mismo un cursillo de instrucción de dos semanas para familiarizarse con los aparatos ${ }^{95}$.

La idea de crear un servicio de salvamento de náufragos neutral, para atender a los pilotos de ambos bandos en conflicto que cayeran en las costas españolas caló en los dirigentes de la Luftwaffe germana que accedieron a la venta de una docena de hidroaviones preparados para tal fin.

En efecto, el primero de los hidros amerizó en aguas de la bahía de Palma de Mallorca en mayo de 1944 con el comandante Pombo Somoza a sus mandos, y el último, en el mes de noviembre de ese mismo año. Curiosamente, estos aparatos habían sido construidos en Holanda para la Luftwaffe por la firma neerlandesa Aviolanda,

\footnotetext{
${ }^{93}$ Cartas remitidas por Juan F. Sturm, delegado en España de "Heinkel", al Secretario de la Junta Económica Central y al jefe de fabricación de la Dirección General de Industria y Material del Ministerio del Aire, respectivamente. 2 y 5 de julio de 1943. Ref. Expediente de compras 3289/1. AHEA Exp. M$8350 / 2$.

${ }^{94}$ Iba montado sobre calzos, izado para cualquier operación, por uno de los pescantes-grúa del crucero. Nunca se dispuso de catapulta para lanzarlo. VV.AA. Aviones militares españoles, op. cit., págs.370 y 371.

${ }^{95}$ Toda la documentación sobre estos aparatos figura en Archivo Intermedio del Cuartel General del Ejército del Aire (AICGEA), Caja 256 y Ávila Cruz, Gonzalo, "Historia de los Do 24 en el Ejército del Aire. Revista "Fuerza Aérea" no 60, Año VII, Vol. 6, pág.121.
} 
aunque llevaban -como el resto de aparatos de este modelo asignados a la Luftwaffemotores Bramo Fafnir 323-R de 985 Cv.

Pese que en algunas ocasiones, sobre todo entre historiadores foráneos, se ha escrito $^{96}$ que los Dornier Do $24 \mathrm{~T}$ fueron un regalo del III Reich a la España de Franco para utilizarlos en el salvamento de náufragos alemanes, nada más lejano a la realidad. El 23 de octubre de 1944 la Dirección General de Industria y Material del Ministerio del Aire hacía una "Propuesta de Adquisición"97 de 12 hidroaviones "Do 24", con importe aproximado de $10.800 .000 \operatorname{marcos}^{98}$ con cargo a la Agrupación $6^{\mathrm{a}}$, Concepto $1^{\mathrm{o}}$, Presupuesto Extraordinario. La mayoría de los hidros estaba ya en España, pero la tramitación legal de la adquisición y el pago, seguía sus trámites. En efecto, en un documento posterior, fechado en Madrid el 14 de diciembre de 1944, la Junta Económica Central de la Dirección General de Industria y Material abría el expediente de compra $n^{\circ} 4403 / 1$ al proveedor exterior "Dornier Werke A.G"., para adquirir 12 hidroaviones tipo Do-24, a 900.000 marcos por unidad ${ }^{99}$.

Pese a todo, lo que sí es cierto que en la compra de estos aparatos se cometieron varias irregularidades administrativas. Por un lado, cuando se empezó a mover el asunto de la adquisición, casi todos los aparatos estaban ya en España, a donde llegaron en vuelo. Por ello, no hizo ya falta solicitar el correspondiente permiso de importación y además, como se puede leer en el informe elevado al Consejo de Ministros por el titular del Aire, general D. Juan Vigón Suerodíaz, no se presentó el preceptivo informe del Instituto Español de Moneda Extranjera que autorizara el gasto, adjuntando sólo el certificado de existencia de crédito y el informe del Interventor General de la Administración del Estado y la propuesta del propio ministro ${ }^{100}$.

\footnotetext{
96 "Spring 1944 the German government offered 13 Do-24T-3's (of which one was for spare parts) for free to Spain for the use of rescuing people from the western Mediterranean." http://www.dornier24.com/

${ }^{97}$ Propuesta de adquisición. Ministerio del Aire. Dirección General de Industria y Material. Sección: Material de Vuelo. Referencia 2113. Acta n 10. AICGEA. Caja n 256.

${ }^{98} \mathrm{Al}$ cambio, esta adquisición supuso un desembolso de 46.872 .000 pesetas de la época, que hubo que ingresar en el "clearing” hispano-alemán, como ocurría habitualmente en las relaciones económicas entre ambos países.

${ }^{99}$ Pedido a Dornier Werke A.G. valorado. Expediente de compra no 4403/1 AICGEA. Caja n ${ }^{\text {o }} 256$.

${ }^{100}$ Dirección General de Industria y Material. Junta Económica Central. Escrito proponiendo a SE el Ministro del Aire someter a aprobación del Consejo de Ministros el expediente $n^{\circ}$ 4.403/1 (44) instruido para contratar con la casa "Dornier Werke" el suministro de 12 hidroaviones por un importe de 46.872.000 pesetas. AICGEA. Caja nº 256.
} 
Estos hidroaviones incluían unos aparatos sumamente sofisticados, debido a la misión que tenían encomendada, entre los cuales había varios equipos de radio, un identificador amigo-enemigo ( $I F F$ en transcripción anglosajona), un equipo de aterrizaje sin visibilidad, otro de radioayudas, un radioaltímetro y un radiocompás. En España fueron destinados a la Comisión de Salvamento de Náufragos, y más tarde, tras ser revisados y reparados, algunos de ellos al SAR (Servicio Aéreo de Rescate).

A mediados de noviembre de 1944 los doce Dornier estaban ya en Pollensa ${ }^{101}, \mathrm{y}$ un mes más tarde pasaban al recién creado 53 Grupo de reconocimiento lejano del 51 Regimiento de $\operatorname{Hidros}^{102}$.

\section{I.1.7- Los aviones de enlace}

En julio de 1943 la Dirección General de Industria y Material realizó una propuesta de adquisición de 20 avionetas Fieseler Fi 156 C-3 "Storch" en Alemania, suponiendo dicha adquisición un montante total de 1.678.000 marcos ${ }^{103}$. Estas avionetas ya eran conocidas para los aviadores españoles, pues las había empleado la Legión Cóndor, dejando cuatro de ellas en España al finalizar el conflicto.

Se trataba de un monoplano triplaza de ala alta, capaz de volar a $50 \mathrm{~km} / \mathrm{h}$ y aterrizar a tan sólo $40 \mathrm{~km} / \mathrm{h}$, gracias a unos dispositivos "hipersustentadores"104. La cabina estaba totalmente acristalada, y estaba propulsado por un motor Argus As 10C de $240 \mathrm{cv}$. Se empleó con profusión en misiones de enlace, transporte de mandos militares e, incluso, para corregir el tiro de artillería, haciéndose mundialmente famosa en la operación militar que liberó al Duce Benito Mussolini, cuando estaba prisionero

\footnotetext{
${ }^{101}$ Los cinco primeros aviones llegaron en vuelo desde Marsella entre mayo y agosto de 1944. El resto, lo hicieron desde la ciudad de Friedrichhaven, vía Innsbruck y Génova. Es muy curioso y debemos constatar que uno de los Dornier -el que llegó a Pollensa el día 16 de noviembre a las nueve de la mañana-, llevaba 60 kilos de planos y documentos de Rheinmetall con destino al Consejo Ordenador de Construcciones Navales Militares. Según el Agregado Naval en Berlín, capitán de fragata Espinosa, quedaban todavía en la Embajada más de 100 kilos de planos y documentos de la misma casa en espera de ocasión para enviarse a España. Debían de ser planos de los cañones de 3,7 cm en montaje sencillo, cuya licencia de fabricación y patente fue adquirida por la Armada a la casa Rheinmetall. Archivo privado familia Espinosa (APFE). Embajada en España en Berlín. Agregado Naval. Telegrama transmitido no 878 de 17 de noviembre de 1944, dirigido al Almirante Jefe de Estado Mayor de la Armada.

${ }^{102}$ Los cuatro últimos ejemplares en servicio fueron dados de baja en 1969, veinticinco años después de su llegada. VV.AA. Aviones militares españoles, op. cit, págs. 378 y 379.

${ }^{103}$ Carta del delegado para España del Consorcio de Industrias Aeronáúticas de Alemania -Erich Gäbeltal Secretario de la Junta Económica de la Dirección General de Material del Ministerio del Aire, con fecha 28 de septiembre de 1943. Lo cierto es que los aviones completos tenían un precio de 70.800 marcos cada uno. Las piezas de repuesto costaron un total de 210.000 marcos y el transporte de los aviones hasta España, desde la factoría de Kasel, 52.000 marcos. AICGEA. Caja n ${ }^{\circ} 254$.
}

${ }^{104}$ VV.AA. Aviones militares españoles, op. cit., pág. 241. 
en el Gran Sasso después de su deposición por el mariscal Badoglio. Los paracaidistas alemanes lo liberaron y Otto Skorzeny, junto al piloto y al propio Mussolini, despegaron en una Fieseler Fi 156 "Storch" rumbo a la libertad ${ }^{105}$.

El pedido de estas 20 avionetas se materializó y el pago se debió de realizar de la misma manera que se hacían entonces todos los pagos: ingresando el contravalor en pesetas a la ROWAK, antes de su entrega, mediante la cuenta de "clearing" hispanoalemán. De los 20 aparatos contratados sólo se llegaron a recibir 19, llegando el primero de ellos en enero de 1944 y el décimo noveno, en agosto. Como ocurrió con otro material, el cierre de la frontera francesa tras la invasión aliada fue determinante en los transportes.

\section{I.1.8- Los Heinkel He 111 meteorológicos}

En la primera mitad de la década de los años cuarenta del siglo XX, la unidad más enigmática del Ejército del Aire español fue la denominada "Escuadrilla de Sondeos Meteorológicos", cuyos aviones -tres Heinkel He $111 \mathrm{~J}-1$ - estaban adscritos a la Dirección General de Protección al Vuelo del Servicio Meteorológico Nacional. Se llegó a especular que esta unidad realizaba actividades clandestinas de reconocimiento al servicio de la Luftwaffe germana, ya que el personal de dotación de los aviones era alemán -exceptuando el piloto-y la apariencia de los aparatos era totalmente civil, un inmejorable sistema de camuflaje para operar sin exponerse a un ataque de aviones aliados.

Debemos remontarnos a comienzos de 1939, a punto de finalizar la guerra civil española, para constatar la llegada a España -integrados en la compañía HISMA Ltda. ${ }^{106}$, de tres aparatos Heinkel He 111 de la variante J-1, a los que se bautizó "Sevilla", "Madrid" y "Barcelona"107. Finalizada la contienda, estos aviones no fueron transferidos a la compañía "Iberia", como ocurriría con los Junkers Ju 52/3m de HISMA Ltda, sino que fueron entregados al Servicio Meteorológico Nacional, organismo dependiente del recién creado Ministerio del Aire.

\footnotetext{
${ }^{105}$ Hay numerosos textos que recogen este hecho de armas, aunque nosotros nos inclinamos por la narración de: González López, Óscar. Fallschirmajäger sobre el Gran Sasso. AF Editores, Valladolid, 2007, págs. 41 y ss.

${ }^{106}$ Dicha compañía asistió a los sublevados a la hora de importar de Alemania material de toda clase durante el conflicto civil. Su representante y gerente fue Johannes Eberhardt Bernhardt. Para mayor información sobre esta compañía y sus funciones durante la Guerra Civil española ver Molina Franco, Lucas. El legado de Sigfrido, op. cit., págs.38 y ss.

${ }^{107}$ Sus números de fabricación eran: 5.162, 5.192 y 5.199 y sus matrículas 25-100; 25-101 y 25-102.
} 
Afirman Arráez y Sales sobre la escuadrilla en la que fueron integrados estos aviones ${ }^{108}$ :

“...El Ministerio del Aire asignó administrativamente los Heinkel He 111 J1 (Sic) a la Dirección General de Protección al Vuelo... o habría que decir "Wetterflugstelle Madrid", tal y como aparece en algunos documentos de la Luftwaffe conservados en el Archivo de Koblenz. Si vital era mantener en activo las misiones de reconocimiento, no lo era menos la recogida de datos atmosféricos, batallando en el "Frente Meteorológico" con un constante rastreo del cielo. Una información que las tres armas alemanas sabían apreciar sobremanera..."

El 2 de agosto de 1944 la Dirección General de Industria y Material del Ministerio del Aire realizaba propuesta de adquisición de estos aviones por un precio total de 202.593 pesetas con cargo a la Agrupación 6 ${ }^{\mathrm{a}}$, concepto $1^{\mathrm{o}}$ del Presupuesto Extraordinario de dicho año. Curiosamente ocho meses antes de esta propuesta, el 29 de diciembre de 1943, la Luftwaffe entregaba al Ministerio del Aire español tres Heinkel He 111 nuevos -en este caso de la variante $\mathrm{H}$ - equipados convenientemente para misiones meteorológicas, uniéndose al trío existente de la variante J-1. El día 20 de ese mismo mes, es decir, un semana antes de su llegada, el agregado aéreo alemán en Madrid remitía una carta al general Vigón, ministro del Aire, en la que le decía que las tres aeronaves eran un regalo del Mariscal Hermann Göring a España ${ }^{109}$.

No deja de ser sorprendente que Alemania -en la persona de su ministro del Aire- regalara a España tres excelentes aviones Heinkel He $111 \mathrm{H}^{110}$ en las mismas fechas en que estaba llegando a España la mayor cantidad de material bélico del "Programa Bär", un programa que contemplaba la venta de material militar a España a precios considerablemente elevados, y en el que se negó expresamente la adquisición de estos mismos aviones por parte de los negociadores germanos al considerar éstos que

\footnotetext{
${ }^{108}$ Para analizar este asunto, ver: Arráez Cerdá, J. y Sales Lluch, J.M. "Una unidad muy especial: la Escuadrilla de Sondeos Meteorológicos”. Revista Española de Historia Militar no 3, (mayo -2000), págs. 175-179.

${ }^{109}$ Carta del general Krahmer al ministro del Aire, general Juan Vigón Suerodíaz de 20 de diciembre de 1943. El texto completo de dicha carta reza así: "Mi general: Tengo el gran placer de poder comunicarle que con motivo de mi reciente visita en el Cuartel General ha sido resuelto ofrecer como obsequio al Ministerio del Aire español los tres aviones Heinkel 111 cuya adquisición fue deseada por la Dirección General de Protección de Vuelo de su Ministerio. Por la presente tengo el honor de entregarle los aviones en nombre del Sr. Ministro del Aire del Reich. Me reitero de Va. Excelencia con la expresión de mi consideración más distinguida. E.R. Krahmer. General de División”. AHEA Leg. A-13061.

${ }^{110}$ No se conoce con certeza la variante exacta de estos aparatos, aunque los autores del artículo citado se inclinan por la H-6. Sus matrículas fueron 25-103, 25-104 y 25-105.
} 
toda la producción de las fábricas teutonas era necesaria para la fuerza aérea del Tercer Reich en África ${ }^{111}$.

Estos aviones venían con una gran cantidad de equipos sofisticados, entre los que podemos citar: dos transmisores Telefunken y uno Lorenz; seis emisoras FüG X; seis receptores, tres receptores Telefunken, dos generadores eléctricos; seis goniómetros y seis aparatos de búsqueda.

Curiosamente, en 1946 se produjo una reclamación al Estado Español de material alemán que estaba en España sin haber sido legalmente adquirido a aquel país. Los representantes en España de la Comisión Aliada de Control para Alemania, solicitaron en diversas notas remitidas en octubre de 1946 la entrega de diverso material propiedad del antiguo gobierno alemán -el del Tercer Reich-, entre los que se hallaban:

"Tres Heinkel He 111 que se encuentran en el aeropuerto de Barajas, traídos a España por cuenta del Ministerio del Aire y que se utilizan, al parecer, con fines meteorológicos."112

Los aviones regalados por Goering no figuraban en ningún documento de compra, no se podía justificar su adquisición por lo que hubo que improvisar. El Director General de Protección de Vuelo, Luis de Azcárraga, remitió un documento al general Subsecretario del Ministerio del Aire en el que justificaba la presencia de los $\mathrm{He}$ 111 meteorológicos en España como adquisición enmarcada en el "Programa Bär"113:

“...en sustitución de los aviones Ju 87 y Messerschmitt, no recibidos" $" 114$ (Sic)

Además, para salvar la inexistencia de facturas de los mismos, decía:

“...En el escrito anteriormente citado, se disponía igualmente que, por tratarse de un acuerdo de carácter reservado entre ambos gobiernos, para la formalización de dichos pagos se sustituirían las facturas por un certificado del Director de Industria y Material que comprendiese las cantidades globales sin especificar materiales".

No tenía más sentido que justificar que los aviones no eran de la Luftwaffe, sino del Estado español. Justificaban también que debido a la escasez en España de personal

\footnotetext{
${ }^{111}$ Ver Capítulo V, epígrafe: "La reunión de Martínez Campos del 11 de mayo".

${ }^{112}$ Memorandum $\mathrm{n}^{\circ} 161$ de los Representantes en España del Consejo Aliado de Control para Alemania. 31 de marzo de 1947. AHEA. A-70/39.

${ }^{113}$ Ministerio de Aire. Dirección General de Protección de Vuelo. Escrito n ${ }^{\circ} 6280$. AHEA. A-70/39.

${ }^{114}$ Jamás se habló en el "Programa Bär" de la adquisición de Junkers Ju 87 "Stuka". Si bien uno de los Bf 109 F-4 del Programa Bär no se recibió por accidente del mismo en el viaje de incorporación a España desde la base francesa de Villacoubley.
} 
técnico especializado, esos aviones fueron utilizados por un equipo mixto de personal español y alemán, y fue al prescindir de este personal alemán en este servicio, cuando se realizó la entrega plena del material a la Aviación española.

\section{I.1.9- Los aviones internados}

Durante el transcurso de la Segunda Guerra Mundial fueron muchos los aviones de ambos contendientes que, por diferentes motivos, tuvieron que tomar tierra en suelo español. Al ser España un país neutral $-\mathrm{o}$ no beligerante en algunos estadios del conflicto-, el Derecho Internacional obligaba a internar esos aparatos y a sus tripulaciones, ocurriendo así en la mayoría de las ocasiones.

Por lo que hace a material aeronáutico alemán internado en el transcurso del conflicto mundial, hemos de decir que quedaron en territorio español 42 aeronaves, de las que 28 eran Junkers Ju 88 de diferentes variantes; cuatro, Focke Wulf Fw 200 “Cóndor”; seis, Heinkel He 111, dos, Messerschmitt Bf 109; uno, Junkers Ju 290 y por último, un hidroavión Blohn und Vöss Bv 138.

El Ministerio del Aire español adquirió la totalidad de los 28 aparatos Junkers Ju 88 que aterrizaron en España hasta febrero de 1944, mes en el que se firmaría el contrato de compra de los mismos entre el citado ministerio y la casa fabricante alemana "Junkers Flugzeug und Motorenwerke $A G$ " 115. Tan sólo 13 de los 28 aparatos se pondrían en condiciones de vuelo, utilizando cinco de las células restantes para instrucción de vuelo y el resto, como fuente de repuestos para estos aparatos. Al menos fueron seis las variantes de Junkers $\mathrm{Ju} 88$ que aterrizaron en suelo español y se adquirieron a Alemania, a saber: Ju 88 D-1Trop; Ju 88 A-4Trop; Ju 88 A-14; Ju 88 D5Trop; Ju 88 D-1 ${ }^{116}$ y Ju 88 C-6.

El contrato firmado obligaba a la casa Junkers a reparar los aviones una vez trasladados a la Maestranza aérea facilitada por el Ministerio del Aire español, suministrando todo lo necesario para realizar dichas reparaciones, así como a preparar a

\footnotetext{
115 Para mayor información sobre estos aviones, son de obligada lectura los trabajos de: González Serrano, J.L. "Notas sobre el 13 Regimiento y los Ju-88". Revista Aeroplano no 14 (1996), pp. 4 a 10, y VV.AA. "Spanish Schnellbomber. Ju 88s with Spanish Air Force", Revista Flypast no 182, Sept. 1996, págs. 35-37.

${ }^{116}$ Fue el primero en tomar tierra en suelo español. Lo hizo en Melilla, en la Mar Chica, el 11 de octubre de 1942, sufriendo graves averías. Su indicativo alemán era F6+KK; su número de serie, 430.319 y pertenecía al 2.(F)/Aufklarungsgruppe 122. González Serrano, J.L. "Notas sobre el 13 Regimiento y los Ju-88”. Revista Aeroplano no 14 (1996), pág. 5.
} 
los técnicos españoles en estos aparatos para que pudieran realizar todas las tareas por sí mismos en el futuro.

En el aspecto económico se fijó un precio base para estos aviones, 500.000 marcos, que se reduciría proporcionalmente a las horas de vuelo realizadas por el material. De esta cantidad, 412.400 marcos correspondían a la célula y 43.800 a cada uno de los dos motores. El pago de los aviones, que se iría realizando a medida que se fueran recibiendo "en vuelo" los aviones, se haría por la cuenta de "clearing" hispanoalemán, "de la forma acostumbrada." Estos 13 Junkers Ju 88 internados se unirían a los diez aviones de este mismo modelo adquiridos en el seno del "Programa Bär", y se integrarían en el 13 Regimiento de Bombardeo, con base en Albacete, sustituyendo a los vetustos SB "Katiuska" soviéticos, procedentes de los capturados a la Aviación republicana al final del conflicto civil. Los Junkers Ju 88 sirvieron en esta misma unidad del Ejército del Aire hasta mediados de los años cincuenta, cuando fueron dados de baja y reemplazados por los Heinkel He 111 fabricados por CASA.

Por lo que se refiere a los Focke Wulf Fw 200 “Cóndor" internados, tres de ellos eran de la variante C-4 y sus números de fabricación eran 118, 166 y 175. El cuarto pertenecía a la variante C-7 y su número de fabricación era el 221. El 118 y el 175 aterrizaron en el aeródromo de Tablada (Sevilla) el 31 de diciembre de 1942, presumiblemente por falta de combustible. Los otros dos, en peores condiciones, tomaron tierra en Galicia en agosto de $1943^{117}$. El 10 de abril de 1944, el ministro del Aire comunicaba al de Exteriores, Conde de Jordana, que el Agregado aéreo alemán en España había sugerido que su gobierno estaría dispuesto a ceder a la compañía Iberia los tres "Cóndor" en mejor estado ( $\mathrm{n}^{\mathrm{o}} 118,166$ y 175), siempre que fueran empleados en un servicio a establecer entre Lisboa y Berlín ${ }^{118}$. Lo cierto fue que entre diciembre de 1944 y enero de 1945 una misión de la casa Focke Wulf intentó poner los tres aparatos en condiciones de vuelo.

\footnotetext{
${ }^{117}$ Los otros dos aviones de este modelo realizaron aterrizajes de emergencia en España bastante dañados: el 13 de agosto de 1942, tras un combate con aviones aliados en la zona de Finisterre, el "Cóndor" n' 221 tuvo que realizar una toma de emergencia en Camariñas (La Coruña). Dos días más tarde, el 15 de agosto de 1943, otro "Cóndor" -en este caso el n n 166- fue alcanzado por la antiaérea del buque británico "HMS Stork", debiendo aterrizar de emergencia en el aeropuerto de Labacolla (Santiago de Compostela- La Coruña), siendo internado. Salgado Rodríguez, Juan Carlos. Focke Wulf 200 Condor. Perfiles aeronáuticos I, Quirón Ediciones, Valladolid, 2002, págs. 196-206.

${ }^{118}$ Carta confidencial del ministro del Aire al de Asuntos Exteriores fechada en Madrid el 10 de abril de 1944. AHEA Leg. A. 13099.
} 
El n 175 fue entregado a Iberia el 12 de enero de 1945 como compensación del Junkers Ju 52/3m de la compañía que resultó destruido en Stuttgart por un bombardeo aliado el 5 de septiembre anterior, cuando realizaba vuelos charter para Lufthansa. Dicho aparato sería entregado al Ejército del Aire por la compañía Iberia, al no ser rentable su transformación en avión comercial. El otro aparato lo adquirió el Ejército del Aire al ciudadano Erich Gabelt en diciembre de $1944^{119}$. Sólo uno de ellos -el 175llegó a volar luciendo las escarapelas del Ejército del Aire español el 27 de agosto de 1947.

La Comisión Aliada de Control para Alemania reclamó en 1946 el pago de dos "Cóndor" que según sus noticias pertenecían a la Luftwaffe: el de Sevilla, que se había adquirido a Gabelt, y el de Santiago de Compostela. Al final se demostró que sólo uno, el que permanecía en la capital gallega sin sus motores, era, en efecto, del arma aérea alemana, por lo que hubo que pagar al citado organismo de Control la suma de 50.000 pesetas, 30.000 por los restos del aparato y 5.000 por cada uno de los cuatro motores. Pero esto ocurrió ya en $1951^{120}$.

Por lo que respecta a los bombarderos Heinkel He 111, un total de seis quedaron en España -en mejor o peor estado- en el transcurso de la Guerra Mundial. Un Heinkel He 111 H-11To (torpedero) tomó tierra el 20 de mayo de 1943 en el aeródromo de Son San Juan (Mallorca-Baleares), quedando internado en España. Dicho aparato fue adquirido por el Ejército del Aire, que lo puso en servicio, sustituyendo a uno de los tres meteorológicos regalados por el Mariscal del Aire alemán Hermann Goering, que tuvo un grave accidente y no volvió a volar. A la postre sería el único de los seis aparatos que se pondría en estado de vuelo y se integraría en el Ejército del Aire.

Cuatro aviones de este modelo cayeron en territorio español en diferentes fechas y sus restos fueron internados, aunque su mal estado hizo que nunca más pudieran volar $^{121}$. Aún así, la Comisión Aliada de Control reclamó 90.000 pesetas por tres de los

\footnotetext{
${ }^{119}$ Se pagó la suma de $1.984 .550,00$ pesetas. AHEA. A-70/39.

120 Ministerio de Asuntos Exteriores. Política Económica. Comisión de Expropiación de Bienes Extranjeros. Ref. A-7201 No 24. Documento remitido al Secretario General del Ministerio del Aire, fechado el 6 de febrero de 1951. AHEA. A-70/39.

${ }^{121}$ Los restos de los cuatro aparatos fueron a parar a la Maestranza de Logroño, donde se encontraban en 1946. Se trataba de los aviones matriculados IH-CK, caído en San Javier; IH-LH, caído en Egea de los Caballeros; TQ-MU, caído en San Sebastián -en el que llegó a España el general de la Waffen SS y líder del movimiento Rexista belga, León Degrelle- y el IH-CN, del que no constan datos del lugar de aterrizaje. AHEA. A-70/39.
} 
aviones -los que estaban en mejor estado- de las que 60.000 correspondían a los restos de los aparatos y 30.000 a los seis motores (a 5.000 pesetas por motor). Lo que quedaba del cuarto aparato, el que se estrelló en la playa de La Concha (San Sebastián), fue adquirido por 4.000 pesetas.

El último día de la guerra, el 8 de mayo de 1945, un Heinkel He 111 tomó tierra en Reus procedente de Rostock y el gobierno español hizo gestiones con la Comisión de Control Aliado para adquirirlo. Por lo visto, el avión debía llevar a bordo una gran cantidad de accesorios y repuestos que no fueron reclamados por la citada Comisión, algo que sí ocurrió con los restos del avión, por el que se pagaron 4.000 pesetas en $1951^{122}$.

Unicamente dos cazas Messerschmitt Bf 109 serían internados en España a lo largo del conflicto mundial, aviones que serían reclamados en 1946 por la Comisión Aliada de Control para Alemania. Uno de ellos había capotado en Salinas (Mallorca) el 14 de junio de 1943, y se encontraba averiado en el aeródromo de Son Bonet. El otro había aterrizado en La Bañeza (León) y el piloto le prendió fuego. Sus restos, inútiles, fueron llevados a la Maestranza de la capital leonesa, donde se encontraban en 1946. Por el primero se pagarían 3.000 pesetas en 1951, y por los restos del segundo, 600 pesetas. $^{123}$

Un enorme tetramotor Junkers Ju 290 de Lufthansa tomó tierra en el aeródromo del Prat de Llobregat (Barcelona) el 6 de abril de 1945, accidentándose en la citada maniobra debido a la baja visibilidad reinante el dicho campo. El avión pasaría a formar parte del Ejército del Aire tras diversas peripecias con la Comisión Aliada de Control y unos industriales vascos ${ }^{124}$.

Por último, el enorme hidroavión Blohm und Boss Bv 138 C-1 que recogió en pesquero bilbaíno "Reina de los Ángeles" el 24 de septiembre de 1943 al norte de Cabo Machichaco-en pleno Cantábrico- cuando se encontraba a la deriva, y que pasó casi tres años en la Ría de Bilbao, sería entregado a la Comisión Aliada de Control para Alemania el 1 de julio de $1946^{125}$.

\footnotetext{
122 AHEA. A-70/39.

${ }^{123}$ AHEA. A-70/39.

${ }^{124}$ VV.AA. Aviones militares españoles, op. cit., pág. 386.

${ }^{125}$ Para seguir las vicisitudes de este cusioso aparato: : Herrera Alonso, Emilio. "Un hidro Blohn un Voss Bv 133C-1, tres años en la Ría de Bilbao”. Revista Aeroplano no 8 (1996), págs. 100-103.
} 
TABLA I-D

AVIONES ALEMANES INTERNADOS EN ESPAÑA (1939-1945)

\begin{tabular}{|l|l|l|l|}
\hline Tipo de avión & Internados & En servicio en el E.A. & $\begin{array}{l}\text { Adquiridos a la } \\
\text { Comisión de Control }\end{array}$ \\
\hline Junkers Ju 88 & 28 & 13 & - \\
\hline Heinkel He 111 & 6 & 1 & 5 \\
\hline Messerschmitt Bf 109 & 2 & - & 2 \\
\hline Focke Wulf Fw 200 & 4 & 2 (solo 1 llegó a volar) & 1 \\
\hline Junkers Ju 290 & 1 & 1 & - \\
\hline Blohn und Vöss Bv 138 & 1 & - & - \\
\hline Total & $\mathbf{4 2}$ & $\mathbf{1 6}$ & $\mathbf{8}$ \\
\hline
\end{tabular}

Fuente: elaboración propia con los datos anteriormente expuestos.

A finales del año 1944, había en España 17 personas relacionadas con la industria aeronáutica alemana trabajando para el Ejército del Aire, bien en las Maestranzas de Albacete o Logroño, bien en "CASA" (Sevilla, Cádiz y Madrid); tres de ellos eran de la casa "Heinkel"; cinco, de la casa "Junkers"; uno, de las casas "Messerschmitt" y "Daimler-Benz", respectivamente; y siete de la casa "Dornier". A cuatro maestros mecánicos, el Ministerio del Aire español les pagaba una mensualidad de 1.200 pesetas. La relación completa figura en la tabla mostrada a continuación.

\section{TABLA I-E}

\section{PERSONAL ALEMÁN TÉCNICO EN AVIACIÓN EN ESPAÑA (1944)}

\begin{tabular}{|l|l|l|l|l|}
\hline Nombre & Casa & Ciudad & Cargo & Aviones \\
\hline Franz Bockholdt & Heinkel & Madrid & Inspector & He 111 \\
\hline Herbert Seeliger & Heinkel & Sevilla & Ingeniero & He 111 \\
\hline Franz Luebs & Heinkel & Logroño & Maestro mecánico & He 111 \\
\hline Karl von den Eichen & Junkers & Albacete & Ingeniero & Ju 88 \\
\hline Dominik Kosciely & Junkers & Albacete & Maestro mecánico & Ju 88 \\
\hline Kurt Stephan & Junkers & Albacete & Mecánico & Ju 88 \\
\hline Martin Beckert & Junkers & Albacete & Mecánico & Ju 88 \\
\hline Hans Witte & Junkers & Logroño & Maestro mecánico & Jumo 211 \\
\hline Heinrich Stegmeier & Messerschmitt & Logroño & Maestro mecánico & Me 109 \\
\hline
\end{tabular}




\begin{tabular}{|l|l|l|l|l|}
\hline Hans von Thun & Daimler-Benz & Logroño & Maestro mecánico & DB 601 \\
\hline Hans Deyhle & Dornier & Cádiz & Ingeniero & Do 24 \\
\hline Karl Ege & Dornier & Cádiz & Maestro mecánico & Do 24 \\
\hline Paul Schenk & Dornier & Cádiz & Mecánico & Do 24 \\
\hline Herbert Keydel & Dornier & Cádiz & Mecánico & Do 24 \\
\hline Wolfgang Sachse & Dornier & Cádiz & Mecánico & Do 24 \\
\hline Walter Grimm & Dornier & Cádiz & Mecánico & Do 24 \\
\hline Max Wisse & Dornier & Cádiz & Mecánico & Do 24 \\
\hline
\end{tabular}

Fuente: AHEA Leg. A-11033

Juan Yagüe Blanco, en el transcurso de su corta permanencia en el recien creado Ministerio del Aire español, y Juan Vigón Suerodíaz - ambos generales del Ejército de Tierra al frente del organismo superior de la Aviación- fueron los máximos responsables de la política aeronáutica española en la primera mitad de la década de los años 40 del siglo XX. Dicha política, en cuestiones referentes a adquisición de nuevos materiales, tuvo una profunda ligazón a la industria aeronáutica alemana hasta el final de la segunda conflagración mundial. La decisión de articular programas de construcción de aeronaves tomando como modelo la Luftwaffe, cuyo origen estuvo ligado a la ayuda prestada por el III Reich al bando nacional durante el conflicto civil hispano, si bien estaba absolutamente justificada, tanto por la calidad y eficacia de los materiales como por la viabilidad de los proyectos acometidos, estuvo lastrada desde septiembre de 1939 debido al inicio de la Segunda Guerra Mundial y las consecuencias que para uno de los actores principales del conflicto, significaba el tener que abastecer su propia demanda, a todas lucas creciente según avanzaban las operaciones y se involucraban en el mismo países con una capacidad industrial que superaba con creces la germana.

Lo que inicialmente estaba previsto como un apoyo técnico permanente -en materiales, patentes de fabricación, especialistas, etc-, se convirtió por mor del conflicto en un continuo tira y afloja entre la industria nacional y la alemana. Pese a las tremendas dificultades en todos los órdenes que supuso la guerra, la aviación española pudo disponer -en mayor o menor medida- del apoyo de la potente industria aeronáutica alemana, que con las restricciones lógicas debidas al retraso tecnológico de 
nuestro país, marcó las pautas de una flota aérea cuyo diseño tendría repercusión en el material del Ejército del Aire español hasta bien entrada la década de los años sesenta. Solo la firma de los acuerdos con los Estados Unidos de América a mediados de los años cincuenta del siglo XX, varió el sentido de esa política e invirtió los designios que habían previsto Yagüe y su sucesor, Vigón.

\section{I.2 LA MARINA ESPAÑOLA}

La Marina española llegó a firmar un acuerdo marco con la Kriegsmarine en junio de 1940, aunque los términos del mismo nunca llegarían a cumplirse. En la primavera de 1941, la necesidad de adquirir el material solicitado el año anterior hizo que la Armada retomara las negociaciones, llegando en esta ocasión a buen puerto por lo que se firmó un contrato para la cesión de licencias de fabricación de torpedos, así como algunas adquisiciones más, importando el conjunto un montante total de 1,7 millones de marcos, una cifra realmente pequeña si la comparamos con los contratos celebrados más tarde.

Podemos considerar como el punto de partida para las adquisiciones que la Armada española realizaría en Alemania a partir de 1940, un viaje que giró a Alemania el entonces coronel de Ingenieros de la Armada, Juan Antonio Suanzes, junto a un grupo de oficiales navales españoles, viaje en el que la Kriegsmarine, su anfitriona, no tuvo ningún problema en mostrar lo más avanzado de la tecnología naval germana del momento. Tras analizar someramente los trabajos y visitas de los marinos españoles en el III Reich, estudiaremos la adquisición de licencias para construir en España buques de origen germano, analizaremos en profundidad el más importante de los Rahmenverträge de Marina, firmado con el almirantazgo alemán en julio de 1942, así como los negociados con la Kriegsmarine con posterioridad a esta fecha -de menor trascendencia, pues la mayoría quedaron englobados en el programa de armamentos que se negoció a partir de diciembre de 1942-, así como todas las adquisiciones de material naval teutón de origen atípico, o lo que es lo mismo, fuera de los cauces, llamémosle normales o habituales, del comercio de armamento. 


\section{I.2.1- La Comisión "Suanzes" en Alemania ${ }^{126}$}

La visita de la comisión presidida por el entonces director de Construcciones e Industrias Navales Militares, el coronel de Ingenieros de la Armada, Juan Antonio Suanzes Fernández ${ }^{127}$, puede considerarse el verdadero punto de partida de todas las negociaciones de material naval con Alemania durante los complejos años de la Segunda Guerra Mundial. Dicha comisión estuvo compuesta por el propio Suanzes, el capitán de navío Francisco Regalado Rodríguez, el capitán de fragata Pablo Suances Jáudenes, el teniente coronel de Ingenieros de la Armada Luis Santomá Casamor y el teniente coronel del Cuerpo de Artillería de la Armada Manuel Bescós Lasierra.

Tras su llegada a Berlín el 5 de junio de 1940, fueron alojados en el hotel Adlon y después de visitar al embajador español, acudieron al Ministerio de Marina alemán donde fueron recibidos por el entoces jefe de la Kriegsmarine, almirante Erich Raeder, quien les expresó su deseo de apoyar técnica y materialmente a la Marina de guerra española en su labor de reconstrucción, aunque no ocultó que la Kriegsmarine se encontraba sometida a un extraordinario trabajo de creación y de acción debido a la guerra europea. Más tarde se entrevistaron con el vicealmirante Otto Schniewind ${ }^{128}$, jefe de operaciones de la armada germana, y con el contralmirante Leopold Siemens ${ }^{129}$,

\footnotetext{
${ }^{126}$ La documentación sobre esta Comisión se encuentra en el Servicio Histórico del Estado Mayor de la Armada (SHEMA). Madrid, Legajo N.C. Información $\mathrm{n}^{\circ} 33$ de 15 de julio de 1940, remitida por el Agregado Naval español en Berlín sobre la Comisión de la Marina española presidida por D. Juan Antonio Suanzes Fernández.

${ }^{127}$ Juan Antonio Suanzes Fernández nació en Ferrol el 20 de mayo de 1891 y falleció en Madrid el 6 de diciembre de 1977. Marino, ingeniero naval de la Armada, ministro de Industria y Comercio (1938-39) y (1944-51), presidente y fundador del Instituto Nacional de Industria (INI) (1941-63), alcanzó el empleo de general de división del Cuerpo de Ingenieros Navales de la Armada. Ha estudiado todo lo relacionado con esta Comisión: O’Donnell Torroba, César. "Misión en Alemania" Ares Enyalius nº 3, julio-agosto de 2008, págs. 50-54.

${ }^{128}$ Otto Schniewind (14-12-1887- 26-3-1964) ingresó en la Kaiserlichemarine en 1907, sirviendo como comandante de torpederos durante la Primera Guerra Mundial. Siguió sirviendo en la Reichmarine y en 1932 fue destinado a mandar el crucero ligero "Köln". Ascendió a contralmirante en 1937 y a vicealmirante en 1940. Entre 1938 y 1941 fue jefe de estado mayor en el Seekriegsleitung. En 1944 ascendió a almirante. http://en.wikipedia.org/wiki/Otto_Schniewind.

${ }^{129}$ Leopold Siemens (17-5-1889-7-12-1979) ingresó en la marina alemana en 1911 y participó en la Primera Guerra Mundial embarcado en diversos buques de la Kaiserlichemarine. Continuó en la marina tras la guerra, llegando a mandar, en 1935, el crucero "Karlsruhe". Desde 1937 y hasta el inicio de las hostilidades, fue agregado naval alemán en la embajada de Londres. Tras pasar por el OKM, fue nombrado $2^{\circ}$ jefe de la Flota alemana, cargo que ostentó hasta junio de 1941, pasando en esta fecha a mandar la zona costera norte (Noruega) hasta noviembre de 1944. Pasó a retirado en enero de 1945. http://www.geocities.com/ orion47/WEHRMACHT/KRIEGSMARINE/Vizeadmirals/SIEMENS_LEOP OLD.html.
} 
encargado de los asuntos relacionados con los sumergibles -U-Boote- en el Estado Mayor de la Kriegsmarine.

La siguiente visita se cursó al contralmirante Werner Fuchs ${ }^{130}$, jefe del departamento de Construcciones Navales, quien se puso a su disposición para facilitar las labores de la Comisión española. Durante los siguientes cinco días los miembros de la Comisión española visitaron diversos astilleros: el día 6 visitaron Oderwerke AG en Stettin, donde vieron la construcción de los nuevos modelos de rastreadores de minas. E1 8, estuvieron en los astilleros "F. Krupp Germaniawerft AG" en Kiel, donde tomaron nota de la construcción de submarinos. El día 10 por la mañana visitaron los astilleros "Bremer Vulkan-Vegesacker Werft", de Bremen, donde quedaron muy impresionados con la construcción de los submarinos Tipo VII, y sobre todo con el sistema de soldadura eléctrica continua. Ese mismo día por la tarde acudieron a visitar los astilleros "Lürssen Yacht und Boots Werft", dedicados a lanchas rápidas torpederas y los de "Abeking" y "Rasmussen", empleados en la construcción de dragaminas de madera. Al día siguiente regresaron a Berlín, donde estuvieron hasta el día 21. Durante esos diez días realizaron visitas a diferentes fábricas de material militar, se reunieron con las autoridades navales y negociaron sobre diferentes asuntos, como la adquisición de patentes para submarinos, minas, minadores, lanchas torpederas, artillería, etc...

El citado día 21 dejaron Berlín cargados de documentación, entre la que podemos destacar planos detallados y licencias de fabricación de submarinos Tipo VII, dragaminas Tipo 35 y 40, lanchas rápidas torpederas Tipo “S” y rastreadoras Tipo "R".

\section{I.2.2- Licencias de construcción de buques}

Tras el regreso de la Comisión "Suanzes", se adquirieron diversas licencias para construir buques de guerra en España. Por una parte, se adquirieron los planos para la serie de dragaminas clase "Bidasoa" y "Guadiaro", basados en el diseño alemán Minensuchboote 1940, denominado en España como "Dragaminas del Báltico"; por

\footnotetext{
${ }^{130}$ Werner Fuchs (18-1-1891 - 30-6-1976) ingresó en la armada imperial alemana en 1910 tomando parte en la Primera Guerra Mundial en los cruceros ligeros "Kolberg" y "Regensburg". Durante la República de Weimar siguió prestando servicio en la Marina alemana, llegando a mandar el crucero ligero "Koln" entre 1934 y 1935. Durante toda la guerra fue jefe del departamento de construcciones navales del OKM hasta que pasó a la reserva en noviembre de 1944. Datos obtenidos en la página web: http://www.geocities.com/ orion47/WEHRMACHT/KRIEGSMARINE/Admirals/FUCHS_WERNER.ht $\mathrm{ml}$.
} 
otra, los famosos U-Boote fueron también blanco de los deseos de la Armada Española, consiguiendo los derechos de fabricación, aunque como veremos más adelante, dificultades de todo tipo dieron al traste con la construcción en España de estos iconos de la industria naval germana. Finalmente, también se compró la licencia para fabricar en España las lanchas rápidas torpederas $\mathrm{S} 38$, aunque esta adquisición quedó englobada en el Rahmenverträge firmado en julio de 1942, por lo que la analizaremos en el siguiente epígrafe para no distorsionar el discurso expositivo cronológico.

La Comisión Especial de la Marina española desplazada a Alemania recibió información de dos tipos de buques dragaminas en servicio en Alemania, los Tipos $35 \mathrm{y}$ 40, decidiendo el EMA la construcción en España del segundo de los modelos, más moderno y más sencillo de producir. Este sería el origen de una serie de buques que en España se denominaría clase "Bidasoa""131.

El 24 de octubre de ese mismo año se ordenó la realización de las gestiones necesarias para la adquisición de la patente en Alemania, incluyendo los equipos de rastreo de minas que debían llevar de dotación estos buques. Una vez obtenida ésta, se procedió a la construcción de una primera serie de siete unidades, cinco de las cuales serían construidas en Cartagena y dos en Ferrol ${ }^{132}$.

Los "Dragaminas del Báltico", que así se denominó a esta serie de buques, resultaron unidades desfasadas en el momento de su alistamiento, pues no dispusieron de equipos modernos de dragado debido a la falta de suministro del material alemán; y su diseño -adecuado para las calmadas aguas del Mar Báltico- no dio resultado en las complicadas aguas del Océano Atlántico ${ }^{133}$.

La anulación por parte de la Armada del proyecto de guardacostas clase "Rigel", que también se había estudiado y analizado en esas fechas, dio origen a la construcción de otros siete dragaminas del tipo alemán Minensuchboote 1940, denominados en esta

\footnotetext{
${ }^{131}$ Quien mejor ha estudiado los avatares de estos buques de la Armada española ha sido Coello Lillo, Juan Luis. Buques de la Armada española. Los años de la postguerra. Aldaba ediciones, Madrid, 1995, págs. 204-215.

${ }^{132}$ Eran las unidades bautizadas "Tambre" y "Guadalete". Citado por González-Llanos Caruncho, José María. El Decenio. La construcción naval militar en la factoría de Ferrol. 1936-1946. Quirón Ediciones, Valladolid, 2006, págs. 114-115.

${ }^{133}$ Pese a los problemas que dieron estos buques, el último de la serie fue dado de baja en la Lista Oficial de Buques de la Armada (L.O.B.A.), en noviembre de 1973.
} 
ocasión, clase "Guadiaro". Dicha construcción sería autorizada en 1947 y en su diseño se mejorarían los inconvenientes detectados en la precedente serie "Bidasoa", como la sustitución de las calderas de carbón por otras que quemaban petroleo, y se rediseñaría el casco, evitando así los enormes problemas de navegación en las aguas atlánticas. De los siete buques de esta clase, dos de ellos serían construidos en Cartagena y los cinco restantes, en la factoría de La Carraca, entrando en servicio a partir de $1953^{134}$.

Continuando con la serie de licencias de fabricación negociadas con Alemania tras la "Comisión Suanzes", en septiembre de 1941, a propuesta del Ministro de Marina, el Consejo de Ministros autorizaba mediante decreto reservado la construcción de seis submarinos -U-Boote- del tipo VII C alemán, con un gasto de 118.533 .660 pesetas, a repartir en cuatro anualidades ${ }^{135}$. Se trataba del modelo más numeroso de los que formaron el arma submarina alemana durante la II Guerra Mundial y su construcción en España significaba un verdadero hito para las autoridades navales de entonces así como para la incipiente industria naval hispana. El contrato para la cesión de la licencia de fabricación fue remitido por la casa "Krupp Germania Werft" - con el visto bueno del mando de la Kriegsmarine- en noviembre de 1940 y tras leves retoques sería aprobado en julio del año siguiente, procediéndose en noviembre a la adjudicación de los trabajos a la Factoría de Cartagena, dependiente entonces del Consejo Ordenador de las Construcciones Navales Militares ${ }^{136}$.

Siempre siguiendo la línea argumental de Coello Lillo, quien ha estudiado más profundamente este asunto, hay que concretar las enormes dificultades surgidas con este proyecto. Se adjudicaron los motores diesel principales a la Factoría de Cartagena, los eléctricos, a la Constructora Nacional de Maquinaria Eléctrica (CENEMESA), las

\footnotetext{
${ }^{134}$ Tras una profunda modernización emprendida tras la firma de los acuerdos con USA a partir de 1953, el último minador de la clase "Guadiaro" fue dado de baja en la Armada española el verano de 1979.

${ }^{135}$ En mayo de 1940 se había recibido una invitación personal del almirante Raeder -jefe de la Marina alemana- al entonces Director de Construcciones de la Armada, coronel de Ingenieros navales Juan Antonio Suanzes para informarse sobre el terreno de la construcción de submarinos. Como ya hemos visto, un mes más tarde, Suanzes y varios oficiales visitarían los astilleros F. Krupp Germaniawerft AG en Kiel, donde tendrían ocasión de ver el sistema de fabricación de los sumergibles alemanes. Coello Lillo, Juan Luis. Buques de la Armada española. Los años de la postguerra, op. cit., págs. 146-152.

${ }^{136}$ Como bien señala Coello Lillo, "El acuerdo alcanzado con Alemania para la construcción de los submarinos Tipo VII C en España preveía la aportación por la industria germana de la mayor parte de los materiales destinados a los cuatro primeros buques, en tanto que la pareja restante y las series que posteriormente aprobase la Armada se construirían con materiales de fabricación nacional, realizados con las correspondientes licencias y patentes transferidas a nuestra industria en base a dicho acuerdo." Coello Lillo, Juan Luis. Buques de la Armada española. Los años de la postguerra, op. cit., pág. 149.
} 
baterías de acumuladores a Tudor, las grandes piezas de fundición a la fábrica de Reinosa de la S.E.C.N. y los aceros especiales, a los Altos Hornos de Vizcaya ${ }^{137}$. De los materiales encargados en Alemania ${ }^{138}$ sólo llegaron en la segunda mitad de 1943 una gran parte de las cuadernas y los grandes mamparos, no así los aceros de alto límite de resistencia, empleados en la construcción de los forros de los cascos ${ }^{139}$.

Tras el final de la Guerra Mundial, el aislamiento de España hizo patentes las muchas y graves carencias de la industria, provocando que numerosos proyectos, como éste de los submarinos, quedaran absolutamente paralizados, esperando tiempos mejores en los que se pudiera, bien importar, bien fabricar, los materiales que faltaban.

Pese a que en 1946 el Consejo Ordenador de Construcciones Navales Militares presentó un proyecto para la modificación de los submarinos "G", empleando en su construcción acero dulce corriente en lugar del de alta elasticidad, y que el acero fue encargado a a Altos Hornos de Vizcaya, no sería hasta 1952 cuando se logró disponer del encargo... y para un único sumergible. Entre tanto, a principios de 1949, se habían caído del proyecto dos de los seis submarinos previstos, ascendiendo lo invertido en este proyecto hasta aquel momento, 29.456.103,97 $\operatorname{pesetas}^{140}$.

\footnotetext{
${ }^{137}$ La siderurgia española de aquellos años no era capaz de suministrar los aceros especiales especificados en el proyecto, por lo que en 1945 se paralizaron las obras. Coello Lillo, Juan Luis. Buques de la Armada española. Los años de la postguerra, op. cit., pag. 150.

138 El Consejo Ordenador de Construcciones Navales Militares tenía concertado un contrato para la colaboración técnica con Alemania para la construcción de las seis unidades previstas de estos submarinos. Para los cuatro primeros sumergibles la Marina inició gestiones para obtener de Alemania el material de acero necesario para la construcción de cuatro cascos, con un peso total aproximado de 1.200 toneladas. También se deseaba adquirir motores diesel de $1.500 \mathrm{HP}$, motores eléctricos de $375 \mathrm{HP}$, periscopios para los cuatro submarinos, aparatos de navegación y otros aparatos especiales para los mismos. "Ministerio de Marina. Dirección de Construcciones e Industrias Navales Militares. Nuevos pedidos necesarios. 4 de febrero de 1943.” AMAE. AR. Sig. R-2066-2

139 A finales de 1942 hubo una propuesta de las casas Stahlunion-Export y Krupp Essen para la adquisición de material de acero para la construcción de dos cascos de submarino tipo G. Dicha adquisición estaba aceptada por el Ministerio de Marina alemán, aunque la validez de la oferta terminó el 25 de febrero de 1943 sin que, al parecer, se hubieran cumplido los compromisos por parte de España: pedido en firme y copia fotográfica de los permisos de importación-exportación. En las listas de adquisición de material la "Comisión Antón", figuraba material de acero para la fabricación de cuatro cascos de submarino - desconociendo si estaban incluidos los dos anteriores o no-. Una parte del material necesario para la construcción de los submarinos pasó a formar parte del denominado "Programa Bär", negociado entre abril y mayo de 1943, como tendremos ocasión de estudiar con más profundidad en capítulos posteriores. Embajada española en Berlín. Agregado Naval. Carta remitida al Ministro de Marina el 22 de enero de 1943. Archivo de la Fundación Nacional Francisco Franco (AFNFF). Caja 27.444 .

140 Doce años después de la adquisición de la licencia, el 18 de mayo de 1953 se ponía la quilla del denominado "G-1" en Cartagena y un año más tarde se conseguía adquirir acero de alto límite de
} 


\section{I.2.3- Las adquisiciones de julio de 1942}

El más importante de los Rahmenverträge fue firmado por el Ministerio de Marina en julio de 1942, en las mismas fechas que el Ejército del Aire, poco antes de que dieran comienzo las negociaciones bilaterales sobre comercio entre Alemania y España. En este caso, una Comisión presidida por el general De la Rocha, convino con los negociadores del III Reich la adquisición de diverso material de artillería naval, minas, torpedos y motores así como diversas licencias de fabricación. Como contrapartida, se comprometió la entrega de metales y aleaciones para cumplir el Acuerdo de Restitución de metales no férricos, vigente para todas las transacciones industriales con Alemania en esas fechas. Los datos exactos junto al monto económico de cada operación vienen recogidos en las tablas siguientes, teniendo en cuenta que todo este material estaba contratado antes del 31 de julio de 1942.

\section{TABLA I-F}

\section{CONTRATOS FIRMADOS POR LA MARINA}

\begin{tabular}{|l|l|}
\hline Concepto & Valor total \\
\hline $\begin{array}{l}12 \text { cañones de } 8,8 \mathrm{~cm} \text { para submarino con } \\
\text { munición }+3 \text { id. id. id. id. }\end{array}$ & 4.952 .325 \\
\hline $\begin{array}{l}26 \text { piezas antiaéreas en cureña doble de } 3,7 \mathrm{~cm} .+ \\
26.000 \text { granadas rompedoras de } 3,7 \mathrm{~cm}+26.000 \\
\text { granadas rompedoras para ejercicio de } 3,7 \mathrm{~cm}\end{array}$ & 5.642 .000 \\
\hline 52.000 granadas rompedoras de $3,7 \mathrm{~cm}$ & 1.710 .000 \\
\hline 26 transformadores para antiaéreos de $3,7 \mathrm{~cm}$ & 299.850 \\
\hline
\end{tabular}

resistencia en Alemania para así continuar el desarrollo de los "G-2", "G-3" y "G-4". Pero el proyecto de los Tipo VII C germanos era cosa de un pasado muy lejano; se trataba de un sumergible diseñado quince años atrás, cuando la guerra mundial no había hecho más que empezar. En 1943 y 1944, estos buques constituían la espina dorsal del arma submarina germana, pero ya estaban superados. Los U-Boote Tipo IX, XXI o XXV eran ya una realidad que había dejado obsoletos a los Tipo VII C. Era obvio, que en 1953 esta circunstancia se había agravado, dando al traste con toda la buena intención de los planificadores españoles. La puntilla para este proyecto serían los acuerdos firmados por España con los Estados Unidos de América ese mismo año de 1953, pese a lo cual, la decisión de cancelación del proyecto se retrasaría, incomprensiblemente, ocho años más, hasta octubre de 1961. Habían pasado ya veinte años desde la firma del contrato y se habían invertido hasta entonces casi 180 millones de pesetas de entonces, una cantidad muy superior a la inicialmente prevista para los seis submarinos completos. Los motores diesel principales Krupp F-46, de 1.400 caballos, fueron empleados en tres remolcadores de la clase "RR-50", construidos en Cartagena a mediados de la década de los años sesenta, además de servir como fuente de repuestos para el submarino “G-7”, un Tipo VII alemán (U-573) incorporado a la Marina española en 1942, tras ser internado en Cartagena, donde se refugió tras el ataque de un Lockheed "Hudson" británico, el 2 de mayo de ese mismo año. Coello Lillo, Juan Luis. Buques de la Armada española. Los años de la postguerra, op. cit., págs. 151 y 156. 


\begin{tabular}{|l|l|}
\hline Diversos espejos para reflectores & 297.000 \\
\hline 80 torpedos con accesorios & 3.444 .000 \\
\hline $\begin{array}{l}40 \text { motores de lanchas rápidas con piezas de } \\
\text { repuesto }\end{array}$ & 12.400 .000 \\
\hline 459 minas con accesorios & 1.193 .869 \\
\hline TOTAL & $\mathbf{2 9 . 9 3 9 . 0 4 4}$ \\
\hline
\end{tabular}

Fuente: AFNFF. Caja 27.444 y AMAE. R-2065 Leg. 15 y 16 (Cantidades en marcos)

\section{TABLA I-G}

\section{LICENCIAS DE FABRICACIÓN FIRMADAS}

\begin{tabular}{|l|l|}
\hline Concepto & Valor total \\
\hline Cañones antiaéreos automáticos de $3,7 \mathrm{~cm}$ & 400.000 \\
\hline Cureña pívot para los anteriores & 200.000 \\
\hline Cureña de pedestal idem. & 170.000 \\
\hline Plataformas triangulares idem. & 40.000 \\
\hline Chasis idem. & 60.000 \\
\hline Munición de 3,7 cm & 200.000 \\
\hline Lanchas rápidas & 400.000 \\
\hline Minas “EMC” & 500.000 \\
\hline TOTAL & $\mathbf{1 . 9 7 0 . 0 0 0}$ \\
\hline
\end{tabular}

Fuente: AFNFF. Caja 27.444 y AMAE. R-2065 Leg. 15 y 16. (Cantidades en marcos)

Los cañones de $8,8 \mathrm{~cm}$. L/45 eran del modelo empleado por los alemanes en los submarinos, y su adquisición respondía al deseo del Estado Mayor de la Armada de armar con ellos los futuros sumergibles tipo $\mathrm{G}$-idénticos a los alemanes tipo VII C-, cuya construcción se había autorizado el 25 de septiembre de $1941^{141}$. Otros tres cañones solicitados de este mismo modelo se destinarían a armar los submarinos de la clase $\mathrm{D}$, cuya construcción estaba muy retrasada debido al parón que se produjo en su

\footnotetext{
${ }^{141}$ Los submarinos alemanes tipo VII C montaban un único cañón a proa. Los planes del EMA pasaban, al principio, por la realización de 10 submarinos de esta clase; una primera serie de seis unidades y cuatro más en una segunda por lo que no resulta extraño que se deseara adquirir una docena de piezas artilleras para así disponer de una reserva.
} 
construcción con motivo de la guerra civil. Estos cañones se montarían, efectivamente, en los tres submarinos "D" y en diversos buques menores de la Armada tras la cancelación del proyecto de los submarinos "G". Sólo se llegaron a suministrar 12 de los 15 cañones solicitados.

Las 26 piezas antiaéreas dobles de $3,7 \mathrm{~cm}$. correspondían a un diseño semiautomático de la casa Rheinmetall, muy empleado en Alemania por los buques de la Kriegsmarine como artillería antiaérea secundaria. Se remitieron en varios envíos, recibiéndose las últimas dos piezas por la frontera de Irún a finales de febrero de $1943^{142}$. Estaba previsto emplearlas para dotar de armamento antiaéreo moderno a los cruceros "Cervantes", "Galicia", "Méndez Núñez" y "Navarra", aunque este último nunca los montaría. Sí se le llegarían a instalar al "Canarias" así como a la mayoría de los destructores clase "Audaz" " Para cada cañón se adquirió un lote de 3.000 proyectiles rompedores y 1.000 de ejercicio.

Los 80 torpedos adquiridos eran del modelo $\mathrm{G}$ 7-a y fueron comprados a la Deutsche Werke de Kiel, finalizando su entrega a finales de febrero de 1943. Estaban destinados a armar los submarinos clase " $\mathrm{D}$ ” pues durante su construcción se procedió a la modificación de los tubos de lanzar para que pudieran emplear estos torpedos de origen teutón y así homogeneizar el armamento con la proyectada serie G.

Las 459 minas que figuraban en contrato eran del tipo $\mathrm{EMD}^{144}$, un modelo de contacto y de anclaje por escandallo, fabricado en Alemania desde 1924, cuyo proceso de producción ya había finalizado y del que este país tenía excedentes. Por la documentación del Agregado Naval en Berlín ${ }^{145}$ que hemos utilizado para realizar este estudio, nos consta que hubo otro contrato -desconocemos su fecha- por el que se adquirieron 495 minas holandesas (sin duda, procedentes de botín de guerra) del modelo Vickers H-2 -análogo a la EMD- y que se organizó cierto conflicto con los alemanes,

\footnotetext{
${ }^{142}$ Embajada Española en Berlín. Agregado Naval. Carta remitida al Ministro de Marina el 22 de enero de 1943. AFNFF. Caja 27.444

${ }^{143}$ Hay que constatar que además de estos 26 montajes dobles semiautomáticos adquiridos en 1942, en el seno del "Programa Bär" también se recibirían varios montajes de esta misma clase y modelo.

${ }^{144}$ Una vez recibidas estas 459 minas, se firmó un nuevo contrato por parte del Agregado Naval en Berlín que contemplaba la adquisición de 66 nuevas minas de este mismo modelo. Dichas minas de recibieron en España.

${ }^{145}$ Carta citada del 22 de enero de 1943. AFNFF. Caja 27.444.
} 
quienes querían cobrar el material de respeto enviado junto a las minas, no habiendo sido éste contemplado en contrato, y habiendo asegurado al Agregado Naval que dicho material no se cobraría bajo ningún concepto. Entre estos respetos había muchos kilómetros de cables de orinque, que en aquella época eran muy necesarios para la Marina. Es posible que estas últimas minas procedieran de un Rahmenverträge anterior.

Las licencias de fabricación de material para la Armada comprendían, por un lado, cañones antiaéreos automáticos sencillos de $3,7 \mathrm{~cm}$ con sus cureñas, plataformas y municiones y por otro, lanchas rápidas y minas.

El material de 3,7 cm cuya autorización para ser fabricado en España se adquiría, era idéntico al comprado en montaje doble, pero en este caso en afuste de un solo tubo. Se trataba de muy buenos cañones - como bien afirma el almirante García Parreño ${ }^{146}$-, con gran velocidad inicial y precisión en el tiro, aunque frente a las ametralladoras antiaéreas de $40 \mathrm{~mm}$ presentes ya en el panorama artillero en esos mismos años, poco o nada tenían que hacer. Casi un centenar de estos cañones iban a ser fabricados en España, en los Talleres de artillería de La Carraca, y con ellos se llegarían a armar gran cantidad de unidades menores de la Armada, permaneciendo hoy día, algunos de ellos en servicio en los Arsenales de Ferrol y Cartagena como encargados de dar los "cañonazos" diarios reglamentarios al orto y al ocaso, así como los de rigor en caso de acontecimientos extraordinarios o visitas de buques extranjeros.

Otra de las visitas de la ya citada "Comisión Suanzes" en Alemania giró en torno a los astilleros "Lürssen Yacht und Boots Werft", (Bremen) con objeto de estudiar las lanchas rápidas que allí se producían. El interés de los marinos españoles se centró en las lanchas torpederas, redactando a su regreso de Alemania, un detallado informe al EMA sobre las que, a partir de entonces se denominarían LT-40.

Tras diversos estudios e infinidad de informes, el Ministerio de Marina tomó la decisión de fabricar este tipo de lanchas torpederas en España; en consecuencia se adquirió licencia ${ }^{147}$ para fabricar una decena de lanchas rápidas del modelo $\mathrm{S} 38$, que

\footnotetext{
146 García-Parreño y Kaden, Jorge. Las armas navales españolas. E.N. Bazán, edición no comercial, Madrid, 1982, pág. 273.

${ }^{147}$ El coste de la citada licencia fue de $1.736 .000,00$ pesetas, equivalentes a 400.000 marcos alemanes. AMAE. AR. Sig. R-2066-2.
} 
fue autorizada por el OKM en el mes de junio de 1942, firmando el contrato con la casa "Lürssen" a finales de ese mismo mes, contrato por el que la fábrica alemana se comprometía a facilitar a la Marina española los planos y la asistencia técnica para la construcción en astilleros hispanos de las embarcaciones. Dichos planos fueron enviados en enero de 1943 y convenientemente traducidos al español, autorizando "Lürssen" el envío de varios técnicos subalternos españoles a Bremen para estudiar el proceso de construcción de las lanchas y así poder ponerlo en práctica en España ${ }^{148}$.

Por lo que respecta a los motores de lanchas rápidas se trataba de los MB 501, de 2.000 caballos, que dotaban en Alemania a las torpederas alemanas S 38, cuya adquisición también se negociaba con la casa "Daimler-Benz" de Stuttgart. Para motorizar las diez lanchas previstas, el EMA contrató la adquisición de cuatro equipos por lancha, los tres "reglamentarios" y uno de respeto para cada una ${ }^{149}$. Al final, la marina sólo recibiría 27 motores, lo que hizo imposible la construcción de las 10 unidades inicialmente previstas, quedando reducidas únicamente a seis torpederas. Los 13 motores restantes nunca llegarían a España porque cuando estuvieron disponibles para su transporte ya no era posible cruzar Francia en $\operatorname{tren}^{150}$. El OKM dio la posibilidad a la Marina española de obtener la devolución de lo pagado por anticipado ${ }^{151}$ pero el EMA dio orden de transferir el exceso pagado por los motores no suministrados -un total de 1.458.104,03 RM- a la casa "Rheimetall”, con la que quedaba pendiente parte de la deuda contraída por la adquisición de cañones y patentes.

La construcción de las lanchas en factoría de La Carraca se redujo a seis ejemplares (S-27 a S-32), que fueron saliendo de los astilleros gaditanos con

\footnotetext{
${ }^{148}$ El envío de la documentación tuvo algún retraso debido a que el Ministerio de Marina germano solicitó a Lurssen que aclarara las abreviaturas para así facilitar la traducción al español de la misma. Embajada española en Berlín. Agregado Naval. Carta remitida al Ministro de Marina el 22 de enero de 1943. AFNFF. Caja 27.444.

${ }^{149} \mathrm{El}$ coste de los 40 motores era de 12.400 .000 marcos (310.000 marcos cada motor), que equivalían a 53.816.000 pesetas de la época. AMAE. AR. Sig. R-2066-2.

${ }^{150}$ El Agregado Naval en Berlín transmitió a la Daimler Benz los deseos del Estado Mayor de la Armada de fijar fecha para enviar personal técnico a Stuttgart, para estudiar la construcción, armado y pruebas de dichos motores. En cualquier caso, un oficial de Máquinas y cuatro mecánicos españoles, pertenecientes a la Comisión Fernández de la Puente, fueron destinados algún tiempo a una unidad de Lanchas rápidas, donde estudiaron el funcionamiento de dichos motores. Las vicisitudes de esta y otras comisiones en Alemania se analizarán en capítulos posteriores. Embajada española en Berlín. Agregado Naval. Carta remitida al Ministro de Marina el 22 de enero de 1943. AFNFF. Caja 27.444.

${ }^{151}$ APFE. Telegrama no 755 remitido por el Agregado Naval en Berlín al EMA, con fecha 9 de octubre de 1944.
} 
“exasperante lentitud", como afirma Coello Lillo ${ }^{152}$, entre 1949 -fecha de botadura de las primeras- y 1952 -fecha de entrega de la última de ellas a la Armada-, y que prestaron servicio encuadradas en la Flotilla de Lanchas Rápidas, con base en Tarifa ${ }^{153}$.

Por último, la licencia adquirida para la fabricación de minas daba paso a la posibilidad de construir en España las modernas minas EMC, remitiéndose todos los planos de las mismas a finales de 1942. Hay que hacer constar que además de la licencia también se solicitó la adquisición de 1.000 unidades de minas EMC, aunque ésta se englobaría en las peticiones realizadas por la Comisión de Armamento del capitán de navío Antón, por lo que quedaría inmersa en el "Programa Bär".

\section{IB.4- Los Rahmenverträge posteriores a julio de 1942}

En el transcurso de las negociaciones económicas con Alemania, que dieron origen a finales de 1942 al Acuerdo Bilateral de Comercio entre ambos países para los siguientes doce meses, salieron a la luz varios contratos, tanto de material como de licencias, que estaban todavía pendientes de firma. Algunos de ellos se llegaron a firmar aunque otros quedaron subsumidos en las negociaciones ulteriores que dieron origen al denominado "Programa Bär", cuya negociación inició la Comisión enviada a Alemania en enero de 1943, a las órdenes del capitán de navío Santiago Antón Rozas.

Analicemos, aunque sea someramente, estos contratos, que encontraremos resumidos en las tablas I-H y I-I siguientes.

Los seis cañones antiaéreos de 10,5 cm. en montaje doble y con estabilización en los tres ejes, iban a servir para como modelo para la fabricación por la industria española de la artillería principal de los cañoneros tipo "Pizarro", y de los destructores “Oquendo". El Agregado naval en Berlín, capitán de fragata Espinosa, decía en su informe reservado de 22 de enero de $1943^{154}$ :

\footnotetext{
${ }^{152}$ Coello Lillo, Juan Luis. Buques de la Armada española. Los años de la postguerra, op. cit., pág. 225.

${ }^{153}$ Las cuatro restantes, de la serie inicial de diez contratadas, pese a que se iniciaron los estudios para su construcción -modificando el diseño original en diversos aspectos-, al final no se llegaron a terminar, suspendiéndose definitivamente el proyecto en 1962. Las dos últimas lanchas en servicio serían dadas de baja en la Lista Oficial de Buques de la Armada en 1977.

${ }^{154}$ Carta citada remitida al Ministro de Marina. 22-1-1943. AFNFF. Caja 27.444.
} 
“... 10,5 para cañoneros. Este asunto está aun un poco turbio. El general Rocha cuando estuvo en Berlín pidió autorización al Ministerio para el suministro de estos cañones y el Almirantazgo alemán deseaba se resolviese cuanto antes qué dirección de tiro habían de llevar. La comisión del capitán de corbeta D. Mario Romero habló con la casa Rheinmetall y con la Hazemeyer sobre estas direcciones de tiro (...) La comisión del capitán de navío Antón que ha venido a Berlín formando parte de la Comisión general de adquisición de material de guerra trae entre sus peticiones direcciones de tiro para estos cañones. Respetuosamente comunico a V.E. que no he visto una gran seguridad técnica en cuanto a la posibilidad de que los cañoneros proyectados resistan la artillería antiaérea de 10,5 que se le desea montar ni si técnicamente será posible que unos barcos tan pequeños lleven cañones pareados y estabilizados de este calibre. Procuraré en reuniones con los técnicos del Ministerio de Marina alemán aclarar esta posibilidad..."

Al final la adquisición de estos cañones pasaría a ser objeto de los acuerdos del "Programa Bär" y su precio fue negociado en Madrid, en las reuniones mantenidas entre técnicos militares españoles y alemanes. Pese a ello, como veremos más adelante, nunca se llegarían a recibir piezas de este modelo, aunque sí vendrían una docena de cañones sencillos de este mismo calibre y casa constructora, enmarcados en el "Programa Bär".

El contrato para la adquisición de telémetros sería firmado por los representantes de la Marina española y la casa Zeiss, con el visto bueno del OKM. Se trataba de la fabricación en Alemania de 32 telémetros con destino a diversos buques de guerra españoles. Hubo con este contrato numerosos problemas entre el EMA y la casa constructora, que intentó dilatar el período de entrega poniendo como excusa la falta de conformidad del Almirantazgo alemán. La adquisición de estos 32 telémetros pasaría también a formar parte de las negociaciones del "Programa Bär", recibiendo los mismos a finales de 1943 en dos lotes: 12 aparatos de $2 \mathrm{~m}$ de base procedentes de la fábrica Goerz y otros 20 de $1,25 \mathrm{~m}$ de base, fabricados por la casa Zeiss.

En el informe del Agregado Naval español en Berlín -ya citado anteriormente-, aparece otro encargo de telémetros Zeiss, Goerz y S.O.M. negociado directamente entre el EMA y la empresa AGK, también denominada AGEKA $^{155}$, nombre comercial de la empresa oficial del gobierno alemán para la venta de armamentos. Estos telémetros, al

\footnotetext{
${ }^{155}$ Corresponde a las siglas Ausfuhrgemeinschaft für Kriegsgerät, o lo que es lo mismo, el organismo comercial del Estado Mayor del Ejército alemán (Oberkommando der Wehrmacht -O.K.W.) para la exportación de material de guerra.
} 
parecer, se encontraban almacenados en Kiel a finales de 1942 y salieron con destino a la frontera de Irún el día 20 de enero de 1943. Desconocemos la cantidad de aparatos remitidos, aunque sí sabemos que se trataba de telémetros de 1,5 metros de base ${ }^{156}$.

Por lo que respecta a los 100 torpedos G 7 a, la Kriegsmarine retrasó la firma del contrato y su ulterior envío aduciendo que mientras no estuvieran listos los tubos de lanzar de los nuevos submarinos españoles, con los 80 torpedos remitidos anteriormente la Marina tendría suficiente para instruir al personal y realizar prácticas.

Al igual que ocurrió con estos contratos, quedaron sin firmar las licencias de fabricación de los cañones antiaéreos dobles de 10,5 cm, sus direcciones de tiro y los torpedos G7a.

\section{TABLA I-H}

ADQUISICIONES. CONTRATOS POR FIRMAR

\begin{tabular}{|l|l|}
\hline Concepto & Valor total \\
\hline 6 cañones antiaéreos dobles de $10,5 \mathrm{~cm}$ con munición & 9.000 .000 \\
\hline 32 telémetros & 890.300 \\
\hline 100 torpedos & 400.000 \\
\hline Total & $\mathbf{1 0 . 2 9 0 . 3 0 0}$ \\
\hline
\end{tabular}

Fuente: AFNFF. Caja 27.444 y AMAE. R-2065 Leg. 15 y 16. (Cantidades en marcos)

\section{TABLA I-I}

\section{LICENCIAS DE FABRICACIÓN POR FIRMAR}

\begin{tabular}{|l|l|}
\hline Concepto & Valor total \\
\hline Fabricación de cañones antiaéreos dobles de $10,5 \mathrm{~cm}$ & 5.200 .000 \\
\hline Direcciones de tiro para cañones de $10,5 \mathrm{~cm}$ & 1.000 .000 \\
\hline Fabricación de torpedos & 1.000 .000 \\
\hline TOTAL & $\mathbf{7 . 2 0 0 . 0 0 0}$ \\
\hline
\end{tabular}

Fuente: AFNFF. Caja 27.444 y AMAE. R-2065 Leg. 15 y 16. (Cantidades en marcos)

\footnotetext{
${ }^{156}$ Carta citada. Archivo de la Fundación Nacional Francisco Franco. Caja 27.444.
} 
Se negoció también la adquisición de aparatos para la instrucción de tiro de torpedos y para la instrucción de timoneles, con la casa "Askania-Werke", así como de cuatro instalaciones de escucha submarina y cuatro de señales marítimas, ambas de la empresa "Atlas Werke". También hubo intentos de comprar 72 telémetros fabricados por “Zeiss" y "Goertz", y una prensa para minas a "Sculer A.G”., importando todo ello 3.335.401 marcos, aunque estos suministros nunca se llegaron a concretar.

Otros asuntos que interesaban al capitán de fragata Espinosa a comienzos de 1943 eran, por una parte los radio-telémetros (radares) alemanes, todavía considerados por el OKW como alto secreto y de los que, hasta entonces, ninguna de las tres ramas del Ejército alemán había dado información a los países amigos ${ }^{157}$. Por otra, ametralladoras -sencillas y cuádruples- de $20 \mathrm{~mm}$, en montaje naval antiaéreo, asunto sobre el cual, "Rheinmetall" había dado largas al propio Agregado.

Además, se estaba negociando la adquisición de sendas direcciones de tiro de lanzar torpedos con destino a los submarinos italianos en servicio en España, "General Mola" y "General Sanjurjo"; la construcción en Torrevieja de un polígono de tiro de torpedos con el apoyo de la "Deutsche Werke" de Kiel; la adquisición de maquinaria con destino al Consejo Ordenador de las Construcciones Navales Militares; varias prensas para imprimir cartas marinas, solicitadas por el Observatorio de Marina y por último, varias agujas giroscópicas solicitadas a la casa "Anschütz" con destino a diversos buques de guerra.

El 8 de diciembre de $1944^{158}$, el Almirante Jefe del EMA comunicaba al Agregado en Berlín que los 3.429.375,20 marcos que las firmas alemanas debían reintegrar a España, correspondientes a material contratado y no suministrado, serían destinados a completar el pago del "Programa Bär". En concreto, estos contratos parcialmente incumplidos se referían a tres de los cañones para submarino de $8,8 \mathrm{~cm}$. ("Rheinmetall") por valor de 990.465 marcos; a 13 motores para lanchas rápidas ("Daimler-Benz") con un montante total de 1.458.104,02 marcos; a material de torpedos

\footnotetext{
${ }^{157}$ El Agregado naval español hizo saber a las autoridades de la Marina alemana: "en el caso de que a España se le entreguen aparatos de radiotelemetría, la Marina española tiene también necesidad de los mismos..." Documentos inéditos para la historia del Generalísimo Franco. Tomo IV. Azor. Colección de Estudios Contemporáneos. Fundación Nacional Francisco Franco, Burgos, 1994, pág. 46.

${ }^{158}$ APFE. Embajada en España en Berlín. Agregado Naval. Telegrama recibido no 664. Ref. 11346/6180 con fecha 8 de diciembre de 1944.
} 
("Deutsche Werke") por un importe de 10.669,28 marcos; aparatos de instrucción de comandantes y timoneles de submarinos (“Askania") cuyo importe era de 455.520 marcos y a dos contratos de telémetros y estereotelémetros (“Zeiss"), así como una máquina de grabar contratada con "Friedrich Dekel" cuyo valor estaba tasado en $5.766,90$ marcos.

\section{I.2.5- Adquisiciones atípicas de material naval}

Además de las compras programadas y enmarcadas en el Plan de Construcciones Navales de 1939, la Marina española realizó varias adquisiciones de material naval fuera de estos cauces, llamémosles normales o habituales. Hemos de incluir aquí la compra de cañones de costa para reforzar la defensa de las islas Canarias, una misión que en España era tarea exclusiva del Ejército de Tierra; la adquisición de un $U$-Boote internado en Cartagena o la de tres lanchas de salvamento de náufragos procedentes de la Luftwaffe.

\section{I.2.5.1 -Operación "Isabella"}

Una de las más atípicas y extrañas negociaciones llevadas a cabo entre la Marina española y la Kriegsmarine germana, en el período que venimos tratando, fue la adquisición por parte de la primera de una docena de cañones costeros de segunda mano, de 15 y de $17 \mathrm{~cm}$ de calibre, operación que en la documentación oficial hallada en los archivos españoles consultados, se conoce con el nombre clave de "Isabella". Aunque fue la Armada la que negoció la adquisición del material bélico en cuestión, sería beneficiario del mismo el Ejército de Tierra, de ahí los problemas económicos surgidos al hilo de este contrato que derivarían, a la larga, en la falta de pago de estas baterías al Tercer Reich al finalizar la Segunda Guerra Mundial.

A finales de 1940, el Ministerio de Marina español se ponía en contacto a través de su Agregado en Berlín con el Oberkommando der Kriegsmarine (OKM) con el fin de adquirir piezas de costa para guarnecer las débilmente artilladas Islas Canarias. Y la gestión se realizó a través de la Armada porque en Alemania la artillería costera era misión de la Marina de Guerra, que utilizaba cañones y calibres idénticos a los embarcados en los buques. Entre el 12 y el 19 de diciembre se desplazó a las islas el capitán de fragata Krauss, de la Kriegsmarine, con objeto de analizar "in situ" el estado 
de las defensas costeras de las Canarias. Tras su paso por Tenerife y Gran Canaria Kraus redactó un informe de 19 páginas en el que exponía a las autoridades germanas el estado de las defensas de las islas - precario, poco efectivo y obsoleto- ${ }^{159}$

Los argumentos españoles y el interés militar y estratégico de las islas para el desarrollo de los acontecimientos bélicos del momento, hicieron que el gobierno del Reich se desprendiera de doce cañones de $\operatorname{costa}^{160}$ para artillarlos en las islas españolas de Tenerife y Gran Canaria.

Entre el 13 de julio y el 4 de agosto de 1941 llegaron por ferrocarril a la frontera de Irún, diferentes expediciones de material de artillería de costa ${ }^{161}$ hasta completar dos baterías de tres piezas cada una de $15 \mathrm{~cm}$ (una del modelo S.K. L/45 $5^{162}$ y otra del modelo S.K. L/40 ${ }^{163}$ ) y otras dos baterías, igualmente de tres piezas cada una, de $17 \mathrm{~cm}$, del modelo S.K. L $/ 40^{164}$. Todo el material fue recibido en la frontera por personal de la

${ }^{159}$ Citado por Díaz Benitez, Juan José. La planificación militar española y la no beligerancia durante la II Guerra Mundial: el caso de Canarias. Comunicación presentada por el autor en el IV Congreso de Historia de la Defensa. "Fuerzas Armadas y políticas de defensa durante el franquismo". Madrid, 3-5 de noviembre de 2009. Instituto Universitario General Gutiérrez Mellado. UNED, pág. 13. Para profundizar en el viaje del capitán de fragata Krauss: Díaz Benitez, Juan José. "Colaboración hispano-alemana para la defensa de Canarias: el viaje del capitán de fragata Krauss”. Boletín Millares Carlo no 21, 2002, págs. 147-164.

${ }^{160}$ Estos cañones eran modelos ya anticuados en Alemania, que los había utilizado durante la I Guerra Mundial embarcados en algunas unidades de su flota de superficie.

${ }^{161}$ La mayor parte de los datos sobre este asunto figuran en: Dirección General de Industria y Material. Ministerio del Ejército. Secretaría. Cuenta para S.E. Documento fechado el 4 de abril de 1944. Traducción de carta recibida de la casa Ageka de fecha 8 de febrero de 1944 dirigida al agregado naval en Berlín. N/Refer ${ }^{a}$ S 413/44 IV-Spanien-4 Boe. Asunto: Batería Isabella. Ambos en AGMAV. Caja 20.903. Fondo del antiguo Ministerio del Ejército.

${ }^{162} \mathrm{Su}$ diseño original era de 1906, entrando en servicio dos años más tarde. Durante la Primera Guerra Mundial, estos cañones formaron parte del armamento secundario de la mayoría de los cruceros de la marina de guerra alemana (clases "Dresde II", "Königsberg II", "Frankfurt", "Elbing" y "Bremse"). Finalizada la misma, se montaron para armar los cruceros clase "Emden" ("Köln", "Emdem", "Königsberg" y "Wiesbaden"). Durante la Segunda Guerra Mundial, las supervivientes se artillaron sobre el mercante "Kormoran", en misión de corso. Vid. http://www.navweaps.com/Weapons/WNGER_5945_skc16.htm.

${ }^{163}$ Su diseño databa de 1897 , entrando en servicio un año después en varios“"pre-dreadnoughts. Durante la Primera Guerra Mundial montaban estas piezas, como artillería secundaria, cruceros de las clases "Kaiser Friedrich III", "Wittelsbach"y "Victoria Louise" así como de los cruceros acorazados "SMS Fürst Bismarck", "Priz Heinrich y los de las clases "Prinz Adalbert", "Roon" y "Scharnhorst". Debido a su obsolescencia como buques de guerra, en el transcurso del conflicto se les desmontaron los cañones. Dichas piezas pasaron a formar parte de algunas baterías de costa, siendo empleadas durante la Segunda Guerra Mundial para artillar algunos buques mercantes, como el crucero auxiliar "Wolf”. Este mismo cañón fue usado por el Ejército alemán montado sobre afuste de campaña, conocido como "15 cm Feldkanone i.G.”. Vid. http://www.navweaps.com/Weapons/WNGER_59-40_skc96.htm.

164 Cuenta para S.E. Reservada. Dirección General de Industria y Material. Ministerio del Ejército. Sección Secretaría, $2^{\circ}$ Jefe. AGMAV. Fondo del antiguo Ministerio del Ejército. Armamento- Alemania. 1942-1960. Caja 20.903. 
Dirección General de Industria y Material (D.G.I.M.) del Ministerio del Ejército, que redactó las actas correspondientes, lo transportó a Canarias e intervino en su distribución y emplazamiento. Dado que las gestiones de adquisición fueron llevadas por el Agregado Naval en Berlín, sin conocimiento de ningún organismo del Ejército de Tierra, la D.G.I.M. del Ministerio del Ejército interpretó que estos cañones y todo el material que les acompañaba venían con carácter de "prestación", lo que podríamos entender hoy día como regalo o donación, por lo que la Comisión nombrada por el Jefe de Artillería de Canarias, levantó acta e inventario de todos los elementos recibidos aunque el material nunca causaría alta en la Cuenta de Efectos de los Parques de Artillería de Tenerife y Las Palmas, obrando como cargo la copia del acta de recepción.

Los tres modelos de cañones eran diseños navales de la empresa "Krupp A.G.”, datando todos ellos de principios del siglo XX, antes de comenzar la Primera Guerra Mundial $^{165}$. Las piezas destinadas a Tenerife fueron artilladas a partir de agosto de 1941 en las posiciones de "Las Tiñosas" y "Punta a la Vista", constituyendo la defensa del Frente Sur de Santa Cruz de Tenerife ${ }^{166}$. En la posición de "Las Tiñosas" se emplazó la denominada $6^{a}$ Batería de Costa, armada con tres cañones "Krupp" de $15 \mathrm{~cm}$ S.K. $\mathrm{L} / 45^{167}$. Como defensa próxima de la batería, esta tenía asignadas dos ametralladoras antiáereas de 20 mm "Oerlikon".

La denominada $8^{a}$ Batería sería emplazada en la posición de "Punta a la Vista", montando tres cañones "Krupp" de $17 \mathrm{~cm} \mathrm{S.K.} \mathrm{L/40}{ }^{168}$. El estado de conservación de estas piezas, a diferencia de las de $15 \mathrm{~cm}$, no era muy bueno, manifestando un acusado desgaste, además de otras deficiencias que las hacían perder alcance y precisión. Al igual que la otra batería, disponía de dos ametralladoras antiaéreas de $20 \mathrm{~mm}$. «Oerlikon» para la defensa inmediata de la batería.

\footnotetext{
${ }^{165}$ Para los detalles de artillado de estas piezas en Tenerife y Gran Canaria y la tipología de los cañones ver: Gómez Vizcaíno, Juan Lorenzo. "La defensa de costa de las islas Canarias" Revista Española de Historia Militar no 24, junio 2002, pp. 271-281.

${ }^{166}$ García Argüelles, Amador. Historia de la Artillería en Tenerife. El Regimiento Mixto de Artillería $n^{o}$ 93. Gráficas Tenerife, Santa Cruz de Tenerife, 1982, pág. 96.

${ }^{167} \mathrm{La} 1^{\mathrm{a}}, 2^{\mathrm{a}}$ y $3^{\mathrm{o}}$ pieza tenían los números de fábrica $1.380,1.151$ y 1.382 respectivamente. APEC.

${ }^{168} \mathrm{La} 1^{\mathrm{a}}, 2^{\mathrm{a}}$ y $3^{\mathrm{o}}$ pieza tenían los números de fábrica 137,41 y 104 respectivamente. APEC.
} 
Las obras para emplazar los cañones destinados a Gran Canaria comenzaron al mismo tiempo que las de Tenerife, siendo elegidos para su artillado los lugares denominados "Melenara" y "Mesas de San Juan". En la loma de Melenara, sobre la playa, se organizó la denominada $12^{\mathrm{a}}$ Batería de costa del Regimiento, compuesta por tres piezas "Krupp" de $17 \mathrm{~cm} \mathrm{S.K.L/40169} \mathrm{y} \mathrm{en} \mathrm{San} \mathrm{Juan,} \mathrm{a} 800$ metros de la antigua batería de obuses "Ordóñez" de 21 cm, en el lugar denominad "Las Mesas", se constituyó la $11^{\text {a }}$ Batería de costa, armada con tres cañones "Krupp" de $15 \mathrm{~cm} \mathrm{S.K.}$ $\mathrm{L} / 40^{170}$.

Las obras de emplazamiento finalizaron en febrero del año siguiente, quedando a partir de entonces las citadas baterías, activadas y en servicio. Las dos baterías de 17 $\mathrm{cm}$, achacosas por el paso de los años y sin repuestos, pasaron a la situación de reserva a finales de la década de los cuarenta ${ }^{171}$.

El 8 de febrero de 1944 la AGEKA se puso en contacto con el capitán de corbeta Espinosa en la Embajada de Berlín para negociar el pago de las baterías del grupo "Isabella". Pero el Agregado Naval, que ya nada sabía de estas piezas, le pasó el asunto al coronel de Ingenieros Carlos Marín de Bernardo, entonces Agregado Militar en la

\footnotetext{
${ }^{169} \mathrm{La} 1^{\mathrm{a}}, 2^{\mathrm{a}}$ y $3^{\mathrm{o}}$ pieza tenían los números de fábrica 174,145 y 43 . La pieza 174 había realizado 130 disparos, según se desprendía de su libreta de filiación original, desde su puesta en servicio en la Marina Alemana hasta su entrega en España. Aquí sólo realizó 67.

${ }^{170}$ No ha sido posible hallar los números de fabricación de estas tres piezas.

${ }^{171}$ En un informe fechado en diciembre de 1949 y realizado por la Junta Facultativa de Estudios, Proyectos y Experiencias de la Dirección General de Industria y Material, se hacía constar el estado de las piezas de $17 \mathrm{~cm}$. de la batería de Melenara. Dicho informe rezaba: “... del minucioso estudio de las piezas puede decirse que se encuentran en un estado acentuado de desgaste, pudiendo ser incluidas en el cuadro de inutilidades...". Uno de los tubos, el $n^{\circ} 145$, tenía un desgaste de tal entidad que de haber disparado un proyectil, éste iniciaría su movimiento sin rotación por no existir materialmente el rayado hasta la mitad del ánima. Como a partir de ese punto los campos y rayas comenzaban a tener un desgaste normal, podría haberse producido un frenado al iniciarse la rotación, que a su vez daría como consecuencia una brusca variación en la aceleración del proyectil, motivando la explosión del mismo dentro del ánima. Informe de diciembre de 1949. Archivo del Polígono de Experiencias de Carabanchel (APEC). (Madrid).

La Fábrica de Trubia elaboró un proyecto en 1952 para intentar recomponerlas y transformarlas al calibre $15,24 \mathrm{~cm}$, en lo que, según la nomenclatura de la propia fábrica, sería el cañón "F.T. de 152,4/50 Mod. 1951 ", lo cierto es que ya poco o nada se podía hacer con ellas. Causaron baja en las unidades y fueron desartilladas en 1959. Informes $\mathrm{n}^{\mathrm{o}} 52$ y 53 de 26 y 29 de febrero de 1952 del Polígono de Experiencias de Carabanchel. Las otras dos baterías de $15 \mathrm{~cm}$. serían más longevas, desapareciendo de la plantilla de los Regimientos en 1965, con la Reforma Menendez Tolosa. También para estas piezas se realizó un estudio sobre la posibilidad de transformarlas al calibre 15,24 cm. APEC. Informes $\mathrm{n}^{\circ} 93$ y 94 de 2 y 10 de abril de 1951 del Polígono de Experiencias.
} 
Embajada española en Berlín ${ }^{172}$. Al recibir éste la factura $n^{0} 933$ de 3 de febrero de 1944, correspondiente al material artillero por valor de 5.398.500 marcos, o lo que era lo mismo 23.429.490 pesetas de la época, la sorpresa fue mayúscula, provocando varias conferencias telefónicas con el Director General de Industria y Material en Madrid con el fin de buscar el origen de esta operación y discutir el precio solicitado, a todas luces exagerado según la opinión de los militares españoles.

El coronel Marín de Bernardo envió la factura al Estado Mayor Central del Ejército, donde se pensó incluir la discusión del precio de estas baterías costeras en las conversaciones de la segunda fase del "Programa Bär" de maquinaria y del nonato "Programa Ankara", próximas a celebrarse. En cualquier caso, la AGEKA exigía en la propia factura el pago de la cantidad adeudada “...enseguida, en efectivo y via Clearing ROWAK-Instituto Español de Moneda Extranjera" ${ }^{\prime 17}$.

El asunto se fue dilatando en el tiempo y las baterías de Canarias no se pagaron de la forma que solicitaba AGEKA. El 11 de diciembre de 1944 el capitán de fragata Espinosa comunicaba al Almirante Jefe del EMA que, al fin, los alemanes presentarían nueva factura al Ministerio del Ejército ${ }^{174}$. La última mención a las mismas se encuentra en un documento fechado el 3 de mayo de 1945 (a menos de una semana de la capitulación alemana) donde se resume la situación de créditos y deudas con el Reich en

\footnotetext{
Caja 20.903. La factura se componía de los siguientes elementos:

-3 Cañones de $15 \mathrm{~cm}$ SKL/40

-3 cañones de $15 \mathrm{~cm}$ SKL/45

-Municiones para los cañones anteriores

-6 cañones de $17 \mathrm{~cm} \mathrm{SKL/40}$

-Municiones para los cañones anteriores

-4 cañones de $2 \mathrm{~cm}$

-Municiones para los cañones anteriores

-Proyectores

-Aparatos de Marina

-Óptica

517.500 marcos

517.500 marcos

1.035.000 marcos

1.125.000 marcos

1.102.500 marcos

90.000 marcos

36.000 marcos

375.000 marcos

225.000 marcos

375.000 marcos
}

${ }^{172}$ Traducción de la carta recibida de la casa AGEKA (Ausfuhrgemeinschaft fur Kriegsgerät), Berlín, de fecha 8 de febrero de 1944. AGMAV, Caja 20.903. Fondo del antiguo Ministerio del Ejército.

${ }^{173}$ Carta remitida por la Sección $4^{\text {a }}$ del EMCE, con el n $n^{\text {o }} 4150-\mathrm{F}$ de fecha 20 de abril de 1944. AGMAV.

-Total
5.398.500 marcos (23.429.490 pesetas)

174 APFE. Embajada en España en Berlín. Agregado Naval. Telegrama transmitido no 904 de 11 de diciembre de 1944. 
esa misma fecha, figurando como única deuda española las baterías de la "Isabella", por un importe de 24.429 .490 pesetas $^{175}$, compensando ampliamente dicha deuda con los depósitos en Alemania realizados por distintos organismos del Ministerio del Ejército español para el pago de diversos $\operatorname{contratos}^{176}$, que no llegaron a buen fin por las circunstancias que impuso el desfavorable desarrollo de los acontecimientos bélicos para la Alemania hitleriana.

\section{I.2.5.2 -U-Boote en España. Los U 573 y U 760 ${ }^{177}$}

El 2 de mayo de 1942, un submarino alemán del tipo VII-C ${ }^{178}$ entraba por sus propios medios en el puerto de Cartagena entre el asombro de las autoridades y la población local. Se trataba del U-573 que al mando del teniente de navío Heinrich Heinsohn acababa de resultar alcanzado pocas horas antes, por las cargas de profundidad lanzadas por un avión Lockheed "Hudson" perteneciente al 233 Squadron del Coastal Command de la Royal Air Force.

Pese a la buena voluntad del Gobierno español con el Tercer Reich, ofreciéndole un tiempo superior al fijado por la Convención de La Haya de 1907, para su reparación y salida del puerto, al final dichos plazos no se pudieron cumplir y tras diversas negociaciones entre el Ministerio de Marina español y la Kriegsmarine, el gobierno alemán accedió a su venta al Estado español por la cantidad de 1,5 millones de marcos (que suponían unos 6,5 millones de las antiguas pesetas), incluyendo todo el material que el submarino llevaba, excepto los torpedos, que se negociaron aparte. De esta manera se evitaron suspicacias -si no problemas- con los Aliados, quienes no

\footnotetext{
${ }^{175}$ Curiosamente la deuda alcanzaba un millón de pesetas más que cuando se recibió la factura el año anterior. AGMAV. Caja 24.704. Fondo del antiguo Ministerio del Ejército.

${ }^{176}$ Como tendremos ocasión de analizar en el Capítulo 6.

${ }^{177}$ Para seguir este epígrafe se ha consultado: Coello Lillo, Juan Luis. Buques de la Armada española. Los años de la postguerra, op. cit., págs. 153-162.

${ }^{178}$ Este modelo de submarino correspondía al tipo oceánico de gran autonomía de la Kriegsmarine. Su armamento principal consistía en cinco tubos lanzatorpedos de $533 \mathrm{~mm}$, cuatro a proa y uno a popa, pudiendo llevar el submarino hasta 14 torpedos. También llevaba un cañón de $88 \mathrm{~mm}$ y 45 calibres $\mathrm{SKC} / 35$, y una ametralladora antiaérea de $20 \mathrm{~mm}$ en la parte posterior de la torre. Su dotación la formaban unos 45 hombres, de ellos cuatro oficiales, pudiendo llevar víveres y agua potable para casi dos meses de patrulla. Coello Lillo, Juan Luis. Buques de la Armada española. Los años de la postguerra, op. cit., pág. 161.
} 
estuvieron de acuerdo desde un principio con la forma tan particular que los españoles aplicaban la Convención de La Haya.

Es muy interesante constatar que en el caso de este submarino, precisamente debido al plazo tan largo que se ofreció a los alemanes para su reparación-del 2 de mayo que entró en Cartagena hasta las 10 de la mañana del 3 de agosto que debía haber salido de puerto- nunca llegó a estar internado en España. Un día antes de que venciera el plazo, el 2 de agosto de ese mismo año, a las 10 de la mañana, tras una sencilla ceremonia y previas las formalidades de rigor, el buque pasaba a engrosar la Lista de Buques de la Armada, arbolando desde entonces pabellón español y pasando a denominarse "G-7"

Un año más tarde, el 8 de septiembre de 1943, otro U-Boote se refugiaba con averías en un puerto español; en esta ocasión se trataba del U-760, otro sumergible germano del tipo VII C que entraba en Vigo después de ser atacado por un avión Wellington del 179D Squadron de la Royal Air Force. Su comandante, el teniente de navío Otto Ulrich Blum tomó esta decisión tras evaluar los daños sufridos en el buque. En este caso, la Armada no se interesó por adquirir el $U$-Boot, que quedó amarrado, primero en Vigo y luego en Ferrol, hasta el final del conflicto mundial. En mayo de 1945 fue entregado a los Aliados, que lo destruyeron en la denominada "Operación Deadlight".

Los trabajos de reparación del "G-7" se prolongaron hasta 1947, incorporándose al servicio activo en la Armada Española en noviembre de ese mismo año ${ }^{180}$.

\footnotetext{
${ }^{179}$ Es muy curioso el asunto de la denominación de este submarino. Al recibirse en Cartagena, el 1 de agosto de 1942, las instrucciones para hacerse cargo del buque, en estas se disponía que de momento no se asignaba numeral ni nombre a la nave, designándolo de manera provisional, para referirse a él, como "submarino tipo G-7”, “...sin dar a esta designación más valor que el de una simple y accidental referencia." Esta denominación provisional e inicialmente sin valor para la Armada, terminó convirtiéndose en definitiva, y como afirma Coello: “... siendo por lo demás perfectamente adecuada, ya que los submarinos de la clase G, pertenecientes también al Tipo VIIC, habían sido bautizados como G-1 a G-6. Coello Lillo, Juan Luis. Buques de la Armada española. Los años de la postguerra, op. cit., pág. 157.

${ }^{180}$ Hasta 1959, año en que entró en servicio el primer submarino norteamericano transferido a España en virtud de los Acuerdos con USA, el "G-7" fue la mejor unidad de la flota submarina española, pese a que su diseño estaba ciertamente desfasado. En junio de 1961 fue rebautizado como S-01 y poco después sería pintado de negro, color adoptado por todos los buques del Arma Submarina española, hasta su baja definitiva en la Lista Oficial de Buques de la Armada, que se produjo el 2 de mayo de 1970, a los 28 años exactos de su llegada a Cartagena en 1942. Fue el U-Boot más longevo de todos los construidos por los alemanes durante la Segunda Guerra Mundial.
} 


\section{I.2.5.3 -Las lanchas de salvamento alemanas FL.S y FL.B de la Luftwaffe}

En el verano de 1944 la Armada española adquirió tres lanchas de salvamento denominadas “LS 1", "LS 2" y "LS 3". Al parecer, según Coello Lillo ${ }^{181}$, su llegada a España está relacionada con la adquisición -coetánea en el tiempo- de la escuadrilla de hidroaviones Dornier Do 24T3, a la cual ya nos hemos referido en el capítulo anterior.

Fueron recibidas el 4 de junio de 1944, la primera, y el 1 de agosto de ese mismo año las otras dos, siento todas ellas del tipo FL.B serie IV de la Luftwaffe, estacionándose de forma inmediata en Pollensa (Baleares), con objeto de apoyar a los Dornier de salvamento allí estacionados, adscritos al recién creado Regimiento $\mathrm{n}^{\mathrm{o}} 51$ de hidros. De hecho, ya durante la guerra civil había llegado -procedente de Alemaniauna embarcación muy parecida a éstas acompañando al AS/ $88^{182}$ de la Legión Cóndor, que fue denominada, precisamente, "Pollensa", y quedó asignada al finalizar el conflicto, al Ejército del Aire. Tras la Segunda Guerra Mundial, las tres lanchas fueron asignadas a tareas de vigilancia costera, reconvirtiéndolas en lanchas guardapescas ${ }^{183}$.

El 21 de agosto de 1944, con una buena parte de Francia en manos de las fuerzas aliadas desembarcadas dos meses atrás en Normandía, se refugiaron en el Puerto de Pasajes (Guipúzcoa) los buques de salvamento de aviones "Immelmann" y "Richthofen", de 1.200 toneladas de desplazamiento. Junto a ellos, entraron también en el puerto vasco tres lanchas de auxilio a aviones de 200 toneladas de la serie FL.S. Las citadas embarcaciones carecían de armamento, que había sido arrojado por sus tripulaciones al mar. De todos estos buques se hizo cargo la Comandancia de Marina de San Sebastián.

El 5 de octubre, el Agregado Aéreo alemán en Madrid se ponía en contacto con el jefe de la $2^{\text {a }}$ Sección del Estado Mayor del Aire, coronel Sedano, para tratar el caso del internamiento en el campo de concentración de Ferrol, de las tripulaciones de estas embarcaciones, que pretendía realizar el Gobierno español. Dejaba claro en general

\footnotetext{
${ }^{181}$ Coello Lillo, Juan Luis. Buques de la Armada española. Los años de la postguerra, op. cit., pág. 254.

${ }^{182}$ Aufklärungsstaffel See $/ 88$ (Escuadrilla de Hidroaviones de reconocimiento 88). Para más información sobre esta unidad aeronaval: Permuy López, Rafael Ángel; O’Donnell Torroba, César. As de Picas. La Escuadrilla de Hidros de la Legión Cóndor en la Guerra Civil española (1936-1939), Galland Books, Valladolid, 2008.

${ }^{183}$ Estas lanchas serían dadas de baja entre 1949 y 1964.
} 
Krahmer que todo el personal de los cinco buques pertenecía a la Luftwaffe germana, bien como personal civil contratado, bien como personal militar de la aviación teutona. En ningún caso se les debería tratar como personal de la Marina, por lo que solicitaba a sus colegas del Ejército del Aire que mediaran para que no fueran llevados a Ferrol.

Decía de las embarcaciones el general alemán:

“...El alejamiento de la tripulación entera de los buques y lanchas no es posible y tampoco habitual según las disposiciones españolas, pues los tripulantes tienen que cuidar del mantenimiento y conservación de los buques y lanchas. Una vez que las embarcaciones hayan pasado a la propiedad del gobierno español podrían desembarcar las tripulaciones. (...) Me permito proponerle dejar a bordo a toda la tripulación hasta que haya sido efectuada la compra de los buques y lanchas por el gobierno español. Después de la venta tendría que ser decidido sobre el modo de alojamiento del personal..."

Desconocemos el fin que se dio a este asunto, pero lo cierto es que ninguno de estos cinco buques fueron adquiridos por el Gobiernon español.

\section{I.3.- EL EJÉRCITO DE TIERRA}

Desde el final de la Guerra Civil española, al igual que ocurriera con la Marina y el Ejército del Aire, se mantuvieron relaciones con las Fuerzas Armadas germanas para la adquisición de diverso material militar necesario en la reconstrucción del Ejército. Diferentes comisiones acudieron a Berlín desde 1939, las primeras -como la presidida por el general Antonio Aranda ${ }^{185}$ en mayo-junio de 1939, o la del general Cánovas Lacruz $^{186}$, efectuada entre el 2 y el 13 de junio de 1940, e incluso la presidida por el

\footnotetext{
${ }^{184}$ Documentación contenida en AHEA. A-11033.

${ }^{185}$ Fue esta una comisión que acompañó a los miembros de la Legión Cóndor en su viaje de regreso a Alemania una vez finalizada la guerra. Además del general Antonio Aranda, que ejercía de jefe de la citada comisión, ésta estuvo compuesta por los generales Juan Yagüe Blanco, José Solchaga, Rafael García Valiño, Carlos Martínez Campos, Camilo Alonso Vega, el contralmirante Agacino, cinco coroneles, un capitán de navío, 13 tenientes coroneles, un capitán de fragata, 22 comandantes, un capitán de corbeta, 15 capitanes, un teniente de navío, siete tenientes y dos suboficiales. En total, 75 militares.

${ }^{186}$ Componían esta comisión, además del general Enrique Cánovas Lacruz, el coronel de Estado Mayor Luis de Madariaga Espinosa, el coronel de Artillería Carlos Las Gaminde, el coronel de Infantería José Pujales Carrasco, el coronel de Ingenieros José Molla Noguerol, el teniente coronel de Estado Mayor José Díaz de Villegas, los tenientes coroneles de Infantería Alejandro Mediavilla Alejandro, José Díaz Fernández y Manuel Carrasco Verde, el teniente coronel de Caballería Emilio López de Letona, los tenientes coroneles de Artillería Joaquín Canterio Ortega y Fernando Pérez Porro, el comandante de Estado Mayor Luis García Loygorri, el comandante del Servicio de Estado Mayor Gonzalo Peña Muñoz, el comandante de Ingenieros Celestino López Pardo y el comandante de Artillería Alfonso Criado Molina. Para los trabajos desarrollados en Alemania el personal asistente se dividió en cinco grupos que estudiaron aspectos relacionados con la organización general de Alemania, defensa química, coordinación
} 
coronel Alberto Lagarde Aramburu en mayo y junio de 1941, a visitar diferentes tipos de acuartelamientos en Alemania e Italia-, fueron más bien comisiones informativas, en las que todos los informes elevados a la superioridad por sus componentes, versaban sobre la organización de la Wehrmacht en cada uno de los múltiples aspectos estudiados.

A partir de finales de 1940, las comisiones enviadas al país teutón por el Ministerio del Ejército fueron con unos objetivos más claros: adquirir material y licencias de fabricación para el Ejército en sus distintas especialidades.

Vamos a relacionar a continuación los contratos establecidos por Ministerio del Ejército con diferentes empresas alemanas, con un seguimiento de su realización y envío a España del material, así como su vertiente económica, en el caso de disponer de datos sobre la misma. Todos estos contratos fueron firmados por la Dirección General de Industria y Material del Ejército de Tierra para adquirir material militar y/o patentes de fabricación, con destino a diferentes armas o servicios del Ejército de Tierra.

\section{I.3.1- Contratos con la empresa "WAFFENWERKE BRÜNN A.G."}

Con esta empresa localizada en el Protectorado de Bohemia y Moravia, se celebraron tres contratos para la compra de armamento. El primero, para la adquisición de 250 ametralladoras pesadas de $15 \mathrm{~mm}$ y su dotación de municiones ${ }^{187}$; el segundo, contemplaba la adquisición de ametralladoras Z.B.-37, fusiles ametralladores Z.B.-26 y de la patente para fabricar el fusil ametrallador ZB-30J. Un tercer contrato con esta casa abría la puerta a la compra de componentes y medios auxiliares para fabricar en España los fusiles ametralladores Z.B.-30J, aunque éste no tuvo plasmación real y no se llegó a depositar cantidad alguna ni en la fábrica ni en ROWAK. Analicemos con más detalle estos contratos y su evolución.

El Consejo de Ministros, celebrado en Madrid el 23 de enero de 1942, tomaba el acuerdo de adquirir en Alemania una partida de 250 ametralladoras pesadas Z.B. 60 , de

entre la aviación y el ejército, ampleo de la artillería antiaérea, servicio de información y de propaganda, fusiles antitanque, servicios de abastecimiento y vestuarios, empleo de la caballería y de las unidades acorazadas y motorizadas en la campaña polaca, blindados de caballería, empleo de las unidades de carros y antitanque, servicio de transportes en campaña, automovilismo militar, ferrocarriles en campaña, equipos de radio, escucha, radiogoniometría, transmisiones en general, municionamiento, tropas de fotalezas, fortificaciones polacas, línea "Sigfrido", etc... Archivo del general José Varela Iglesias (AGJVI). Leg. 113.

${ }^{187}$ Informe de la Comisión de Compras del Ministerio del Ejército en Alemania 15 de noviembre de 1944. Ficha 2. AGMAV. Caja 24.705. Fondo del antiguo Ministerio del Ejército. 
$15 \mathrm{~mm}$., con su correspondiente munición, sumando la citada operación un importe total de $131.556 .250,00$ ptas $(30.312 .500 \text { marcos })^{188}$.

El 31 de marzo de 1942 se firmaba en Berlín ${ }^{189}$ el contrato entre el Ministerio del Ejército español y la casa "Waffenwerke Brünn” (antigua “Zbrojovká Brno”, la cual, después de la anexión alemana, se le denominó con terminología teutona) por el que la empresa checa (ahora del Tercer Reich) se comprometía a suministrar al Ejército Español las ametralladoras Z.B. 60 de $15 \mathrm{~mm}$., así como la cantidad de 3.250 .000 cartuchos de ese calibre para las citadas armas ${ }^{190}$.

La ametralladora Z.B. 60 era un arma automática que funcionaba con toma de gases en el cañón, el cual estaba refrigerado por aire, efectuando un corto movimiento hacia atrás al producirse el disparo. Los gases tomados en el cañón actuaban sobre el émbolo por el que, a su vez, se ponía en movimiento el mecanismo de cierre del arma. El extractor sacaba de la recámara la vaina vacía, expulsándola de su alojamiento a la vez que el cierre empujaba el cartucho siguiente fuera de la banda, introduciéndolo en la recámara y produciéndose de esta manera la obturación, y luego el disparo. Podemos resumir las características de esta excepcional arma de la siguiente forma: elevada cadencia de tiro: 430 disparos por minuto; gran estabilidad en el tiro, con la consiguiente precisión y seguridad; facilidad de servicio y gran eficacia balística (alcance y penetración); munición muy fiable para la lucha contra aviones y contra carros, así como para las demás clases de tiro. Se trataba del arma más ligera de las de su clase.

Para el tiro antiaéreo -misión principal (aunque no la única) por la que se adquirieron estas armas-, disponían de un corrector especial, sencillo, pero de alto grado de perfección, y de funcionamiento enteramente automático por el cual, después de marcarse en él los dos elementos menos variables: la altura y la velocidad del avión,

\footnotetext{
${ }^{188}$ Carta del Director General de Industria y Material del Ministerio del Ejército al Director General de Adquisiciones de la Presidencia del Gobierno de 25 de febrero de 1943. Archivo Histórico Nacional (AHN). Sección Presidencia del Gobierno. Adquisiciones. Leg. 143, exp. 30.

${ }^{189}$ Los pliegos de condiciones técnicas para la adquisición de de las ametralladoras de $15 \mathrm{~mm}$ y de la munición correspondiente, obran en el índice de Actas del Polígono de Experiencias de Carabanchel de 1942, con los números 16 y 24, respectivamente. APEC.

${ }^{190}$ A finales de 1941 se habían realizado pruebas en el Polígono de Experiencias de Carabanchel con una serie de armas presentadas al Ejército Español por la "Wafferwerke Brünn". Concretamente se evaluaron las siguientes: fusil ametrallador Z.B. 30 de $7,92 \mathrm{~mm}$; ametralladora antitanque y antiaérea de $15 \mathrm{~mm}$ Z.B. 60; ametralladora Z.B. 37 de 7,92 mm; fusil automático Z.K. 391; pistola ametralladora Z.K. 383 de $9 \mathrm{~mm}$ y lanzaminas de $50 \mathrm{~mm}$. Actas $\mathrm{n}^{\circ} 185,191,192$ y 203 . APEC.
} 
el corrector permitía obtener todos los elementos, automática y simultáneamente, con la variación del ángulo de situación.

Tras la firma del acuerdo, la empresa "Waffenwerke Brün" comenzó la fabricación de las armas con destino al Ejército Español, en las cuales, y como signo distintivo inequívoco de su destino, se grabó en el cajón de mecanismos el entonces escudo de España, consistente en el águila de San Juan, con el escudo cuartelado de Castilla, León, Aragón y Navarra, yugo y flechas de los Reyes Católicos, todo ello orlado por el lema "Una, Grande, Libre".

El primer envío tuvo lugar a primeros de noviembre de $1942^{191}$, recibiéndose las primeras cuarenta ametralladoras en la Maestranza de Artillería de Madrid el día 10 de ese mismo mes. Prácticamente sin solución de continuidad, diez días después de la primera expedición, un tren compuesto por ocho vagones cargados con 64 ametralladoras Z.B. 60 con sus afustes universales Z.B. 405 y pies de afuste, además de abundante munición, cruzaba por la frontera de Irún con destino a nuestro Ejército. Cuatro meses más tarde, el 28 de marzo, llegaban otras dos expediciones compuestas por cinco y diez vagones, respectivamente, en las que se recibieron otras ciento diez armas.

La última partida, con 36 piezas, llegaba a finales de julio de 1943, y con ella se completaba el total de 250 armas de este tipo y calibre adquiridas al Reich alemán y enmarcadas dentro de los denominados "Suministros Especiales de Material de Guerra". Mucho más compleja fue la recepción de la munición contratada que ascendía, como se ha dicho antes, a 3.250 .000 cartuchos.

Con cada envío de ametralladoras, se recibían pequeñas partidas de proyectiles para las mismas, siendo éstos de los tipos PLV (antiaéreo perforante explosivo), P (de guerra perforante), PV (de guerra perforante explosivo) y C (de fogueo). Además, alguna expedición de este material llegó de manera independiente, no acabando de completarse nunca el pedido inicial, debido al cambio de las condiciones del transporte terrestre, motivado por el desembarco de Normandía y el corte de las líneas de comunicación alemanas.

\footnotetext{
${ }^{191}$ La documentación sobre transportes, llegadas a España, franquicias arancelarias, aduanas, etc... en AHN. Sección Presidencia del Gobierno. Adquisiciones. Leg. 143, exp. 8, 30 y 32.
} 
A finales de junio de 1944 se habían recibido en España 2.640.000 cartuchos, por lo que faltaban para completar el lote, un total de 610.000. De ellos, 460.000 fueron cargados en un tren alemán junto a las 50 alzas ópticas, 1.300 fusiles ametralladores Z.B. 26 y algunas piezas para los 100 fusiles ametralladores que ya estaban en España. Dicho tren, enviado en julio de 1944, sufrió toda clase de peripecias en territorio francés, llegando a perderse seis de sus vagones, en los que viajaban los proyectiles, apareciendo dos meses más tarde en alguna estación intermedia del recorrido. Si bien el Agregado Militar español en Berlín les siguió la pista y logró encontrarlos, nada se pudo hacer para que alcanzaran la frontera española.

Resulta interesantísima la lectura de una carta escrita el 14 de abril de 1945 por el Agregado Militar español en Berlín, y dirigida al Jefe de la $4^{\text {a }}$ Sección del Estado Mayor Central del Ejército, coronel D. Jesús Aguirre, en la que el primero pone de manifiesto -entre otros temas- el asunto del estado del contrato con la Waffenwerke. De ella extraemos un interesantísimo párrafo ${ }^{192}$ :

“...Esta casa (Waffenwerke Brünn) es la que más diligentemente contestó dando su conformidad a las diversas propuestas que se le habían hecho. Lo primero que iba a hacer era el envío de las 50 alzas ópticas que quedaban por remitir. Por la dificultad de transporte que desde hace tiempo existe en Alemania, es necesario para cualquier envío recibir del OKW un número especial, un Vollfahrtnummer, que la Casa, vistas las dificultades que tenía para conseguirlo, nos pidió nuestra influencia cerca del OKW Como la mayor parte de este organismo se había trasladado a Mannhein, allí fue a parar mi petición, y allí ha perecido, quedando muerto el envío de las alzas ópticas. Todos los demás asuntos de esta Casa han quedado igualmente difuntos por obra y gracia de los rusos. El dinero que tenía la Casa se ha perdido, a no ser que después de la guerra se consiga algo con negociaciones diplomáticas, cosa que veo bastante difícil..."

Además de las 50 alzas que nunca llegaron, otras 53 se destruyeron en la Maestranza de Sevilla, por lo que sólo 147 de estas armas estaban en condiciones óptimas para ser empleadas.

De los 131.556.250 ptas (30.312.500 marcos) que importaba esta operación, el Estado español puso a disposición de la casa un total de 118.502.339,92 ptas (27.304.686 marcos), de los cuales sólo se había recibido material por valor de

\footnotetext{
192 Documantación diversa del "Programa Bär". Datos generales y correspondencia con el Agregado Militar (1943-1947). AGMAV. Caja 24.707. Fondo del antiguo Ministerio del Ejército.
} 
111.975.385,20 ptas (25.800.778 marcos), quedando en poder de la fábrica 6.526.954,72 ptas (1.503.906) marcos como saldo a favor de España por el material pagado y no recibido. Este es el dinero al que se refería el Agregado Militar en Berlín.

El Ministerio del Ejército llegó a un segundo acuerdo ${ }^{193}$-independiente del anteriormente analizado- con la "Waffenwerke Brünn", el 28 de junio de 1943, por el que España adquiriría 1.000 ametralladoras Z.B.-37 y 5.000 fusiles ametralladores Z.B.26, así como la patente y ayuda técnica para fabricar en España el fusil ametrallador Z.B.-30. Este contrato se encontraba comprendido en el Plan de Labores aprobado para el año 1943, a pagar con los créditos concedidos por presupuesto extraordinario, y su importe alcanzó los 79.942.800,00 ptas (18.420.000 marcos).

La ametralladora Z.B.-37 era una máquina con funcionamiento por toma de gases en un punto del cañón y alimentación por cinta metálica. Su cañón, recubierto de un generoso manguito anillado para propiciar la refrigeración por aire, era flotante, dispuesto entre dos gualderas laterales por cuyas guías interiores retrocedía un corto trecho tras el disparo unido al cerrojo hasta que el impulso de los gases actuantes sobre el émbolo deshacía el acerrojamiento y permitía que aquel prosiguiera, libre, su retroceso expulsando la vaina vacía y tomando a la vuelta un nuevo cartucho de la cinta. El cañón podía cambiarse con facilidad, accionando el asa de transporte; dispositivo este que ofrecía un sólido anclaje, aunque era de manejo algo más incómodo que el de las Z.B.-26 y Z.B.-30. El trípode Mod. 308 era tremendamente sólido, resultando a cambio bastante pesado; disponía de un tubo suplementario, cuya longitud se graduaba a cremallera, para emplazar la ametralladora en posición antiaérea, a cuyo efecto la máquina disponía de las miras oportunas. En cuanto a la calidad de la ametralladora, resulta muy ilustrativo el texto con que se inicia el capítulo "Interrupciones" en el manual de la misma ${ }^{194}$ : "Las interrupciones son poco frecuentes... algunas de ellas son rarísimas."

\footnotetext{
${ }^{193}$ Informe de la Comisión de Compras del Ministerio del Ejército en Alemania 15 de noviembre de 1944. Ficha 1. AGMAV. Caja 24.705. El pliego de condiciones técnicas para la compra de 5.000 fusiles ametralladores Z.B. 26 y 1.000 Z.B. 37 consta en el Acta $n^{0} 50$ del Polígono de Experiencias de Carabanchel y el de adquisición de la patente para fabricar en España el fusil ametrallador Z.B. 30, figura en el Acta n ${ }^{\circ} 37$ del mismo establecimiento militar. APEC.

${ }^{194}$ Manual. La ametralladora Z.B. 37 de dotación en los Escuadrones de Ametralladoras de las Brigadas de Caballería. Escuela de Aplicación de Caballería y Equitación del Ejército. F-4. Septiembre de 1944.
} 
El 8 de agosto de 1943, junto a diferente munición de $15 \mathrm{~mm}$, se recibió el primer lote de 500 ametralladoras Z.B.-37, que serían entregadas en el Parque y Maestranza de Artillería de Madrid en fechas posteriores. Estas armas vinieron incompletas por no acompañarlas las alzas ópticas ni los correctores antiaéreos. El 30 de septiembre, la "Waffenwerke Brün" manifestó que dichos elementos serían enviados con el segundo lote, el cual se encontraría dispuesto para su recepción a finales de noviembre de 1943, extremos uno y otro, incumplidos por la fábrica germana ${ }^{195}$.

El proceso se fue dilatando en el tiempo, y lo que en principio debería estar solucionado antes de finalizar el año 1943, se prometió que lo estaría en enero de 1944. Los motivos expuestos por la empresa aludían a demoras en el acopio de materias primas y dificultades en el desarrollo normal de los planes de trabajo previstos por consecuencia de las necesidades de la guerra, lo que parece lógico pues las circunstancias por las que pasaba Alemania eran extraordinarias y, sin duda alguna, influyeron en la demora citada.

La segunda remesa de 500 ametralladoras llegaría a España el 20 de marzo de 1944 siendo recibida y revisada en la Maestranza de Madrid el 14 de abril de 1944. Según lo estipulado, con esta expedición se recibieron los 500 correctores antiaéreos correspondientes a las ametralladoras recibidas en la primera expedición pero no así las alzas antiaéreas para las 1.000 ametralladoras, que nunca se llegarían a recibir. En su visita a España en mayo de 1944, el Director de "Waffenwerke Brünn”, Herr Stockach, discutió con las autoridades españolas la entrega de estas alzas asegurando y prometiendo el alemán, el comienzo del suministro para el último trimestre de 1944 o el primero de 1945. Dicha promesa, evidentemente, no se cumplió.

Los fusiles ametralladores Z.B.-26 -conocidos desde la guerra civil por nuestro ejército- fueron elegidos como armamento normal del mismo. Para ello se decidió la fabricación en nuestro país de esta arma (aunque en su versión Z.B.-30, que se diferenciaba de su predecesor en un regulador de gases y alguna otra mejora de menor entidad), a lo que los alemanes accedieron pero con ciertas condiciones. Estas pasaban por adquirir 5.000 armas Z.B.-26 directamente a la "Waffenwerke Brünn".

\footnotetext{
${ }^{195}$ Carta del Director General de Industria y Material del Ministerio del Ejército al Director General de Adquisiciones de la Presidencia del Gobierno de 13 de agosto de 1943. Se recibieron un total de seis vagones de ferrocarril con 500 cajas numeradas de la 0001 a 0500 conteniendo otras tantas ametralladoras Z.B.-37 y 358 cajas numeradas de la 1101 a la 1458, conteniendo 14 cajones cada una con dos bandas. AHN. Sección Presidencia del Gobierno. Adquisiciones. Leg. 143, exp. 30. También hay información sobre este material en el legajo 130.
} 
El 15 de febrero de 1944 se recibían en la frontera de Irún los 100 primeros fusiles ametralladores Z.B.-26 del contrato, que a la postre serían los únicos que llegarían a España. Dos meses más tarde, la Maestranza de Madrid, en Acta $n^{0} 118$ bis, se hacía cargo de los mismos. Quedaron, por tanto, sin entregar al Ejército español las 1.000 alzas de las ametralladoras Z.B.-37, 4.900 fusiles ametralladores Z.B.-26 completos $^{196}$ y los 100 correctores y accesorios de otras tantos fusiles ametralladores Z.B.-26 entregados en febrero de 1944.

En noviembre de 1944, del importe total del contrato se habían pagado ya a la casa 35.233.566,62 ptas $(8.118 .333,1$ marcos) y se habían depositado en ROWAK 846.300 ptas (195.000 marcos). Pero el valor del material recibido en España era solo de 26.735.250 ptas (6.160.195,8 marcos), por lo que había un exceso en poder de la casa contratante de $8.498 .316,02$ ptas (1.958.137,3 marcos).

Se produjo un tercer contrato con la Waffenwerke Brünn para la adquisición de componentes y medios auxiliares para fabricar los fusiles ametralladores Z.B.-30J ${ }^{197}$. Se trataba de un importantísimo acuerdo que, desgraciadamente no se llevó a efecto, para adquirir en Alemania componentes parcialmente acabados y maquinaria-herramientas para la fabricación en España del fusil ametrallador Z.B.-30 cuya patente se había adquirido a "Waffenwerke Brünn". De no conseguir el transporte a España del herramental, calibres y plantillas -como así ocurrió- habría que construirlo, por lo que la fabricación de los fusiles se retrasaría los años que se hubieran que emplear en la producción de estas herramientas.

El montante de este contrato ascendía a 17.360 .000 ptas $(3.986 .175,1$ marcos), del cual no se llegó a depositar nada ni en la propia casa contratante ni en ROWAK.

Por último, aunque se negoció un contrato con la casa checa para una nueva adquisición de ametralladoras de $15 \mathrm{~mm}$ y su munición, que preveía un importe, en su

\footnotetext{
${ }^{196}$ Como hemos visto en el epígrafe anterior, 1.600 fusiles ametralladores Z.B.-26 estaban en camino en los 16 vagones remitidos por "Waffenwerke Brün" y se perdieron en Francia.

${ }^{197}$ Informe de la Comisión de Compras del Ministerio del Ejército en Alemania 15 de noviembre de 1944. Ficha 3. AGMAV. Caja 24.705. Fondo del antiguo Ministerio del Ejército.
} 
primer plazo, de 44.000.000,00 ptas. (10.138.248 marcos), nunca se llegó a firmar ni pasó de ser una mera especulación.

\section{I.3.2- Contratos con la empresa "KRUPP".}

Tiempo antes de que el "Programa Bär" comenzara su andadura, uno de los contratos en curso más deseados por los militares españoles era el que se negociaba con la casa "Krupp" para adquirir la patente de fabricación del antiaéreo alemán por excelencia, el Flak de 88/56 mm. El importe negociado con la citada casa constructora germana fue de 13.020.000,00 pesetas y el citado contrato fue aprobado y firmado en Consejo de Ministros, ordenando la Dirección General de Industria y Material del Ministerio del Ejército el importe del primer plazo en el Instituto Español de Moneda Extranjera.

Ya el 14 de noviembre de 1940 la "Krupp"198 había hecho una oferta al gobierno español en la que entre otros materiales se ofrecían 20 baterías de $88 \mathrm{~mm}$ con sus direcciones de tiro, 20 secciones de proyectores y 80 fonolocalizadores "Electroacustic"; oferta que originó el envío - un mes más tarde- de una comisión militar a Alemania presidida por el coronel Salgado Muro. En dicha visita de los militares españoles a Alemania se propuso a la dirección de la empresa "Krupp" la posible venta de la patente para fabricar estos cañones en España, cuestión que sería contestada por la casa fabricante mes y medio más tarde con una clara negativa. El asunto se paralizó entonces (febrero de 1941) hasta finales de ese mismo año, fecha en la que el Estado Mayor del Ejército comunicaba al Agregado Militar en Berlín entonces el teniente coronel José Luis Roca de Togores- que las necesidades de material de artillería antiaérea eran 30 baterías de cañones de 88/56 con respetos, accesorios, carrillos para el transporte y direcciones de tiro completas así como 16 proyectores y ocho fonolocalizadores, precisando que la Embajada iniciara las gestiones

\footnotetext{
198 Para seguir este apartado, hemos analizado la documentación que conserva el AHEA 11035. 2 $2^{\mathrm{a}}$ Sección, $3^{\mathrm{a}}$ y $15^{\mathrm{a}}$ División. Agrupación Embajadas. Comisiones. Adquisiciones Expediente $\mathrm{n}^{\mathrm{o}} 553$ referente a correspondencia entre la $2^{a}$ Sección del EMA y el Agregado Aéreo en Berlín sobre adquisiciones de material y publicaciones que solicitan diversos organismos del Ministerio del Aire a Alemania. También se incluyen la correspondencia referente a Comisiones del Ejército del Aire español que visitan Alemania para asuntos diversos (generalmente relacionados con pedidos de material. Años 1940-1945. EMA . División de Operaciones.
} 
con el gobierno alemán para que este otorgara la autorización necesaria para que este material pudiera ser suministrado por la "Krupp".

En marzo de 1942, el Ministerio del Ejército autorizaba una comisión para Alemania a los tenientes coroneles de artillería D. Germán Castro Gómez y D. Ramón Páramo Díaz, así como al comandante D. Cesáreo Martín Alonso, con tres objetivos definidos. Por un lado estudiar las posibilidades de compra de material y patentes relacionados con la artillería antiaérea: cañones de 88/56, proyectores, fonolocalizadores y direcciones de tiro. En segundo lugar, gestionar con las autoridades alemanas el estudio del material de artillería de campaña Rheinmetall de 150/52 mm y la posible adquisición de la patente para fabricar en España dicho material artillero. Por último, analizar y estudiar la dirección de tiro de costa "Siemens".

Como en Alemania la artillería antiaérea estaba bajo el mando de la Luftwaffe y la artillería de costa, de la Marina, para realizar esta comisión, se vieron implicados los tres agregados militares en Berlín, ya que el aeronáutico tuvo que solicitar la autorización al mando de la Luftwaffe para que los tres jefes españoles pudieran visitar los establecimientos y fábricas correspondientes, así como las fechas previstas para dicha visita, y el naval tuvo que hacer lo propio con el mando de la Kriegsmarine.

Entre el 7 y el 15 de abril de 1942, la comisión presidida por el teniente coronel Germán Castro, visitó las fábricas "Krupp", “Zeiss”, "Electroacustic”, "Rheinmetall” y "Siemens", entrevistándose con personal de las mismas, y analizando el material de artillería que habían solicitado. El 30 de abril, " Krupp” remitía al general jefe del Estado Mayor del Ejército español una carta con un anexo en la que básicamente se hacía una oferta sobre la concesión de la licencia ${ }^{199}$ de construcción del cañón antiaéreo

\footnotetext{
${ }^{199}$ Se trataba de la oferta de la casa "Krupp" no 1208, que comprendía:
}

A).- Un juego de planos calcables del conjunto y los de grupos con las listas de piezas así como los planos de detalle indicados en dichas listas con las denominaciones normalizadas de los materiales, para la construcción de la pieza con tren de rodaje especial, dispuesta para receptores eléctricos de índices coincidentes. No entraba en la patente ni la dirección de tiro, ni los receptores eléctricos para dirección y elevación, ni la instalación eléctrica, ni la óptica ni el freno de marcha accionado por aire comprimido (sistema "Knorr") ni las partes que se pudieran adquirir usualmente en el comercio, como cojinetes de bolas, ruedas con sus neumáticos, etc.

B).- Un juego de planos calcables del conjunto y los de grupos con las listas de piezas así como los planos de detalle indicados en dichas listas con las denominaciones normalizadas de los materiales, para la construcción de el cuerpo de la granada explosiva L 4,5 con culote atornillado y vaina del multiplicador, la vaina de cartucho y el estopín C/12 n.A., además de diversos datos técnicos para la carga de 
de $8,8 \mathrm{~cm} \mathrm{~L} / 56$ con su munición. También se prometía estudiar la oferta española, manifestada por la comisión, de fabricar en España ciertas partes sueltas del cañón antiaéreo citado y suministrarlas a Alemania, a cambio del envío a España de cañones completos. El convenio definitivo sobre la licencia de construcción del cañón antiaéreo de $88 \mathrm{~mm}$ y la munición dependería, como es obvio, de la autorización del Ministerio del Aire alemán y del resultado del estudio de las posibilidades de fabricación en España. El precio que proponía "Krupp" para esta patente era de 3.000.000 de marcos y toda la documentación sería entregada en idioma alemán.

Para las cuestiones relacionadas con el pago, "Krupp" proponía un 30\% del mismo en el momento de firma del contrato, otro 30\% a los tres meses de la firma del mismo y el $40 \%$ restante, a la entrega de los últimos planos y datos a la Embajada española en Berlín. La empresa se comprometía a comenzar la entrega de información, a los tres meses de la firma del contrato y exigía a España la fabricación en el territorio nacional, por empresas españolas y "exclusivamente para las necesidades de su propio ejército, quedando excluida expresamente su utilización para fines de exportación a otros países (ni siquiera a título de préstamo)”. La oferta era válida hasta el 31 de julio de 1942.

El 6 de mayo de 1942, los militares españoles de la comisión de artillería presidida por el teniente coronel Castro, se entrevistaron con el jefe de la sección de aprovisionamiento del Ministerio de Aire germano, señor Müller, con el objetivo de concretar las gestiones relativas a la adquisición de licencias de material antiaéreo. Dicho representante comunicó a los militares españoles que la propuesta de licencia entregada por "Krupp", tras el informe favorable del mariscal Milch, se encontraba en ese momento pendiente sólo de la firma del Mariscal Goering. Todo lo referente a suministro de direcciones de tiro, proyectores, fonolocalizadores y material de transporte de dichas piezas, era imposible en aquellos momentos, por ser necesarios para las tropas alemanas en los diferentes frentes de batalla y en la defensa antiaérea de

proyección, la carga explosiva y el multiplicador. No entraban en la licencia las espoletas con mecanismo de relojería.

C).- Las hojas de normas para las partes normalizadas indicadas en las listas de piezas

D).- Para todos los materiales, de cuya construcción "Krupp" no estuviera autorizada a disponer y los cuales Krupp adquiriera a proveedores, se entregarían los datos técnicos para hacer los pedidos y una lista de las casas proveedoras respectivas, pero sin indicación de precios. 
ciudades y objetivos estratégicos. Quizás, en el plazo de uno o dos años, cuando los cañones españoles pudieran empezar a salir de las fábricas -comentó el señor Müller-, fuera posible suministrarlos.

Otros aspectos tratados en la reunión fueron el ofrecimiento por parte alemana de fonolocalizadores franceses de botín de guerra, las gestiones con la casa holandesa "Hazemeyer" por si ésta pudiera suministrar direcciones de tiro antiaéreas, la gestión del cambio de una de las cláusulas del contrato de "Krupp", para poder usar en España espoletas de construcción nacional para los proyectiles de $88 \mathrm{~mm}$ y la promesa de estudio del ofrecimiento español de fabricar para Alemania determinados elementos del cañón de 88 L/56 a cambio de piezas completas de este cañón, que serían enviadas a España como contraprestación. Evidentemente, los alemanes querían condicionar esta propuesta hispana a la visita a las fábricas españolas de ingenieros germanos que estudiarían las posibilidades de la industria y la clase de elementos a fabricar.

Tras su estudio y aceptación por ambas partes ${ }^{200}$, la licencia de fabricación de los famosos cañones antiaéreos de $88 \mathrm{~mm} \mathrm{L/56} \mathrm{fue} \mathrm{vendida} \mathrm{por} \mathrm{"Krupp"} \mathrm{al} \mathrm{gobierno}$ español por el importe pactado de 13.020.000,00 ptas. (3.000.000 marcos), dando origen a la construcción en España del que se llamaría a partir de entonces "Cañón antiaéreo de 88 mm FT-44", correspondiendo las letras FT a "Fábrica de Trubia", instalación fabril donde se llevó a cabo la fabricación de los elementos principales, y el número 44, por el año en el que comenzó realmente la fabricación de la serie.

La pieza fabricada en España integraba un cañón RA.1 (idéntico al que montaba la versión Flak 18) y un montaje similar al de las últimas versiones del Flak 36 y las primeras del Flak 37, con la nueva plataforma cruciforme adaptada para los carrillos "Sonderhanger 202" y el sistema de recepción y transmisión de datos de índices coincidentes “Ubertragungsgerät 37” (UTG 37) ${ }^{201}$.

\footnotetext{
${ }^{200}$ El contrato fue aprobado en Consejo de Ministros de 27 de febrero de 1943, ordenándose el ingreso en el IEME del importe del primer plazo de manera inmediata. "Contratos con casas alemanas pendientes y en tramitación por esta comisión de compras". Documento sin fecha, pero es posible que sea de abrilmayo de 1943. AGMAV Caja 24.711. Fondo del antiguo Ministerio del Ejército.

201 La patente para fabricar estos aparatos de transmisión-recepción de datos se adquirió a la casa "Siemens", independientemente de este contrato con "Krupp". En el "Programa Bär", los cañones de esta clase que llegaron a España venían sin este sistema instalado, aunque en ese mismo programa se adquirieron uno para cada pieza de las contratadas. Su nombre era "SAM" (Siemensapparatemaschine).
} 
La variante española del famoso Flak alemán -quizás la más importante, conocida y versátil pieza artillera de todos los tiempos-comenzó a fabricarse en Trubia (Asturias) en julio de 1943, y después de 12 años y casi 250 cañones construidos, se daba por finalizada en 1955, como consecuencia de dos circunstancias: por un lado, la pieza española se había quedado técnicamente desfasada pese a los esfuerzos de algunos que, bien intentaron prolongar su vida activa mediante la incorporación de adelantos técnicos que la hicieran más acorde con los nuevos tiempos, o idearon posibles usos alternativos aprovechando el magnífico sistema de armas que proporcionaba ${ }^{202}$.

Por otro, los pactos firmados en 1953 con los Estados Unidos de Norteamérica, incluyeron el envío de material antiaéreo de 90 mm L/50 M-1 y la posibilidad de fabricar en España, bajo patente sueca, los famosos cañones antiaéreos ligeros de $40 \mathrm{~mm} \mathrm{L/70}$ Bofors, lo que hizo innecesario seguir fabricando los " 88 " alemanes por más tiempo.

Cuando ya estaba ampliamente superada en cometidos antiaéreos por cañones mucho más modernos y eficaces, se le dio un cometido de artillería antilancha, encuadrada en Regimientos de Artillería de Costa, prolongando su vida activa hasta finales de la década de los ochenta del siglo XX, fecha en que se dieron de baja las últimas piezas de este modelo, todavía en servicio en el ejército español.

\section{I.3.3- Contratos con la empresa "RHEINMETALL BORSIG A.G.}

La existencia en España, desde los tiempos de la Guerra Civil, de cañones de 37 mm fabricados por esta empresa - unos en configuración antitanque y otros, antiaéreadio origen a un contrato para la adquisición de 50.000 disparos completos para cañón antitanque y 10.000 disparos completos para cañón antiaéreo, con el fin de disponer de

\footnotetext{
${ }^{202}$ En nuestro país se intentó alargar la vida operativa de este cañón mediante diferentes procedimientos. Se diseñó un nuevo tubo, con más longitud, para aumentar el alcance de la pieza, se montó un servosistema de puntería automática de diseño italiano modelo "Galileo" e, incluso, se utilizó el montaje para albergar un lanzamisiles de costa. Molina Franco, Lucas. El legendario cañón antiaéreo de $88 \mathrm{~mm}$. Su historia y evolución en el Ejército español. Quirón Ediciones, Valladolid, 1996, págs. 87-94.
} 
munición para ambos modelos. El importe de dicho contrato ascendió a 1.573.732,7 marcos $(6.830 .000,80$ pesetas $)$. Nos consta que se recibió la partida completa ${ }^{203}$.

Por otro lado, con esta misma empresa se negoció la adquisición de la patente del cañón de $15 \mathrm{~cm}$ largo y su munición ${ }^{204}$. Conviene detenernos en el estudio del desarrollo y consecución de esta licencia por su trascendencia posterior y la entidad de la fabricación de la pieza artillera.

El cañón de 150/55 mm K18 había sido proyectado en 1933 por la empresa "Rheinmetall-Borsig"como pieza pesada de campaña para la artillería divisionaria alemana que entonces iniciaba su rearme, entrando en servicio con la Wehrmacht en $1938^{205}$. El interés que este material había despertado en España se debía al deseo de contar con un arma de largo alcance como pieza pesada de campaña y defensa móvil de $\operatorname{costa}^{206}$, modalidades a que se prestaba perfectamente el "K 18", pues disparaba un proyectil de 43 kilogramos a una distancia de casi veinticinco kilómetros; como contrapartida su peso, en torno a las 13 toneladas, y la longitud de su tubo, hacían del mismo una pieza ciertamente engorrosa que debía dividirse en dos cargas para su transporte.

Las piezas que componían una batería podían emplearse con puntería centralizada -especialmente indicada, en el caso de tiro de costa- enlazadas a una estación directora "Siemens". En esta configuración los movimientos de puntería de cada pieza se realizaban de acuerdo con los datos enviados por la dirección de tiro.

La licencia de fabricación fue adquirida a principios de 1943 por un importe de 13.020.000,00 ptas. (3.000.000 marcos), firmando el correspondiente contrato para su adquisición y recibiendo autorización por parte de las autoridades germanas para que

\footnotetext{
${ }^{203}$ Secretaría Técnica del Consejo Ordenador de Minerales Especiales de Interés Militar. $2^{\circ}$ Jefe. Asunto: Restitución de metales no férricos. 17 de marzo de 1944. AGMAV. Caja 24.713. Fondo del antiguo Ministerio del Ejército.

${ }^{204}$ Informe de la Comisión de Compras del Ministerio del Ejército en Alemania 15 de noviembre de 1944. Ficha 10. AGMAV. Caja 24.705. Fondo del antiguo Ministerio del Ejército.

${ }^{205}$ Mortera Pérez, Artemio. "Kanone Rheinmetall K.18 de 15 cm." Revista Española de Historia Militar $\mathrm{n}^{\mathrm{o}} 125$. Valladolid, 2012, págs. 152-161.

${ }^{206}$ Frente a los emplazamientos tradicionales fijos, situados en lugares de la costa escogidos por su gran visibilidad y buenas características geográficas, la defensa móvil de costa se basaba en la utilización de materiales artilleros de calibre medio, que pudieran cambiar de posición con relativa facilidad, debido a su gran movilidad, y que dispusieran de gran energía de perforación de blindajes, gracias a la gran velocidad inicial que imprimían a sus proyectiles.
} 
dicha fabricación se llevase a cabo en España. En ese mismo contrato, concretamente la cláusula 13, dejaba la puerta abierta a la firma de un nuevo contrato con la misma casa como veremos en el apartado siguiente-, para la adquisición de una pieza tipo de esta clase y calibre, que sirviera de modelo para la serie fabricada en España. Dicha pieza vendría provista de los mecanismos correspondientes para recibir los receptores de la dirección de tiro.

Con posterioridad a la decisión del Ministerio del Ejército de adquirir en Alemania esta patente, la Comisión que negoció en Berlín el material que compondría el denominado "Programa Bär", a las órdenes del general de división Carlos Martínez de Campos adquirió 150 cañones de $122 \mathrm{~mm}$ de procedencia rusa y su correspondiente munición. Como quiera que esta cantidad era suficiente para dotar a todos los cuerpos de ejército españoles de la época con un grupo de artillería de ese calibre, el propio Martínez de campos en mayo de 1943 escribió al Jefe del Estado Mayor Central del Ejército, Rafael García Valiño ${ }^{207}$ :

“...algunas consideraciones conducentes a simplificar nuestra fabricación de material, reduciéndola al menos número posible de tipos:

1- El sistema actualmente previsto (cañón de 10,5 y cañón de 15 $\mathrm{cm}$ ) podría ser reemplazado por el sistema intermedio de 122 (a condición de impulsar la adopción de modelo para cañón de $21 \mathrm{~cm}$ y la construcción correspondiente.

2- Esto daría lugar a tener que seguir construyendo baterías de $15,24 \mathrm{~cm}$ Vickers para costa.

3- Se evitaría la puesta en marcha de cañón de 10,5 y del de 15 $\mathrm{cm}$, se tendrían las manos libres para impulsar los cañones de 20 o 21 $\mathrm{cm}$, se tendría un solo material de $15 \mathrm{~cm}$ en costa y se simplificaría el municionamiento. Por contra, como inconvenientes, habría una pequeña falta de intercambiabilidad entre una pequeña parte de los materiales de campaña y costa y se perderían los 3.000 .000 de marcos invertidos en comprar la patente del cañón de $15 \mathrm{~cm}$ Rheinmetall.

Por todas estas razones me tomo la libertad de proponer a VE lo siguiente:

a- Gestionar aquí el reemplazo de la patente adquirida del C. 15 $\mathrm{cm}$ por la del C. $21 \mathrm{~cm}$ de la misma casa, mediante el compromiso leal de devolver la colección de planos ya recibidos.

b- Abonar la diferencia entre los valores de ambas patentes y un tanto por ciento prudencial para compensar la operación.

\footnotetext{
${ }^{207}$ Carta del presidente de la Comisión Extraordinaria para material de guerra. Num. 18 Berlín 11 de mayo de 1943. AGMAV. Caja 24.711. Fondo del antiguo Ministerio del Ejército.
} 


\section{c- Renunciar a la adquisición del C. $15 \mathrm{~cm}$ Rheinmetall.}

d- Gestionar la adquisición de un C. $21 \mathrm{~cm}$ Reinmetall...”

Nada de lo propuesto por Martínez de Campos fue aceptado por García Valiño aunque en buena parte de lo que afirmaba en su escrito estaba bastante acertado, a la vista de los acontecimientos posteriores y del empleo real de los cañones rusos de 122 mm así como del desgraciado proyecto del cañón Rheinmetall de $15 \mathrm{~cm}-$, por lo que la gestión del cañón de $15 \mathrm{~cm}$ siguió su camino, un camino lleno de espinas, sinsabores y gastos que no produjeron, a la larga, ningún beneficio al Ejército de Tierra español.

Al final se decidió emplear los planos que se habían adquirido y acometer la construcción en España de estos cañones con objeto de disponer de artillería de Ejército de calibre $15 \mathrm{~cm}$ y simultanear su empleo para lo que se conoció como "Defensa Móvil de Costa".

El EMCE determinó en 1944 el armamento que había de construirse para armar al ejército español debidamente, señalando que en el caso de este tipo de cañón pesado, las necesidades eran de 46 baterías, lo que significaban 184 cañones $^{208}$.

La Fábrica de Trubia fue la consignataria principal de los encargos para la construcción de estos cañones en España, comenzando la misma en marzo de 1945. Seis años después, en 1951, finalizaba la fabricación de la primera de las piezas, remitiéndose la misma a Cádiz, al Polígono de Experiencias "Costilla", para realizar con ella un período de pruebas. Sea como fuere, tras diversas órdenes de construcción en diferentes años y cantidades, en 1963 se entregaba la pieza $n^{\circ} 17$, última de las construidas. Veinte años después de la adquisición de la patente de fabricación, la industria española terminaba un proceso lleno de dificultades y contratiempos; pero si en 1943 el cañón era moderno y con una buenas prestaciones, en 1963 la pieza estaba completamente desfasada, a lo que había que añadir la inexistencia de direcciones de tiro adecuadas para su empleo ${ }^{209}$ y la calidad de los materiales utilizados en su proceso

\footnotetext{
${ }^{208}$ En un informe de la Fábrica Nacional de Trubia fechado el 22 de junio de 1947 y firmado por el coronel ingeniero de armamento José Lacleta, se afirmaba que en el otoño de ese mismo año estaría finalizada la primera de las piezas, teniendo previsto terminar otras tres -para completar la batería- a comienzos del año siguiente. Las previsiones, según los informes de la Fábrica, eran completar 24 piezas anuales "si se puede disponer de las primeras materias necesarias y créditos suficientes para el costo que representa". Ninguna de estas previsión se llegó a cumplir. "Origen y principales características de algunos de los materiales de artillería en construcción y para ser fabricados por la Factoría Nacional de Trubia. 1947”. AFNFF. Leg. 15.301.

${ }^{209}$ En el transcurso de los viajes del general Martínez de Campos a Alemania -presidente de la Comisión Especial para Material de Guerra- para negociar el "Programa Bär", como tendremos ocasión de ver en
} 
constructivo, que dieron más de un problema a los artilleros del Polígono de Experiencias donde se probó el cañón $n^{\circ} 1^{210}$.

Como complemento del contrato anterior se firmó otro contrato con Rheinmetall para de adquirir en Alemania un cañón completo de $15 \mathrm{~cm} \mathrm{~L} / 55$ junto a su munición (100 proyectiles rompedores y 100 perforantes) que sirviera de muestra para construir en España la serie para la que se había comprado la licencia a la misma empresa ${ }^{211}$.

El contrato se firmó entre el representante de la casa "Rheimetall Borsig" y el teniente coronel Ignacio Moyano Araiztegui, de la Dirección General de Industria y Material, el 24 de diciembre de 1943 por un importe de 1.472 .128 ptas. (339.200 marcos), cantidad que se depositó en ROWAK para ser abonada a "Rheinmetall" cuando se recibiera la documentación del envío, importando la pieza 1.150.100,00 pesetas (265.000 marcos) y los proyectiles el resto.

El 11 de abril la pieza adquirida estaba dispuesta en el polígono militar de Underluess para su recepción por los representantes del Ejército español, misión para la que fue comisionado el teniente coronel del arma de Artillería José Villegas Silva. El cañón completo fue entregado por las autoridades alemanas a la comisión española presente en Berlín, compuesta por el teniente coronel Villegas y el comandante Ulzúrrun, dando éstos su conformidad.

Una vez regresaron a España estos dos jefes, se recibió en el EMCE el protocolo de recepción para su firma material por parte de Villegas, llevando implícita dicha firma, la obligatoriedad del pago de la pieza a la casa fabricante, sabiendo a ciencia

capítulos posteriores, visitó diferentes empresas de armamento, entre las que hay que destacar la llevada a cabo a la casa "Hazemeyer", donde estudió una dirección de tiro apropiada para estos cañones de $15 \mathrm{~cm}$, que se fabricarían en España. AGMAV. Caja 24.711. Fondo del antiguo Ministerio del Ejército.

${ }^{210}$ En la década de los años sesenta del siglo XX, el Ejército español había perdido el interés real por estos cañones, motivo por el cual nunca se integraron en ninguna unidad de Artillería, permaneciendo más de una década almacenadas en varios parques y maestranzas, pasando después a adornar los jardines de diversos acuartelamientos, como material de ornamentación. Se conoce la existencia de cañones de este modelo en los siguientes lugares: Sevilla (piezas $n^{0} 1$ y 2 en acuartelamientos Torreblanca y El Copero, respectivamente), Zaragoza (pieza ${ }^{\circ}$ 9, Academia General Militar), Madrid (piezas $\mathrm{n}^{\circ} 13$ y 14 , El Goloso), Cartagena (pieza $n^{\circ} 4$, Museo Militar), León (pieza $n^{\circ} 16$, Acuartelamiento "Conde de Gazola"), Burgos (Acuartelamiento "Diego Porcelos")

211 Informe de la Comisión de Compras del Ministerio del Ejército en Alemania 15 de noviembre de 1944. Ficha 6. AGMAV. Caja 24.705. Fondo del antiguo Ministerio del Ejército. 
cierta que en aquellos momentos -octubre de 1944- era imposible su transporte a España.

Aún así, el ministro del Ejército, Asensio, decretó que se hicieran gestiones con Asuntos Exteriores por si ellos pudieran garantizar el transporte del modelo.

Como quiera que el citado protocolo lo había remitido el coronel Marín de Bernardo desde Berlín a la $4{ }^{\text {a }}$ Sección del EMCE - a su amigo y compañero el coronel Jesús Aguirre-, este jefe comunicó su particular visión de los acontecimientos que estaban ocurriendo alrededor del asunto de la pieza de $15 \mathrm{~cm}$, al Agregado en Berlín el 9 de diciembre de 1944, en una curiosísima misiva que no nos resistimos a reproducir por su evidente interés, que pone en evidencia la situación nacional e internacional a finales de ese año. Esta es la carta ${ }^{212}$ :

"Recibí los protocolos y se los llevé al general con una pequeña nota explicativa.

Es cierto que en realidad la conformidad está dada por Villegas y Ulzúrrum al gobierno alemán. Ahora bien, el firmar los protocolos significa que hemos de pagar. Después de esto ¿qué hacemos con la pieza? El Decreto del Ministro es el siguiente:

Que se hagan gestiones con Asuntos Exteriores por si pueden darnos garantía del transporte del modelo.

Yo creo:

-que Asuntos Exteriores terminará sus gestiones allá para los principios de la próxima guerra.

-que lo más que podrá conseguir es el depósito en Suiza. Esto, según mi impresión, cada vez lo veo más difícil porque como ya les advertí, lo de Suiza habría que decidirlo pronto porque todo el mundo se ha anticipado y nosotros nos hemos dedicado a pensar... y vinieron los perros.

-que no conceptuo viable el que De Gaulle nos deje pasar ahora la pieza por Francia, y menos después de su visita a Moscú que a mi entender está clarísima. No hay más que abrir los ojos.

-que podría ser una solución el sencillo depósito en Suiza en espera de tiempos mejores. Pero si, lo que no creeré jamás, Alemania desaparece, ¿qué suerte correrá la pieza?

-por último, y en reserva. Creo firmemente que Industria y Material no fabrica la pieza sólamente con los planos, sino que necesita el modelo y después ya veremos.

\footnotetext{
${ }^{212}$ No $^{\mathrm{o}}$ 4878-0 4 a A./Ch Madrid, 9 de diciembre de 1944. Asunto.- Modelo de la pieza de 150/55 AGMAV. Caja 20.707. Fondo del antiguo Ministerio del Ejército.
} 
¿Qué se te ocurre? Todo esto te lo digo de modo oficioso porque veo que si no presentamos soluciones, la próxima guerra nos cogerá en gestiones ${ }^{213}$. Abrazos."

Pese a los esfuerzos realizados por el Agregado Militar en Berlín por traer parte de este material vía aérea (sólo el freno, el cierre y el recuperador), fue imposible y nunca se recibió en España. En vista de la imposibilidad de su envío se solicitó al Agregado el envío de fotografías de aquellas partes que siendo complicadas, pudieran dar una idea que no ofrecían los planos. Fracasadas las gestiones para el envío por avión del cierre, freno y recuperador, el Agregado Militar español se negó al pago de la pieza.

Es muy importante no confundir este cañón, cuya adquisición por parte de España fue objeto de contrato firmado en diciembre de 1943 y la cantidad correspondiente fue depositada en la AGEKA, con la oferta realizada en 1944 por el presidente de este consorcio alemán, Sr. Eltze, de otra pieza de las mismas características y fabricada también por Rheinmetall-Borsig, enmarcada en unas negociaciones posteriores al "Programa Bär", que jamás se llegó a materializar y solo se plasmó en la documentación que se generó a lo largo del citado año ${ }^{214}$.

Muy poco se conoce de un contrato gestionado por la Comisión de Compras de la Dirección General de Industria y Material del Ministerio del Ejército con "Rheinmetall Borsig A.G" para adquirir la licencia de fabricación del obús de infantería de $7,5 \mathrm{~cm} \mathrm{~L} / 12^{215}$.

Las negociaciones estaban en marcha en marzo de 1944 el importe de dicho contrato ascendía a 300.000 marcos, equivalentes a 1.302 .000 ptas, no exigiendo la casa fabricante la compensación de primeras materias ni el pago en

\footnotetext{
${ }^{213}$ Subrayado en el original.

${ }^{214} \mathrm{Ha}$ escrito sobre estos cañones el investigador Artemio Mortera, quien incluye como parte del "Programa Bär" la pieza de 150/55 que serviría como modelo a la serie que se pensaba construir en España. Como acabamos de ver, la adquisición de esta pieza se había negociado por parte de la Dirección General de Industria y Material del Ministerio del Ejército con la casa "Rheinmetall", directamente, no teniendo ninguna relación dicha adquisición con el denominado "Programa Bär". En muchas ocasiones, las adquisiciones de material militar en Alemania se engloban, sin razón alguna, en el Programa de armamentos "Bär", cuando simplemente se trataba de compras a una empresa de armamentos alemana. Mortera Pérez, Artemio. "Kanone Rheinmetall K.18 de 15 cm." Revista Española de Historia Militar no 125. Valladolid, 2012, pág. 158.

${ }^{215}$ Informe de la Comisión de Compras del Ministerio del Ejército en Alemania 15 de noviembre de 1944.Pág. 8. AGMAV. Caja 24.705. Tambien existe información sobre las negociaciones en "Licencia para construir en España el cañón de infantería de 7,5 cm L/12" AMAE AR. Sig. R-2244. Leg. 53.
} 
moneda nacional. El Agregado Militar en Berlín era el encargado de recibir los planos para que los remitiera a España, respondiendo la empresa de los planos que no llegasen por cualquier problema en su envío. Desconocemos por completo los pormenores del mismo, aunque es muy posible que no se llevara a cabo.

\section{I.3.4- Contratos con la empresa "DEMAG G.m.b.H.",216}

Tenemos conocimiento de la existencia de, por lo menos cuatro contratos celebrados por el Ejército español con esta fábrica alemana, tres de ellos con el Arma de Ingenieros del Ejército de Tierra y el cuarto con la Fábrica de Armas de Trubia.

El Parque Central de Ingenieros del Ejército de Tierra firmó tres contratos sucesivos en el tiempo. El primero - del que desconocemos la fecha exacta, aunque debíó de ser en 1941-, contemplaba la adquisición de 30 motocompresores por un importe de 1.044.950,00 ptas. (240.771,88 marcos). En este caso, todo este material fue entregado por la empresa alemana y pagado por España.

El segundo contrato se firmó el 25 de marzo de 1942 -elevado a definitivo el 27 de octubre de ese mismo año- y contemplaba la adquisición de 46 motocompresores portátiles tipo RC-013L, 46 martillos excavadores modelo SP, 46 martillos perforadores modelo FT-55B1, 46 juegos completos de herramientas y piezas de recambio para martillo excavador, 30 hincapilotes ligeros (martinetes neumáticos de $50 \mathrm{mkg}$ ) Mod. SR-50, 16 hincapilotes pesados (martinetes neumáticos de $200 \mathrm{mkg}$ ). Mod. FR-200 y 10 máquinas aguzadoras modelo BS-3; material destinado a la especialidad de zapadores.

Su importe total ascendía a 1.961.437,39 ptas. (431.944,10 marcos), y aunque se había pagado a la casa un $10 \%$ al firmar el contrato -196.143,74 ptas $(43.194,41$ marcos)- y se había depositado en ROWAK el resto hasta completar el precio final, ningún material de este tipo llegó a España, luego el saldo real del Estado español en poder de la casa "Demag Export GmbH", era de 43.194,41 marcos ${ }^{217}$.

Se llegó a firmar un tercer contrato el 30 de noviembre de 1942 -elevado a definitivo el 14 de marzo de 1944- en el que se contemplaba la adquisición de 10

\footnotetext{
${ }^{216}$ Informe de la Comisión de Compras del Ministerio del Ejército en Alemania 15 de noviembre de 1944. Ficha 4. AGMAV. Caja 24.705. Fondo del antiguo Ministerio del Ejército.

${ }^{217}$ Alguno de estos materiales (parte de los motocompresores y de los hincapilotes ligeros) llegó a salir de Alemania por vía terrestre en diversas expediciones, aunque su paso por Francia fue tortuoso y nunca alcanzaron la frontera española.
} 
motocompresores modelo MZSD 17/25 y 20 martillos perforarores modelo FT-55B1. Obviamente, este material jamás alcazó la frontera española.

Por último tenemos noticias de un contrato con esta casa para suministrar a la Fábrica de Trubia un tren de laminación, una instalación cuyo peso alcanzaba la respetable cifra de 2.000 toneladas. Nunca se llegó a recibir.

\section{I.3.5- Contrato con la empresa "SIEMENS-SCHUCKERWERKE".}

Conocemos un único contrato con esta casa constructora germana para la adquisición de 49 espejos parabólicos para proyectores de luz por el importe de $1.289 .163,60$ ptas. $(283.956,84$ marcos $)$.

A finales de 1943 se habían recibido 29 de los espejos. Aunque no tenemos constancia documental, lo lógico es que los 20 restantes se recibieran antes de julio de 1944 -fecha de cierre de la frontera con Francia-, ya que no hemos encontrado ningún documento del Ejército español en el que se le reclame a "Siemmens-Schuckert" el exceso pagado y no servido, como sí ha sucedido con otras partidas.

\section{I.3.6- Contrato con la empresa "HANS SCHEIBERT"218.}

Al igual que en el caso anterior, el Parque Central de Ingenieros trataba de adquirir material, en esta ocasión para la especialidad de pontoneros: botes neumáticos y tramos para puentes ${ }^{219}$. Fue firmado este contrato en Berlín y su importe ascendía a. $144.388,45$ marcos $(655.296,60$ pesetas $)$.

Se había negociado el suministro de 24 botes M.2, 24 botes M.4, dos botes Ma.2, dos botes Ma.3 y 48 botes M.6, así como diferentes elementos para pasaderas de infantería, para puentes de dos y cuatro toneladas y rampas para los mismos.

En diciembre de 1944 sólo se habían recibido los 96 botes M.2, M.4 y M.6 y dos botes Ma.2, faltando por tanto los dos botes Ma.3 y todos los elementos para pasaderas y puentes, así como las rampas de acceso y dos botellas de anhídrido carbónico.

\footnotetext{
218 Informe de la Comisión de Compras del Ministerio del Ejército en Alemania 15 de noviembre de 1944. Ficha 5. AGMAV. Caja 24.705. Fondo del antiguo Ministerio del Ejército.

219 Estado Mayor Central del Ejército. Asunto: Botes Neumáticos y tramos para puentes. Casa Hans Scheibert. 11 de diciembre de 1944. AGMAV. Caja 24.705. Fondo del antiguo Ministerio del Ejército.
} 
El material recibido importaba 126.920 marcos (550.832,80 pesetas), y el que nunca llegó a España, 16.880 marcos $(73.259,20 \text { pesetas })^{220}$.

Los pagos que hizo España fueron: el 5\% del valor total contrato, 7.190 marcos (31.204,60 pesetas), a la firma del mismo y el 95\% del valor del material recibido, 126.920 marcos (550.832,80 pesetas), cuando dicho material llegó a España, sumando ambas cantidades 134.110 marcos (582.037,40 pesetas). Al no recibirse una parte del material contratado, el saldo a favor de España en diciembre de 1944 era de 844 marcos (3.662,96 pesetas), habiendo depositado también en ROWAK 16.880 marcos $(73.259,20$ ptas $)$.

En la fecha antes citada, interesó al Ejército anular este contrato -ya que era imposible traer lo que faltaba- recoger los 844 marcos y disponer del saldo en la ROWAK, no perdiendo los derechos sobre el material en el futuro, si fuera posible. Curiosamente, desde Madrid se instó al Agregado Militar en Berlín para que indagara si en Suecia existía este material o similar.

\footnotetext{
${ }^{220}$ Valor del material recibido

24 botes M.2 19.704 marcos $(85.515,36$ pesetas $)$

24 botes M.4 24.952 marcos (108.291,68 pesetas)

2 botes Ma.2 $2.120 \operatorname{marcos}(9.200,80$ pesetas $)$

48 botes M.6 78.144 marcos (339.144,96 pesetas)

Total $\quad 126.920$ marcos $(550.832,80$ pesetas $)$

( $1 \mathrm{RM}=4,34$ pesetas)
}

\section{Valor del material no recibido}

$\begin{array}{ll}2 \text { botes Ma.3 } & 1.830 \text { marcos }(7.942,20 \text { pesetas }) \\ 1 \text { elemento pasadera Infantería } & 618 \text { marcos }(2.682,12 \text { pesetas }) \\ 1 \text { id puente } 2 \text { Tm botes M.4 } & 1.941 \text { marcos }(8.423,94 \text { pesetas }) \\ 1 \text { id. puente } 2 \text { Tm botes M.6 } & 1.941 \text { marcos }(8.423,94 \text { pesetas }) \\ 1 \text { id. puente } 4 \mathrm{Tm} & 2.200 \operatorname{marcos}(9.548,00 \text { pesetas }) \\ 1 \text { rampa para el anterior: } & 2.730 \text { marcos }(10.285,80 \text { pesetas }) \\ 1 \text { rampa para el anterior } & 2.730 \text { marcos }(11.848,20 \text { pesetas }) \\ 1 \text { rampa para el anterior } & 2.730 \text { marcos }(11.848,20 \text { pesetas }) \\ 2 \text { botellas anhídrido carbónico } & 160 \text { marcos }(694,40 \text { pesetas }) \\ \text { Total } & \mathbf{1 6 . 8 8 0} \text { marcos } \mathbf{( 7 3 . 2 5 9 , 2 0} \text { pesetas })\end{array}$




\section{I.3.7- Contrato con la empresa "RINGSDORFF A.G."221}

La Dirección General de Industria y Material del Ministerio del Ejército firmó un contrato con la empresa "Ringsdorff" y con el Ministerio del Ejército alemán por un importe de $18.570 .304,48$ ptas. (4.276.567,7 marcos), para la adquisición de patentes de bandas de acero para proyectiles, maquinaria e instalaciones. Las Fábricas de Armas de Toledo y Palencia enviaron a Alemania cierto número de obreros para especializarse.

El 15 de noviembre de 1944 se había pagado por la patente y la licencia para reproducir en España las bandas de forzamiento para los proyectiles de hierro sinterizado $4.774 .000,00$ ptas $(1.100 .000$ marcos $)$ y se había depositado en la casa Ringsdorf un montante de 4.958.502,08 ptas (1.142.511,9 marcos) como anticipo de la maquinaria que iba a suministrar la empresa germana. En esa misma fecha se habían recibido dos entregas de maquinaria por valor de $994.441,56$ ptas (229.134 marcos). No fue posible obtener nada más. El saldo real del Estado español en poder de "Ringsdorf" a finales del año 1944 era de 3.964.060,52 ptas (913.377,99 marcos), cantidad resultante de restar lo que el Ministerio del Ejército había pagado ya a dicha empresa y el valor real del material enviado a España hasta ese momento.

\section{I.3.8- Contrato con la empresa "POLTE"222.}

Se firmó este contrato con una de las mayores fábricas de munición alemanas, la casa Polte de Magdeburgo, para adquirir la patente y ayuda técnica para producir en España vainas de acero embutido para calibres 7, 7,92 y $20 \mathrm{~mm}$ correspondientes a cartuchería de ametralladoras y mosquetones, conviniéndose también gestionar la adquisición de la maquinaria supletoria que fuese necesaria para el proceso de fabricación. Para la mejor conservación de la cartuchería, la casa "Polte" aplicaba un proceso final denominado "Procedimiento Bonder", a base de aplicar unas lacas y barnices cuya composición era totalmente secreta. El importe de este contrato ascendía a $2.083 .200,00$ ptas. $(480.000$ marcos $)$

\footnotetext{
221 Informe de la Comisión de Compras del Ministerio del Ejército en Alemania fechado el 15 de noviembre de 1944. Ficha 7. AGMAV. Caja 24.705. Fondo del antiguo Ministerio del Ejército.

${ }^{222}$ Informe de la Comisión de Compras del Ministerio del Ejército en Alemania 15 de noviembre de 1944. Ficha 9. AGMAV. Caja 24.705. Fondo del antiguo Ministerio del Ejército.
} 
Finalizado el año 1944 no se había recibido nada de esta fábrica. Se había realizado un depósito en la casa germana por valor de 520.800 ptas (120.000 marcos) en concepto de anticipo. Pese a que el Agregado Militar en Berlín hizo todo lo posible para que la citada casa enviara los planos de construcción de la maquinaria y diferentes elementos necesarios para poner en marcha la fabricación, así como unos bidones con los barnices, todo fue vano.

\section{I.3.9- Contrato con la empresa AGEKA.}

El 22 de mayo de 1943 se reunían en la Agregaduría Aérea española en Berlín, representantes españoles y alemanes para tratar sobre la adquisición de 71 fonolocalizadores 223 “Tepas Belge”, modelo V-20 tipo 1940, ofrecidos a España por AGEKA en carta remitida al Agregado militar español el 19 de enero de 1940. En el mes de marzo, una comisión española al mando del comandante Moiño, había visitado la empresa constructora y había examinado los citados fonos, resultando que unos 60 eran aparatos nuevos ${ }^{224}$.

El día 24 de ese mismo mes de mayo, en otra reunión entre los mismos representantes, se estudió la viabilidad de la adquisición al margen del "Programa Bär", firmando un contrato con la AGEKA. Se informó a los españoles que se disponía de un total de 85 fonos de este modelo, además de dos que estaban incompletos y uno, averiado, que podrían adquirirse para tener piezas de repuesto. El precio por aparato nuevo era de 40.000 marcos, aunque AGEKA se avino a hacer una rebaja del 10\% en el lote a adquirir por España para tener en cuenta la diferencia entre los aparatos nuevos y reparados, proponiendo que cada fonolocalizador completo costara 36.000 marcos. El

\footnotetext{
${ }^{223}$ Se denominaba fonolocalizador a un aparato acústico de localización apto para la defensa contra aeronaves, destinado a determinar las coordenadas angulares de un avión "invisible", bien de día o de noche, en cualquier condición climática. Los ofrecidos a España eran de un modelo de campaña capturado por los alemanes en la invasión de Bélgica, cuyas bases acústicas tenían 3 metros de separación.

${ }^{224} \mathrm{El}$ trabajo desarrollado por la comisión española fue, por una parte un estudio histórico de los aparatos, por otra el estudio de la descripción y el funcionamiento, para terminar con una visita y examen de las diversas fases de su fabricación y una demostración práctica de su funcionamiento con aviones en vuelo, atendidos los fonos por personal de la defensa antiaérea alemana. Para seguir el tema de los fonolocalizadores: "Asunto Fonolocalizadores TEPAS-BELGE y dirección de tiro C.A. Hasemmayer (Sic)" Documentación del general Martínez de Campos en Berlín. AGMAV. Caja 24.711. Fondo del antiguo Ministerio del Ejército.
} 
general Martínez de Campos decidió aceptar los 88 fonos, comunicándoselo así al Ministro del Ejército español y ordenando su adquisición al Agregado Militar en Berlín el 26 de mayo de 1943.

Los primeros 71 fonos "Tepas" se prepararon y se remitieron a España en dos trenes completos, uno de ellos con 35 aparatos y el otro con 36, numerados como trenes $\mathrm{n}^{\mathrm{o}} 12$ y 13 y enviados al finalizar el denominado "Sofortprogramm", el 11 y el 17 de agosto de 1943 respectivamente ${ }^{225}$. El coste de estos fonolocalizadores fue de 11.093.040 ptas (2.556.000 marcos) pagados con un crédito especial habilitado para este fin.

Tras la adquisición de estos 71 aparatos, todavía quedaban en Bélgica otros 25 aparatos en diferentes estados de conservación, que fueron ofrecidos por la AGEKA a diferentes precios, según dicho estado, oscilando éstos entre los 12.000 marcos que pedían por cada aparato de los siete considerados "para desguace", y los 34.000 marcos que solicitaban por cada uno de otros siete fonos en perfecto estado. Además había aparatos sin accesorios, más o menos arreglados, a 20.000, 28.000 y 32.000 marcos por unidad $^{226}$.

A finales de febrero de 1944 la Dirección General de Industria y Material del Ministerio del Ejército se decidió a la adquisición de otros 16 aparatos, eligiendo los mejores de entre los 25 ofrecidos por AGEKA, por los que habría que pagar un montante de 486.000 marcos. Dichos fonos venían cargados en el denominado "Tren $\mathrm{n}^{\text {o }}$ 27" del "Programa Bär", tren que nunca llegaría a España, como veremos en capítulos posteriores.

La misma comisión militar española que estudió in situ la adquisición de los fonos, también analizó la posibilidad de compra de direcciones de tiro de origen holandés fabricadas por la empresa Hazemeyer, unos modernos aparatos para dirigir el tiro de baterías artilleras, totalmente mecánicos, y que requerían para su manejo un número muy pequeño de sirvientes. Los militares españoles se vieron gratamente

\footnotetext{
${ }^{225}$ En los anexos se detallan estas expediciones así como los trenes en los que venían y todos los pormenores de los mismos.

${ }^{226}$ Carta de AGEKA fechada en Berlín el 9 de febrero de 1944 Dr. M/Hn IV-Spanien-1 S449/44 Entrega de fonolocalizadores Tepas-restantes. AGMAV. Caja 24.707. Fondo del antiguo Ministerio del Ejército.
} 
sorprendidos por la fiabilidad, su construcción robusta y sus características, adaptables a cualquier material artillero.

La dirección de la empresa, por expreso deseo de los comisionados españoles, accedió al envío de un aparato a España, junto a un ingeniero especializado, para evaluar la en nuestro país. El precio de un aparato completo con transporte, transmisión electrica y grupo electrógeno no pasaría de un millón de pesetas, cantidad que pareció adecuada a los españoles ${ }^{227}$.

En julio de 1943, el ingeniero director de la casa Hazemeyer visitó en Berlín al teniente coronel de artillería Ricardo Castro Caruncho, para tratar del envío de la citada dirección de tiro. En dicha reunión se plantearon los problemas que existían para ese suministro, pues la fábrica no disponía de ningún aparato moderno en stock, ya que toda la producción se hacía bajo pedido para la Luftwaffe y la Kriegsmarine. Sólo tenían disponible para remitir un antiguo aparato de mediados de los años 30, anticuado y poco apropiado para realizar ejercicios o pruebas encaminadas a la adquisición de modernos directores de tiro.

La única vía de obtener un aparato moderno era solicitarlo en préstamo al gobierno alemán, comunicando a la empresa Hazemeyer el tipo de cañones con el que se desarrollarían los ejercicios para que la empresa suministrase los transmisores y reflectores necesarios. Lo engorroso del procedimiento hizo que algunos miembros de la comisión antiaérea que visitó Alemania para familiarizarse con los nuevos procedimientos empleados en la guerra moderna, visitasen la fábrica Hazemeyer y participasen en algunos ejercicios de tiro de alguna batería alemana dotada de este aparato.

\section{I.3.10- Otros contratos}

A principios de 1943, en fecha no determinada, dieron comienzo unas negociaciones llevadas a cabo por el Agregado Militar español en la capital del Reich, Carlos Marín de Bernardo, con militares alemanes, para adquirir:

\footnotetext{
227 "Asunto Fonolocalizadores TEPAS-BELGE y dirección de tiro C.A. Hasemmayer (Sic)". 20 de marzo de 1943. Documentación del general Martínez de Campos en Berlín. AGMAV. Caja 24.711. Fondo del antiguo Ministerio del Ejército.
} 
“...algunas armas denominadas Lanza-nieblas o Lanzagranadas de humo de tubos múltiples y los proyectiles que le corresponden, adquisición que deberá incluirse en el "Programa Bär"228.

Esta negociación no fructificaría y en mayo de ese mismo año, el Agregado en Berlín comunicaba que los alemanes no podían suministrar esas armas por necesidades propias de las mismas.

En octubre de 1943, cuando el "Programa Bär" estaba en pleno desarrollo, la $4^{\text {a }}$ Sección del EMCE solicitó al Agregado Militar en Berlín que hiciera gestiones para conseguir que el gobierno alemán cediera un aparato de radar "Würzburg" modelo A 229 -diferente a los adquiridos en el Programa, que eran del modelo D- para organizar una Escuela en el seno del Ejército de Tierra, pues se había llegado a un acuerdo con el Ministerio del Aire para que los radares adquiridos de este modelo -en su variante D-, pasaran a depender del Ministerio del Ejército. Las gestiones no dieron resultado y dicho aparato jamás se recibió en España.

Debido al tiempo transcurrido entre la petición, la confirmación alemana de su disponibilidad y la aceptación española del material, un contrato para adquirir 25 coches todo-terreno "Steyr" se truncó por haber sido destruidos en la fábrica debido a un bombardeo aliado ${ }^{230}$.

El 16 de febrero de 1944 se autorizó la importación de un equipo de corte subacuático completo con destino al Parque Central de Ingenieros, adquirido a la empresa "Dortmund Hoerder Huttenverein A.G."

En marzo de 1944 la Jefatura de Transmisiones del Ejército fue autorizada por el EMCE para contratar la adquisición directa de 15 aparatos "Telefunken" AE 1076, cuatro adaptadores Hell AZ-1085 y otros cuatro Telescritores "Siemens-Hell" completos. Dicha Jefatura había llegado a un acuerdo verbal con el representante de la empresa alemana en España para dicho suministro, teniendo en cuenta que el precio a pagar no superaría nunca las 200.000 pesetas. Con este material se tenía la previsión de

\footnotetext{
228 "Nota para el Agregado Militar a la Embajada de España en Berlín n ${ }^{\circ}$ F-2186" de la Sección segunda del Estado Mayor Central del Ejército. Fechada el 15 de abril de 1944. AGMAV. Caja 24.708. Fondo del antiguo Ministerio del Ejército.

${ }^{229}$ Oficio n ${ }^{\circ} 4971-\mathrm{L}$ de la $4^{\text {a }}$ Sección del Estado Mayor del Ejército. Asunto: Formación de Especialistas en el manejo de la radiotelemetría Freyer (Sic) Würzburg. AGMAV. Caja 24.708. Fondo del antiguo Ministerio del Ejército.

${ }^{230}$ Oficio n $^{\circ} 4109-J$ de la 4 a Sección del EMCE. AGMAV. Caja 24.705. Fondo del antiguo Ministerio del Ejército.
} 
montar cinco puestos de escucha en Barcelona, Cartagena, Málaga, Badajoz y La Coruña, a razón de un puesto por población, dependientes del Centro de Transmisiones del Ejército de Tierra ${ }^{231}$. Como tendremos ocasión de ver en el Capítulo VIII, este material fue recibido en España por vía aérea en mayo de 1945, en el último vuelo realizado a España por un avión de Lufthansa antes del fin de la Segunda Guerra Mundial. Es curioso el hecho de que varios de los aparatos de similar clase y características contratados en el "Programa Bär" un año antes, nunca se llegaron a recibir en España.

En marzo de 1945, el Agregado Militar en Berlín remitía una nota al EMCE en la que ponía de manifiesto que la empresa "Telefunken" pasaba una factura por $84.381,05$ marcos por el suministro realizado de 15 estaciones de radio para carros de combate adquiridas por encargo del general Orgaz, por la comisión que había desempeñado el teniente coronel Priego Gabarrón. El material, aseguraba Marín de Bernardo, ya estaba en España, y como el asunto había escapado al control de la Agregaduría, aún no había sido pagado ${ }^{232}$.

También tenemos noticia de la celebración de un contrato con la empresa "Atlas Werke" para suministrar al Parque de Artillería de Cádiz un hidrófono con sus cables por un importe de $348.171,00$ ptas $(80.223,73$ marcos). Tampoco tenemos conocimiento de su cumplimiento.

Uno de los aspectos más desconocidos en lo que respecta a la adquisición de material militar en Alemania son los contratos que diversas Fábricas Militares negociaron directamente en Alemania para adquirir diversos materiales necesarios para su funcionamiento.

Debido a que dichos contratos fueron celebrados de manera independiente, sin seguir un plan trazado por ningún organismo, su seguimiento se antoja harto difícil. De hecho en toda la documentación utilizada solo se han encontrado referencias indirectas y, a menudo, inconexas ${ }^{233}$. Por ejemplo, la Fábrica de Pólvoras de Murcia negoció un contrato para adquirir material en Alemania referente a una instalación de óleum y

\footnotetext{
${ }^{231}$ Escrito $n^{\mathrm{o}}$ F-2656 del Estado Mayor Central del Ejército al coronel jefe accidental de la Jefatura de Transmisiones del Ejército. AGMAV. Caja 24.709. Fondo del antiguo Ministerio del Ejército.

232 Documentación sobre compra de material y transporte. AGMAV. Caja 24.705. Fondo del antiguo Ministerio del Ejército.

${ }^{233}$ Una carpeta en AGMAV. Caja 24.706. Fondo del antiguo Ministerio del Ejército.
} 
nitroglicerina. Las fábricas de Toledo y Palencia negociaron la adquisición de copas de acero para vainas de cartuchería de fusil. Estas dos fábricas citadas, también habían contratado la adquisición de barnices y sales para la cartuchería de fusil con vaina de acero, independientemente del contrato firmado por la Dirección General de Industria y Material, estudiado con anterioridad, con la casa "Polte" de Magdeburgo. Otros dos contratos para la Fábrica de Trubia ${ }^{234}$ incluian motores y dispositivos eléctricos (negociados con "A.E.G.") y hornos para recalentar (suministrados por la casa “O.F.O.”), aunque ninguno de ellos llegó a buen fin.

A principios de enero de $1945^{235}$, se había depositado en diversas casas fabricantes alemanas la cantidad de $14.594 .476,76$ ptas $(3.362 .782,4$ marcos) por cuenta de las fábricas militares españolas, aunque aquellas solamente habían remitido materiales por valor de 2.685.085,14 ptas (618.683,2 marcos). El saldo, pues, depositado por el Estado español en empresas alemanas en aquel momento era de 11.909.391,62 ptas (2.744.099,3 marcos). A ésta cantidad había que sumar las 916.963,91 ptas (211.282 marcos) que España había depositado a su vez en la ROWAK por cuenta de las fábricas militares. El total de saldo a favor de España por este motivo era de $12.826 .355,53$ ptas $(2.955 .381,3$ marcos $)$.

Existen numerosos contratos de diferente envergadura -aunque habitualmente de pequeña cuantía- con otras empresas germanas para adquirir elementos sueltos de maquinaria, materiales, armamento ligero, etc... que constan en los libros de Actas del Polígono de Experiencias de Carabanchel y que sería arduo detallar aquí.

\section{I.3.11- Una visión general de los contratos negociados por la Dirección}

\section{General de Industria y Material del Ministerio del Ejército}

De todos estos contratos negociados en Alemania y enmarcados en la categoría de "Suministros especiales", independientes todos ellos del "Programa Bär" que estudiaremos a continuación, pocos fueron los que se llevaron a la práctica en su

\footnotetext{
${ }^{234}$ Secretaría Técnica del Consejo Ordenador de Minerales Especiales de Interés Militar. $2^{\circ}$ Jefe. Asunto: Restitución de metales no férricos. 17 de marzo de 1944. AGMAV. Caja 24.713. Fondo del antiguo Ministerio del Ejército.

${ }^{235}$ Resumen de las cantidades depositadas en ROWAK, valor del material recibido y no abonado, y saldo en Alemania a favor y en contra del Estado español, consecuencia de diversos contratos establecidos para adquirir material de guerra y maquinaria. AGMAV. Caja 20.903. Fondo del antiguo Ministerio del Ejército.
} 
totalidad, quedando muchos a medias en su cumplimiento, debido sobre todo al cierre de la frontera con Francia después del Desembarco de Normandía. Si bien la mayoría se habían firmado en 1942 o a principios de 1943, la tardanza en la fabricación del material específico que se había encargado, las dificultades en el transporte o, incluso, la indecisión de los organismos españoles responsables, dieron al traste, en muchas ocasiones, con las expectativas de recepción de muchos de los materiales contratados.

El 7 de mayo de 1945, con Berlín tomado ya por las tropas soviéticas y Hitler muerto una semana antes, el coronel Aguirre, jefe de la Sección cuarta del EMCE remitía al general jefe de este organismo la nota $n^{0}$ 4369-F (A/M), relacionando el estado, en el mes de abril, de los contratos especiales negociados por la Dirección General de Industria y Material del Ministerio del Ejército ${ }^{236}$. Causas relacionadas con la fase terminal del conflicto mundial impidieron que la documentación remitida el mes anterior por el Agregado Militar en Berlín, llegaran antes de la fecha en la que se emitió la nota, pero poco o nada, es de suponer, habría cambiado respecto a lo que en ella se relacionaba.

En esta nota, muy curiosa por la descripción desoladora del estado de las fábricas de armamento y material alemán un mes antes del fin de las hostilidades en Europa, se narraba lo que había ocurrido con las empresas con las que el Ministerio del Ejército tenía algún contrato sin rematar, y que eran las siguientes:

La casa "Waffenwerke Brünn" había quedado ya en poder del Ejército ruso, aunque previamente, habían prometido al coronel Marín de Bernardo que enviarían por vía aérea las 50 alzas ópticas que faltaban por remitir de uno de los contratos. El problema para este tipo de envíos era que en los últimos meses de la guerra se necesitaba una autorización especial del OKW -denominada Vollfahrtnummer- y debido a que dicho OKW se había trasladado a Mannheim, se había complicado mucho la concesión de la misma. Todo lo que faltaba por entregar de los dos contratos que se habían firmado con esta empresa, quedó como fallido.

Con respecto a la casa "Polte" de Magdeburgo, no se consiguió el envío por avión de las muestras de barniz ni del líquido de bonderización, ni tampoco de los

\footnotetext{
${ }^{236}$ Seccíon cuarta. No 4369-F A/M. Asunto: Contratos especiales de la Dirección General de Industria y Material en Alemania independientes del Plan Bär. Negociaciones. Documentación General, resúmenes. Documentación general de la Comisión de Compras. AGMAV Caja 24.704. Fondo del antiguo Ministerio del Ejército.
} 
planos de los hornos de recocido ni de la instalación de barnizado y bonderizado. La empresa había quedado en poder de los americanos.

De la casa "Carl Zeiss" solo se pudo obtener el envío por vía aérea de nueve cajas de vidrio óptico, entregadas ya al Taller de Precisión de Artillería. Dicha fábrica había quedado reducida a escombros según comprobación visual del Agregado Militar español. La empresa "Ringsdorf" había dispuesto el envío a Suiza de cinco vagones de ferrocarril con el material que restaba por entregar, aunque se desconocía el paradero de los mismos.

Como hemos visto, también fracasaron las negociaciones para el envío por avión del cierre, freno y recuperador de la pieza de $15 \mathrm{~cm} \mathrm{~L} / 55$.

Las casas "Demag" y "Scheibert" dieron su conformidad de palabra para la devolución del saldo en su poder, aunque nunca se recibió confirmación por escrito.

El 30 de enero de 1945, la Comisión de Compras de la Dirección General de Industria y Material elaboraba un cuadro sinóptico con el estado de los contratos en vigor con empresas alemanas. En ese momento, las casas contratantes alemanas tenían en su poder un total de 36.864.835 marcos (159.993.389,76 pesetas), cuando la deuda real del Estado español con las mismas en esa fecha era de 32.323 .376 marcos (140.283.451,80 pesetas); por ello había un saldo deudor de éstas con España de 4.541.460 marcos (19.709.937,96 pesetas). De la misma manera, la ROWAK tenía un depósito de 957.830 marcos (4.156.980,85 pesetas).

Por todo ello, el total desembolsado por esta Comisión de Compras cuya contrapartida en material de guerra no se recibió en España ascendía a 5.499.289 marcos (23.866.918,81 pesetas). El detalle de cada una de ellas viene recogido en las tablas siguientes. 
TABLA I-J

CONTRATOS EN VIGOR CON EMPRESAS ALEMANAS. EXCESO EN PODER DE LAS CASAS

\begin{tabular}{|l|r|r|r|}
\hline Empresa & \multicolumn{1}{l|}{ Debe } & \multicolumn{1}{l|}{ Exceso en poder de las casas } \\
\hline Waffenwerke Brünn (ZB 60) & 25.800 .780 & 27.304 .686 & 1.503 .906 \\
\hline Waffenwerke Brünn (ZB 30 y 26) & 6.160 .196 & 8.118 .333 & 1.958 .137 \\
\hline Demag Export & - & 45.194 & 45.194 \\
\hline Hans Scheibert & 133.266 & 134.110 & 844 \\
\hline Ringsdorff & 229.134 & 1.142 .512 & 913.378 \\
\hline Polte & - & 120.000 & 120.000 \\
\hline Total & $\mathbf{3 2 . 3 2 3 . 3 7 6}$ & $\mathbf{3 6 . 8 6 4 . 8 3 5}$ & $\mathbf{4 . 5 4 1 . 4 5 9}$ \\
\hline
\end{tabular}

Fuente: AGMAV. Caja 24.705. (Cantidades en marcos)

\section{TABLA I-K}

\section{CONTRATOS EN VIGOR CON EMPRESAS ALEMANAS. EXCESO EN PODER DE ROWAK}

\begin{tabular}{|l|r|r|r|}
\hline Empresa & Debe & Haber & Exceso en poder de ROWAK \\
\hline Waffenwerke Brünn (ZB 30 y 26) & - & 195.000 & 195.000 \\
\hline Demag Export & - & 406.750 & 406.750 \\
\hline Hans Scheibert & - & 16.880 & 16.880 \\
\hline Rheinmetall Borsig (Pieza 15,5 cm) & - & 339.200 & 339.200 \\
\hline Total & $\mathbf{9 5 7 . 8 3 0}$ & $\mathbf{9 5 7 . 8 3 0}$ \\
\hline
\end{tabular}

Fuente: AGMAV. Caja 24.705. (Cantidades en marcos)

En los meses posteriores se afinaron las cifras por parte del Ministerio del Ejército, analizando las cantidades entregadas a ROWAK y el material recibido, e incorporando las baterías de costa de Canarias - "Isabella"-, que aunque habían sido servidas por la Kriegsmarine y contabilizadas en un primer momento como deuda de la Marina Española, al final pasarían a formar parte de los materiales servidos y no pagados por el Ejército de Tierra. Con ello se elaboró una nueva y definitiva tabla de créditos y deudas con Alemania el día 3 de mayo de $1945^{237}$, la cual, suponemos de una

\footnotetext{
${ }^{237}$ Ministerio del Ejército. Dirección General de Industria y Material. Resumen de la situación de créditos y deudas con Alemania. Madrid, 3 de mayo de 1945. AGMAV. Caja 24.707. Fondo del antiguo
} 
alta fiabilidad y fiel reflejo de la situación real en aquellos momentos, a punto de finalizar el conflicto bélico mundial en el teatro de operaciones europeo.

La cifra en poder de las casas alemanas entregada por la Comisión de Compras de la DGIM había disminuido en 120.000 marcos (520.800 pesetas) con respecto a la contabilizada en enero, alcanzando un valor de 4.421.460 marcos (19.189.137,96 pesetas).

Por lo que respecta a las cantidades depositadas o pagadas por diversas fábricas militares, aumentaron 2.626 marcos (11.395,04 pesetas) los depósitos en ROWAK, alcanzando la cifra definitiva de $213.907,59$ marcos $(928.358,95$ pesetas), y curiosamente, desaparecieron los 2.744.099,3 marcos (11.909.391,62 pesetas) que existían como exceso en poder de las casas fabricantes alemanas por material pagado en adelanto y no servido. Desconocemos absolutamente el motivo de esta desaparición.

\section{TABLA I-L}

\section{RESUMEN DE SALDOS Y DEPÓSITOS EN MAYO DE 1945}

\begin{tabular}{|l|l|l|l|l|}
\hline & $\begin{array}{l}\text { Depositado en } \\
\text { Rowak }\end{array}$ & $\begin{array}{l}\text { En poder de las } \\
\text { casas alemanas }\end{array}$ & $\begin{array}{l}\text { Saldo a favor de } \\
\text { España }\end{array}$ & $\begin{array}{l}\text { Saldo en } \\
\text { contra de } \\
\text { España }\end{array}$ \\
\hline $\begin{array}{l}\text { Comisión de } \\
\text { compras }\end{array}$ & 957.830 & 4.421 .460 & 5.379 .290 & ------- \\
\hline Fábricas Militares & 213.908 & ------ & 213.908 & ------ \\
\hline $\begin{array}{l}\text { Baterías de } \\
\text { Canarias }\end{array}$ & ------- & ------ & ------- & 5.628 .915 \\
\hline Total & $\mathbf{1 . 1 7 1 . 7 3 8}$ & $\mathbf{4 . 4 2 1 . 4 6 0}$ & $\mathbf{5 . 5 9 3 . 1 9 8}$ & $\mathbf{5 . 6 2 8 . 9 1 5}$ \\
\hline Diferencia & & & & $\mathbf{3 5 . 7 1 7}$ \\
\hline
\end{tabular}

Fuente: AGMAV. Caja 24.707. (Cantidades en marcos)

Ministerio del Ejército. En el documento original se tiene en cuenta, además de las que recogemos aquí, la partida correspondiente a los créditos depositados en ROWAK por partidas del "Programa Bär". Como quiera que el estudio de dicho programa de armamento se desarrolla en capítulos posteriores, aquí no vamos a tener en cuenta esta cifra, dejando su estudio para el Capítulo VI. 


\section{Capítulo 2}

\section{EL CONVENIO COMERCIAL CON ALEMANIA DE DICIEMBRE DE 1942}

\section{II.1. -INTRODUCCIÓN}

Desde el final de la Guerra Civil española muchas comisiones militares españolas visitaron Alemania con diferentes motivos; algunas veces fueron políticos, pero la mayoría de ellos fueron comerciales. España acababa de salir de un conflicto bélico y necesitaba adquirir nuevos materiales que sustituyeran a los empleados en la contienda, la mayoría fatigados por su empleo en las operaciones y por el tiempo transcurrido, así como por la falta de repuestos de la mayor parte del armamento capturado al enemigo, de procedencia soviética en la mayoría de las ocasiones.

Afirma Rafael García Pérez ${ }^{238}$ que en septiembre de 1942 las negociaciones comerciales entre Alemania y España iniciadas en julio habían alcanzado un punto conflictivo debido a la indefinición que guiaba a la delegación española. La llegada al Ministerio de Asuntos Exteriores del general Gómez Jordana en sustitución del defenestrado Serrano Súñer significó un vuelco en dichas negociaciones, las cuales estaban tomando un cariz verdaderamente dañino para los intereses de España, considerando la comisión española todas las propuestas realizadas hasta ese momento por la delegación alemana, propuestas que ponían contra las cuerdas la salvaguarda de los intereses comerciales españoles en sus relaciones con el Tercer Reich. En el acuerdo comercial que se estaba cerrando se asumía de manera implícita un desequilibrio en el Clearing de 200 millones de marcos a añadir al ya existente en ese momento.

Jordana, un hombre cauto y cabal, después de estudiar como se habían llevado hasta entonces las negociaciones, cambió a los miembros de la comisión negociadora, empezando por su presidente, Luis Calderón, y colocó en su lugar a un peso pesado de las relaciones internacionales: José Pan de Soraluce Español ${ }^{239}$

\footnotetext{
${ }^{238}$ García Pérez, Rafael, Franquismo y III Reich, op. cit., pág. 328.

${ }^{239}$ Nació en La Coruña en 1879. Después de finalizar sus estudios diplomáticos, fue destinado a París, donde desempeñó el cargo de vicecónsul. Posteriormente, regresó a La Coruña y fue elegido diputado en Cortes en 1918. Tres años más tarde obtuvo un puesto en el Senado y en 1930 fue nombrado subsecretario del Ministerio de Economía Nacional. Después de su actividad política, volvió a la carrera
} 
Pero el personaje más importante para definir la estrategia que a partir de aquel momento iba a seguir el Ministerio de Asuntos Exteriores, en comandita con los del Ejército, Marina y Aire, iba a ser el diplomático José María Doussinague Teixidor ${ }^{240}$, Director General de Política Exterior. En un informe ${ }^{241}$ presentado a Jordana, Doussinague fue el primero que presentó la alternativa de que para adquirir el armamento que España necesitaba en aquellos momentos no habría nada mejor que utilizar el superavit comercial con Alemania y negociar la adquisición de material bélico contra el envío de las materias primas requeridas por el Reich germano.

Su pretensión pasaba por presentar a los alemanes las amenazas que en esos meses se cernían sobre el régimen franquista, amenazas de orden internacional, y sobre todo en el Mediterráneo, como un asunto de trascendencia europea, para lo cual, España debía estar ciertamente preparada para actuar como cortafuegos, algo que debía pretender para su propia seguridad el régimen hitleriano. Y ahí estaba el quiz de la cuestión: Alemania debía colaborar con España, aportando material militar en cantidad suficiente para que ésta pudiera hacer frente a todas las amenazas contra su soberanía y la del sur del continente.

No es este el lugar para extendernos en las negociaciones previas a la firma del nuevo Tratado Comercial, que tuvieron lugar durante los meses de septiembre, octubre y noviembre, pues antes que nosotros ya la ha hecho de manera magistral el profesor García Pérez, amén de sobrepasar las intenciones de este trabajo, enfocado a desvelar los entresijos militares de la cuestión, mucho más que los políticos o los meramente económicos.

diplomática y fue destinado a embajadas de diversos países. Tras la Guerra Civil, ocupó los cargos de consejero del Ministerio de Industria y jefe de la sección europea de la Dirección General de Política del Ministerio de Asuntos Exteriores. Falleció en Madrid el 19 de marzo de 1948. (www.galegos.es)

\footnotetext{
240 Jurista, historiador y diplomático, José María Doussinague y Teixidor nació en Montevideo el 19 de enero de 1894 y falleció en Obanos (Navarra) el 11 de agosto de 1967. Estudió Derecho en la Universidad de Salamanca, y se incorporó a la carrera diplomática, ingresando en el Instituto Diplomático y Consular. Fue Director General de Política Exterior del Ministerio de Asuntos Exteriores bajo el mandato del ministro Jordana, jefe de Comercio Exterior en el Ministerio de Economía, presidente de la comisión interministerial de Comercio Exterior, secretario de la Delegación Española en la Sociedad de Naciones y en la Conferencia del Desarme, representante de España en el Tribunal Internacional de Arbitraje de La Haya y ministro plenipotenciario de España en los Países Bajos, Uruguay, Grecia y Turquía y presidente de la Comisión de Concordato. Entre 1950 y 1962 fue embajador en Santiago de Chile y Roma, y desde 1962 en la Santa Sede hasta su jubilación en 1965. Historiador, escritor y conferenciante fue miembro del Consejo Superior de Investigaciones Científicas. (http://www.euskomedia.org/aunamendi/45407)
}

${ }^{241}$ AMAE. AR. Sig. R-1371-17. Informe de Doussinague a Gómez Jordana fechado el 18 de septiembre de 1942. 
Por el contrario, sí hemos de constatar, por su importancia para las futuras negociaciones militares, la resolución del Consejo de Ministros transmitida el 18 de septiembre de 1942 por la que Gómez Jordana imponía el control efectivo de su Ministerio para todos los contactos, negociaciones y acuerdos que se mantuvieran con países extranjeros ${ }^{242}$. No cabe la menor duda de que se quería poner coto a cualquier tipo de veleidad en la adquisición de materiales de cualquier tipo por parte de determinados ministerios militares, que en la etapa anterior ya habían seguido, y que pervertía y dañaba la actividad del propio ministerio de Asuntos Exteriores español, garante de la dirección política -y si cabe económica- en la acción exterior de nuestro país.

Como bien afirma el profesor García Pérez ${ }^{243}$ :

“...La recuperación de esa política de Estado (de Gómez Jordana) daría frutos inmediatos, frustrados durante los años anteriores. En el caso concreto de Alemania, en pocos meses España conseguía normalizar sus intercambios comerciales, adquiría una importante cantidad de armamento y, desbloqueadas las dificultades políticas, ya en el otoño de 1943, procedía a liquidar la antigua deuda de guerra...".

Llegados a este punto resulta realmente interesante como explica José María Doussinague en su libro ${ }^{244}$ la llegada a la legación española en Berlín del nuevo embajador nombrado por Gómez Jordana y los cambios que se proponía realizar en las estancadas relaciones comerciales y militares entre ambos países.

Relata Doussinague:

“...En el primer Consejo de Ministros a que asistió (Gómez Jordana) había planteado el nuevo Ministro de Asuntos Exteriores el problema de la necesidad de prestar especial atención a las fuerzas armadas para no vernos arrastrados contra nuestra voluntad al torbellino de la guerra. Al dar con fecha 12 de noviembre de 1942, cuatro días después del desembarco en África, sus instrucciones al señor Vidal, le decía lo siguiente:

'Procede actuar siempre dentro de la estrecha amistad marcada por la línea política que viene siguiendo nuestro país con respecto a aquel al cual va V.E. acreditado. Siendo sustantivo para España el mantenimiento de esta amistad, es preciso en algunas ocasiones ceder

\footnotetext{
242 Oficio reservado no 84 del Ministro de Asuntos Exteriores al Ministro del Aire. AHEA. Exp. 2795, secc. $2^{\mathrm{a}}$, div. $3^{\mathrm{a}}$. Citado por García Pérez, Rafael, Franquismo y Tercer Reich, op. cit., pág. 326.

${ }^{243}$ García Pérez, Rafael, Franquismo y Tercer Reich, op. cit., pág. 326.

${ }^{244}$ Doussinague Teixidor, José María, España tenía razón. (1939-1945), Op. cit., págs. 203 y ss.
} 
algo de los intereses nacionales que, en otras ocasiones, hubiéramos tenido que defender con ahínco, siempre que se trate de cosas en cierto modo secundarias, a fin de que lo sustantivo, la confianza mutua absoluta y sin reservas, se mantenga en pie. Es preciso, en efecto, que el Gobierno alemán tenga la convicción completa de que España (única nación del mundo que profesa abierta y sinceramente su amistad por él) merece su más absoluta confianza.

Sentada así la base misma de nuestra política con Alemania, se pasaba a señalar el objetivo específico que tendría que perseguir el nuevo embajador en esta forma:

'De una manera concreta ha de entender el Embajador que se le envía en los momentos actuales principalmente para gestionar un esfuerzo extraordinario por parte de Alemania a fin de proporcionar a España el material de guerra que ha de convertirla el día de la paz en una potencia bien armada y con un Ejército intacto. Igualmente será precisa abundante maquinaria y el instrumental correspondiente para que nuestras industrias puedan producir todos los pertrechos que la defensa nacional requiere."

La necesidad de que España pudiera disponer de un armamento moderno y en cantidad suficiente era la premisa número uno del gobierno y de la política española a finales de 1942 en sus relaciones con el único país que podría suministrárselo en las complicadas circunstancias de esos momentos. Vidal recibió del ministro un detallado estudio sobre las negociaciones en curso con Alemania y sobre la forma en la que el nuevo representante de la diplomacia española debía enfocar las relaciones con el Reich. Doussinague describe la situación de la siguiente manera:

"No puede enfocarse el problema como si se tratara de hacer un beneficio a España que, por el contrario, tiene que hacer un grave sacrificio por los gastos que supone el mantenimiento en pie de guerra de un Ejército y por los trastornos graves que ésto trae consigo para una economía todavía no restablecida. El proporcionar armamento a España es, pues, cosa que interesa en primer lugar a Alemania y en segundo término a nuestro propio país, que cree no corre peligro de un ataque en lo que se puede prever."

El ministro remataba su razonamiento con dos premisas que, en su valoración, habían de darse inexcusablemente:

Que el armamento se entregara sin condición política de ninguna clase ni cláusula que comprometiera a España en ningún sentido y que dicho armamento se 
entregara de forma totalmente gratuita, sin compensarlo con las exportaciones que se solicitaban de España ${ }^{245}$.

Como se verá más adelante, ninguna de las dos se cumpliría y el gobierno español habría de pasar por el aro de firmar un protocolo secreto, condicionante político claro marcado por el Reich para la entrega del armamento, y pagando religiosamente todo el armamento, compensándolo con las exportaciones españolas a Alemania.

En la presentación de credenciales a Hitler el 5 de diciembre de 1942, el nuevo embajador español habló al Führer precisamente del tema del armamento que garantizara la soberanía española y el alejamiento del conflicto todo lo que fuera posible. En una carta enviada a Jordana, afirmaba Vidal:

"Me esforcé en presentar el asunto como de interés común, teniéndolo Alemania tanto como España en evitar cualquier golpe de mano o eventualidad análoga en nuestro territorio" ${ }^{, 246}$.

Hitler le contestaría que haría lo que fuera posible, y que esperaba sólo una lista con las prioridades españolas para así poder tomar una decisión. Pero esa decisión todavía se demoraría bastante tiempo.

\section{II.2. -LA FIRMA DEL CONVENIO}

El 8 de noviembre de 1942 los aliados comenzaban una operación a gran escala en el norte de África, tras las peticiones de Stalin de abrir un segundo frente en Europa para aliviar la presión a la que se estaba viendo sometida la Unión Soviética desde junio del año anterior.

Pese a que los norteamericanos pretendían un desembarco aéreo en la Europa ocupada, se impuso el punto de vista inglés, que preconizaba el asalto, mediante desembarco, en el África del Norte francesa (Marruecos y Argelia), controlada por el gobierno de Vichy, con tres objetivos bien definidos: liquidar la presencia del Eje en ese territorio, afianzar el control naval del Mediterráneo y disponer de una base para preparar el asalto posterior a Europa desde el Sur.

\footnotetext{
${ }^{245}$ Doussinague afirma que el documento en el que se recogen estas afirmaciones, entregado al embajador Vidal por el ministro Gómez Jordana, tiene fecha 24 de noviembre de 1942. Doussinague, José María, op. cit., pág. 204.

${ }^{246}$ Carta de Vidal a Jordana, fechada en Berlín el 5 de diciembre de 1942. AMAE. AR. Sig. R-1371/17.
} 
En los albores del día " $D$ ”, unos 600 buques de guerra desembarcaron a cerca de 70.000 soldados ingleses y norteamericanos en Casablanca, Orán, Argel y Safi, comenzando la invasión. El gobierno español ordenó la movilización del Ejército; la Segunda Guerra Mundial se acercaba peligrosamente a la frontera Sur y ponía a España en primera línea. La debilidad defensiva del Ejército español era evidente en esas fechas y las bazas que podía jugar España en el enfoque estratégico aliado, en concreto las islas Baleares, e incluso las Canarias, eran algo que preocupaba a los alemanes. Un suministrador de materias primas básicas para el III Reich, como era España, no podía caer en la órbita aliada. Como bien afirma Rafael García Pérez ${ }^{247}$ :

"El armamento se convirtió para el Tercer Reich en la mejor fórmula a su alcance para conservar una relación comercial privilegiada con un país suministrador que, a la altura de 1943 y para determinados productos estratégicos (los metales no férricos), era insustituible."

En efecto, más de la mitad del wolframio ${ }^{248}$ consumido por Alemania procedía de la Península Ibérica y el $90 \%$ de la ambligonita ${ }^{249}\left(\mathrm{LiAlPO}_{4} \mathrm{~F}\right)$, que cubría las necesidades alemanas de litio, procedía de España. También era español el 100\% del zinc usado por el Reich germano, y una gran cantidad de la fluorita ${ }^{250}$ (Ca F2), la mica $^{251}$, el berilo ${ }^{252}\left(\mathrm{Be}_{3} \mathrm{Al}_{2} \mathrm{Si}_{6} \mathrm{O}_{18}\right)$ o el hierro necesarios para mantener el esfuerzo de guerra.

\footnotetext{
${ }^{247}$ García Pérez, Rafael, Franquismo y Tercer Reich, op. cit., pág. 374.

${ }^{248}$ El wolframio, también denominado tungsteno, es un elemento químico muy escaso en la corteza terrestre, que se encuentra en forma de óxido y sales en ciertos minerales. Es de color gris acerado, muy duro y denso y tiene el punto de fusión más elevado de todos los metales y el punto de ebullición más alto de todos los elementos conocidos. Se utiliza en los filamentos de lámparas incandescentes, en electrodos de soldaduras, en resistencias eléctricas y en aleación con el acero, para la fabricación de aceros especiales muy resistentes. Se trata de un material estratégico y ha estado en la lista de productos más demandados desde la $2^{\mathrm{a}}$ Guerra Mundial. Es un metal fundamental para entender las sociedades modernas. Se extrae de varios minerales como la wolframita, la scheelita, la cuproscheelita, la ferberita etc... En España se encuentran minerales de wolframio en el Bierzo (León), Salamanca, Galicia, y Extremadura. (www.lenntech.es/periodica/elementos/w.htm)

${ }^{249} \mathrm{La}$ ambligonita es un fluosfato de aluminio y litio y como tal es una importante fuente de este último metal. En Cáceres hay importantes yacimientos de este mineral: Valdeflores, El Trasquilón, las Navas y Tres Arroyos son los más importantes. Se emplea para obtener sales de litio. (caceresnatural.blogspot.com.es/2010/01/minerales-de-caceres-ambligonita.html)

${ }^{250}$ La fluorita es un mineral muy empleado en la industria metalúrgica, química y óptica. Su uso principal es la extracción de ácido fluorhídrico, aunque también se utiliza en la producción de aluminio y para aumentar la fluidez de las escorias en metalurgia. Sus cristales cúbicos y bien formados, se emplean en la construcción de lentes. En España los principales yacimientos se hallan en Asturias. (www.asturnatura.com)

${ }^{251}$ Las micas son minerales pertenecientes a un grupo numeroso de silicatos de alúmina, calcio, hierro, magnesio y minerales alcalinos. Figuran entre los minerales más abundantes de la naturaleza. Constituyen
} 
En la mañana del 17 de noviembre de 1942 se presentaba en el Ministerio de Asuntos Exteriores español Hermann Sabath ${ }^{253}$, representante del Ministerio de Asuntos Exteriores alemán quién, circunstancialmente, iba a sustituir a Johannes Hemmen ${ }^{254}$, de viaje en Francia, como presidente de la Delegación alemana ${ }^{255}$. El motivo de la visita no era otro que mantener un cambio de impresiones con los españoles, para aclarar el estado de las negociaciones comerciales en ese momento ${ }^{256}$.

Primero acusó recibo de una carta enviada por el Ministro de Asuntos Exteriores español, general Gómez Jordana, al Embajador de Alemania en Madrid, Eberhardt von Stohrer, de la cual deseaba aclarar algunos extremos a los que concedía especial importancia. Quería saber si se había cambiado de posición -y en caso afirmativo, la causa- en el criterio adoptado con anterioridad respecto a la entrega de metales no férricos que servirían de primeras materias para la fabricación de maquinaria en Alemania.

El asunto era ciertamente importante para los intereses alemanes. En conversaciones celebradas con anterioridad se había llegado a un principio de acuerdo entre los negociadores de ambos países, en el sentido de que España debería suministrar a Alemania todos los metales que formaran parte de la maquinaria o armamento de cualquier tipo que este país fabricase por encargo de España con destino a su industria o a sus fuerzas armadas. Este suministro no podría ser considerado técnicamente una exportación ya que, volvería a España una vez finalizado el proceso debidamente

un importante material para la industria como aislantes eléctricos y térmicos. Se utilizan en máquinas de alta tensión, motores eléctricos y condensadores. (http://es.wikipedia.org/wiki/Mica)

${ }^{252}$ El berilo es un ciclosilicato de berilio y aluminio, base fundamental para la extracción del berilio. El berilio se utiliza, habitualmente, como endurecedor en aleaciones, especialmente de cobre, con numerosas aplicaciones en la industria (herramientas, industria aeronáutica, instrumentos de precisión, etc... (www.gemselect.com/spanish/gem-info/beryl/beryl-info.php)

${ }^{253}$ Hermann Sabath (Colonia, 3-10-1888/ Bonn, 29-5-1968). Era desde 1936 consejero jefe de la sección tercera del Departamento de Política Comercial del Auswärtiges Amt, encargada dicha sección de la Península Ibérica. En este puesto permaneció hasta el final de la Segunda Guerra Mundial. García Pérez, Rafael, op. cit., pág. 337.

${ }^{254}$ Johannes Hemmen, nombrado Presidente de la Delegación alemana para negociar un nuevo acuerdo comercial con España, era el jefe superior de los servicios económicos de la ocupación alemana en Francia. Fue enviado personalmente por el ministro de Asuntos Exteriores alemán, Ribbentrop. García Pérez, Rafael, Franquismo y Tercer Reich, op. cit., pág 283.

${ }^{255}$ La Delegación alemana para las negociaciones bilaterales se constituyó poco antes de dar comienzo las citadas negociaciones, el 29 de julio de 1942. Formaban parte de ella, además de Hemmen y Sabath, Bethke, jefe del consejo de servicios especiales en el RWM. García Pérez, Rafael, Franquismo y Tercer Reich, op. cit., pág. 284.

256 "Negociaciones con Alemania”, de fecha 17 de noviembre de 1942. AMAE. AR. Sig. R-2066, pág. 1. 
transformado. Esta regla general tendría una excepción: Alemania no solicitaría que España le entregase ningún metal para la fabricación de esa maquinaria o armamento, de los que pudiera obtener con los diferentes minerales cuya exportación hubiese sido aceptada por España, como el hierro, blenda de zinc, etc...

La posición española no era básicamente distinta de estos presupuestos a los que aludía Sabath, pero en la carta enviada por el Ministro de Asuntos Exteriores al Embajador alemán Stohrer, se traslucía un planteamiento menos rígido, buscando convenciones entre un exceso de minerales de una calidad determinada que pudieran conjugarse con déficits en otras entregas ${ }^{257}$. A continuación Sabath se refirió a otro punto contenido en la carta, en el cual Jordana sugería con insistencia al Embajador de Alemania von Stohrer, la conveniencia de un suministro de armamento a España por valor equivalente al desnivel en el intercambio comercial ${ }^{258}$.

Sabath preguntó si este aspecto se incluía por la situación en el teatro de operaciones del norte de África, y si el mencionado equilibrio en la balanza significaba un cambio de posición en lo acordado en la entrevista celebrada en El Pardo entre el Generalísimo y el Embajador Stohrer, en la que aquel reconoció que el Acuerdo al que se debía llegar no sería de tipo económico y por lo tanto había que contar con una entrega de mercancías por parte de España más importante que la de importaciones de Alemania.

Se le respondió a la segunda de las cuestiones manifestando que se desconocía la conversación mantenida en El Pardo, por no figurar en el expediente de las negociaciones, y respecto a la primera pregunta, no podía responderse por no haber recibido comunicación alguna en tal sentido.

Pero a la vez que se le daban estas respuestas, vagas e imprecisas, se le inquiría si una entrega de armamento equivalente al desnivel de la balanza comercial, o sea, de unos 300 millones de marcos como máximo, era problemático en aquellos momentos para el ejército alemán.

\footnotetext{
257 "Negociaciones con Alemania”, AMAE. AR. Sig. R-2066, pág. 2

${ }^{258}$ Documento "Armamento y financiación”, de fecha 18 de noviembre de 1942. AMAE. AR. Sig. R2066, pág. 1.
} 
Era evidente que a lo largo de las negociaciones ya se habían solicitado "Suministros Especiales"259 por parte del Gobierno de España. Se estimaba que al ampliar las posibilidades de suministro de mercancías de Alemania a España con productos como el armamento, en el cual el coste del manufacturado no guardaba relación con el de las primeras materias, de las que a la vez España era una importante suministradora, se facilitaba de modo tan extraordinario la posibilidad del equilibrio económico, que era importantísimo saber si era una decisión terminante la de no lograr aquel equilibrio, fueran cuales fueren los procedimientos que la Delegación española sugiriera.

Sabath afirmó que la intención de Alemania era suministrar armas a España pero el canal sería diferente al de tráfico normal de mercancías, donde se mantendría el principio del desequilibrio en la balanza comercial. Por este nuevo canal, Alemania suministraría a España una cantidad importante de armamento (sin precisar en ese momento el volumen del mismo), para lo que se debería llegar a un acuerdo con una serie de cláusulas políticas. No era la misión de la comisión analizar ni negociar asuntos políticos sino económicos, y se dejó claro a los alemanes que se definiera el marco de negociación, pareciendo a los españoles raro el hecho de querer emplear un doble canal para un tema tan significativo como era el armamento ${ }^{260}$.

El representante alemán quería saber en que forma se realizaría la financiación de la deuda alemana con España, dejando claro para sus interlocutores que estaban decididos a contraer dicha deuda en sus relaciones comerciales con España, aunque para sus contrapartes españoles era básico conocer cual sería la cantidad máxima de dicha deuda, para ser reflejada en los acuerdos que surgieran y tener reflejo en las garantías que se solicitaran.

La entrevista terminó con el compromiso del teutón de traer más datos en su siguiente entrevista, aunque dejó claro que la deuda debería ser superior la que alcanzaba en aquel momento ${ }^{261}$.

\footnotetext{
259 En toda la documentación consultada hay continuas referencias a unos inconcretos e indefinidos "Suministros especiales", que para cualquier lector no avezado o suficientemente introducido en la materia no significarían nada. Con estas dos palabras se quiso camuflar la adquisición de armamento y material alemán para los tres ejércitos españoles desde los tiempos de la Guerra Civil. Documento “Armamento y financiación”, de fecha 18 de noviembre de 1942. AMAE. AR. Sig. R-2066, pág. 1.

${ }^{260}$ Documento “Armamento y financiación”. AMAE. AR. Sig. R-2066, pág. 2.

${ }^{261}$ Documento “Armamento y financiación”. AMAE. AR. Sig. R-2066, pág. 3.
} 
La impresión de los negociadores españoles tras la conversación con Sabath fue una evidente contrariedad germana ante la idea de suministrar armamento a cambio de mercancías, y una voluntad total de evitar esa fuente de suministro, condicionando la entrega de armas a cláusulas de tipo político.

Una posición en buena medida intransigente por parte de las autoridades españolas en lo referente a las condiciones de financiación de esa deuda alemana podría forzar a que Alemania prefiriera entregar armamento antes que aceptar las condiciones de financiación. Y estas condiciones habrían de pasar, necesariamente, por exigir como garantía las propiedades alemanas en España, sobre todo las mineras. Si de esta manera, como solución al desnivel de la balanza comercial, se lograran repatriar valores y propiedades alemanas en España, mejoraría la situación de la economía española, sin duda alguna ${ }^{262}$.

El sábado día 20 de noviembre de 1942, se mantuvo otra reunión entre las delegaciones española y alemana, en la que se plantearon por parte española unas bases para intentar cerrar el acuerdo ${ }^{263}$. Dichas bases contenían seis puntos básicos:

-1.- Equilibrio en el valor del intercambio.

-2.- Margen de tolerancia con carácter de reciprocidad que pudiera permitir un desequilibrio de hasta 70 millones de marcos.

-3.-Las exportaciones españolas serían las previstas por acuerdo entre las dos delegaciones $^{264}$.

•4.- Las exportaciones alemanas que servirían de contrapartida a las españolas estarían integradas:

a) Por exportaciones de tipo normal

b) Por "Suministros especiales",265

\footnotetext{
${ }^{262}$ Documento “Armamento y financiación”. AMAE. AR. Sig. R-2066, pág. 4.

263 "Bases del Acuerdo con Alemania comunicadas verbalmente a la Delegación alemana en la sesión del sábado día 20 de noviembre de 1942”. AMAE. AR. Sig. R-2066-2.

${ }^{264}$ La Delegación española aseguraba a la alemana que se tendrían en cuenta las promesas hechas hasta ese momento.

265 Como hemos indicado anteriormente, estas dos palabras eran el eufemismo que definía las exportaciones de armamento a España hasta el momento de la firma del Acuerdo Comercial de diciembre de 1942. Los negocios en curso hasta ese momento por parte de los tres ministerios militares, que ya hemos tenido ocasión de analizar en el capítulo anterior, se siguieron manteniendo hasta el final de la guerra y mantuvieron ese discreto apelativo, con el que podían pasar desapercibidos.
} 

c) Por maquinaria
d) Por armamento

•5.- La partida d), "armamento", serviría durante la ejecución del Acuerdo de reguladora, con lo que se quería decir que la cantidad prevista por ambas delegaciones debería ser incrementada por valor equivalente al de otras exportaciones alemanas también previstas, pero que por cualquier circunstancia no pudieran realizarse.

-6.- Debido a la proximidad de la campaña naranjera y a la necesidad de crear una contrapartida rápida para que aquella no desbordara el margen de tolerancia previsto en el artículo $2^{\circ}$, sería recomendable que se realizase rápidamente una importación sustanciosa de armamento.

Los contactos se aplazaron hasta el 7 de diciembre de 1942, fecha en la que tuvo lugar la siguiente reunión entre las delegaciones española y germana, enmarcada en las negociaciones comerciales en curso $^{266}$.

Componían dichas delegaciones, por parte alemana los señores Sabath (que actuaba como presidente de la delegación), Koppelmann, Eberl y Enge; y por parte española, el director de política económica, Taberna, actuando como presidente, y los señores Huete, Zulueta, Vila, Alba, Suárez y Muñoz de Miguel.

Vicente Taberna, después de dar la bienvenida a los componentes de la Delegación alemana, recapituló las conversaciones preliminares mantenidas en los días anteriores, recordando las bases que como fundamento del futuro Acuerdo formuló la representación española en la sesión del día 20 de noviembre anterior.

En primer lugar, se debía partir del equilibrio en el valor del intercambio total; además había de preverse la posibilidad de un margen de tolerancia, con carácter de reciprocidad, que pudiera permitir un desequilibrio, el cual fue señalado en un principio en 70 millones de marcos.

A estos efectos, las exportaciones españolas previstas por ambas delegaciones tendrían como contrapartida las exportaciones alemanas por los cuatro conceptos citados anteriormente, que habían sido analizados en el documento entregado a Sabath el 20 de noviembre anterior. Como se había supuesto, la partida denominada

\footnotetext{
266 "Negociaciones económicas con Alemania. Extracto de la primera reunión celebrada con la Delegación alemana el 7 de diciembre de 1942”. AMAE. AR. Sig. R.2304-1, pág. 1.
} 
"Armamento" sería utilizada como elemento regulador del principio de equilibrio del Acuerdo que se iba a negociar.

En aquel momento el presidente de la Delegación alemana, Sabath, transmitió a los componentes de la Delegación española un acuerdo de las autoridades alemanas, que tranquilizó mucho los ánimos e hizo vislumbrar un camino que facilitaría en gran medida las negociaciones; Berlín había aprobado, en principio, la petición española de regular el equilibrio del intercambio a base de suministros de armamento ${ }^{267}$.

Esto sentó muy bien a los españoles, y Taberna, como presidente de la Delegación hispana, se congratuló por las manifestaciones Sabath e insistió en su proposición, dando lectura a un cálculo de valoración aproximado de los intercambios con arreglo a las bases antes mencionadas, y del cual dio conocimiento en la última reunión preliminar al propio Sabat. Explicó así mismo la diferencia de significado que la Delegación española asignaba a los conceptos "suministros especiales" y "armamento", aclarando que todas las entregas alemanas de material de guerra, a efectos de expresión en la negociación, se considerarían divididas en dos grupos: por una parte, el material de guerra que había sido o era en aquel mismo momento objeto de contratación. Por otra, el resto de material de guerra que hasta ese momento no había sido objeto de negociación y que serviría de regulador del equilibrio en el global de los intercambios

Al material bélico comprendido en el primer grupo se le denominaría "suministros especiales" y al del segundo, "armamento". Este último, precisamente, era el que, poco después, recibiría la denominación clave de "Programa Bär"268

\footnotetext{
267 "Negociaciones económicas con Alemania. Extracto de la primera reunión celebrada con la Delegación alemana el 7 de diciembre de 1942”. AMAE. AR. Sig. R.2304-1, pág. 1

268 La valoración aproximada de los intercambios hispano-alemanes previstos con arreglo a las bases del Acuerdo que se negociaba fueron las siguientes:
}

-Exportaciones españolas: (en millones de Reichmarks)

-a) Situación actual del “Clearing” (Deficit alemán) (1)..................186

-b) Concesiones realizadas en anteriores conversaciones (2)...........400

-c) Nuevas concesiones y reajustes (3)...........................................64

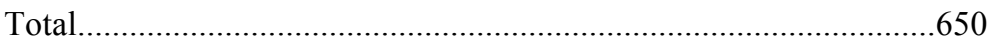

-Exportaciones alemanas:

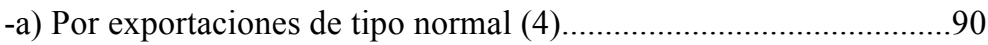

-b) Por Suministros especiales (5)................................................... 
Sabath comunicó que la imposibilidad de conocer la cifra del concepto "armamento" (que en esos momentos se estudiaba en Berlín y que sería objeto de determinación por técnicos militares de ambos países en un momento posterior), le llevaba a proponer a la Delegación española que la mesa de la negociación se ocupara de aquellas entregas alemanas cuya exportación había sido ya acordada y que tendría lugar en el transcurso de la vigencia del Acuerdo. Llegado ese momento hizo entrega al Sr. Taberna de la lista de dichas exportaciones ${ }^{269}$.

Entonces Koppelmann empezó a explicar a los españoles que la cifra de 253 millones de $\operatorname{marcos}^{270}$, que era la suma que se debería ingresar durante el período comprendido entre los doce meses siguientes, era el conjunto de las posibilidades de exportación alemana en el siguiente año, por lo que se refería a las mercancías respecto de cuya exportación podía dar seguridades de que tendría una efectividad inmediata. Por ello propuso que los trabajos de la mesa de negociaciones se circunscribieran a la citada

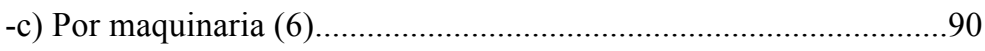

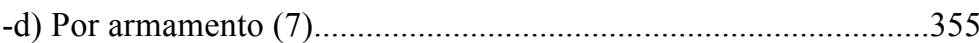

-Margen de tolerancia (8)......................................................................

-Equilibrio en el intercambio.............................................................650

(1) Descubierto en el momento de la negociación: 86.000.000 marcos. Mercancías pagadas sin recibir: 100.000.000 marcos.

(2) Añadido a lápiz en el documento original: "concedidos por Carceller".

(3) Tachado a lápiz en el documento original.

(4) Según declaraciones de la Delegación alemana.

(5) Según resulta del cómputo aproximado de las listas alemanas y las presentadas por técnicos españoles. Fueron añadidos a lápiz en el documento original 55.000.000 marcos con la siguiente anotación: "son los contratos pendientes con Tierra, Marina y Aire".

(6) Contando para las industrias privadas con 29.000.000 RM, según declaración de la Delegación alemana el resto con arreglo a los planes del Instituto Nacional de Industria (INI) (sólo 60.000.000 marcos en lugar de 100.000.000 marcos, como precisó la Delegación alemana en un principio).

(7) Como regulador del equilibrio en el intercambio.

(8) Comunicado a los negociadores alemanes en la sesión del 20 de noviembre último. Escrito a lápiz al lado de la cifra "70" figura lo siguiente: "Se puede llegar a 100 millones y tolerancia mayor para naranjas". Fuente: Extracto de la primera reunión celebrada con la Delegación alemana el 7 de diciembre de 1942. Anejo n ${ }^{\circ}$ 1. AMAE. AR. Sig. R.2304-1, pág. 2.

269 "Negociaciones económicas con Alemania. Extracto de la primera reunión celebrada con la Delegación alemana el 7 de diciembre de 1942”. AMAE. AR. Sig. R.2304-1, pág. 2.

${ }^{270}$ Esta cifra de 253 millones de marcos está desglosada en el Anejo $\mathrm{n}^{\mathrm{o}} 2$ de las conversaciones, y nosotros la recogemos en el denominado ANEXO II. AMAE. AR. Sig. R-2066-2. 
lista, dejando para más adelante la ampliación del volumen de los intercambios, una vez que los técnicos militares llegaran a un acuerdo sobre la cuestión del armamento.

Sin embargo, el presidente de la Delegación española reiteró la necesidad de partir, como base de la negociación, de un volumen total de intercambio, incluido el concepto "Armamento", si bien pudiera dejarse para más adelante la determinación de las clases, calidades y distribución de dicho material. Hizo observar Taberna, una cuestión de fondo muy importante cual era que si más tarde se llegaba a un acuerdo sobre la cuestión de armamento, todas las dificultades, retrasos y dilaciones que en las reuniones en curso se pudieran producir, al estar limitados a un plan menor, resultarían perfectamente inútiles, por consiguiente, insistió no ya en la posibilidad sino en la necesidad de prever un plan "grande" que incluyera la partida de "armamentos", ya que siempre se estaría a tiempo de reducirlo a los límites que las circunstancias exigieran. Al final se pidió a la Delegación alemana que meditara estas consideraciones y que estudiara ambos planes conjuntamente.

Más tarde tomarían la palabra los señores Koppelmann, Sabath, Huete y Taberna, insistiendo cada uno de ellos en los respectivos puntos de vista de sus propias delegaciones, pero sin llegar a ningún acuerdo. Taberna después de hacer un pequeño resumen del encuentro, dio por finalizada la reunión y emplazó a los representantes de ambas delegaciones para una próxima cita que tendrá lugar el día 9 a las 17,30 horas, y donde, según su propia creencia, los miembros de las delegaciones habrían meditado sobre las propuestas lanzadas en la reunión que acababa de tener lugar ${ }^{271}$.

Tras la reunión del día 9, el presidente de la Delegación alemana entregó al de la española una nota que comprendía dos extremos que serían la base para regular el intercambio hispano-alemán en el siguiente trimestre:

1.- El deseo alemán de que se autorizara la exportación de una serie de productos cifrados en 110.000.000 marcos, lista que debería revisar el Ministerio de Industria y Comercio.

2.- La fórmula para financiar dichas exportaciones fue concretada de la siguiente manera: El descubierto del Clearing en ese momento $\left(86.000 .000 \operatorname{marcos}^{272}\right.$ se

271 "Negociaciones económicas con Alemania. Extracto de la primera reunión celebrada con la Delegación alemana el 7 de diciembre de 1942”. AMAE. AR. Sig. R.2304-1, pág. 3.

${ }^{272}$ La nota alemana contenía el error de fijar el descubierto del Clearing en diciembre de 1942 en 40.000.000 de marcos en lugar de 86.000.00. AMAE. AR. Sig. R.2304-1. 
ampliaría hasta 140.000 .000 marcos con créditos habilitados por España, comprometiéndose el Gobierno alemán a mantener un ritmo de suministros con España de 18.500.000 marcos mensual en el siguiente trimestre, no sobrepasando el descubierto en los nueve meses restantes de la cifra de 70.000.000 marcos, fijada en principio como margen de tolerancia, la cual debería alcanzarse lo más tarde, el 30 de noviembre de 1943.

La realidad sería, entonces, que sumando el déficit existente en diciembre de 1942 con las exportaciones españolas solicitadas para el siguiente trimestre, el 28 de febrero de 1943 Alemania tendría un déficit acumulado de 140.500.000 marcos (cantidad resultante de restar 55.500.000 de marcos de las exportaciones alemas comprometidas ese trimestre a los 196.000.000 de marcos de déficit), una cifra que superaría el doble de los 70.000.000 de marcos señalados como margen de tolerancia a alcanzar a finales del año 1943.

El comentario interno por parte de la Delegación española a esta propuesta germana -absolutamente revelador de que todo iba por buen camino- fue el siguiente ${ }^{273}$ :

"Con las cláusulas de garantía de que el descubierto al final del año no sobrepase la cifra citada de 70.000.000 marcos, además de la relativa a la adquisición de armamento para enjugar el desnivel del intercambio, podría probarse en principio la elevación del déficit actual hasta la cifra indicada, por cuanto a mayor desequilibrio creado estos tres meses corresponderá mayor cantidad de armamento."

En otro documento interno ${ }^{274}$ elaborado por la Comisión, en el que se resumían las negociaciones en curso, se afirmaba:

“...es preferible para los intereses de España arrostrar el peligro de un desequilibrio todavía mayor que el actual, durante un breve período de dos o tres meses, que es el que separa el envío del armamento de los envíos actuales del intercambio comercial. Por ello, propone la negociación en el sentido de exportar por nuestra parte con arreglo al plan previsto, y dar a Alemania la sensación de amplia generosidad durante este período de tres meses, confiados en la declaración hecha reiteradamente de que 'las Altas autoridades

273 "Observaciones sobre la nota entregada por los delegados alemanes el 10 de diciembre de 1942". AMAE. AR. Sig. R.2304-1.

274 "Negociaciones económicas con Alemania. Diciembre de 1942”. AMAE. AR. Sig. R.2304-1. 
alemanas $^{275}$ han acordado acceder a lo solicitado por España. (Armamento).

Si durante dicho período o a su terminación no se hubiera iniciado la referida exportación, la posición de España sería francamente favorable para adoptar decisiones en el sentido de reducir sus exportaciones a aquel país. Si por el contrario, como así es de suponer, comenzase la exportación de armamento en el próximo trimestre, se habría creado (...) un fondo de desequilibrio sobradamente sustancioso para colocar aquella segunda negociación (la de armamento) en posición favorable a España, por cuanto no solicitaríamos en tal caso más que enjugar un desequilibrio creado con previsión.”

El mismo día 10, se recibía en el Ministerio de Asuntos Exteriores ${ }^{276}$ un apunte de la Embajada alemana en Madrid que venía a confirmar lo que estaba ya en las mentes de todos los negociadores: Berlín aceptaba pasar a la fase de la negociación "in situ" sobre los diferentes materiales que España necesitaba.

El gobierno del Reich proponía iniciar de inmediato negociaciones verbales sobre este asunto para averiguar lo que Alemania podía llegar a suministrar de lo que España necesitaba. Para ello, una comisión reducida de oficiales españoles, expertos en armamento de cada uno de los tres ejércitos, era invitada a la capital germana, por disponer allí de todos los medios e informaciones necesarias sobre las materias a tratar en las conversaciones, pudiendo de esta manera acelerar las negociaciones.

En el citado apunte, la embajada alemana, como portavoz del Gobierno del III Reich, aconsejaba -o por lo menos daba pistas de por donde tenía que ir- la composición de la comisión militar española, en la que deberían estar representados los ministerios de Tierra, Marina y Aire, así como:

“...expertos especiales de las diferentes categorías de armamentos deseados por el Gobierno español", y otro "experto especial de la industria española de armamentos, particularmente de municiones y de la explotación de las licencias alemanas".

El 13 de diciembre de 1942, el Embajador de España en Berlín, Ginés Vidal y Saura $^{277}$, cursaba un telegrama en clave al Ministerio de Asuntos Exteriores ${ }^{278}$

\footnotetext{
${ }^{275}$ En el original, “Altas” con mayúscula y las cuatro palabras entrecomilladas a posteriori, con lápiz. Es posible que fueran un circunloquio para referirse al propio Hitler.

${ }^{276}$ AMAE. AR. Sig. R.2304-1.

${ }^{277}$ Una de las primeras decisiones de Gómez Jordana al obtener la cartera de Asuntos Exteriores, fue nombrar a Ginés Vidal y Saura Embajador de España en Berlín en sustitución del comandante de Artillería y secretario personal de Serrano Súñer, José Finat y Escribá de Romaní, conde de Mayalde. Vidal nació en Cartagena en 1890. Doctor en Derecho y diplomático de carrera, estuvo destinado en
} 
comunicando a Madrid que por decisión personal de Hitler, Berlín invitaba a una comisión militar española de distintas armas para discutir detalles de la entrega de armamento. El embajador, afirmaba que esta decisión probaba:

“...que negociación está ya resuelta a nuestro favor en lo más importante y esencial."

El 17 de diciembre, tras la preceptiva autorización del Consejo de Ministros, reunido dos días antes, Jordana y Stohrer firmaban el Acuerdo Comercial entre España y Alemania ${ }^{279}$. Se trataba, aparentemente, de un sencillo compromiso resuelto en un preámbulo y cuatro artículos (apenas un folio y medio), en el que ambos países aceptaban el discutido principio de equilibrio comercial durante el año siguiente a la firma, con el consabido primer trimestre de "carencia". Gómez Jordana solicitó que no se diese publicidad al Acuerdo para así evitar las posibles reacciones de los aliados ${ }^{280}$. (Véase Anexo I).

En un anexo se especificaban con detalle los suministros españoles a Alemania para el período comprendido entre el 1 de diciembre de ese año y el 30 de noviembre del siguiente, distinguiendo entre materias primas y productos para el sector industrial por una parte y productos para el sector alimenticio, por otra.

En otro anexo se recogía el acuerdo sobre el suministro de metales no férricos y aleaciones, un interesantísimo y complejo documento que ajustaba las entregas de ciertos minerales que componían las mercancías elaboradas en Alemania y adquiridas por España. La normativa alemana en la materia exigía a cualquier país que importara productos industriales manufacturados, la entrega previa -independientemente del

legaciones como La Habana, San Salvador, Copenhague, Varsovia, Berlín o La Haya, así como en la Comisaría Superior de España en Marruecos. El 13 de agosto de 1936, un decreto del Ministerio de Estado, de conformidad con el decreto de la Presidencia del Consejo de Ministros del 21 de julio de ese mismo año, expulsaba de la carrera diplomática a Ginés Vidal, entonces ministro plenipotenciario de $2^{\mathrm{a}}$ clase en Copenhague, junto a otros compañeros de diferentes legaciones europeas. Siguió desempeñando su labor en la zona sublevada hasta el final de la Guerra Civil española. El 22 de octubre de 1942, tras el cese de Serrano Súñer como ministro de Asuntos Exteriores, Ginés Vidal era nombrado nuevo embajador en la capital del III Reich, uno de los puestos diplomáticos más relevantes del momento. "Un avezado diplomático de carrera con larga experiencia”, decía de él José $\mathrm{M}^{\mathrm{a}}$ Doussinague en su libro "España tenía razón”. El nuevo embajador partió de España el 16 de noviembre, presentando sus credenciales a Hitler el 5 de diciembre. Pocos días antes de la caída de Berlín, Vidal abandonaba la capital del Reich con destino a Berna, donde fallecería el día 28 de manera repentina por una embolia cerebral. Información obtenida en: Diario "La Vanguardia” de 13 de agosto de 1936, pág. 12 y www.forocartagena.com.

${ }^{278}$ Telegrama $n^{\circ} 521$ cursado a las 11,40 h. del 13 de diciembre de 1942. AMAE. AR. Sig. R.2304-1.

${ }^{279}$ En el Anexo I Se reproduce íntegramente el citado Acuerdo. La copia al carbón de este documento, sin firmar por ninguno de los representantes, se puede encontrar en AMAE. AR. Sig. R.2066-1.

${ }^{280}$ Ruhl, Klaus-Jörg, Franco, Falange y III Reich, op. cit., pág. 165. 
precio de los mismos- de ciertas cantidades de minerales especiales empleados en el proceso de fabricación. En el caso que nos ocupa, Alemania renunciaba a exigir a España la entrega de suministros adicionales de plomo, zinc, wolframio y mercurio, así como cualquier metal no férrico y sus aleaciones que no se produjeran en España.

En el acuerdo se marcaban los kilogramos a entregar en el año de vigencia del acuerdo, de cobre, latón, fundición roja, bronce, cromo y molibdeno, en función de los pedidos españoles englobados en tres categorías: suministros especiales (armas), negocios industriales y exportaciones normales. En el primer caso, los denominados "negocios especiales" o "suministros especiales" comprendían los contratos de armamento o patentes que ya estaban concertados antes de la firma del Convenio entre el Ejército y las autoridades alemanas; se trataba de 15 partidas, 13 de las cuales correspondían a adquisiciones de material militar y dos a instalaciones industriales también de carácter militar. El segundo, los denominados en la lista "negocios industriales", era maquinaria para la industria privada (Altos Hornos, Uniquesa, Fefasa, etc...), tenía siete partidas, correspondientes a instalaciones para la industria (seis) y 150 vagones de ferrocarril para ganado. En lo referente a exportaciones normales se imputaron datos estimados, a la luz de lo que había sucedido en años anteriores ${ }^{281}$.

Como colofón, pocas horas después de la firma del Acuerdo -el mismo 17 de diciembre de 1942-, el embajador alemán en Madrid, Stohrer, era cesado fulminantemente de su cargo por Ribbentrop. Esta decisión del ministro de Exteriores germano probablemente llevaba en el cajón desde septiembre, cuando fue destituido Serrano Súñer y si no se comunicó con anterioridad fue para no entorpecer las complicadas negociaciones económicas que se estaban llevando a cabo. Según Ruhl ${ }^{282}$ :

“...El cese cogió de sorpresa al propio Stohrer. Años más tarde no llegaría aún a comprender este proceder. Stohrer... fue retirado de la escena diplomática, cuando se convirtió en un obstáculo para una

\footnotetext{
${ }^{281}$ Las cantidades previstas de metales no férricos para su entrega a Alemania, contempladas en el Convenio Comercial de diciembre de 1942, eran las siguientes: 589,87 Tm de cobre; 223,44 Tm de latón; 21,25 Tm de metal rojo; 24, $30 \mathrm{Tm}$ de bronce; 30,07 Tm de cromo y 2,15 Tm de molibdeno. Por parte española, tenemos constancia de que el Consejo Ordenador de Minerales Especiales de Interés Militar un organismo dependiente de la Presidencia del Gobierno- envió a Alemania tres remesas de minerales, una en junio de 1943, otra en enero de 1944 y otra en marzo de ese mismo año. En la primera se remitieron 148,83 Tm de cobre, 143,22 Tm de latón, 9,27 Tm de cromo y 0,5 Tm de molibdeno. En la segunda se enviaron 151,15 Tm de cobre y en la tercera, $100 \mathrm{Tm}$ de latón. Como se puede apreciar, España iba algo retrasada en la entrega de metales no férricos. Exportación de metales no férricos a Alemania. AMAE. AR. Sig. R-2066-3.

${ }^{282}$ Ruhl, Klaus-Jörg, Franco, Falange y III Reich, op. cit., pág. 166.
} 
política secreta que perseguía el objetivo de unir a España más estrechamente con el Eje, con el fin de lograr la entrada de España en guerra, si se diera el caso derrocando al Jefe del Estado."

Por el contrario, García Pérez apunta ${ }^{283}$ :

“...no creemos que el cese de Stohrer marque el principio de una nueva política hacia España, tal como sugiere el profesor Ruhl. Una nueva política marcada por las maniobras encubiertas y la conspiración. Por el contrario, la salida de Stohrer es el punto final de una etapa cuyo ritmo de evolución estaba marcado por los acontecimientos internos españoles."

En cualquier caso, los cimientos de la entrega masiva de armamento alemán a España estaban ya montados. El Acuerdo comercial de diciembre de 1942, abría la puerta.

${ }^{283}$ García Pérez, Rafael, Franquismo y Tercer Reich, op. cit., pág. 356. 


\section{Capítulo 3}

\section{EL PROGRAMA BÄR. GÉNESIS, NEGOCIACIONES POLÍTICAS Y MILITARES}

\section{III.1. -GÉNESIS DEL PROGRAMA}

Aparte de los suministros de material de guerra y de maquinaria que aparecían comprendidos en el Convenio Comercial hispano-alemán de diciembre de 1942, se propuso entonces la adquisición de armamento y maquinaria fuera del mismo (lo que a partir de aquellos momentos se conocerá como "Programa Bär") y una primera aproximación al detalle del solicitado lo compone una lista que consta en el Ministerio de Asuntos Exteriores ${ }^{284}$, mostrada en la Tabla III-A. Este fue, en esencia, el documento al que tuvo acceso el embajador alemán Stohrer el 3 de diciembre de 1942 -de manera confidencial- y su contenido le pareció excesivo ${ }^{285}$.

\section{TABLA III-A}

\section{SOLICITUD ESPAÑOLA DE MATERIAL MILITAR}

\begin{tabular}{|c|c|c|}
\hline I.- Ejército & II.- Marina & III. Aire \\
\hline Ametralladoras AA de 15 o $20 \mathrm{~mm}$ & Equipos dobles 10,5 antiaéreos & Aviones "Me 109G" caza \\
\hline Cañones antitanque de 50 o $60 \mathrm{~mm}$ & Equipos sencillos 10,5 & Aviones "Ju 52G10e2" transporte \\
\hline Cañones largos de $150 \mathrm{~mm}$ & Equipos dobles de 8,8 antiaéreos & Aviones "He 111H6" bombardeo \\
\hline Cañones antiaéreos de $88 / 56 \mathrm{~mm}$ & Equipos semiautomáticos de $37 \mathrm{~mm}$ & Repuestos \\
\hline Fonolocalizadores & Ametralladoras de $37 \mathrm{~mm}$ & Piezas AA de $37 \mathrm{~mm}$ \\
\hline Proyectores guías & Ametralladoras de $20 \mathrm{~mm}$ & Camiones remolque $\mathrm{AA}$ \\
\hline Proyectores satélites & Direcciones de tiro para 10,5 & Municiones \\
\hline Carros de combate Tipo I & Direcciones de tiro para $120 \mathrm{~mm}$ & $\begin{array}{l}\text { Grupos radio campaña } 1,5 \mathrm{Kw} \text { de } \\
\text { onda corta y larga }\end{array}$ \\
\hline Carros de combate Tipo II & $\begin{array}{l}\text { Direcciones de lanzamiento de } \\
\text { torpedos }\end{array}$ & $\begin{array}{l}\text { Grupos de radio de pequeña } \\
\text { potencia }(100 \mathrm{w})\end{array}$ \\
\hline Carros de combate Tipo III & Minas submarinas tipo EMD & Camiones meteorológicos completos \\
\hline Municiones & Torpedos G-7 y torpedos eléctricos & $\begin{array}{l}\text { Grupos móviles alumbrado de } \\
\text { campo }\end{array}$ \\
\hline
\end{tabular}

${ }^{284}$ No consta la fecha en la que se elaboró la lista, aunque lo más probable es que date del mes de noviembre de 1942, previamente al desplazamiento a Berlín de la Comisión del capitán de navío D. Santiago Antón Rozas. "Relación de armamento que solicitan los ministerios de Defensa Nacional". AMAE. AR. Sig. R-2066-2.

${ }^{285}$ Ruhl, Klaus-Jörg, Franco, Falange y III Reich, op. cit., pág. 165. 


\begin{tabular}{|l|l|l|}
\hline & Cargas de profundidad & \\
\hline & Equipo cineteodolitos Askania & \\
\hline & Anteojos de observación y tijera & \\
\hline & Telémetros Zeiss & \\
\hline & Telémetros Goerz & \\
\hline & Vidrio óptico Zeiss & \\
\hline
\end{tabular}

Fuente: AMAE. Leg. R-2066-2

En el citado documento se acompañaban dos listados correspondientes a los nuevos pedidos necesarios, correspondientes a los Ministerios de Marina y Ejército.

Por lo que respecta al de Marina se hacían constar diferentes tipos de materiales y aparatos, tanto para los nuevos submarinos "G", cuya licencia se había negociado con la Kriegsmarine teutona, como para talleres del Consejo Ordenador de Construcciones Navales Militares y la fábrica de artillería naval de San Carlos (La Carraca- Cádiz) ${ }^{286}$.

El Ejército de Tierra fue más escueto, y en su listado sólo figuraban 200.000 minas ligeras antitanque y varias máquinas con destino, probablemente, a la Fábrica de Trubia, todas ellas relacionadas con la fabricación de piezas de artillería, así como 100 kilos de Widia en lenguetas, para fabricar herramientas.

El 28 de diciembre de 1942, el ministro de Marina nombraba al capitán de navío Santiago Antón Rozas y al teniente coronel de Artillería de la Armada, Lorenzo Pallarés Cacha, representantes de la Marina en la comisión que acudiría a Alemania a gestionar la entrega de $\operatorname{armamentos}^{287}$. De hecho, el capitán de navío Antón, al ser el oficial de

${ }^{286}$ Los seis epígrafes que recogían los pedidos de la Armada española eran los siguientes:

1.- Para la construcción de cuatro submarinos tipo "G": $1.200 \mathrm{Tm}$ de acero, motores diesel de $1.500 \mathrm{Hp}$, periscopios, aparatos de navegación y otros aparatos especiales.

2.- Para talleres de las Factorías del Consejo Ordenador de las Construcciones Navales Militares: máquinas-herramientas de todas clases como: tornos horizontales y verticales, mandrinadoras universales, cepillos, fresadoras, taladros, etc.

3.- Para completar tres submarinos tipo "D", en construcción: periscopios, aparatos de navegación, aparatos de aire comprimido y aparatos especiales...

4.- Para la construcción de otros dos submarinos tipo "G": periscopios y aparatos especiales.

5.- Para la Fábrica de Artillería de La Carraca: instalaciones especiales, laboratorios y diversa maquinaria.

6.- Otros: tres catapultas Heinkel para tres cruceros, cuatro hidros He 114, equipos motobombas de la casa AEG, aparatos y equipos para los distintos buques en construcción y patentes y diversos contratos sobre material de guerra relativos a la Marina.

"Relación de armamento que solicitan los ministerios de Defensa Nacional”. AMAE. AR. Sig. R-2066-2.

${ }^{287}$ Archivo General de la Administración. AGA. Sección de Marina. Caja 2868. 
mayor graduación, presidiría la Comisión española hasta el nombramiento del general de división Carlos Martínez de Campos, en marzo del año siguiente.

El nuevo embajador alemán en Madrid, Hans-Adolf von Molkte ${ }^{288}$ se reunía el 13 de enero de 1943 con el ministro de Asuntos Exteriores español, Gómez Jordana, advirtiéndole que sólo se entregarían armas a España si el Gobierno garantizaba que se utilizarían para defenderse de un ataque de los aliados ${ }^{289}$. Tras sendas entrevistas de Molkte con el propio Franco - una el 23 de enero, para presentar sus credenciales, y otra una semana más tarde-, el 8 de febrero el Gobierno español se declaró dispuesto a garantizar a Alemania su disposición a defenderse de un hipotético ataque aliado. Dos días después, el 10 de febrero, se firmaba un protocolo secreto con el texto enviado por von Molkte al Ministerio de Exteriores español, con el que Alemania tenía la garantía por escrito, que dichas armas nunca se emplearían contra ella y que España repelería cualquier acción ofensiva aliada contra el propio territorio, peninsular, insular o contra

288 Hans-Adolf Helmuth Ludwig Erdmann Waldemar von Molkte nació el 29-11-1884 en Oppeln (Silesia). Era hijo de Federico von Molkte, que había sido ministro de Estado en Prusia. Miembro de la aristocracia prusiana, era diplomático de carrera desde 1913, desempeñando sus funciones en Atenas (Grecia) y Estambul (Turquía) como agregado a dichas Legaciones. Tras la Primera Guerra Mundial, volvió a Estambul, como Consejero, desempeñando ese mismo cargo, más tarde, en el Ministerio de Asuntos Exteriores alemán. Tras dirigir el departamento para las cuestiones del Este, fue destinado a Varsovia, primero como Ministro Plenipotenciario y después como embajador. Al comenzar la Segunda Guerra Mundial, von Molkte volvió a Berlín, actuando en el Ministerio de Exteriores. El 18 de diciembre de 1942 fue designado para cubrir la vacante de Eberhardt von Stohrer - tras su cese- en la embajada alemana en Madrid. Falleció en la capital de España el 22 de marzo de 1943, apenas tres meses después de su nombramiento, debido a un ataque de apendicitis.

En el Boletín Oficial del Estado del 23 de marzo se publicó un decreto firmado por Franco, por el que el Gobierno español concedía honores de Capitán General al embajador fallecido, debiéndole tributar los honores fúnebres que las Ordenanzas españolas señalaban para un "capitán general del Ejército que moría en plaza con mando de jefe". A la conducción del cadaver acudirían ministros del gobierno y comisiones de todos los cuerpos, tanto civiles como militares. Ha de señalarse, por su indudable valor político en ese momento, lo que el citado decreto señalaba en su parte introductoria:

"Queriendo dar un testimonio del profundo dolor que ha causado en mi ánimo el fallecimiento del excelentísimo señor doctor Hans-Adolf von Molkte, embajador extraordinario y plenipotenciario del Reich alemán, asi como patentizar los amistosos sentimientos que profeso a su Führer y a la nación que tan dignamente ha representado..."

Cuenta José María Doussinague en su libro de memorias "España tenía razón. 1939-1945”, referente al boato dado a la conducción del cadaver de Molkte por el Paseo de la Castellana, lo siguiente: "No faltó quien comentara aquello en tono de censura desde el punto de vista de los aliados. Y cuando el embajador de la Gran Bretaña, Sir Samuel Hoare, se refirió a ello, el conde de Jordana, con su rostro impasible, replicó instantaneamente:

-Le aseguro que hubiéramos hecho lo mismo con el Embajador de Inglaterra.

Lo que no dejó de desconcertar a su interlocutor, según aquél comentó luego...”

Los datos biográficos del embajador von Molkte en ABC nº 12.360 del martes 23 de marzo de 1943. Edición de Andalucía y Doussinague Teixidor, José Maa, op. cit., pág. 189.

${ }^{289}$ Ruhl, Klaus-Jörg, Franco, Falange y III Reich, op. cit., pág. 205. 
el protectorado marroquí. ${ }^{290}$. Hitler acababa por autorizar el envío masivo de armamento a España, aunque condicionado por una garantía política ${ }^{291}$. Las relaciones entre ambos países daban un vuelco tras la firma de este protocolo. El ansiado armamento moderno alemán sería ya más que un sueño una realidad, aunque todavía quedaban escollos por superar hasta que las primeras remesas de material militar llegaran a suelo español.

El 18 de febrero la Dirección General de Industria y Material del Ministerio del Ejército firmaba cuatro importantes contratos con Alemania, completamente independientes del "Programa Bär", y que ya hemos analizado en el primer capítulo. Dos de ellos estaban referidos a la adquisición de las patentes para fabricar en España dos modelos de cañones: los famosos antiaéreos de $88 \mathrm{~mm}$ y los pesados de campaña de $150 \mathrm{~mm}$, con las casas "Krupp" y "Rheinmetall", respectivamente. Otro, con la importante casa "Polte", de Magdeburgo, tenía como fin la adquisición de patentes y ayuda técnica para fabricar cartuchería de acero. El último, firmado con la casa "Ringsdorf” y la AGEKA, comprendía diversas patentes y maquinaria para fabricar bandas de acero para proyectiles.

\section{-III.2. LA COMISIÓN INTERMINISTERIAL PARA LA ADQUISICIÓN DE MATERIAL DE GUERRA}

Dos días antes de la firma de los citados contratos, el 16 de febrero de 1943, mediante telegrama cifrado con origen la Embajada de España en Berlín y destino el Ministro de Asuntos Exteriores ${ }^{292}$, el embajador español Ginés Vidal y Saura comunicaba a Madrid que la Comisión técnica había recibido una propuesta alemana para la entrega de material al Ejército - similar por otra parte a la ya recibida por

\footnotetext{
${ }^{290}$ El texto decía: "El Gobierno español, a petición del Gobierno del Reich declara que está decidido a resistir a toda acción de las fuerzas armadas anglo-norteamericanas para poner pie en la Península Ibérica y territorios españoles fuera de la Península, es decir, en el Mediterráneo, Océano Atlántico y África, así como en el Protectorado español en Marruecos y defenderse contra tal acción con todos los recursos de que disponga." En cualquier caso, hay una ligera discrepancia en las fechas de firma del citado protocolo. Mientras García Pérez cita el día 10 como día de la firma, Ruhl afirma que fue el día 12. Nos inclinamos por la ofrecida por García Pérez. AMAE. AR. Sig. R-1371-17. Citado por García Pérez, Rafael, Franquismo y Tercer Reich, op. cit., pág. 381 y Ruhl, Klaus-Jörg, Franco, Falange y III Reich, op. cit., pág. 211.

${ }^{291}$ García Pérez, Rafael, Franquismo y Tercer Reich, op. cit., pág. 365.

292 AMAE. AR. Sig. R-2304-1 Telegrama cifrado $n^{\circ}$ 117. Curiosamente, la fecha que consta en el telegrama -16 de febrero de 1942- es incorrecta, pues dicho telegrama lo firma el embajador, Ginés Vidal y Saura, quien se incorporó a la legación española en la capital del III Reich en diciembre de 1942. Es posible que el redactor del mensaje, al ser muy próxima la fecha al inicio del nuevo año, mantuviera en el subconsciente el año que acababa de finalizar y cometiera el citado error.
} 
Aviación-, condicionando la entrega del citado material bélico a su aprovechamiento técnico mediante instrucción especial del personal competente, por unidades enteras. Hitler, por lo visto, deseaba supeditar la entrega de material pesado a España, a las necesidades orgánicas de nuestro Ejército, y al parecer, de manera rápida.

La Comisión española que estaba ya en Berlín desde principios de enero de 1943, se vio atada de pies y manos para desarrollar su trabajo pues las autoridades alemanas tuvieron a sus miembros "entretenidos" hasta la firma del protocolo secreto del 10 de febrero de ese mismo año, tratando de dilatar las negociaciones ${ }^{293}$. Estaba compuesta por nueve jefes y oficiales de los tres ejércitos, entre ellos, los tres agregados militares presentes en la Embajada española en Berlín, y su misión era presentar a las autoridades alemanas las listas de armamento elaboradas en España y analizar la viabilidad técnica de su adquisición. Tenían prohibido terminantemente hablar de cuestiones políticas o económicas y su primera reunión tendría lugar el 15 de enero de 1943 en la sede del Auswärtiges $A m t^{294}$ bajo la presidencia del embajador español, Ginés Vidal y del Secretario de Estado del organismo alemán, Ernst von Weizsäcker ${ }^{295}$.

En España, se tenía la conciencia de que cuando se salvaran los escollos para que las negociaciones avanzaran, habría que enviar a Alemania a un general del Ejército con prestigio y capacidad para tomar decisiones en cuanto a la cantidad y calidad del armamento a negociar con el Reich, siempre sujeto a las directrices marcadas por el Ministerio de Exteriores. El general Gómez Jordana conocía desde hacía muchos años la personalidad, la eficacia y el prestigio de uno de los más capacitados militares españoles de la época: el entonces profesor principal de la Escuela Superior del Ejército, jefe de la Reserva General de Artillería, de la Junta de Armamento del Estrecho, y subinspector de la Artillería de Costa española, el recién ascendido a general de división, D. Carlos Martínez de Campos y Serrano. Tras una reunión de los ministros militares con Franco, celebrada en el Palacio del Pardo el 21 de febrero, Martínez de Campos fue nombrado presidente con plenos poderes de la Comisión.

\footnotetext{
${ }^{293}$ Afirma Ruhl que a los miembros de la Comisión "se les mantuvo ocupados viajando en plan turístico. Solamente cuando los españoles se enfadaron por la demora, Hitler se declaró dispuesto a dejar negociar al general Thomas". Ruhl, Klaus-Jörg, Franco, Falange y III Reich, op. cit., pág. 226.

${ }^{294}$ Denominación germana del Ministerio de Asuntos Exteriores.

295 Ernst Freiherr von Weizsäcker. Marino, diplomático y político alemán que ejerció el cargo de Secretario de Estado del Ministerio de Asuntos Exteriores desde 1938 hasta 1943. Después, hasta el final del conflicto, fue embajador en la Santa Sede.
} 
Llegados a este punto, conviene detenernos y profundizar en los datos biográficos del que iba a ser presidente de la "Comisión Extraordinaria para Material de Guerra" en Alemania. El general de división Carlos Martínez de Campos y Serrano es un personaje, sin duda, interesante por su enorme prestigio, demostrada y sobrada capacidad de trabajo y una intensa vida al servicio del Ejército en los más variados cometidos, tanto de combate, en primera línea de fuego en la campaña de Melilla de 1909, en la guerra de Marruecos entre 1921 y 1926 y en la propia Guerra Civil española, como de representación en diferentes legaciones diplomáticas e incluso, ya en su última época, como preceptor del entonces Príncipe de España, Juan Carlos de Borbón.

Carlos Martínez de Campos y Serrano ${ }^{296}$ nació en París el día 6 de octubre de 1887, hijo de José Martínez de Campos y Martín de Molina, duque de Latorre, y de Concepción Serrano Domínguez. Ingresó como alumno en la Academia de Artillería de Segovia el 1 de septiembre de 1903, cursando sus estudios durante los siguientes años, y siendo promovido al empleo de segundo teniente alumno el 18 de julio de 1906. Por R.O. de de 15 de julio de 1908 ascendía al empleo de primer teniente de Artillería, pasando destinado al $10^{\circ}$ Regimiento montado de Vicálvaro (Madrid). Tomó parte en la denominada Campaña de Melilla de 1909, agregado en varias baterías expedicionarias y columnas de municiones, entrando en contacto con el enemigo en diversas ocasiones, acciones por las que fue felicitado por el mando y recompensado con la Cruz al Mérito Militar con distintivo rojo.

Ascendió a capitán con antigüedad de 21 de julio de 1914, mientras realizaba el curso de Equitación Militar, especialidad de la que sería nombrado profesor y en la que destacó a lo largo de su vida. Así mismo, tomó parte en el curso de la Escuela Superior de Guerra, finalizándolo con aprovechamiento en septiembre de 1918 y pasando destinado en esa fecha al Grupo de Getafe del $15^{\circ}$ Regimiento de Campaña.

Compatibilizó sus tareas militares y su presencia permanente en el Protectorado marroquí durante las prácticas de sus cursos, con el desarrollo de una labor intelectual como escritor, pudiendo resaltar obras como "Consideraciones militares sobre la zona francesa de Marruecos. Impresiones de viaje", "Instrucción a caballo" o "Artillería y aviación. Su empleo y enlace en la guerra moderna", por lo que fue recompensado con

\footnotetext{
${ }^{296}$ Según la hoja de servicios del citado oficial general que se custodia en el Archivo General Militar de Segovia (AGMS), Secc. 1 ${ }^{a}$ División 732/12, pág. 2.
} 
sendas Cruces de $1^{\text {a }}$ Clase al Mérito Militar con distintivo blanco por las dos primeras y mención honorífica sencilla por la última.

En 1919, y siendo todavía capitán, fue destinado al Estado Mayor Central (E.M.C.), y un año más tarde, en mayo de 1920, se le confió una comisión de servicio de un año de duración en Japón, para auxiliar en sus cometidos al Agregado Militar en el país nipón. Su preparación intelectual fue muy apreciada por el Agregado Militar, quien escribiría de él ${ }^{297}$ :

“...este capitán tenía al llegar a dicho país una preparación especial con relación con la historia del mismo y un conocimiento del idioma que no han traído hasta ahora ninguno de los funcionarios españoles que han pasado por aquí..."

Asistió durante su estancia en Japón, a numerosos establecimientos militares nipones, siendo invitado por el Ministro de la Guerra a presenciar las grandes maniobras militares del otoño de 1920; al finalizar las mismas fue autorizado a visitar Pekín (China) y Seúl (Corea), donde obtuvo una gran cantidad de información sobre la organización militar de ambos países, la cual, organizada y transcrita convenientemente, remitió al Estado Mayor Central. Mediante la preceptiva sanción imperial, fue destinado al $10^{\circ}$ Regimiento de Artillería de Campaña japonés por un período de seis meses, incorporándose en enero de 1920 y asistiendo al período de instrucción de los reclutas japoneses a la citada unidad, traduciendo y estudiando los reglamentos vigentes entonces en ese país asiático.

Además de su conocimiento de japonés, el entonces capitán Martínez de Campos conocía el alemán y dominaba a la perfección el inglés y el francés, lo que puede darnos una ligera idea de su vasta cultura. Reza así en su hoja de servicios $^{298}$ :

“...Este capitán (...) tiene amor a la profesión, muy buen espíritu, notoria cultura, aplicación y capacidad y por su comportamiento y manera de conducirse, su paso por el Japón ha sido muy beneficioso para el servicio y ha redundado en prestigio de nuestro ejército."

\footnotetext{
${ }^{297}$ Escrito del Agregado Militar de España en Japón, de 12 de marzo de 1921. Hoja de servicios de D. Carlos Martínez de Campos y Serrano. Doc. cit., pág. 19.

${ }^{298}$ Id., pág. 20.
} 
De esta época es su obra “El Japón, notas militares y políticas para la historia de un pueblo de pocos años", por la que sería nuevamente recompensado con una Cruz al Mérito Militar de $1^{\text {a }}$ clase con distintivo blanco.

Tras su regreso a España, fue destinado al Grupo de Artillería de Instrucción, ubicado en el campamento de Carabanchel, donde se estaban recibiendo y se preparaban los nuevos obuses de campaña Schneider de 155/13 cm. para la guerra africana. El 20 de noviembre partía con destino a Melilla encuadrado en el Grupo organizado en Carabanchel, actuando como ayudante del mismo, quedando allí a las órdenes del general Sanjurjo. Desde el día 8 de ese mismo mes, el entonces capitán Martínez de Campos entraba a formar parte, como Caballero, de la Real y Militar Orden de Calatrava. Su estancia en el territorio marroquí se prolongaría hasta finales de diciembre de 1922, fechas en las que, tras múltiples servicios de guerra llevados a cabo con su Grupo de Instrucción, regresó a Madrid, a su destino en Carabanchel.

El 3 de febrero de 1923, la Real Academia de la Historia nombraba miembro correspondiente de la misma, al todavía joven capitán de Artillería D. Carlos Martínez de Campos y Serrano, Conde de Llovera, y pocos días más tarde, era citado como "Muy Distinguido" en la Orden General de Melilla por su meritorio comportamiento en diferentes operaciones artilleras desarrolladas en los meses de marzo y abril del año anterior.

El 1 de mayo de 1924 se incorporaba a un nuevo destino, que esta vez le llevaría a la Agregaduría Militar en Italia, donde tendría el honor de acompañar a los Reyes de Italia en su viaje a España, llevado a cabo en junio de 1924. Un año más tarde, el 6 de julio de 1925, ascendía Martínez de Campos al empleo de comandante por antigüedad y se le confirmaba desde España en su destino de Agregado Militar en Roma. Dos años más tarde se le ampliaban sus funciones y su trabajo, pasando a desempeñar también el cargo de Agregado Aeronáutico en la misma legación. A partir de 1929, y tras una importante reorganización de las Agregadurías militares en el extranjero, el comandante Martínez de Campos asumía la representación en Grecia, Bulgaria, Turquía y, eventualmente, Albania, sin dejar su cargo y residencia en Roma.

En agosto de 1931, tras la proclamación de la República, fue destinado al Estado Mayor Central del Ejército, regresando a España un mes más tarde y desempeñando 
trabajos relativos a su nuevo destino. Cuatro años más tarde, su hoja de servicios recoge una importante anotación, relativa a su vasta cultura y a su reconocimiento por parte de las autoridades militares:

“...por ley de 21 de febrero (D.O. $\mathrm{n}^{\circ}$ 50) se le concede la Cruz de $2^{\text {a }}$ clase del M.M. con distintivo blanco (...) por ser autor de la obra titulada "La ocupación de Fezzan ${ }^{299}$ por las tropas italianas" y otros trabajos que ponen de relieve su gran cultura militar, puesta al servicio de la profesión castrense..."

El alzamiento militar del 18 de julio de 1936 le sorprendió en Biarritz, donde disfrutaba de su permiso de verano. Tras diversos intentos consiguió incorporarse a la zona navarra, dominada por los sublevados, presentándose en Pamplona al coronel Solchaga el 19 de julio. Tres días más tarde sería nombrado jefe de Estado Mayor de la columna al mando del coronel Ortiz de Zárate, pasando una semana después a desempeñar el mismo cargo en la columna del coronel Beorlegui. Tras la toma de San Sebastián y las operaciones en la provincia de Guipúzcoa, el 5 de noviembre el comandante Martínez de Campos fue habilitado para el empleo de teniente coronel y nombrado jefe de la $2^{a}$ Agrupación de Infantería de la columna, formada ésta por cuatro grupos, con un total de 20 compañías. Un mes más tarde, se le comunicaba el ascenso por antigüedad a teniente coronel.

El 20 de diciembre de 1936 fue nombrado Comandante Principal de Artillería de las Brigadas de Navarra ${ }^{300}$ y cuatro meses más tarde, por orden de 13 de abril de 1937 , se le concedía la habilitación para el empleo de coronel. Después de la transformación de las cuatro Brigadas de Navarra en Divisiones, llevada a cabo el 29 de abril de 1937, y la creación de una quinta, el coronel Martínez de Campos siguió en su puesto, dirigiendo la artillería de estas unidades que actuaban en el Norte vasco, aproximándose ya al "cinturón de hierro" bilbaíno.

\footnotetext{
${ }^{299}$ Región de Libia situada al suroeste del país, en pleno corazón del Sahara. Italia había conquistado la región costera de Libia en 1911, aunque no lograría dominar toda la zona del Fezzan hasta marzo de 1930. El entonces comandante Martínez de Campos, agregado militar y aeronáutico español en Roma, fue testigo de primera mano de esta acción italiana, desplazándose a la Tripolitania en diciembre de 1929 para seguir estas operaciones desde el puesto de mando del general Graziani y encuadrado en los Grupos Saharianos del Regio Esercito italiano. Hoja de servicios de D. Carlos Martínez de Campos, págs. 30 y 31.

${ }^{300}$ En ese momento, a finales de 1936, había cuatro Brigadas, llamadas de Navarra, combatiendo en el frente norte: la primera en Vergara, la segunda en la zona de Deva, la tercera en Mondragón y la cuarta en Vitoria. Hoja de servicios de D. Carlos Martínez de Campos, pág. 38.
} 
Tras la toma de Santander y Asturias, y con ello la liquidación del frente del Norte, el coronel Martínez de Campos fue nombrado Comandante General de Artillería del Ejército del Norte, al mando del general Fidel Dávila desde la muerte en accidente aéreo del general Mola, alma mater de la sublevación. En diciembre se hizo cargo provisionalmente de la Comandancia Principal de Artillería del Cuerpo de Ejército de Castilla, sin abandonar su cargo en el Ejército del Norte, organizando mandos y servicios artilleros de la gran unidad. Sería largo relatar con detalle la participación del coronel Martínez de Campos en el resto de la Guerra Cil; baste decir que tomó parte en todas las operaciones del Ejército del Norte hasta el 1 de abril de 1939, siendo acreedor de la Medalla Militar individual, concedida el 5 de enero de 1939. El 22 de febrero de 1939 fue ascendido al empleo de coronel efectivo y una semana después, el 1 de marzo, se le habilitaba como general de brigada y era designado $2^{\text {a }}$ Jefe de la Comandancia General de Artillería del Cuartel General del Generalísimo.

Después de finalizar la guerra, el 26 de mayo de 1939, embarcó en Vigo formando parte de la Comisión que acompañó a la Legión Cóndor en su viaje de regreso a Alemania. Durante su permanencia en el país germano tuvo ocasión de visitar las baterías de costa de la región de Kiel, la Línea Sigfrido, las fortificaciones de Checoeslovaquia, y varias escuelas militares y fábricas de armamento, regresando a España el 26 de junio.

El 15 de agosto de 1939 se le destinó a las órdenes del Ministro para que organizara el Estado Mayor del Ejército y un mes más tarde ocupaba el puesto de Jefe de dicho Estado Mayor, en plaza de superior categoría. En marzo de 1941 fue ascendido al empleo efectivo de general de brigada por méritos de guerra con antigüedad de 1 de julio de 1940 y el 5 de mayo siguiente, se le nombraba Jefe de la Reserva General de Artillería, cargo que simultaneó con el de Gobernador Militar de Cádiz y Presidente de la Junta de Defensa y Armamento del Estrecho.

En enero de 1942 pasó a desempeñar el cargo de Profesor Principal de la Escuela Superior del Ejército, sin cesar en sus otros destinos. Por estas fechas se dio la curiosa situación de que al mismo tiempo que impartía sus conferencias sobre estudios estratégicos en calidad de profesor principal, asistía como alumno "concurrente" al curso de Mandos Superiores para su habilitación para el ascenso a general de división. 
El 7 de enero de 1943 ascendía al empleo de general de división, manteniendo sus anteriores destinos y cargos.

A finales de febrero de ese mismo año se le informó de su nombramiento como Presidente de la Comisión Extraordinaria para Material de Guerra, que operaba en Alemania para la consecución de un acuerdo de adquisición de armamento y material militar para los tres ejércitos (tierra, mar y aire). El acuerdo para su nombramiento fue tomado el 21 de febrero en El Pardo, residencia oficial de Franco, en una reunión mantenida por el Jefe del Estado con los ministros militares para discutir las nuevas ofertas alemanas presentadas por el general Krahmer.

\section{III.3.- -EL INFORME “KRAHMER"}

Poco después de finalizar la Guerra Civil española fue destinado a Madrid un nuevo Agregado Aéreo alemán: el entonces coronel (oberst) Eckard Krahmer. Se trataba de un oficial de 48 años, procedente del arma de artillería, que había combatido en la Primera Guerra Mundial en la aviación germana y que en 1934 había sido transferido a la nueva Luftwaffe creada por Hermann Göring.

Desde el 1 de abril de 1942 -ya ascendido desde octubre del año anterior a generalleutnant- hasta el final de la guerra mundial, Krahmer actuó como Agregado Militar y Aéreo en Madrid, tomando parte activa en todo el proceso que nos ocupa ${ }^{301}$.

En un informe confidencial sin fecha ${ }^{302}$, remitido por Krahmer a su homónimo español, Carlos Martínez de Campos, y que se conserva en el Archivo General Militar de Ávila ${ }^{303}$, se hacen constar explícitamente los deseos del mando alemán de enmascarar el futuro suministro de armas a los españoles, aprovechando como pretexto la División Azul que en esos momentos combatía en el Frente ruso.

\footnotetext{
301 Datos de la biografía de Eckard Krahmer extraidos de la página web: http://www.geocities.com/ orion47/WEHRMACHT/LUFTWAFFE/Generalleutnant/KRAHMER_ECKA RD.html

${ }^{302}$ Diversos datos que en el mismo se aportan, como la existencia en España de dos aviones Fw 200 internados (hecho que ocurrió el 31 de diciembre de 1942), o la respuesta a este informe, fechada a finales de febrero de 1943, o el hecho mismo de estar dirigido a Martínez de Campos, que fue nombrado Presidente de la Comisión el 21 de febrero, me hacen pensar, sin temor a error, que el informe de Krahmer pudiera estar redactado la última semana de febrero de 1943.

303 Informe Confidencial sin fecha, dirigido al general Carlos Martínez de Campos. AGMAV. Caja 24.711. Carpeta: Informes y documentación diversa sobre Alemania de los viajes del general Martínez Campos.
} 
Según los alemanes, y para el caso concreto del material que se remitiría con destino a la aviación española ${ }^{304}$ (tanto de vuelo como de artillería antiaérea) habría que realizar el siguiente programa, en el cual figuraría como pretexto la mejora en la preparación de los militares españoles destinados al frente oriental:

-1.) En España se recibiría, procedente del III Reich, cierto número de armas, similares a las empleadas en el frente oriental por la División Española de Voluntarios para entrenar con ellas a los futuros relevos que acudieran a Rusia procedentes de la Península.

-2.) En la Francia ocupada se formarían unidades españolas que serían dotadas de armamento, material y combustible por parte de la Wehrmacht, y que servirían como unidades de enseñanza para proporcionar a los voluntarios españoles las experiencias más recientes en táctica, estrategia y mando de formaciones militares.

-3.) Los voluntarios españoles, después de pasar por estas unidades de instrucción en España y Francia, marcharían al Frente oriental para integrarse en la División Azul y aprender de las experiencias prácticas de la guerra moderna.

Para que estos tres puntos fueran realizables, Krahmer proponía el envío inmediato de 15 cazas Messerschmitt Bf 109 F-4 y 10 bombarderos Junkers Ju 88 A-4. Los primeros serían recogidos y pilotados por militares españoles y los segundos, en cambio, serían conducidos a España por pilotos alemanes, debido, sin duda, a la falta de experiencia en el manejo de estos aviones por parte de los españoles. Krahmer añadía que los dos Junkers Ju 88 internados entonces en territorio español, tras sendos aterrizajes de emergencia ${ }^{305}$ quedarían también en poder del Ejército español, con lo que habría un total de doce bombarderos Ju 88 en España para fines de instrucción. Además, se pondría a disposición de los españoles enseguida un Junkers Ju 88 con doble mando, además de un piloto alemán, un ingeniero y un mecánico, para que sirvieran como profesores de este material, los cuales regresarían a Alemania tan pronto como el

\footnotetext{
${ }^{304}$ Como veremos a continuación, el general Krahmer remitió un informe muy similar a este al Ejército de Tierra, en el que señalaba qué debía de hacerse con el material terrestre solicitado por el Ministerio del Ejército.

${ }^{305}$ Se trataba de un Ju 88 D-1 trop. que aterrizó en San Javier (Murcia) el 8 de noviembre de 1942 y un Ju 88 D-5 trop. que había tomado tierra el 27 de octubre de 1942 en el aeródromo mallorquín de Son San Juan. Posteriormente se incorporarían al Ejército del Aire y recibirían las matrículas 29-11 y 29-18 respectivamente. Datos facilitados por el investigador aeronáutico D. José Luis González Serrano.
} 
Ejército del Aire tuviera personal capacitado en el manejo de los aviones. Así mismo, se proponía que los dos aviones Focke Wulf 200 que se encontraban en esos momentos en Sevilla ${ }^{306}$, fueran adquiridos por el Ejército del Aire para, posteriormente, ser devueltos a Alemania como pago parcial por los Ju 88 suministrados en esta operación.

Krahmer aludía también a la recepción en España de un Grupo completo de artillería antiaérea pesada, compuesto de tres baterías $8,8 \mathrm{~cm}$. (con cuatro piezas cada una) y dos baterías de $2 \mathrm{~cm}$., compuesta por diez cañones cada una, incluyendo todo el material necesario para su correcto funcionamiento y despliegue. Este material se suministraría sin medios de tracción, asunto que habría de resolverse en España de la mejor manera posible. A continuación, Alemania iría remitiendo más grupos completos de esta clase, llegando a asegurar que las baterías de $8,8 \mathrm{~cm}$. se aumentarían de cuatro a seis cañones cada una. Además, se declaraba conforme con el deseo español de enviar una veintena de jefes y oficiales de artillería a unidades alemanas de artillería antiaérea situadas en Francia para enterarse de las experiencias modernas en tiro y táctica.

De la misma forma, la Luftwaffe formaría de inmediato en Francia un grupo de caza y una escuadrilla de bombardeo, ambos españoles, compuesto el primero por tres escuadrillas equipadas dos de ellas con cazas Messerschmitt Bf 109 F4 y otra con aparatos franceses Dewoitine, y la segunda con aparatos Junkers Ju 88, con posibilidad de ser aumentada hasta formar un grupo. En el caso de que España entrara en guerra, ambas unidades se trasladarían a territorio español, a disposición del mando del Ejército del Aire para su empleo inmediato. También se pensó formar en territorio francés un grupo antiaéreo español al completo, totalmente motorizado, suministrado por la Luftwaffe. Al igual que en el caso de los aviones, estaría a disposición de España en caso de que se entrara en la guerra.

Por último, el general Krahmer proponía aumentar la escuadrilla española de voluntarios, que luchaba en el sector central del Frente del Este, a un grupo, organizando de inmediato una escuadrilla de bombardeo dotada -como no- de los

\footnotetext{
${ }^{306}$ Estos dos aparatos, de la variante C-4/U3, habían tomado tierra en el aeródromo de San Pablo (Sevilla) el 31 de diciembre de 1942 después de participar, junto a otros seis aparatos más, en un bombardeo sobre la ciudad de Casablanca la noche anterior. Se trataba de los aviones codificados F8+AS (Werk nummer 0175) y F8+HS (Werk nummer 0118), ambos pertenecientes a la octava escuadrilla del del KG 40 y alcanzados por la artillería antiaérea aliada. A pesar de los intentos alemanes por recuperar estos aviones, las presiones aliadas fueron lo suficientemente fuertes para que esas iniciativas no llegasen nunca a su fin. Salgado Rodríguez, Juan Carlos. Focke Wulf 200 “Condor” Op. cit., págs. 178, 184, 196 y 197.
} 
Junkers Ju 88, la cual dependería de un grupo de bombardeo alemán y se pondría en acción en el sector Norte del Frente del Este, donde combatía la División Azul. Esta escuadrilla de bombardeo podría ser aumentada a un grupo de tres escuadrillas si hubiera bastante personal español formado en esta clase de aparatos.

“...Cuantos jefes, oficiales y soldados de los instruidos en España y Francia serán enviados a estas unidades en el Frente del Este, sería únicamente asunto de España. La formación de estos grupos se haría solamente por razones de enmascaramiento de la acción total..."

Los voluntarios que regresaran del Frente oriental encontrarían en España las armas entretanto suministradas por Alemania, por lo que éstos se equiparían con el material más moderno en servicio y con el que estarían perfectamente familiarizados.

Krahmer, sin duda, estaba tentando a los militares españoles para una entrada en la guerra mundial al lado del eje, prometiendo no sólo el entrenamiento de los militares españoles a costa de los propios alemanes, sino el envío continuo de aviones y cañones antiaéreos de los más modernos fabricados por el Tercer Reich. Era sin lugar a dudas, y viniendo de quien venía -el Agregado militar y aéreo alemán en Madrid-, una buena manera de ganarse a las autoridades militares españolas, deseosas de que mejorara el parque armamentístico español, que según todos los informes que manejaban estaba obsoleto, desgastado y sin posibilidad de repuestos.

Era, en fin, una alternativa posible para modernizar el ejército español, pero cuyo coste político no estaba en absoluto dispuesto a pagar el gobierno español; una entrada en la guerra al lado de Alemania no estaba en la mente de Franco, ni en la de ninguno de sus colaboradores más estrechos.

El 25 de febrero de 1943, el general Vigón, Ministro del Aire, contestaba a la informe del general Krahmer, entregando a Martínez de Campos, dos días más tarde ${ }^{308}$, una "Nota Confidencial" en la que se afirmaba que el método propuesto por el general

\footnotetext{
${ }^{307}$ Informe Confidencial sin fecha, dirigido al general D. Carlos Martínez de Campos. AGMAV. Caja 24.711. Carpeta: Informes y documentación diversa sobre Alemania de los viajes del general Martínez Campos.

308 Nota Confidencial mecanografiada, fechada a mano por el general Martínez de Campos el 27 de febrero de 1943. AGMAV. Caja 24.711. Carpeta: Informes y documentación diversa sobre Alemania de los viajes del general Martínez Campos.
} 
alemán parecía demasiado complicado y barroco, amén de tener que mantener continuamente fuera de España un número relativamente elevado de jefes y oficiales, cuya presencia en las unidades y escuelas nacionales se estimaba indispensable.

La contrapropuesta era clara y concisa, y tenía en cuenta la supuesta solidez y bagaje adquirido por los pilotos españoles en la pasada Guerra Civil, tras la cual se habían hecho cargo, sin problema alguno, de todo el material alemán de la Legión Cóndor. Ésta pasaba por seleccionar a una docena de jefes y oficiales de los que habían prestado servicio en Rusia con la $1^{\mathrm{a}}$ y $2^{\mathrm{a}}$ escuadrillas expedicionarias ${ }^{309}$, que realizarían un curso de perfeccionamiento en Alemania, regresando posteriormente a España con los 15 aviones Messerschmitt Bf 109 F4 para organizar la Escuela de Caza. Además, otros dieciocho jefes y oficiales y veintidós especialistas pasarían a una Escuela de Bombardeo en Alemania e incorporándose más tarde los primeros a escuadrillas alemanas de bombardeo en Rusia para adquirir experiencia y traer en vuelo los diez aviones Junkers Ju 88 para constituir en España la Escuela de Bombardeo

Cuando se hubieran entrenado suficientemente las tripulaciones para constituir los primeros grupos de caza y bombardeo, Alemania debería enviar el material necesario para organizarlos. A medida que las Escuelas fueran formando nuevos grupos, éstos habían de ser dotados de material en la amplitud que las circunstancias de la guerra lo permitieran; entre tanto, las industrias aeronáuticas alemanas continuarían prestando su cooperación técnica a la industria española, desarrollando los convenios establecidos entre los ministerios del Aire de ambos países.

De la misma manera, el Ejército de Tierra, del que en España dependía la artillería antiaérea, tomó idéntica decisión que el del Aire, considerando oportuna la presencia de la Comisión para el estudio de la especialidad en la Francia ocupada, pero no la formación de unidades antiaéreas españolas en el país vecino. De hecho, el 26 de febrero, el Estado Mayor Central del Ejército (E.M.C.E.) remitió al ministro de

\footnotetext{
${ }^{309}$ España, además de enviar una división de Infantería, compuesta por voluntarios del Ejército de Tierra, a combatir junto Alemania al frente ruso, organizó también una escuadrilla del Ejército del Aire para participar en la ofensiva alemana en el Este. Las rotaciones en personal de esa escuadrilla fueron denominadas $1^{\text {a }}$ Escuadrilla, $2^{\text {a }}$ Escuadrilla, etc... hasta la $5^{\text {a }}$, última enviada, aunque ésta prácticamente no combatió pues coincidió con la retirada del frente de los soldados españoles. Para más información es muy interesante el libro de Fernández-Coppel Larrinaga, Jorge. La Escuadrilla Azul. La Esfera de los Libros, Madrid, 2008.
} 
Exteriores, general Jordana, un informe ${ }^{310}$ relativo a la propuesta de Krahmer, redactado en la misma línea que el del Ejército del Aire, y en el que se reiteraba la necesidad y la urgencia de disponer de todo el armamento, municiones y material solicitado al gobierno alemán, y en la cuantía solicitada.

El EMCE consideraba mucho más lógico que Alemania enviase los cañones antitanques, las ametralladoras antiaéreas y las piezas de campaña Rheinmetall de 150 mm solicitadas por España, sin la necesidad de enviar personal a Francia y Alemania, pues era obvio que había en España mucho personal entrenado y conocedor de esos materiales u otros similares. Por lo que hacía a los carros de combate pedidos por el Ejército español, la situación era algo diferente pues el EMCE era consciente de que la evolución que, tanto en el material como en el empleo del mismo, se había producido durante la guerra mundial, exigía un mejor conocimiento de los carros que Alemania enviaría como de las nuevas tácticas puestas en práctica en el transcurso de la contienda. Fue por ello que el EMCE comunicó al Agregado alemán que aceptaba el envío de una comisión de jefes, oficiales, suboficiales y especialistas para que en las Escuelas alemanas a consolidar y ampliar su instrucción, habituarse en su manejo y servir, con posterioridad, de instructores del material a sus compatriotas en España. Además, y como caso especial, el alto organismo español no tendría inconveniente en organizar una compañía armada con el modelo de carro previsto para entregar, con cuadros y personal español, que se instruyera en la misma escuela a la que debía asistir el personal citado, para servir de complemento a la instrucción que se les diese.

\section{III.4.- -EL PRIMER VIAJE DE MARTÍNEZ DE CAMPOS A ALEMANIA}

Una vez asumida la presidencia de la Comisión Extraordinaria para Material de Guerra, el 10 de marzo de 1943 partía de España por ferrocarril, vía Hendaya y París, con destino a Berlín, el recién ascendido a general de división, D. Carlos Martínez de Campos y Serrano, Duque de Latorre y conde de Llovera, como hemos visto anteriormente, uno de los más prestigiosos militares españoles en el que se aunaban las más altas virtudes castrenses, una gran capacidad intelectual y una constancia pertinaz en el trabajo diario.

\footnotetext{
310 AGMAV. Caja 24.711. Carpeta "Datos anteriores al primer viaje".
} 
Su llegada a Berlín, la capital del Reich, junto a su asistente, el soldado de $2^{\mathrm{a}}$ Joaquín Huertas García, de la Reserva General de Artillería, se produjo el día 13 de marzo $^{311}$. Permaneció en esa ciudad, hospedado en el hotel "Avalon", hasta el 18, manteniendo varias reuniones los días 15, 16 y 17 con los alemanes, referentes al material militar que había de negociarse. El mismo día 18 emprendió un viaje de seis días a Prusia Oriental, donde se entrevistaría con Hitler en la denominada "Guarida del Lobo", Cuartel General avanzado del Führer. Tras su regreso a Berlín el día 23, permaneció en la capital alemana otros cinco días más, tras los que emprendió su viaje de regreso a España, a donde llegaría el 30 de marzo.

Martínez de Campos llegaba a Berlín con plenos poderes para negociar el suministro de armamento a España, aunque el ministro de Exteriores español destacaba en sus instrucciones -como afirma Rafael García Pérez- el carácter técnico de su misión; esto es: toda cuestión económica o política que se planteara, debía ser puesta en conocimiento del embajador español en Berlín, Vidal y Saura ${ }^{312}$.

La primera reunión mantenida por Martínez de Campos con la comisión alemana que había de negociar la entrega de material militar tuvo lugar el día 15, y en ella se trató básicamente del armamento que España deseaba adquirir para los tres ejércitos ${ }^{313}$.

Se dividió el armamento en tres grupos; en el primero se englobaban aviones de caza, material para localización y protección de vuelo, cañones antiaéreos, diverso material ya contratado por el Ministerio del Aire para el desarrollo de la industria aeronáutica, maquinaria para fábricas militares, municiones de ametralladora de $15 \mathrm{~mm}$, material de transmisiones y material diverso en vías de contratación por el Ministerio de Marina. En el segundo grupo se encontraban aviones de bombardeo, artillería de 150 $\mathrm{mm}$, material antitanque pesado, material acorazado y tractores para artillería antiaérea y artillería pesada. En el tercero había aviones de caza nocturna y transporte,

\footnotetext{
${ }^{311}$ Dato importante pues hasta ahora se creía que la llegada a Berlín se produjo el día 12 de marzo. Este y otros datos referentes a los viajes del general a Alemania, se pueden ver en la carpetilla: "Duplicados de asuntos liquidaciones de dietas y viáticos de S.E.”. AGMAV Caja 24.711. Fondo del antiguo Ministerio del Ejército.

${ }^{312}$ García Pérez, Rafael, Franquismo y Tercer Reich, op. cit., pág. 386.

${ }^{313}$ Para todas estas reuniones, Martínez de Campos llevaba unos listados confeccionados por el EMCE, correspondientes a los materiales que estaban en servicio en el Ejército de Tierra en esos momentos. Por su importancia a la hora de evaluar la situación material del Ejército por esas fechas, dichos listados son reproducidos en el ANEXO IV.
} 
motocicletas, lanzallamas, granadas de fusil contracarros, artillería de asalto, cañones de infantería, minas contracarro y de contacto y ametralladoras en fase de contratación.

Conviene detenerse a analizar someramente los listados de peticiones españolas pues nos pueden dar una idea cabal de las necesidades militares de los ejércitos en esos momentos, y mostrar, comparativamente, los recortes que, a la postre, se produjeron sobre estas peticiones iniciales. Se trataba de la primera vez en todo el proceso que España presentaba por escrito, de manera sistemática y cuantificada, unas propuestas de armamento a entregar por parte de las autoridades alemanas ${ }^{314}$.

El Ejército del Aire solicitaba 520 aviones, de los cuales la mayor parte eran de caza y bombardeo, aunque también entraban los aparatos de transporte y de caza nocturna. Además también se pedían equipos de radio, meteorológicos, de aterrizaje sin visibilidad y de radiolocalización. Por último se incluían 480 cañones antiaéreos, de los cuales 80 eran de $88 \mathrm{~mm}$ y 400, de $37 \mathrm{~mm}$ en montaje móvil, así como municiones para los mismos.

La Marina pedía hasta 345 piezas de artillería de diversos calibres y diferentes montajes, todas ellas para emplazar en sus buques de guerra o para la defensa de sus bases navales, con su correspondiente munición, así como direcciones de tiro y aparatos ópticos para las mismas. También entraba en el pedido una docena de lanchas torpederas, diversos motores para cañoneros, remolcadores y submarinos, así como torpedos, minas submarinas, cargas de profundidad, equipos de radio, válvulas, radiogoniómetros, agujas giroscópicas, acero para construir submarinos, periscopios e hidroaviones.

Por su parte, el Ejército de Tierra completaba sus listas con material para fábricas militares, munición para ametralladoras de $15 \mathrm{~mm}$ recién adquiridas en Alemania, equipos de transmisiones, material pesado para Artillería de campaña,

\footnotetext{
${ }^{314}$ De manera mucho más caótica y poco precisa, las diferentes subcomisiones presentes en Berlín en enero de 1943 al mando del capitán de navío D. Santiago Antón Rozas, efectuaron por escrito diversas peticiones de material y armamento en una reunión celebrada el 16 de enero de ese mismo año. Documento completo "Spanien. Sonderkomission für kriegsmaterial" con índice y 21 relaciones de material, incluido entre la documentación del primer viaje a Berlín del general Martínez de Campos. AGMAV. Caja 24.711 Fondo del antiguo Ministerio del Ejército. Un resumen de este documento puede verse en el Anexo III.
} 
cañones antitanque, carros de combate, tractores de artillería, motocicletas, ametralladoras y minas.

Los listados completos de peticiones españolas negociadas por el general Martínez de Campos en Berlín el 15 de abril de 1943, pueden estudiarse en el Anexo III de este trabajo.

Para la negociación, el general Martínez de Campos utilizó unas plantillas de dotaciones y necesidades del Ejército de Tierra, que marcaron las aceptaciones y denegaciones de material, en varias fases de las conversaciones con sus homónimos alemanes. En las reuniones se discutió, sobre todo, el material solicitado en los grupos segundo y tercero, así como se renunció a diversas partidas solicitadas por Marina en el primero, pero vayamos por partes.

Tras constatar la falta de la relación de material ya contratado por el Ministerio del Aire para el desarrollo de la industria aeronáutica, los alemanes discutieron la viabilidad de las relaciones 9, 10, 11 y 12 del $2^{\circ}$ grupo, correspondientes a material de artillería y carros de combate pedido por España. La relación $n^{\circ} 9$ correspondía a las piezas de artillería de $150 \mathrm{~mm}$. Rheinmetall, de las que se pedían un total de 150, para completar 50 baterías a tres piezas cada una, además de seis direcciones de tiro. Los teutones negaron la posibilidad de desprenderse de este material, pero a cambio ofrecieron 24 cañones (dos grupos) dotados con cañones soviéticos de 122/46, de los cuales había suficientes en los almacenes del Reich, pues habían sido objeto de presa bélica en la campaña de Rusia hasta finales de 1942.

La relación $\mathrm{n}^{\mathrm{o}} 10$ contenía las necesidades españolas respecto al material antitanque pesado, que se cifraban en 125 cañones de esa especialidad, de un calibre entre 50 y $75 \mathrm{~mm}$. Y los germanos en este caso superaron las previsiones hispanas ofreciendo 150 cañones de $50 \mathrm{~mm}$, otros 150 de $75 \mathrm{~mm}$ y 150 más de $25 \mathrm{~mm}$. En los dos primeros casos estaríamos hablando de material diseñado y fabricado por la industria alemana, y en el tercero, de cañones de pequeño calibre capturados al Ejército francés en 1940, y por eso algo desfasados en 1943.

La relación $\mathrm{n}^{\mathrm{o}} 11$ versaba sobre material acorazado, aspecto sobre el cual las necesidades españolas desbordaban por completo las posibilidades alemanas en ese momento. La comisión germana ofreció la posibilidad de remitir un grupo mixto, 
compuesto en total por 20 carros de combate y 10 cañones de asalto, y del que poco o nada sabían los españoles durante la negociación.

Por último, la relación $\mathrm{n}^{\mathrm{o}} 12$ presentada por los españoles recogía la entrega de tractores para la artillería antiaérea y pesada, propuesta que fue denegada categóricamente por los alemanes por no poder desprenderse en ese momento de ningún medio de arrastre debido a sus propias necesidades de guerra.

Por lo que respecta a las discusiones sobre el material que componía el tercer grupo hemos de decir que la oferta de la Comisión alemana no concretó nada acerca de material lanzallamas, considerando desistida esta partida por parte de los españoles; cuantificó la oferta de fusiles y granadas contracarro en 1.000 fusiles, 10.000 boquillas adaptadoras (denominadas brocales), 200.000 granadas antipersonal y 25.000 granadas contracarro; ofreció la entrega de una batería completa de la llamada "artillería de asalto"; concretó en 120 los cañones de infantería de calibre 76,20 mm -rusos de recuperación-, a entregar a España y ofreció 20.000 granadas de humo que se entregarían antes de cuatro meses, 6.000 minas de contacto y 200.000 minas anticarro, de las cuales 150.000 serían francesas, procedentes de botín de guerra.

Curiosamente, los ofrecimientos de la Comisión alemana no se circunscribieron a los listados que manejaban tanto ellos mismos como el general Martínez de Campos, sino que fueron más allá, considerando la posibilidad, si los españoles los aceptaban, de entregar también 3.000 ametralladoras medias MG 34, 300 morteros pesados de $81 \mathrm{~mm}$, 200 morteros cortos del mismo calibre, 4.000 granadas de rabiza de calibre $6,6 \mathrm{~cm}$ para cañones contracarro franceses de $25 \mathrm{~mm}$ y 15 granadas de rabiza para cañones contracarro Pak de $37 \mathrm{~mm}$-reglamentarios en esa época en el Ejército español-, por cada uno de los existentes en el parque artillero hispano.

El 18 de marzo, previa a su reunión con Hitler, Martínez de Campos mantuvo una conversación en Berlín con el general Wilhelm Keitel, jefe del OKW, el órgano de mando más elevado de las Fuerzas Armadas germanas durante la Segunda Guerra Mundial. A dicha reunión asistieron, además de los dos citados, el almirante Wilhelm Canaris, jefe del $\mathrm{Abwehr}^{315}$, y el vicealmirante Leopold Bürkner ${ }^{316}$, jefe de la Sección

\footnotetext{
315 AMAE. AR. Sig. R-2066-7. En realidad, el nombre completo del servicio secreto alemán era "Amt Ausland Nachtrichten und Abwehr", que traducido al español significa "Oficina de información exterior y defensa". Su jefe, a partir del 1 de enero de 1935, en sustitución del anterior -Honrad Patzig- fue el entonces capitán de navío Wilhelm Canaris, a propuesta del entonces Almirante Raeder, jefe del
} 
"Ausland" del mismo organismo, así como el teniente coronel Carlos Marín de Bernardo, Agregado Militar español en Berlín ${ }^{317}$. Quizás lo más destacado de esta reunión, y como tema recurrente a todas las negociaciones en marcha, los alemanes insistieron en conocer el empleo orgánico del armamento que se estaba negociando, planteando reuniones al más alto nivel para consensuarlo. Martínez de Campos entendió estas consideraciones, tentativas germanas para complicar las negociaciones originadas en las dificultades reales de Alemania para suministrar armamento.

El día 21 de marzo, un día después de la reunión de Martínez de Campos con el Führer alemán en su Cuartel General, el embajador español en Berlín, Ginés Vidal y

Oberkommando der Kriegsmarine (OKM). Varios de sus más cercanos colaboradores en el servicio secreto alemán serían compañeros de armas que, como él, procedían de la marina de guerra germana.

${ }^{316}$ Leopold Bürkner nació en Zerbst el 29 de enero de 1894 y falleció en Frankfurt Main el 15 de julio de 1975. Ingresó en la Armada en 1912 y participó en la Primera Guerra Mundial en varios buques de la Marina Imperial. Continuó en el Ejército alemán de entreguerras y llegó a mandar el crucero "Emden" entre 1937 y 1938. A partir de junio de 1938, hasta el final del conflicto mundial ejerció como jefe del Amtsgruppe "Ausland"/Abwehr en el Oberkommando del Wehrmacht. (OKW). http://www.geocities.com/ orion47/WEHRMACHT/KRIEGSMARINE/Vizeadmirals/BUERKNER_LE OPOLD.html

${ }^{317}$ Carlos Marín de Bernardo Lasheras era teniente coronel de Ingenieros y diplomado de Estado Mayor. Había sido nombrado Agregado Militar en Berlín en sustitución del teniente coronel Roca de Togores a finales de 1942 y como tal actuó durante el resto de la guerra mundial, siendo uno de los personajes más importantes en las negociaciones del "Programa Bär". Nació en Logroño el 14 de enero de 1896 e ingresó en la Academia de Ingenieros de Guadalajara en 1909, cuando tan sólo contaba 13 años. Alcanzó el empleo de $2^{\circ}$ teniente en 1912 y el de $1^{\circ}$ teniente, en 1914, ascendiendo a capitán en 1918. Participó en la guerra de África desde 1921 hasta la total pacificación del territorio, en 1926. También tomó parte en la Revolución de Asturias -ya como comandante-, a las órdenes del general López Ochoa, donde resultó herido de gravedad y fue condecorado con la Medalla Militar individual por su heróico comportamiento en los combates de la Corredoria.

El alzamiento militar de 1936 le sorprende en Italia, donde seguía estudios en el "Istituto Superiore di Guerra”, apoyando desde el primer momento la sublevación. Poco después se incorporaba a Mallorca, donde desarrollará su cometido durante una parte de la guerra. En noviembre de 1938 fue destinado al estado mayor del Ejército de Levante, a las órdenes del general Orgaz. Terminada la guerra de España, marchó a Turín para finalizar sus estudios en el centro superior del Ejército italiano. En 1942 fue destinado como Agregado Militar en Berlín, donde ascendió a coronel, permaneciendo en la legación española en la capital del Reich hasta mayo de 1945.

Tras sucesivos ascensos, alcanzó el máximo empleo del ejército en 1961, año en el que como teniente general fue nombrado Capitán General de la VI Región Militar, con cabecera en Burgos. Su afición por los idiomas le llevó al perfecto conocimiento del francés, italiano, alemán e inglés. El ruso, latín y árabe no pasaron de ser un mero entretenimiento. Falleció, ya retirado, en el pueblo de Cadavedo (Asturias) a la longeva edad de 96 años, el 22 de septiembre de 1992.

Es importante hacer constar que debido a que no han pasado los 25 años reglamentados desde su fallecimiento, ha sido imposible obtener para consulta la Hoja de Servicios del teniente general Carlos Marín de Bernardo Lasheras en el Archivo General Militar de Segovia. Los datos aquí expuestos han sido tomados del artículo publicado en el Boletín de Letras del Real Instituto de Estudios Asturianos $\mathrm{n}^{\text {o }} 169$ (2007) por Enrique Junceda Avello págs. 233- 241. 
Saura, remitía al general Jordana un mensaje cifrado comunicando las impresiones de la entrevista. En él podemos leer ${ }^{318}$ :

"General Martínez Campos (sic) ha regresado del Cuartel General trayendo buenas impresiones de su entrevista con el Führer; aunque todavía no ha recibido respuesta a nuestras peticiones. En cambio, se le hicieron numerosas preguntas, siendo la primera de todas si considerábamos pedido de armas asunto de carácter político o comercial, pues para Alemania no era indiferente el saber nuestro propósito. Dándose perfecta cuenta del alcance de la pregunta, nuestro general contestó hábilmente que en su opinión puramente personal no se trataba de un asunto político, pero tampoco podía considerarsele como cuestión puramente comercial, respuesta que no pareció agradar mucho al Führer. Las otras preguntas eran de carácter técnico y fueron cumplidamente contestadas. El planteamiento de esta cuestión previa, lejos de sorprenderme, lo había yo previsto en conversación que celebré con nuestro general en víspera de su marcha y me confirma en punto de vista que expongo a V.E. en telegramas 201 y 207 y en despacho reservado 195 expedido en valija de ayer; respecto conveniencia al dar aspecto económico negociación a menos de situarla en terreno exclusivamente político con todas sus consecuencias. Aceptando tratar el tema, podremos imprimirle un carácter que subraye el interés político del asunto, como se ha hecho hasta ahora, sin excluir el comercial, pero no sería fácil, ni quizá oportuno desaprovechar uno $\mathrm{y}$ otro $\sin$ despertar recelos $\mathrm{o}$ desconfianza poco favorable para nuestro fin.-VIDAL"

La cuestión manifestada por Hitler era, sin duda, importante pues éste quería aclarar de alguna manera la postura española respecto al armamento que con tanta insistencia pedían los negociadores hispanos. Si el suministro de armas era sólo un asunto comercial, con el que Madrid trataba de compensar el desbalance contemplado en el convenio comercial de diciembre de 1942, los plazos de entrega serían tan amplios como lo fueran las contrapartidas de materias primas españolas. Pero si dicho suministro tenía una dimensión política, un acuerdo entre aliados, los plazos de entrega los marcaría él.

Rafael García Pérez afirma ${ }^{319}$ :

“...Las preocupaciones de Hitler respondían a una consideración económica de peso: Alemania estaba siendo incapaz de cumplir el compromiso comercial con España suscrito en diciembre

\footnotetext{
${ }^{318}$ Mensaje del gabinete de cifra no 210-Cif. De 21 de marzo de 1943. AMAE. AR. Sig. R-2066/2.

${ }^{319}$ García Pérez, Rafael, Franquismo y Tercer Reich, op. cit., pág. 388.
} 
de 1942 y tenía que asegurarse, por otros medios, la adquisición de minerales estratégicos que, en condiciones normales, agravada por el alza de los impuestos, no podía cubrir..."

En cualquier caso, las palabras, poco tranquilizadoras del embajador, fueron contestadas por el ministro de Asuntos Exteriores, Jordana, en un telegrama fechado dos días después, el 23 de marzo en los siguientes términos:

"Con toda urgencia sírvase V.E. visitar Secretario General Asuntos Exteriores en relación con su telegrama n 207 para manifestar que España advierte con sorpresa gran retraso envío armamento de que se viene tratando hace más de seis meses dando por nuestra parte toda clase de muestras de buena disposición, enviando comisión técnica y firmando sin dificultad acta secreta propuesta por Embajador Alemania en Madrid. Insista V.E. en que situación mundial exige con urgencia para bien Europa y Alemania que sin pérdida de tiempo se envíe material moderno abundante a España siendo grave responsabilidad aplazarlo por cuestiones trámite. Manifieste oficialmente que España ofrece total saldo favorable a nosotros deuda comercial o sea alrededor 300 millones de marcos como contravalor inicial dicho armamento, esperando que esta manifestación solemne bastará para que inmediatamente empiecen entregas. Como pedido excede dicha cifra, una vez entregado material de guerra cuyo precio agote saldo comercial a nuestro favor, España está dispuesta a hacer entonces nuevos envíos primeras materias en forma y detalles que se irían precisando después recibidos esos primeros envíos armamento. En estas condiciones estimo inútil envío técnico, pudiendo puntualizarse modalidades pago en conversaciones ordinarias este Ministerio y Embajada alemana en Madrid, sin que entregas puedan subordinarse a esas conversaciones de puro detalle ni deban aplazarse más por ningún concepto. Insista V.E. con toda energía en este último punto expresando discretamente y en la medida que V.E. lo estime oportuno, descrédito para Alemania a que daría lugar nuevo aplazamiento que se interpretaría por opinión pública y militares como prueba falta elementos o incapacidad satisfacer modestos pedidos hechos por España y demostración falta reciprocidad a constantes pruebas amistad España hacia Reich. Jordana. ${ }^{320,}$

Un alegato, sin lugar a dudas, de como se interpretaba en España la dilación de las autoridades alemanas en la entrega del armamento -ya eran tres los meses que se llevaba negociando sin resultado práctico alguno-y de cuales eran las líneas básicas de la diplomacia española para acelerar el proceso de negociación, que debía entrar de inmediato en una fase resolutiva. De esta manera, el futuro de la cuestión pasaba,

\footnotetext{
${ }^{320}$ Telegrama 182 Cifrado, del Ministro de Asuntos Exteriores al Embajador en Berlín, fechado el 23 de marzo de 1943. AMAE. AR. Sig. R-2066/4.
} 
necesariamente, por las negociaciones económicas en las que diversas comisiones alcanzaran acuerdos en cuanto a la valoración de las armas germanas y las contrapartidas españolas. Éstas, como veremos, tendrían lugar en Madrid y la postura española de "revisión total de precios" de dicho armamento, sería para los alemanes una auténtica pesadilla. Una pesadilla que denota el verdadero esfuerzo negociador y una interesantísima postura de fuerza de los diplomáticos y los militares españoles que tomaron parte en las subcomisiones organizadas al efecto, que lejos de contemporizar con los todavía "todopoderosos amigos germanos", no tuvieron empacho en ir desmontando, uno a uno, todos y cada uno de los precios presentados por los teutones, en todos los casos cuadruplicados y hasta quintuplicados, con respecto a los que se podrían considerar como "justos" o si se quiere, realistas.

El 28 de marzo, el embajador español en la capital del Reich comunicaba al ministro Jordana -mediante telegrama cifrado-:

"General Martínez Campos sale esta noche para Madrid llevando consigo oferta definitiva armamento que someterá Superioridad. En ella no figuran precios, dejando cuestión para conversaciones (?) aspecto económico."321

El mes que transcurrió desde el regreso de Martínez de Campos a Madrid y el segundo viaje a Berlín, fue de continuas reuniones con los representantes de los ministerios militares y de Asuntos Exteriores, preparando los listados definitivos que España presentaría a Alemania como contrapartida a los entregados en Berlín al Presidente de la Comisión española.

El 20 de abril, el mismo día que Martínez de Campos firmaba la carta que días más tarde, ya en Berlín, entregaría al general Becker aceptando parte del material ofrecido y solicitando otro nuevo, la Embajada alemana en Madrid remitía al Ministerio de Asuntos Exteriores español un documento "Pro-Memoria" en el que afirmaba que, pese a la que las negociaciones al respecto todavía no habían finalizado, el gobierno alemán estaba dispuesto a comenzar de inmediato con envíos sueltos de armamento, dejando para las negociaciones económicas a desarrollar en Madrid el asunto de los precios. Es fácil suponer una relación causa-efecto entre esta nota de la embajada

\footnotetext{
${ }^{321}$ Telegrama 212 Cifrado, del Embajador en Berlín al Ministro de Asuntos Exteriores, fechado el 28 de marzo de 1943. AMAE. AR. Sig. R-2066/4.
} 
teutona y el telegrama de Jordana del día 28 que acabamos de reproducir páginas atrás. Para Alemania el asunto se había convertido en una olla a presión de tal magnitud que, para que no hiciera explosión había que reconducir el asunto, dejando escapar algo de vapor de agua, aun a riesgo de que los precios fuesen, posteriormente, discutidos y ampliamente reducidos ${ }^{322}$.

\section{III.5.- INFORME Y REUNIÓN DE MARTÍNEZ DE CAMPOS EL 29 DE} ABRIL DE 1943

El 29 de abril, tras el regreso a Alemania del general Martínez de Campos, tenía lugar una reunión en Berlín entre las comisiones alemana y española. Y en ella el duque de Latorre entregaba un informe ${ }^{323}$ al Generalmajor Becker ${ }^{324}$ en respuesta al emitido por éste un mes atrás (el 27 de marzo), poco antes de la partida hacia España de Martínez de Campos después de su primer viaje. Se trata de un documento de enorme

\footnotetext{
${ }^{322}$ Para el suministro inmediato entraban en consideración partidas para el Ejército de Tierra, Aviación y Marina de Guerra. Algunas de ellas podrían servirse antes del 25 de abril, otras, entre el 25 de abril y el 1 de mayo y otras, a partir del 1 de mayo. Las partidas más importantes ofrecidas en este documento de la Embajada de Alemania eran: 80 cañones antitanques de $50 \mathrm{~mm}$ (luego rechazados por la Comisión española), 120 cañones-obuses de infantería de 7,62 mm (r) (también rechazados por la Comisión española en ulteriores negociaciones), 24 cañones de $122 \mathrm{~mm}$ Mod. K 390 (r) (partida que sería ampliada más tarde por los alemanes tras las negociaciones de Martínez de Campos), 500 motocicletas de varios tipos y modelos, 50.000 minas, 15 aviones de caza, 10 aviones de bombardeo, cuatro millones de disparos para Aviación, tres radares "Lichtenstein", 30 cañones varios para Marina, 100 cargas de profundidad, 38 torpedos (éstos serían eliminados de las listas por la Comisión española) y 500 minas EMC. AMAE. AR. Sig. R-2066/4. Pro-Memoria de la Embajada alemana de 20 de abril de 1943.

${ }^{323}$ AGMAV. Caja 20.903. Fondo del antiguo Ministerio del Ejército. Carta fechada en Berlín el 29 de abril de 1943 del general Martínez Campos al general Becker. Este mismo documento consta en el Archivo del Ministerio de Asuntos Exteriores, acompañado de un escrito presentado al ministro Jordana el día 20 de ese mismo mes de abril. En dicho escrito, Martínez de Campos afirma que la carta que presentará a finales de mes a las autoridades alemanas "...ha sido redactada teniendo en cuenta todas las instrucciones verbales que me han sido hechas por los Excmos. Señores Ministros del Aire, Marina y Ejército...". AMAE. AR. Sig. R-2066/4.

${ }^{324}$ El entonces Maj. General Wilhelm Becker, de la Luftwaffe, era el jefe del Departamento de Economía de Guerra del Oberkommando der Wehrmacht. Había nacido el 27 de octubre de 1897 en Hanau, ingresando en el ejército en diciembre de 1914. Prestó servicio en el 88 Regimiento de Infantería y de febrero a julio de 1916 se instruyó como piloto de combate. Finalizó la Primera Guerra Mundial como piloto de la $30^{\text {a }}$ Jasta (escuadrilla de caza). Permaneció en el nuevo Ejército alemán surgido del Tratado de Versalles y fue transferido al nuevo Reichsluftministerium (RLM) en diciembre de 1933 como asesor, con el empleo de Oberstleutnant (teniente coronel). Allí dirigió el departamento de asuntos económicos hasta enero de 1938, que ascendió a Oberst (coronel) y fue confirmado en su destino. El 31 de octubre de 1942 fue nombrado jefe del Departamento de Economía de Guerra del O.K.W., que dirigió con el empleo de general de brigada, permaneciendo en este puesto hasta septiembre de 1944. Tras el fin de la guerra, estuvo en cautividad hasta 1947, que fue liberado y se afincó en Göttingen. Murió con 66 años en enero de 1964. Al terminar la guerra había alcanzado el empleo de Generalleutnant der Flieger. (ww2gravestone.com/general/becker-Wilhelm). Ver también: VV.AA. Germany and the Second World War. Volume V/II. Organization and mobilization in the german sphere of power. War administration, Economy and manpower resources. 1942-1944/5. Oxford University Press, 2003.
} 
relevancia por ser el auténtico pistoletazo de salida del "Programa Bär" pues en él, el general Carlos Martínez de Campos manifestaba la aceptación de una serie de materiales por parte de su gobierno, ponía las bases para la firma de todos los contratos y comisionaba -con nombres y apellidos- a los responsables del proceso de adquisición extraordinaria del material de guerra. En el informe, el general español, jefe de la “Comisión Extraordinaria para Material de Guerra”, remitía a su homólogo alemán el listado que éste le había entregado el mes anterior ("Material ofrecido a España") después de marcar en rojo las partidas que el gobierno español aceptaba de dicho listado, así como señalar -también en color rojo- las condiciones determinantes de cada una de ellas.

Martínez de Campos anotaba que los plazos de entrega del material se aceptaban íntegramente y que:

“...Independientemente de las citadas listas de material, el gobierno español desea recibir también todos LOS MATERIALES DE AIRE, MAR Y TIERRA, CUYA ADQUISICIÓN HA SIDO YA CONCERTADA O SE HALLA EN VÍAS DE CONCERTACIÓN ${ }^{325}$."

Estaba claro el deseo español de independizar las entregas del programa especial de adquisición de armamento ("Bär") de todos los negocios previos concertados o en vías de concertar, por parte de los ministerios militares con casas constructoras alemanas o con la propia ROWAK, lo que también incluía los contratos de patentes e intercambios.

Otro de los puntos realmente importantes de este informe de Martínez de Campos es el referido al enorme interés que despertaba en medios militares españoles la adquisición de material de radiolocalización; lo que hoy se denomina radar y es de uso absolutamente común, en 1943 era uno de los secretos militares mejor guardados por ambos bandos en conflicto y su desarrollo no había cumplido ni siquiera una década. De la misma manera, y en lo que se refería al Programa de adquisición de maquinaria para construcciones de artillería, antitanques, ametralladoras antiaéreas, municiones, pólvoras y explosivos, el general español adjuntaba otro listado a Becker -el más

\footnotetext{
${ }^{325}$ En mayúscula en el original. AGMAV. Caja 20.903. Fondo del antiguo Ministerio del Ejército.
} 
grande de todos los presentados-, indicando el material que el gobierno español deseaba adquirir en lo que a partir de ese momento se denominaría "Programa Bär. Maquinaria".

Por otra parte, ponía en conocimiento de Becker la composición de las Comisiones presentes en Berlín para firmar los contratos, recibir el material y proceder a ampliaciones o nuevas peticiones que España considerase realizar. Dichas comisiones eran las mostradas en la tabla siguiente.

\section{TABLA III-B}

\section{COMISIONES MILITARES ESPAÑOLAS EN BERLÍN}

\begin{tabular}{|c|c|c|}
\hline & Ejército de Tierra & \\
\hline 1 (Agregado Militar en Berlín)) & Teniente coronel (Ingenieros) & Carlos Marín de Bernardo Lasheras \\
\hline 2 (De la DGIM. Maquinaria) & Teniente coronel (Artillería) & José Villegas Silva \\
\hline 3 (De la EATI. Armamento) & Comandante (Infantería) & Alfonso Romero de Arcos \\
\hline 4 (2 Agregado. Armamento) & Comandante (Artillería) (EM) & Ignacio Moyano Araiztegui \\
\hline 5 (Mat. Artillería Antiaérea) & Comandante (Artillería) & Ricardo Castro Caruncho \\
\hline 6 (De la JT. Mat. Transmisiones) & Comandante (Ingenieros) & Enrique Guiloche Bayo \\
\hline \multirow[t]{2}{*}{7 (De la IGE) } & Comandante (Intervención) & José Bercial Esteban \\
\hline & Marina & \\
\hline 8 (Agregado Naval en Berlín) & Capitán de fragata & Manuel Espinosa Rodríguez \\
\hline $9\left(2^{\circ}\right.$ Agregado $)$ & Teniente de navío & Agustín Miralles de Imperial Díaz \\
\hline 10 & Comandante (Intendencia) & Edmundo Núñez Limón \\
\hline 11 (Miembro no permanente) & Teniente coronel (Artillería) & Lorenzo Pallarés Cacha \\
\hline \multirow[t]{2}{*}{12 (Miembro no permanente) } & Ingeniero naval (Civil) & Andrés Barcala Moreno \\
\hline & Ejército del Aire & \\
\hline 13 (Agregado Aéreo en Berlín) & Teniente coronel & José Pazó Montes \\
\hline 14 De la E.S. & Teniente coronel & Ángel Salas Larrazábal \\
\hline 15 & Comandante & Enrique Cárdenas Rodríguez \\
\hline $16\left(2^{\circ}\right.$ Agregado $)$ & Comandante & Álvaro Soriano Muñoz \\
\hline
\end{tabular}

Fuente: AGMAV. Caja 24.711. "Relaciones nominales de la composición de comisiones y equipos".

También solicitaba autorización al gobierno del Reich para que varios equipos de jefes, oficiales y especialistas efectuaran prácticas en las materias correspondientes al equipo más complejo del Programa ${ }^{326}$. En cualquier caso, quedaba claro que estos

\footnotetext{
${ }^{326}$ Los equipos eran los siguientes:
} 
equipos eran independientes de otros que ya habían sido enviados con anterioridad al convenio "Bär".

Los anexos a la citada carta contenían el material aceptado por el Gobierno español, que constituirían, a la postre, el grueso del denominado "Programa Bär". Estos anexos se pueden consultar debidamente comentados al final de este trabajo, numerados respectivamente como Anexos VI, VII, VIII y IX. Relacionamos en ellos lo que fue, en origen, el material solicitado y aceptado por la Comisión española, con todas sus partidas, señalando que la numeración asignada por nosotros no coincide con la original y se pone a título meramente expositivo.

En esta reunión ${ }^{327}$ con sus homólogos alemanes, Martínez de Campos comunicó a la Comisión germana sus conversaciones con los tres ministros españoles interesados en el "Programa de Armamento", manifestando que los de Marina y Aire le hicieron partícipe de su decepción al ver mermadas sus esperanzas debido al recorte presentado en la lista alemana. En cualquier caso, los tres responsables ministeriales españoles deseaban adquirir la mayor parte del armamento y material ofrecido por Alemania, exceptuando sólo algunas partidas que obligaban a un trabajo industrial o a unos cambios demasiado grandes. El duque de Latorre manifestó a Becker la enorme confianza puesta en este programa por las autoridades españolas y los buenos precedentes que había en España de los envíos de material bélico durante y después de la contienda española, todos ellos recibidos en magníficas condiciones, tanto cuantitativas como cualitativas.

Al comenzar la reunión, el español comentó a sus contrapartes germanos que en el asunto del material de Marina la aceptación era completa. Todo el material ofrecido se consideraba necesario por los responsables del Ministerio de Marina español. Respecto al Ejército del Aire, comunicó Martínez de Campos que no se aceptaban los

-Fuerzas aéreas: Equipo de pilotos de caza, equipo de pilotos de bombardeo, equipo para instruirse en la reparación de material Messerschmitt, equipo para instruirse en la reparación de material de bombardeo, equipo para instruirse en la reparación de radiolocalizadores, equipo para instruirse en la reparación de radiofaros direccionales "Electra" y radiogoniómetros "Adcock" de onde corta y larga y equipo de Flak.

-Fuerzas terrestres: Equipo de carros de combate y equipo para radiolocalización.

-Fuerzas navales: se nombrarían con posterioridad.

${ }^{327}$ Seguimos las actas-resúmenes de las sesiones celebradas en Berlín entre las Comisiones española y alemana. AGMAV. Caja 24.711. Fondo del antiguo Ministerio del Ejército. 
aviones de caza "Dewoitine" ofrecidos por el agregado de la Luftwaffe en Madrid, general Krahmer, y que existían algunas variaciones en los equipos de bombarderos a petición del mismo general alemán y los equipos de caza acudirían a Francia a recoger los aparatos Messerschmitt Bf 109 concedidos. Así mismo rogó a los alemanes explicaran qué entendían en Alemania por un "Grupo de Artillería Antiaérea de Posición" y cual era la composición y el material que se integraba en un equipo completo de $8,8 \mathrm{~cm}$ (proyectores, fonolocalizadores, etc...) ${ }^{328}$.

En lo tocante al Ejército de Tierra, Martínez de Campos comentó que se aceptaba la transformación de 50 cañones de $75 \mathrm{~mm}$ de campaña -de origen francés-, en antitanques ${ }^{329}$. A tal efecto, se enviarían desde Madrid a Berlín dos cañones de este modelo para realizar el estudio preliminar de la modificación, con 250 disparos para cada una. Así mismo, en el mismo envío se remitirían dos fusiles de 7,92 $\mathrm{mm}$ para la adaptación de los brocales lanzagranadas aceptados y otros dos de $7 \mathrm{~mm}$ para la cartuchería que se solicitaba.

Un aspecto fundamental, según el general español, el cual pidió urgencia en su resolución, era el de los radiolocalizadores solicitados por las tres ramas del Ejército español, así como la maquinaria para la fabricación de artillería y cartuchería de distintos calibres así como pólvoras y explosivos. A las preguntas del español sobre el asunto, Becker respondió con evasivas referente a los radares y con imprecisiones al

\footnotetext{
${ }^{328}$ Ambas preguntas eran ciertamente capciosas, sobre todo porque el que las hacía era un general de división procedente del arma de artillería y que conocía a la perfección el asunto consultado. En la Guerra Civil española los sublevados habían adquirido en Alemania media docena de modernísimas baterías antiaéreas de $88 \mathrm{~mm}$ Flak 18 junto a sus direcciones de tiro e instrumentos de medida correspondientes. Este material era lo más avanzado de la época, empleándolo también el Grupo F/88 de la Legión Cóndor en sus baterías pesadas. Con posterioridad, el denominado "Regimiento de Artillería Antiaérea" del Ejército nacional recibiría ya en 1938, para complementar estas baterías germanas, una batería especial compuesta por proyectores de luz y aparatos de sonido denominados "fonolocalizadores", destinados todos ellos a localizar, detectar y señalizar a las direcciones de tiro de los cañones, el lugar exacto donde se encontraban los aviones atacantes cuando las condiciones climatológicas eran adversas y no se podían detectar las aeronaves por medios ópticos normales.
}

Así mismo, por los informes recibidos de la organización de la "Flak" en Alemania, en el Ejército español se sabía que las citadas baterías de "localización", con su material correspondiente, eran independientes de las baterías de cañones, tanto ligeros como pesados. Memoria de la Comisión de Artillería Antiaérea. Julio a septiembre-1943. Escuela de Aplicación y Tiro de Artillería. Documento mecanografiado publicada para "consumo interno" de la Escuela. s/f. APEC. Gmeline, Patrick de. La "Flak": 1935-1945. La DCA allemende, Editions Heimdal, París, 1994, págs. 20 y ss.

${ }^{329}$ Alemania había propuesto la modificación de 200 cañones de esta clase, adaptándoles el afuste de las piezas contracarro de $50 \mathrm{~mm}$, del modelo 38. Como veremos en capítulos posteriores, estas modificaciones no se podrían llevar a cabo y los dos cañones enviados a Alemania volverían en uno de los trenes del "Programa Bär". 
asunto de la maquinaria, en el sentido de señalar las dificultades del suministro debido a la centralización que tienen establecida las distintas casas fabricantes germanas.

Como Martínez de Campos viera la imposibilidad de cerrar el asunto, cambió de tema y pidió a Becker que avisaran con tiempo los envíos de material para así poder preparar transportes en España antes de que las armas llegaran a la frontera. Así mismo indicó al teutón que desde ese mismo día serían los tres agregados militares los encargados de firmar los contratos y recibir el material cedido de gobierno a gobierno, quedando a disposición del mando alemán mientras permaneciera en Berlín y asegurando su presencia cuantas veces hiciera falta en viajes cortos y rápidos desde Madrid, para asegurar el buen fin de las negociaciones.

Curiosamente, en la reunión Becker se interesó mucho en los motivos por los que el gobierno español había rechazado varias de las partidas ofrecidas por Alemania, como por ejemplo las pistolas ametralladoras, las ametralladoras ligeras, los morteros de $81 \mathrm{~mm}$, la munición de 7,92 mm, los cañones contracarro de $50 \mathrm{~mm}$ así como la disminución de la cantidad de cañones franceses de $75 \mathrm{~mm}$ a modificar en Alemania. A todas las preguntas respondería Martínez de Campos con datos reales de las plantillas españolas; aquel material se rechazaba por estar la dotación del ejército español al completo de sus plantillas previstas.

También Becker quería saber el orden de prioridad en la entrega del material, pues aludió en la reunión, a una carta que acompañaba los listados entregados un mes antes por los alemanes, en la que se solicitaba que se indicara ese orden de prelación. El general español contestó que desconocía esta carta pero que, en cualquier caso, todo el material ofrecido y aceptado podría salir cuando los alemanes quisieran.

Pero era obvio que no todo lo ofrecido por Alemania estaba dispuesto de inmediato para salir con destino a España. Becker aclaró este asunto y propuso a Martínez de Campos el que las Comisiones de Tierra, Marina y Aire, en sucesivas reuniones, fueran marcando el orden de urgencia español.

La reunión, que había resultado muy cordial, tocaba a su fin. Becker dio las gracias a su homólogo español por su gran trabajo al frente de la Comisión y ofreció a éste un bonito "regalo", inesperado pero muy importante para el Ejército español: le 
anunció que en lugar de los 24 cañones de 122/46 soviéticos ofrecidos en los listados alemanes, podrían enviar "unos 150 de la misma clase". Al general de división Carlos Martínez de Campos se le iluminó la cara. Era artillero y sabía lo que significaba ese incremento en el ofrecimiento alemán de artillería de campaña de ese calibre y modelo. Se podrían armar 13 grupos de artillería de campaña fiable, potente y barata, con lo que se cubrirían las expectativas de otros tantos cuerpos de ejército españoles.

Martínez de Campos aceptó -sin dudarlo- la propuesta alemana y emplazó al general Becker para una última reunión antes de su partida para Madrid. El 3 de mayo fue el día previsto para esta reunión. Mientras tanto, en días sucesivos, los Agregados militares -el teniente coronel de Ingenieros del Ejército de Tierra Carlos Marín de Bernardo, el capitán de fragata Manuel Espinosa y el teniente coronel del Ejército del Aire José Pazó- mantuvieron reuniones parciales, correspondientes al material solicitado por cada uno de ellos en la sede del OKW, en Berlín.

\section{III.6.- LOS PROBLEMAS DE LA ENTREGA DE MATERIALES}

Ese mismo día 29 de abril, jornada en la que el general presidente de la comisión española que negociaba el armamento en Berlín, se reunía con las autoridades germanas, tenía lugar otra reunión en la sede del Oberkommando der Wehrmacht, en este caso entre el presidente de la subcomisión del Ejército de Tierra español, teniente coronel Carlos Marín de Bernardo, el coronel Otto Beutler ${ }^{330}$ y el capitán de fragata $^{331}$ Flüss, responsables alemanes de este programa del citado organismo alemán.

En dicho encuentro, los alemanes pusieron en conocimiento de los españoles las dificultades que ellos intuían en el proceso de entrega del material a España. Con razón comentaron que la entrega del armamento debía ser realizada oficialmente en Alemania, pues cualquier incidente, deficiencia o dificultad podría ser subsanada de forma rápida.

\footnotetext{
${ }^{330}$ Otto Beutler era el jefe de estado mayor del Departamento de Economía de Guerra del Oberkommando der Heer. (OKH). Había nacido en Chemnitz el 16 de marzo de 1894 e ingresó en el Ejército en marzo de 1913 como cadete de Caballería. Tras finalizar la Primera Guerra Mundial, Beutler permaneció en el pequeño Ejército alemán de entreguerras, alcanzando el empleo de coronel en marzo de 1940. Entre agosto de 1942 y septiembre de 1943, desarrolló su trabajo en el departamento antes citado, ascendiendo a Generalmajor el 1 de octubre y pasando a la Führer-Reserve al ser denunciado. Tras el preceptivo juicio fue rehabilitado y un mes después del desembarco de Normandía se le confirió el mando de la 340 División de Infantería, falleciendo en acción de guerra el 21 de julio de 1944. http://www.geocities.com/ orion47/WEHRMACHT/HEER/Generalmajor/BEUTLER_OTTO.html

${ }^{331}$ Graduación de la armada. Es equivalente a teniente coronel. Nos ha sido imposible localizar a este oficial de la armada alemana.
} 
De otro modo, cualquier trámite se dilataría en el tiempo si las citadas cuestiones se suscitasen en Madrid, en la recepción física del material.

Por otro lado, los responsables alemanes comunicaron algo que los españoles ya tenían en cuenta: el transporte desde Alemania del material de guerra por vía ferroviaria, entrañaba peligro evidente, con daños que debería asumir España, pues durante el trayecto podría ser atacado por la aviación enemiga ${ }^{332}$.

Por último, debido a la diferencia de ancho de vía de los ferrocarriles españoles, al llegar a la frontera todo el material procedente de Alemania debería ser transbordado a otros vagones con el ancho de vía adecuado. Sólo se debería enviar aquel material que pudiera ser físicamente transbordado de manera inmediata a los vagones españoles, evitando el estacionamiento y la acumulación de material.

Beutler hizo presente la experiencia obtenida en las entregas de material a Italia, y sugirió la conveniencia de adoptar soluciones análogas. De la misma manera recomendó a Marín de Bernardo la empresa de transportes que realizó los envíos a Italia, empresa con experiencia y que cumplió exactamente su cometido; su nombre era Schenker ${ }^{333}$ y tenía sucursal en Madrid. Era preciso que los españoles contestaran con rapidez para ultimar un encuentro con los responsables de la empresa.

Para centrar el estudio previo de los envíos, Beutler indicó a Marín que lo más práctico sería formar una relación del diferente material y su destino al objeto de estudiar la distribución de los envíos sobre las diferentes entradas en España, para evitar acumulaciones en la frontera. También informó que debería tenerse en cuenta la relación de capacidad entre vagones de ferrocarril alemanes y españoles, siendo esta aproximadamente cuatro a seis, o sea, que se necesitarían 600 vagones españoles para

\footnotetext{
${ }^{332}$ Es muy importante hacer constar que los militares alemanes sólo concedían valor al "riesgo" de ataque aéreo, y no al que pudiera haber debido al sabotaje o ataques de la resistencia francesa en el trayecto. Es evidente que en abril de 1943, las actividades de los resistentes en territorio francés eran mínimas.

${ }^{333}$ En 1872 Gottfried Schenker junto a dos socios, fundó en Viena (Austria) una pequeña empresa de transportes denominada Schenker und Co. Dos años más tarde la empresa abría oficinas en Praga, Bucarest y Budapest, y en 1901 se hacía cargo de la misma su hijo adoptivo, August. Tras la primera Guerra Mundial, Schenker centró su negocio en servicios de entrega express, transporte de mercancías regional y mudanzas, así como servicios para ferias comerciales. En 1922, Schenker se consolidaba como una de las más importantes empresas de transportes alemana y trasladó su sede a Berlín. Nueve años más tarde, en 1931, los ferrocarriles alemanes adquirían el control de la compañía, actuando desde entonces como empresa de transportes oficial del gobierno alemán. Datos obtenidos de la Web oficial de la empresa DB Schenker (www.logistics.dbschenker.es/log-es-es/start/compania/historia_html).
} 
trasbordar el material transportado por 400 alemanes. Un tanteo previo permitía, según el alemán, asegurar que serían varios miles de vagones españoles los necesarios para la operación.

Marín de Bernardo comunicó a Beutler que desconocía todavía los puntos de destino definitivos así como la cantidad, peso y volumen del material, datos estos tres últimos que tendrían que ofrecer los alemanes, cuestiones que Beutler prometió facilitar en breve.

Tras zanjar los asuntos referidos a capacidad de transporte, otro de los asistentes a la reunión, el capitán de fragata Flüss, requirió de Marín de Bernardo algunas aclaraciones respecto a la carta que había entregado Martínez de Campos a Becker. En concreto consultó el asunto de las patentes, preguntando a Marín si se refería sólo a las de Marina o si había otras en tramitación; prometiendo el español una relación de las gestionadas por el Ejército de Tierra. También quería conocer los especialistas españoles en radiolocalización y carros de combate que, según la carta citada, iban a acudir a Alemania a formarse.

Trataron, así mismo, otros asuntos como la visita a unidades alemanas para ver las motocicletas usadas de cilindrada media, incluidas en el programa; o el de la adaptación de los brocales lanzagranadas para fusiles españoles. Pero quizás el más curioso fue el tema de las granadas para fusil; los alemanes manifestaron a Marín su extrañeza por la poca cantidad de granadas solicitada por Martínez de Campos, habida cuenta que en Alemania la dotación por fusil dotado de brocal lanzagranadas es de 50 granadas. Como quiera que se habían solicitado y aprobado un total de 10.000 brocales, lo propio sería disponer de 500.000 granadas, pero los españoles sólo pidieron 25.000.

Tras una discusión, se llegó al convencimiento de que se trataba de un error y que la culpa de todo la tenía un cero que había bailado: los alemanes habían ofrecido la mitad de la dotación normal en su país, o sea, 25 granadas por brocal, lo que harían 250.000, pero se había transcrito con un cero menos. Al final se corrigió ese error y los españoles, tras la preceptiva consulta con sus superiores, aceptaron las 250.000 granadas. De esta manera finalizó el encuentro. 
La “Comisión” en Berlín seguía trabajando y así el 1 de mayo, el general Martínez de Campos remitía al ministro del Ejército, general Carlos Asensio Cabanillas ${ }^{334}$, una carta de tres páginas en la que le comunicaba, entre otros temas:

"...algunos datos referentes a los materiales que ya han sido puestos a nuestra disposición y la forma y dirección en que hemos de procurar encauzarlos para España..." 335

Le decía también que los materiales destinados a Marina entrarían por la frontera de Irún, y los de Aire, por la de Port-Bou, enviando el material de tierra, alternativamente y dependiendo de los parques y maestranzas que lo recibieran por los tres pasos fronterizos, a saber: Irún, Canfranc y Port-Bou.

En un anexo de la misma carta -escrito el 3 de mayo, antes de su envío al ministro-, Martínez de Campos, después de la siguiente reunión con los alemanes que se analizará a continuación, apostilló:

"Después de escrito lo anterior, he aceptado en firme la llegada a las tres estaciones fronterizas de cuatro vagones alemanes diarios (a cada una) que son equivalentes en capacidad a seis vagones españoles, o sea, en total 18 vagones diarios a partir del 20 de mayo..."

Finalizaba el Presidente de la Comisión diciendo al ministro que los alemanes seguían en la idea de entregar a España todo lo aceptado y enviarlo poco menos que sin solución de continuidad.

\footnotetext{
${ }^{334}$ Asensio Cabanillas, Carlos. (Madrid, 1896- Madrid 1970). En 1911 ingresó en la Academia de Infantería, saliendo de ésta como oficial con destino a África tres años más tarde. Tras varias heridas en combate y ascensos por méritos de guerra, pronto sería comandante. En 1930 ingresaba en la Escuela Superior de Guerra, de la que saldría cinco años después con el diploma de Estado Mayor y el empleo de teniente coronel por antigüedad. En 1936 se le confirió el mando del Grupo de Fuerzas Regulares de Tetuán, incorporándose el 17 de julio a la sublevación que devino en Guerra Civil. Tras pasar a la Península con sus hombres, combatió al frente de los mismos, y a las órdenes del general Varela, en Badajoz, Talavera y Toledo, avanzando hacia Madrid hasta alcanzar la Ciudad Universitaria. Después vendrían Brunete, Teruel y Barcelona; y ya ascedido a general de Brigada fue destinado al frente del Sur poco antes de finalizar la contienda. Tras la guerra fue nombrado, sucesivamente, Alto Comisario español en Marruecos en 1939, jefe del Alto Estado Mayor dos años más tarde, ministro del Ejército en 1942, tras el cese de Varela, Capitán General de Baleares en 1945, director de la Escuela Superior del Ejército en 1948 y jefe de la casa Militar del Generalísimo en 1955, cargo en el que estuvo siete años. En 1966 pasó a retirado, falleciendo cuatro años más tarde. Diario ABC. 28 de abril de 1970, pág. 43. Archivo Linz de la Transición española.

${ }^{335}$ Carta remitida por el general Carlos Martínez de Campos al Ministro del Ejército. AMAE. AR. Sig. R2066-4.
} 


\section{III.7.- MARTÍNEZ DE CAMPOS SE VUELVE A REUNIR EL 3 DE}

\section{MAYO DE 1943}

En la mañana del lunes 3 de mayo de 1943, como estaba previsto, se presentó en la sede del Alto Mando de la Fuerzas Armadas alemanas el general de división Martínez de Campos para mantener la última entrevista con su homólogo germano el generalmajor Becker. Tras intercambiar los saludos de rigor, Becker manifestó que los envíos podrían empezar a remitirse en cuestión de 15 días, salvo para los materiales que exigieran un embalaje complicado.

La decisión cogió algo de sorpresa a Martínez de Campos, quien había comunicado a Madrid que se empezaría a recibir material a partir de junio, pero este adelanto podría aceptarse si la decisión era tomada en esa misma reunión, pues un comandante destinado en la Agregaduría del Ejército de Tierra, Alfonso Romero de $\operatorname{Arcos}^{336}$, salía al día siguiente para Madrid para llevar noticias concretas y exactas de los envíos. Becker aseguró que la decisión alemana de comenzar el 20 de mayo era firme y que todos los materiales que figuraban en la lista entregada dos días antes de la reunión, el sábado 1 de mayo, podrían salir a partir de esa fecha. El total de esa lista, que reproducimos a continuación, equivalía aproximadamente, a unos 400 vagones de ferrocarril alemanes.

Entre los encargos que el comandante Romero llevaría en su viaje a Madrid estaba el que en las estaciones de recepción se encontraran las máquinas y los vagones necesarios para el trasbordo de todo el material, así como soldados preparados y un representante del Estado Mayor y otro de la empresa de transportes que tuviera el encargo del Estado español.

Precisamente, el asunto del transporte era algo que todavía no estaba solucionado pues, era la primera reunión en la que se cerraban fechas de envío del

\footnotetext{
${ }^{336}$ El comandante (ascendido en Berlín a teniente coronel) Alfonso Romero de Arcos va a tener una importancia capital en el desarrollo del "Programa Bär" del Ejército de Tierra, pues a partir de este momento será el encargado, a las órdenes siempre de su jefe, el Agregado Militar, de gestionar las adquisiciones con las empresas alemanas y con la AGEKA, así como de mantener informado al Ministerio del Ejército español de todas las gestiones a través de la $4^{a}$ Sección del Estado Mayor Central del Ejército. Por su valor histórico y humano, y por ser un documento de primera mano de cómo se vivía en la capital del Reich la dureza del conflicto mundial, algunos extractos de las numerosas cartas remitidas por este jefe español al coronel Jesús Aguirre, jefe de la citada sección del EMCE, las reproducimos en los Anexos.
} 
material. Becker recomendó a su homólogo la empresa a la que el gobierno alemán encargaba los transportes, que no era otra sino Schenker, la misma que el coronel Beutler le había hablado en la reunión previa a Marín de Bernardo. El suministro estaría garantizado diariamente, según Becker, salvo las bombas y los explosivos, que irían en trenes independientes y completos.

El coronel Beutler, presente en la reunión, comunicó que todos los suministros irían identificados con nombres especiales que antepondrían la palabra "Bär" a "Luftwaffe" -si el suministro era para la Fuerza Aérea-, "Kriegsmarine" -si era para la Marina-o "Heer" -si era para el Ejército de Tierra"-. Estas inscripciones irían en cada caja.

Como eran tres las estaciones españolas que se barajaban para la recepción de los envíos, Martínez de Campos comunicó a los alemanes, que sería preferible, para el buen desarrollo de la logística del Programa, que todo el material para Marina se recibiera en la estación de Irún, el destinado a la de Aviación, por la de Port Bou, y lo del Ejército de Tierra, bien por Canfranc -el material ligero-, bien por cualquiera de las otras dos, según conviniera en cada momento por razones de destino o compensación de envíos -el material pesado-.

Antes de finalizar la reunión, Martínez de Campos solicitó del coronel Beutler la posiblidad de firmar el contrato del transporte con Schenker, a lo que el citado coronel contestó que programaría una reunión enseguida con los representantes de la agencia de transportes, si fuera posible, al día siguiente, para cerrar el acuerdo.

Se trataba de lo que a partir de este momento se iba a denominar en alemán "Sofortprogramm", lo que traducido al español significa "Programa inmediato"

\section{TABLA III-C}

PROGRAMA BÄR. "SOFORTPROGRAMM"

\begin{tabular}{|c|c|c|}
\hline PARTIDA No & EJÉRCITO & MATERIAL \\
\hline Partida $n^{\circ} 1$ & Marina & 4 Flak de 3,7 cm SK C/30 en montaje doble estabilizado \\
\hline Partida $n^{\circ} 2$ & Marina & 16 Flak de 3,7 cm SK C/30 en montaje $\mathrm{C} / 39$ de submarino \\
\hline Partida $n^{\circ} 3$ & Marina & 10 Flak 38 de $2 \mathrm{~cm}$ en montaje $\mathrm{C} / 30$ \\
\hline Partida $\mathrm{n}^{\circ} 4$ & Marina & Cañones de repuesto de $3,7 \mathrm{~cm}$. \\
\hline
\end{tabular}




\begin{tabular}{|c|c|c|}
\hline Partida $n^{\circ} 5$ & Marina & 20.000 proyectiles explosivos de $2 \mathrm{~cm}$ \\
\hline \multirow[t]{2}{*}{ Partida $n^{\circ} 6$} & Marina & 40.000 proyectiles explosivos de $3,7 \mathrm{~cm}^{337}$ \\
\hline & Marina & 38 Torpedos Whitehead-Wymouth ${ }^{338}$ \\
\hline Partida $n^{\circ} 7$ & Marina & 500 minas tipo EMC \\
\hline Partida $\mathrm{n}^{\circ} 8$ & Marina & 100 cargas de profundidad WBF \\
\hline Partida $\mathrm{s} / \mathrm{n}$ & Aire & 15 aviones Messerschmitt Bf $109 \mathrm{~F}^{339}$ \\
\hline Partida $\mathrm{s} / \mathrm{n}$ & Aire & 10 aviones Junkers $\mathrm{Ju} 88 \mathrm{~A}^{340}$ \\
\hline Partida $\mathrm{n}^{\circ} 9$ & Aire & Accesorios para 15 equipos de vuelo. Dotaciones. \\
\hline Partida $n^{\circ} 10$ & Aire-Tierra & 12 Flak de $8,8 \mathrm{~cm}$ móviles (Pasaron a Tierra. Originalmente para Aire) \\
\hline Partida $n^{\circ} 11$ & Aire-Tierra & 3 aparatos de dirección de tipo Modelo 40 para Flak (Idem anterior) \\
\hline Partida $\mathrm{n}^{\circ} 12$ & Aire-Tierra & 12 Flak 28 de $2 \mathrm{~cm}$ Oerlikon (Idem anterior) \\
\hline Partida $\mathrm{n}^{\circ} 13$ & Aire-Tierra & 4 proyectores de $60 \mathrm{~cm}$ para Flak 28 Oerlikon (Idem anterior) \\
\hline Partida $\mathrm{n}^{\circ} 14$ & Aire-Tierra & $\begin{array}{l}4 \text { telémetros de } 1 \mathrm{~m} \text { R-36 para Flak } 28 \text { y herramientas para armero de Flak } \\
37 \text { de } 8,8 \mathrm{~cm} \text { (Idem anterior) }\end{array}$ \\
\hline Partida $\mathrm{n}^{\circ} 15$ & Aire & 4 aparatos de radio fijos para el aterrizaje \\
\hline Partida $\mathrm{n}^{\circ} 16$ & Aire & 15 grupos electrógenos Still con remolque especial \\
\hline Partida $n^{\circ} 17$ & Aire & 1.000 .000 de proyectiles de $7,92 \mathrm{~mm}$ para ametralladora \\
\hline Partida $n^{\circ} 18$ & Aire & 3 localizadores de buques "Liechtenstein"341 \\
\hline Partida $\mathrm{s} / \mathrm{n}$ & Aire & 4 equipos móviles pesados de radio (onda corta) ${ }^{342}$ \\
\hline Partida $\mathrm{s} / \mathrm{n}$ & Aire & 4 equipos móviles pesados de radio (onda larga) \\
\hline Partida $\mathrm{s} / \mathrm{n}$ & Aire & 15 equipos móviles FuG 10 ligeros \\
\hline Partida $\mathrm{s} / \mathrm{n}$ & Aire & 8 equipos radiogoniométricos móviles \\
\hline Partida $\mathrm{n}^{\circ} 19$ & Aire & 50 teléfonos de campaña (Estaba previsto recibirlos en el "Restprogramm") \\
\hline Partida $n^{\circ} 20$ & Tierra & 10.000 brocales de fusil \\
\hline Partida $\mathrm{n}^{\circ} 21$ & Tierra & 1.000 fusiles lanzagranadas \\
\hline Partida $\mathrm{n}^{\circ} 22$ & Tierra & 10.000 granadas de humo contracarros \\
\hline
\end{tabular}

${ }^{337}$ Pese a que el número de cartuchos de $3,7 \mathrm{~cm}$ ofrecido para esta primera parte del Programa era de 40.000, la realidad es que se recibieron 48.800, de ahí las modificaciones al alza que más tarde veremos reflejadas en el importe global del "Sofortprogramm" correspondiente a Marina.

${ }^{338}$ Estos torpedos nunca se recibieron, pues la marina renunció a su adquisición.

${ }^{339}$ Los aviones no constituyeron partida alguna en el transporte del material del "Sofortprogramm", pues se recibieron por vía aérea.

${ }^{340}$ Lo mismo que lo comentado en la nota anterior.

${ }^{341}$ Este material, como tendremos ocasión de comprobar más adelante, fue recibido por el Ejército de Tierra y transportado a Cádiz, aunque más tarde, advertido el error, pasaría al Ejército del Aire, pues se trataba de equipos para montar en los aviones.

${ }^{342}$ Curiosamente, ni los equipos pesados móviles de onda corta, ni los de onda larga, ni los equipos ligeros FuG 10, ni los radiogoniómetros, llegaron a España en trenes específicos del Programa, ni se les asignó un número de partida. Es posible que se desplazaran por sus propios medios desde alguna base francesa de la Luftwaffe cercana a la frontera o bien que fueran transportados por vía férrea en algún tren previo al desarrollo del "Programa Bär". No he podido aclarar este extremo, aunque lo que sí es cierto es que todos estos equipos móviles sobre vehículo motor y los remolques fueron recibidos y el Ejército del Aire realizó los correspondientes informes sobre su estado. 


\begin{tabular}{|l|l|l|}
\hline Partida $^{\circ} 23$ & Tierra & 46.000 minas anticarro modelo T-42 \\
\hline Partida $^{\circ} 24$ & Tierra & 4.000 minas ligeras anticarro \\
\hline Partida $\mathrm{n}^{\circ} 25$ & Tierra & 100 cañones de campaña de $122 / 46$ \\
\hline Partida $\mathrm{n}^{\circ} 26$ & Tierra & 3.000 proyectiles de $122 / 46$ \\
\hline Partida $\mathrm{n}^{\circ} 27$ & Tierra & 400 motos ligeras sin carro lateral \\
\hline Partida $\mathrm{n}^{\circ} 28$ & Tierra & 100 motos medias con carro lateral \\
\hline Partida $\mathrm{n}^{\circ} 29$ & Tierra & 6 multiamplificadores de baja frecuencia tipo $38^{344}$ \\
\hline Partida $\mathrm{n}^{\circ} 30$ & Tierra & 20 teletipógrafos mecánicos \\
\hline Partida $\mathrm{n}^{\circ} 31$ & Tierra & $\begin{array}{l}6 \text { aparatos calculadores Malsi» y } 6 \text { juegos de aparatos transmisores Modelo } \\
37 \text { para cañones antiaéreos de } 8,8 \text { cm Flak }\end{array}$ \\
\hline
\end{tabular}

Elaboración propia. (Cantidades en marcos). Datos obtenidos en AMAE. Leg. R-2065-5. En fondo azul claro, las partidas de la Armada, azul oscuro, las del Ejército del Aire y marrón, las del Ejército de Tierra.

El encuentro finalizaba con el compromiso de volver a verse la semana siguiente para rematar los flecos que quedasen antes de comenzar los envíos de material a España.

\section{III.8.- 11 DE MAYO. LA ÚLTIMA REUNIÓN DE MARTÍNEZ DE}

\section{CAMPOS}

Una semana después de la última reunión y poco antes de partir con destino a Viena para supervisar parte del material adquirido, el general español Martínez de Campos se volvía a reunir con el general Becker, esta vez en presencia también del coronel Beutler y del capitán de fragata Flüss. Una vez iniciada la reunión, el jefe de la delegación alemana cedió la palabra al Oberst Beutler, quien expuso el estado de los trabajos desarrollados la semana anterior por parte alemana ${ }^{346}$.

Pasó Beutler, entonces, a manifestar las últimas dudas que todavía quedaban a los negociadores militares germanos. Respecto al Ejército de Tierra, estas se referían al asunto las fechas en que podrían acudir a Alemania el equipo de carros español que recibiría un curso para el manejo de los concedidos en el Programa; al material de

\footnotetext{
${ }^{343}$ Como se verá en capítulos posteriores, sólo se recibieron 297, pasando las 103 que faltaban a formar parte de la segunda fase del Programa. Pese a ello, esas 103 motos serían recibidas en el último tren del primer cupo.

${ }^{344}$ Pasarían al $2^{\circ}$ cupo, o "Restprogramm".

${ }^{345}$ Id. Anterior. Pasarían al "Restprogramm".

${ }^{346}$ Comunicó al general español que la casa de transportes Schenker se haría cargo del transporte del material hasta la frontera española, disponiendo de tres rutas diferentes a los tres puntos de entrada comentados en la reunión previa. La tarifa que Schenker cobraría al Estado español será la denominada "Tarifa Militar", entendiendo que era más barata que la que pudiéramos denominar "Civil".
} 
transmisiones presentado por el comandante Guiloche y que no estaba en la lista ofrecida por los alemanes; al asunto de la homogenización a solo tres marcas diferentes, de las 400 motocicletas usadas; la inspección previa en Berlín de muestras del material y las cargas a enviar a España; los accesorios y elementos que se podrían entregar para los cañones rusos de $122 \mathrm{~mm}$, y por último, los derechos para fabricar en España granadas contracarro.

Martínez de Campos dio contestación a todas y cada una de las cuestiones planteadas por Beutler, fijando la fecha de envío del equipo español de carros de combate para entrenarse en Alemania ${ }^{347}$, para el 5 de julio próximo. Estuvo conforme con la reducción de marcas de motocicletas a como máximo tres, intentando mantener las 400 unidades previstas, aunque daba preferencia a la homogeneidad de materiales frente al número de máquinas a traer a España. En lo que se refería a las piezas de 122 $\mathrm{mm}$ soviéticas, manifestó que era prioritario disponer de los accesorios para las mismas, y si no estaban incluidos en el material a enviar, era preciso que, de alguna manera, se adquirieran aparte del programa dichos elementos.

En cuanto al programa de Marina hubo dos cuestiones por parte de los alemanes, una referida a los 24 equipos de ametralladoras de $20 \mathrm{~mm}$ para submarinos con 48.000 disparos, cinco direcciones de lanzamiento de torpedos y 10 goniómetros, de los que Beutler comentó que todavía estaba en estudio y que, posiblemente, hubiera que rebajar las cifras, y por otra, los radiolocalizadores para cruceros y destructores, lo que los germanos todavía estaban examinando.

Referido al programa para el Ejército del Aire, Beutler comentó que no era posible el cambió de los Junkers Ju 88 por los Heinkel He 111, como habían solicitado los españoles, pues según el coronel alemán, esos aviones hacían falta en África. Afirmó también que se había pedido autorización para que se incorporara el equipo español de oficiales, suboficiales y especialistas en artillería antiaérea pesada, cuestión a la que Martínez de campos replicó que el Agregado Aéreo alemán en Madrid, general Krahmer, había entregado dicha autorización dos meses antes. Beutler mantuvo que el plan de instrucción de los españoles estaba todavía en estudio y que todavía no se podían adelantar las fechas en las que deberían incorporarse.

\footnotetext{
${ }^{347}$ Las prácticas se planeaba que fueran impartidas con los mismos carros que habían de venir a España y la instrucción duraría unas seis semanas. Como veremos más adelante, nada de esto sucedió en realidad.
} 
Para terminar, se habló también del programa de maquinaria, y los teutones afirmaron que había que examinar bien las peticiones españolas, y que el suministro se podría realizar en un plazo de cuatro años a partir de la fecha de aprobación del material concedido, debiendo respetar los datos de producción de las fábricas alemanas. No obstante, Beutler dejó abierta la puerta para acortar ese plazo si España aceptaba, en lugar de maquinaria nueva, que habría que fabricarla, maquinaria usada, empleada en las fábricas germanas. Inmediatamente Martínez de Campos se dirigió a Becker para interesarse por este asunto, preguntando al general de la Luftwaffe si él pensaba que en el plazo de esos cuatro años, se daría toda la maquinaria nueva que se había solicitado en la carta del 29 de abril. Becker respondió afirmativamente, aunque manifestó que era su creencia. En el contraataque, el general español se puso en lo peor y volvió a preguntar al alemán que si se aceptaba maquinaria usada, se serviría con celeridad una cantidad importante de ésta.

Becker prometió contestar con un listado de la maquinaria disponible en unos 15 días, pues el asunto estaba en consultar con las fábricas la disponibilidad de las mismas. Pese a que los españoles no iban a tratar directamente con las fábricas, sino con el OKW, éste era el único que podía autorizar a las empresas a concertar la venta con las autoridades españolas. Martínez de Campos manifestó entonces su conformidad en aceptar alguna maquinaria usada, pero con la condición de que el teniente coronel Villegas, que permanecería en Berlín esos días, inspeccionase dicha maquinaria, una por una $^{348}$.

\footnotetext{
${ }^{348}$ En efecto, el 24 de mayo la Sección Económica del Ejército, del Oberkommando der Wehrmacht, remitía al general Martínez de Campos, una carta sin firma y una relación adjunta, en la que se marcaban los tiempos que la industria alemana tardaría en entregar maquinaria nueva, e incluso en algunos casos usada, de la solicitada por España. La maquinaria era para construir artillería antitanque, antiaérea, ametralladoras, municiones, pólvoras y explosivos. La maquinaria de fundición, forja y tratamientos térmicos, por término medio tardarían en entregarla un año. Las máquinas herramientas para artillería, entre medio y un año. La maquinaria para calibres de 3,7 y $4,5 \mathrm{~cm}$ (artillería antitanque) y $2 \mathrm{~cm}$ (antiaérea) tardarían medio año, y la maquinaria para fabricar proyectiles de grueso, medio y pequeño calibre, algo más de medio año. Otro tipo de maquinaria universal y maquinaria de precisión, tardaría un año y medio en poder suministrarse, lo mismo que una instalación para fabricar municiones de $2 \mathrm{~cm}$ con vaina de acero. Por último, diversa maquinaria para fabricación de pólvoras y explosivos y para un taller de herramientas de cartuchería, tardaría entre año y medio y dos años en ser enviada por Alemania. Asunto: Máquinas herramientas. Para la Comisión Española para Material de Guerra, para entregar a S.E. el General de División Martínez de Campos. Oberkommando der Wehrmacht. Sección Económica del Ejército. W Stb (Extranjero) Sección 3. Az 3 i 24 IIIc Num. 4818/43. Berlín, mayo 24 de 1943. AGMAV. Caja 24.706. Fondo del antiguo Ministerio del Ejército.
} 
Finalizados los cuatro grandes grupos de materiales incluidos en el Programa, la conversación derivó de manera natural a las valoraciones de todo el material del que se estaba tratando. Por parte alemana, Beutler comentó que había que conocer exactamente la cantidad de envíos y el material que compondrá cada expedición, y que en esas valoraciones tendrá gran influencia el coste de las patentes e inventos. Según el coronel Beutler, Alemania no pretendía hacer un negocio pero quería recibir a cambio materiales del mismo valor. Como tendremos ocasión de analizar con posterioridad en este trabajo, esas palabras de Beutler estaban cargadas, o bien de cinismo o bien de un profundo desconocimiento de lo que los negociadores alemanes en materia de precios iban a realizar en Madrid en reuniones posteriores.

Martínez de Campos necesitaba conocer una valoración aproximada para saber si podía o no seguir solicitando materiales en función de los compromisos económicos adquiridos. Debería conocer precios de los lotes para actuar en consecuencia. Pero era evidente que en ese momento los alemanes no se los podían facilitar; otras comisiones, encargadas de negociar los precios, iban a actuar en Madrid para establecer la contraprestación económica de cada partida solicitada. Becker le dijo al español que esperaba entregarle una lista de esos precios en breve espacio de tiempo, aunque Martínez de Campos la quería de inmediato ${ }^{349}$.

Se trataba de una reunión para ultimar detalles del material que habría de comenzar a llegar a España en breve tiempo y predominaban las cuestiones técnicas de índole militar, que eran las indicadas en ese tipo de reuniones, aunque no cabe duda que Martínez de Campos dejaba entrever cierto nerviosismo por la cuestión de los precios, cuestión capital, sin duda, aunque no cabía bajo ningún concepto en ese momento de la negociación. Era obvio que de los precios dependerían las cantidades de material militar que llegarían a España como contraprestación a las exportaciones de nuestro país, pero la actitud del general presidente de la comisión española solicitandolos de manera

\footnotetext{
${ }^{349}$ En esta fase de la reunión hubo algún momento de tensión, terciando el general Becker, quien afirmó que Alemania no pedía de España más primeras materias de las que España podía ofrecer, o sea, lo que tenía en su suelo: cobre, bronce, fundición de hierro, latón, cromo. Dijo también que cuando enviaran materiales manufacturados que tuvieran goma (neumáticos especialmente) sería preciso que España devolviera caucho o goma cruda. A estas afirmaciones el general español respondió afirmativamente, en la creencia de que su gobierno estaría dispuesto a este intercambio, aunque él no estaba autorizado para contestar. Lo que él veía complejo era el asunto del caucho pues España era deficitaria en esta materia prima.
} 
inmediata no fue acertada pues sus interlocutores del OKW nada sabían del asunto y nada podían adelantar.

Finalizó la reunión interesándose Martínez de Campos en unos fonolocalizadores $^{350}$ (fonos) belgas de botín de guerra que los alemanes habían ofrecido en compra al gobierno español, aunque ajenos al "Programa Bär", y solicitando de manera insistente, radiolocalizadores para los tres ejércitos. A todo ello los alemanes se comprometieron a contestar de inmediato, en un par de días a lo sumo.

\section{III.9 - GESTIONES CON AGEKA PARA ADQUIRIR FONOS}

El general Martínez de Campos tenía una agenda muy apretada en este segundo viaje a Alemania y el día 12 salió de Berlín con destino a Viena, para revisar y supervisar el material militar objeto de la negociación. Allí permaneció cinco días, regresando a la capital alemana el día 17. Tras dos días de descanso en Berlín, el 20 inició otro viaje para visitar la importante factoría artillera sueca de Bofors.

Fue precisamente en estos días, concretamente el 22 de mayo, cuando se iniciaron conversaciones de los comisionados españoles con la AGEKA para recabar información sobre los citados fonolocalizadores belgas que habían sido ofrecidos por la entidad germana en carta al Agregado Aéreo en Berlín, de fecha 19 de enero de ese mismo año. Pese a que la oferta de AGEKA indicaba como fecha límite de caducidad el día 31 de marzo, la comisión española reunida con el representante oficial alemán Barón von Waltershausen ${ }^{351}$ solicitó al teutón la posibilidad de prorrogar dicha oferta, pues debido a retrasos imprevistos, los españoles no pudieron formalizar la compra antes de la citada fecha. La comisión española, en ausencia del Agregado Aéreo, José Pazó Montes, estaba presidida por el comandante de Artillería, Ricardo Castro Caruncho, siendo vocales de la misma los comandantes de Aviación Álvaro Soriano y Enrique Cárdenas. Como ya en el mes de marzo una comisión española había examinado en la fábrica constructora los citados fonos, ante la respuesta afirmativa del representante de

\footnotetext{
${ }^{350}$ Se trataba de aparatos de detección de aeronaves por el sonido, empleados por los ejércitos desde la Primera Guerra Mundial y muy útiles cuando todavía no se había inventado el radar, pero ya desfasados en 1943.

${ }^{351}$ Pudiera tratarse de Bodo von Waltershausen, descendiente de Antonius von Waltershausen, noble que adquirió el castillo del mismo nombre y parte de la villa en 1420 .

(www.vonbibra.net/Waltershausen.html).
} 
AGEKA, los españoles expusieron su deseo de recibir, en el menor tiempo posible, una oferta detallada con los precios, características técnicas completas, fechas de envío, etc... a fin de formalizar el contrato de adquisición antes de que el general Martínez de Campos abandonara Berlín de vuelta a España ${ }^{352}$.

Como así se había comprometido con la comisión española, el día 24 de mayo se presentó en la Agregaduría aérea española de Berlín el barón von Waltershausen, quien comunicó a los militares hispanos, puesto que los fonolocalizadores habían sido objeto de oferta especial y no habían sido incluidos en la relación general del "Programa Bär", sería muy conveniente, con el fin de acelerar todos los trámites y remitir con prontitud el citado material de guerra procedente de botín, que se firmara un contrato por separado con AGEKA. El barón dio a sus interlocutores una lista en la que manifestaba que disponían de un total de 88 fonolocalizadores Tepas Belge, de los cuales 85 estaban completos, dos incompletos y uno averiado, y que por lo tanto podría aumentarse la cifra de aparatos para adquirir España y disponer de piezas de repuesto con los tres fonos en malas condiciones.

Pese a no poder dar una cifra exacta de cuantos fonos eran nuevos y cuantos usados de los 85 ofrecidos en buenas condiciones, el representante de AGEKA ofreció un precio unitario rebajado y homogéneo, válido tanto para fonos nuevos como usados, de 36.000 marcos por unidad.

Transmitidos todos estos asuntos al general Martínez de Campos a su regreso de la visita a la factoría Bofors, éste decidió aceptar los 88 aparatos, comunicándoselo al Ministro del Ejército por correo y ordenando su adquisición al Agregado Militar en Berlín.

\footnotetext{
${ }^{352}$ El barón confirmó a los españoles que el día 24 tendría todos los datos para entregárselos y a preguntas de los comisionados de cuántos de los fonos ofrecidos eran nuevos, contestó que aproximadamente unos 60 estaban en esa categoría. El alemán respondió, así mismo, a otras preguntas de los españoles, incluyendo una petición enviada tiempo atrás por el propio general Martínez de Campos, para adquirir los correspondientes proyectores de luz, algo que no había quedado muy claro para los alemanes. Para terminar la reunión, los españoles solicitaron del alemán, con independencia del asunto tratado, la posibilidad de envío a España de un fono de la misma casa constructora, pero de $1,80 \mathrm{~m}$ de base, con destino a montaña, a fin de realizar ensayos y comprobar la precisión del aparato, campo de vigilancia y alcance. No se obtuvo respuesta concisa del representante alemán, pues necesitaba un plazo mayor para dar informarse.
} 


\section{TABLA III-D}

\section{PRIMER VIAJE A BERLÍN DE MARTÍNEZ DE CAMPOS}

\begin{tabular}{|l|l|l|}
\hline Fechas & Situación & Observaciones \\
\hline 12-13 de marzo de 1943 & Viaje por ferrocarril Hendaya-Berlín, vía París & \\
\hline 14-17 de marzo de 1943 & Estancia en Berlín & \\
\hline 18-23 de marzo de 1943 & Viaje a Prusia Oriental y regreso & Visita a Hitler el día 20 \\
\hline 24-28 de marzo de 1943 & Estancia en Berlín & \\
\hline 29-30 de marzo de 1943 & Viaje por ferrocarril Berlín-Hendaya, vía París & \\
\hline
\end{tabular}

Elaboración propia. Fuente: Declaración jurada para liquidación por dietas y viáticos reglamentarios de fecha 8 de junio de 1943 . Carpeta: correspondencia posterior al $2^{\circ}$ viaje.

\section{TABLA III-E}

\section{SEGUNDO VIAJE A BERLÍN DE MARTÍNEZ DE CAMPOS}

\begin{tabular}{|c|c|c|}
\hline Fechas & Situación & Observaciones \\
\hline 26-27 de abril de 1943 & Viaje por ferrocarril Hendaya-Berlín, vía París & \\
\hline 28 de abril a 3 de mayo & Estancia en Berlín & \\
\hline $3-8$ de mayo & $\begin{array}{l}\text { Viaje de ida y vuelta en avión al frente de la } \\
\text { División Azul }\end{array}$ & \\
\hline 9-12 de mayo & Estancia en Berlín & \\
\hline 12-17 de mayo & $\begin{array}{l}\text { Viaje por ferrocarril y estancia en Viena para } \\
\text { inspeccionar material adquirido }\end{array}$ & \\
\hline 18-19 de mayo & Estancia en Berlín & \\
\hline 20 de mayo & Viaje en avión Berlín-Estocolmo & \\
\hline 21 de mayo & Viaje por ferrocarril Estocolmo-Bofors & $\begin{array}{l}\text { Billetes por cuenta de casa de } \\
\text { armamento Bofors }\end{array}$ \\
\hline $22-23$ de mayo & $\begin{array}{l}\begin{array}{l}\text { Estancia en } \\
\text { armamento }\end{array} \\
\end{array}$ & $\begin{array}{l}\text { Alojamiento y manutención } \\
\text { por cuenta de la casa Bofors }\end{array}$ \\
\hline 24 de mayo & Viaje por ferrocarril Bofors-Escocolmo & $\begin{array}{l}\text { Billetes por cuenta de casa de } \\
\text { armamento Bofors }\end{array}$ \\
\hline 25 de mayo & Viaje en avión Estocolmo-Berlín & \\
\hline 26-27 de mayo & Estancia en Berlín & \\
\hline 28 de mayo & $\begin{array}{l}\text { Viaje Berlín-Saarbruck y Metz-París por } \\
\text { ferrocarril. Viaje Saarbruck-Saargemund- } \\
\text { Ritch-Saargemund-St.Avold-Metz } \\
\begin{array}{l}\text { carretera, en visita de fortificaciones de } \\
\text { frontera }\end{array}\end{array}$ & \\
\hline 29 de mayo & Viaje París St. Quintin-Lille por carretera & \\
\hline 30 de mayo & $\begin{array}{l}\text { Viaje Lille-Calais-Boulogne-Le Touquet por } \\
\text { carretera en visita de fortificaciones }\end{array}$ & \\
\hline 31 de mayo & $\begin{array}{l}\text { Viaje Le Touquet-Abedille-Le Treport- } \\
\text { Dieppe-Rouen-Nantes-Saint Germain-París } \\
\text { por carretera en visita de fortificaciones }\end{array}$ & \\
\hline 1 de junio & Estancia en París & \\
\hline
\end{tabular}




\begin{tabular}{|l|l|l|}
\hline 2 de junio & $\begin{array}{l}\text { Viaje París-La Rochelle por ferrocarril. Viaje } \\
\text { La Rochelle-Rochefort-Royan-Le Verdon- } \\
\text { Bourdeaux por carretera en visita de } \\
\text { fortificaciones }\end{array}$ & \\
\hline 3 de junio & $\begin{array}{l}\text { Viaje Bourdeaux-Biarritz-Hendaya por } \\
\text { carretera }\end{array}$ & \\
\hline
\end{tabular}

Elaboración propia. Fuente: Declaración jurada para liquidación por dietas y viáticos reglamentarios de fecha 8 de junio de 1943. Carpeta: correspondencia posterior al $2^{\circ}$ viaje. 


\section{Capítulo 4}

\section{EL PROGRAMA BÄR. NEGOCIACIONES ECONÓMICAS}

Las negociaciones para evaluar y fijar los precios del material militar encuadrado en el "Programa Bär", dieron comienzo en mayo de 1943 en la capital de España, por sendas delegaciones española y alemana. En la primera sesión, celebrada en Madrid el 5 de mayo de 1943, los alemanes presentaron un proyecto que contemplaba la entrega en los dos próximos años de armamento, cuyo valor aproximado estaba en torno a los 1.000 millones de marcos. La mayor parte de las entregas se efectuarían durante el año 1943 (aproximadamente un 60\%), mientras que aproximadamente un 30\% se harían al año siguiente, dejando únicamente un 10\% para 1945. El proyecto alemán hacía necesaria una revisión de los precios de los productos de ambos países, para de esta manera intentar estabilizarlos durante la vigencia del acuerdo. Estos 1.000 millones de marcos servirían para enjugar el desequilibrio del Clearing hispano-alemán en ese momento y financiarían parte de las nuevas exportaciones de productos españoles a Alemania, que se preveían unos 600 millones de marcos anuales ${ }^{353}$.

\section{IV.1.- REUNIONES EN MADRID}

En la reunión mantenida entre las delegaciones el 11 de mayo de ese año ${ }^{354}$, se puso sobre la mesa el asunto de los precios que planteaba el párrafo $5^{\circ}$ del proyecto alemán de "Convenio Complementario" al firmado en diciembre del año anterior. La delegación española propuso la designación de una subcomisión de técnicos que estudiara este problema, haciendo ver a la delegación germana la necesidad de proveer a los delegados españoles de los datos precisos respecto a las valoraciones -hasta ese momento, desconocidas- de los suministros de armamento que habrían de figurar como contrapartida alemana así como las bases que para la fijación de los precios Alemania hubiera utilizado para cada una de estas contrapartidas.

\footnotetext{
353 Nota resumen de las negociaciones económicas hispano-alemanas. Madrid, 31 de mayo de 1943. AMAE. AR. Sig. R-2066/4.

354 "El problema de los precios en el convenio complementario hispano-alemán que se negocia". AMAE. AR. Sig. R-2066/4.
} 
Pero los alemanes objetaron que, pese a que les parecía correcta la creación de esa subcomisión que estudiara el problema, los precios del armamento escapaban de las competencia de la delegación germana ya que estos eran objeto de estudio en las comisiones militares que tenían lugar en Berlín en esos momentos ${ }^{355}$. Por ello, el presidente de la comisión alemana propuso que la misión esencial de esta subcomisión sería:

“...el estudio de los precios de las mercancías españolas que habrán de constituir la contrapartida de España para aquellos suministros no comerciales; y ésto con objeto de encontrar el precio justo para dicho armamento, el cual se establecería agregando un coeficiente de aumento que se derivará del porcentaje que el alza de precios de mercancías españolas haya sufrido estos últimos tiempos" ${ }^{\prime 356}$.

La delegación española planteó la necesidad ineludible de utilizar el principio de reciprocidad para fijar los precios, tanto del armamento como de las mercancías españolas, solicitando a los alemanes conocer el coeficiente de aumento que aplicarían y el precio base de todos los suministros no comerciales.

Como si de un "toma y daca" se tratase, los teutones respondieron nuevamente a las exigencias españolas que no podían fijar precios para cada partida militar, pues estaba reservado a las comisiones militares que negociaban en la capital del Reich; y que en Berlín se había partido de un precio base en un año concreto anterior a la guerra y el coeficiente de aumento sería el de las mercancías españolas a partir de entonces. En cualquier caso, dicho coeficiente de aumento no debería estimarse como una exigencia impuesta por Alemania, sino que habría posibilidad de discutirlo en la subcomisión de precios y llegar a un acuerdo beneficioso para ambas partes.

De esta manera, en la reunión celebrada el 16 de mayo, los alemanes pusieron encima de la mesa el coeficiente de aumento que debería regir -según ellos- en la negociación de los precios. En una confrontación ${ }^{357}$ de los precios españoles de las

\footnotetext{
355 Esta afirmación no era cierta pues las comisiones militares reunidas en Berlín sólo se estaban ocupando en esos momentos de definir el material militar que se iba a incluir en el "Programa Bär", y en ningún momento fue objeto de estudio de las mismas el precio de dicho material.

356 "El problema de los precios en el Convenio Complementario hispano-alemán que se negocia. Anejo n” 2, pág. 1 AMAE AR. Sig. R-2066/4.

357 La lista incluía productos del sector industrial como plomo, wolframio, blenda, mercurio, pirita, estroncio, espato-fluor, pieles, corcho, lana, etc, y del sector alimenticio como aceite de oliva o conservas
} 
mercancías que contenía la lista de deseos alemanes de suministro, entre 1939 y 1940, marcaron el coeficiente de 4 sobre 1, para el armamento, como consecuencia de la subida de los precios españoles de exportación entre esos dos años.

La indignación española se puso también de manifiesto en la reunión, facilitando argumentos numéricos extraídos de las estadísticas oficiales, y señalando a la consideración de la comisión alemana los índices ponderados de precios al por mayor para unos 100 productos alimenticios e industriales, tomando como base el año 1913 y teniendo en cuenta el diferente tipo de cambio que regía en España para la divisa alemana en los años 1939 y 1943. Estos datos marcaban un coeficiente muy inferior al calculado por los técnicos en Berlín. Añadieron los españoles un historial de la trayectoria de los precios españoles antes y después de la guerra civil y de los alemanes en esos mismos años, llegando a la conclusión de que los germanos habían sufrido también aumentos considerables. Por último, pusieron como ejemplo las relaciones comerciales con otros países como Argentina, Estados Unidos o Brasil, donde en ningún caso se empleaba este coeficiente ${ }^{358}$. En una nueva reunión llevada a cabo el día 20, la delegación española, debidamente autorizada por el gobierno rechazó el coeficiente corrector de 4 a 1, intentando demostrar su injusticia.

En el fondo, los españoles estaban negando la "teoría del coeficiente corrector al alza" que querían imponer los alemanes, cuyo interés -por otra parte obvio- era garantizarse con el envío del armamento, una mayor importación de productos españoles; concretamente cuatro veces más.

La comisión alemana, como era de esperar, no aceptó la postura española con una serie de argumentos técnicos que escapan por completo a nuestro desarrollo. Dicha comisión hizo saber a los españoles que, planteada así la cuestión, solo existían dos procedimientos para resolver el problema: el primero sería tomar como base el año 1939 y comprobar el valor de las mercancías alemanas no comerciales y de las españolas en el mismo período. En este caso, al verificar los precios alemanes, España podría fijar los aumentos de precios para dichos suministros. En este caso bastaría partir de los precios

\footnotetext{
de pescado en aceite. En total eran 32 productos, y el coeficiente de aumento calculado por los alemanes tomando como base los años 1939 y 1940 era de 4,419. Anejo n 4. AMAE. AR. Sig. R-2066/4.

358 Acta española de las sesiones negociadoras entre las comisiones española y alemana para fijar los precios del armamento. AMAE. AR. Sig. R-2066/4.
} 
de la paz para multiplicar por el coeficiente de aumento de las mercancías españolas de exportación.

El segundo procedimiento sería aceptar los precios actuales, pero en este caso habría que examinar una por una las partidas de suministros de armamento, resultando una tarea ardua y larga. De ser esta la solución elegida, la delegación alemana no podría llevar a cabo el trabajo, que debería realizarse en Berlín. Con este segundo método la labor se reduciría a comparar los precios actuales de los productos españoles con los valores de los productos, uno por uno, que constituyeran el armamento ${ }^{359}$.

Antes de finalizar su intervención, el presidente de la delegación alemana, Ernst Eisenlohr ${ }^{360}$, hizo un alegato algo lacrimógeno en el que entendía que España no debería desear "precios inferiores a los justos" (difícil de entender la justicia o no de unos precios) y por ello pretendía que España valorase el esfuerzo que para Alemania suponía el desprenderse de armamento en las circunstancias por las que atravesaba (lo cual era cierto), para lo cual Alemania necesitaba las materias primas que representaban el contravalor de las entregas alemanas a España (sin duda). Esperaba que España no dificultara la compra de mercancías que precisaban para la fabricación de productos necesarios para continuar la lucha.

Para terminar la reunión, la delegación española, tras una seria y larga disertación sobre teorías económicas que pudieran seguirse a la hora de interpretar el asunto de la fijación de los precios y la huida de posturas inamovibles que pudieran lastrar el resultado de las conversaciones, planteó a la consideración de los alemanes la necesidad de basar el estudio en datos exactos de las materias primas que entraban en la elaboración del armamento, para así calcular el precio que aquellas tenían en 1939 y ver las alteraciones del mismo hasta 1943. Dicho aumento debería ser, para la delegación española, la base para la fijación del coeficiente de aumento del precio del citado armamento. La observación final española dejó claro que España fue siempre una fuente

\footnotetext{
${ }^{359}$ Anejo $\mathrm{n}^{\circ} 4$. Nota sobre el primer examen de la cuestión de precios en las negociaciones hispanoalemanas del 20 de mayo de 1943. AMAE. AR. Sig. R-2066/4.

${ }^{360}$ Diplomático y político alemán (Heidelberg, 12-11-1882/ Badenweiler, 20-1-1958). Tras su paso por diferentes consulados y legaciones, fue embajador en Grecia entre 1931 y 1936, y en Checoslovaquia desde este último año hasta la proclamación del Protectorado de Bohemia y Moravia, en 1939. Desde entonces trabajó en el Auswartiges Amt. Entre 1946 y 1955 fue elegido alcalde de Badenweiler. http://forum.axishistory.com/viewtopic.php?f=45\&p=1420456.
} 
importante de exportación de minerales a Alemania, a precios nada exagerados y que nunca discutió al relacionarlos con las contrapartidas de los productos recibidos del Reich.

El 26 de mayo ${ }^{361}$ tuvo lugar otra reunión entre las delegaciones. El presidente de la alemana indicó que antes de la salida de Berlín del general Martínez de Campos, se le entregaría una lista con los precios de los materiales que estaban dispuestos en ese momento para su envío a España, cifrando el valor de los mismos en, aproximadamente, 150 millones de marcos. Añadió que los precios estaban calculados sobre la base del valor vigente en ese momento de la mercancía en Berlín, decisión tomada tras las dificultades surgidas en la reunión anterior, donde se habló de un coeficiente corrector al alza y el malestar entre la delegación española por este sistema. En cualquier caso, afirmaba el teutón, este sistema de precios vigentes era más lógico ya que entre el material que se iba a exportar a España había buena parte de nueva fabricación e invención, y que por lo tanto no se podían manejar precios de tiempo de paz, ya que dicho material no existía.

Esta propuesta sería más fatigosa para las delegaciones y, sin duda, prolongaría las negociaciones pues habría que esperar que sendas subcomisiones técnico-militares se reunieran en Berlín para discutir sobre los precios del armamento y se llegara a acuerdos. En ese momento, las delegaciones comerciales seguirían actuando en Madrid. La fórmula propuesta fue la siguiente: por un lado estudiar la lista de las contrapartidas españolas, o sea, de las mercancías que desea recibir Alemania de España, bajo distintas hipótesis, debido al desconocimiento que se tenía en ese momento del valor del material de guerra del "Programa Bär". Se plantearon que dicho material fuese valorado en $1.000,800,600$ o incluso 400 millones de marcos. En segundo término, el estudio finalizado de las contrapartidas españolas en cada una de las hipótesis, facilitaría el trabajo de la las negociaciones. Dichas negociaciones habría que suspenderlas durante un cierto período de tiempo hasta que el general Martínez de Campos regresara de Berlín con datos sobre valoración de materiales.

Los representantes españoles se sorprendieron por el cambio de estrategia alemana con respecto a la reunión anterior, pero fueron muy críticos a la hora de

\footnotetext{
${ }^{361}$ Anejo $^{\circ}$ 5. Estado actual de las negociaciones hispano-alemanas. Cambio de táctica alemana en la negociación. (Sesión del 26 de mayo de 1943). AMAE. AR. Sig. R-2066/4.
} 
abordar el nuevo sistema propuesto, inquiriendo a sus contrapartes si era, precisamente por el desconocimiento de los factores que influían en la determinación de los precios del armamento por lo que era necesario hablar de cifras globales calculadas de forma aproximada.

Los alemanes no se apeaban de sus asertos en favor de este sistema, afirmando su mayor efectividad frente al anterior propuesto, completando sus intervenciones con el convencimiento de que los técnicos militares recibirían en breve, la información detallada de los factores que intervenían en la determinación de los precios de cada una de las partidas de armamento en curso de suministro en el "Programa Bär".

Nada hacía variar la postura española de incertidumbre por la dilación en el hecho de presentar una lista de precios, y que esta fuera a posteriori de los envíos de material del "Sofortprogramm", que estaba ya en proceso de envío. La reunión finalizó casi igual que empezó, prometiendo los españoles informar al gobierno de estas nuevas propuestas y requerir instrucciones.

Dos días mas $\operatorname{tarde}^{362}$ volverían a reunirse ambas delegaciones en Madrid. La española volvería a la carga manifestando a los alemanes su desconcierto y -en cierta medida- su incomprensión, a la propuesta germana de duplicar las comisiones que negociaban sobre los precios, transfiriendo la misión de la de Madrid a otra, militar, en Berlín, no adaptándose al sistema español de negociaciones. Quedaría reducido el papel de las delegaciones de Madrid a la mera relación de los productos españoles que debían exportarse a Alemania como contrapartida de las armas, con una indeterminación absoluta del valor de conjunto de dichas armas. No alcanzaba a comprender la delegación española, las ventajas de crear dos comisiones para estudiar el mismo asunto. Además, arguyeron los españoles, que la comisión militar española presente en Berlín estaba constituida por técnicos militares cuyo cometido se reducía al estudio de las calidades y eficacia del material militar contratado, así como a su posible integración en el Ejército español, sin que pudieran discutir el asunto de los precios y los valores necesarios para su financiación.

\footnotetext{
${ }^{362}$ Anejo n ${ }^{\circ}$ 6. Negociaciones económicas hispano-alemanas. Nota sobre la reunión del 28 de mayo de 1943. AMAE. AR. Sig. R-2066/4.
} 
Los alemanes, además de agradecer el esfuerzo español para alcanzar un acuerdo, comunicaron a la delegación española que gran parte de los materiales militares de la primera parte del programa ya se habían enviado, exponiendo el interés de su gobierno por facilitar por todos los medios, el funcionamiento del clearing hispano-alemán, haciendo de esta manera posibles las exportaciones españolas a su país. He aquí el nudo gordiano de las negociaciones. Berlín quería desbloquear el parón de las exportaciones españolas debido al enorme desbalance en los intercambios entre ambos países, ofreciendo, en gesto de buena voluntad, el envío de cierto material militar -sin haber llegado a ningún acuerdo en el precio del mismo-, al que había de seguir, en gesto también de buena voluntad recíproca, una exportación española de productos básicos para mantener la economía de guerra del Reich.

La delegación española era consciente de las diferencias de puntos de vista que separaban los planteamientos de ambas, concretando el problema:

“...en si la capacidad económica de España permitirá o no comprometer una exportación de productos españoles como contrapartida de unos suministros cuyo volumen y valor hasta ahora se desconocen....,363

Llegados a este punto es muy interesante constatar la aseveración que sobre el particular hace el profesor García Pérez:

“...La situación del abastecimiento era tan comprometida para Alemania que necesitaba asegurar esta venta para mantener su producción de guerra. Estos condicionantes tan peculiares propiciaron una negociación puramente bizantina....364

Mientras tanto, Jordana había enviado por valija a la Embajada española en Berlín, una carta urgente dirigida al general Martínez de Campos ${ }^{365}$, solicitando, por una parte, una relación detallada de todo el material militar aceptado en firme en el "Programa Bär", por otra, una relación de precios del citado material y para finalizar, una tercera relación de las materias primas que hacían falta para la elaboración del

\footnotetext{
363 Anejo $n^{\circ}$ 6, pág. 3. Negociaciones económicas hispano-alemanas. Nota sobre la reunión del 28 de mayo de 1943. AMAE. AR. Sig. R-2066/4.

${ }^{364}$ Gacía Pérez, Rafael, Franquismo y Tercer Reich, op. cit., pág. 398.

${ }^{365}$ Carta reservada del ministro de Asuntos Exteriores al presidente de la comisión española en Berlín. Madrid, 24 de mayo de 1943. AMAE. AR. Sig. R-2066/4.
} 
citado material. Por ausencia del presidente de la Comisión española, general Martínez Campos, por estar visitando la línea Maginot y la costa franco-belga, la carta del ministro fue abierta y contestada el día 28 por el agregado militar en Berlín, el entonces teniente coronel Marín de Bernardo. Y en la contestación volvía a hacer referencia a la dificultad a enviar datos de precios:

“...pues cuantas veces hemos preguntado por ellos en el Alto Mando de las Fuerzas Armadas alemanas, nos han contestado que ese dato lo dará la Comisión del Ministerio de Economía alemán que se encuentra ahora en España..."366

El 4 de junio, el agregado militar español volvía a escribir a Jordana para informarle de las averiguaciones que había realizado en la cuestión de precios del material militar alemán. Dichos precios los comparaba con otros que figuraban en la Agregaduría, correspondientes a años anteriores para el mismo material, y la conclusión a la que llegaba era, en cierta medida, sorprendente:

“...De esta comparación, que figura en la nota adjunta, podrá vd. deducir que los precios actuales son superiores, llegando algunos a cuadruplicar los anteriores..."

El coeficiente corrector de 4 a 1 se había abandonado en las negociaciones, pero los precios vigentes en Alemania, según los datos que manejaba la representación militar española en la embajada de Berlín, mantenían ese mismo coeficiente.

\section{TABLA IV-A}

\section{COMPARACIÓN DE PRECIOS ALEMANES DE ARMAMENTO}

\begin{tabular}{|l|c|l|l|l|l|}
\hline Material & $\begin{array}{l}\text { Munición Flak } \\
\mathbf{3 7} \mathbf{~ m m}\end{array}$ & $\begin{array}{l}\text { Cañones Flak } \\
\text { de 88 } \mathbf{~ m m}\end{array}$ & $\begin{array}{l}\text { Munición de } \\
\mathbf{1 2 2} \mathbf{~ m m}\end{array}$ & Minas & $\begin{array}{l}\text { Cañones Oerlikon } \\
\text { de 20 } \mathbf{~ m m}\end{array}$ \\
\hline Precio 1943 & 98 & 480.000 & 300 & 196 & 57.500 \\
\hline Precio anterior & 23 & 111.000 & $106^{368}$ & $40^{369}$ & $20.134^{370}$ \\
\hline
\end{tabular}

\footnotetext{
${ }^{366}$ Carta del Agregado Militar en Berlín al ministro de Asuntos Exteriores de 28 de mayo de 1943. AMAE. AR. Sig. R-2066/4.

${ }^{367}$ Carta del Agregado Militar en Berlín al ministro de Asuntos Exteriores de 4 de junio de 1943. AMAE. AR. Sig. R-2066/4.

${ }^{368}$ El precio de 106 marcos correspondía a munición de $88 \mathrm{~mm}$ con espoleta mecánica, ofrecida por la casa Krupp en 1940 .

${ }^{369}$ Las minas a que se refiere el agregado militar español eran unas de recuperación francesa, ofrecidas en 1942. Es posible que fueran de inferior calidad que las alemanas.
} 
Estaba claro que Alemania necesitaba las exportaciones españolas y que los precios se iban a inflar todo lo posible para asegurarse el abastecimiento. La habilidad negociadora de la comisión española sería un factor determinante en la posición de nuestro país para reclamar la justipreciación del material militar enviado, algo que redundaría en beneficio del suministro armamentístico a España, penalizando, sin lugar a dudas, la posición germana.

Como habían prometido los representantes de la delegación teutona a sus contrapartes españoles, pocos días más tarde, el 12 de junio, Alemania daba a conocer

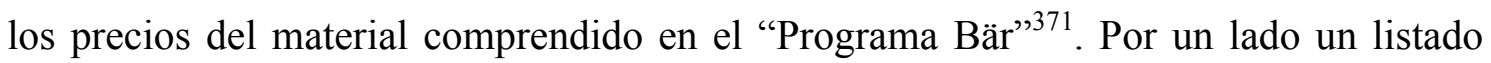
del armamento del "Sofortprogramm" y por otro el del "Restprogramm".

La cifra global que presentaron los alemanes correspondiente al programa de entrega inmediata fue, inicialmente de 119.626.878 marcos, pronto corregida a la baja por unos errores en la valoración ${ }^{372}$, pasando a 115.289.998 marcos. De este total, correspondían a Marina 19.623.900 marcos, al Ejército del Aire 49.817.954 marcos y al Ejército de Tierra, 45.848.144 marcos.

\section{TABLA IV-B}

PRECIOS ALEMANES DEL "PROGRAMA BÄR". "SOFORTPROGRAMM"

\begin{tabular}{|l|l|r|r|}
\hline EJÉRCITO & \multicolumn{1}{|c|}{ MATERIAL } & \multicolumn{1}{|c|}{$\begin{array}{c}\text { PRECIO } \\
\text { SOLICITADO }\end{array}$} & $\begin{array}{c}\text { PROPUESTA } \\
\text { ESPAÑOLA }\end{array}$ \\
\hline Marina & $\begin{array}{l}\text { 4 Flak de } 3,7 \mathrm{~cm} \mathrm{SK} \mathrm{C/30} \mathrm{en} \mathrm{montaje} \mathrm{doble} \\
\text { estabilizado }\end{array}$ & 1.768 .800 & 617.600 \\
\hline Marina & $\begin{array}{l}\text { 16 Flak de } 3,7 \mathrm{~cm} \mathrm{SK} \mathrm{C/30} \mathrm{en} \mathrm{montaje} \mathrm{C/39} \mathrm{de} \\
\text { submarino }\end{array}$ & 2.793 .600 & 640.000 \\
\hline Marina & 10 Flak 38 de 2 cm en montaje C/30 & 980.000 & 228.000 \\
\hline Marina & 20.000 proyectiles explosivos de $2 \mathrm{~cm}$ & 581.000 & 157.000 \\
\hline
\end{tabular}

\footnotetext{
${ }^{370}$ Los cañones con los que estaba comparando los ofrecidos en el "Programa Bär", Oerlikon de 20 mm, eran los Skoda de $15 \mathrm{~mm}$, adquiridos por España en 1941, y que en esos momentos se estaban suministrando al Ejército.

${ }^{371}$ Zusammenstellung der Preise für die Geräte im Sofortprogramm “Bär”. AMAE AR. Sig. R-2065-5. Existe una copia del documento traducido al castellano.

${ }^{372}$ En concreto, se bajaron los precios de los equipos de radio móviles pesados de onda larga y corta, los FuG 10 ligeros, los equipos radiogoniométricos, los radiofaros de aterrizaje y los radiolocalizadores "Lichtenstein". AMAE. AR. Sig. R-2065-5.
} 


\begin{tabular}{|c|c|c|c|}
\hline Marina & 40.000 proyectiles explosivos de $3,7 \mathrm{~cm}$ & 3.948 .000 & 1.316 .000 \\
\hline *Marina & 38 Torpedos Whitehead-Wymouth & 3.325 .000 & $\begin{array}{r}\text { Se renunció a su } \\
\text { adquisición }\end{array}$ \\
\hline Marina & 500 minas tipo EMC & 5.947 .500 & 1.500 .000 \\
\hline Marina & 100 cargas de profundidad WBF & 280.000 & 100.000 \\
\hline Aire & 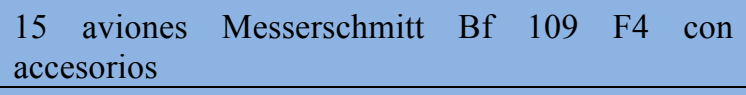 & 10.350 .000 & $3.326 .400^{373}$ \\
\hline Aire & 10 aviones Junkers Ju 88 A4 & 28.000 .000 & $5.900 .000^{374}$ \\
\hline Tierra & $\begin{array}{l}12 \text { Flak de } 8,8 \mathrm{~cm} \text { móviles, } 3 \text { aparatos de dirección } \\
\text { de tipo Modelo } 40 \text { y herramientas para armero. } \\
\text { Con eléctrica y óptica }\end{array}$ & 8.888 .220 & 2.250 .000 \\
\hline Tierra & $\begin{array}{l}12 \text { Flak } 28 \text { de } 2 \mathrm{~cm} \text { Oerlikon y } 4 \text { telémetros de } 1 \mathrm{~m} \\
\text { R-36 para Flak } 28\end{array}$ & 690.000 & 360.000 \\
\hline Tierra & 4 proyectores de $60 \mathrm{~cm}$ para Flak 28 Oerlikon & 312.606 & 132.000 \\
\hline Aire & 4 aparatos de radio fijos para el aterrizaje & 904.000 & 226.000 \\
\hline Aire & 15 grupos electrógenos Still con remolque especial & 464.454 & 240.000 \\
\hline Aire & $\begin{array}{l}1.000 .000 \text { de proyectiles de } 7,92 \mathrm{~mm} \text { para } \\
\text { ametralladora }\end{array}$ & 357.500 & 169.825 \\
\hline Aire & 3 localizadores de buques "Liechtenstein" & 342.000 & 342.000 \\
\hline Aire & 4 equipos móviles pesados de radio (onda corta) & 3.440 .000 & 828.000 \\
\hline Aire & 4 equipos móviles pesados de radio (onda larga) & 4.080 .000 & 828.000 \\
\hline Aire & 15 equipos $\mathrm{FuG} 10$ ligeros con generador & 1.320 .000 & 261.000 \\
\hline Aire & 8 equipos radiogoniométricos móviles & 560.000 & 112.000 \\
\hline Tierra & 10.000 brocales de fusil & 2.715 .000 & 1.520 .000 \\
\hline Tierra & 1.000 fusiles lanzagranadas & 2.070 .000 & 1.100 .000 \\
\hline Tierra & 10.000 granadas de humo contracarros. & 64.000 & 45.000 \\
\hline Tierra & $\begin{array}{l}46.000 \text { minas anticarro modelo } \mathrm{T}-42 \text { y } 4.000 \text { minas } \\
\text { ligeras anticarro }\end{array}$ & 9.800 .000 & 2.750 .000 \\
\hline Tierra & 100 cañones de campaña de $122 / 46$ & 18.793 .750 & 11.200 .000 \\
\hline Tierra & 3.000 proyectiles de $122 / 46$ & 900.000 & 510.000 \\
\hline Tierra & 297 motos ligeras sin carro lateral & 587.660 & 445.500 \\
\hline Tierra & 100 motos medias con carro lateral & 600.000 & 223.000 \\
\hline *Tierra & 6 multiamplificadores de baja frecuencia tipo 38 & 304.200 & 105.600 \\
\hline \multirow[t]{2}{*}{ *Tierra } & 20 teletipógrafos mecánicos & 122.700 & 90.000 \\
\hline & TOTAL & 115.289 .998 & 37.522 .925 \\
\hline
\end{tabular}

Nota: Con asterisco las partidas que no se recibieron en el "Sofortprogramm", bien porque se anularon (torpedos), bien porque se retrasaron para ser recibidas con el "Restprogramm" (transmisiones). (Cantidades en marcos) Elaboración propia. Datos obtenidos en AMAE. AR. Sig. R-2065-5. En fondo azul claro, las partidas de la Armada, azul oscuro, las del Ejército del Aire y marrón, las del Ejército de Tierra.

${ }^{373}$ Incluía los repuestos para una escuadrilla de nueve aparatos, calculados en el $20 \%$ del valor de la citada escuadrilla.

${ }^{374}$ Idem anterior. 
Para los precios del resto del "Programa Bär" ("Restprogramm") los alemanes enviaron otra tabla en donde se recogían las siguientes cifras: para Marina, el importe era de 218.117.385 marcos; para el Ejército del Aire, era de 153.939.630 marcos y para Tierra, 138.221.873 marcos, lo que hacía un total de 510.278.888 marcos.

La siguiente tabla recoge el global de precios del "Programa Bär" tal y como fueron enviados por Alemania en junio de 1943.

\section{TABLA IV-C}

\section{PRECIOS DEL “PROGRAMA BÄR” (SOLICITADOS POR ALEMANIA)}

\begin{tabular}{|l|l|l|l|l|}
\hline & Tierra & Marina & Aire & Total \\
\hline “Sofortprogramm" & 45.848 .144 & 19.623 .900 & 49.817 .954 & 115.289 .998 \\
\hline "Restprogramm" & 138.221 .873 & 218.117 .385 & 153.939 .630 & 510.278 .888 \\
\hline Total & 184.070 .017 & 237.741 .285 & 203.757 .584 & 625.568 .886 \\
\hline
\end{tabular}

Elaboración propia. (Cantidades en marcos). Datos obtenidos en AMAE. AR. Sig. R-2065-5.

Era obvio que los españoles no iban a aceptar estos precios sin compararlos con los que estaban pagando en esos momentos por material de similares características en la propia Alemania o en Suiza, o con las múltiples ofertas realizadas por las casas germanas desde el final de la Guerra Civil española. Y se pusieron manos a la obra.

\section{IV.2.- REUNIONES SOBRE LOS PRECIOS DEL MATERIAL DE} GUERRA

El 15 de junio de 1943 se reunián en el Ministerio de Asuntos Exteriores, representantes de este ministerio y de los de Tierra, Marina y Aire, poniendo en conocimiento de los militares la lista de precios de los materiales suministrados por el gobierno alemán en el "Sofortprogramm", facilitada por la Embajada en Berlín.

Los representantes del Ministerio del Aire, que ya tenían conocimiento de la relación de precios, propusieron que hasta que se llegara a un acuerdo en ese asunto, se suspendiera la entrada de material de la primera expedición, considerando muy elevados los precios de todo el armamento que correspondía a su departamento. Los de Marina, por el contrario, no conocían la nota de precios facilitada desde Berlín, como tampoco 
sabían qué materiales correspondientes a la Armada habían llegado a España por esas fechas, pero la impresión que les produjo la lectura de los precios fue la de encontrar, por lo menos triplicados, los del armamento si bien, en algunos casos, la proporción era aún mayor. Los militares del Ejército de Tierra, al igual que los de Marina, desconocían el documento de precios, y por la premura de la reunión, no disponían de datos fehacientes para comparar los precios. Aún así estimó que la elevación sufrida oscilaba entre el 350 y el $750 \%$.

Al final de esta reunión, se acordó que cada departamento ministerial realizaría un estudio exahustivo partida por partida, recabando las instrucciones oportunas para una próxima reunión, a celebrar lo antes posible.

La Marina remitió al Ministerio de Asuntos Exteriores una comparativa de precios demoledora ${ }^{375}$. Veamos unos ejemplos. Para las piezas antiaéreas de $2 \mathrm{~cm}$ Flak 38 en montaje $\mathrm{C} / 30$, los alemanes pedían en ese momento 98.000 marcos por unidad cuando según una oferta germana al Estado Mayor de la Armada el 31 de julio de 1941, sólo dos años antes, se solicitaban 22.800 marcos por cada una. El incremento era del $429,8 \%$. Para los torpedos Whitehead-Wymouth, procedentes de botín de guerra ${ }^{376}$, se marcaba un precio unitario de 87.500 marcos, y pese a que no se disponía de una comparativa de precios con torpedos de la misma clase, el Estado Mayor de la Armada tenía un contrato de adquisición de 80 torpedos G-7a completamente nuevos, firmado el año anterior, cuyo precio unitario llegaba hasta los 39.800 marcos. Un $219,8 \%$ de incremento en precio por unos torpedos de segunda mano, de un modelo antiguo y sin precedentes en España. Y obviamente, los G-7a eran mejores que los holandeses. Al final, se decidió prescindir de su adquisición.

\footnotetext{
${ }^{375}$ La Marina elaboró unos cuadros comparativos de precios de los materiales contenidos en la primera relación del "Programa Bär" para justificar ante el Ministerio de Asuntos Exteriores el aumento artificial de precios exigidos por Alemania en este programa. "Precios de los suministros de material de guerra por Alemania. Material del primer envío correspondiente a la Marina”. AMAE. AR. Sig. R-2065-5.

${ }^{376}$ Los torpedos Whitehead-Wymouth eran de patente británica y su calibre era de $533 \mathrm{~mm}$ (21 pulgadas). La marina holandesa adquirió tres partidas de tres variantes diferentes: 200 torpedos adquiridos en 1928 para los destructores clase Admiralen y para los submarinos clases K-11 y K-14; otros 22 torpedos adquiridos en 1935 para el submarino O-16 y por último, 252 torpedos con destino a sus submarinos clase O-19, comprados al Reino Unido en 1937. Esta última versión tenía mayor alcance que las anteriores. Los alemanes capturaron una partida de estos últimos torpedos, que es la que intentaban vender a España. http://www.netherlandsnavy.nl/Torpedoes.html.
} 
De la misma manera, el Ejército del Aire hizo lo propio, enviando su propia comparativa de precios ${ }^{377}$. Aquí llaman mucho la atención tres partidas. Los aviones de bombardeo Junkers Ju 88-A4 tenían un precio tasado por los alemanes en 2.800.000 marcos cada uno, cuando el Estado Mayor del Aire disponía de una oferta de aparatos similares completos de fecha 15 de diciembre de 1942 (seis meses antes) por 500.000 marcos la unidad. Un 560\% de incremento con respecto al año anterior. Los equipos de radio pesados móviles de onda larga habían sido valorados en 1.020 .000 marcos cada uno. La casa fabricante, Lorenz, en oferta de junio de 1941, había ofrecido emisoras de onda larga de 1,5 Kw al precio de 29.500 marcos. Estas emisoras eran las mismas que figuraban en los equipos móviles, a los que habría que añadir el precio del camión, el grupo electrógeno y el material de antena. Como cada equipo llevaba dos camiones (emisor y receptor), el precio que proponían los militares españoles como más ajustado era de 207.000 marcos por equipo, muy lejos del planteado en los famosos listados germanos. En concreto, hablamos de un aumento del 492,7\%. Por lo que se refiere a los equipos de transmisiones ligeros FuG 10, los alemanes los habían presupuestado en 88.000 marcos por unidad, aunque el Ejército del Aire argumentó que su precio no podría superar los 15.000 marcos ya que en 1939 se había vendido a España una aparato similar aunque de menores prestaciones, el FuG 3, por 7.500 marcos/unidad

Para terminar, el Ejército de Tierra hizo lo mismo que sus "hermanos", y envió al Ministerio de Asuntos Exteriores sus conclusiones respecto a los listados del material contenido en el "Sofortprogramm" ${ }^{378}$. Una batería antiaérea completa, dotada de cuatro cañones Flak de $88 \mathrm{~mm}$ y toda su óptica y elementos, estaba valorada en el documento alemán en 2.962.742 marcos, cuando en 1941 la casa Krupp había ofrecido al Ejército de Tierra estas mismas baterías por 720.000 marcos, un 411,49\% más económicas de lo que figuraba en el listado.

\footnotetext{
${ }^{377}$ Son muy interesantes los cuadros comparativos de precios presentados por el Ministerio del Aire al de Asuntos Exteriores, donde se recogen, con datos exhaustivos, las diferencias económicas observadas en las diiversas ofertas de material pasadas al ministerio español los años anteriores y los exigidos en el seno del "Programa Bär". "Nota dada al Ministerio de Asuntos Exteriores. Ministerio del Aire. Sección de Fabricación. Precio de los suministros de material de guerra alemán. Primera expedición correspondiente al Ministerio del Aire". AMAE. AR. Sig. R-2065-5.

${ }^{378}$ Pese a que el Ejército de Tierra disponía de menos argumentos de comparación con precios anteriores, también elaboró un documento para justificar ante el Ministerio de Exteriores la descabellada petición alemana respecto a los precios marcados para el material del "Programa Bär". Ministerio del Ejército. Madrid, 18 de junio de 1943. AMAE. Leg. R-2065-5.
} 
Creo que no es preciso ofrecer más ejemplos de los precios que los alemanes habían propuesto para el material del "Sofortprogramm", completamente artificiales y exagerados, algo que propició, enseguida, la convocatoria de reuniones urgentes entre técnicos de ambos países, para llegar a un acuerdo sobre los los precios del armamento, pieza fundamental a la hora de aceptar el material que componía el resto del "Programa Bär” y que estaba todavía pendiente para ser enviado desde Alemania.

En esos días, el Ministerio de Asuntos Exteriores, a través de la Embajada alemana en Madrid, reclamaba la presencia de profesionales militares alemanes para constituir junto a otros españoles, una subcomisión técnico-militar que informara y negociara respecto a los precios del armamento alemán comprendido en el "Programa Bär”. En esta subcomisión únicamente tomarían parte, además de los militares, los intérpretes y los secretarios de ambas delegaciones, estos últimos para levantar acta de las reuniones. La citada subcomisión se constituyó en Madrid y tuvo su primera reunión el 15 de junio $^{379}$, trabajando para alcanzar el precio más cercano a la realidad de los envíos ya realizados y conocidos en el denominado "Programa de entrega inmediata" y de los envíos por realizar en el "Programa restante".

En el detallado informe firmado por el Director General de Política Económica del Ministerio de Asuntos Exteriores y presidente de la Delegación española en las negociaciones económicas con Alemania, Vicente Taberna, el 30 de junio de $1943^{380}$, se

\footnotetext{
${ }^{379}$ Los representantes españoles en la citada subcomisión fueron el teniente coronel de Artillería, José Salgado Muro (Ejército de Tierra), el teniente coronel de Armas Navales, Lorenzo Pallarés Cachá, el comandante de Intendencia de la Armada, Antonio González Guzmán y el coronel ingeniero aeronáutico, Antonio Núñez Rodriguez. Se celebraron reuniones de la subcomisión los días 15, 16, 17, 21, 22, 23, 25, 28 y 30 de junio y 1, 2, 12, 13, 16 y 19 de julio de 1943. AMAE. AR. Sig. R-2065-15.

380 "Síntesis de la evolución de las negociaciones con Alemania para la adquisición del armamento alemán. AMAE. AR. Sig. R-2066-5.
}

Se trata de un soberbio resumen de las negociaciones sobre los precios del "Programa Bär". Es muy sintomático que los negociadores españoles fueran capaces de coger la lista de precios presentada por Alemania el 12 de junio, referente al "Sofortprogramm", valorada en 115.000 .000 de marcos, y en menos de 20 días justipreciarla -llegando a un acuerdo con los técnicos alemanes de la subcomisión-, en 37.000.000 de marcos. En el transcurso de la negociación de las subcomisiones, y viendo la realidad de los hechos que iban en contra de los intereses alemanes, el presidente de la delegación germana se reunió con el de la española manifestando, en nombre de su gobierno, el deseo de que la labor de la subcomisión militar no se considerara como definitiva ni fundamental, y fuera el gobierno español el que diera una valoración global al armamento que iba a recibir, señalando una cantidad a tanto alzado, en la cual intervinieran no solo los factores exactos de la labor de la subcomisión sino valoraciones de conjunto. Es muy curioso constatar esta actitud en los teutones, conociendo el tradicional y acusado sentido de la minuciosidad que es consustancial en su política, cuando estaban viendo la estricta y exacta labor de los comisionados españoles a la hora de valorar unos materiales cuyos precios estaban exageradamente inflados. Era un recurso que intentaba llevar al terreno de la camaradería y buena amistad entre países 
puede seguir con detalle el curso de las negociaciones con los alemanes; negociaciones que tuvieron como objetivo justipreciar el armamento alemán llegado a España y en curso de transferencia, con la vista puesta en la necesidad vital teutona de que las negociaciones referentes al envío de las tan necesarias materias primas se desbloquease cuanto antes.

Afirma Taberna en el citado informe que las negociaciones se estaban llevando con ventaja por parte española, ya que jugaban con un déficit alemán en el clearing comercial de más de 150.000.000 de marcos, muy por encima de los 115.000.000 de marcos asignados por los propios germanos al valor de la primera lista de armamento, por lo que en defensa de los interes españoles, lo mejor era dejar que llegaran todos los envíos propuestos en el "Sofortprogramm" y discutir luego sobre su precio real. Una vez en España todo el armamento, no solamente se reforzó la facultad de discusión sino que las conclusiones de los técnicos alcanzadas en Madrid fueron muy favorables a las tesis españolas, algo que, indudablemente hubiera sido mucho más complejo si las reuniones se hubieran celebrado en Belín. La rebaja en los precios llegó a los 78 millones de marcos, pasando de los 115 millones solicitados en la nota del día 12 de junio a los 37 millones consensuados en la Subcomisión Técnica.

Hasta ese momento -30 de junio de 1943- habían llegado a territorio español ocho trenes con la mayor parte del material militar contemplado en el "Sofortprogramm", restando únicamente tres trenes para completar el este programa inmediato. La delegación alemana solicitó entonces al gobierno español la cantidad de 37.000.000 de marcos, correspondiente a esta primera entrega del armamento, para que fuera invertida en la adquisición de contrapartidas en productos españoles, tan necesarios para la economía del Reich en esos momentos.

A la vista del informe de Taberna, el ministro de Asuntos Exteriores, general Jordana ordenó suspender el envío de todo el material del "Restprogramm" en tanto no se llegara a un acuerdo en los precios del mismo.

amigos, unas negociaciones económicas que se habían puesto francamente difíciles a la vista de los informes técnicos. Se puede constatar que en 1940, cuando se trató de analizar y valorar el material militar germano aportado al bando nacional durante la Guerra Civil española, los técnicos alemanes que participaron en las reuniones no habían adoptado las medidas que solicitaban que España tomara en 1943. 
Debido al estancamiento de las negociaciones, el 6 de julio Gómez Jordana, solicitó a los ministerios militares su valoración en el asunto de la posible suspensión de los envíos de la segunda parte del "Programa Bär", ya que no había acuerdo en el tema de los precios. El general Camilo Alonso Vega -subsecretario del Ejército- en nombre del ministro del ramo y el almirante Salvador Moreno como ministro de Marina remitieron sendas misivas al Ministerio de Asuntos Exteriores ${ }^{381}$ en la misma línea: los envíos de Alemania no habrían de suspenderse de un modo absoluto por el gran interés que existía en recibir algunas partidas del programa de armamento, partiendo de la base de que los precios excesivamente exagerados fijados en principio por la comisión alemana, habrían de ser modificados dentro de lo que pudiera estimarse como lógico y natural. Ambos unían a sus cartas, relación de material que no convendría renunciar en ningún caso, entre el que se hallaban los cañones y ametralladoras antiaéreas, las motocicletas, las ametralladoras MG 34, los cañones antitanque de $75 \mathrm{~mm}$ y los de campaña de $122 \mathrm{~mm}$ rusos, así como diversa munición y equipo de transmisiones, los equipos para los submarinos tipo $\mathrm{G}$ que se iban a construir en España, diversos cañones navales y sus municiones, telémetros y direcciones de tiro, minas y seis lanchas rápidas.

Ya el 13 de julio, antes de finalizar las negociaciones la Subcomisión TécnicoMilitar, se comunicó a la delegación alemana que el Ministerio de Asuntos Exteriores, de acuerdo con el de Industria y Comercio, había dado su conformidad a la petición teutona de que se autorizasen exportaciones de productos españoles para el pago del material de guerra recibido en el "Sofortprogramm", por valor de 32.000.000 de marcos aproximadamente. De hecho, el Ministerio de Industria y Comercio había facilitado ya la exportación de algunos productos con destino a Alemania, entre ellos 200 toneladas de wolframio, 20.000 de hierro y 200.000 mantas $^{382}$.

La delegación germana manifestó su satisfacción y recordó a que uno de los puntos que tuvo presentes su gobierno a la hora de autorizar la exportación a España de este material de guerra, fue movilizar el clearing hispano-alemán para que el valor del armamento, convertido en pesetas, formase un fondo en dicha cuenta de clearing para atender el pago pendiente a los exportadores españoles que habían vendido productos a

\footnotetext{
${ }^{381}$ La correspondiente al Ministerio del Ejército estaba fechada el 7 de julio y la de Marina, el día 9. AMAE. AR. Sig. R-2065-5.

${ }^{382}$ Nota sobre las negociaciones en curso con Alemania (13 de julio de 1943) AMAE. AR. Sig. R-2065-5.
} 
Alemania y que todavía no habían cobrado, como consecuencia del déficit existente entonces en dicha cuenta.

El acuerdo final alcanzado el 19 de julio de 1943, tras las reuniones de la subcomisión técnico-militar sobre los precios de los suministros de material militar del denominado "Sofortprogramm" por parte de Alemania dio origen a los números mostrados en las siguientes tablas para los programas "de entrega inmediata", "restante" y general, englobando ambos.

\section{TABLA IV-D}

ACUERDO DE PRECIOS DEL "SOFORTPROGRAMM"

\begin{tabular}{|l|r|r|r|r|}
\hline & \multicolumn{1}{|c|}{ Tierra } & \multicolumn{1}{c|}{ Marina } & \multicolumn{1}{c|}{ Aire } & \multicolumn{1}{c|}{ Total } \\
\hline Precios alemanes $^{383}$ & 45.845 .086 & 19.343 .900 & 50.057 .954 & 115.246 .940 \\
\hline Precios españoles & 20.731 .100 & 4.558 .600 & 12.233 .225 & $37.522 .925^{384}$ \\
\hline Precios consensuados & 21.073 .100 & 4.948 .200 & 13.268 .425 & 39.289 .725 \\
\hline $\begin{array}{l}\text { Variación. Precio consensuado } \\
\text { versus Precio alemán }\end{array}$ & -24.771 .986 & -14.395 .700 & -36.789 .529 & -75.957 .215 \\
\hline Porcentaje disminución & $54,03 \%$ & $74,41 \%$ & $73,49 \%$ & $65,91 \%$ \\
\hline
\end{tabular}

Elaboración propia. (Cantidades en marcos). Datos obtenidos en AMAE AR. Sig. R-2065-5 y R-2066-4

\section{TABLA IV-E}

\section{ACUERDO DE PRECIOS DEL “RESTPROGRAMM"}

\begin{tabular}{|l|r|r|r|r|}
\hline & \multicolumn{1}{|c|}{ Tierra } & \multicolumn{1}{c|}{ Marina } & \multicolumn{1}{c|}{ Aire } & \multicolumn{1}{c|}{ Total } \\
\hline Precios alemanes & 138.221 .873 & 218.117 .385 & 153.939 .630 & 510.278 .888 \\
\hline Precios consensuados & 90.929 .350 & 70.805 .293 & 15.484 .435 & 177.219 .078 \\
\hline $\begin{array}{l}\text { Variación. Precio consensuado } \\
\text { versus Precio alemán }\end{array}$ & -47.292 .523 & -147.312 .092 & -138.455 .195 & -333.059 .810 \\
\hline Porcentaje disminución & $34,21 \%$ & $67,54 \%$ & $89,94 \%$ & $65,27 \%$ \\
\hline
\end{tabular}

Elaboración propia. (Cantidades en marcos) Datos obtenidos en AMAE AR. Sig. R-2065-5 y R-2066-4

\footnotetext{
${ }^{383}$ Los precios alemanes de la nota inicial del 12 de junio, al finalizar los acuerdos de la subcomisión técnico-militar, habían sido modificados ligeramente. Los de Tierra y Marina a la baja, 3.058 y 280.000 marcos respectivamente, y el de Aire al alza en 240.000 marcos. El resultado final se vio modificado muy ligeramente a la baja, pasando de la cifra inicial de 115.289.998 a la de 115.246.940.

${ }^{384}$ En primera instancia, España ofreció un total de 32.141 .885 marcos, cifra que fue subiendo hasta la definitiva de 39.289.725 tras escuchar y aceptar algunos de los argumentos ofrecidos por los técnicos alemanes de la subcomisión. "Negociaciones hispano-alemanas. Subcomisión Técnico-Militar. Resultado definitivo del estudio de valoración del material de guerra." Documento sin fecha. AMAE. AR. Sig. R2065-5.
} 
TABLA IV-F

ACUERDO DE PRECIOS CONJUNTO DEL "PROGRAMA BÄR"

\begin{tabular}{|l|r|r|r|r|}
\hline & \multicolumn{1}{|c|}{ Tierra } & \multicolumn{1}{c|}{ Marina } & \multicolumn{1}{c|}{ Aire } & \multicolumn{1}{c|}{ Total } \\
\hline “Sofortprogramm" & 21.073 .100 & 4.948 .200 & 13.268 .425 & 39.289 .725 \\
\hline "Restprogramm" & 90.929 .350 & 70.805 .293 & 15.484 .435 & 177.219 .078 \\
\hline Total (SP + RP) & 112.002 .450 & 75.753 .493 & 28.752 .860 & 216.508 .803 \\
\hline Porcentaje sobre el total & $51,73 \%$ & $34,99 \%$ & $13,28 \%$ & $100 \%$ \\
\hline
\end{tabular}

Elaboración propia. (Cantidades en marcos) Datos obtenidos en AMAE R-2065-5 y R-2066-4

Se había comenzado hablando de una cifra aproximada de unos 1.000 millones de marcos y se terminaba después de dos meses de intensas negociaciones y trabajos preparatorios, a una cifra que rondaba la quinta parte de aquella, y que estaba mucho más cerca de la realidad que la que inicialmente marcaron los alemanes en beneficio propio.

En cualquier caso, los representantes del Ministerio de Asuntos Exteriores español advirtieron un problema de orden político si las negociaciones sobre los precios del material de guerra, que habían sido llevadas con tanto afán de buscar la perfección por parte de los técnicos españoles, dejando ciertamente en evidencia a los teutones por la sobrevaloración de los materiales, se cumplían a rajatabla. Dicho problema podría originarse si la percepción del gobierno alemán, tras el esfuerzo realizado en la entrega de un armamento ciertamente necesario para su ejército en campaña, era que no conseguía lo que en ese momento necesitaba de España: crédito. Veamos la realidad del momento $^{385}$.

En el mes de julio de 1943, y según los informes del Instituto Español de Moneda Extranjera (IEME), el estado del clearing hispano-alemán era de, aproximadamente, 200.000.000 de marcos a favor de España. Como quiera que las cifras que barajaba la delegación germana en Madrid sobre el valor del armamento del Programa Bär rondaban los 625.000.000 de marcos, si se restaba la deuda que tenían que saldar del clearing, aun tendrían a su disposición, para adquirir productos españoles 425.000.000 de marcos más otros 70.000.000 de desfase aprobados en el Acuerdo

\footnotetext{
385 Es muy interesante un documento sin fecha, con toda seguridad finalizado tras el fin de las negociaciones de las subcomisiones técnico-militares de Madrid -posterior al 19 de julio de 1943- y titulado "Anejo no 1. Propuesta al Consejo de Ministros", obra sin duda de Vicente Taberna aunque en este caso no consta firma. AMAE. AR. Sig. R-2065.
} 
Comercial de diciembre de 1942. En total, unos 500.000.000 de marcos que le permitirían seguir importando materiales españoles sin necesidad de recurrir a figuras económicas como un empréstito, ajenas al citado Acuerdo y que nada podrían beneficiar a España frente a los Aliados -proveedores de importantes materias primas como el petroleo-.

Pero el trabajo de los negociadores españoles en la Subcomisión Técnico-Militar había sido tan brillante y tan sumamente puntilloso para los intereses hispanos, que aquel valor del armamento con el que contaban los alemanes se vio reducido a, únicamente, 216.500 .000 de marcos, con lo que podrían cubrir el saldo negativo existente y poco más. Con esto, la percepción germana de un esfuerzo descomunal de entrega de un bien vital para sus intereses bélicos, podría generar no solo desconfianza sino desolación al ver que no tenía una compensación de productos y materias primas vitales para su economía de guerra.

Entonces, una solución radical de aplicar estricto sensu la cifra resultante de las negociaciones técnicas podría ser perjudicial para España, no sólo por la percepción alemana de perder tiempo y dinero, sino por la realidad del momento del conflicto bélico mundial, en el que todavía los intereses españoles pasaban por un apoyo más o menos disimulado a la causa alemana, por mucho que la política exterior del general Jordana se quisiera desvincular más pronto que tarde de un país que se dirigía de manera directa a una derrota total en el conflicto ${ }^{386}$.

El embajador alemán en Madrid remitía un escrito a Jordana el 15 de julio, con las negociaciones técnicas a punto de terminar, y con la conciencia clara de la tremenda baja conseguida por los negociadores españoles. En dicho documento, tras hacer un estudio sintético de las negociaciones entonces en curso, finalizaba solicitando el apoyo del ministro:

“...Para llegar a un resultado satisfactorio para ambas partes y para así estimular de nuevo el intercambio comercial, igualmente importante para los dos países, quedaría muy agradecido a V.E., si, tomando en consideración las circunstancias anteriormente expuestas, dignase hacer valer su influencia, a fin de que la suma global a ofrecer

\footnotetext{
${ }^{386}$ Hay que recordar que todavía estaban bajo las órdenes de la Wehrmacht los integrantes de la División y de la Escuadrilla Azules, y que algunos marinos españoles vestirían pronto el uniforme germano para entrenarse en diversas unidades de la Kriegsmarine.
} 
corresponda, de un lado, desde luego a las posibilidades financieras de España, pero que, del otro lado, esta suma global coloque a Alemania en una posición de poder adquirir aquellas materias españolas que necesita para mantenerse victoriosamente en la lucha actual." ${ }^{387}$

Una solicitud evidente de revisión global de las cifras alcanzadas en las reuniones. Una decisión política que escapaba del alcance de los negociadores y que ponía a las más altas autoridades ante la tesitura de tomar medidas trascendentes, de carácter únicamente político.

Pocos días después de finalizar el trabajo de la subcomisión técnico-militar, los ministros militares comunicaban al de Asuntos Exteriores su disposición de solicitar al ministro de Hacienda los créditos correspondientes para depositar en el IEME, el contravalor en pesetas equivalente a las cantidades correspondientes al "Sofortprogramm"388.

Pese a los oficios de Jordana, intentando por todos los medios que se aceptara un incremento en la cantidad establecida por la subcomisión técnica, la indignación en los medios militares era evidente, pues pensaban que se les había intentado tomar el pelo con los precios sobrelevadísimos que les fueron presentados desde Berlín. Los aspectos políticos no primaron sobre la "prusiana" intransigencia de los ministerios militares españoles. Los alemanes no tuvieron más remedio que aceptar la propuesta española ya que, como afirma García Pérez ${ }^{389}$ :

“...una renuncia implicaba anular la venta de armamento, lo que suponía en la práctica la interrupción del tráfico comercial al no disponer Alemania de medios de pago suficientes para enjugar el déficit comercial ya existente..."

El 18 de agosto de 1943, tras la propuesta de Eisenlohr al Ministerio de Asuntos Exteriores, se firmaba en San Sebastián un Acuerdo Adicional al Convenio Comercial hispano-alemán de diciembre del año anterior, en el que se estipulaba la totalidad del

\footnotetext{
${ }^{387}$ Deutsche Botschaft in Spanien. Pro memoria. De fecha 15 de julio de 1943. AMAE. AR. Sig. R-2065.

${ }^{388}$ AMAE. AR. Sig. R-2066-5.

${ }^{389}$ García Pérez, Rafael, Franquismo y Tercer Reich, op. cit., pág. 400.
} 
armamento comprendido en el "Programa Bär", que Alemania debía suministrar a España $^{390}$.

Este acuerdo prorrogaba durante otro año el período de vigencia del Convenio de diciembre de 1942, manteniendo el principio de equilibrio y el posible descubierto en el clearing hispano-alemán de hasta 70.000.000 de marcos al final de 1944. Además, autorizaba la exportación a España de armamento por valor de 216. 508.803 de marcos, importe alcanzado en las negociaciones de Madrid.

En esa fecha, el primer envío se encontraba ya íntegro en España y estaba comenzando a llegar el material del resto del programa. Todo el trabajo desarrollado por la Subcomisión Mixta Técnico-Militar durante las reuniones celebradas en Madrid había desembocado en la valoración real y consensuada del material militar que se enmarcaba en el "Programa Bär".

\section{IV.3.- CRÉDITO EXTRAORDINARIO. LAS CORTES ACTÚAN ${ }^{391}$}

Una vez solventados todos los escollos de las comisiones de compras, delegaciones negociadoras y subcomisiones técnicas, ya sólo faltaba un trámite, quizás el más importante a la hora de hacer efectivo el dinero a los exportadores españoles y dar movimiento a esa cuenta de clearing hispano-alemana, que tanto lo necesitaba. Ese trámite no era otro que aprobar un crédito extraordinario para pagar el armamento del "Programa Bär". Para ello el general Jordana se puso en contacto con el presidente de las Cortes, el tradicionalista Esteban Bilbao, una vez firmado el Acuerdo Adicional al Convenio Comercial hispano-alemán, para estudiar la mejor manera de su tramitación rápida y discreta por la institución.

La fórmula alcanzada fue, en palabras del presidente de las Cortes:

“...dar una interpretación extensiva al Reglamento, de manera que permita esquivar las dificultades de publicidad y enmiendas a que me refiero, y en este sentido he citado a la Comisión Permanente para el día 2 de septiembre, con el propósito de conseguir de ella, si no

\footnotetext{
390 "Acuerdo adicional al Convenio Comercial hispano-alemán de 16 de diciembre de 1942" AMAE. AR. Sig. R-2066-2.

${ }^{391}$ Para seguir este epígrafe ver AMAE. AR. Sig. R-2064-4.
} 
surgieran dificultades superiores a mi voluntad, la resolución del expediente y que quede terminado en tan breve plazo..."

En efecto, la Comisión Permanente de las Cortes españolas, en su reunión del día 2 de septiembre de 1943, aprobó el proyecto de Ley ${ }^{393}$ relativo a la concesión de un suplemento de crédito de 506.000.000 de pesetas al Ministerio del Ejército, aplicado a la agrupación cuarta, concepto $3^{\circ}$ del presupuesto extraordinario en vigor, destinado a la adquisición de material de guerra. Éste sería sancionado por el Jefe del Estado el día 4, aunque no se publicó la Ley de referencia en el Boletín Oficial del Estado por el carácter reservado de la misma.

Por la ausencia de los titulares de Marina y Aire - estaban disfrutando su permiso estival-, este mismo procedimiento se demoró en el tiempo y provocó repetidas mociones por parte de la embajada alemana en Madrid, reclamando el cumplimiento del Convenio por lo que se refería al pago del material recibido, expresando su extrañeza por la lentitud en la tramitación del libramiento de los créditos correspondientes para ponerlos a disposición del IEME.

En efecto, mientras que como acabamos de ver, el Ministerio del Ejército ya había tramitado la habilitación de los créditos a través de un presupuesto extraordinario por la totalidad del material concedido en el "Programa Bär", los otros dos Ministerios sólo habían gestionado parcialmente cada remesa concedida, aunque en ningún caso se

\footnotetext{
${ }^{392}$ Carta de Esteban Bilbao al ministro de Asuntos Exteriores, general Jordana. 26 de agosto de 1943. AMAE. AR. Sig. R-2064-4.

${ }^{393}$ Su texto era el siguiente: "Para continuar el plan de adquisiciones y construcciones de material con destino al Ejército resulta preciso suplementar nuevamente el crédito figurado para esta clase de gastos en el presupuesto extraordinario en vigor del Ministerio del Ejército y ampliar la expresión del mismo en el sentido de incluir en su texto los gastos de transporte del material que se adquiera.- En el expediente instruido a tales fines constan los informes de la Intervención general y el Consejo de Estado favorables a la habilitación de recursos y ampliación del concepto y el acuerdo coincidente del Consejo de Ministros.- En su virtud, y de conformidad con la propuesta elaborada por la Comisión Permanente de las Cortes Españolas, dispongo: Artículo primero. Se concede un suplemento de crédito de quinientos seis millones de pesetas al figurado en el presupuesto extraordinario en vigor del Ministerio del Ejército, concepto tercero, "Material de Guerra", subconcepto único, cuya redacción queda también modificada en la siguiente forma: "para adquisición, construcción y transporte de material de guerra, incluso instalaciones para su fabricación".- Artículo segundo. El importe del antedicho suplemento de crédito se cubrirá en la forma determinada por el artículo cuarenta y uno de la Ley de Administración y Contabilidad de la Hacienda Pública.- Dada en El Pardo a cuatro de septiembre de mil novecientos cuarenta y tres.- Francisco Franco. Oficio (personal y reservado) de Presidencia del Gobierno de fecha 7 de septiembre de 1943 dirigido a los ministros de Exteriores, Hacienda y Ejército y firmado por el subsecretario, Luis Carrero Blanco". AMAE. AR. Sig. R-2066-4.
} 
había puesto una sola peseta a disposición del IEME para que éste pagara a proveedores españoles que habían enviado sus mercancías a Alemania en descubierto.

Fue por ello que para evitar la demora y sus efectos perniciosos en la imagen de España frente a Alemania, amen de aplacar falsas interpretaciones por parte de este país en el retraso de los pagos, así como para facilitar una unidad de acción en los tres Ministerios implicados en el Programa, el general Jordana llevó a Consejo de Ministros el 27 de septiembre, una propuesta ${ }^{394}$ en el sentido de ordenar a los agregados militares, naval y aeronáutico en Berlín, firmar todos los contratos de armamento pendientes, acelerar la concesión de los créditos globales para pagar la totalidad del Programa y que cada uno de los Ministerios fuera concediendo créditos parciales para el pago del material ya recibido y el que se fuera recibiendo. Así mismo, urgía a los ministros de Marina y Aire para que solicitasen urgentemente de la Comisión Permanente de las Cortes, la aprobación de los suplementos de crédito correspondientes, al igual que ya había hecho el del Ejército un mes antes.

Afirma Rafael García Pérez que las continuas demoras en el depósito de las cantidades correspondientes al "Sofortprogramm" en el IEME por parte de los Ministerios españoles, se pueden explicar bien por una profunda desorganización interna, cuando no por una división de pareceres entre Jordana y los tres ministros militares, "empeñados en no pagar" militares estuvieran empeñados en no pagar, más bien creemos que todo se debía al desconocimiento por parte de los titulares de las carteras militares, de la burocracia en materia diplomática, y del funcionamiento del procedimiento de clearing, algo que no exime la dejadez que dejaban traslucir a ojos del gobierno alemán, aun, probablemente, sin hacerlo a propósito.

\footnotetext{
${ }^{394}$ Informe de Jordana al Consejo de Ministros el 27 de septiembre de 1943. AMAE. Leg. R-2066-2. El Ministro del Ejército solicitó al Consejo de Ministros, por una parte, la autorización para contratar por gestión directa con el organismo comercial del OKW del Ejército alemán la compra del material de guerra por un montante total de 112.002 .450 marcos, a los precios fijados en la subcomisión técnica hispano-alemana. Por otra, la aprobación del proyecto de contrato redactado por la comisión de compras de material en Berlín, correspondiente al denominado "Sofortprogramm", por un importe de 21.073.100 marcos. Además de la solicitud para que el Agregado Militar en Berlín formalizara el contrato citado en representación del Gobierno español, el ministro del Ejército pedía al Consejo autorización para ingresar en el IEME y abonar en la cuenta de clearing a la AGEKA, la cantidad citada anteriormente, a fin de no demorar los pagos.

${ }^{395}$ García Pérez, Rafael, Franquismo y Tercer Reich, op. cit., pág. 412.
} 
Diez días después del Consejo de Ministros, se desbloqueaba la situación y los créditos comenzaban a ser abonados en la cuenta del IEME para que este iniciara los pagos a exportadores españoles.

\section{IV.4.- LOS ENVÍOS DE MATERIAL}

Durante poco más de un año (el tiempo transcurrido entre el 31 de mayo de 1943 -fecha de llegada del primer tren del "Sofortprogramm"- y el 18 de junio de 1944 fecha de llegada del último tren del "Restprogramm" que logró alcanzar la frontera española-), el trasiego de mercancías militares que supuso el "Programa Bär" mantuvo más que ocupados a numerosos militares españoles en la labores burocráticas de gestión, transporte y reubicación del material y de revisión, clasificación y dotación del mismo a las unidades españolas, así como de aprendizaje y manejo de los nuevos sistemas de armas por las unidades receptoras ${ }^{396}$.

En lo que atañe al primer envío, al que hemos llamado constantemente "Sofortprogramm" -su denominación germana- se pusieron en España un total de once trenes, que transportaron 326 vagones con materiales para el Ejército de Tierra, la Marina y la Aviación españolas, encuadrados en 37 partidas diferentes, alcanzando un peso transportado que superó las 2.300 toneladas.

El "Restprogramm" puso en marcha 28 trenes especiales más de 800 vagones y 8.000 toneladas transportadas, de los cuales solamente alcanzaron nuestras fronteras 25 convoys, cargando un total de 758 vagones. Los trenes numerados como 25, 27 y 28 así como tres vagones del número 26, nunca lograron llegar a España y su cargamento se perdió totalmente (tren $\mathrm{n}^{\mathrm{o}} 25 \mathrm{y}$ los tres vagones del 26) o parcialmente por efecto de los bombardeos (trenes $\mathrm{n}^{\mathrm{o}} 27$ y 28), logrando salvar una parte del material, que volvería a Alemania.

En la Tabla IV-G se puede observar un resumen de lo que supuso en "Programa Bär” en conjunto, en cuanto a número de trenes, vagones y pesos transportados, así como la distribución de los mismos a las estaciones de recepción en la frontera con

\footnotetext{
${ }^{396}$ En los Anexos XIII y XIV desarrollaremos el proceso de recepción, tren por tren, vagón por vagón, de todo el material de Tierra, Marina y Aviación, detallando pormenorizadamente el material transportado, las fechas de recepción en frontera, los vagones alemanes en los que viajaba, los pesos transportados y transbordados en cada uno de los puestos fronterizos por los que se fue recibiendo, las vicisitudes y problemas surgidos al hilo de la recepción y clasificación del material, etc...
} 
Francia (Irún, Canfranc y Port Bou), datos que van a ser ampliados y detallados minuciosamente en los anexos correspondientes.

\section{TABLA IV-G}

\section{RESUMEN DE TRENES, VAGONES ${ }^{397}$ Y PESOS TRANSPORTADOS EN EL “PROGRAMA BÄR" CON DETALLE DE LAS ESTACIONES DE DESTINO}

\begin{tabular}{|c|c|c|c|c|c|}
\hline & Irún (nº̂) & Canfranc $\left(n^{\circ} 3\right)$ & Port Bou (nº5) & Total & Peso \\
\hline "Sofortprogramm" & $\begin{array}{l}126 \text { vagones } \\
\text { (80 G y } 46 \mathrm{R})\end{array}$ & $\begin{array}{l}121 \text { vagones } \\
\text { (73 G y } 48 \mathrm{R})\end{array}$ & $\begin{array}{l}79 \text { vagones } \\
\text { (50 G y } 29 \mathrm{R})\end{array}$ & $\begin{array}{l}326 \text { vagones } \\
\text { (203 G y } 123 \mathrm{R})\end{array}$ & $2.371 \mathrm{Tm}$ \\
\hline “Restprogramm” & $\begin{array}{l}338 \text { vagones } \\
(246 \mathrm{G}, 60 \mathrm{R}, \\
2 \text { OM y } 30 \mathrm{FFM})\end{array}$ & $\begin{array}{l}146 \text { vagones } \\
\text { (41 G, } 86 \text { R y } \\
19 \text { especiales) }\end{array}$ & $\begin{array}{l}\mathbf{2 7 0} \text { vagones } \\
(167 \mathrm{G} \text { y } 103 \\
\text { R) }\end{array}$ & $\begin{array}{l}754 \text { vagones } \\
(454 \mathrm{G}, 249 \mathrm{R}, \\
2 \text { OM, } 19 \text { especiales } \\
\text { у } 30 \mathrm{FFM})\end{array}$ & $7.509 \mathrm{Tm}$ \\
\hline Total & $\begin{array}{l}464 \text { vagones } \\
(326 \mathrm{G}, 106 \mathrm{R}, \\
2 \text { OM y } 30 \mathrm{FFM})\end{array}$ & $\begin{array}{l}\mathbf{2 6 7} \text { vagones } \\
(114 \mathrm{G}, 134 \mathrm{R} \text { y } \\
19 \text { especiales })\end{array}$ & $\begin{array}{l}349 \text { vagones } \\
(217 \mathrm{G} \mathrm{y} \\
132 \mathrm{R})\end{array}$ & $\begin{array}{l}\mathbf{1 . 0 8 0} \text { vagones } \\
(657 \mathrm{G}, 372 \mathrm{R}, \\
2 \mathrm{OM}, 19 \text { especiales } \\
\text { у } 30 \mathrm{FFM})\end{array}$ & $9.880 \mathrm{Tm}$ \\
\hline Carga total & $\begin{array}{l}\mathbf{5 . 4 4 7} \mathbf{T m} \\
(55,13 \%)\end{array}$ & $\begin{array}{l}\mathbf{1 . 9 6 8} \mathbf{T m} \\
(19,92 \%)\end{array}$ & $\begin{array}{l}\mathbf{2 . 4 6 5} \mathbf{T m} \\
(24,95 \%)\end{array}$ & $9.880 \mathrm{Tm}$ & \\
\hline
\end{tabular}

Elaboración propia. Datos obtenidos en los Anexos XIII-C y XIV-C

Desgraciadamente, el material perdido en el tren $n^{\circ} 25$ tuvo que asumirlo el Estado español por completo, como si hubiera llegado, pues no estaba cubierto frente al riesgo de guerra, pese a que los españoles mantenían que la culpa de la pérdida del tren era responsabilidad de la casa de transportes Schenker, por el poco celo con el que actuaron los miembros de la citada compañía. Aseguraba el Agregado Militar, Carlos Marín de Bernardo ${ }^{398}$ :

“...Este tren constaba de cinco tristes vagones. Tristes por la soledad en que viajaban y tristes por el triste fin que les ha cabido en suerte. Estos vagones llegaron a Dijon; después de larga e infructuosa espera, decidió el Begleiter de la casa Schenker marcharse a Port Bou a pasarse unos días comiendo bien, sin marcas de racionamiento. Cuando después de múltiples peripecias, regresó a Dijon el bien

\footnotetext{
${ }^{397}$ Había vagones de varias clases: los más comunes eran los denominados G (vagones cubiertos) y los llamados R (plataformas descubiertas). Había otros especiales, como los denominados FFM (bateas portacarros de combate) o los denominados OM, de los que desconocemos su utilidad.

${ }^{398}$ Carta del Agregado Militar en Berlín a la $4^{\mathrm{a}}$ Sección del Estado Mayor Central del Ejército en Madrid. AGMAV. Caja 24.707.
} 
nutrido y poco celoso funcionario de Schenker, los vagones habían salido aunque dicho funcionario no sabía para donde, afirmando que habían sufrido un bombardeo de la aviación aliada, para evitarse así el pago del seguro, ya que este tren no lo habíamos cubierto frente al riesgo de guerra. Nosotros sostenemos que se han perdido por abandono de Schenker. (...) Preveo que va a haber lío con Schenker...”

Tres de los vagones del tren $\mathrm{n}^{\mathrm{o}} 26$ quedaron rezagados en Francia y fueron un buen botín para el maquis o la Resistencia francesa, aunque este asunto se solucionó de manera satisfactoria pues los vagones iban cubiertos contra todo riesgo. De la misma forma, el material perdido en los trenes 27 y 28, también estaba asegurado y se pudo reclamar ante la compañía aseguradora.

Baste señalar aquí que a partir del 6 de junio de $1944^{399}$, tras el desembarco de fuerzas anglo-norteamericanas en Normandía, y debido al incremento exponencial de las labores de sabotaje del maquis, los envíos por ferrocarril desde Alemania con destino a la Península Ibérica fueron ya imposibles, con el consiguiente parón en el programa de armamentos con destino a España. El Agregado Militar español en Berlín, coronel Marín de Bernardo, avisó a su contraparte en el Estado Mayor Central, coronel Jesús Aguirre, de los problemas que originaría dicha parada de los envíos por ferrocarril $^{400}$ :

“...Según el contrato tipo, elaborado minuciosamente por la Comisión Martínez de Campos, con el asesoramiento de valiosos representantes de las ramas administrativas del Ejército y de la Armada, y que recibió la confirmación y demás sacramentos de todos los ministros, el material del Programa Bär pasa a ser propiedad del estado español en cuanto la casa Schenker, en representación del estado español se hace cargo de él. Este material, que es el que se iba recibiendo y enviando a $\operatorname{Perl}^{401}$ para constituir los sucesivos trenes (...) Como quiera que ya no se puede pensar ni remotamente en enviar este

\footnotetext{
399 Ya incluso antes del Desembarco de Normandía, la cuestión de los transportes estaba dando quebraderos de cabeza a los directivos de Schenker. En un oficio despachado al Agregado Militar español en Berlín, fechado el 27 de abril de 1944, el responsable de la empresa de transportes germana -Krausadvertía a Marín de Bernardo que en el futuro habría que contar con una mayor duración de los transportes desde Perl hasta los pasos fronterizos de Irún o de Port Bou (por donde se habían centralizado todos los envíos desde unos meses atrás). Debido a la situación por la que atravesaban "los territorios del Oeste" (frase textual), habría que contar con al menos 10 días desde la salida hasta la recepción en frontera. Spetra KM/Kr/Le. Asunto Distintivo "Bär". Al Sr. Agregado Militar. Berlín. AGMAV. Caja 24.708. Fondo del antiguo Ministerio del Ejército.

${ }^{400}$ Carta enviada por Carlos Marín de Bernardo a Jesús Aguirre el 30 de agosto de 1944. AGMAV, caja 24.707. Fondo del antiguo Ministerio del Ejército.

${ }^{401}$ Perl es una localidad alemana situada en la región del Sarre, fronteriza con Francia y Luxemburgo. Aquí se preparaban los envíos ferroviarios de material militar, con destino a España.
} 
material a España, han decidido las autoridades militares alemanas que vuelva todo él a los depósitos y fábricas de procedencia, quedando en propiedad del Estado español.

Este material queda en una situación un tanto aventurada, pues no creo que sea pecar de pesimista el considerar que los alemanes pierdan la guerra, en cuyo caso no habría ni que pensar (opinión personal mía) en que los aliados nos dejaran disponer de él. Como con arreglo a los contratos tenemos que pagar todos estos trastos a los dos meses de efectuada la recepción por Schenker, habríamos perdido unos cuantos millones..."

Para evitar las complicaciones derivadas de todo esto, Marín recomendaba que el gobierno español gestionara por vía diplomática el que el gobierno alemán se quedara con todo este material, con el compromiso de que, si las condiciones variaran, lo entregasen a España cuando existieran comunicaciones factibles, con lo cual se perdería el material, pero no el dinero. Otra posibilidad que contemplaba era, en el caso de no querer perder el material, negociar con los suizos para depositarlo en la zona franca de Basilea y, cuando hubiera oportunidad, transportarlo a España.

La postura más inteligente era, sin duda, negociar con los alemanes la finalización del "Programa Bär" de manera inmediata, dejando la puerta abierta a futura mejora de la situación de los transportes y al transporte vía aérea de parte del material de menor peso y volumen. El 7 de octubre de 1944 el OKW remitía una carta $^{402}$ al Agregado Militar español en Berlín en la que le comunicaba que, conforme al escrito remitido por el español el 27 de septiembre pasado, se manifestaba completamente de acuerdo con que se interrumpiera el resto de la entrega del material de guerra previsto en el "Programa Bär".

Atendiendo a la sugerencia española, el OKW daría orden de no preparar más material para enviar a España, quedándose con aquel que había pasado a ser propiedad española pero que entonces, todavía estaba en territorio del Reich. El organismo alemán tomaba nota de los deseos españoles de transportar algún material de transmisiones por vía aérea a España, estando dispuesto a apoyar aquellos deseos en tanto que se dieran las adecuadas posibilidades de transporte para aquellos fines.

\footnotetext{
402 "Desarrollo del Programa Bär (traducción)" Oberkomando der Wehrmacht. Feldwirtschaftsamt. Fwi Amt (Ausl) 3.Abt./IIIc. Az. 3 i 24-Nr. 02121/44 de fecha 7 de octubre de 1944. AGMAV. Caja 24.707 Cp. 16. Fondo del antiguo Ministerio del Ejército.
} 
Las dotes diplomáticas de Marín de Bernardo eran evidentes, pues el peso de la negociación con el OKW lo llevó él, alcanzando todos los acuerdos con el Estado Mayor germano de manera impecable, sin menoscabo del bolsillo de la parte española y defendiendo con uñas y dientes - con evidente éxito- los intereses de España.

\section{IV-5 -NUEVO ACUERDO SOBRE MINERALES NO FÉRRICOS}

El marco previsto en el Acuerdo Comercial con Alemania de diciembre de 1942 fue ampliamente superado como consecuencia de los nuevos suministros de material militar pactados en la primavera de 1943 en Berlín y valorados -tras un mes de reuniones celebradas en Madrid-por las subcomisiones técnicas de ambos países.

Estos nuevos suministros alemanes de material militar se acordó se realizaran sobre la base del mismo principio que rigió el Convenio de diciembre de 1942: había que tener en cuenta la restitución de metales no férricos que formaban parte del armamento y la maquinaria contratada ${ }^{403}$. En el Convenio de San Sebastián se acordó que los técnicos de los gobiernos de ambos países se deberían poner de acuerdo acerca de las cantidades de metales no férricos y otros productos que integraban las denominada "mercancías no comerciales”, que España debería restituir a Alemania.

En enero de 1944, la delegación comercial alemana presentó al Consejo Ordenador de Minerales Especiales de Interés Militar (COMEIM), la nueva propuesta de restitución de minerales no férricos derivada del "Programa Bär", propuesta que fue aprobada por el citado Consejo y por el Alto Estado Mayor, y que sería remitida a la Dirección General de Política Económica del Ministerio de Asuntos Exteriores, organismo administrativo encargado de recoger los datos de los destinatarios de las importaciones germanas, y controlar la ejecución de los acuerdos.

Las cifras de estos metales comprendidas en el nuevo programa eran las siguientes: $153 \mathrm{Tm}$ de cobre; $7 \mathrm{Tm}$ de fundición roja; $52 \mathrm{Tm}$ de latón, $3 \mathrm{Tm}$ de bronce; 0,76 Tm de molibdeno y $45 \mathrm{Tm}$ de cromo. Pese a que se fijaron estas cantidades adiccionales, no se llegó a precisar un programa de plazos para su ejecución efectiva, algo que sí había sucedido en el Acuerdo de diciembre de 1942. En ningún caso, los representantes del Ministerio de Asuntos Exteriores español se avinieron a firmar un

\footnotetext{
${ }^{403}$ Política Económica. Restitución de metales no férricos. Nota para el Señor Ministro fechada el 4 de abril de 1944. AMAE AR. Sig. R-2066-3.
} 
nuevo tratado de restitución y las entregas de minerales se fiaron a la capacidad de las reservas españolas. Pero hay suficientes indicios para pensar que España no estaba en condiciones de practicar estos envíos por el desabastecimiento crónico -en muchos casos- de algunos de estos minerales. En el asunto concreto del cobre, se afirmaba en la nota de la Dirección general de Política Económica citada anteriormente:

"Careciendo España del cobre suficiente para su consumo y teniendo necesidad de importarlo, precisando para ello los navicerts ingleses, la exportación de las $153 \mathrm{Tm}$ dichas llegaría probablemente a conocimiento de los angloamericanos y pudiera crearnos una situación difícil..."

Es muy interesante constatar un hecho curioso, a la vista de una nota confidencial $^{404}$ emitida por uno de los técnicos españoles participantes en las subcomisiones técnicas, el teniente coronel de Armas Navales, Lorenzo Pallarés, quien se manifiesta sorprendido pues:

“...todo ello se puntualizaría mediante la terminación de un convenio comercial especial y se supuso siempre que ello no llevaba consigo la devolución a Alemania de las material primas necesarias para la elaboración del material de guerra que suministrase. (...) Por haber quedado fuera de la relación de precios aprobada alguna partida del material que necesitaba el Ministerio de Marina, pedí aclaraciones sobre el procedimiento que debía seguirse para adquirir este material y se me contestó que el procedimiento de adquirir el material no incluido en las relaciones sería el corriente seguido hasta la fecha, es decir pago en clearing y devolución de las materias primas necesarias para su elaboración. Esto afianzó más la idea de que el material incluido en las referidas relaciones sería adquirido mediante un acuerdo especial sin devolución de las materias primas necesarias para su fabricación..."

En cualquier caso, pese al compromiso adquirido con Alemania de la restitución de metales no férricos, y pese a todos los envíos de armamento realizados en el marco del "Programa Bär", lo cierto es que el Tercer Reich no volvería a recibir mineral estratégico alguno por este concepto ${ }^{405}$.

\footnotetext{
${ }^{404}$ Ministerio de Marina. "Nota confidencial y reservada sobre las negociaciones hispano alemanas", fechada en Madrid el 6 de marzo de 1944. AGMAV. Caja 24.713. Fondo del antiguo Ministerio del Ejército.

${ }^{405}$ García Pérez, Rafael. Franquismo y Tercer Reich, op. cit., pág. 487.
} 


\section{Capítulo 5}

\section{EL PROGRAMA “BÄR”. DESARROLLO E IMPLICACIONES MILITARES. MATERIAL PARA EL EJÉRCITO DE TIERRA}

En el marco de las relaciones hispano-germanas, y tomando como base el Acuerdo Comercial firmado el 1 de diciembre de 1942, verdadero punto de partida del denominado "Programa Bär", ambos países regularon los intercambios comerciales para el año siguiente, con un compromiso expreso por parte del gobierno alemán de disminuir gradualmente los desequilibrios existentes en la balanza comercial de ambos países, llegándose el 30 de noviembre del año siguiente, fecha de finalización del Acuerdo, a un máximo de descubierto en el clearing hispano-alemán de 70 millones de marcos. Durante el primer trimestre de vigencia del Acuerdo, esto es, entre el 1 de diciembre de 1942 y el 28 de febrero de 1943, España exportaría mercancías a Alemania por valor de 130 millones de marcos (de los que 30 correspondían a naranjas), adelantando el gobierno español a los propios exportadores españoles el valor de las mismas. Esta financiación del gobierno español haría aumentar previsiblemente el ya abultado desequilibrio anterior hasta cifras nunca alcanzadas en el comercio exterior de ambos países.

Con el fin de alcanzar los objetivos previstos en el acuerdo, y teniendo en cuenta que las importaciones normales de mercancías alemanas, sumadas a las importaciones de maquinaria y de armamento en curso de suministro y negociación en esos momentos no serían suficientes para compensar las exportaciones españolas previstas, parecía necesario arbitrar un mecanismo para que al llegar al final del período marcado, 30 de noviembre de 1943, el desequilibrio fuera como máximo el pactado en el Acuerdo.

Para ello la Comisión española que tomaba parte en las negociaciones propuso a su homónima alemana que el mecanismo compensador del clearing fuera una entrega de armamento alemán, que serviría al mismo tiempo para modernizar el ya en muchos casos obsoleto material español.

La proposición española, después de varias consultas del Presidente de la Comisión alemana, Sr. Sabath, con altas autoridades de Berlín, fue aprobada. Por su parte, el Presidente de la Comisión española, Vicente Taberna, a la sazón Director de Política Económica del Ministerio de Asuntos Exteriores, aclaró a los alemanes que 
habría que distinguir a partir de ese momento entre dos conceptos, a los que denominó "Suministros Especiales" y "Armamento".

Con la primera expresión se designaría al material militar que ya había sido o era en ese momento objeto de contratación con el gobierno español (contratos firmados o pendientes de firma); y con la segunda se haría referencia al resto de material de guerra que hasta ese momento no había sido objeto de contratación y que serviría de regulador del equilibrio en el total de los intercambios. Todo lo que se engloba en este segundo concepto es lo que hoy día conocemos como "Programa Bär".

En el capítulo anterior hemos desarrollado todos los acontecimientos que sucedieron y que, evidentemente, corresponden al procedimiento lógico de petición, contra-petición, oferta, contra-oferta, viajes, reuniones, negociaciones, etc. En este capítulo y el siguiente, estudiaremos de manera desglosada y pormenorizada todo en diverso material que compuso el tantas veces citado programa de adquisición de armamento, realizando una sistematización del mismo y un somero repaso de su integración en los ejércitos españoles en los años posteriores.

En este capítulo analizaremos con detalle todo lo concerniente al material militar recibido en el seno del Programa por el Ejército de Tierra, para lo que agruparemos el armamento terrestre del "Programa Bär" en varias categorías, a saber: material acorazado, material automóvil, artillería de campaña, artillería antiaérea, artillería contracarro, otro material para la lucha contra carros, material de transmisiones y material de radiolocalización. En este último grupo trataremos de manera conjunta los radares -denominados en Alemania radiolocalizadores y radiotelémetros- solicitados y recibidos por los tres ejércitos, pues lo cierto es que además de ser un asunto absolutamente novedoso en nuestro país en esa época, todo lo relativo a la llegada de estos ingenios en el marco del "Programa Bär" se enredó sobremanera, recibiendo Tierra radares destinados a los aeroplanos de Aviación; o solicitando Tierra, posteriormente a su llegada, otros consignados a Aviación pero necesarios para el tiro de las baterías artilleras antiaéreas.

En el capítulo VI trataremos el material consignado en el "Programa Bär" a la Marina española y al Ejército del Aire, determinando el que llegó en el denominado “Sofortprogramm” y el que lo hizó en el "Restprogramm”. Detallaremos la tipología del 
mismo, la cantidad recibida y el empleo que se le dio tras su incorporación a los buques de la Armada o a las unidades de vuelo o terrestres del Ejército del Aire, comentando los entresijos que rodearon la entrega del mismo así como su tipología y otros aspectos de interés.

\section{V.1.- MATERIAL ACORAZADO}

\section{V.1.1.- Los carros de combate}

Si hay un carro de combate que caracterice a las tropas acorazadas alemanas en el transcurso de la Segunda Guerra Mundial, ese es el Panzerkampfwagen IV, tanto por el número de ejemplares fabricados (más de 8.500 de todas las variantes), como por su presencia en todos los frentes de combate, así como por su exportación a países amigos y aliados del III Reich ${ }^{406}$.

En cualquier caso, en torno a este magnífico producto de la industria de guerra del Tercer Reich, se ha venido manteniendo cierta confusión a la hora de determinar tanto los orígenes como las razones de su presencia en España.

Finalizada la Guerra Civil, el parque acorazado español se componía mayoritariamente de dos modelos de carros de combate, denominados a partir de esos momentos como Tipo I y Tipo II ${ }^{407}$.

El Tipo I correspondía a los modelos Panzerkampfwagen I alemán y Fiat L3-35 italiano, que habían llegado durante la contienda como ayuda al bando nacional. En ambos casos se trataba de carros ligeros, armado el alemán con dos ametralladoras de 7,92 mm emplazadas en una torrecilla giratoria y el italiano de dos ametralladoras de 7 mm en un montaje fijo delantero. En los dos casos estaban tripulados por dos hombres: un jefe de carro-ametrallador y un conductor.

El denominado Tipo II era el carro T-26B, enviado por la Unión Soviética al bando republicano y capturado en grandes cantidades durante la guerra por los nacionales, que lo utilizaron con profusión. Se trataba de un moderno vehículo de

\footnotetext{
${ }^{406}$ Caballero Jurado, Carlos; Molina Franco, Lucas. Panzer IV. El "puño de la Wehrmacht", Valladolid, Quirón Ediciones, 2006, pag. 3.

${ }^{407}$ Molina Franco, Lucas, Manrique García, José María. "Los carros de la División Acorazada", R.E.H.M. nº 40, (octubre de 2003), pág. 207.
} 
combate, armado con un potente cañón de $45 \mathrm{~mm}$ y de una o dos ametralladoras Degtyarev de 7,92 $\mathrm{mm}$ (podían incluso llegar a montarse tres armas de este tipo).

Dos años y medio después de terminada la contienda, el número de carros de estos dos modelos que todavía prestaban servicio en España, ascendía a 283, correspondiendo 144 al Tipo I (Panzer I Ausf A-B y Fiat L3-35) y 139 al Tipo II (T$26 \mathrm{~B})^{408}$.

En esta situación, con un material viejo, desgastado y totalmente superado por las propias circunstancias que imponía la Guerra Mundial, y con el agravante añadido de la escasez de repuestos, pareció atisbarse una luz de esperanza cuando Alemania, presionada por la urgencia de recibir materiales necesarios para la conducción de la guerra, aceptó de manera oficial el envío de armamento para compensar la balanza negativa que ofrecían sus cuentas comerciales con la España de Franco.

Iniciemos pues nuestro relato en Berlín, el 15 de marzo de 1943, en la sala de conferencias del OKW, donde la Delegación española presidida por el general de Artillería Carlos Martínez de Campos, negociaba la adquisición de material de guerra para el ejército. En el caso que nos ocupa, la petición transmitida por Martínez de Campos a la Comisión alemana iba recogida en el documento "Material y armamento que se desea adquirir. $2^{\circ}$ Grupo, Relación no 11: Material Acorazado." 409

Dicha petición incluía 250 carros de combate con cañón de 45 ó de $50 \mathrm{~mm}^{410}$ y dos ametralladoras de 7,92 mm; y 100 carros con cañón de $75 \mathrm{~mm}^{411}$ y dos ametralladoras de 7,92 mm. Como era de esperar, la contrapropuesta germana sólo incluía en este concepto "un Grupo Mixto compuesto por 20 carros de combate M-IV y 10 cañones de asalto StuG III’. Haciendo unos sencillos cálculos se puede comprobar que, los carros ofrecidos no llegaban siquiera al seis por ciento de los solicitados por España.

\footnotetext{
${ }^{408}$ Datos obtenidos del "Resumen general de necesidades de armamento (pie de paz)", redactado por la Sexta Sección del Estado Mayor del Ejército en Diciembre de 1942. Estos datos fueron entregados a la Comisión Extraordinaria para el Material de Guerra y con ellos se evaluaron las necesidades de carros de combate del Ejército de Tierra. AGMAV, Caja 24.711. Fondo del antiguo Ministerio del Ejército. Carpeta: Informes y documentación diversa sobre Alemania de los viajes del general Martínez Campos.

${ }^{409}$ AGMAV, Caja 24.711. Fondo del antiguo Ministerio del Ejército. Carpeta: Informes y documentación diversa sobre Alemania de los viajes del general Martínez Campos.

410 Pudieran corresponder al modelo germano Panzerkampfwagen III, cuyo armamento principal lo constituía un cañón de 37 o de $50 \mathrm{~mm}$.

411 Se corresponderían con los Panzerkampfwagen $I V$, carro de combate principal de la Panzerwaffe germana en las fechas a que nos referimos.
} 
Mes y medio más tarde, el 29 de abril, y después de una estancia en Madrid informando a sus superiores de las disponibilidades alemanas de entrega de armamento y recibiendo órdenes para su ulterior trabajo en la capital germana, Martínez de Campos regresaba a Berlín con la relación de material militar aceptado por España, entre el que, obviamente, estaba el de carros de combate. Se trataba del denominado Panzerkampfwagen IV Ausf. $H^{412}$, ingenio germano que según el profesor Caballero Jurado:

“...fue el único carro de combate alemán que, habiendo empezado a fabricarse antes de la Segunda Guerra Mundial, siguió saliendo de las factorías hasta el final de la guerra."413

Era, sin lugar a dudas, el mejor y más numeroso carro de combate alemán en marzo de 1943, fecha en la que estaban teniendo lugar las reuniones entre españoles y alemanes para adquirir armamento.

El Agregado Militar de la Embajada española en Berlín, fue el encargado de gestionar y firmar todos los contratos con las casas suministradoras del material militar que componía el "Programa Bär". Para los carros de combate, se firmó un contrato de

\footnotetext{
${ }^{412}$ Enmarcado en el proceso de rearme alemán, iniciado poco después de la llegada de Hitler al poder, los carros de combate fueron una de las prioridades acometidas por los diseñadores de la política militar germana, con el general Lutz y el teniente coronel Guderian, a la cabeza de estos programas de desarrollo y evolución de la llamada Panzerwaffe. Una de las consecuencias del estudio y desarrollo de estos planes de preguerra fue el carro de combate modelo IV, diseñado por la Krupp -Grussonwerke AG de Magdeburgo, quien a principios de 1938 presentó oficialmente los primeros 35 ejemplares del Modelo A, también denominado 1/BW (Vs Kfz 622). Entre abril y septiembre de ese mismo año serían 42 ejemplares del modelo B (2/BW) y al año siguiente, un total de 134 unidades del modelo C (3/BW). Estos 211 Panzer IV eran todos los que tenía el ejército alemán en la invasión de Polonia y en los primeros meses de la Campaña de Francia. No fue hasta la primavera de 1942 cuando la factorías de KruppGrussonwerke, así como la Vomag Maschinenfabrik y la Nibelungenwerke, comenzaron a producir las series más amplias y potentes de las fabricadas hasta entonces: hablamos de la denominada serie G, de la que se construyeron 1.687 ejemplares, la $\mathrm{H}$, con 3.774 carros y la J, con 1.758 ingenios. El total sumaba la nada despreciable cifra de 7.219 Panzer IV.
}

El arma principal en las tres versiones citadas $-\mathrm{G}, \mathrm{H}$ y J- era un cañón de $75 \mathrm{~mm} \mathrm{KwK40} \mathrm{L/48,}$ complementado con dos ametralladoras de 7,92 mm MG 34. Su planta propulsora era un potente motor de gasolina Maybach HL 120 TRM de 12 cilindros en V y $300 \mathrm{Cv}$ a $3.000 \mathrm{rpm}$ y refrigerado por agua. Aunque se construyeron 3.935 chasis para la versión Ausf. H, sólo 3.774 se convirtieron en carros de combate, pasando el resto a servir como base para cañones de asalto StuG IV y piezas autopropulsadas de gran calibre "Brummbär".

Para todos los datos de fabricación y variantes del carro de combate Panzer IV ver: Caballero Jurado, C.; Molina Franco, L., Panzer IV. El "puño de la Wehrmacht", op. cit., pp. 3 y ss; Jentz, Thomas L., Doyle, Hilary L., Germany's Panzers in World War Two. From Pz I to Tiger II, Pensilvania, Schiffer Military History Publishing, 2001. pp. 133, 139, 143, 149, 155, 161, 167, 173 y 179; Mazarrasa Coll, Javier de, Blindados en España. $2^{a}$ parte: la difícil postguerra, 1939-1960, Valladolid, Quirón Ediciones, 1994, págs. $45-52$.

${ }^{413}$ Caballero Jurado, Carlos; Molina Franco, Lucas, Panzer IV. El "puño de la Wehrmacht”, op. cit., pag. 4. 
adquisición con la casa "Fried Krupp Aktiengesellschaft" de Essen. En el mismo, firmado en Berlín el 9 de diciembre de $1943^{414}$, se especificaba en el artículo ${ }^{415}$ :

"El Ministerio del Ejército español concierta con "Krupp" el suministro de: 20 carros de combate IV con cañón de 7,5 cm L/48 (Kw.K.40) completos con chasis, superestructura, torre e instalación eléctrica, cada carro con una ametralladora mod. 34 montada en torre y otra en el blindaje esférico de cañonera de la superestructura. Los veinte irán equipados con una instalación de radiotelefonía Fu 5 SE 10 U y ocho de ellos equipados además con una instalación de radiotelefonía para fines especiales $\mathrm{Fu}$ 2. Además 20 juegos de herramientas y accesorios, 3 juegos de repuestos y 3 juegos de repuestos para motor y transmisión."

Así mismo se pensó en la munición para estos nuevos modelos de carro de combate y se compraron 6.000 disparos completos con granada perforante de $7,5 \mathrm{~cm}$ modelo 39, 4.000 disparos completos con granada rompedora de 7,5 cm modelo 34, 127.680 cartuchos de ametralladora, tipo S.m.K., de ellos 63.840 trazadores, y 40 cargas destructoras, 20 de ellas del modelo Z 85 para motor y otras 20 del modelo Z 72 para cañón.

Según el artículo IX del contrato, el coste de todo el material comprendido en el mismo ascendía a 7.157.078,45 marcos, sin contar con los gastos de transporte y el seguro contra los "riesgos de la guerra"

En el artículo $\mathrm{X}$ se hacía constar explícitamente que todos los pagos que resultaren por el cumplimiento del contrato se efectuarían dentro del clearing germanoespañol y que las obligaciones de pago del Ministerio del Ejército se considerarían cumplidas en el momento en que se depositaran las cantidades correspondientes en la ROWAK de Berlín, a disposición de la casa "Krupp".

En el artículo XII se especificaban las materias primas que serían necesarias para la fabricación del material que se iba a suministrar ${ }^{417}$. Esta cuestión no dejaba de ser

\footnotetext{
${ }^{414}$ Es muy interesante constatar la fecha de celebración del contrato de compraventa: 9 de diciembre de 1943. Cuando la mayoría de los 20 carros estaban ya en España.

415 Contrato de adquisición de 20 carros de combate Panzerkampfwagen IV Ausf H. AGMAV. Caja 24.712. Fondo del antiguo Ministerio del Ejército.

416 En el coste citado iban incluida la munición para la batería de StuG III que estudiaremos en el siguiente epígrafe, y que era la siguiente: 2.500 proyectiles perforantes de $7,5 \mathrm{~cm} \bmod .39 ; 2.500$ proyectiles rompedores de 7,5 cm mod. 34; 63.840 proyectiles de 7,92 S.m.K. (la mitad trazadores), 10 cargas destructoras Z 85 para motor y 10 cargas Z 72 para cañón. Ver página 4 del citado contrato.

${ }^{417}$ Comprendían $8.360 \mathrm{~kg}$ de cromo, $540 \mathrm{~kg}$ de molibdeno, $1.800 \mathrm{~kg}$ de cobre, $3.060 \mathrm{~kg}$ de latón, $480 \mathrm{~kg}$ de latón rojo, $240 \mathrm{~kg}$ de bronce y $2.340 \mathrm{~kg}$ de goma bruta.
} 
relevante pues estaba en vigor el denominado "Acuerdo de restitución de metales no férricos y sus aleaciones", que obligaba a España a remitir a Alemania, según unos cupos que se firmaron en el Acuerdo Comercial de diciembre de 1942, las cantidades de estos minerales que formaban parte de las armas que adquiría.

El 23 de junio, una comunicación de $\mathrm{OKW}^{418}$ a la Comisión española ponía de manifiesto que, además del suministro de los veinte carros Panzer IV previstos y aceptados por Alemania, el organismo correspondiente de la Wehrmacht había dado luz verde a una solicitud planteada por Martínez de Campos, relativa al envío de dos carros adiccionales para la Plana Mayor del Grupo. Para este fin, el OKW indicaba a los españoles que disponían de dos carros Panzer III con cañón de $5 \mathrm{~cm}$, mod. 42, para entregarles. La respuesta de los españoles fue categórica: para no diversificar aún más los modelos de carros de combate en servicio en España, sería preferible que los dos carros de mando, fueran del modelo Panzer IV, iguales a los veinte recibidos.

El OKW aprobaría la propuesta española y pocos días después se firmaba en Berlín un segundo contrato ${ }^{419}$ en el que "Krupp" se comprometía a suministrar al Ministerio del Ejército español dos carros de mando Panzer $I V$, con cañón de 7,5 cm L/48 (KwK 40), equipados ambos con una instalación de radio para fines especiales modelo Fu 5 SE 10 U; una instalación de radio modelo Fu 8 SE 30; un juego de accesorios para carro de mando, dos juegos de accesorios y herramientas, un juego de repuestos y un juego de repuestos para motor y cañón. Con los carros, se contrató un equipo de munición para los mismos ${ }^{420}$. Tanto los carros de línea como los dos de mando, constituyeron la denominada partida 59 del "Restprogramm".

Para la instrucción del personal que había de manejar los modernos carros de combate que llegarían a España, se solicitó a las autoridades alemanas el permiso para enviar un equipo español que adquiriera los conocimientos necesarios in situ. A esta petición, contestó positivamente el OKW el 19 de mayo, adjuntando una relación del personal necesario para la instrucción. Las prácticas se realizarían en la Escuela de

\footnotetext{
${ }^{418}$ Oficio no $5744 / 43$ de 23 de junio de 1943. Suministro de carros de combate. AGMAV. Caja 24.704. Fondo del antiguo Ministerio del Ejército.

${ }^{419}$ Contrato de adquisición de 2 carros de combate de mando Panzerkampfwagen $I V$ con cañón de 7,5 cm L/48 (KwK 40). AGMAV. Caja 24.712. Fondo del antiguo Ministerio del Ejército.

${ }^{420}$ Estaba compuesto por 600 proyectiles perforantes mod. 39; 400 rompedores mod. 34; 6.384 disparos de 7,92 mm tipo S.m.K. (la mitad trazadores) y dos cargas destructoras de motor y otras dos de cañón.
} 
Carros de Wünsdorf. Se trataba de un grupo de 84 personas, incluyendo jefes, oficiales, suboficiales, tropa y diverso personal técnico.

La realidad fue que este grupo tan numeroso quedó muy reducido una vez se hubo planificado el curso en Alemania, ya que las autoridades españolas no consideraron conveniente que acudiera al país teutón tal cantidad de personal, sino más bien una representación de cada una de las dos unidades a las que, en un principio, estaba pensado destinar los carros.

El 5 de junio de 1943, un equipo formado por 26 españoles se presentaba en Wünsdorf, localidad situada muy cerca de la capital del Reich, donde se encontraba la Escuela de Carros de Combate y el Regimiento de Instrucción, para seguir el curso de especialización en el Panzerkampfwagen IV.

En el tren $\mathrm{n}^{\mathrm{o}} 17$ de la $2^{\mathrm{a}}$ fase del Programa, además de diverso material para la Marina española, vinieron consignados los veinte carros de combate Panzer IV. El precio total que supuso esta adquisición, reflejado en la factura $\mathrm{n}^{\circ} 119-51 / 150818$ de 8 de diciembre de 1943, fue de 5.260.000 $\operatorname{marcos}^{421}$, precio acorde con el establecido para esta clase de material en las conversaciones económicas desarrolladas en Madrid. Dicho tren llegó a la estación de Irún el día 6 de diciembre, donde el material fue recibido de conformidad por el comandante Vidaurreta, del Estado Mayor del Ejército. Una vez descargados de los vagones alemanes, la Agrupación de Movilización y Prácticas de Ferrocarriles se hizo cargo de los Panzer, montándolos en vagones españoles y evacuándolos con destino a Madrid y a Sevilla. ${ }^{422}$

\section{TABLA V-A}

\section{PANZER IV Ausf $\mathrm{H}$ dotados de equipo de radio $\mathrm{Fu} 5$}

\begin{tabular}{|l|l|l|l|l|l|l|l|l|l|l|l|l|}
\hline Vagón n $^{\circ}$ & 997 & 613 & 0310 & 434 & 0905 & 010 & 2139 & 5071 & 0630 & 067 & 2679 & 495 \\
\hline Carro n $^{\mathrm{o}}$ & 4579 & 4583 & 4608 & 4609 & 4611 & 4617 & 4619 & 4624 & 4627 & 4630 & 4632 & 4634 \\
\hline
\end{tabular}

Protocolo de entrega de los carros en Irún. AGMAV. Caja 24.705.

\footnotetext{
${ }^{421}$ El precio de cada carro de combate era de 263.000 RM. Libro Mayor de la Comisión Extraordinaria para Material de Guerra. AGMAV. Caja 24.712. Fondo del antiguo Ministerio del Ejército.

${ }^{422}$ Los carros vendidos a España, cuyos chasis estaban comprendidos entre el 84.579 y el 84.634, correspondían a los primeros de la serie, ya que ésta se inició con el 84.401, finalizando en el 91.500. Dos características apreciables a simple vista que denotan este hecho son: la rueda tensora trasera, idéntica a la utilizada en la serie $\mathrm{G}$ y los rodillos de vuelta, con cubierta maciza de caucho.
} 


\section{TABLA V-B}

\section{PANZER IV Ausf $H$ dotados de equipos de radio Fu 5 y Fu 2}

\begin{tabular}{|l|l|l|l|l|l|l|l|l|}
\hline Vagón $\mathrm{n}^{\mathrm{o}}$ & 3020 & 193 & 2624 & 992 & 4364 & 153 & 264 & 606 \\
\hline Carro $^{\mathrm{o}}$ & 4587 & 4606 & 4614 & 4622 & 4623 & 4629 & 4631 & 4633 \\
\hline
\end{tabular}

Protocolo de entrega de los carros en Irún. AGMAV Caja 24.705

Pero de los veinte carros que deberían haber llegado a la estación de Irún el día 6 de diciembre de 1943, sólo se recibieron dieciocho. Este hecho estaba motivado en que dos de los vagones especiales (modelo FFM) en los que venían, tuvieron problemas mecánicos, quedando por ello retenidos en Francia, hasta que, una vez solventados dichos problemas, llegaron a la frontera de Irún el día 15 de ese mismo mes.

Entre la carga del denominado tren $n^{\circ} 19$, venían las partidas $n^{\circ} 61$ y 62 (Factura $\mathrm{n}^{\mathrm{o}} 1213-51 / 150818$ de 18-1-44 Krupp), directamente relacionadas con el material de carros de combate del que estamos hablando ${ }^{423}$. Se trataba de la munición destinada a estos carros, valorada en 778.552,30 marcos. Este material era parte de las dos dotaciones de municiones para carros de combate, contratadas por la Comisión española junto a los propios Panzer IV.

Por último, en el tren $\mathrm{n}^{\mathrm{o}} 21$ se envió el resto de las dotaciones de munición para los carros de combate, correspondiente a la factura $n^{0} 1248-51 / 150817$ de 10-3-44, por un importe global de 502.000 marcos.

Inmediatamente a su recepción fueron asignados a la recién organizada, según patrón germano, División Acorazada ${ }^{424}$; la mitad de estos nuevos y potentes carros

\footnotetext{
${ }^{423}$ Eran 2.400 proyectiles rompedores mod. $34 ; 3.600$ proyectiles perforantes mod. $39 ; 3.840$ cartuchos de ametralladora de 7,92 mm; 63.840 cartuchos de ametralladora trazadores; 20 cargas de destrucción Z 85; 20 cargas de destrucción Z 72 .

${ }^{424}$ En agosto de 1943, tras varias visitas a Alemania de una comisión militar española, se decidió organizar un División Acorazada a imagen y semejanza de las Panzerdivisionen germanas. La Instrucción General Reservada $\mathrm{n}^{\circ} 2$ del Estado Mayor Central del Ejército, de ese mismo mes de agosto de 1943, denominada "pase a la nueva organización en la Península", fue el acta de nacimiento de esta unidad. En la misma se determinaba la composición global de la misma, asignándose los acantonamientos que debían ser la sede de las unidades y citándose su ubicación y su encuadramiento. En ese mismo documento se recogían la creación de la denominada Novena Región Militar (Granada, Málaga y Almería), la supresión de tres divisiones, la retirada de Marruecos de la 41 División Expedicionaria y el aumento de una división de montaña, a añadir a las tres entonces existentes.
}

La composición y ubicación teóricas de la División Acorazada eran las siguientes:

-Cuartel General de la División en Madrid

-Primera Brigada en Madrid 
fueron enviados al Regimiento de Carros de Combate n 61 "Alcázar de Toledo" 425 , de guarnición en Madrid. El resto, la otra mitad, al Regimiento n 62 "Brunete"426, de guarnición en Sevilla.

A los pocos días de su llegada, se organizó cierto revuelo en medios militares ${ }^{427}$ con el número de carros que habían de venir de Alemania. El baile de cifras que se había originado con los Panzer IV provenía de unos listados que circulaban en medios ministeriales, establecidos en las conversaciones económicas llevadas a cabo en Madrid en julio de 1943 por las subcomisiones técnicas hispano-germanas. En dichos listados, y probablemente por error, se decía que el grupo mixto de carros que se enviaría a España, constaba de 24 carros Panzer $I V$ y seis cañones de asalto $S t u G I I I$. Por el contrario, las listas oficiales, así como los contratos, como ya hemos visto, hablaban de

-Cuartel General

-Regimiento de Infantería $n^{\circ} 42$ (Leganés)

-Regimiento de Carros $n^{\circ} 1$ (Leganés)

-Segunda Brigada en Madrid

-Cuartel General

-Regimiento de Infantería n ${ }^{\circ} 43$ (El Goloso)

-Regimiento de Carros n 2 (El Goloso) (Estaba todavía en Sevilla)

-Grupo de Exploración de Caballería (Aranjuez)

-Batallón de Cazadores de Carros

-Regimiento de Artillería no 13 (Getafe)

-Grupo de Zapadores (Campamento)

-Grupo de Transmisiones (El Pardo)

-Grupos de Intendencia, Sanidad, Automovilismo, Parque de Artillería Divisionario, Sección de Desimpregnación de Defensa Química y Jefaturas de Artillería, Ingenieros e Intendencia divisionarias. Manrique García, José María y Molina Franco, Lucas, La Brunete. 60 años de historia. Valladolid, Quirón Ediciones, 2003, págs. 3, 21-26.

${ }^{425}$ Era el antiguo Regimiento de Carros de Combate $\mathrm{n}^{\mathrm{o}}$ 1, con base en Campamento. Pasó a denominarse Regimiento de Carros de Combate n 61 "Alcazar de Toledo" por el Decreto de 21 de diciembre de 1943 publicado en el Diario Oficial del Ejército no 1 de 1944.

${ }^{426}$ Se trataba del antiguo Regimiento de Carros de Combate $\mathrm{n}^{\mathrm{o}} 2$, acantonado en Sevilla. Cambió su denominación a Regimiento de Carros de Combate no 62 "Brunete" por el citado Decreto de 21 de diciembre de 1943.

${ }^{427}$ Nota $^{\text {o }}$ 4442-A A/B de la 4 a Sección del EMCE, fechada el 13 de enero de 1944. AGMAV. Caja 24.707. Fondo del antiguo Ministerio del Ejército. 
20 carros y 10 cañones de asalto. Una comunicación del Agregado en Berlín dirigida al coronel Jesús Aguirre, del Estado Mayor Central del Ejército, aclaraba el entuerto"428.

En cada uno de los dos regimientos citados, se organizó una compañía a tres secciones de tres carros, y uno de mando, utilizando para este cometido uno de los carros de línea, ya que los contratados con Alemania nunca llegarían a recibirse.

En 1949, se disolvía el Regimiento de Carros de Combate "Brunete" no 62, pasando su nombre a la División Acorazada, y el material a los Regimientos de Carros “Alcázar de Toledo" n 61 y "Oviedo" n 63, de guarnición en Laucién (Marruecos), así como a varias unidades de Caballería. Los diez Panzerkampfwagen IV del Regimiento n 62 pasaron al "Alcázar de Toledo" para organizar, junto a los diez que este poseía, el $2^{\circ}$ Batallón acorazado, conviviendo todavía durante varios años con los vetustos T-26B soviéticos ${ }^{429}$.

En España se conservan tres de estos carros de combate: uno de ellos en el Museo de Medios Pesados de la Base Militar de El Goloso (Madrid); otro en la Base Militar de "El Empecinado", (Valladolid) y el tercero, en la Antigua Academia de Ingenieros (hoy Mando de Fuerzas Pesadas) en Burgos.

\footnotetext{
${ }^{428}$ De hecho en las conversaciones económicas desarrolladas en Madrid, se establecieron los presupuestos y las cuentas de débito tomando como base estos datos. A posteriori, hubo que rectificar la contabilidad utilizando las cifras reales: 20 carros de combate y 10 cañones de asalto.

${ }^{429}$ Entre 1954 y 1955, cuando el material acorazado norteamericano comenzaba a llegar al Ejército español, diez Panzer IV del "Alcázar de Toledo" fueron enviados al Regimiento de Carros "Oviedo" $\mathrm{n}^{\circ}$ 63 de Laucién, quien los tendría en servicio hasta junio de 1957, fecha en la que este Regimiento perdía la categoría de "acorazado", pasando a ser "Mixto de Infantería y Morteros". A partir de esa fecha, los panzer españoles cambiarían de Arma, pasando a Caballería, quien los mantuvo en servicio en tres de sus Regimientos: "Dragones de Santiago" no 1, "Dragones de Almansa" no 5 y "Dragones de Farnesio" no 12. Ocho años más tarde, en 1965, por lo menos 16 carros de este modelo fueron vendidos al Ejército de Siria, con el que combatieron en los Altos del Golán durante la llamada "Guerra de los Seis Días", en junio de 1967. Era el "canto del cisne" de un extraordinario material de guerra, fabricado por las industrias del extinto III Reich alemán un cuarto de siglo antes, con la esperanza de vida de no más de dos meses, pero que llegaron a sobrevivir casi un cuarto de siglo encuadrados en el ejército español. De los otros cuatro carros, tres quedaron en España adornando los acuartelamientos de las unidades carristas; el último, al parecer volvió a Alemania donado por el Estado Español para ser expuesto en uno de sus Museos. Corresponde al carro de combate con el chasis $\mathrm{n}^{\circ}$ 84.611. Fue restaurado en Alemania tras su cesión por el Estado Español, pasando a ser expuesto en el Wehrtechnische Studiensammlung de Koblenz. En la actualidad se cree que ha sido trasladado a Meppen o Trier. El ejército de Israel conserva, al menos un Panzer IV capturado a los sirios, en la Escuela del Cuerpo Acorazado de la Tsah Haganah LeIsrael, aunque no necesariamente debería ser de los procedentes de lo España, pues también Francia vendió Panzer IV a los sirios. Datos obtenidos en: Archivo General Militar de Madrid (AGMM). Historiales de las unidades de Infantería. Regimiento de Infantería no 63. Manrique García, José María; Molina Franco, Lucas. La Brunete. 60 años de historia, op. cit., pag 31. Mazarrasa Coll, Javier de, Blindados en España. $2^{a}$ parte, op. cit., págs. 48 y 50.
} 


\section{V.1.2.- Los cañones de asalto StuG IIIG}

Entre la variada gama de material militar enviado a España por el Reich alemán, en el cumplimiento del "Programa Bär", nos encontramos con un ingenio hasta ese momento desconocido en España: el denominado "cañón de asalto" Sturmgeschutz III. A simple vista podría parecer un verdadero carro de combate, pues disponía de orugas, barcaza y cañón, al igual que los carros. Pero sus diferencias eran evidentes para los militares.

La denominada "Artillería de Asalto" surgió en el seno de la Wehrmacht germana como un arma para el ataque, debido fundamentalmente a una necesidad creada en el propio campo de batalla.

Según las opiniones de algunos de los oficiales alemanes, profesores de la Escuela de Artillería de Asalto de Burg (Magdeburgo) ${ }^{430}$, las piezas de asalto se concibieron para apoyar a los carros de combate; es decir, para sustituir a la artillería de las unidades acorazadas ${ }^{431}$. Pero al mismo tiempo que se diseñaba la pieza de asalto, veia la luz el carro de combate modelo IV A (Panzerkampfwagen IV Ausf A) al que se armó con el mismo cañón de $75 \mathrm{~mm}$ modelo 39, por lo que el propio carro podía hacerse el mismo apoyo artillero que iba a hacerle la pieza de asalto, quedando ésta para misiones especiales que en general consistían en batir fortines a pequeñas distancias apoyando a los zapadores de asalto encargados de volar estas fortificaciones.

La primera vez que se empleó "Artillería de Asalto" en una operación militar fué en la ruptura de Sedan, donde una batería de cañones de asalto (Stug-III Ausf A Sdkfz 142) batió uno a uno todos los nidos de ametralladoras que los franceses habían organizado en la orilla sur del Mosa, facilitando de esta forma el paso del río por parte de las fuerzas de la 2a División Acorazada alemana. Estamos hablando de 1940 y entonces la Artillería de Asalto sólo disponía de cuatro baterías.

En Alemania, durante la $2^{\mathrm{a}}$ Guerra Mundial, las unidades de artillería de asalto, grupos, baterías o secciones, resolvieron de forma satisfactoria la crisis del

\footnotetext{
${ }^{430}$ Hasta el verano de 1943 la Escuela de Artillería de Juteberg tenía entre otras, una Sección de Artillería de Asalto. En esas fechas la Sección se independizó y se creó la denominada Escuela de Artillería de Asalto en Burg contando con un Grupo de Instrucción, con piezas de asalto del Regimiento de Instrucción $\mathrm{n}^{\mathrm{o}}$ 2. Datos obtenidos del informe de la Comisión Militar Española en la Escuela de Artillería de Asalto de Jüteberg. APEC.

${ }^{431}$ Opinión no compartida por el General Martinez Campos, Presidente de la Comisión de Compras en Alemania y Jefe de la Reserva General de Artillería, como veremos más adelante.
} 
acompañamiento inmediato a la Infantería, y permitieron que los carros de combate no se emplearan en este cometido. De la misma forma las piezas de asalto también tuvieron actuación en el seno del Arma Acorazada alemana, acompañando a Regimientos de carros con misiones anticarro, sustituyendo en algunas ocasiones al batallón de cazadores de carros e incluso al de carros "Tiger".

Como hemos visto en el epígrafe anterior, en las conversaciones de Berlín, la delegación alemana ofreció a los españoles un grupo mixto compuesto en total por 30 vehículos blindados de cadenas, incluyendo veinte carros Panzer IV mod. H (dos compañías) y diez cañones de asalto Stug III mod. G. (una batería). ${ }^{432}$

Poco después, el general Becker comunicaba a Martinez Campos que para entrenar a los españoles en el manejo de los nuevos cañones de asalto, habría de asistir una comisión a Alemania para la instrucción con las piezas, en la Escuela de Artillería de Jüteberg ${ }^{433}$.

La empresa que había de suministrar los cañones de asalto era la "Daimler-Benz A.G." de Stuttgart-Untertürkheim, y el modelo que enviarían era el Sturmgeschütz 40 Ausf G (Sd Kfz 142/1) $)^{434}$, denominado coloquialmente StuG III G, como ya indicamos anteriormente. En total se fabricaron en Alemania 7.720 StuG III $G$ desde diciembre de 1942 hasta marzo de 1945, y además otros 173 fueron transformados directamente de Panzer III Ausf M en 1944.

\footnotetext{
${ }^{432}$ Posteriormente, se ampliaría la cifra de carros de combate concedidos con otros dos de mando, aunque estos nunca llegaran a España. Documentación del General Martínez de Campos. AGMAV. Caja 24.711. Fondo del antiguo Ministerio del Ejército. Carpeta: Informes y documentación diversa sobre Alemania de los viajes del general Martínez Campos.

${ }^{433}$ Luego se cambiaría a Burg debido al traslado de la Sección de Artillería de Asalto a esta población.

${ }^{434}$ El vehículo sobre el que iba montada la pieza de asalto era el mismo que el carro de combate Panzer III-Ausf L, con la única diferencia de que carecía de torre giratoria. En el tercio delantero del vehículo, desplazado a la izquierda, iba situado el puesto de conducción, en el central la cámara de combate y en el trasero, el compartimento del motor. Éste era un Maybach HL 120 TRM de 300 Hp, 12 cilindros en V, 12 litros de cilindrada y 6.400 revoluciones por minuto. Estaba refrigerado por aceite. Los depósitos de gasolina tenían una capacidad de 300 litros lo que permitía un recorrido de 100 a $120 \mathrm{~km}$ por carretera o bien 80 campo a través. El peso del vehículo era de $22 \mathrm{Tm}$ y podía desarrollar una velocidad de $40 \mathrm{~km} / \mathrm{h}$ en carretera y $20 \mathrm{~km} / \mathrm{h}$ en todo terreno. El cañón, fabricado por "Rheinmetall-Borsig", era el mismo que montaba el carro Panzer IV Ausf H, de $75 \mathrm{~mm}$ y 48 calibres modelo 42. Iba instalado en el vehículo en posición muy baja y desplazada ligeramente a la derecha. El cierre era de cuña con movimiento vertical y funcionamiento semiautomático. Podía disparar varios tipos de munición, entre los que podemos destacar un modelo de granada rompedora de acero (Mod.34); dos modelos de granada perforante (Mod. 39 y Mod. 40); dos modelos de carga hueca (Mod. 38A y 38B) y un modelo de granada de niebla similar a la rompedora modelo 34.Los datos técnicos del vehículo están tomados de Mazarrasa Coll, Javier de, Blindados en España... op. cit., págs. 53-58.
} 
Siguiendo las normas dictadas por el Estado Mayor Alemán, el Ministerio del Ejército español designó una Comisión para el estudio in situ de la artillería de asalto alemana. Dicha Comisión estuvo formada por un comandante, dos capitanes, dos sargentos y otros dos maestros ajustadores, tal y como se indica en la tabla siguiente.

\section{TABLA V-C}

\section{COMISIÓN DE CAÑONES DE ASALTO EN ALEMANIA}

\begin{tabular}{|l|l|}
\hline Empleo & \multicolumn{1}{|c|}{ Nombre y apellidos } \\
\hline Comandante & Enrique Gasset de las Morenas \\
\hline Capitán & Luis Mataix Lorda \\
\hline Capitán & José Hernandez Ballesteros \\
\hline Sargento & Ramón Liste Cendal \\
\hline Sargento & Pedro Solis Barroso \\
\hline Maestro ajustador & José García Alvarez \\
\hline Maestro ajustador & Baldomero Santos Gutiez \\
\hline
\end{tabular}

Elaboración propia. Informe de la Comisión Militar Española en la Escuela de Artillería de Asalto de Jüteberg. Archivo del Polígono de Experiencias de Carabanchel

Una vez en Alemania, la Comisión se dividió en tres ponencias: una para el estudio de la organización y empleo táctico de la Artillería de Asalto, otra para la instrucción para el servicio de las piezas y otra para el estudio del material: pieza y vehículo.

Curiosamente, la llegada de los militares españoles a la Escuela de Artillería de Asalto coincidió con el traslado de la misma al pueblo de Burg, independizándose así de la Escuela de Artillería de Jüteberg, de la que dependía hasta ese momento.

La comisión española fué recibida a su llegada, el 1 de septiembre de 1943, por el director de la Escuela, teniente coronel Hoffmann-Schoenborn, caballero de la Cruz de Hierro con hojas de roble, quien además de su cargo en la citada Escuela, asumía el de Inspector de la Artillería de Asalto, ya que la propia Escuela además de la formación tenía la misión de organizar unidades de Artillería de Asalto listas para ser enviadas al Frente. El director del curso de los españoles, además de profesor de táctica, era el teniente movilizado Fuchs, cuya verdadera profesión era la de profesor de educación 
física en las Juventudes Hitlerianas. Y decimos esto pues es muy curioso el comentario que de él hizo el comandante Gasset ${ }^{435}$ :

“...Su interés y el trabajo desarrollado son dignos de encomio y es de justicia añadir que desempeñó su cometido sin que se notara diferencia alguna con relación a la actuación, por ejemplo, del comandante Haarberg, Jefe de Estudios, que aunque procede de la reserva, ha hecho la campaña de Grecia y gran parte de la de Rusia. ..."

La enseñanza en esta Escuela se limitó a la teoría indispensable, expuesta en clase a base de los reglamentos y cuadros, y la práctica a base de un gran número de ejercicios realizados con la Unidad de instrucción y en el gabinete de armamento y material.

La Unidad de Instrucción era el Grupo de Artillería de Asalto ${ }^{\circ}$ 191, al que pertenecían el teniente coronel Director y la mayoría de los profesores de la escuela, y que disponía de tres baterías en armas y dos baterías -no organizadas-, una con material diverso y otra de depósito.

Dos de las baterías en armas se alojaban en el campamento de Alten Grabow, donde se hallaba el campo de tiro y maniobras de la escuela, y la tercera en Burg.

Después de un mes en la Escuela de Artillería de Asalto de Burg, el 1 de octubre de 1943 la Comisión española se desplazó a Gross Born ${ }^{436}$ para seguir un curso informativo de 15 días de duración sobre los materiales de la Artillería acorazada alemana, en el que además de exposiciones de material y visitas a instalaciones, se desarrollaron ejercicios sobre el plano y sobre el terreno con diverso material.

A mediados del mes de noviembre de 1943 llegaba a la estación de Irún el tren número 14 del segundo cupo del Programa Bär ("Restprogramm”), compuesto por once vagones $^{437}$, que transportaban la partida $n^{\circ} 60$ : diez cañones de asalto Stug-III-G, todos sus accesorios y dos dotaciones de munición (excluidas las correspondientes al cañón).

\footnotetext{
${ }^{435}$ Todos estos datos están recogidos en la "Memoria sobre el estudio de la artillería de asalto y la artillería acorazada", desarrollada por la Comisión Militar en Alemania (1-9-1943 al 15-10-1943). Documento mecanografiado de 119 páginas. APEC.

${ }^{436}$ A causa de la orden de evacuación de Berlín, la Escuela de Artillería II de Juteberg se trasladó al campo de maniobras de Gross Born, en Pomerania, a 290 km de Berlín.

437 Diez de ellos eran especiales FFM, porta-carros de combate, y el otro, un furgón modelo "G".
} 
La firma alemana "Schenker G.m.b.H" hacía entrega de la mercancía al representante del Ejército de Tierra en la Comisión receptora de material, quien dirigió las operaciones de descarga del tren alemán y carga en el español, y reexpidió la mercancía con destino a la estación de Cuatro Vientos (Madrid).

A su llegada a Cuatro Vientos, el Sevicio Militar de Ferrocarriles se encargó del desembarque de las piezas, las cuales, una vez en tierra, se entregaron a los representantes de la Escuela de Aplicación y Tiro de Artillería, quienes firmaron el correspondiente acta de recepción. Como no se disponía de camiones capaces de transportar los vehículos hasta Campamento, éstos realizaron el recorrido por sus propios medios bajo la atenta mirada de mecánicos y especialistas en carros de combate, llegando a su nuevo alojamiento, el patio del Regimiento de Artillería a Caballo no 36.

El contrato de adquisición de estas piezas $^{438}$, rubricado en Berlín en representación del Ministerio del Ejército español por el Agregado, se estipulaba que el material a enviar a España lo componían:

“... diez cañones de asalto $7,5 \mathrm{~cm}$ modelo $\mathrm{G}$ con 7,5 stuka $40 \mathrm{~L}$ 48 completo con accesorios (según anexo 1) con carruaje y superestructura, instalación eléctrica, cada carro con una ametralladora MG 34 en la cubierta, la ametralladora con una caja de repuestos (según anexo 2), dos pistolas ametralladoras MP 40 con accesorios (según anexo 3), dos cajas de herramientas y accesorios 8 según anexo 4), anteojo de puntería y anteojo de antenas, incluso fundas. Además cuatro cañones de asalto (carruaje $n^{\circ}$ 95.797, 93.214, 95.774 y 93.263) con radio $\mathrm{Fu} 5$ y $\mathrm{Fu} 2$ así como un juego de accesorios de radio (según anexo 5), los demás 6 vehículos solo con radio $\mathrm{Fu}-5$ y un juego de accesorios de radio (según anexo 6), así como herramientas de fortificación y caja de curas de urgencia con contenido (según anexo 7). (...)

Además "Daimler Benz" entregará dos ejemplares de impresos, planos folletos y descripciones redactados en alemán...”.

En el momento de la firma del contrato, el material ya había sido entregado al Ejército español.

Los diez cañones de asalto, aunque provenían de los parques de la Wehrmacht eran nuevos, estaban en perfecto estado de servicio y eran del modelo Ausf $G$, con la

\footnotetext{
${ }^{438}$ Contrato de adquisición de diez cañones de asalto Sturmgeschutz III Ausf G. AGMAV. Caja 24.712. Fondo del antiguo Ministerio del Ejército.
} 
única diferencia de que cuatro de ellos estaban dotados de dos aparatos de radio -el Fu5 y el Fu2- y los otros seis llevaban solamente uno -el Fu5- ${ }^{439}$.

\section{TABLA V-D}

\section{STUG III Ausf G y su dotación de equipos de radio Fu 5 y Fu 2}

\begin{tabular}{|l|c|c|c|c|c|c|c|c|c|c|}
\hline StuG III G & 2 radio & 2 radio & 2 radio & 2 radio & 1 radio & 1 radio & 1 radio & 1 radio & 1 radio & 1 radio \\
\hline Werk nr. & 93.214 & 93.263 & 95.767 & 95.774 & 93.205 & 93.211 & 93.225 & 93.227 & 93.241 & 95.783 \\
\hline
\end{tabular}

Elaboración propia. Protocolo de entrega de los cañones de asalto. AGMAV. Caja 24.705.

Para estas piezas de asalto se contrató el suministro de dos dotaciones completas de munición, tanto para el cañón como para las ametralladoras ${ }^{440}$. Toda esta munición componía la partida $\mathrm{n}^{\circ} 62$ del $2^{\circ}$ lote del "Programa Bär" y llegó a mediados de marzo de 1944 en los trenes $n^{\circ} 19$ y 21, a excepción de parte de la de las ametralladoras, que no se llegó a recibir. También llegaron 20 pistolas ametralladoras MP 40 y 10 pistolas de señales junto a su munición 20.000 cartuchos ordinarios, 380 trazadores, 200 de señales verdes y 200 rojos. La munición correspondiente a estas armas hubo que pagarla aparte pues no entraba en el precio de los $\mathrm{StuG}^{441}$.

De acuerdo con los precios fijados en las conversaciones económicas del “Programa Bär", desarrolladas en Madrid en la primavera de 1943, cada cañón de asalto con todos los accesorios costó al Ministerio del Ejército español, 240.000 marcos. Por el transporte de los diez hasta España, la casa "Schenker” cobró 74.175 marcos.

Una vez en España los $S t u G I I I$, se decidió organizar una batería experimental en el seno de la Escuela de Aplicación y Tiro de Artillería (EATA), aunque mientras no se habilitaran créditos y aumentara la plantilla nada se hizo con ellas. La desesperación del general Martínez de Campos al ver las piezas "tiradas" se hacía patente en una carta dirigida al general García Valiño, Jefe del EMCE, en la que el primero ponía de manifiesto su disgusto al ver:

\footnotetext{
439 “OKW a la Comisión Extraordinaria. Num. 5744/43. Berlín, 23 de julio 1943. Asunto: Suministro de Carros de Combate”. AGMAV Caja. 24.705. Fondo del antiguo Ministerio del Ejército.

440 Se trataba de 1.600 granadas modelo 34 (rompedoras), 2.500 granadas modelo 39 (perforantes), 31.920 cartuchos perforantes para ametralladora y 31.920 cartuchos trazadores para ametralladora.

${ }^{441}$ El importe de la citada munición ascendió a 42.824 marcos.
} 
“... las famosas piezas acorazadas que vinieron del extranjero, en medio del patio del Regimiento a caballo, sin que nadie se ponga en plan de utilizarlas..." 442 .

Para mandar la batería fue destinado el capitán Hernández Ballesteros y poco después, al ascender éste, tomó el mando el capitán Maestre Salinas, de la sección de campaña de la propia EATA, aunque antes de un año, en junio de 1945, le entregó el mando al capitán Lorenzo Uriarte Rubio, quién lo desempeñaría hasta 1950, año en el que éste oficial fue destinado a la Escuela de Geodesia y Topografía.

El último jefe de la batería, hasta que ésta se dio de baja en 1954, fue el teniente Cándido Estaún González ${ }^{443}$.

En el Diario Oficial (D.O.) n ${ }^{\circ} 145$ de 29 de junio de 1944 se publicaban vacantes para subalternos en la "Unidad Especial de Instrucción de la EATA" y un mes después, el 4 de agosto, salían destinados con fecha 29 de julio y con carácter voluntario varios tenientes procedentes de la Academia de Transformación. La batería se organizó de la siguiente manera: una pieza de mando y tres secciones de tres piezas cada una. Además se asignaron diez motos BMW con sidecar, procedentes también de material llegado en el marco del mismo programa, y dos algibes, además de varios camiones y algún coche.

Los StuG III llegaron pintados en color arena medio (mittlegelb), cubiertos de pasta antimagnética (Zimmerit) con la que experimentaron los zapadores con minas magnéticas, demostrando que era eficaz. Con el paso del tiempo y los golpes, el zimmerit se iba cayendo y al cabo de algunos años, el capitán Uriarte ordenó quitarlo. También traían los faldones para cargas huecas (schürzen) montados sobre unos railes soldados a los laterales de la estructura, pero como en España no se sabía muy bién para que servían, nunca se les llegaron a montar.

Los vehículos fueron numerados del 1 al 10, portando cada uno de ellos el numeral correspondiente en ambos laterales de la casamata, así como también en el centro de la chapa trasera del motor. Estos números iban pintados en rojo con el borde blanco. Los integrantes de la Batería Experimental llevaban un uniforme muy similar al

\footnotetext{
${ }^{442}$ Carta del General Martínez Campos dirigida al general García Valiño. AGMAV. Caja 24.711. Fondo del antiguo Ministerio del Ejército.

${ }^{443}$ Todos estos datos y los que se explican a continuación fueron facilitados por el coronel de Infantería D. Luis Moya Pimentel quien se entrevistó en los años noventa del pasado siglo con uno de los que en su día fueron tenientes de la Batería experimental, el ya coronel retirado D. Fernando de Haza Cañete.
} 
de carros de combate, azul con boina negra y correaje completo de cuero negro con la hebilla metálica y un emblema ovalado de la unidad a la izquierda del pecho.

La unidad tenía su sede en la calle Zurbano $\mathrm{n}^{\circ} 21$ de Madrid, aunque las piezas estaban -de manera provisional- en los hangares de la $3^{\text {a }}$ Compañía del I Batallón del Regimiento de Carros de Combate "Alcazar de Toledo", en Campamento y la tropa en el cuartel del Regimiento de Artillería Antiaérea $n^{\circ} 71$.

La batería experimental realizó continuamente ejercicios y demostraciones a los numerosos visitantes de la EATA, así como también participó en varios "Desfiles de la Victoria" por el Paseo de la Castellana de Madrid. A finales de los cuarenta alguna de las piezas sirvió de "conejillo de indias" para experimentar proyectos españoles de piezas autopropulsadas, aunque dichos proyectos nunca se llegaron a materializar ${ }^{444}$.

Con la llegada masiva de material de ayuda americana, las piezas de asalto

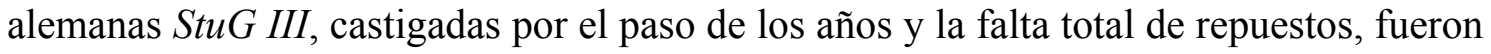
dadas de baja y la unidad que las encuadraba fue disuelta. Algunas quedaron como ornamentación en varios acuartelamientos españoles ${ }^{445}$.

\section{V.2.- MATERIAL AUTOMÓVIL. MOTOCICLETAS}

Aunque tímidamente, fue en la Primera Guerra Mundial cuando se dió por primera vez el empleo militar de las motocicletas. Italia, Gran Bretaña y Estados Unidos de Norteamérica, además de otros países como Bélgica, Alemania o Francia, fueron pioneros en el empleo de estas máquinas en misiones de guerra en los frentes de batalla. De esta guerra se extrajeron lecciones prácticas muy importantes, llegando al acuerdo generalizado de que eran un medio idóneo para determinadas competencias y que debían impulsarse, desarrollando nuevas máquinas específicamente militares.

Por desgracia, tendría que ser la Guerra Civil española la que pusiera a nuestro país a nivel de nuestros vecinos en ésta, así como en otras muchas materias.

\footnotetext{
${ }^{444}$ Por lo menos sobre una de ellas se llegó a montar un obús de 105/26 mm R-43 modelo Reinosa. Mazarrasa Coll, Javier de, Blindados en España... op. cit., págs. 130-132.

${ }^{445}$ Hoy día se conservan en bastante buen estado por lo menos tres de ellas, una totalmente restaurada y en funcionamiento en el Museo Militar de Cartagena, otra en el Museo de Medios Pesados de la Base Militar de El Goloso (Madrid) y la tercera, en el jardín del Centro de Mantenimiento de Sistemas Acorazados de Segovia, estas dos últimas al aire libre.
} 
En el caso que nos ocupa, no será hasta la llegada del contingente alemán denominado "Legión Cóndor", cuando se comience a generalizar el uso de las motocicletas en el bando nacional.

La "Legión Cóndor" recibiría a lo largo de toda la guerra un total de ciento cuarenta y ocho motocicletas, de las que setenta y seis fueron para el contingente aéreo y setenta y dos para el terrestre (Grupo Imker) ${ }^{446}$. De la misma manera, a través de la sociedad "HISMA Ltda", el Ejército sublevado dispuso de motocicletas de origen alemán BMW de varios modelos, llegando a importar cerca de 175 unidades ${ }^{447}$.

Todas las correspondientes a la aviación estaban dotadas de side-car, y fueron empleadas en misiones de enlace. Aunque hubo algún otro modelo (DKW, Zündapp), destacaron, tanto por la calidad como por su elevado número, las BMW R-12, de 20 HP y $750 \mathrm{cc}$.

Al igual que ocurrió con las motos utilizadas por el contingente aéreo, la mayoría de las supervivientes que todavía utilizaba el Grupo “Imker” quedaron en poder de las unidades del Ejército español a partir del 1 de mayo, y así se las vería, no sólo en el Desfile de la Victoria de 1939, sino en los desfiles de los años sucesivos.

\section{V.1.1.- La motorización de la postguerra.}

Finalizada la contienda civil en España, el ejército vencedor, que se había nutrido sobre todo de material alemán e italiano, acometió la desmovilización de tan ingente número de personal que formaba en sus filas. Los materiales supervivientes, los capturados a los vencidos, y los que dejaron en España los contingentes extranjeros cuando partieron a sus países de origen, conformaron un impresionante elenco nunca antes visto en nuestro país.

La verdadera motorización del Ejército español, cuyos tímidos comienzos habían sido en las campañas de Marruecos, llegaba, desgraciadamente, después de una larga y terrible contienda civil, y como siempre, con materiales foráneos y a imagen y semejanza de los países de nuestro entorno.

\footnotetext{
446 Molina Franco, Lucas y Manrique García, José María, Legión Cóndor. La historia olvidada. Valladolid, Quirón Ediciones, 2000, págs. 57 y 74

${ }^{447}$ De los modelos R 4, R 5, R 6, R 12 y R 35. Mata Duaso, Josep, Atlas ilustrado de motores en guerra. Guerra Civil española, Susaeta Ediciones, Madrid, 2011, págs. 65 y 66.
} 
En cualquier caso, el inicio de la Segunda Guerra Mundial el 1 de septiembre de 1939, -sólo cinco meses más tarde del final de la Guerra Civil española- dio al traste con las expectativas de reducción del Ejército y dejó obsoleto, en pocos meses, todo el material militar español que, por si fuera poco, llevaba a sus espaldas una larga y dura campaña. Enseguida comenzó la búsqueda de nuevos materiales aunque, obviamente, en los mismos mercados, únicos en esos momentos: se reanudaron los contactos (realmente, nunca se habían interrumpido después de la guerra civil) con las empresas alemanas e italianas fabricantes de armamento.

Las necesidades españolas en lo que se refiere a material motociclista, fueron claramente determinadas en las evaluaciones previas a las reuniones formales de los negociadores hispano-alemanes. Deberían conseguirse al menos 750 motos pesadas con side-car, nuevas o usadas, y otras 400 de menor cilindrada sin el carro lateral. Y así se hizo constar en los documentos que llevó a Berlín el presidente de la Comisión negociadora española, general Martínez de Campos, el 15 de marzo de $1943^{448}$.

En la relación $\mathrm{n}^{\mathrm{o}} 14$ del documento presentado a los alemanes por la delegación española, figuraba una partida de "Motocicletas para los Regimientos de Caballería, División de Caballería, Grupo de Exploración y División Acorazada”. En dicha relación se hacía constar una detallada explicación de lo que querían los españoles. En lo referente a las motos de mediana cilindrada, se requería una moto sin carro, dotada de una gran autonomía y un dispositivo para montar un arma automática ligera, o lo que es lomismo, un fusil ametrallador, del que se solicitaba, además, uno por motocicleta. Las motos pesadas debían disponer de carro lateral, también denominado side-car, y de un dispositivo para montar una ametralladora MG 34 de 7,92 mm, arma de la que se necesitaba, al igual que en las motos medianas, una por motocicleta. De la misma manera, en el documento se dejaba constancia de la necesidad española de todo tipo de accesorios y piezas de recambio para las motocicletas y para sus motores.

Los alemanes estudiaron la petición española y asintieron en conceder todo el material motociclista solicitado en el "Programa Bär", lo cual resultó del agrado de los miembros de la comisión, sobre todo de su presidente, el general Martínez de Campos, quien, únicamente, puso un "pero" a la oferta alemana: Los fusiles ametralladores y las

\footnotetext{
448 Documentación del general Martínez de Campos. AGMAV. Caja 24.711. Fondo del antiguo Ministerio del Ejército. Carpeta: Informes y documentación diversa sobre Alemania de los viajes del general Martínez Campos.
} 
ametralladoras se aceptarían siempre que pudieran utilizar la munición española de 7,92 y que los técnicos germanos dieran resuelto el problema de montaje de las armas sobre las motocicletas.

Este asunto dio origen al cruce de varias cartas entre los negociadores y a la emisión de varios informes del OKW, que exponían la filosofía alemana del empleo de las motocicletas medianas y de las pesadas con carro lateral. En las normas de empleo germanas, cada dos motocicletas medianas tenían de dotación un fusil ametrallador, pero en Alemania éste no iba montado sobre la motocicleta sino que se transportaba en la misma, pudiendo utilizarlo cuando la moto paraba y el sirviente lo ponía en servicio $^{449}$. Por lo que se refiere a las motos pesadas, había varias modalidades de empleo, aunque los alemanes consideraban como las más eficientes, o bien una ametralladora mediana por cada pareja de motos, o bien una por cada trío.

La comisión alemana, como hemos indicado, estuvo de acuerdo en la entrega de las cantidades solicitadas por los españoles, ofreciendo, en principio, las 1.150 motocicletas usadas, o como hoy se diría, "de segunda mano", distribuidas tal y como se cursó la solicitud: 400 medianas sin el carro lateral y el resto pesadas con carro lateral. Sólo restaba verlas... y recibirlas.

Los españoles, tomando como base los informes del OKW, rectificaron su pedido inicial de 400 fusiles ametralladores y 750 ametralladoras del modelo MG $34^{450}$, reduciéndolo, únicamente, a 375 de estas últimas; o lo que es lo mismo, se rehusaba a montar fusiles ametralladores en las motocicletas medianas y se reducían a la mitad las ametralladoras MG 34; se aceptaban los consejos de los alemanes y se adquiría una máquina por cada pareja de motocicletas con carro lateral adquiridas.

\section{V.2.2.- Las motos medianas.}

En la reunión celebrada en Berlín el 29 de abril de 1943, entre las subcomisiones del Ejército de tierra español y alemán, presidida la primera por el Agregado Militar en Berlín, teniente coronel del arma de Ingenieros Carlos Marín de Bernardo, y la segunda por el Oberst (coronel) Beutler, se aconsejó, a la vista de los listados alemanes de

\footnotetext{
${ }^{449}$ En una de las motocicletas medianas se llevaba el fusil ametrallador y en la otra, la munición para el mismo.

${ }^{450}$ Fue la ametralladora media y pesada más importante de las empleadas por la Wehrmacht en la Segunda Guerra Mundial y constituyó el arma principal y/o secundaria de numerosos vehículos de combate y transporte germanos en el conflicto.
} 
entrega, la eliminación de una partida compuesta por 103 motos de distintas marcas y $\operatorname{modelos}^{451}$. Era una cuestión logística: España no quería hacerse cargo de una partida tan dispar en cuanto a modelos y cilindradas. A la vista de la Tabla XXVIII, podemos observar que se trataba, nada menos, que de ocho marcas y catorce modelos diferentes.

\section{TABLA V-E}

\section{MOTOS MEDIANAS OFRECIDAS A ESPAÑA POR EL OKW ${ }^{452}$}

\begin{tabular}{|l|l|l|}
\hline MARCA & CILINDRADA & TOTAL \\
\hline BMW & $350 \mathrm{cc}$ & 9 \\
\hline BMW & $500 \mathrm{cc}$ & 34 \\
\hline DKW & $350 \mathrm{cc}$ & 78 \\
\hline DKW & $500 \mathrm{cc}$ & 64 \\
\hline NSU & $350 \mathrm{cc}$ & 44 \\
\hline NSU & $500 \mathrm{cc}$ & 40 \\
\hline PUCH & $350 \mathrm{cc}$ & 63 \\
\hline PUCH & $500 \mathrm{cc}$ & 8 \\
\hline HOREX & $350 \mathrm{cc}$ & 9 \\
\hline HOREX & $500 \mathrm{cc}$ & 1 \\
\hline ZUNDAPP & $350 \mathrm{cc}$ & 13 \\
\hline ZUNDAPP & $500 \mathrm{cc}$ & 16 \\
\hline VIKTORIA & $350 \mathrm{cc}$ & 8 \\
\hline TRIUMPH & $350 \mathrm{cc}$ & 13 \\
\hline TOTAL & & $\mathbf{4 0 0}$ \\
\hline
\end{tabular}

Elaboración propia. AGMAV Caja 24.711. (En tipografia roja, las rechazadas por la Comisión)

Entre los días 5 y 7 de mayo de 1943, el teniente coronel Moyano Araiztegui ${ }^{453}$ y el comandante Guiloche, miembros a su vez de la subcomisión, visitaron los Parques

451 Documentación del general Martínez de Campos. AGMAV, Caja 24.711. Fondo del antiguo Ministerio del Ejército. Carpeta: Informes y documentación diversa sobre Alemania de los viajes del general Martínez Campos.

${ }^{452}$ Las motocicletas rechazadas por la subcomisión española van marcadas en rojo. Se trataba de todas las Horex, Viktoria, Triumph, Zündapp y BMW. En total 103 motocicletas.

${ }^{453}$ Ignacio Moyano Araiztegui era comandante de Artillería y ejercía como adjunto de la Agregaduría Militar en Berlín. Era Caballero Laureado de San Fernando por su actuación y comportamiento durante el bombardeo de la isla de Alhucemas, el 20 de agosto de 1925, al mando de dos baterías, en la campaña de Marruecos. Había obtenido el diploma de aptitud para el Servicio de Estado Mayor y formó parte de la División Azul en el momento de su constitución, como responsable del armamento entregado por Alemania para la organización de la citada unidad expedicionaria española. En noviembre de 1941 fue destinado a Berlín como Agregado Militar Adjunto en la Embajada de España. Desempeñó este cometido hasta mayo de 1944, que volvió a España y se incorporó a su nuevo destino. Alcanzaría el empleo de general de brigada en 1955, retirándose del ejército con el de general de división. Hoja de Servicios del citado oficial. AGMS. 
alemanes de Tropas Motorizadas en Viena y Linz, donde había preparadas dos partidas de 337 y 63 motocicletas, respectivamente, para su entrega a los españoles ${ }^{454}$. Todas ellas estaban recién reparadas, con un recorrido máximo de $25.000 \mathrm{~km}$, bien presentadas y pintadas de color beige. Disponían de bolsas laterales, herramientas, faro, cuentakilómetros, claxon y, en su mayor parte, neumáticos nuevos o, en algunos casos, usados con poco recorrido. Desgraciadamente, no disponían de repuestos de ninguna clase, los cuales sería preciso solicitar al OKW.

Cuatro días más tarde, el 11 de mayo, Martínez de Campos se reunía con su homónimo Becker, tratando, entre otros, el asunto de las motos y llegando al acuerdo de reducir el número de marcas a tres (DKW, Püch y NSU), con la consiguiente rebaja del número de máquinas a 297. El general español insistió ante Becker de que se completara la entrega, intentando que se mantuvieran las 400 solicitadas, aunque si esto era a costa de incrementar el número de marcas, bastarían con las 297 aceptadas. Además insistió para que el OKW tuviera en consideración la solicitud española del suministro de repuestos para todas máquinas ${ }^{455}$.

El 6 de junio, el Agregado Militar en Berlín dirigía una misiva al general Martínez de Campos, en la que le comunicaba que el OKW había aceptado completar las 400 motos medianas con otras 103 DKW de los tipos admitidos. Quedaba, pues, zanjado el asunto, y los intereses españoles no se verían menoscabados.

En el tren $n^{\circ} 6$ del "Sofortprogramm”, llegaban a la estacion de Canfranc el 13 de junio de 1943, doscientas noventa y siete motocicletas de las marcas y cilindradas antes $_{\text {citadas }}^{456}$-que formaban parte de la denominada Partida $\mathrm{n}^{\mathrm{o}} 27-$, las cuales pasarían inmediatamente a la Base de Parque y Talleres de Automovilismo, sita en Torrejón de Ardoz, quedando allí depositadas según consta en el Acta de la citada unidad militar de 8 de julio del mismo año.

El día 20 de julio llegaban a la misma estación, incluidas en el tren $\mathrm{n}^{\mathrm{o}} 11$ (el último del "Sofortprogramm”), las ciento tres motocicletas medianas restantes, todas

\footnotetext{
${ }^{454}$ España. Comisión extraordinaria para el material de guerra. Asunto: Visita a los parques de tropas motorizadas en Viena y Linz por los comandantes Moyano y Guiloche del 5 al 7 de mayo de 1943. AGMAV, Caja 24.711. Fondo del antiguo Ministerio del Ejército.

455 Documentación del general Martínez de Campos. Carpeta: Informes y documentación diversa sobre Alemania de los viajes del general Martínez Campos. AGMAV, Caja 24.711. Fondo del antiguo Ministerio del Ejército.

${ }^{456}$ El desglose de las 297 motocicletas, por marcas, era el siguiente: 142 motocicletas DKW (mod. SB350, SB-500 y NZ-350); 84 NSU (mod. 351 OSL y 501 OSL); y 71 Püch (mod 350 GS y 500).
} 
ellas de la casa DKW en los distintos modelos aceptados con anterioridad. Junto a ellas, llegaron las piezas de repuesto solicitadas por Martínez de Campos para todas las motocicletas de esta categoría. Al igual que las recibidas con anterioridad, se almacenaron en Torrejón de Ardoz y con su recepción finalizaba la entrega de todas las máquinas de esta partida.

El precio de estas motocicletas, estipulado en las reuniones que tuvieron lugar en Madrid fue, por término medio, de 1.484,6 marcos por unidad; sumando el importe de todas ellas 593.840 marcos.

\section{VB.3.- Motocicletas pesadas: Las BMW R-75}

La aceptación inicial por parte española de las 750 motocicletas usadas BMW R75 con side-car, se vio recompensada al asumir Alemania el envío de estas magníficas motocicletas completamente nuevas ${ }^{457}$.

Tras las correspondientes negociaciones, el 27 de mayo el general Martínez de Campos conseguía que las "motos pesadas con carro lateral” BMW R-75 se entregaran

\footnotetext{
${ }^{457}$ La BMW R-75 era un producto típicamente alemán. Fue diseñada por el ingeniero Rudolf Schleicher, quien abandonó la idea del chasis de chapa estampada, utilizado en el modelo R-12, para utilizar un chasis tubular de ocho piezas atornilladas, muy fácil de mantener y reparar. Con Schleicher colaboraron estrechamente en la realización del proyecto, los ingenieros Boning y Alex von Falkenhausen. De la BMW R-75 se llegaron a construir entre 1941 y 1945, aproximadamente, 16.500 ejemplares que se repartieron por todos los frentes de batalla, desde las gélidas estepas rusas hasta las sofocantes arenas del desierto norteafricano.
}

El motor estaba fabricado en aleación de aluminio, excepto los cilindros que eran de hierro fundido, con una capacidad 745,4 cc. y una relación de compresión de 5,6:1, rindiendo una potencia de $26 \mathrm{CV}$ a 4.400 $\mathrm{rpm}$. La alimentación se realizaba a través de dos carburadores Graetzin de doble cable, accionados desde el puño del acelerador Magura. El filtro de aire, muy llamativo, estaba situado sobre el depósito de gasolina, protegido por una especie de capacete.

La caja de cambios era de cuatro relaciones hacia delante y se accionaba desde el pedal izquierdo o desde la palanca del lado derecho del depósito; contaba, así mismo, con marcha atrás, que se accionaba con la misma palanca. La transmisión se realizaba por cardán a la rueda trasera, y mediante un grupo cónico y el correspondiente diferencial, a la rueda del side-car, lo que posibilitaba a la moto el paso por casi todos los obstáculos. El bastidor era de doble cuna, desmontable para poder sacar el motor y el cambio por debajo, aunque con rigidez suficiente para soportar los $420 \mathrm{~kg}$. de peso del conjunto. Por lo que respecta al carro lateral modelo BW-40, diremos que estaba compuesto por un robusto chasis y una no menos potente estructura de la casa Steib. Dentro, un cómodo asiento y un enrejado de madera en el suelo para servir de aislante. En la parte delantera, sobre el capó del side, iba el anclaje de la ametralladora y los soportes para las maletas. En la zona posterior, detrás del asiento, se hallaba un espacioso maletero donde se guardaban las cajas de munición, las herramientas y los elementos de limpieza de la ametralladora, además de los depósitos complementarios de gasolina.

Todos los datos técnicos y de desarrollo de esta motocicleta están tomados de Hommes, Hans Peter, Das Wehrmachtsgespann BMW R 75. Dokumente, Zeichnungen und Fotos, edición del autor, D-41363 Jüchen (Alemania) 1999. También se ha consultado el folleto descriptivo denominado "Carnet del instructor. Motocicleta pesada B.M.W. de $750 \mathrm{cm3}$, con carro lateral tipo R.75. Descripción del vehículo e instrucciones para su manejo". Editorial Gran Capitán, Madrid sin fecha. 
recién salidas de fábrica. Se llegó al acuerdo de que en la primera fase del "Programa Bär", se enviarían un centenar de máquinas. Las 650 restantes, llegarían en sucesivas partidas en la segunda fase de dicho programa.

El día 20 de junio de 1943 llegaba a la estación de Canfranc el tren $n^{\circ} 8$ del "Sofortprogramm", compuesto por 17 vagones $^{458}$ que contenían 100 motocicletas BMW R-75 correspondientes a la partida $\mathrm{n}^{\circ} 28$. Fueron recibidas por las autoridades militares allí desplazadas, y una vez descargadas se remitieron a Madrid con destino al Parque de Automovilismo de Torrejón de Ardoz.

Conocemos la distribución por unidades que se dió a estas primeras $100 \mathrm{BMW}$ R-75 recibidas en España, y es la mostrada en las tablas siguientes:

\section{TABLA V-F}

\section{REPARTO DE MOTOS BMW R-75 POR REGIONES MILITARES}

\begin{tabular}{|l|l|}
\hline UNIDADES & CANTIDAD \\
\hline $2^{\text {a }}$ Región Militar & 8 motos \\
\hline $3^{\text {a }}$ Región Militar & 8 motos \\
\hline $4^{\text {a }}$ Región Militar & 8 motos \\
\hline $6^{\text {a }}$ Región Militar & 1 moto \\
\hline $7^{\text {a }}$ Región Militar & 5 motos \\
\hline $8^{\text {a }}$ Región Militar & 6 motos \\
\hline Total & $\mathbf{3 6}$ motos \\
\hline
\end{tabular}

Elaboración propia. AGMAV. Caja 24.711

\section{TABLA V-G}

\section{REPARTO DE MOTOS BMW R-75 EN LA DIVISIÓN DE CABALLERÍA}

\begin{tabular}{|l|l|}
\hline DIVISIÓN DE CABALLERÍA & CANTIDAD \\
\hline Cuartel General de la División & 2 motos \\
\hline Regimientos 3 y 5 & 44 motos \\
\hline C. G Brigada Mecanizada & 5 motos \\
\hline Regimientos de Sables & 3 motos \\
\hline Regimiento de Artillería n ${ }^{\mathbf{0}} 36$ & 10 motos \\
\hline Total & $\mathbf{6 4}$ motos \\
\hline Elaboración propia. AGMAV. Caja 24.711
\end{tabular}

${ }^{458}$ Ver Anexo XIII B. 
Las restantes 650 motocicletas BMW R-75 llegarían en la segunda fase del "Programa Bär". La primera expedición de esta segunda fase llegó a Port Bou el día 2 de octubre de 1943. Estaba formada por cien motos que venían, junto a otros materiales, en el tren $n^{\circ} 3$. La segunda llegó a Canfranc el 14 de octubre y venía en el tren $n^{\circ} 6$. En ésta se recibieron 150 motos BMW con carro lateral. Las cuatrocientas motos restantes llegaron por partes iguales en los trenes numerados como 9 y 12, o sea, doscientas en cada uno de ellos. El tren n 9 llegó a Canfranc el 22 de octubre, y el $n^{0} 12$, a la misma estación, el 8 de noviembre ${ }^{459}$.

En junio de 1943, mientras se recibía el armamento del "Sofortprogramm", y para hablar del asunto de los precios, se reunieron en Madrid las subcomisiones de técnicos militares hispano-germanos. En la reunión del día 25 se trató el precio de las motocicletas BMW R-75, exigiendo los alemanes 6.000 marcos por unidad. La delegación española lo consideró excesivo y contestó a los teutones con una contraoferta: 2.230 marcos cada motocicleta completa. Como en casi todas las partidas negociadas, se impuso el criterio español, llegando al acuerdo de que las cien primeras motos que se estaban entregando en el "Sofortprogramm" se cobrarían, exactamente, a ese valor; a 2.230 marcos. El resto, las 650 motos del "Restprogramm", se pagarían a 2.650 marcos por moto. El precio medio unitario sería, entonces, 2.594 marcos. Para cobrar estas motos, la "BMW AG" de Munich emitió cuatro facturas, utilizando para todas ellas el precio medio por moto.

En esas negociaciones también se fijó el precio de las 375 ametralladoras medianas de 7,92 mm. MG 34, adquiridas por España, y aunque los alemanes solicitaron 6.520 marcos por arma, se llegó al acuerdo de pagar 2.380 marcos por cada ametralladora con su dispositivo de fijación a la moto. Fueron suministradas por la casa "Rheinmetall Borsig AG” y llegaron en cuatro lotes de 200, 50, 50 y 75 ametralladoras, en los trenes $n^{\circ} 15,19,20$ y 21 , respectivamente ${ }^{460}$.

Las motos BMW estuvieron en servicio hasta finales de los años sesenta del pasado siglo XX, momento en el que se fueron dando de baja, subastándose muchas de ellas, siendo adquiridas por empresas y particulares. Por ello, todavía hoy perviven algunas en manos de coleccionistas privados en perfecto estado de conservación.

\footnotetext{
${ }^{459}$ Ver Anexo XIV B.

${ }^{460}$ Por problemas de última hora, el segundo lote de 100 unidades hubo que dividirlo y enviar cincuenta en el tren $n^{\circ} 19$ y otras cincuenta en el tren $n^{\circ} 20$.
} 


\section{V.3.- MATERIAL DE ARTILLERÍA DE CAMPAÑA. LA ARTILLERÍA "SOVIÉTICA" DEL "PROGRAMA BÄR"}

A finales de los años veinte del pasado siglo, la URSS acometió un ambicioso plan de modernización de sus materiales artilleros que, por esas fechas, no eran sino modelos procedentes de la Primera Guerra Mundial o de su propia guerra civil, contienda esta última cuya prolongación había retrasado precisamente el comienzo de tal modernización.

Los mejores de entre los materiales anticuados en servicio fueron reacondicionados y actualizados recibiendo, en buen número de casos, nuevos tubos de mayor longitud que los originales, dentro del criterio soviético de disponer de piezas con el máximo alcance posible. No es extraño, por tanto, que los cañones de nuevo diseño que habrían de constituir el nervio de la nueva artillería soviética, se caracterizaran por disponer de un tubo de gran longitud que les proporcionaba un alcance considerable. Este fue el caso de una de las piezas de campaña más importantes del plan de modernización: el cañón de $122 \mathrm{~mm}$ Mod. $1931^{461}$, que fue proyectado con un tubo de 46 calibres de longitud con el que se obtenía un alcance máximo de casi 21 kilómetros. Esta característica, unida a la tradicional calidad de las piezas soviéticas, producto de los excelentes materiales empleados en su fabricación, ha logrado que la vida en servicio de tal cañón se prolongara hasta finales del siglo XX.

Si analizamos las peticiones españolas, llevadas a Berlín el 15 de marzo de 1943 por el General de División Carlos Martínez de Campos, Presidente de la Comisión negociadora española en Berlín ${ }^{462}$, nos encontramos que las necesidades españolas

\footnotetext{
${ }^{461}$ La pieza del modelo 1931/37 -390/2 (r) - se componía de un tubo de ánima de 5,650 metros de longitud (46,34 calibres), recubierto por un manguito de refuerzo. El ánima estaba surcada por 44 rayas de paso constante a una vuelta en 25 calibres y en sentido dextrorsum. El cierre era de tornillo cilíndrico, con dos sectores lisos y dos roscados, y la obturación se efectuaba mediante vaina metálica. Iba montado sobre una cureña bimástil con ruedas metálicas recubiertas por bandas de goma maciza que posibilitaban su arrastre mecánico. Para el mismo se retrasaba el largo tubo a la posición de camino y se apoyaban los extremos de los mástiles, unidos, sobre un carrillo que hacía las veces de avantrén. Como quiera que presentaba los muñones bastante retrasados se hacía indispensable la presencia de dos equilibradores de muelles y un contrapeso de culata para compensar la preponderancia de boca. Un escudo de protección para los sirvientes aparecía tras los equilibradores. Su montaje bimástil A/19 le permitía un sector de tiro horizontal de 58 grados y una elevación de 65. Datos obtenidos del Ministerio del Ejército. Dirección General de Industria y Material, Catálogo T-0-4-1 Armamento y material (Tomo I), Imprenta del Polígono de Experiencias de Carabanchel, 1973, mat. 122/46.

${ }^{462}$ Documentación del general Martínez de Campos. Carpeta: Informes y documentación diversa sobre Alemania de los viajes del general Martínez Campos. AGMAV, Caja 24.711. Fondo del antiguo Ministerio del Ejército.
} 
aconsejaron incluir en la relación $\mathrm{n}^{\circ} 9$ de la lista: “...25 baterías, de tres piezas cada una, de cañones de gran alcance y calibre $150 \mathrm{~mm}$, con todos sus elementos..." Además, la citada relación incluía seis direcciones de tiro y 14.100 proyectiles, a razón de 188 por pieza. Obviamente, y como antes comentábamos, las peticiones españolas en éste, y en otros muchos temas, parecieron desorbitadas, y en el propio documento, que imaginamos serviría de guía al general Martínez de Campos, éste apuntó de su puño y letra: "ofrecieron 24 c. 12,2".

Y así fue. El Generalmajor Becker, del que ya hemos hablado anteriormente, ofreció al militar español en la reunión celebrada en Berlín ese mismo día, una partida de 24 piezas de cañones soviéticos de $122 \mathrm{~mm}$ mod. K 390 (r), capturados por el ejército alemán en su avance por tierras rusas.

El 28 de marzo, Martínez de Campos regresaba a Madrid con una oferta definitiva de armamento para someterla a la superioridad, aunque en ésta no figuraban precios, dejando el aspecto comercial para reuniones posteriores. Pero aún no estaba todo dicho. Justo un mes después de su partida hacia España, el 29 de abril, Martínez de Campos regresaba a Alemania y se volvía a reunir con la Comisión germana en Berlín, comunicando al general Becker que la partida referente a los cañones rusos de $12 \mathrm{~cm}^{463}$ :

“...se aceptaría siempre que se aumentara su número de 24 a unos 150 cuando menos...".

Becker, después de múltiples consultas que, al parecer, llegaron hasta el propio Hitler, le anunció que podía estar seguro de la entrega de los 150 cañones solicitados. La intervención personal del general Martínez de Campos en este asunto, manifestada por él mismo en su libro, titulado $A y e r^{464}$, hizo que ésta fuera la partida con un crecimiento más espectacular de todo el "Programa Bär". Lo cierto es que estamos ante un material producto del botín de guerra, que no había sido fabricado ni desarrollado en las fábricas del Reich, por lo que prescindir de él era menos esfuerzo que hacerlo de un

\footnotetext{
${ }^{463}$ Documentación del general Martínez de Campos. Carpeta: Informes y documentación diversa sobre Alemania de los viajes del general Martínez Campos. AGMAV, Caja 24.711. Fondo del antiguo Ministerio del Ejército.

464 “Antes de acabar, el presidente (Generalmajor) Becker me comunica, en nombre de su Führer, que el OKW ha hecho un esfuerzo para completar un núcleo de elmentos que interesa especialmente al Arma de que procedo, y que ese esfuerzo se ha efectuado para ofrecerme una prueba personal de su cordialidad; y me veo en la precisión de agradecer el gesto porque se trata de un material cuyo valor cualitativo se había tenido muy presente, siquiera lamentando la falta de interés cuantitativo de la oferta. (...) Esta oferta se refiere a un centenar de piezas de $122 \mathrm{~mm}$ de origen ruso que han caído, en buen estado, en poder de los germanos". Martinez de Campos, Carlos, Duque de Latorre. Ayer. 1931-1953, Instituto de Estudios Políticos, Madrid, 1970, pág. 259.
} 
material propio. Aún así, Alemania empleaba todo el armamento que capturaba a sus enemigos, bien en misiones de primera línea si éste era moderno y de calidad-como era el caso de estas piezas-, bien en tareas de segunda línea o lucha antipartisana, si se trataba de material más obsoleto o deficiente.

La semana siguiente a la reunión de Martínez Campos, dos jefes españoles de la Comisión, el teniente coronel Moyano Araiztegui y el comandante Guiloche, acudieron al parque del ejército alemán de Ludenburg para ver las municiones de $122 \mathrm{~mm}$ que allí se fabricaban. Dicho parque ocupaba una extensión de 250 hectáreas, con edificios de una sola planta muy espaciados, y en él trabajaban unas 1.500 personas, la mayoría mujeres alemanas y ucranianas. Tenía instalaciones ferroviarias y podía cargar de ocho a diez mil proyectiles diarios, con un máximo mensual de 200.000 disparos.

En la visita al Parque pudieron comprobar que las municiones de 122 estaban ya preparadas para enviar a España y eran de fabricación alemana. Se trataba de proyectiles de acero provistos de espoleta alemana AZ 23, con cartucho metálico, tres cargas de proyección y empacado individual en caja de madera.

Contento y con la partida ganada, el 1 de mayo de 1943 Martínez de Campos escribía una extensa carta al Ministro del Ejército, general Carlos Asensio, en la que le comunicaba los materiales que habían sido puestos a disposición de los españoles y la forma y dirección en la que iba a procurar encauzarlos hacia España ${ }^{465}$. Lo que a partir de ese momento se denominaría "Programa de Entrega Inmediata" iba a traer a España una buena cantidad de material militar para los tres ejércitos, aunque la mayor de todas las partidas serían los cañones rusos de 122/46. Los cien ejemplares incluidos en el primer envío llegarían, como el resto del armamento, por ferrocarril, aunque según los deseos del jefe de la Comisión, su llegada habría de producirse por grupos completos, y alternativamente por Irún, Canfranc y Port-Bou, a fin de que los 100 cañones pudieran ser evacuados directamente sobre los ocho regimientos de artillería de cuerpo de ejército de la Península ${ }^{466}$.

\footnotetext{
${ }^{465}$ Documentación del general Martínez de Campos. Carpeta: Informes y documentación diversa sobre Alemania de los viajes del general Martínez Campos. AGMAV, Caja 24.711. Fondo del antiguo Ministerio del Ejército.

${ }^{466}$ Una vez finalizada la contienda civil española se organizó territorialmente el nuevo ejército español. En la península se formaron ocho cuerpos de ejército, a los que había que sumar los dos desplegadas en el Protectorado de Marruecos así como diversas unidades insulares de Baleares y Canarias. Cada uno de estos Cuerpos de Ejército disponía, entre otras muchas unidades de las distintas armas y cuerpos, un regimiento de artillería de campaña "para cuerpo de ejército", donde se integraría un grupo de 12 cañones
} 
La conveniencia de realizarlo de esta manera estaba justificada, según el general español, por el hecho de que:

“... estos señores están interesados en conocer el empleo orgánico que hemos de dar a todo lo recibido, ya que este empleo ha de servirles de base para -si no lo abandonamos en nuestros Parquesmandarnos más..."467.

A partir del 27 de mayo de 1943, los trenes alemanes comenzaron su periplo desde la estación de partida -Perl- con destino a España, con su particular cargamento de armas y municiones para los tres ejércitos. Concretamente, el último día del mes de mayo, partía el tren $\mathrm{n}^{\circ} 3$ compuesto de treinta y seis vagones tipo " $\mathrm{R}$ " $\mathrm{y}$ uno del tipo "G" ${ }^{, 468}$, cargados con otros tantos cañones de 122/46 mod. 390/2 (r), cargados uno en cada vagón "R", además de accesorios y repuestos, todos ellos contenidos en el vagón “G”. Estas piezas llegarían a Canfranc el 4 de junio, siendo recibidas en la estación oscense por el teniente coronel Torres Chacón (Para más información de ésta y de las siguientes expediciones ver anexos XII y XIII).

En el tren $n^{\circ} 4$ llegarían doce cañones y accesorios; en el $n^{\circ} 5$ se recibieron 40 cañones más; en el $\mathrm{n}^{\mathrm{o}} 8$ vendrían los doce restantes para así completar el centenar y en el denominado $\mathrm{n}^{\circ} 8 \mathrm{a}$, accesorios para las piezas.

El 5 de julio de 1943, un mes después de comenzar los envíos, ya habían llegado a España todos los cañones del "Programa Inmediato", cuyo reparto entre los Regimientos de Artillería para Cuerpo de Ejército, fue el mostrado en la tabla siguiente:

\section{TABLA V-H}

\section{REPARTO DE CAÑONES DE $122 \mathrm{~mm}$ EN LOS REGIMIENTOS DE ARTILLERÍA PARA CUERPO DE EJERCITO}

\begin{tabular}{|c|c|c|c|c|c|c|c|c|}
\hline $\operatorname{RA}^{\circ} 41$ & $\operatorname{RA} n^{\circ} 42$ & RA n 44 & $\operatorname{RA}^{0} 45$ & $\operatorname{RA~n}^{\circ} 46$ & $\operatorname{RA}^{0} 47$ & RA n 48 & RA n 49 & RA n $n^{\circ} 50$ \\
\hline Segovia & Córdoba & Barcelona & Calatayud & Vitoria & M. Campo & La Coruña & Ceuta & Melilla \\
\hline 12 piezas & 12 piezas & 12 piezas & 12 piezas & 12 piezas & 8 piezas & 8 piezas & 12 piezas & 12 piezas \\
\hline
\end{tabular}

Elaboración propia. AGMAV. Caja 24.711.

rusos de $122 \mathrm{~mm}$. Para esta organización de postguerra es muy interesante el libro: VV.AA. Al pie de los cañones. La artillería española, Tabapress, Madrid, 1994, pág. 587.

${ }^{467}$ Carta del general Martínez de Campos al Ministro del Ejército, general Carlos Asensio el 1 de mayo de 1943. AGMAV, Caja 24.711. Fondo del antiguo Ministerio del Ejército.

${ }^{468}$ Los vagones tipo "R" eran bateas descubiertas y los tipo "G", iban cerrados. 
También se habían recibido 3.000 granadas rompedoras de $122 \mathrm{~mm}$ (partida $\mathrm{n}^{\mathrm{o}}$ 26). Dicha munición se transportó de Zaragoza a Sevilla para repartir 1.500 disparos a cada uno de los Grupos de los Regimientos no 49 y 50 en Marruecos ${ }^{469}$.

El 12 de junio de 1943 la Comisión alemana hizo llegar a la española una nota de precios para el material de la primera expedición, en la que, curiosamente, los cien cañones enviados eran separados en dos partidas independientes de cincuenta piezas cada una y con diferentes precios. Dichas partidas tenían un coste de 9.700.000 y 9.093.750 marcos, respectivamente, lo que pudiera dar origen a pensar que eran modelos diferentes ${ }^{470}$. Pero no era así. En el citado listado, más adelante, venían consignados los precios del material que había de llegar en el "Restprogramm", y los otros cincuenta cañones tendrían un precio de 10.306.250 marcos; los 606.250 marcos de diferencia entre las dos partidas iniciales, se les había sumado a estos 50 cañones que habrían de llegar con posterioridad. Mera cuestión contable.

En la reunión de las subcomisiones técnico-militares para la revisión de los precios del armamento del 22 de junio, se discutió por vez primera el precio solicitado por Alemania para los cañones de campaña de origen soviético. Este día, después del estudio de los precios de diversas partidas correspondientes a la Armada, le llegó el turno a las piezas de 122/46 (partida no 25 del "Sofortprogramm") ${ }^{471}$. Los técnicos alemanes solicitaron 194.000 marcos y explicaron, en primer lugar, el gran sacrificio que había supuesto para Alemania la condición exigida por el general Martínez de Campos para adquirir 150 piezas en lugar de 24, como ofreció Alemania. Hicieron una exposición de las características de este cañón, “...de muy alto valor militar...”, según sus palabras, ya que incluso para Alemania había sido una auténtica sorpresa comprobar

\footnotetext{
${ }^{469}$ En esa época, las unidades más amenazadas por los recientes desembarcos Aliados en el norte de África, eran los Regimientos de Artillería para los Cuerpos de Ejército de ambas circunscripciones del Protectorado marroquí, por eso los primeros proyectiles que llegaron de Alemania para estos cañones se remitieron a Ceuta y Melilla.

${ }^{470}$ En la URSS se habían fabricado dos modelos de cañones de $122 \mathrm{~mm}$ : el denominado 390/1 ó modelo 1931 y el denominado 390/2 ó modelo 1931/37. Pese a que en diversos manuales de empleo de este material se indicaban las características de ambas piezas, dando pie a algunos investigadores a afirmar que ambos modelos vinieron a España, lo cierto es que todas las piezas conocidas, así como las fabricadas en España posteriormente, pertenecían a la variante más perfeccionada 390/2 ó Modelo 1931/37. Ministerio del Ejército. Dirección General de Industria y Material, Catálogo T-0-4-1 Armamento y material (Tomo I), Imprenta del Polígono de Experiencias de Carabanchel, 1973, mat. 122/46, pág. 2.

471 "Síntesis de la evolución de las negociaciones con Alemania para la adquisición del armamento alemán. AMAE. AR. Sig. R-2066-5.
} 
el gran alcance que ofrecía. Ante la disposición de la subcomisión española de reducir el precio hasta 86.000 marcos por pieza, los alemanes sacaron a relucir nuevamente el gran sacrificio que representaba para Alemania desprenderse de estas piezas, con la necesidad añadida de haber tenido que recurrir hasta el propio Führer para que la oferta se elevase hasta las ciento cincuenta piezas prometidas.

Tres días más tarde, el 25 de junio, se volvía a tratar en las reuniones de las subcomisiones el tema de los cañones de 122/46, aportando los alemanes nuevas tablas de tiro de estas piezas, en las que se apreciaba un alcance máximo de $20.400 \mathrm{~m}$-frente a los $15.000 \mathrm{~m}$ indicados anteriormente a los españoles- y una velocidad inicial de 800 $\mathrm{m} / \mathrm{s}$. El error provenía, por lo visto y según la subcomisión alemana, de que el Ejército ruso había señalado un alcance de $15.000 \mathrm{~m}$ para intentar confundir al Ejército alemán al utilizar los mencionados cañones. Una comprobación posterior deshizo el engaño.

Estas explicaciones hicieron reconsiderar el precio ofrecido en primer lugar por España, aumentándolo hasta 112.000 marcos por cada uno de los cañones, precio que al final fue aceptado como definitivo por las subcomisiones.

Una vez solventados los problemas económicos relativos a los precios, el gobierno español, que bajo su responsabilidad había decidido suspender momentáneamente la segunda fase del Programa, dio luz verde a la continuación de los envíos del denominado "Restprogramm".

El día 26 de septiembre se recibieron treinta y tres cañones de 122/46 en el primero de los trenes de la segunda fase del "Bär". Veinte días después, en el tren $n^{\circ} 4$, se recibían los diecisiete que completaban las cincuenta piezas, todas ellas del modelo 390/2, que se recibirían en el marco de esta segunda fase del programa. En el tren $n^{\text {o }} 2$, además de otro armamento, se habían recibido 12.000 disparos completos de este calibre. Con estas cincuenta piezas se completaron a doce piezas todos los Grupos de los Regimientos para Cuerpo de Ejército (RACE), y se organizaron otros tres grupos más, asignados a los Regimientos de Artillería nº 62 y 63.

Sabemos con seguridad, por la documentación alemana consultada, que 138 piezas de las 150 entregadas, pertenecían al modelo 390/2, o lo que es lo mismo, al mod. 1931/37 ó A-19 en terminología rusa. De las otras doce no tenemos certeza absoluta de su modelo, pues en la documentación solo consta el que pertenecían a la variante 390. Por otra parte también hay que apuntar que no existe constancia gráfica o 
fotográfica de la existencia en España de ninguna pieza de la variante 390/1, aunque sí se habla de ella en los manuales militares españoles de la época.

La fábrica de artillería Trubia (Asturias) fue la encargada del entretenimiento y mantenimiento de ese material y de la producción de sus municiones ${ }^{472}$. Varias órdenes de fabricación fechadas entre 1944 y 1945 prueban que se fabricaron 20.000 proyectiles al menos, además de vainas, de las que 3.500 habrían de terminarse en el Plan de Labores de 1945. A partir de entonces, proyectiles y vainas de este calibre fueron de fabricación corriente e ininterrumpida en la factoría asturiana en los años siguientes ${ }^{473}$.

El comportamiento de las piezas no defraudó las esperanzas que se habían cifrado en ellas, dando un resultado lo suficientemente bueno como para aconsejar la construcción en España de algunas unidades más en la década de los cincuenta del pasado siglo XX, construcción que es de suponer se llevaría a cabo sin ningún tipo de licencia ni documentación, pues ni Alemania estaba en situación de proporcionarla, ni con la Unión Soviética se tenía por aquellos años, unas relaciones que autorizaran a solicitarla.

La fabricación de los 122 españoles corrió a cargo de la misma Fábrica de Trubia, cuyo Plan de Labores de 1952 incluía la primera orden de fabricación ( $\mathrm{n}^{\circ} 5306$ ) para la realización de cuatro piezas completas de este tipo; a partir de ese momento, irán emitiéndose sucesivas órdenes, siempre para pequeñas cantidades, en los planes de los años siguientes: ocho piezas en el de 1953, cuatro en el de 1954, ocho en el de 1955, ocho en el de 1956 y siete tubos en el de $1957^{474}$.

A finales de los años setenta, 173 piezas, tanto de origen soviético, como fabricadas en España, volverían a pasar por la Fábrica de Trubia para ser sometidas a remodelación ${ }^{475}$. Estas últimas modificaciones proporcionaron a estos magníficos cañones, unas prestaciones a la altura de las mejores de su clase.

\footnotetext{
${ }^{472}$ Órdenes de fabricación de la Fábrica de Trubia. Archivo de la Fábrica de Artillería de Trubia (AFAT) (Asturias).

${ }^{473}$ Mortera Pérez, Artemio. La fábrica de Trubia. Dos siglos de tecnología artillera, Fundación Alvargonzález, Gijón, 2005, pp. 247 y 248.

${ }^{474}$ Órdenes de fabricación $\mathrm{n}^{\mathrm{o}} 6.001,6.093,1.3-55-\mathrm{L}, 1.6-56-\mathrm{L}$ y 1.3-57-L, respectivamente. AFAT.

${ }^{475} \mathrm{La}$ modernización afectó tanto a las cureñas, cuyas ruedas metálicas con bandajes de goma fueron reemplazadas por otras provistas de neumáticos, se cambiaron las rejas por otras nuevas de modelo
} 
Solo el tratado FACE-ELT ${ }^{476}$ pudo con ellas. Los casi dos centenares de 122/46 fueron dados de baja progresivamente a principios de los noventa, pasando a los Parques y siendo vendidas como chatarra.

\section{V.4.- MATERIAL DE ARTILLERÍA ANTIAÉREA}

En España, la artillería antiaérea había experimentado un auge considerable en el transcurso de la Guerra Civil española, con la aportación a ambos bandos de material tanto alemán como soviético, sin desdeñar las aportaciones italianas e incluso de piezas modernísimas de origen sueco y suizo (Bofors y Oerlikon), estas últimas recibidas por el Ejército Popular de la República ${ }^{477}$.

A partir del 1 de septiembre de 1939 se organizaron en España las siguientes unidades de artillería antiaérea:

-Cuatro regimientos de artillería antiaérea de la reserva general cuya misión principal era la de constituir la espina dorsal de la especialidad para atender a la defensa de puntos sensibles del territorio nacional, reforzando cuando fuera necesario a la antiaérea orgánica de las grandes unidades. Para cumplir con este objetivo serían dotados con el material más moderno en servicio: el alemán Flak 18 de 88 mm L/56.

-Un regimiento -con cinco grupos- y tres grupos independientes de artillería antiaérea asignados tácticamente todos ellos al Ejército del Aire, aunque organizados y nutridos por personal del Ejército de Tierra. Los cinco grupos del citado regimiento vigilaban el cielo de otros tantos aeródromos peninsulares, cabeceras de cada una de las

desplazable, se instalaron frenos de marcha de funcionamiento por aire y se dotó a las piezas de gatos de elevación que, apoyándose sobre la oportuna placa base, elevaban el eje de ruedas hasta dejarlas emplazadas sobre tres puntos de apoyo.

476 Tratado multilateral entre los miembros de la Organización del Tratado del Atlántico Norte (OTAN) y del Pacto de Varsovia para reducir el nivel de fuerzas militares convencionales desplegables por los Estados partes dentro del área cubierta por el Tratado. El Tratado se firmó en París el 19 de noviembre de 1990 y entró en vigor formalmente el 9 de noviembre de 1992, una vez recibida la última ratificación. (De hecho, el Tratado entró en vigor provisionalmente el 17 de julio de 1992.) El Tratado de FACE restringe el nivel del llamado equipo limitado por el Tratado (ELT) -vehículos acorazados de combate, helicópteros de ataque, carros de combate, aviones de combate y artillería de gran calibre- que los Estados partes pueden desplegar dentro de la zona de aplicación del Tratado. En terminología anglosajona se denomina CFE-Treaty. Tulliu, Steve y Schmalberger, Thomas. En buenos términos con la seguridad. Diccionario sobre control de armamentos, desarme y aumento de confianza. UNIDIR, Naciones Unidas, Ginebra, 2003, pág. 28.

${ }^{477}$ La información para redactar este epígrafe está tomada del libro: Manrique García, José Maa; Molina Franco, Lucas; Mortera Pérez, Artemio. Historia de la Artillería antiaérea española. (Volumen I). Quirón Ediciones, Valladolid, 1998, págs. 167-206. 
Regiones Aéreas en las que se dividió el territorio nacional. Los tres grupos independientes prestaban el mismo servicio en los archipiélagos canario y balear así como en el protectorado marroquí. Para dotarlos se eligió los numerosos cañones alemanes Flak 14, de 75 mm L/36.

-Diez grupos antiaéreos integrados en cada uno de los regimientos de artillería asignados a los Cuerpos de Ejército existentes en España para dar cobertura antiaérea en su aérea de responsabilidad. El material con el que fueron dotados era de lo más variopinto, dependiendo de las posibilidades de cada Cuerpo de Ejército, conviviendo material de recuperación del antiguo ejército republicano con piezas italianas, checas de preguerra e, incluso, alemanas.

-Los ocho regimientos de costa disponían, asímismo, en su organización, de un grupo antiaéreo, habitualmente dotado de material fijo, cuya misión era defender el espacio aéreo del puerto o base naval y dar cobertura a las piezas costeras de grueso o mediano calibre situadas en las inmediaciones. Al igual que en el caso anterior, el material empleado en cada uno de los regimientos dependía de las existencias, siendo la mayor parte de él de emplazamiento fijo, destacando piezas Vickers de preguerra, junto a otras de origen italiano OTO y Armstrong, así como numerosos "Pichis",478 de 75 mm.

En diciembre de 1942 la realidad era más dura de lo que las plantillas oficiales del ejército hacían ver. Todo el material en servicio había "hecho la guerra civil” y, pese a que el más moderno (Flak 18 alemanes, Mod. 31 soviéticos y Ansaldo italianos) no había quedado obsoleto por concepto, si es cierto que las mejoras surgidas en el mismo con motivo los tres años de Guerra Mundial, habían dejado a los cañones españoles en un discreto segundo plano. Pero los cañones antiaéreos que pudiéramos denominar

\footnotetext{
${ }^{478}$ Los cañones antiaéreos denominados "Pichis" y en algunas ocasiones "Flit", fueron una improvisación fruto del comienzo de la Guerra Civil española y de la falta de material antiaéreo que hiciera frente a la amenaza real de los aviones militares presentes desde el primer día en el conflicto. Consistía el "Pichi" en un cañón de campaña Schneider Mod. 1906 de $75 \mathrm{~mm}$ y 28 calibres de longitud de tubo, reglamentario en esa época en la Artillería española, al cual se le quitaron las ruedas y se apoyó en un armazón de viguetas metálicas que le permitía efectuar puntería por grandes ángulos de elevación. Para que tuviera posibilidad de efectuar puntería en dirección, el conjunto descansaba sobre una plataforma circular provista de una corona dentada sobre la cual, accionada por su correspondiente volante, podía efectuar un giro de 360 grados. Posteriormente, el modelo fue evolucionando, desapareciendo la cureña de campaña con su mástil, quedando el trineo de la pieza asentado directamente sobre el montaje. En el transcurso del conflicto se pusieron en servicio más de 120 cañones de este tipo, en diferentes variantes según el lugar en el que fueron transformados. Toda la información sobre estas y otras piezas antiaéreas de circunstancias en: Molina Franco, Lucas; Manrique García, José $\mathrm{M}^{\mathrm{a}}$. Antiaéreos improvisados en la Guerra Civil española. Galland Books, Valladolid, 2007.
} 
$\operatorname{modernos}^{479}$ eran solamente el $29 \%$ del parque total artillero español. De las aproximadamente 340 piezas artilleras antiaéreas existentes en España en $1942^{480}$, había un total de 52 Flak 18, de $88 \mathrm{~mm}$; 22 Mod. 31, de 76,2 mm; 12 Bofors, de $40 \mathrm{~mm}$ y ocho Ansaldo, de $75 \mathrm{~mm}$. Un total de 94 cañones, con una creciente falta de repuestos (sobre todo en los de procedencia soviética y sueca) y unos medios de puntería y dirección de fuego poco aptos para hacer frente a las cada vez más rápidas y potentes aeronaves que se estaban desarrollando en todos los países presentes en el conflicto.

Aunque las plantillas daban por hecho que los grupos antiaéreos disponían de proyectores de luz y fonolocalizadores, elementos fundamentales en la detección de las amenazas aéreas nocturnas, lo cierto es que el Ejército español sólo disponía de dos baterías dotadas de estos aparatos, adquiridos en Alemania durante la Guerra Civil ${ }^{481}$, además de algunos ingenios soviéticos capturados durante el conflicto. Con estos materiales no estaban cubiertas ni el $10 \%$ de las citadas plantillas.

\section{TABLA V-I}

\section{CAÑONES ANTIAÉREOS EN ESPAÑA. 1942}

\begin{tabular}{|c|c|c|c|c|}
\hline Modelo & Calibre & Procedencia & $\mathbf{N}^{\mathbf{a}}$ piezas & Eficacia \\
\hline Flak 18 & $88 \mathrm{~mm} \mathrm{~L} / 56$ & Alemania & 52 & Alta \\
\hline Flak 14 & $75 \mathrm{~mm} \mathrm{~L} / 36$ & Alemania & 88 & Media. Sin direcciones de tiro \\
\hline Krupp & $88 \mathrm{~mm} \mathrm{~L} / 45$ & Alemania & 4 & Media \\
\hline Mod. 31 & $76,2 \mathrm{~mm} \mathrm{~L} / 55$ & URSS & 22 & Alta \\
\hline Ansaldo & $75 \mathrm{~mm} \mathrm{~L} / 46$ & Italia & 8 & Alta \\
\hline C.K. & $75 \mathrm{~mm} \mathrm{L/27}$ & Italia & 16 & Baja \\
\hline
\end{tabular}

\footnotetext{
${ }^{479}$ Se trataría de los Flak 18 de $88 \mathrm{~mm} \mathrm{~L} / 56$ alemanes; los Modelo 31 de 76,2 mm L/55 de origen soviético, los Bofors de $40 \mathrm{~mm} \mathrm{~L} / 56$ de fabricación sueca y los Ansaldo de $75 \mathrm{~mm} \mathrm{~L} / 46$ italianos.

${ }^{480}$ Solamente se consideran piezas antiaéreas las de calibre igual o superior a $37 \mathrm{~mm}$. Las de calibre inferior, habitualmente son conocidas como ametralladoras antiaéreas. La cantidad de éstas en servicio en España era de 341 de $20 \mathrm{~mm}$, siendo las más importantes las Flak 30 alemanas, las Breda italianas y las Oerlikon suizas. Estaban en proceso de recepción las 250 ametralladoras ZB-60, de $15 \mathrm{~mm}$, contratadas a primeros de 1942 con la casa Waffenwerke Brünn. Resumen General de Necesidades. Ver Anexo IV.

${ }^{481}$ Los alemanes eran proyectores Siemens de $150 \mathrm{~cm}$ de diámetro y fonolocalizadores Elascop. Una de las baterías fue adquirida por el gobierno español y combatió encuadrada con la unidad antiaérea nacional durante el conflicto. La otra batería, era la utilizada por la Legión Cóndor en su Grupo antiaéreo F/88. A1 finalizar la guerra, quedó en España. Los soviéticos eran proyectores Sperry DCA, de $152 \mathrm{~cm}$ de diámetro y patente inglesa, y fonolocalizadores Tepas, de origen belga. También se llegaron a fabricar en España este tipo de proyectores. Al parecer, en Madrid se organizó la fabricación de reflectores para la DCA con la colaboración de los ingenieros búlgaros Iván Schérev (Táshek) y Zhecho Gumushev (Grynchárov). VV.AA. La solidaridad de los pueblos con la República española". Academia de Ciencias de la URSS. Editorial Progreso, Moscú, 1974, pag. 89.
} 


\begin{tabular}{|c|c|c|c|c|}
\hline Skoda & $76,5 \mathrm{~mm} \mathrm{~L} / 40$ & Checoslovaquia & 14 & Baja \\
\hline Bofors & $40 \mathrm{~mm} \mathrm{~L} / 56$ & Suecia & 12 & Alta. Sin direcciones de tiro \\
\hline Vickers & $105 \mathrm{~mm} \mathrm{~L} / 43,5$ & España & 44 & Media. Obsoletos \\
\hline OTO & $100 \mathrm{~mm} \mathrm{~L} / 47$ & Italia & 7 & Baja \\
\hline Armstrong & $76,2 \mathrm{~mm} \mathrm{~L} / 40$ & Italia & 20 & Baja \\
\hline Vickers & $101,6 \mathrm{~L} / 45$ & España & 4 & Baja \\
\hline Vickers & $76,2 \mathrm{~mm} \mathrm{~L} / 48$ & España & 4 & Baja \\
\hline Vickers & $47 \mathrm{~mm} \mathrm{L/50}$ & España & 12 & Nula \\
\hline Schneider & $75 \mathrm{~mm} \mathrm{L/28}$ & España & 25 & Nula \\
\hline Vickers & $40 \mathrm{~mm} \mathrm{~L} / 40$ & España & 4 & $\mathbf{3 3 6}$ \\
\hline
\end{tabular}

Fuente: elaboración propia. Las armas de la Guerra Civil española, op. cit.

Es evidente, a la vista de la precedente tabla, la dispersión de calibres, modelos y fabricantes de cañones antiaéreos que existía en el Ejército español, así como su pobre y maltrecho parque, necesitaba una urgente modernización y homogeneización.

Los deseos españoles, plasmados en uno de los documentos aportado por Martínez de Campos en todas las fases de la negociación, era el denominado "Resumen General de Necesidades" (Ver Anexo IV), en el cual se recogían -en el caso que nos ocupa-, un total de 212 cañones antiaéreos pesados de $88 \mathrm{~mm} \mathrm{~L} / 56$ para adecuar las plantillas teóricas a las necesidades reales. Había que luchar para conseguir las 53 baterías (a cuatro cañones cada una) que se necesitaban.

Por lo que respecta a ametralladoras antiaéreas ligeras (con calibres comprendidos entre 12,7 y $37 \mathrm{~mm}$ ), los materiales existentes en España tras la guerra eran, comparativamente, de mejor calidad que sus "hermanos mayores", los cañones.

Hay que hacer constar que Alemania envió un total de 116 piezas Flak 30, de 20 $\mathrm{mm}$, parte de las cuales las empleó la propia Legión Cóndor en sus baterías ligeras ${ }^{482} \mathrm{y}$ otra, la Agrupación de Infantería de Ametralladoras Antiaéreas del Ejército Nacional, contando con alguno de estos cañones como defensa contra vuelos a baja cota, las

\footnotetext{
${ }^{482}$ Molina Franco, Lucas; Manrique García, José Ma . Legión Cóndor. La historia olvidada. op. cit. pág. 27. También se puede ver un detalle de la distribución en el Ejército nacional en: Molina Franco, Lucas; Manrique García, José Ma . Cuadernos de la Guerra Civil española. La Agrupación de Infantería de Ametralladoras Antiaéreas. Galland Books, Valladolid, 2012, pág. 14-18. Para el total de piezas, ver: Manrique García, José Ma; Molina Franco, Lucas. Las armas de la Guerra Civil española. La Esfera de los libros, Madrid, 2006, pág. 215.
} 
baterías pesadas de la Agrupación de Artillería Antiaérea, transformada en regimiento en 1938.

Italia, por su parte, no se quedó corta y remitió, integradas en el CTV y también con destino al Ejército español, máquinas Breda de $20 \mathrm{~mm} \mathrm{L/65}$, de buen diseño y excelente factura, las cuales prestaron un excelente servicio durante el conflicto y en la postguerra, permaneciendo operativas hasta bien entrados los años sesenta. En total, se recibieron 143 piezas de este modelo y calibre ${ }^{483}$.

El Ejército de la República recibió durante la contienda un total de 210 ametralladoras automáticas Oerlikon de $20 \mathrm{~mm}$, un arma de magníficas prestaciones, superiores sin duda, a sus homólogas alemanas e incluso italianas, muy apreciada tanto por sus usuarios como por sus enemigos, quienes tras su captura, las ponían en servicio y las empleaban sin dilación ${ }^{484}$.

A finales de 1942 prestaban servicio en España un total de 341 máquinas de estos modelos, que se repartían casi a tercias. También habían llegado parte de las 250 máquinas contratadas con la Waffenwerke Brünn, ametralladoras de $15 \mathrm{~mm}$ de origen checo $^{485}$.

Pero según el EMCE, en las plantillas españolas hacían falta un total de 1.437 ametralladoras antiaéreas. En el mejor de los casos, si tuviéramos presentes las 341 de $20 \mathrm{~mm}$ y las 250 de $15 \mathrm{~mm}$, harían falta no menos de 850 máquinas para cubrir el déficit planteado. Una cifra que, vagamente, los alemanes iban a cubrir.

Era también muy notable la falta de elementos de dirección de tiro -verdadero cerebro de las baterías antiaéreas-, y de localización de aeronaves en condiciones adversas -fonolocalizadores ${ }^{486}$ y proyectores ${ }^{487}$-ya que exceptuando las aportadas por

\footnotetext{
${ }^{483}$ Manrique García, José Ma'; Molina Franco, Lucas. Las armas de la Guerra Civil española. op. cit., pág. 235.

${ }^{484}$ Manrique García, José Maa; Molina Franco, Lucas. Las armas de la Guerra Civil española. op. cit., págs. 258-259.

${ }^{485}$ Ver apartado I.3.1 de este mismo trabajo.

${ }^{486}$ Como ya se ha comentado con anterioridad, los fonolocalizadores eran aparatos mecánicos que podían determinar la dirección de un foco sonoro situado en el espacio. La facultad de percibir la dirección de una fuente de sonido se debe a la apreciación de una desigualdad de sensaciones auditivas simultáneas en los dos oídos de la persona que escucha. El sentido intuitivo de la citada dirección del foco sonoro se puede agudizar si aumentamos la base de escucha (que es la separación normal de los dos oídos del hombre). De hecho, la precisión de la localización es función de la longitud de base. Los aparatos construidos por las diferentes fábricas dedicadas a ello, solían emplear dos bases acústicas perpendiculares entre sí, en cuyos extremos se colocaban unas bocinas construidas en metal, cuyos ejes tenían una separación muy superior a la de los oídos humanos. Dos de estas bocinas se utilizaban para
} 
los alemanes y los rusos en el conflicto civil, así como el material Vickers adquirido en preguerra, el resto de piezas antiaéreas venía simplemente con telémetros de coincidencia y planchetas, elementos empleados en la Primera Guerra Mundial, pero absolutamente desfasados ya en la Guerra Civil española y mucho más en 1943.

Las necesidades reales de aparatos de dirección de tiro, proyectores y fonolocalizadores estaban perfectamente clasificadas por el Ejército de Tierra español, figurando en un documento manejado por el general Martínez de Campos en sus viajes a Berlín ${ }^{488}$. En total, el Ejército de Tierra necesitaba 27 aparatos de dirección de tiro para otras tantas baterías antiaéreas que no disponían de ese material, 32 fonolocalizadores y 87 proyectores, así como 34 telecomandos para sincronizar los citados fonolocalizadores con los proyectores ${ }^{489}$.

\section{V.4.1- Materiales negociados con Alemania}

En la negociación con las autoridades alemanas, una de las partidas más relevantes, tanto para el Ejército de Tierra como para la Armada y el Ejército del Aire eran las armas antiaéreas, debido a la extrema precariedad de las existentes en España y a la enorme importancia que en esa época estaba alcanzando la aviación en el conflicto mundial que estaba teniendo lugar. Ya en el tercer capítulo hemos analizado las listas de los pedidos españoles en las comisiones correspondientes a los diferentes ministerios militares. Estudiaremos ahora la negociación llevada a efecto con el Reich, los

determinar el ángulo de situación de la base sonora (en este caso, un avión), y los otros dos, para determinar el ángulo de orientación. Molina Franco, Lucas. El legendario cañón antiaéreo de $88 \mathrm{~mm}$. Su historia y evolución en el Ejército español, op. cit., pág. 125.

${ }^{487}$ Los proyectores de luz se agrupaban, junto a los fonolocalizadores, en unidades complementarias de artillería antiaérea, cuya misión principal era iluminar el espacio aéreo de noche, para así descubrir y mostrar a los cañones el avión o aviones a batir mediante el fuego artillero. Molina Franco, Lucas. El legendario cañón antiaéreo de $88 \mathrm{~mm}$, op. cit. pág. 119.

488 "Necesidades en las unidades antiaéreas de esta Reserva General de Artillería" 22 de abril de 1943. AGMAV. Caja 24.711. Fondo del antiguo Ministerio del Ejército.

${ }^{489}$ Por lo que se refería a elementos de dirección de tiro, en el Regimiento $\mathrm{n}^{\mathrm{o}} 74$ faltaba un aparato, en el Regimiento $\mathrm{n}^{\circ} 75$, un total de 12 aparatos, en los Grupos independientes de Baleares y Marruecos se necesitaban tres aparatos y en los de Canarias y Melilla, un total de cuatro aparatos en cada uno. De proyectores y fonos había únicamente dos baterías completas alemanas y algunos modelos rusos supervivientes de la Guerra Civil, por lo que, en números redondos, eran necesarias un total de 10 baterías más, teniendo en cuenta que cada batería tenían en su seno tres fonolocalizadores, nueve proyectores (tres de ellos principales, denominados "guías" y otras seis secundarios, denominados "satélites") y tres aparatos telecomando. "Necesidades en la unidades antiaéreas de esta Reserva General de Artillería". 22 de abril de 1943. AGMAV. Caja 24.711. Fondo del antiguo Ministerio del Ejército. 
diferentes materiales que se exportaron al Ejército de Tierra ${ }^{490}$ y su integración en el las unidades militares españolas de la época. Por lo que respecta a las armas antiaéreas exportadas por Alemania a la Marina de Guerra, las estudiaremos en el capítulo dedicado al "Programa Bär" negociado por este ministerio.

El "Programa Bär" contemplaba la adquisición de una treintena de baterías completas de cañones Flak de 88/56 mm, que sumaban 120 piezas. De ellas, 36 serían adquiridas sin plataforma ni carrillos de transporte, para ser montadas en emplazamiento fijo y otras 108 serían del modelo transportable. En ningún caso los alemanes accedieron a facilitar medios de transporte para estas baterías. Cada batería sería acompañada de su dirección de tiro, un moderno aparato denominado "Modelo 40"491.

Además, se pactó con la casa Siemens la adquisición de 120 instalaciones eléctricas - una por pieza- denominadas S.A.M. (acrónimo de "Siemens Aparaten Maschinen") también denominadas Ubertragungsgerät 37, para poder emplear las piezas con la dirección de tiro "Modelo 40". Se había mejorado el sistema de seguimiento de blancos aéreos empleado en los modelos anteriores (Flak 18 y 36), adaptando a las piezas y a la dirección de tiro un sistemade transmisión/recepción de datos de índices coincidentes que hacía más sencillo y eficaz el proceso de dirección centralizada de fuego.

Además, se acordó la adquisición de otras 168 ametralladoras antiaéreas de 20 mm Oerlikon (Flak 28), de dotación en el Ejército alemán desde finales de los años 20, por tanto bastante obsoletas y usadas en la Wehrmacht, que las había destinado, fundamentalmente, a las defensas costeras (fijas y móviles) de la "Muralla del Atlántico" y a posiciones de segunda línea. Junto a estas baterías se adquirieron telémetros de un metro de base EM 34 y proyectores AEG de $60 \mathrm{~cm}$ de diámetro, aptos para iluminar blancos aéreos.

\footnotetext{
${ }^{490}$ Hay que hacer constar que debido a que en Alemania la defensa antiaérea (la Flak) formaba parte de la Fuerza Aérea (la Luftwaffe), todas las armas antiaéreas negociadas en el Programa Bär tuvieron que pasar, necesariamente, del Programa del Ministerio del Aire español al del Ministerio del Ejército. De hecho, podemos constatar que en el documento "Composición de precios del resto del Programa Bär" (AMAE AR. Sig. R-2065-5), constan en el Programa del Aire 108 cañones antiaéreos de 8,8 cm todo terreno y 156 cañones antiaéreos de $2 \mathrm{~cm}$ Oerlikon, entre otros materiales.

${ }^{491}$ La dirección de tiro "modelo 40" se desarrolló en Alemania al mismo tiempo que se mejoraba el diseño original del Flak 18, de 88/56, convirtiéndose en Flak 36 y Flak 37. Este aparato, de funcionamiento electromecánico, reducía al mínimo la intervención personal en el proceso calculatorio gracias a sus modernos mecanismos. La Dirección de tiro modelo 40 se componía de telémetro (el R-40 de 4 metros de base), aparato de cálculo y base. Molina Franco, Lucas. El legendario cañón antiaéreo de $88 \mathrm{~mm}$, op. cit. págs. 112 y 113.
} 
Por último, se adquirieron, con destino a las baterías de proyectores y fonos, un total de 43 fonolocalizadores RRH, fabricados por la casa "Electroacustic", de Kiel, aparatos idénticos a los que había utilizado la Legión Cóndor en la Guerra Civil española, y por tanto conocidos en las unidades de artillería antiaérea del Ejército de Tierra.

Ya se ha hecho referencia a la presencia en España de cañones antiaéreos de 88/56 mm, llegados durante la Guerra Civil española. Se trataba de la primera versión de este extraordinario cañón pesado, diseñado por los técnicos alemanes a principios de los años treinta. Finalizada la $1^{\mathrm{a}}$ Guerra Mundial, las cláusulas ciertamente restrictivas del Tratado de Versalles cayeron como un baldón sobre el pequeño Ejército de la nueva República de Weimar. El denominado por los propios alemanes "Diktat" impuso severas sanciones y prohibiciones a las tradicionales empresas de armamento teutonas, hasta el punto de tener que reorientar muchas de las actividades de la mayoría de ellas a la industria civil para seguir subsistiendo.

Una de las más reputadas y famosas empresas armeras alemanas, la "Krupp", alcanzó un acuerdo con la sueca "Bofors" en 1921 por el cual, un importante equipo de trabajo formado por ingenieros alemanes desarrollara una serie de proyectos en el país escandinavo. A cambio, "Bofors" recibiría los derechos de fabricación de los cañones de "Krupp" en el extranjero ${ }^{492}$.

La "Bofors", cuyos orígenes se remontaban a mediados del siglo XVII, era una fábrica especializada en el ramo de material de guerra, que podía centralizar todas las operaciones de transformación, desde el mineral hasta el producto finalizado, y efectuar un minucioso control de todas las fases de fabricación.

Desde 1922, el equipo de ingenieros germanos fue financiado por la Departamento de Guerra alemán, a la vez que la propia "Krupp" creaba en Berlín un departamento bajo el nombre de "Koch und Kienzle", que encubriría al equipo. Entre 1925 y 1930, los ingenieros trabajaron en el diseño de un cañón antiaéreo de $75 \mathrm{~mm}$ (Krupp 7,5 cm L/60), que aportaba muchas soluciones innovadoras que luego se aplicarían en el desarrollo del Flak 18 de $88 \mathrm{~mm}$.

\footnotetext{
492 Manrique García, José $\mathrm{M}^{\mathrm{a}}$; Molina Franco, Lucas, El cañón alemán de $88 \mathrm{~mm}$., Galland Books, Valladolid, 2008, pág. 5.
} 
Como el calibre $75 \mathrm{~mm}$ no cumplió con los requerimientos propuestos por las autoridades militares germanas por lo que se refiere a potencia de fuego, el proyecto no sería aceptado, pese a que una preserie de estas piezas había sido fabricada. A partir de ese momento, los técnicos alemanes trabajaron en un calibre más potente, considerando uno que ya habían desarrollado durante el conflicto anterior: $88 \mathrm{~mm}$. Todos los detalles fueron cuidadosamente tratados y un año después, en 1931, los técnicos trasladaron a Essen -ciudad donde se asentaba la casa "Krupp"- los planos del nuevo diseño del "Flugzeugabwehrkanone $18^{493}$ " de $88 \mathrm{~mm}$ y 56 calibres de longitud de tubo. Antes de finalizar ese año ya se había construido el primer prototipo y, a comienzos de 1932, se ensayaba con éxito en el polígono de experiencias de la fábrica.

La llegada al poder del partido nazi y la denuncia de las condiciones de Versalles, favorecieron el desarrollo de este y de otros proyectos militares. En 1933 el Flak 18 de 88/56 mm fue declarado reglamentario en el Ejército alemán y poco después entraba en servicio.

Con el paso del tiempo y las experiencias adquiridas por los militares alemanes en la Guerra de España, la primera versión de este cañón fue mejorada sensiblemente,

\footnotetext{
${ }^{493}$ El colocar cifras - correspondientes a años- tras la denominación de diferentes armas, respondía de alguna forma a la necesidad de hacer creer a otros países que se trataba de diseños antiguos. Recordemos que por entonces permanecían en vigor las condiciones restrictivas del Tratado de Versalles y, oficialmente, Alemania no podía fabricar cierto tipo de armas, como cañones antiaéreos, tanques, etc... Es por ello que todos los diseños de esta época van acompañados de cifras entre 14 y 18.
} 
derivando la segunda y tercera variante del mismo, denominadas Flak $36^{494}$ y Flak $37^{495}$, respectivamente.

Las partidas numeradas como 10 y 11 del Programa de Entrega Inmediata eran, respectivamente, 12 cañones fijos de $88 \mathrm{~mm} \mathrm{~L} / 56^{496}$ (no traían ni carrillos de transporte ni plataforma) y tres direcciones de tiro "Modelo 40" para los mismos. Los 12 cañones fueron recibidos en la estación de Port-Bou el 16 de junio de 1943 en el tren $n^{\circ} 4^{497}$. Una de las direcciones de tiro venía en el tren $n^{\circ} 4$, aunque debido a ciertos problemas

${ }^{494}$ El Flak 36 se caracterizó, básicamente, por la sustitución del tubo de una sola pieza de fundición denominado Rohr Aufbau 1 (RA.1) -que utilizaba el Flak 18-, por otro de tres piezas denominado Rohr Aufbau 9 (RA.9). Después de numerosos estudios y evaluaciones, el Estado Mayor germano consideró demasiado corta la vida útil de los tubos del Flak 18, teniendo en cuenta que todas las previsiones militares anticipaban una guerra europea de corta duración pero de gran intensidad. Dichos tubos se desgastaban rápidamente debido a la gran velocidad inicial de los proyectiles que disparaba, a las cargas de proyección y a las bandas de forzamiento de cobre que tenía la munición empleada. En los informes del mando se indicaba que habría que reemplazar un gran número de tubos inservibles con la consiguiente sobrecarga en el transporte y en ñas fábricas de reparación, amén del elevado coste que supondría la construcción y el almacenamiento de tubos completos. Como quiera que un equipo de ingenieros de Krupp detectó la zona del tubo que más sufría el desgaste, se determinó que se procediera a fabricar un tubo con secciones separables, envueltas en un tubo intermedio e introducido todo ello en el manguito del tubo. Para cambiar la sección más desgastada, el tubo podría ser desmontado "in situ" y dicha sección, ser sustituida. Los costes disminuirían sensiblemente y el procedimiento se haría más sencillo para el personal que manejara estos cañones. Todas estas soluciones innovadoras tenían sus problemas: debía usarse acero de muy alta calidad en la construcción de las secciones y la tolerancia de las piezas había de ser muy fina. Además, se empleaba más cantidad de mano de obra en su construcción y el peso del tubo era mayor que el del RA.1. Las primeras piezas de este modelo entraron en servicio en Alemania en 1937 y eran idénticas el Flak 18 en el resto de características. Manrique García, José Ma; Molina Franco, Lucas. El cañón alemán de $88 \mathrm{~mm}$, op. cit., págs. 35-36.

${ }^{495}$ En 1939 se desarrollarían unos nuevos carrillos de transporte para las piezas Flak 36, mejorando sensiblemente sus prestaciones, pues sólo requerían de la presencia de un sirviente para todas las operaciones de puesta en posición de fuego y de marcha y además permitían hacer fuego a la pieza sobre los mismos carrillos de marcha, sin tener que prepararla para tal efecto, algo imposible en las versiones anteriores. Ese mismo año se empezó a utilizar un nuevo sistema de transmisión y recepción de datos entre los cañones y la dirección de tiro. Este sistema denominado "de índices coincidentes", muy mejorado frente a la versión anterior -que se basaba en la iluminación de una serie de pequeñas bombillas-, era conocido como Ubertragungsgerät 37 (UTG 37). A partir de ese año, todas las piezas del modelo 36 fueron modificadas para poder utilizar el nuevo sistema de transporte y elevación, lo que conllevó la modificación de la plataforma, y a muchas de ellas también se les montó el nuevo sistema de transmisión UTG 37. Manrique García, José Maa; Molina Franco, Lucas. El cañón alemán de 88 mm, op. cit., pág. 36.

${ }^{496}$ Se produjeron varios intentos por parte de la Jefatura de Artillería del Ejército para conseguir diversas direcciones de tiro destinadas a las tres baterías antiaéreas de $88 / 45 \mathrm{~mm}$ (procedentes de la Guerra Civil) en servicio en los Regimientos de Artillería no 5, 9 y 41, así como otra batería de 88/56 Flak 18 (también procedente del conflicto español) encuadrada en el Regimiento de Artillería n ${ }^{\circ} 74$. El coronel Aguirre, de la $4^{\mathrm{a}}$ Sección del EMCE, solicitó al Agregado Militar en Berlín si era posible adquirir material direcciones de tiro de esta clase, bien al margen o bien integrado en el "Programa Bär". No fue posible. AGMAV. Caja 24.704. Fondo del antiguo Ministerio del Ejército.

${ }^{497}$ Uno de los vagones de este tren descarriló en el viaje; este vagón llevaba tres tubos de 88/56 mm que sufrieron ciertos golpes en las guías, algo que generó cierta correspondencia entre las autoridades militares españolas, que culparon a Schenker y los maquinistas del tren el caos que acompañó a la recepción de la mercancía que traía este convoy. Dirección General de Industria y Material del Ministerio del Ejército. Nota para el Estado Mayor del Ejército. (4a Sección). AGMAV. Caja 24.704. Fondo del antiguo Ministerio del Ejército. 
del maquinista, algunos de los vagones de este tren quedaron retrasados en el camino. Uno de los vagones afectados era el que transportaba esta dirección de tiro, que llegaría el 28 de junio a Port Bou. Las otras dos llegarían el 2 de julio en el tren $n^{\circ}$, también a la misma estación de Port Bou.

A finales octubre de 1943 se recibió el tren no 7 del "Restprogramm", con 24 cañones Flak 36 de $88 \mathrm{~mm}$ (la mitad móviles y la otra mitad fijas), seis instalaciones eléctricas UTG 37 y seis direcciones de tiro “Modelo 40” para las citadas piezas.

El 16 de diciembre alcanzaba Port Bou el tren $\mathrm{n}^{\mathrm{o}} 16$ de esta segunda parte del "Programa Bär", donde venían consignadas tres baterías completas - un grupo- de 88 mm Flak 36 con 12 cañones de emplazamiento fijo (sin plataforma ni carrillos de transporte), tres instalaciones UTG 37 y tres direcciones de tiro "Modelo 40".

Un mes más tarde, en el tren $n^{\circ} 18$ se recibían otros dos grupos - en esta ocasión móviles ambos- de 88/56 mm, compuestos de 24 cañones, seis instalaciones UTG 37 y seis direcciones de tiro "Modelo 40".

Casi cuatro meses después del anterior envío, en el tren n 22 llegaban a España los últimos cañones de este tipo de los recibidos en el "Programa Bär". Se trataba de un grupo fijo y otro móvil de 88/56, dotado cada uno de ellos de 12 cañones, tres instalaciones UTG 37 y seis direcciones de tiro "Modelo 40". Estos cañones fueron recibidos en la estación de Port-Bou el 4 de abril de 1944 y el 16 de ese mismo mes se reunió la Junta Facultativa de la Maestranza de Artillería de Barcelona para realizar un reconocimiento del material ${ }^{498}$.

En total, entre el "Sofortprogram" y el "Restprogram" se alcanzó la cifra de 96 cañones antiaéreos de $88 \mathrm{~mm}$ recibidos, 48 de ellos en montaje fijo y los otros 48 en montaje móvil.

Por lo que respecta al reparto de estas baterías a la Artillería española, hay que apuntar que se envió un grupo completo móvil (12 piezas) a cada uno de los Regimientos de Artillería Antiaérea $n^{\circ} 71,72,73$ y 74; en total 48 piezas. Uno de los

\footnotetext{
${ }^{498}$ Por el Acta levantada por la citada Junta Facultativa sabemos en que consistía el material recibido: 24 cañones de $88 / 56 \mathrm{~mm}$ con máquina de graduar espoletas; seis direcciones de tiro con sus carrillos; seis grupos electrógenos; seis telémetros de 4 metros de base; 24 alzas y 24 goniómetros de pieza y diverso material como herramientas, protectores, soportes, baterías, escobillones de limpieza, fundas y diversos cables para unir las piezas con la dirección de tiro. AGMAV., Caja 24.708. Fondo del antiguo Ministerio del Ejército.
} 
grupos fijos se montó en Algeciras (Cádiz) y otro en Tablada (Sevilla) y las otras 24 piezas fijas se repartieron entre los grupos del Regimiento de Artillería Antiaérea $n^{0} 75$.

No habían pasado más que unos meses desde la llegada de las últimas piezas de 88/56 y el Estado Mayor Central del Ejército estaba ya pensando transformar el material fijo en móvil, o incluso, semimóvil. Así se desprende de la correspondencia entre el coronel Marín de Bernardo y el coronel Jesús Aguirre, jefe de la $4^{\text {a }}$ Sección del $\mathrm{EMCE}^{499}$.

El precio pactado por cada batería completa de $88 / 56 \mathrm{~mm}$ fue de 750.000 marcos, incluyendo en la misma cuatro cañones, una dirección de tiro "Modelo 40" y cuatro aparatos SAM, UTG 37, así como accesorios, herramientas y demás material necesario para el funcionamiento de la misma.

Por otra parte, si se analiza el denominado "Resumen General de Necesidades. Armamento", de diciembre de 1942, que Martínez de Campos utilizó en las conversaciones de Berlín celebradas en abril y mayo de 1943 (Anexo 4), nos daremos cuenta que, además de cañones antiaéreos pesados de $88 \mathrm{~mm}$, la artillería española necesitaba también material ligero de $20 \mathrm{~mm}$, utilizado para la defensa antiaérea de las baterías pesadas contra vuelos a baja cota. En esas fechas se estaba recibiendo en España parte del pedido de máquinas antiaéreas de $15 \mathrm{~mm}$ Z.B.-60, firmado por el Ministerio del Ejército en 1942 con "Waffenwerke Brünn", de Brno (antigua Checoslovaquia). Un año antes, en 1941, después de diversas negociaciones con la neutral Suiza, el Ejército de Tierra consiguió adquirir la licencia para fabricar en España la conocida pieza de 20/70 mm tipo 4JLa con cañón mod. 1 SS de la casa Oerlikon, material que en la guerra civil ya había demostrado sus magníficas prestaciones como arma antiaérea ${ }^{500}$.

\footnotetext{
499 "Nota para el coronel Marín de Bernardo". 5-10-1944. AGMAV. Caja 24.708. Fondo del antiguo Ministerio del Ejército.

${ }^{500}$ Manrique García, José Ma; Molina Franco, Lucas; Mortera Pérez, Artemio. Historia de la Artillería antiaérea española. (Volumen I), op. cit., págs. 212 y 222. Se construyó en España y entró en servicio a partir de 1944 con el nombre de OKN, para diferenciarla con las Oerlikon procedentes de la Guerra Civil española (Oerlikon tipo $1 \mathrm{LaS}$, con cañón mod. 1S; cartucho de 20 x 110, desarrollada en 1930, 280 disparos por minuto) y de las adquiridas en el Programa Bär (Oerlikon dotadas de cañón mod. SS, mismo cartucho, desarrollada en 1938, 470 disparos por minuto). La Oerlikon tipo 4JLa con cañón mod. 1.SS tenía un tubo rediseñado, y su cadencia de fuego era también muy superior a sus antecesoras, alcanzando los 600 disparos por minuto. (datos técnicos tomados de la obra de Anthony G. Williams.
} 
Alemania disponía en su arsenal de preguerra, de las denominadas en el argot germano como Flak 28 y Flak 29, que no eran sino ametralladoras antiaéreas Oerlikon de $20 \mathrm{~mm}$. Las negociadas en el seno del "Programa Bär" con destino al Ejército de Tierra español eran, precisamente, Flak 28, de las que la Wehrmacht accedió a desprenderse de una partida. En total se trataba de 14 baterías de 12 piezas cada una (168 cañones), complementadas con 56 telémetros y otros tantos proyectores ligeros AEG de $60 \mathrm{~cm}$ de diámetro.

Una batería completa de estas piezas se había incluido en el "Sofortprogramm", con sus telémetros y sus proyectores correspondientes. Ésta se recibió en el denominado Tren no 4, que llegó a Port Bou el 16 de junio de 1943.

En el tren $n^{\circ} 3$ del "Restprogramm", recibido en Port Bou el 2 de octubre de 1943, llegaron otras 72 ametralladoras de $20 \mathrm{~mm}$ Oerlikon Flak 28 así como 24 proyectores AEG de $60 \mathrm{~cm}$. Poco después, el 14 de ese mismo mes de octubre, en el tren $\mathrm{n}^{\circ} 6$, se recibían 24 telémetros de 1 metro de base $\mathrm{R} 36$.

El 16 de diciembre de 1943 llegaba a Port Bou el tren $\mathrm{n}^{\circ}$ 16, donde venían consignadas 12 ametralladoras, 20 telémetros modelo 36 y cuatro proyectores de $60 \mathrm{~cm}$. Por último, en el tren $\mathrm{n}^{\circ}$ 18, que llegó a Port Bou el 10 de enero de 1944, se recibieron 24 ametralladoras y ocho proyectores AEG; y el el nº 22, que alcanzó la misma estación ferroviaria el 4 de abril de 1944, llevaba otros ocho proyectores de la misma marca y modelo.

Cuarenta y ocho armas de este modelo -las últimas del lote contemplado en el "Programa Bär"-, ocho telémetros de $1 \mathrm{~m}$ de base y otros tantos proyectores de $60 \mathrm{~cm}$, formaban parte del cargamento del Tren $n^{\circ} 27$, que nunca llegaría a España, pues fue bombardeado en su recorrido por Francia. Curiosamente estas armas no se destruyeron en el ataque de la aviación aliada y pudieron ser recuperadas por los alemanes, que las incorporaron nuevamente a su parque artillero, descontando su valor de las deudas del Ejército español por el "Programa Bär".

El precio unitario de las piezas ligeras Flak 28, alcanzado en las reuniones de las Subcomisiones Técnico-Militares de Madrid fue de 29.700 marcos, alcanzando cada telémetro R-36 un precio de 4.800 marcos y cada proyector AEG de $60 \mathrm{~cm}$, el de 29.100

(http://www.quarry.nildram.co.uk/apib.html). El 28 de noviembre de 1941 se le entregaban al representante de la casa Oerlikon en España, Guillermo F. Mallet, tres cajas conteniendo planos y dibujos destinados al Ministerio del Ejército español. 
- casi el valor del arma-. La batería completa de estos cañones ligeros, dotada de 12 cañones, cuatro telémetros y cuatro proyectores, costaba 492.000 marcos.

Al final, El Ejército español dispuso de 120 piezas Flak 28 -el equivalente a 10 baterías de 12 cañones cada una-, 48 telémetros y otros tantos proyectores, complemento necesario para las baterías ligeras dotadas de estos cañones. Del lote contemplado en el "Programa Bär", quedarían sin recibirse cuatro baterías completas (perdidas en el tren $\mathrm{n}^{\circ} 27$ ), ocho telémetros y ocho proyectores, que corrieron la misma suerte que las piezas, como ya hemos apuntado anteriormente.

En el "Restprogramm" se recibieron 54 fonolocalizadores $\mathrm{RRH}$, de la firma Electroacustic, destinados a las baterías antiaéreas de 88/56, de ellos 12 para baterías fijas, sin medios de transporte. Las primeras 27 unidades llegaron en el tren $n^{\circ} 6$, y las siguientes fueron llegando en diferentes convoyes: seis en el tren $n^{\circ} 12$, seis en el tren $n^{\circ}$ 16 , tres en el tren $\mathrm{n}^{\mathrm{o}} 18$ y las últimas 12 en el tren $\mathrm{n}^{\circ} 22$.

Es preciso señalar que estos fonolocalizadores estaban en servicio en Alemania desde 1935 y se emplearon por las unidades Flak de la Luftwaffe durante toda la Segunda Guerra Mundial como modelo standard germano ${ }^{501}$. De los 54 aparatos contratados en el "Programa Bär", 24 eran para dotar a todas las baterías antiaéreas alemanas procedentes de la Guerra Civil que no disponían de estos aparatos. Con el resto se cubrirían las 30 baterías de $88 / 56 \mathrm{~mm}$ que estaban previstas en el "Programa Bär".

El precio unitario pactado en Madrid para estos aparatos fue de 55.430 marcos, aunque con posterioridad, a la vista de que 12 de estos fonos no vendrían con remolque, sino que serían de emplazamiento fijo - los asignados a las 12 baterías de 88/56 mm denominadas "estacionarias"-, se rebajó el precio de esta docena de aparatos a 50.230 marcos por unidad.

Todos los fonos pactados en el "Programa Bär" alcanzaron suelo español.

\footnotetext{
${ }^{501}$ Müller, Werner. Sound Locators, fire control systems and searchlights of the german heavy Flak units. (1939-1945), Schiffer military/ aviation history. Pensilvania,1998, pág. 47.
} 


\section{V.4.2.- La Comisión antiaérea española en Alemania}

Entre julio y septiembre de 1943, una comisión española formada por un coronel, seis jefes y trece oficiales, pertenecientes todos ellos a diferentes regimientos de artillería antiaérea, realizaron una visita a diferentes unidades alemanas para conocer de primera mano la organización y el material para la defensa antiaérea empleado por la Wehrmacht en los diferentes escenarios de la II Guerra Mundial ${ }^{502}$.

La visita comenzó en París, donde visitaron la $3^{\text {a }}$ Flota Aérea y en ella, diferentes unidades como las centrales de información y alarmas en París, la estación de radio-localización de Saint Germain, el Regimiento antiaéreo encargado de la defensa de la capital francesa, otro regimiento desplegado en la costa belga y francesa y un tercero motorizado destacado en Nantes, así como la Escuela de Secciones de Asalto de Le Mans y las Escuelas de Artillería antiaérea en Alemania, sitas en Garf y Rerik.

Durante su permanencia en París y en la costa belga, la Comisión se dividió en cinco grupos, que fueron agregados a diferentes unidades (Planas Mayores y baterías). En los restantes lugares las visitas se realizaron por todo el grupo reunido.

En los programas se contemplaban diferentes conferencias y explicaciones sobre el material, que fueron completados con ejercicios sobre el plano o sobre el cajón de arena $^{503}$, y ejercicios en el terreno, algunos de ellos con fuego real.

Durante su estancia en el Regimiento antiaéreo de París, la Comisión española estudió la artillería antiaérea en su misión peculiar y característica: el combate contra blancos aéreos. Su permanencia en el Regimiento transportable de la costa belga sirvió para presenciar la actuación de un regimiento antiaéreo desplegado en misión antiaérea pero que a la vez puede desempeñar misiones de tiro de superficie. Los ejercicios llevados a cabo por el Regimiento motorizado de Nantes, estuvieron dedicados casi en su totalidad al empleo de la artillería antiaérea en misiones terrestres, principalmente

\footnotetext{
${ }^{502}$ Memoria de la Comisión de Artillería Antiaérea. Julio a septiembre-1943. Escuela de Aplicación y Tiro de Artillería. Documento mecanografiado publicada para "consumo interno" de la Escuela. s/f. APEC.

${ }^{503}$ El cajón de arena era un método muy empleado en esa época, y que perduró en España hasta bien entrados los años setenta. Consistía, básicamente, en simular una acción militar en tres dimensiones, sobre un cajón en el que se representaba un terreno, y una figuras que representaban las diversas unidades que se querían simular.
} 
con unidades de cañones automáticos, presenciando la Comisión española un ejercicio desarrollado por una División acorazada y visitando una batería antiaérea de la Marina (de $128 \mathrm{~mm}$, en asentamiento fijo y dotada de una dirección de tiro Hazemeyer) así como la base de submarinos de Saint Nazaire.

El poco tiempo de permanencia en la Escuela de artillería antiaérea de Rerik, en Alemania, impidió a los españoles formarse una idea clara de su organización y funcionamiento, algo que no sentó bien a la Comisión pues el planeamiento inicial de la visita incluía la estancia en la misma durante cuatro semanas, alterando de esta forma el programa previsto e impidiendo conocer detalles en profundidad del funcionamiento del material, direcciones de tiro y radiolocalizadores

Los extremos más importantes de la visita de la Comisión española de artillería antiaérea podríamos resumirlos de la siguiente manera:

En primer lugar se observó en todos los lugares visitados el lugar destacado que ocupa la artillería antiaérea alemana. En toda la instrucción existía una gran especialización y el trabajo de las unidades era constante, llamando mucho la atención a los militares españoles la:

\section{“...claridad con que hasta el último soldado explica el cometido que tiene encomendado... "504}

Los oficiales, suboficiales y tropa destinados en el servicio antiaéreo debían tener una psicología especial; al lado de un trabajo minucioso y ciertamente técnico, habían de poseer cualidades de decisión y rapidez para su intervención en el combate, unidos a una elevada acometividad.

La artillería antiaérea alemana estaba caracterizada, según pudieron comprobar los españoles, por una gran flexibilidad en su organización, por lo que las unidades tipo regimiento no disponían de un número fijo de grupos ni de baterías, y la proporción de grupos ligeros y pesados se adaptaba a las circunstancias. La defensa antiaérea estaba organizada a base de grupos antiaéreos dotados de piezas pesadas o ligeras. En tiempo de paz, la antiaérea había estado subordinada a la Jefatura de la Región Aérea o a la Jefatura antiaérea respectiva. En 1939 existían nueve Regiones Aéreas, agrupadas en

\footnotetext{
${ }^{504}$ Memoria.... Escuela de Aplicación y Tiro de Artillería, pág. 4. APEC.
} 
cuatro Flotas Aéreas. Cada Flota tenía dos Regiones Aéreas, excepto la de Berlín, que tenía tres. En mayo de 1939 había organizados en Alemania un total de 83 grupos pesados y 58 ligeros.

En tiempo de guerra, estaba establecido que parte de la Flak estaría subordinada al Ejército de operaciones. Generalmente un grupo antiaéreo pesado ${ }^{505}$ iba afecto a cada Cuerpo de Ejército y un grupo ligero ${ }^{506}$ a cada División Blindada.

La artillería antiaérea estaba preparada e instruida para el combate próximo y la lucha contra carros de combate, para lo cual las unidades contaban con materiales como ametralladoras, minas contracarro, granadas de mano, etc... constituyendo cada posición un centro de resistencia defensivo, concediendo mucha importancia a la fortificación. Llamó la atención de la Comisión el empleo de globos barreras para la protección de objetivos importantes y de nieblas de ocultación.

Además de los grupos pesado y ligeros, existían en Alemania por esas fechas los denominados grupos antiaéreos de plaza, cuya composición no respondía a los mismos estándares de los mencionados, sino que era algo variable y dependía de la importancia de la plaza a defender, dándose el caso de la existencia -en algunas plazas importantesde varios de estos grupos.

Independientemente de los proyectores de que iban provistas las baterías ligeras, existían también los denominados grupos pesados de proyectores. Éstos eran de 1,50 m de diámetro fabricados por "Siemens", y cada proyector del grupo iba provisto de su

\footnotetext{
${ }^{505}$ Cada grupo pesado se componía de una plana mayor, tres baterías pesadas de $8,8 \mathrm{~cm}$ y dos baterías ligeras de $2 \mathrm{~cm}$. De manera extraordinaria, en algún grupo se sustituían una o dos baterías de $8,8 \mathrm{~cm}$ por igual número de baterías de $10,5 \mathrm{~cm}$. Cada grupo disponía, además, de una columna de municiones y de una batería de proyectores pesados de 1,50 m. Cada batería pesada constaba de cuatro cañones Krupp de $8,8 \mathrm{~cm}$, llevando además, como defensa inmediata de la misma, para casos de ataque en vuelo rasante, dos piezas de $2 \mathrm{~cm}$. Las baterías ligeras disponían de doce cañones de $2 \mathrm{~cm}$, agrupados normalmente por la modalidad de fuego que habían de emplear, en cuatro secciones de tres piezas cada una. La columna de municiones del grupo podía transportar, en los carruajes empleados, 42 toneladas de proyectiles.Los efectivos humanos de un grupo pesado alcanzaban los 1.100 hombres.

${ }^{506}$ Cada grupo ligero se componía de una plana mayor, una batería de $3,7 \mathrm{~cm}$, dos baterías de $2 \mathrm{~cm}$ y una columna de municiones. Las baterías de $3,7 \mathrm{~cm}$ se componían de nueve cañones, y normalmente estaban divididas en tres secciones de tres piezas cada una. Las baterías de $2 \mathrm{~cm}$ se estructuraban como en el caso anterior, disponiendo de doce cañones agrupados en cuatro secciones de tres piezas cada una. Tanto las baterías de $3,7 \mathrm{~cm}$ como las de $2 \mathrm{~cm}$, iban provistas cada una de cuatro proyectores de tiro de $60 \mathrm{~cm}$ de diámetro. La columna de municiones podía transportar un total de dos toneladas de proyectiles. El total de la dotación de un grupo ligero era de unos 800 hombres.
} 
fonolocalizador con transmisión eléctrica azimutal y cenital, utilizando para ello dos receptores del mismo tipo que las piezas pesadas de $8,8 \mathrm{~cm}$. Los sirvientes en cada proyector - uno en dirección y otro en elevación- iban dando en cada momento al proyector la dirección y elevación convenientes, utilizando para ello el mismo sistema de lámparas que empleaban los cañones antiaéreos pesados.

Cada grupo disponía de tres baterías de proyectores, llevando cada una de ellas nueve proyectores con sus correspondientes fonos y medios de tracción, haciendo un total de 27 aparatos de luz. Su dotación ascendía a unos 800 hombres.

\section{V.4.3.- Valoración del material antiaéreo recibido en España}

Los cañones Flak de $8,8 \mathrm{~cm}$ recibidos en el "Programa Bär", junto a las direcciones de tiro modelo 40 y los denominados "Siemensapparatenmaschinen" también llamados “Ubertragungsgerät UTG 37”, eran material de defensa antiaérea muy moderno, empleado con profusión en todos los frentes de batalla de la Segunda Guerra Mundial por el Ejército alemán con gran eficacia. Pese a que en España ya se conocían estos cañones desde la Guerra Civil, las piezas recibidas entre 1943 y 1944 eran más avanzadas tecnológicamente al estar dotadas de una dirección de tiro modernizada y unos elementos de puntería muy mejorados frente al modelo Flak 18, que fue el empleado en España por la Legión Cóndor.

Por otra parte, los fonolocalizadores "RRH Elascop" eran empleados también en todos los frentes por la Luftwaffe germana, aunque su época había pasado y su uso estaba decayendo frente a los novedosos y tecnológicamente mucho más avanzados radiotelémetros y radiolocalizadores -la versión alemana del radar anglosajón-.

Las ametralladoras antiaéreas de $20 \mathrm{~mm}$ Flak 28, como ya se ha afirmado anteriormente, eran un arma algo desfasada, ya superada por otros modelos más modernos, aunque en España dio todavía mucho que hablar integrada en unidades, tanto de artillería como de infantería, que la emplearon como defensa antiaérea contra aviones a baja cota. Tanto los telémetros Zeiss de $1 \mathrm{~m}$ de base como los proyectores de $60 \mathrm{~cm}$

que acompañaban a las ametralladoras eran de muy buena calidad, permaneciendo en servicio en España hasta los años sesenta del siglo XX.

En conjunto hemos de convenir que el material antiaéreo del "Bär" era de buena calidad -aunque una parte fuera de segunda mano- y sirvió para completar con piezas 
modernas muchas unidades artilleras armadas hasta entonces con cañones obsoletos y muy desgastados, procedentes todos ellos de los años de la Guerra Civil. Cubrió el hueco existente en la artillería española, hasta la entrada en servicio de los cañones de la misma clase fabricados en Trubia (Asturias), gracias a la adquisición de la correspondiente licencia, piezas que entrarían en servicio a finales de la década de los 40 del pasado siglo y que estaqrían en servicio hasta finales de la década de los años ochenta.

\section{V.5.- ARTILLERÍA CONTRACARRO}

Las armas antitanque (A/T), como se denominaba reglamentariamente entonces a las hoy conocidas como contracarro, estaban constituidas por cañones de 20, 37 ó $45 \mathrm{~mm}$, con precisión en el tiro hasta los 2.000 metros, según el calibre, y ofrecían un medio eficaz contra los carros de combate de la época

“... si la Infantería posee sus morteros y cañones antitanque, no será necesaria la Artillería de Acompañamiento Inmediato fuera de los terrenos cubiertos y compartimentados ${ }^{507}$.

En España, antes de la proclamación de la República, la Sección de Infantería de la Escuela Central de Tiro (Carabanchel, Madrid) y la Academia del Arma (Toledo) contaban con varias piezas del "Canon de $37 \mathrm{~mm}$ Mle 1916 T.R. (tir rapide), sistema Puteaux", y al menos una de ellas participó en la defensa del Alcázar de Toledo $^{508}$.

Desde 1926 el comandante de Artillería Antonio Ramírez Arellano, promocionaba sus prototipos de cañón de 40/25 mm para el acompañamiento de la Infantería, la defensa antitanque y también con destino al carro de combate Trubia A-4. Esta pieza sería declarada reglamentaria en 1933. En julio de 1936 se habían producido ya unos 75 cañones, que se habían repartido entre varias unidades de Infantería, a razón de tres por Regimiento y uno por Batallón de Montaña y de Cazadores ${ }^{509}$.

\footnotetext{
507 Franco Bahamonde, Francisco: Comentarios al Reglamento de Grandes Unidades. Partes principales y análisis. Cuartel General del Generalísimo. Imprenta Aldecoa, Burgos, 1938, pág. 13.

${ }^{508}$ Manrique Gacía, J.M. y Molina Franco, L. Las armas de la Guerra Civil española, op. cit., pág. 242.

${ }^{509}$ Molina Franco, Lucas. El legado de Sigfrido, op. cit., pág. 143.
} 
A lo largo del conflicto civil, los alemanes suministraron a los alzados modernas piezas antitanque del modelo Pak 35/36 de $37 \mathrm{~mm}^{510}$, pasando éstos de una carencia casi absoluta de este tipo de armamento, a poseer al final de la contienda cerca de 350 cañones, si contamos también los capturados al enemigo en el curso de las operaciones militares, aunque las cifras de material alemán fueran exactamente $302^{511}$. Los italianos emplearon dos modelos de piezas antitanque, el Modelo 39 de $47 \mathrm{~mm}$ y otro idéntico al alemán de $37 \mathrm{~mm}$, aunque en pequeñas cantidades e integradas siempre en el CTV. Dicho material no fue entregado a los españoles al finalizar la contienda, acompañando a su regreso a Italia al cuerpo expedicionario latino.

Los republicanos recibieron 341 cañones antitanque de varios modelos, aunque los más importantes, tanto en calidad como en cantidad, además de los suecos Bofors y los norteamericanos MacLean (Maklen), ambos de $37 \mathrm{~mm}^{512}$, fueron los soviéticos de 45 mm. Mod. 1932, versión a mayor escala del alemán Pak 35/36 de 37 $\mathrm{mm}$. Podemos asegurar que era una pieza moderna y eficiente, con mayor poder ofensivo, por su mayor calibre, que la alemana de $37 \mathrm{~mm}$.

En marzo de 1942, Martínez de Campos llevó a las reuniones en Berlín el tantas veces citado "Resumen general de necesidades del Ejército de Tierra", donde se reflejaba el estado de los materiales existentes y lo que el Ejército necesitaba para cubrir las plantillas de maner efectiva. Por lo que se refiere a los materiales antitanque hemos de decir que había en servicio 436 piezas de $37 \mathrm{~mm}$ y otras 248 de $45 \mathrm{~mm}$. Parece necesario constatar aquí que tanto del calibre $37 \mathrm{~mm}$ como del calibre $45 \mathrm{~mm}$, figuraban en ese estadillo muchos más cañones que los recibidos en el transcurso de la guerra civil; ¿cúal podría ser la razón?

No hay duda para los de $45 \mathrm{~mm}$. Desde el año 1939, antes incluso del final de la guerra, la fábrica de Placencia de las Armas (SAPA) (Guipúzcoa) estaba

\footnotetext{
${ }^{510}$ En alemán Panzerabwehrkanone (Pak), cuyo significado es cañón contra carro de combate. La pieza antitanque de $3,7 \mathrm{~cm}$. fue desarrollada por la empresa Rheinmetall en 1933, alcanzando a partir de ese momento una gran difusión y un evidente éxito, y por ello fue adoptada por varios países como Italia, Holanda, Japón, Estados Unidos o la Unión Soviética. En España, este cañón fue válido para combatir contra los carros a los que se enfrentó en el conflicto, quedando obsoleto a principios de los años 40, cuando los carros de combate de los países en conflicto experimentaron un aumento considerable de blindaje.

${ }^{511}$ Molina Franco, Lucas. El legado de Sigfrido, op. cit., pág. 235.

${ }^{512}$ De los que se llegaron a recibir un total de 30 piezas de cada modelo.
} 
produciendo una copia -sin licencia- del cañón ruso de $45 \mathrm{~mm}$ Mod. 32, denominado para diferenciarlo, Modelo Nacional, con ligeras modificaciones del original. Es por tanto plausible que tres años después del final del conflicto, entre las piezas rusas recuperadas y las fabricadas en la villa vasca, sumaran las 248 que afirma el estadillo.

Más complejo resulta seguir la pista a las 436 de $37 \mathrm{~mm}$ que se citan en el mismo documento, pues a las 302 alemanas de este calibre recibidas durante la guerra -Pak 35/36 de 3,7 cm-, habría que sumar 134 piezas procedentes de captura al Ejército de la República. A los Mac Lean (también denominado Maklen) y Bofors, cuyas existencias conjuntas no pasarían de los 30 cañones, habría que añadir los "Hotchkiss" (de procedencia soviética, llamados "Gózquez" en alguna documentación) y "Puteaux"513. En cualquier caso, todos estos cañones -incluidos los alemanes- tenían un calibre que en pleno año 1943 había quedado desfasado por las propias vicisitudes que marcaba la contienda mundial, en la que nuevos diseños -cada vez mejor blindados- de carros de combate hacían a estas piezas completamente inútiles.

\section{V.5.1.- La artillería contracarro del "Programa Bär"}

Al igual que ocurrió con otra clase de materiales, los comisionados españoles para negociar el programa de armamentos en Alemania llevaban una lista de peticiones que plantearon a sus homónimos teutones en diversas reuniones. La petición de armas de esta clase se reducía a 125 piezas, cuyo calibre había de estar comprendido entre 50 y $75 \mathrm{~mm}$, con mil disparos por pieza, y así quedaba reflejado en la relación $\mathrm{n}^{\mathrm{o}} 10$ que presentó a las autoridades germanas la Comisión Extraordinaria para Material de Guerra desplazada a la capital del Reich. Hay que reseñar que para este tipo de armas los alemanes superaron el triple de la cantidad originalmente solicitada por los españoles, algo que no iba a ocurrir con ningún otro material de los contratados en el programa, ni por el Ejército de Tierra, ni por la Marina de Guerra ni por el Ejército del Aire.

En efecto, en el Epígrafe II, -Material para el Ejército de Tierra- de la Relación General del "Programa Bär" ${ }^{\text {"14 }}$, figuran tres tipos de cañones anticarro disponibles para

\footnotetext{
${ }^{513}$ Manrique Gacía, J.M. y Molina Franco, L. Las armas de la Guerra Civil española, op. cit., págs. 242244.

${ }^{514}$ W Stb (Ausl.) 3. Abtl. Anexo 1 Relación General. 29 de abril de 1943. AGMAV Caja 24.711. Fondo del antiguo Ministerio del Ejército.
} 
ser entregados a España: por un lado, piezas galas del modelo Puteaux de 2,5 cm, capturadas como botín de guerra tras la ocupación de Francia en mayo de $1940^{515}$; por otro, piezas alemanas de $5 \mathrm{~cm}$ Pak 38 y finalmente, los modernísimos cañones de 7,5 cm Pak 40 recién estrenados por el propio ejército alemán. En los tres casos citados, la cantidad ofrecida fue de 150 ejemplares por cada uno de los modelos, alcanzando un total de 450 piezas artilleras.

Una vez revisada y valorada la oferta por las autoridades militares españolas, los negociadores de la Comisión comunicaron a sus interlocutores germanos la aceptación de dos de los modelos ofrecidos: el francés de $2,5 \mathrm{~cm}$ y el alemán de 7,5 cm, rechazando en cambio, el modelo intermedio de $5 \mathrm{~cm}$ de calibre, algo realmente insólito y que sorprendió a los comisionados alemanes, ya que no había comparación posible entre éstos y los franceses de $2,5 \mathrm{~cm}$ seleccionados.

Ante las insistentes preguntas del general Becker, y para intentar justificar el rechazo de los 150 cañones anticarro de $5 \mathrm{~cm}$, el general Martínez de Campos ${ }^{516}$ comunicó a sus contrapartes germanas que tal negativa a adquirir estas armas venía avalada:

“...porque tenemos casi abastecido el Ejército con (piezas del calibre) 45 y no queremos tener que montar la fabricación de (proyectiles de) un nuevo calibre para un número de piezas tan reducido..."

Una explicación convincente a primera vista la del general Martínez de Campos, pero que se caía por su propio peso si se compara con la adquisición de los cañones franceses de 2,5 cm: ese calibre también era inexistente en España en ese momento ${ }^{517}$. Probablemente los alemanes desconocían este último extremo; o realmente les daba igual. Y para colmo, las piezas galas estaban totalmente desfasadas en 1943, como veremos a continuación.

Pero además de la venta a España de estos cañones antitanque, Alemania ofreció la ayuda técnica para transformar cañones de campaña en servicio en el

\footnotetext{
${ }^{515}$ Eran denominadas en el argot alemán, 2,5 cm Pak $113(f)$ y en el francés, canon leger de 25 antichar SA-L mle 1937.

516 "Resúmenes de las sesiones". Documentación del general Carlos Martínez de Campos. AGMAV. Caja 24.711 carpeta 5. Fondo del antiguo Ministerio del Ejército.

${ }^{517}$ Hay que hacer la salvedad de que en los últimos meses del conflicto civil español, el Ejército Popular de la República recibió a través de la frontera francesa 16 cañones de este calibre, probablemente del modelo Hotchkiss-Puteaux S.A.L. 37. Manrique Gacía, J.M. y Molina Franco, L. Las armas de la Guerra Civil española, op. cit., pág. 246.
} 
ejército español, en verdaderas piezas aptas para su empleo contra los carros de combate, algo que ya había realizado la industria alemana con alguno de sus aliados.

En la página 7 del documento citado anteriormente -Epígrafe IV. Artillería-, figuraba la modificación de 200 piezas de 7,5 cm españolas L/36 (f), para convertirse en anticarro tras su montaje en el afuste Mod. 38. Esta cantidad se vería disminuida tras las reuniones mantenidas por el general Martínez de Campos en Berlín a únicamente 50 unidades. Al final, solamente se enviaron a Alemania dos de estos cañones completos, con 250 disparos, para estudiar la citada transformación, regresando a España convenientemente modificados en el tren $\mathrm{n}^{\mathrm{o}} 23$ del "Restprogramm", el 21 de abril de 1944, como tendremos ocasión de analizar posteriormente.

Por último, en el Epígrafe V de la Relación General del "Programa Bär", podemos ver que Alemania ofreció munición de rabiza ${ }^{518}$-de carga hueca-, para emplear con los cañones alemanes Pak 35/36, de 3,7 cm que, procedentes de la Guerra Civil, prestaban servicio en las unidades "contracarro" españolas. Se trataba de potenciar unos cañones obsoletos por el paso del tiempo y de los rápidos avances experimentados en el transcurso del conflicto mundial, con una munición potente y apta para los mismos. Se decidió solicitar 15 de estos proyectiles por cada cañón de este modelo presente en España. Como la cantidad de estas piezas existentes en el ejército español era de 302, la suma total de granadas de rabiza incluidas en el “Programa Bär" sería de 4.530.

Se trataba de la denominada en el argot alemán de la Wehrmacht "Stielgranade 41", manufacturada entre 1942 y 1943 y fabricada en número aproximado de 636.000 unidades $^{519}$. Como el Ejército alemán disponía de un gran número de cañones contracarro Pak 35/36, de $3,7 \mathrm{~cm}$, se hizo preciso idear un tipo de munición para estos ingenios, que fuera capaz de destruir los últimos diseños de carros que ya estaban presentes en los escenarios de la contienda. Esta nueva

\footnotetext{
${ }^{518}$ En España se denominó así a los proyectiles que disponían de una prolongación en la parte trasera ("rabo" o "rabiza") y se acoplaban a la boca del cañón, como si fueran de avancarga.

${ }^{519}$ Bishop, Chris. The enciclopedia of weapons of World War Two. Metrobooks, Nueva York, 2002, págs. 182-183.
} 
munición permitió mantener en servicio hasta 1943 los Pak 35/36, desfasados y superados desde varios años atrás por modelos de mayor calibre y prestaciones.

Básicamente la "Stielgrenate 41" era un proyectil dotado de "rabiza", armado con una cabeza antitanque de alto explosivo que se introducía en el tubo del cañón por la boca de fuego, y era capaz de penetrar unos $180 \mathrm{~mm}$ en el blindaje de cualquier carro de combate, siempre que el proyectil impactara con un ángulo de $90^{\circ}$. Sin embargo, debido a que el proyectil pesaba la respetable cifra de $8,5 \mathrm{~kg}$ y que la velocidad inicial que alcanzaba era bastante discreta $-110 \mathrm{~m} / \mathrm{s}-$, el arma era útil siempre que estuviera a muy poca distancia del carro de combate -máximo 600 metros, aunque la distancia efectiva no pasaba de los 300-. Era pues arriegado y peligroso el empleo de esta granada, y sólo era eficaz si las dotaciones de las piezas eran aguerridas y experimentadas ${ }^{520}$.

Analizaremos ahora con más detalle cada uno de los cañones contracarro comprendidos en el "Programa Bär" que España adquirió durante 1943 y 1944, así como los cañones de campaña franceses que se intentó transformar en Alemania.

El más ligero de ellos era un cañón francés de $25 \mathrm{~mm}$ de calibre, que había sido capturado por los alemanes en 1940, tras la ocupación de Francia, cuya denominación germana era 2,5 cm Pak 113 (f). En los primeros años 30 hubo una creciente preocupación por obtener armas aptas para enfrentarse a lo que era ya una nueva amenaza: el carro de combate, también denominado tanque. Francia, que era era una potencia militar de primer orden, sintió esa amenaza y la casa Hotchkiss et Cie aprovechó un diseño finalizado en la década de los años 20, de un cañón de 25 mm para carro de combate y lo montó sobre un afuste ligero de campaña, siendo adoptado por el ejército francés como cañón anticarro de infantería, con la denominación "canon léger de 25 antichar SA-L mle. 1934", conocido también de manera abreviada como "34 SA".

El tubo tenía 72 calibres de largo y a pesar de su elevada velocidad inicial, solo podía perforar vehículos blindados ligeros. Además, sus 496 kilogramos de peso lo hacían relativamente pesado para sus características. Como se necesitaba una pieza más ligera, la empresa armera Puteaux proyectó y desarrolló un modelo denominado

\footnotetext{
${ }^{520}$ Estas granadas de rabiza fueron exportadas también a Finlandia, que adquirió unas 5.000 el 26 de agosto de 1942. http://www.jaegerplatoon.net/AT_GUNS1.htm.
} 
“canon leger de 25 antichar SA-L mle 1937”. Tenía un cañón más largo, de 77 calibres, y mejoraba algo el sector de tiro vertical, pero el resto de características eran prácticamente idénticas a su antecesor ${ }^{521}$.

Las alemanes los incorporaron a su arsenal tras la victoria en el Oeste, denominando a los primeros "2,5 cm Pak 112 (f)" y a los segundos "2,5 cm Pak 113 (f)". Por sus limitadas características, la Wehrmacht desarrolló un brocal para que estos cañones pudieran lanzar granadas de carga hueca de $6,6 \mathrm{~cm}$ de calibre, las cuales se enroscaban en la boca del arma en lugar de la bocacha apagallamas que traía de origen, algo muy parecido a lo que hicieron para sus cañones de preguerra Pak $35 / 36$ de $3,7 \mathrm{~cm}$. Pese a estas mejoras, muy pocas unidades germanas de la Wehrmacht lo tuvieron de dotación; únicamente sería empleado en segunda línea y en determinadas posiciones de la "Muralla del Atlántico", así como en las Islas del Canal de la Mancha. Al igual que sucedía con las armas contracarro de calibre 3,7 cm, estos cañones de 2,5 cm estaban tecnológicamente superados en 1941, tanto por su diseño como por su pequeño calibre y sobre todo, por su concepción, pues no olvidemos que en origen no dejaba de ser una mera pieza de acompañamiento de la infantería. Por todo ello, los alemanes intentaron vender los excedentes a los países a los que suministraban material militar ${ }^{522}$, y España fue uno de ellos.

Incomprensiblemente $-\mathrm{y}$ se trata de un juicio personal-, las autoridades militares españolas y el general Martínez de Campos, a la sazón presidente de la comisión española en Berlín para la negociación del "Programa Bär", aceptó esta "patata caliente" que le colocaron los negociadores germanos en las listas de "material enajenable". El error al aceptar este material -antiguo, usado, desfasado e inutil para la lucha contra el carro de combate en 1943, año de su adquisición, saltó a los documentos oficiales de la época cuando, recién llegadas las piezas en octubre de 1943, en el tren $n^{0} 5^{523}$, el EMCE intentó por todos los medios no aceptarlos y devolverlos a Alemania, algo que como veremos, no fue posible.

\footnotetext{
${ }^{521}$ Bishop, Chris. The enciclopedia of weapons of World War Two, op. cit., págs. 89 y 190.

${ }^{522}$ Finlandia compró a Alemania dos centenares de piezas de este calibre en 1940, producto del botín de guerra. De ellas, 133 eran del modelo "34 SA" y 67, del modelo "37 SA". Estuvieron en servicio en este país hasta finales de la década de los años 50 . Parece ser que Italia también adquirió piezas del modelo "34 SA". http://www.jaegerplatoon.net/AT_GUNS1.htm

${ }^{523}$ De los 150 cañones que se debían recibir en el citado tren $\mathrm{n}^{\mathrm{o}} 5$, solo llegaron 138 , pues 12 que venían en un vagón, quedaron detenidos en París. Se recibirían más tarde. Junto con las piezas, en el mismo tren $\mathrm{n}^{\mathrm{o}} 5$, llegaron 25.000 disparos.
} 
Ya en un informe ${ }^{524}$ redactado en noviembre de 1941 por la Junta Facultativa de Estudios, Proyectos y Experiencias de la Dirección General de Industria y Material, se afirmaba que con los datos con los que entonces se contaba -que eran bastante incompletos-:

“...Sería introducir un calibre nuevo en el Ejército y de una eficacia, si bien superior al cañón de $20 \mathrm{~mm}$, inferior al cañón anticarro de $45 \mathrm{~mm}$, cuyo calibre y aun mayores parecen ser los más ventajosos actualmente para este empleo.

No parece pues, por principio, conveniente, el calibre de 25 $\mathrm{mm}$, sin embargo, si por necesidades o conveniencias de urgencia conviniese su adopción, debe considerarse el arma dentro de su calibre y de no ser antiaérea, como una pieza moderna y de características buenas..."

Creo que no hay ninguna duda en los argumentos ofrecidos por una Junta Técnica militar reunida en 1941 para evaluar este cañón; si bien en aquella fecha podía considerarse "moderna" y de "características buenas" por parte de los españoles, la opinión de la Junta no era favorable a su adquisición por motivos de peso. Que se adquiriera dos años más tarde un centenar y medio de cañones de este mismo modelo, creo que no tiene justificación alguna.

Los cañones aceptados por España, agrupados en la denominada "partida $n^{\circ} 48^{\prime}$ del "Programa Bär", vinieron acompañados tanto de munición normal de varios modelos, como por otra supercalibrada, apta para dispararse por los cañones tras el acoplamiento de brocales fabricados al efecto, como hemos visto anteriormente.

Pese a que se había negociado en Berlín la adquisición de 30.000 proyectiles perforantes Mod. 114, otros 30.000 trazadores Mod. 115 y 4.000 perforantes explosivos Mod. Especial de 6,6 cm, la realidad fue otra muy distinta, pues en este caso, los alemanes jugaban con un material capturado -no fabricado por ellos- y las disponibilidades del mismo eran las que marcaban las posibilidades de entrega. Al final, los 60.000 proyectiles previstos de los modelos 114 y 115 -a partes iguales- tuvieron que convertirse en 48.760 Mod. 114 y 114f, 4.320 Mod. 115 y 6.920 Mod. 116 también trazador-, cifras éstas que sumadas nos dan la misma cantidad de 60.000 proyectiles. La tabla siguiente recoge sus características principales.

\footnotetext{
${ }^{524}$ Acta n $^{\circ} 184$ de la Junta Facultativa de Estudios, Proyectos y Experiencias -Primera Sección, Primer Negociado- de la Dirección General de Industria y Material. Libros de Actas. APEC.
} 


\section{TABLA V-J}

\section{MUNICIÓN ANTITANQUE DE 25 mm}

\begin{tabular}{|l|l|l|l|l|}
\hline $\begin{array}{l}\text { Munición antitanque } \\
\text { de } 25 \mathrm{~mm}\end{array}$ & $\begin{array}{l}\text { Mod. 114 y 114f } \\
\text { Perfor. macizo }\end{array}$ & $\begin{array}{l}\text { Mod. 115. } \\
\text { Perfor. trazador }\end{array}$ & $\begin{array}{l}\text { Mod. 116. } \\
\text { Perfor. trazador }\end{array}$ & $\begin{array}{l}\text { Especial. Perforante } \\
\text { explosivo }\end{array}$ \\
\hline Calibre & $2,5 \mathrm{~cm}$ & Idem. & Idem. & $6,66 \mathrm{~cm}$ de avancarga \\
\hline Peso total & 320 y $326 \mathrm{gr}$ & $317 \mathrm{gr}$ & $313 \mathrm{gr}$ & $2.000 \mathrm{gr}$ \\
\hline Carga de proyección & $135 \mathrm{y} 141 \mathrm{gr}$ & $141 \mathrm{gr}$ & $135 \mathrm{gr}$ & $18 \mathrm{gr}$ \\
\hline Velocidad inicial & 900 y $960 \mathrm{~m} / \mathrm{s}$ & idem & Menor & - \\
\hline Color ojiva y anillo & $\begin{array}{l}\text { Negro- rojo y } \\
\text { negro-negro }\end{array}$ & $\begin{array}{l}\text { Verde claro- } \\
\text { verde claro }\end{array}$ & $\begin{array}{l}\text { Verde oscuro- } \\
\text { amarillo }\end{array}$ & - \\
\hline
\end{tabular}

Fuente: elaboración propia. Dirección General de Industria y Material. Ministerio del Ejército. Folleto R-7. Cañón contra carros calibre 25 mm Hotchkiss-Puteaux Mod. 37-S.A.L. Descripción y funcionamiento del material y sus municiones. Madrid, 1944.

En el tren $\mathrm{n}^{0} 5$ del denominado "Restprogramm" se recibieron, además de los propios cañones, 23.000 proyectiles perforantes Mod. 114f (partida 49) y 4.000 granadas de carga hueca de $6,6 \mathrm{~cm}$ para ser empleadas con el brocal especial (partida 51). En el tren $n^{\circ} 21$ llegaron 25.760 proyectiles perforantes modelo 114 (partida 49), 4.320 proyectiles perforantes-trazadores del modelo 115 (partida 50), y 6.920 proyectiles perforantes-trazadores del modelo 116 (partida 50).

A última hora se amplió el pedido de munición para estos cañones, organizándose la denominada "Partida 83" que contemplaba la entrega de 4.619 proyectiles Mod. 117 y 45.381 del Mod. 118, sumando entre ambos otros 50.000 cartuchos. Dicha partida nunca llegó a salir de Alemania, considerándose la misma como material no suministrado. 
TABLA V-K

MUNICIÓN SOLICITADA Y RECIBIDA PARA PIEZAS DE 2,5 cm PAK 113 (F)

\begin{tabular}{|l|c|c|c|c|c|}
\hline \multicolumn{1}{|c|}{ Proyectiles } & Solicitados & Aprobados & Recibidos & Partida Bär & Tren \\
\hline Mod. 114 y 114f & 30.000 & 48.760 & 48.760 & 49 & 5 y 21 \\
\hline Mod. 115 & 30.000 & 4.320 & 4.320 & 50 & 21 \\
\hline Mod. 116 & 0 & 6.920 & 6.920 & 50 & 21 \\
\hline Mod. 117 & 4.619 & 4.619 & 0 & 83 & No llegó \\
\hline Mod. 118 & 45.381 & 45.381 & 0 & 83 & No llegó \\
\hline Especial rabiza & 4.000 & 4.000 & 4.000 & 51 & 5 \\
\hline Total & $\mathbf{1 1 4 . 0 0 0}$ & $\mathbf{1 1 4 . 0 0 0}$ & $\mathbf{6 4 . 0 0 0}$ & & \\
\hline
\end{tabular}

Fuente: elaboración propia. Carta del teniente coronel Romero de Arcos al coronel Aguirre fechada en Berlín el 10 de marzo de 1944. AGMAV. Caja 24.711.

Tanto los cañones recibidos como la munición para los mismos, quedaron en Irún - estación de llegada- en 28 vagones cerrados y precintados, con guardia militar, a la espera de los resultados de las gestiones de cambio que llevó a cabo el Agregado Militar en Berlín por indicación de las autoridades del Ministerio del Ejército. De hecho, antes de partir para España, ya habían estado retenidos unos días en Alemania cargados en los vagones de ferrocarril-, en espera de una contestación favorable a la solicitud de permuta por otros cañones de la misma clase, pero de calibre $75 \mathrm{~mm}$, por parte de las autoridades alemanas, contestación que no se llegó a recibir

Hasta primeros de noviembre de 1943 estuvieron los cañones retenidos en Irún sin que las gestiones del Agregado Militar español en Berlín surtieran ningún efecto ${ }^{525}$. Cuando se vio que era imposible la devolución de estos cañones a Alemania para su cambio por otros de 7,5 cm, fueron remitidos al Parque de Artillería de Burgos junto a 23.000 disparos completos del modelo 114f, para su recepción y reconocimiento, hecho que ocurriría el 7 de enero de 1944. A partir de ese momento, se supo que las piezas no

\footnotetext{
${ }^{525}$ De hecho, existe un telegrama fechado en Berlín del 4 de noviembre de 1944 que reza así: "Mando alemán no considera posible conceder mayor número de cañones anticarros calibre superior a $25 \mathrm{~mm}$ como compensación eventual renuncia de estos últimos." En la copia de dicho telegrama existe una anotación a lápiz del propio general García Valiño que dice: “ Transpórtese los de 25 a Parque. 5-XI-44". Telegrama recibido en la Sección segunda del EMCE referencia 803 de 4 de noviembre de 1944. AGMAV. Caja 21.006. Fondo del antiguo Ministerio del Ejército. Las gestiones en Berlín del Agregado Militar, teniente coronel Marín de Bernardo no dieron su fruto, pese a que éste había solicitado una entrega mensual de 25 cañones de $7,5 \mathrm{~cm}$ (total seis meses) para sustituir a los 150 cañones franceses.
} 
volverían a Alemania y que deberían ser distribuidas entre las unidades. Por eso el 9 de noviembre de 1943, el coronel Jesús Aguirre, del EMCE, solicitaba información al también coronel Díaz Gómez, destinado en la DGIM del Ministerio del Ejército - donde se habían estudiado las piezas francesas $-{ }^{526}$ :

“...Acerca de esta pieza nos convendría saber para su pronta distribución, su movilidad, peso, etc... y sobre todo la aplicación que os parece se le debería dar. ¿Serviría para los Regimientos de Infantería?..."

Los "cañoncitos" franceses terminarán repartidos entre diferentes regimientos de Infantería del territorio nacional y varias unidades de montaña, donde se integraron en las compañías de armas pesadas, en secciones de defensa contracarro. El pelotón de dos piezas estaba al mando de un sargento, cada pieza la mandaba un cabo y tenía cuatro sirvientes: apuntador, sirviente de cierre, cargador y artificiero ${ }^{527}$.

Muy poco se conoce de su actuación en el seno las unidades españolas, pero por su estado e ineficacia para el cumplimiento de la misión, tuvieron que ser dadas de baja a finales de la década de los años cuarenta, siendo sustituídas por material de 45 y 60 mm producido en España por la SAPA. De los 150 que llegaron solo se conservan dos ejemplares en España: uno es el cañón no 167, fabricado por Puteaux en 1939 y depositado en el Museo de Medios Acorazados de El Goloso (Madrid); y el otro, del que desconocemos su número de identificación, se conserva en el polvorín de Sierra Elvira (Granada).

El cañón de 7,5 cm Panzerabwehrkanone 40 -Pak 40- fue quizás el cañón contracarro alemán más empleado en la Segunda Guerra Mundial. Comenzó su diseño en 1939, cuando el departamento de armamentos germano (Waffenamt) preveía que el incremento del blindaje de los carros de combate modernos iba a dejar obsoletos a todos los diseños en servicio en los países que los poseían. El OKW encargó el desarrollo de armas contracarro pesadas a "Krupp" y "Rheinmetall” en ese año, aunque no sería hasta junio de 1941 cuando se acelerara el proceso, tras observar los alemanes la

\footnotetext{
${ }^{526}$ Nota no 4766-M de la 4 a Sección del EMCE. AGMAV. Caja 24.704. Fondo del antiguo Ministerio del Ejército.

${ }^{527}$ Dirección General de Industria y Material. Ministerio del Ejército. Folleto R-7. Cañón contra carros calibre $25 \mathrm{~mm}$ Hotchkiss-Puteaux Mod. 37-S.A.L. Descripción y funcionamiento del material y sus municiones. Madrid, 1944.
} 
invulnerabilidad frente a sus armas contracarro de los poderosos blindados soviéticos $\mathrm{KV}-1$ y $\mathrm{KV}-2$.

A finales de noviembre de 1941 aparecería en escena el diseño de "RheimetallBorsig", denominado Pak 40, que no era otro que el montaje del precedente Pak 38 (pieza contracarro de $50 \mathrm{~mm}$ ), dotado de un cañón de $75 \mathrm{~mm}$ FK 40 L/46 así como de un escudo protector de los sirvientes plano y de mayor grosor. Comenzó a entregarse a las unidades en el verano de 1942.

Fue la pieza contracarro alemana fabricada en mayor número a lo largo del conflicto bélico, alcanzando la cifra de 23.500 ejemplares $^{528}$, exportándose a varios de los aliados de Alemania como Rumanía, Hungría, Bulgaria, Italia o Finlandia ${ }^{529}$, así como a algunos países no beligerantes, como España.

Se trataba, pues, de una muy buena adquisición ya que era el arma antitanque standard germana en el conflicto mundial y cuando llegó a España, su diseño no hacía todavía dos años que había entrado en servicio con la Wehrmacht. La cantidad de 150 cañones fue también suficiente para cubrir las necesidades españolas en esos años, aunque las autoridades encargadas de su adquisición se percataron -tarde- de que habría sido mucho mejor opción haber renunciado a los 150 cañones franceses de $2,5 \mathrm{~cm}$ y haber incrementado esta partida de piezas de 7,5 $\mathrm{cm}$ Pak 40 en, al menos, otros 50 cañones más.

En cualquier caso, los cañones antitanque de "Rheinmetall" de 7,5 cm Pak 40 (partida 52) contratados en el "Programa Bär" llegaron en tres expediciones diferentes todas ellas comprendidas en el denominado "Restprogramm"-, en concreto lo harían en el tren $n^{\circ} 13$, en el que llegaron a Canfranc los primeros 75 cañones el 20 de noviembre de 1943; en el tren $\mathrm{n}^{\circ}$ 19, donde se recibirían en Irún otras 50 piezas el 2 de febrero de 1944; y por último en el tren $n^{0} 21$, que transportó también a Irún el 11 de marzo de 1944, los 25 cañones restantes para completar la partida. La munición contratada por la Comisión para estas piezas fue de dos tipos: una granada rompedora denominada Mod. 34 y otra de carga hueca referenciada como Mod. 38 H.L./C. El total de proyectiles

\footnotetext{
${ }^{528}$ Gander, Terry y Chamberlain, Peter. Weapons of the Third Reich: An Encyclopedic Survey of All Small Arms, Artillery and Special Weapons of the German Land Forces 1939-1945. Doubleday, Nueva York, 1979, pág. 197.

${ }^{529}$ Los finlandeses recibieron 210 cañones contracarro Pak 40 en sendos envíos realizados entre mayo de 1943 y agosto de 1944. http://www.jaegerplatoon.net /AT_GUNS1.htm.
} 
negociados para estos cañones fue de 45.000 unidades (Partida 53), correspondiendo la mitad de ellos al Mod. 34 y la otra mitad al modelo 38. Tras laboriosas gestiones llevadas a cabo por el teniente coronel Marín de Bernardo, en octubre de 1943 obtuvo el permiso para importar 10.000 proyectiles perforantes modelo PzG.39, considerando esta adquisición dentro del "Programa Bär" y asignándole el número de partida 84, el último de los del Ejército de Tierra.

En el tren $\mathrm{n}^{\mathrm{o}} 15$ llegarían 22.500 proyectiles rompedores Mod. 34 de la partida 53 y 4.000 perforantes de la partida 84; posteriormente, en el tren $\mathrm{n}^{\circ} 19$ se recibieron otros 4.000 proyectiles perforantes de la partida 84 , en el tren $n^{\circ} 21$, vendrían los 2.000 proyectiles restantes de los perforantes de la partida 84 , que quedaba de esta forma completa. Por último, en el tren $\mathrm{n}^{\circ} 24$ llegaron los 22.500 restantes del Mod. 38, correspondientes a lo que quedaba de la partida $n^{0} 53$.

TABLA V-L

MUNICIÓN SOLICITADA PARA PIEZAS DE 7,5 cm PAK 40

\begin{tabular}{|l|c|c|c|c|}
\hline \multicolumn{1}{|c|}{ Proyectiles } & Solicitados & Recibidos & Partida Bär & Tren \\
\hline Mod. 34 & 22.500 & 22.500 & 53 & 15 \\
\hline Mod. 38 & 22.500 & 22.500 & 53 & 24 \\
\hline Perforantes & 10.000 & 10.000 & 84 & 15,19 y 21 \\
\hline Total & 60.000 & 60.000 & & \\
\hline
\end{tabular}

Fuente: elaboración propia. Datos extraidos del Anexo XIV.

Con estas piezas se dotaron las compañías de cañones contracarro de algunos de los Regimientos de Infantería, así como los batallones de defensa contracarro encuadrados en las Divisiones ${ }^{530}$. Según las plantillas de la época, las compañías contracarro disponían de seis cañones de 75/46, y estaban constituidas por tres

\footnotetext{
${ }^{530}$ A partir de mediados de los años sesenta, los cañones alemanes de 75/46 supervivientes se fueron reuniendo en el Regimiento de Infantería de Defensa Contracarro "Toledo" $\mathrm{n}^{\mathrm{o}} 35$, de guarnición de Zamora, conviviendo con los cañones sin retroceso norteamericanos CSR de $106 \mathrm{~mm}$, así como con los misiles filoguiados "Cobra", de patente también alemana. Finalizaron su vida activa en el Ejército español en enero de 1977, cuando se entregaron los últimos 42 cañones Rheinmetall que disponía el Regimiento zamorano, distribuyéndose a continuación por diversos acuartelamientos de la geografía española para ornamentación, conservándose en diferentes estados, hoy día, la mayoría de ellos. Quizás sea España el país del mundo que mayor número de estas piezas conserva. El autor ha localizado más de treinta ejemplares en diversos acuartelamientos y museos españoles, queriendo destacar los del Museo de Unidades Acorazadas de El Goloso (Madrid), donde hay dos ejemplares, el Museo Militar de Valencia (un ejemplar), diversos acuartelamientos de la ciudad de Valladolid (hasta ocho ejemplares), Tenerife (cuatro ejemplares), Burgos, Segovia, Zaragoza, Sevilla, Cartagena, Mallorca, etc...
} 
secciones de dos pelotones cada una. Cada pelotón disponía de una pieza contracarro y encuadraba un jefe (sargento o cabo $1^{\circ}$ ), un cabo apuntador, un soldado de $1^{\mathrm{a}}$ artificiero, un soldado cargador y dos soldados proveedores; además, el pelotón también disponía de un fusil ametrallador de protección, con un cabo y tres soldados; en total diez hombres.

Al igual que ocurriera con muchísimas piezas Schneider de origen francés, capturadas por el Ejército alemán tanto en la campaña polaca como en el frente occidental en 1940, y que fueron transformadas por los alemanes en cañones contracarro $^{531}$, en las conversaciones del general Martínez de Campos en Berlín con las autoridades alemanas se ofreció a España modificar 200 cañones franceses de $75 \mathrm{~mm}$, de los que todavía nuestro ejército mantenía un gran número en servicio tras la guerra, para ser utilizados en este cometido. La transformación, al igual que se había hecho ya para Finlandia ${ }^{532}$, consistía en adaptar un montaje del Pak $38^{533}$ al cañón francés, aunque en este caso sería un modelo diferente: se trataba del Schneider de $75 \mathrm{~mm}$ Mod. $1918-22$ de 40 calibres $^{534}$.

\footnotetext{
${ }^{531}$ Entre 1942 y 1943, los alemanes llegaron a manufacturar la transformación de cerca de 3.700 cañones franceses Schneider de $75 \mathrm{~mm}$ Mod. 1897, que en la jerga militar germana pasaría a denominarse 7,5 $\mathrm{cm}$ Pak 97/38, haciendo referencia los primeros dos dígitos al modelo original francés, y los dos últimos, al montaje sobre el que se había instalado el cañón, correspondiente a un Pak 38. El motivo era obvio: los contracarro en servicio tras la operación "Barbarroja" no podían atravesar el grueso blindaje de los carros soviéticos T-34, KV-1 y KV-2 y el Pak 40 de 75 mm todavía no estaba listo. Disponía como elemento distintivo del original francés, de un prominente freno de boca desarrollado por la empresa suiza Solothurn. Esta pieza no era lo que pudiéramos llamar un buen cañón contracarro, pues no había sido diseñado para ese cometido, pero cumplía su misión de manera discreta y era barato de producir, algo muy importante en esa fase del conflicto. Por su inestabilidad y fuerte retroceso con munición perforante, los alemanes le pusieron el mote de "Mustang". Vid. http://www.jaegerplatoon.net /AT_GUNS1.htm. y http://sturmvogel.orbat.com/GermWeapProd.html

532 En febrero de 1943, Finlandia desmontó todos sus cañones de $75 \mathrm{~mm}$ Mod. 1897 de sus emplazamientos y encargó a Alemania la transformación de 60 piezas de campaña francesas Mod. 1897, de las que disponía en sus arsenales -48 de ellas adquiridas junto a 50.000 disparos en Francia, poco antes de la derrota de 1940-, en cañones contracarro Pak 97/38, aptos para enfrentarse a los potentes soviéticos T-34, KV-1 y KV-2. Los cañones modificados llegarían a Finlandia en marzo y junio de ese mismo año. Los finlandeses los denominaron "Mulatti" (mulato), en clara referencia a su diseño, que combinaba dos modelos diferentes de dos países distintos. Los 39 cañones de este modelo que sobrevivieron a la Segunda Guerra Mundial, se mantuvieron en servicio en el Ejército finés hasta bien entrado el año 1986, en que fueron declarados obsoletos. http://www.jaegerplatoon.net/AT_GUNS1.htm.

${ }^{533}$ En Alemania el Pak 38, con cañón de $50 \mathrm{~mm}$, estaba ya en desuso debido a que había entrado en servicio el Pak 40, de $75 \mathrm{~mm}$, más potente y eficaz en la lucha contra los ingenios blindados presentes en los campos de batalla europeos.

${ }^{534}$ El cañón Schneider Mod 1918-22, de 75 mm y 40 calibres (denominado también “75 largo”) era una pieza francesa fabricada tras el final de la Primera Guerra Mundial, con la intención de ofrecer un cañón con mayor alcance y mejores prestaciones que el modelo 1897, reglamentario en Francia por esas fechas.
} 
Se remitieron desde España sendas piezas Schneider junto a 250 disparos para las mismas, que fueron entregadas por el Agregado Militar en la fábrica de Kunnersdorf, donde los trabajos sobre las mismas no avanzaron lo previsto. Los ingenieros alemanes encontraron bastantes dificultades de adaptación del tubo francés al montaje del Pak 38 alemán ${ }^{535}$.

Poco más se sabe de esta transformación, aunque por los resultados finales es obvio deducir que los técnicos germanos no fueron capaces de acoplar el tubo francés al afuste alemán con todas las garantías, y ambos cañones enviados a Alemania regresaron a España sin que se modificaran más ejemplares y sin que dichos cañones se entregaran al Ejército español para ser utilizados en unidad alguna.

En el tren no 23 del "Programa Bär", que llegó a la frontera española el 24 de abril de 1944, venían de vuelta estos dos cañones de campaña "transformados" en Alemania. No se les asignó ningún número de partida.

Hasta hace muy poco tiempo, se conservaba uno de ellos en el acuartelamiento de Camposoto (Cádiz), para ornamentación.

\section{V.6.- OTRO MATERIAL CONTRACARRO. MINAS, GRANADAS, FUSILES Y BROCALES}

\section{V6.1.- Las minas terrestres.}

La guerra de minas ha sido de uso común desde la antiguedad. Con la aparición de los fulminantes y explosivos se extendió también el uso de "minas automáticas", cuyas improvisadas espoletas funcionaban normalmente por la presión que ejercía el objetivo al pasar sobre ellas. En la Guerra de Cuba (1895-1898) se empleó, contra el tráfico ferroviario, el denominado "Explosor Roqué”, el cual disponía de un contador de

Nunca llegó a ser adoptada en su país de origen, aunque se fabricaron en pequeñas cantidades para otros ejércitos, como el polaco que dispuso de por lo menos una batería. Cuatro cañones serían enviados al Ejército republicano en el vapor "Silvia", que fue capturado por los nacionales, quienes los incorporaron a su parque artillero. Otras cuatro piezas, posiblemente procedentes de Francia, combatieron con la artillería republicana. Habían sido fabricados por Creusot (Francia) en 1929 para Polonia y conservaban el águila blanca del escudo polaco grabada en su culata. Datos aportados por el investigador Javier Villarroya, quien descubrió una de estas piezas en el acuartelamiento de Camposoto (Cádiz), como ornamentación. También vid. Manrique García, J.M. y Molina Franco, L. Las armas de la Guerra Civil española, op. cit., pág. 249.

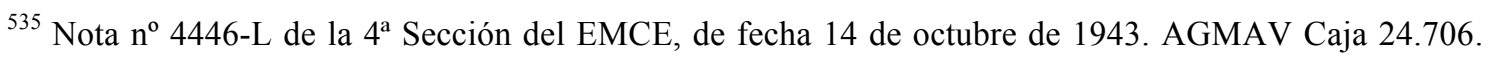
Fondo del antiguo Ministerio del Ejército. 
los ejes de vagón que pasaban sobre él, para hacer estallar la mina en la parte del que se eligiese. Durante la Guerra del Rif (1921 a 1926) se utilizaron en forma de campos de minas eléctricos, en ocasiones se usaron las minas automáticas y rara vez las galerías de $\operatorname{mina}^{536}$.

En el transcurso de la Guerra Civil española se fueron determinando conceptos tales como campo y masa de minas, filas de minas, grupos de minas, minas ancladas, minas trampa, etc, adelantándose a lo que sería muy habitual en la Segunda Guerra Mundial. A los campos de minas contracarros se les añadieron las minas contrapersonal, para hacerlos más eficaces. También llegó a ser habitual su utilización delante de las posiciones.

A partir de los primeros meses de la guerra de España, y en los dos bandos, todas de las minas que se instalaron quedaron perfectamente situadas topográficamente.

En la lucha contra carro que se dio entorno a Madrid el otoño e invierno de 1936 hay constancia documental de una mina denominada "Defensa Contratanques Romero", la cual se utilizó ampliamente durante toda la guerra por el Ejército republicano y que era conocida por los nacionales como "Z-400", era una mina muy desarrollada, con espoleta externa de funcionamiento eléctrico de gran sensibilidad, fiabilidad y seguridad; su peso total era de unos $70 \mathrm{~kg}{ }^{537}$.

Por aquellas mismas fechas el bando nacional utilizaba una mina automática terrestre cargada con trilita y dotada de cuatro detonadores y una espoleta química, aunque no debió tener muy amplia difusión ${ }^{538}$.

En mayo de 1937 Alemania suministró numerosas minas contracarro "T" o "Teller". Eran cilíndricas y compactas $-30 \mathrm{~cm}$ de diámetro por 10 de altura-, su espoleta se accionaba por presión y su eficacia equivalía a la de un proyectil de cañón de $15 \mathrm{~cm}$ actuando sobre la parte menos protegida del tanque. Era de construcción estanca y se suministraba completa. Alemania también suministró rollos de alambre de espino tipo "K" en forma de "concertinas" de $1 \mathrm{~m}$ de diámetro por apenas $20 \mathrm{~cm}$ de ancho (plegado), los cuales podían extenderse hasta 8 a 10 metros y ofrecían cierta

\footnotetext{
536 Arévalo Molina, Jacinto: “Minas en la Guerra Civil Española”; Memorial de Ingenieros $n^{\circ}$ 58, Madrid (Hoyo de Manzanares) 1998.

${ }^{537}$ Bonilla, Miguel. Apuntes para la Escuela de los Ayudantes de Artificiero; Servicio de Recuperación de Material de Guerra, Región Centro, 1940.

${ }^{538}$ Manrique García, J.M. y Molina Franco, L. Las armas de la Guerra Civil española, op. cit., pág. 150.
} 
capacidad de detención contra los carros de la época, sobre todo colocadas en varias filas.

En octubre de 1937 comenzaron a usarse las minas B-2, las cuales eran metálicas y de forma prismática alargada, con el explosivo situado en sus extremos. Durante ese mismo año se diseñaron y fabricaron en Sevilla las minas denominadas "Montoro" y "H-I". Eran cajas rectangulares de madera o baquelita, con espoleta central muy efectiva. Ambas resultaron muy superiores a la B-3 italiana (entregada a los alzados por el CTV y más baratas y fáciles de construir que la mina "T" alemana.

En el campo republicano se perfeccionó la mina Z-400, construyéndola en un cofre de fundición herméticamente cerrado, en el que se alojaban hasta 100 cartuchos de dinamita y dos detonadores y se utilizaron también eficaces minas rusas, de forma cilíndrica y con espoleta de presión, similares a la que posteriormente sería conocida como TM-41.

En las negociaciones mantenidas por la Comisión Extraordinaria para Material de Guerra en Berlín, en marzo y abril de 1943, se trató con mucho detalle el asunto de la lucha contra el carro de combate, al que los negociadores españoles dieron la mayor importancia. Además de los cañones contracarro, arma colectiva de infantería, se negoció la adquisición de armas individuales del soldado de infantería para la citada lucha, así como armas para el soldado de zapadores (Ingenieros), muy expuesto en el combate en primera línea, a los efectos de los carros de combate enemigos. Aquí entraban en juego, precisamente, las minas.

Alemania ofreció entonces el envío de 200.000 minas contracarro, de las cuales 50.000 serían T-42, el modelo germano más avanzado en servicio, y otras 150.000 , de recuperación francesa, de escasa calidad a ojos de los negociadores españoles. También se ofrecieron 6.000 minas magnéticas $\mathrm{H} 2$, que disponían de un dispositivo para ser "pegadas" a los carros de combate enemigos.

En el Epígrafe III -material para el Ejército de Tierra- de la relación general del "Programa Bär" 539, figuraban tres tipos de material para la lucha inmediata contra los carros de combate, ofrecidos por el gobierno alemán: minas de contacto, granadas de humos y minas tradicionales. De las de contacto ofrecían los germanos 6.000 , las cuales

\footnotetext{
${ }^{539}$ W Stb (Ausl.) 3. Abtl. Anexo 1 Relación General. 29 de abril de 1943. AGMAV Caja 24.711. Fondo del antiguo Ministerio del Ejército.
} 
fueron todas ellas aceptadas; de las granadas de humo, ofrecieron 20.000, que al igual que las anteriores, se aceptaron en su totalidad. De las minas tradicionales, solo se aceptaron la mitad de las 200.000 ofrecidas. Además, se consiguió en las reuniones que de la oferta inicial, que correspondía a minas de plato francesas, se pasara a minas T-42 alemanas, las más modernas en servicio en la Wehrmacht y de mucha mejor calidad que las capturadas al ejército francés. Pese a ello, al final sólo 96.000 minas serían del modelo T-42, completando hasta las 100.000 aceptadas, con otras 4.000 denominadas "ligeras", de origen alemán y también empleadas contra los carros de combate.

\section{V.6.1.1.-Las minas $T-42$ y ligeras}

La denominación T-42 era la abreviatura de Tellermine 1942. Este artefacto consistía, básicamente, en un cuerpo de acero cilíndrico de acero de $32,4 \mathrm{~cm}$ de diámetro y 10,2 cm de altura, cargado con amatol, que contenía un detonador en la parte central. Su peso total era de 7,2 $\mathrm{kg}$ y en la parte superior de la mina se encontraba el denominado plato de presión, que activaba el detonador cuando el carro de combate o vehículo pisaba la mina. Eran necesarios $340 \mathrm{~kg}$ de peso para activar la carga y que la mina hiciese explosión. Eran fabricadas en Alemania por la empresa "Richard Rinker GmbH” de Neubrandenburg (Mecklenburg) ${ }^{540}$.

De la misma manera, Rinker fabricaba una mina ligera de tan sólo $4 \mathrm{~kg}$ de peso, cuya denominación germana era lePzMine. El cuerpo de la mina era de material plástico y medía $26 \mathrm{~cm}$ de diámetro y 5,7 de altura, siendo su carga explosiva TNT. En Alemania la utilizaban, básicamente las tropas aerotransportadas y los paracaidistas, y podía ser empleada también como mina antipersonal mediante una ligera activación de cinco tuercas hexagonales que había en su parte superior ${ }^{541}$.

En el marco del "Programa Bär" el Ejército español recibió un total de 100.000 minas, de las cuales 95.950 fueron T-42 y otras 4.050 las denominadas ligeras. Las primeras 50.000 fueron transportadas hasta la frontera en el denominado "Sofortprogramm". Precisamente en el tren $\mathrm{n}^{\mathrm{o}} 1$ de este programa de entrega inmediata, que llegó a Port Bou el 31 de mayo de 1943, se transportaron 45.950 minas T-42 y

\footnotetext{
${ }^{540}$ U.S. War Department. Handbook on German Military Forces. Louisiana State University Press, Louisiana Paperback edition, 1995, pág. 491.

${ }^{541}$ U.S. War Department. Handbook on German Military Forces, op. cit., pág. 495.
} 
4.050 minas antitanque ligeras. Se trataba de las partidas 23 y 24 de este "Sofortprogramm" y necesitaron un total de 38 vagones cubiertos para su transporte, pesando este convoy unas 500 toneladas, de las que 260 correspondían a las minas.

Las otras 50.000 minas T-42 fueron incluidas en el "Restprogramm" y viajaron a España en el tren $n^{0} 11$, que llegó también a Port Bou el 2 de noviembre de 1943. En este caso fueron necesarios 36 vagones cubiertos y el peso total del convoy fue de 507 toneladas, correspondiendo al material transportado 264,6 toneladas.

Las minas venían embaladas de dos en dos, en cajas cajas de madera, y las espoletas para las mismas, con los detonadores enrroscados, se entregaron en cajas denominadas "PK 88", herméticamente cerradas.

Existe documentación de la distribución de las 50.000 minas recibidas en el "Sofortprogramm" ${ }^{, 42}$. Las minas fueron transportadas desde Port Bou hasta el Parque Central de Ingenieros de Villaverde (Madrid). Tras el reconocimiento del material recibido, las minas "T" fueron remitidas a Marruecos, Huelva, Canarias, Baleares, Algeciras y Cádiz, enviando a cada una de estas plazas 6.130 minas. Otras 9.220 quedaron en Madrid.

La distribución de las 4.000 minas ligeras, pese a que en un principio parece ser que se pensó en su envío a Melilla, quedó pendiente del reconocimiento de las mismas.

Se decía en el documento citado sobre estas minas lo siguiente:

"No parece referirse el decreto de S. E. El Ministro a esta mina que, por otra parte, viene en escaso número. El empleo que a la misma parece dársele en Alemania es el establecimiento rápido de pasos minados ante la proximidad de ataques de carros. Parece pues una mina portátil susceptible de colocarse y retirarse con gran facilidad. Podrían distribuirse por partes iguales en las unidades de zapadores de las zonas citadas, dejando un cierto número (50 por ejemplo) para enseñanza en cada uno de los Regimientos de Ingenieros $n^{\circ} 1,3,5,6,7$ y 8 ".

Hay que tener en cuenta que en esas fechas había distribuidas 6.500 minas antitanque de diseño y fabricación española denominadas B.C.G.I., 3.500 en Algeciras, 1.500 en Canarias y otras 1.500 en Marruecos. Por orden del ministro del Ejército se

\footnotetext{
${ }^{542}$ Estado Mayor del Ejército. 4 a S ección. N N 4418-F. A./Ch. Cuenta para S.E. Primera expedición. Asunto.- Distribución de 46.000 minas T (anticarros) y 4.000 minas ligeras, también contracarros. 31 de mayo de 1943. AGMAV. Caja 24.704. Fondo del antiguo Ministerio del Ejército.
} 
estaban fabricando en esas fechas otras 100.000 unidades de estas minas españolas, como también se cita en el documento al que nos referimos.

\section{V.6.1.2.- Las minas magnéticas Hafthohlladung (HHL)}

Esta mina fue utilizada principalmente por las unidades de zapadores para inutilizar carros de combate enemigos. Su base la constituían tres imanes metálicos, lo que permitía que se fijaran al chasis de acero del carro de combate sin dificultad, momento en el que el soldado que colocaba el artefacto tiraba del dispositivo de encendido, situado en la parte trasera de la mina. El eje de la explosión de la mina era perpendicular al chasis en el punto de colocación, siendo capaz de penetrar una plancha de acero de alrededor de $140 \mathrm{~mm}$. Hubo dos versiones, la denominada H3 (pesaba tres kilogramos) y la H3.5 (cuyo peso era 3,5 kilogramos). La H3m, que es la que vino a España, tenía una carga de 1,5 kg de explosivo y usaba espoletas con retardo de 7,5 o 10 segundos, que era el tiempo que tenía el zapador para ponerse lo más lejos posible del carro enemigo ${ }^{543}$.

La utilización de una pasta antimagnética sobre las superficies de los carros de combate hacía inútiles a este tipo de minas.

En el seno del "Programa Bär" se negoció la adquisición de 6.000 minas magnéticas anticarro H3m (Partida $\left.n^{\circ} 54\right)^{544}$, que llegaron a España en octubre de 1943, el tren $n^{\circ} 7$ del "Restprogramm". Dichas minas, fabricadas en Alemania por la empresa "Köln-Rottweil”, llenaban tres vagones completos (denominados Kassel 4.895, 87.394 y 26.566), agrupadas en 666 paquetes de nueve minas y uno de seis.

Las minas fueron transportadas al Parque de Artillería de Zaragoza, donde se recibieron en noviembre de 1943.

\section{V.6.2.- Las granadas de mano fumígenas}

Denominada en Alemania Blendkörper BK-2H, se intodujo en la Wehrmacht a principios de 1943 para sustituir al modelo 1H, y se empleó como arma antitanque. Consistía en un pequeño bote de cristal en forma de huevo, con un pequeño tubo, también de cristal en su interior. Ambos contenían dos soluciones químicas separadas -

\footnotetext{
${ }^{543}$ http://www.wehrmacht-awards.com/forums/showthread.php?p=5726556.

${ }^{544}$ Esta fue la cantidad que ofrecieron los alemanes en las reuniones celebradas en Berlín el 15 de marzo de 1943. Concretamente fueron incluidas en el $3^{\circ}$ Grupo, Partida ${ }^{\circ} 20$ de la relación de material ofrecido.
} 
250 gramos de tetracloruro de titanio $^{545}$ mezclado con tetracloruro de silicio ${ }^{546}$ - y 25 gramos de solución de cloruro de calcio, utilizada ésta para incrementar la efectividad de del humo en condiciones de humedad baja.

Las Blendkörper se lanzaban contra los carros de combate; en el momento del choque de la granada de cristal con el acero del blindado, aquella se fragmentaba permitiendo mezclarse los productos químicos que llevaba en su interior, creando entonces una reacción espontánea que originaba una gran humareda. Las zonas objetivo del carro enemigo eran escotillas, orificios de ventilación u otros lugares cercanos a los accesos a la zona de la tripulación pues de esta manera, los humos venenosos penetrarían en el interior del carro, incapacitando a la dotación para seguir combatiendo dentro del mismo y forzándola a abandonar el vehículo.

Se fabricaron hasta el final de la guerra unos cinco millones de granadas Blendkörper BK-2H y prácticamente todas se emplearon antes del fin del conflicto ${ }^{547}$.

En el "Programa Bär" se negoció la adquisición de 20.000 de estas granadas, considerando su adquisición como arma de zapadores para la lucha contra el carro de combate. Hay que hacer notar que en distintos documentos se las denominó de muy diferentes maneras: bombas cegadoras, granadas fumígenas,

El 20 de junio de 1943, en el denominado tren $\mathrm{n}^{\circ} 8$ correspondiente al "Sofortprogramm", se recibieron 10.000 granadas de mano fumígenas Blendkörper $2 \mathrm{H}$, correspondientes a la partida $\mathrm{n}^{\mathrm{o}} 22$.

Las otras 10.000 granadas se recibían en Port Bou el 2 de octubre de ese mismo año, formando parte del tren $\mathrm{n}^{\mathrm{o}} 3$ del denominado "Restprogramm", y enmarcado en la

\footnotetext{
${ }^{545}$ El cloruro de titanio (IV) o tetracloruro de titanio $\left(\mathrm{TiCl}_{4}\right)$, es un líquido incoloro a amarillo pálido que emite vapores de un fuerte olor. Se usa para fabricar titanio metálico y otros compuestos que contengan titanio, tales como óxido de titanio (IV), usado como un pigmento blanco en pinturas. También se usa para irisar el vidrio y, debido a que en contacto con el aire forma mucho humo, se emplea para formar pantallas de humo artificiales. http://tetraclorurodetitanio.blogspot.com.es/2011/06/tetracloruro-detitanio.html.

${ }^{546}$ El tetracloruro de silicio es un compuesto inorgánico que posee la fórmula $\mathrm{SiCl}_{4}$. Es un líquido incoloro volatil que se vaporiza en el aire. Se lo utiliza para producir silicio de alta pureza y sílice para aplicaciones comerciales. En contacto con el aire emite cloruro de hidrógeno y ácido silícico. Es corrosivo y lacrimógeno. La sustancia es corrosiva de los ojos, la piel y el tracto respiratorio. La inhalación del vapor puede originar edema pulmonar y dificultad respiratoria. La exposición a altas concentraciones puede producir la muerte. http://es.wikipedia.org/wiki/Tetracloruro_de_silicio.
}

${ }^{547}$ U.S. War Department. Handbook on German Military Forces, op. cit., pág. 404. 
partida $n^{\circ} 55$ de esta segunda parte del programa. Estas granadas venían todas en en el vagón nº 653 "Karlsruhe" en 288 cajones, con un peso total de $6.800 \mathrm{~kg}$.

En julio de 1944 las 20.000 granadas se almacenaban en el Parque de Artillería de Madrid, en el destacamento que el mismo poseía en Retamares.

\section{VF.3.- Fusiles lanzagranadas y brocales}

Enmarcados en el "Programa Bär" se adquirieron 1.000 Granatbüchse $39^{548}$, fusiles especiales lanzagranadas, así como 10.000 brocales (coloquialmente denominados «Schiessbecher», que podría traducirse por «taza lanzadora»), aptos éstos últimos para que los fusiles y mosquetones Mauser, reglamentarios en España en esa época, pudieran lanzar el mismo tipo de granada. El brocal para el fusil Mauser Kar 98 fue una mejora para estas armas de infantería introducida en 1942, y denominada en Alemania Gewehrgranatgerät.

Para disparar con los Granatbüchse 39 y para los brocales adaptados a fusiles normales, los alemanes disponían de tres tipos diferentes de proyectiles: uno rompedor contra personal, otro de carga hueca del mismo diámetro que el brocal y un tercero también de carga hueca, con mayor diámetro que el brocal y con rabiza.

Del primer tipo de proyectil, desde el primer momento, se renunció a su adquisición, ya que el motivo de comprar este material era la lucha contra los carros de combate; del segundo se solicitaron 250.000 proyectiles y del tercero, un total de 60.000. Pero como quiera que las granadas con rabiza servían tanto para el brocal del fusil como para el fusil especial lanzagranadas antitanque, al final, la Comisión presidida por Martínez de Campos logró cambiar las cifras ofrecidas por los alemanes de cada uno de los dos modelos de proyectil, pasando finalmente a 110.000 proyectiles sin rabiza y 200.000 con rabiza.

Los fusiles (Partida ${ }^{\circ}$ 21) llegaron a España el 20 de junio de 1943, en el tren $n^{\circ}$ 8 del "Sofortprogramm" y los brocales (Partida n ${ }^{\circ} 20$ ) se recibieron el 20 de julio de ese mismo año en el tren n ${ }^{\circ} 11$ del "Sofortprogramm".

\footnotetext{
${ }^{548}$ Se trataba de un fusil lanzagranadas resultante de una modificación realizada sobre el denominado Panzerbüchse 39, más corto y manejable, con brocal lanzagranadas (Schiessbecher), un visor especial y un bípode más largo. Fue desarrollado por la empresa "Gustlof" a partir de marzo de 1940, y estuvo en producción hasta finales de 1941, llegando a producir casi 30.000 de estos ingenios. http://www.surplusrifleforum.com/viewtopic.php? $\mathrm{p}=558184$.
} 
Los dos tipos de granadas contratadas y los cartuchos de proyección para los fusiles especiales se agruparon en tres partidas diferentes: las numeradas como 45, $46 \mathrm{y}$ 47 del "Restprogramm".

En el tren $n^{0} 3$ del "Restprogramm" llegarían a España 40.000 granadas perforantes para fusil antitanque especial junto a 20.000 cartuchos explosivos mod. 318. Esta carga, correspondiente a las partidas 45 y 47, llegó a España el 2 de octubre de 1943 en dos vagones y fue remitida a la Maestranza de Madrid.

En el tren n ${ }^{\circ}$ 24, que llegó a la frontera de Irún a mediados de mayo de 1944, se recibirían otras 9.000 granadas para fusil antitanque especial (Partida 45), 20.000 para fusil ordinario (Partida 46) y 9.000 cartuchos explosivos mod. 318 (Partida 47).

En los fatídicos trenes $\mathrm{n}^{\mathrm{o}} 25,27$ y 28, que nunca llegarían a España, venía un gran cargamento de esta munición, que se perdió totalmente. Concretamente en el tren $\mathrm{n}^{\mathrm{o}} 25$ se habían cargado en Alemania 14.000 proyectiles para fusil especial, 20.000 proyectiles para fusil ordinario y 14.000 cartuchos explosivos. En el tren $n^{0} 27$ se incluian 44.000 granadas para fusil especial y 14.000 cartuchos explosivos; y por último, en el tren $\mathrm{n}^{\mathrm{o}} 28$ se habían enviado 96.000 granadas de ambos tipos (desconociendo el desglose por cada uno de ellos) y 31.000 cartuchos explosivos. El resto, hasta completar las partidas inicialmente comprometidas, nunca llegó a salir de Alemania.

\section{V.7.- MATERIAL DE TRANSMISIONES}

Uno de los grupos quizás más interesantes del "Programa Bär" del Ejército de Tierra, y menos conocidos por su poca vistosidad, la complicación de su empleo y su asignación orgánica en las unidades militares, fue el del material de transmisiones. Todo el existente en las unidades españolas hasta la fecha de su recepción -entre finales de 1943 y junio de 1944- estaba ya muy desfasado pues procedía del utilizado en la guerra civil, y era de origen bien alemán, bien italiano o bien soviético, en su gran mayoría.

Pese a que estaba previsto recibir varias partidas de este material en el "Sofortprogramm", éstas se pospusieron, pasando junto al resto, al denominado "Restprogramm". Por ello, en cualquier caso, siempre que hablemos de material de transmisiones para el Ejército de Tierra, estaremos haciendo referencia a trenes 
recibidos en la segunda fase del "Programa Bär". Todo este material se agrupó en las partidas comprendidas entre la $\mathrm{n}^{\mathrm{o}} 65$ y la $\mathrm{n}^{\mathrm{o}} 81$, ambas inclusive, -en total 17- que englobaron todo el material de transmisiones solicitado por el Ministerio de Ejército, las cuales fueron aceptadas para su entrega por parte de Alemania.

Los tres fabricantes germanos más importantes de equipos de material radio y telefónico eran, por aquellas fechas, "Siemens-Halske", "Lorenz" y "Telefunken", y todos los equipos suministrados a España tenían una de estas tres procedencias.

Para hacer un seguimiento del material de esta clase, a diferencia de cómo hemos venido actuando hasta ahora con el resto del armamento, vamos a agruparlo en tres categorías: los pedidos realmente recibidos en España, los pedidos que se recibieron de manera parcial -en mayor o menor cantidad y por diversos motivos- y los nunca recibidos en nuestro país.

\section{V.7.1.- Pedidos recibidos en su totalidad}

De las 17 partidas que integraban el material de transmisiones, sólo siete de ellas se recibieron en España en su totalidad. Se trataba de diverso material de radio y equipos repetidores de baja frecuencia, cuyos modelos y demás características resumimos en la tabla siguiente. 
TABLA V-M

MATERIAL DE TRANSMISIONES RECIBIDO EN SU TOTALIDAD

\begin{tabular}{|l|l|l|l|l|}
\hline Material & Fabricante & Recibido & Partida & Trenes \\
\hline $\begin{array}{l}\text { Estaciones radio de 15 watios SE. } \\
469 A^{549}\end{array}$ & Telefunken & 100 & 74 & 7 y 19 \\
\hline $\begin{array}{l}\text { Receptores de radio tipo 860 B.S. o } \\
\text { R-15/36 para todo tipo de onda }\end{array}$ & $\begin{array}{l}\text { Ageka (Material } \\
\text { francés capturado) }\end{array}$ & 10 & 75 & 7 \\
\hline $\begin{array}{l}\text { Receptores de mochila de onda } \\
\text { corta Tipo B de campaña }\end{array}$ & Telefunken & 40 & 77 & 7 \\
\hline $\begin{array}{l}\text { Radiogoniómetros de onda media y } \\
\text { larga Peiler A }\end{array}$ & Lorenz & 10 & 78 & 7 \\
\hline $\begin{array}{l}\text { Estaciones radio transmisoras- } \\
\text { receptoras de 200 watios AS- } \\
\text { 1008 }\end{array}$ & Telefunken & 2 & 80 & 7 \\
\hline $\begin{array}{l}\text { Equipos transmisores de radio de } \\
\text { onda corta de 1 kilowatio }\end{array}$ & Telefunken & 10 & 81 & 4 y 19 \\
\hline $\begin{array}{l}\text { Equipos repetidores de baja } \\
\text { frecuencia Tipo 38, de tres canales } \\
\text { para 2 ó 4 hilos y útiles para su } \\
\text { utilización como intermedios o } \\
\text { terminales. }\end{array}$ & Siemens & 10 & 69 & 7 \\
\hline
\end{tabular}

Fuente: Elaboración propia. Información contenida en Anexo XIV.

549 Aunque eran equipos ligeros fabricados por Telefunken, en las conversaciones llevadas a cabo en Berlín se comprometió Ageka a entregarlos de los depósitos del ejército alemán. Eran por tanto aparatos de segunda mano.

${ }^{550}$ Un radiogoniómetro es un aparato electrónico capaz de determinar la dirección de procedencia de una señal de radio, y su utilidad es evidente en la navegación aérea y marítima, permitiendo a naves y aeronaves seguir un rumbo concreto, aún con visibilidad reducida o nula. Estaban fabricados por la casa Lorenz, aunque fueron suministrados por el ejército alemán de sus existencias, tratándose pues, de material usado.

${ }^{551}$ Se trataba de unos equipos muy potentes y de grandes dimensiones.

${ }^{552}$ Constituyeron los equipos de más potencia de los enviados por Alemania al Ejército de Tierra en el "Programa Bär", y eran similares a los cuatro entregados al Ejército del Aire, con la única salvedad que aquellos disponían de transmisor, receptor y antena y estaban motorizados y los entregados al Ejército de Tierra solo constaban de transmisor y antena, no disponiendo de camiones para su transporte, considerando, por tanto, que el Ministerio del Ejército los usaría en emplazamientos fijos. Su utilidad estaba definida por los norteamericanos en su manual clasificado de material radio del enemigo como "de empleo por los estados mayores de Ejército o Cuerpo de Ejército para sus comunicaciones con los jefes de las unidades. También se empleaban para el enlace con unidades de la aviación". US War Department Technical Manual. TME 11-227, June 1944, pag. 13. 


\section{V.7.2.- Pedidos recibidos parcialmente}

Hubo cuatro partidas, de las 17 referidas a material de transmisiones, cuyo material no se terminó de recibir a lo largo de los meses que duró el desarrollo del "Programa Bär". Se trataba de material de telefonía, teletipógrafos y equipos de telegrafía armónica. Analizaremos estas partidas en la tabla siguiente.

\section{TABLA V-N}

MATERIAL DE TRANSMISIONES RECIBIDO PARCIALMENTE

\begin{tabular}{|c|c|c|c|c|c|c|}
\hline Material & Fabricante & Solicitado & Recibido & Partida & Trenes & Observaciones \\
\hline $\begin{array}{l}\text { Estaciones } \\
\text { terminales de } \\
\text { alta frecuencia } \\
\text { y } 3 \text { canales } \\
\text { MEK-353 }\end{array}$ & AEG & $\begin{array}{l}12 \\
\text { (6 equipos) }\end{array}$ & $\begin{array}{l}\text { Dos } \\
\text { estaciones } \\
\text { junto a } \\
\text { accesorios y } \\
\text { complementos }\end{array}$ & 66 & 23 & $\begin{array}{l}\text { Disponían de sus } \\
\text { cuadros centrales, } \\
\text { un cuadro por canal } \\
\text { y } 12 \text { amplificadores } \\
\text { intermedios de alta } \\
\text { frecuencia para } 3 \\
\text { canales }\end{array}$ \\
\hline $\begin{array}{l}\text { Estaciones } \\
\text { terminales de } \\
\text { alta frecuencia } \\
\text { y } 8 \text { canales } \\
\text { MEK- } 8^{554}\end{array}$ & AEG & $\begin{array}{l}4 \\
\text { ( } 2 \text { equipos) }\end{array}$ & $\begin{array}{l}\text { Cuatro } \\
\text { estaciones } \\
\text { junto a } \\
\text { accesorios y } \\
\text { complementos }\end{array}$ & 66 & 19 y 26 & $\begin{array}{l}\text { Disponían de sus } \\
\text { cuadros centrales, } \\
\text { un cuadro por canal } \\
\text { y } 6 \text { amplificadores } \\
\text { intermedios de alta } \\
\text { frecuencia para } 8 \\
\text { canales }\end{array}$ \\
\hline $\begin{array}{l}\text { Teletipógrafos } \\
\text { de campaña de } \\
\text { larga distancia } \\
\text { Tipo } 58 \text { con } \\
\text { conexión a } \\
\text { red }^{55}\end{array}$ & $\begin{array}{l}\text { Siemens- } \\
\text { Halske }\end{array}$ & 75 & 60 & 71 & 21 & $\begin{array}{l}\text { Se contrataron junto } \\
\text { a sus accesorios, } \\
\text { repuestos, } \\
\text { transformadores, } \\
\text { estabilizadores y } \\
\text { "relais". } \\
\text { Los otros } 15 \text { venían } \\
\text { en el tren n }{ }^{\circ} 28 \text { y } \\
\text { resultaron } \\
\text { destruidos por un } \\
\text { bombardeo }\end{array}$ \\
\hline $\begin{array}{l}\text { Teletipógrafos } \\
\text { mecánicos } \\
\text { (teleimpresoras) } \\
\text { Tipo } 34-i, \text { con } \\
\text { motor para } 220 \\
\text { y } 110 \text { voltios y }\end{array}$ & $\begin{array}{l}\text { Siemens- } \\
\text { Halske }\end{array}$ & 40 & $\begin{array}{l}20 \text { equipos } \\
\text { con sus } 20 \\
\text { amplificadores }\end{array}$ & 72 & $\begin{array}{l}4,19 y \\
21\end{array}$ & \\
\hline
\end{tabular}

\footnotetext{
${ }^{553}$ MEK es el acrónimo de Mehrfach-Einzelkanagerät. Se trataba de un moderno aparato de telefonía multicanal empleado por las unidades de transmisiones en campaña. Bauer Arthur O. Some aspects of military line communication as deployed by the German armed forces prior to 1945. Diemen, 26 December 2004. http://www.cdvandt.org/Wirecomm99.pdf

${ }^{554}$ Además se solicitaron repuestos y cajas de transporte, dos cuadros centrales adicionales MEK-8 para subdividir los equipos de 8 canales en dos de cuatro independientes, así como accesorios para su montaje.

${ }^{555} \mathrm{Su}$ precio eran 341.250 marcos.
} 


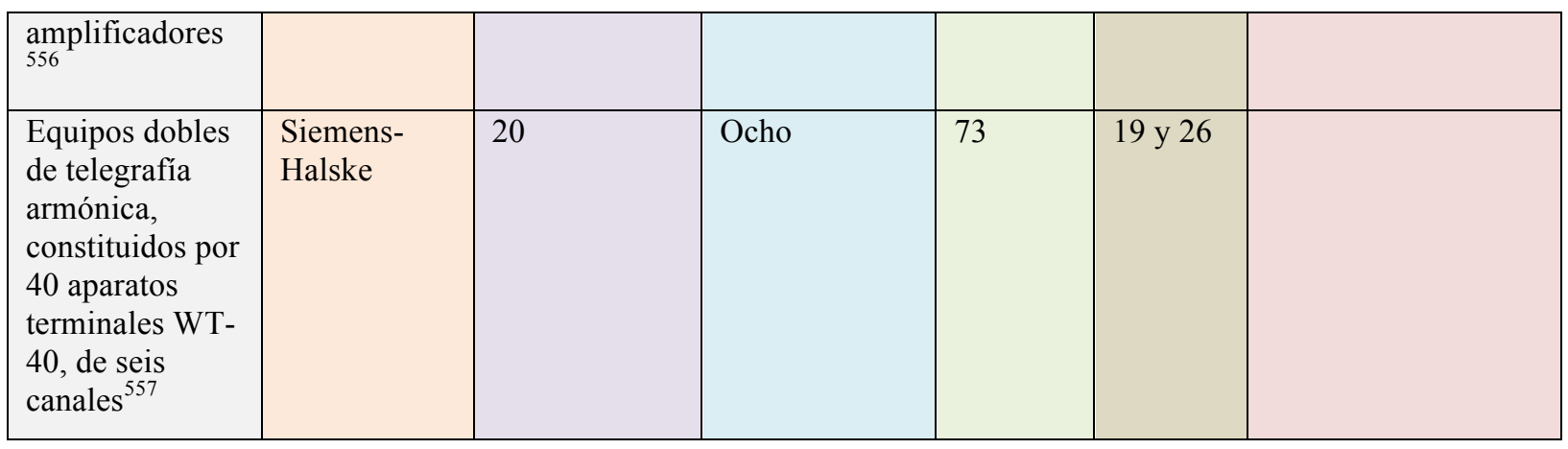

Fuente: Elaboración propia. Información contenida en Anexo XIV

\section{V.7.3.- Pedidos no recibidos}

Por último, seis de las partidas de este material nunca se recibirían en España, bien porque no se llegaron a mandar de Alemania, bien por que los trenes donde venían nunca llegaron a suelo español. Entre ellas se encontraban diversos aparatos de radio, amplificadores, auriculares, cable telefónico de campaña y diferentes modelos de válvulas de radio $^{558}$. Todas ellas vienen recogidas en la Tabla siguiente.

\footnotetext{
${ }^{556}$ Veinte de los equipos serían del modelo TbK36a y otros veinte serían del modelo TbK83b. El precio de todas las contratadas ascendía a 180.000 marcos, y el de los amplificadores 160.000 marcos. No era el mismo el precio de todos los amplificadores. Los TbK36a costaban 2.700 marcos cada uno y los del modelo TbK83b, 5.300 marcos. Contrato firmado por el Agregado Militar español en Berlín con la casa Siemens-Halske. AGMAV. Caja 24.712. Fondo del antiguo Ministerio del Ejército.

${ }^{557} \mathrm{El}$ coste de las 40 estaciones era de 1.020 .000 marcos.

${ }^{558}$ Comentaba Marín de Bernardo al coronel Aguirre, de la $4^{\text {a }}$ Sección del EMCE en una misiva fechada en Berlín el 30 de agosto de 1944 lo siguiente referente a este material: "Después de descubrir que la causa del retraso en el envío de este material estribaba en las ganas de darse importancia que tiene un Sonderführer que atiende por Thomas, me fui a pasarle la mano por el lomo, a decirle que era un tio estupendo y que no pensaba tratar ya con nadie más que con él. Muy satisfecho por la preferencia que le ponía de manifiesto, me concedió en el acto los cuatro tipos de válvulas que consideraba Guiloche como más urgentes: Estos son los que van en nota adjunta, en la que se indica la procedencia de cada tipo. Creo que en un plazo no muy largo, y si el tiempo no lo impide, le sacaré todas las demás que aquí existan..." Desgraciadamente, fue ya imposible que llegara ninguna válvula en el "Programa Bär". Embajada de España en Berlín. Agregado Militar. 30 de agosto de 1944. Carta de cuatro folios remitida al coronel Jesús Aguirre. AGMAV. Caja 24.707. Fondo del antiguo Ministerio del Ejército.
} 
TABLA V-O

\section{MATERIAL DE TRANSMISIONES NUNCA RECIBIDO EN ESPAÑA}

\begin{tabular}{|c|c|c|c|c|}
\hline Material $^{559}$ & Fabricante & Solicitado & Partida & Observaciones \\
\hline $\begin{array}{l}\text { Aparatos de radio de alta } \\
\text { frecuencia y un canal, } \\
\text { denominados } \mathrm{TFb}^{560}\end{array}$ & Siemens-Halske & 16 (ocho juegos) & 65 & $\begin{array}{l}\text { Con las derivaciones de línea, y } \\
\text { repuestos de válvulas y fusibles }\end{array}$ \\
\hline $\begin{array}{l}\text { Aparatos de radio de alta } \\
\text { frecuencia y dos canales, } \\
\text { denominados } \mathrm{Tfb} 2\end{array}$ & Siemens-Halske & 8 (cuatro juegos) & 65 & $\begin{array}{l}\text { Con las derivaciones de línea, y } \\
\text { repuestos de válvulas y fusibles }\end{array}$ \\
\hline Puentes $^{561}$ & Siemens-Halske & 20 puentes & 65 & $\begin{array}{l}\text { Sólo llegarían los citados } \\
\text { puentes en el tren } n^{\circ} 24\end{array}$ \\
\hline $\begin{array}{l}\text { Amplificadores } \\
\text { terminales } 154 \mathrm{c}\end{array}$ & Siemens-Halske & 40 & 67 & Su importe era de 9.800 marcos \\
\hline $\begin{array}{l}\text { Auriculares } \\
\text { amplificadores }\end{array}$ & Siemens-Halske & 110 & 68 & $\begin{array}{l}\text { El precio acordado entre ambos } \\
\text { gobiernos fue de } 22.000 \text { marcos }\end{array}$ \\
\hline $\begin{array}{l}\text { Feldfernkabel }{ }^{562} \mathrm{y} \\
\text { accesorios }\end{array}$ & Siemens-Halske & $1.000 \mathrm{~km}$ & 70 & $\begin{array}{l}\text { No se llegó a recibir ni un solo } \\
\text { metro de este cable telefónico } \\
\text { El precio acordado por este } \\
\text { elemento fue } 3.895 .000 \text { marcos. }\end{array}$ \\
\hline $\begin{array}{l}\text { Receptores de radio de } \\
\text { onda corta y extracorta } \\
\text { con baterías de } 12 \text { voltios }\end{array}$ & Telefunken & 10 & 76 & \\
\hline $\begin{array}{l}\text { Válvulas de radio }^{564} \mathrm{de} \\
\text { distintos modelos }\end{array}$ & $\begin{array}{l}\text { Philips y } \\
\text { Telefunken }\end{array}$ & 12.770 & 79 & $\begin{array}{l}\text { Eran el elemento fundamental } \\
\text { para el funcionamiento de los } \\
\text { equipos de radio de la época, y } \\
\text { lo seguirían siendo hasta la } \\
\text { invención del transistor. }\end{array}$ \\
\hline
\end{tabular}

Fuente: Elaboración propia. Información contenida en Anexo XIV

${ }^{559}$ El precio de estos equipos era de 216.000 marcos más 30.000 por los puentes.

${ }^{560} \mathrm{Tfb}$ es el acrónimo de Trägerfrequenzfernsprechgerät. Había cuatro variantes de estos equipos, que iban desde la Tfb1 hasta la Tfb4, variando sólo la frecuencia de emisión, que para el Tfb1 era de 5,5 KHz y para el Tfb2 era de $11 \mathrm{Khz}$. http://www.wehrmacht awards.com/forums/showthread.php?t=305265. Existía un manual para estos aparatos editado en Alemania por el Reichsminister der Luftfahrt und Oberbefehlshaber der Lutwaffe el 23 de enero de 1942, con el no 507/42.

${ }^{561}$ Para completar el pedido de los aparatos de radio Tfb-1 y Tfb-2 se encargaron con posterioridad veinte juegos de dos filtros en caja hermética, para paso de centrales intermedias, denominados puentes.

${ }^{562}$ Se trataba de cable telefónico de campaña estándar utilizado durante toda la Segunda Guerra Mundial por el ejército alemán. Comprendía la oferta alemana esos 1.000 kilómetros dividido en bobinas de 250 metros cada una (total 4.000 bobinas), con sus enchufes, bobinas, tambores y persianas. El precio final comprendía tambien 25 equipos de tendido con todos sus accesorios. El FKK, acrónimo de Feldfernkabel, contenía cuatro cables, o lo que es lo mismo, dos líneas, aislados y apantallados. Se podían extender hasta $50 \mathrm{~km}$ de este cable para las comunicaciones de voz. http:/Www.cdvandt.org/Wirecomm99.pdf.

${ }^{563}$ Los primeros envíos se realizaron en los trenes del "Restprogramm" no 27 y 28 (50 km en el primero y 100 en el segundo), que ya no pudieron llegar a España.

564 No se recibió ninguna por ferrocarril, aunque como veremos más adelante, la Jefatura de Transmisiones logró algunas del modelo RS-384 por vía aérea -ya en 1945-, aunque no eran las contempladas en el "Programa Bär", sino procedentes de otros pedidos de material de la citada Jefatura. 


\section{V.8.- MATERIAL DE RADIOLOCALIZACIÓN. LOS RADARES.}

La historia de la Segunda Guerra Mundial y todo lo relacionado con ella la han escrito mayoritariamente los vencedores, como no podía ser de otra forma. En ese contexto, tanto las investigaciones en tecnologías estratégicas, como la exportación de armamentos basados en ellas, han sido objeto de tales reservas que, aun hoy, no se conoce la verdadera historia del origen de la bomba atómica y las investigaciones alemanas en ese campo. Sin llegar a tales extremos, los orígenes del radar en Alemania tampoco son muy conocidos por el público en general ${ }^{565}$, y las exportaciones de estos aparatos a España apenas si han trascendido hasta nuestros días ${ }^{566}$.

\section{V.8.1.- Los orígenes del radar}

Está generalmente asumido que fue en el año 1933 cuando de desencadenaron las investigaciones sobre lo que luego se llamaría radar (RAdio Detecting And Ranging) ${ }^{567}$, tanto en Alemania como en Estados Unidos, Inglaterra, Francia, Holanda, URSS, Italia, Japón e incluso Australia, poniéndose en práctica las ideas del alemán Heinrich Hertz (1886, sobre reflexión de ondas), las del italiano Marconi (inventor de la radio en 1896) y, posteriormente, las del teutón Cristian Hülsmeyer (inventor de un semi radar en 1904) ${ }^{568}$. El también alemán Richard Scherl, sin conocer los experimentos de Hülsmeyer, tuvo ideas muy similares que le llevaron a desarrollar un aparato al que denominó Strahlenzieler (Rayo Apuntador), que operaba con longitudes de ondas de 10 cm; ninguno de los dos tuvieron éxito con los organismos oficiales.

\footnotetext{
${ }^{565}$ Son muchos los autores que han estudiado la historia, producción y modelos de radares alemanes, producidos durante la Segunda Guerra Mundial. Quizás los más importantes, por su seriedad sean: Bekker, Cajus, Augen durch Nacht und Nebel: die Radarstory, Gerhard Stalling Verlag, Oldenburg/Hamburg, 1964; Muller W., Ground Radar Systems of the Luftwaffe: 1939-1945, Schiffer Publishing, Pensilvania, 1998 y Trenkle F., Bordfunkgerate der Deutschen Luftwaffe 1935-45, Motorbuch Verlag, 1979.

${ }^{566}$ Manrique García, J. Mª y Molina Franco, Lucas. "El primer radar español de alerta y control”, Revista Española de Historia Militar no 49/50, Valladolid, julio-agosto 2004, págs. 19-27.

${ }^{567}$ Radar es abreviatura norteamericana. El término alemán equivalente era Funkmess Gerät (radio telémetro) o FMG.

${ }^{568}$ Hülsmeyer, puede ser considerado el "abuelo" del radar pues, el 30 de abril del citado año patentó el denominado "Telemobiscopio" (Telemobilskop, "Método para detectar ante un observador los objetos metálicos lejanos, mediante ondas eléctricas, Patente $\mathrm{n}^{\circ} 165.546$ ), un aparato ideado para el control del tráfico naval mediante la reflexión de impulsos radioeléctricos de alta frecuencia. Brown, Louis. A Radar history of World War II, Iop, Bristol, 1999, págs. 40/41, 46 y 456.
} 
Previamente al año 1933, podemos apuntar otros hitos, como la iniciativa de la marina norteamericana en $1922^{569}$ de investigar la aplicación de las ondas radio para la localización de barcos, o como las declaraciones del científico inglés Waston-Watt, junto con los trabajos del Instituto Carnegie relativos a la determinación de la altura de la ionosfera por medio de impulsos de radiofrecuencia (1925), que fueron seguidos por la medida de la altura de la misma por los norteamericanos Breit y Tuve (1926), todos ellos acontecimientos que tuvieron difusión mundial.

También hay que dejar constancia del descubrimiento del radioaltímetro en 1928 por los alemanes; los descubrimientos de la US. Navy localizando aviones por el procedimiento de comparar en un receptor tanto las ondas directas emitidas por un emisor como las reflejadas por la aeronave (1930 y siguientes) y los experimentos ingleses, volcados más en la radiogoniometría (Radio Direction Finding, $R D F$ ) que en la detección y localización a distancia, equipando, por primera vez en el mundo, un barco con un radar elemental diseñado por W.A.S. Butement y P.E. Pollard, en 1931.

Fue en 1933 cuando se iniciaron los ensayos italianos de profesor Ugo Tiberio para el desarrollo del "Radio Detector Telémetro", seguidos por los experimentos ingleses que culminaron en 1935 declarando la viabilidad de la idea de localizar con precisión aviones. En diciembre de aquel año se determinó construir cinco estaciones RDF en las cercanías de Londres, las cuales emitían ondas de $25 \mathrm{~m}$ y tenían un alcance de 58 millas inglesas. Un año más tarde se produjo el embarque del equipo experimental norteamericano denominado CXAM en el USS New York. Este mismo año, los estadounidenses Metcalf y Hahn, de General Electric, inventaron el Klistron, una válvula amplificadora de capital importancia en el desarrollo del radar, al permitir potentes emisiones de radiofrecuencias superiores a los 300MHz. En 1936, también, se montó en el barco francés Normandie un aparato localizador "Icebergs", al que se denominó por primera vez radar. La experimentación inglesa en 1937 consistió en la instalación de equipos RDF en los navíos HMS Rodney y HMS Shefield, junto con el establecimiento por parte de la RAF de una cadena de 20 estaciones ese mismo año, con equipos que ya tenían un alcance de 100 millas inglesas $(161 \mathrm{~km})$. En 1938 se diseñó un detector para dirigir proyectores antiaéreos por parte del Ejército norteamericano. Todo

\footnotetext{
${ }^{569}$ Para los primeros inicios del radar en todas las naciones antes citadas, véase, preferentemente, Brown, Louis. A Radar history of World War II, op. cit., págs. 43 y siguientes.
} 
ello demuestra claramente que en 1938 el "radar" estaba "casi" operativo en muchas naciones. Quedémonos con esa fecha.

\section{V.8.2.- El primer empleo operativo del radar}

En 1933, año de la llegada de Hitler al poder, Alemania espoleó sus investigaciones en este y otros campos, fundamentalmente por parte de la marina de guerra, siendo director científico del departamento de transmisiones de la “Reichsmarine” desde 1929 -año en que se diseña el primer sonar alemán- el profesor Rudolph Kühnhold ${ }^{570}$, uno de los investigadores principales de lo que, ya en 1934, sería el primer "radar" del mundo, capaz de captar ondas reflejadas a $12 \mathrm{~km}$. Kühnhold, había desarrollado previamente, en 1933, otro prototipo que trabajaba en onda corta y contaba con una antena parabólica, el cual no pudo prosperar debido al estado embrionario de la técnica electrónica de aquellos años. Al no conseguir el apoyo de Telefunken, impulsó la creación de la "Gesellschaft für Elektroakustische und Mechanische Apparate" (“GEMA") con Paul-Gunther Erbsloh y Hans-Karl von Willisen. Prácticamente al frente de esta empresa, construyó un prototipo que transmitía en $630 \mathrm{MHz}$, consiguiendo detectar en octubre de 1934, con una versión mejorada del mismo, al viejo navío Grille a una distancia de $12 \mathrm{~km}$. Poco después conseguía "ver" un avión Junkers $W$-34 en vuelo.

Kühnhold prefirió continuar sus trabajos con longitudes de onda de 2 m (150 $\mathrm{MHz}$ ), sin abandonar los prototipos de $48 \mathrm{~cm}$, uno de los cuales fue probado con éxito el 26 de septiembre de 1935 ante el almirante Raeder, y otro montado a bordo de Welle. Estos éxitos trajeron consigo el que se cambiara el nombre genérico de los aparatos, llamados hasta entonces "indicadores eléctricos" o "rayos reflejados", por el de Dezimeter Telegraphie (De-Te ). En las grandes maniobras de otoño de 1937, realizadas en la región de Swinemünde, participaron tres Freya y un Seetakt. En junio de 1938 el Freya sería presentado al propio Hitler.

Previamente, en 1935, el ingeniero de Telefunken Wilhelm Runge, captó ecos de un avión que volaba a $5 \mathrm{~km}$ con otro modelo de Dezimeter-Telegraphie Gerät, o radiolocalizador direccional. Se trataba del antecesor del que conoceremos como

\footnotetext{
${ }^{570}$ Kühnhold, después de su graduación en físicas en la Universidad de Göttingen, ingresó en 1928 en el Departamento de Transmisiones de la Marina, donde inicialmente trabajó en el SONAR (UnterwasserSchall). Llegaría a ser director de las construcciones navales, con el grado de capitán de navío. Von Kroge, Harry. GEMA: Birthplace of German radar and Sonar, Institute of Physics Publising (IoP), Bristol and Philadelphia, 2000, págs. 7 y 166.
} 
Würzburg ${ }^{571}$ y trabajaba con longitudes de onda de $50 \mathrm{~cm}$. En 1937 estos aparatos tenían ya un alcance de $40 \mathrm{~km}$ y en 1938 entraron en producción.

La empresa "GEMA" continuó con sus prototipos de longitudes próximas a los 2 metros, consiguiendo, inesperadamente, localizar un avión a $28 \mathrm{~km}$ en febrero de 1936. Así nació el antecesor del más tarde famosísimo Freya, aparato de radar que en 1938 conseguiría localizar un avión Junkers $J u 52$ a una distancia de 120 km. Poco después, en 1938, la Kriegsmarine embarcaba el radar Seetakt, que funcionaba con una frecuencia de emisión de $375 \mathrm{MHz}$ y tenía un alcance de 9 millas, en el Admiral Graf $S p e e^{572}$ y en el Bismarck, para probar su capacidad de exploración y de corregir el tiro de la artillería de superficie. El Seetakt, empleado también por la artillería de costa, fue designado en los primeros tiempos como FMG 39 G (gl), lo que significaba ser un modelo del año 1939 fabricado por GEMA. Más tarde se le cambió la denominación, pasando a ser FuMO 21, desarrollándose, al menos, seis versiones del mismo. Otros fabricantes, además de la citada "GEMA" fueron: "Telefunken” (T), "Lorenz" (L), “Siemens" (S), y “AEG” (A).

Por su parte la Luftwaffe disponía a comienzos de la $2^{\mathrm{a}}$ Guerra Mundial de un radar de vigilancia aérea plenamente operativo: el Freya, así denominado en honor a una divinidad germánica. Al romperse las hostilidades había ya siete radares de este modelo en dotación en las unidades de la aviación germana.

Los ingleses, como se ha podido comprobar, no "inventaron el radar ", aunque sí fueron los primeros en levantar en torno al mismo un eficaz sistema de defensa aérea, mientras los alemanes dudaban entre organizarlo en base a las ondas electromagnéticas o los rayos infrarrojos.

\section{V.8.3.- Los primeros radares alemanes de defensa aérea}

Antes de adentrarnos en la descripción de sus características y vicisitudes, merece la pena desentrañar un poco la maraña de nombres con los que fueron conocidos. Las denominaciones de los radares alemanes, inicialmente encubiertas para

\footnotetext{
${ }^{571}$ Una magnífica descripción puede verse en Bauer, Arthur O., Deckname "Würzburg": Ein Beitrag zur Erhellung der Geschichte des geheimnisumwittertren deutschen Radargeräts, 1937-1945, Verlag Historischer Technikerliteratur, Herten (Nordrhein-Westflen). El libro está descatalogado, pero se puede descargar una copia en www.cdvandt.org/DecknameWB.pdf.

572 Al parecer sería experimentado en el litoral español durante sus cruceros de control de la "No Intervención" en 1938. Von Kroge, Harry. GEMA: Birthplace of German radar and Sonar, op. cit., pág. 76.
} 
guardar el secreto, y luego cambiadas para acoger el creciente número de modelos en servicio, sufrieron diversas modificaciones. Para empezar, a la conocida, y genérica, de De-Te (Dezimeter-Telegraphie), denominación codificada para ocultar su verdadero empleo, que los propios alemanes confundían, a veces, con Deutsches Technisches Gerät $^{573}$ ), hay que añadir también las de Funkmess (FuM), o Funkmess Gerät (FuMG/FMG) cuya traducción amplia es radar; Funkmess-Ortung (FuMO), que era un radar con indicación precisa de la dirección y otros como Funkmess-Erkennung (FuME), Funkmess-Zusatz (FuMZ), Funkmess-Beobachtung (FuMB), FunkmessTäuschung (FuMT) o Funkmess-Störsender (FuMS).

Aunque bastantes Funkmess Geräte Freya eran operativos desde 1939, su primera acción de guerra tuvo lugar el 18 de diciembre de ése año, cuando el teniente Hermann Diehl al mando de un Freya de la Luftwaffe asentado en la isla de Wangerooge (la mayor de las Frisias, en el Golfo de Heligoland), detectó una formación de 22 bombarderos Wellington ingleses a una distancia de $113 \mathrm{~km}^{574}$, también otro Freya de la Kriegsmarine colaboró en guiar a la caza alemana, y el resultado del choque fue el derribo de 12 bombarderos y la destrucción de otros tres a consecuencia de aterrizajes forzosos; esta acción supuso el fin de los bombardeos aéreos diurnos ingleses. El despliegue de estos radares no se generalizó hasta 1940, existiendo ya por entonces una versión móvil. Al menos un Freya instalado en Wissant (Calais) estaba siendo empleado desde el verano de 1940 en localizar convoyes navales y aviones ingleses. También el teniente Diehl con un Freya guió, el 16 de octubre de ese año, al Meserschmitt Bf 110 del teniente Ludwig Becker a la primera interceptación nocturna por medio del radar, finalizada con el derribo de un Vickers-Wellington inglés.

Para hacernos una idea de la absoluta novedad de los aparatos con que contaría luego España, apenas desvelados por los Aliados, daremos unas pinceladas históricotécnicas de los tres modelos básicos de radar y que componían el terceto básico para el sistema alemán de defensa aérea, ya que cada cédula ó dosel (Himmelbett) en que dividían el territorio ${ }^{575}$, contaba con un radar Freya de vigilancia, dos radares Würzburg

\footnotetext{
573 De-Te se confundía también con Deustche Telefon, que procedía de la abreviatura de la empresa Deutsche Telefon Werke. También con detektor.

${ }^{574}$ Von Kroge, Harry. GEMA: Birthplace of German radar and Sonar, op. cit., pág. 90.

${ }^{575}$ Brown, Louis. A Radar history of World War II, op. cit., pág. 324.
} 
de conducción de la caza nocturna (y tiro antiaéreo) y varios cazas nocturnos dotados de radar Lichtenstein.

El radar Freya era un radar móvil ${ }^{576}$ de vigilancia (alerta temprana, como se dice ahora), es decir, era capaz de detecciones a gran distancia pero con poca precisión, y ausencia de información de la altura de vuelo de los aviones. La antena, denominada por sus sirvientes "somier" o "colchón", era giratoria en orientación (los contemporáneos ingleses eran inmóviles); las dimensiones del conjunto eran de 6’5 m. de largo por $6 \mathrm{~m}$ de ancho, llevando algunas versiones una antena del IFF. Su alcance máximo era de 150 $\mathrm{km}$, que se incrementaría al final de la guerra hasta casi 300, y el mínimo de 20, y su precisión de $1^{\circ}$ en dirección y $100 \mathrm{~m}$ en distancia.

El Freya gozó de diversas modificaciones, tanto externas, como el tamaño de la antena o la capacidad de ser móvil, como internas, incluyendo aumentos en el alcance y la precisión, así como cambios en las frecuencias de emisión para combatir las contramedidas electrónicas aliadas, tanto las tiras de papel metalizado, bien las cortas (media longitud de onda) denominadas "window" y "chaft" por los americanos ${ }^{577}$, bien las largas (hasta 120 m.) o "rope" según los yanquis, como los transmisores de interferencia "Moonshine", primero, y "Mandrel I" (ARI.5171, después) ${ }^{578}$.

Los "window", que eran conocidos por los científicos alemanes como "düppel" (nombre de una fábrica danesa de "Telefunken") desde antes del comienzo de la conflagración mundial, se estrenaron en combate, tras un tímido ensayo inglés en el Norte de África (Bengasi), en el dantesco bombardeo de Hamburgo de la noche del 24 al 25 de julio de 1943, a cargo de 718 cuatrimotores y 73 bimotores (anulando totalmente a la defensa aérea y antiaérea alemana); los alemanes los utilizaron por primera vez en Bizerta el 6 de septiembre de 1943. Los “window” empleados contra estos radares alemanes eran del tipo MB, según la denominación aliada, siendo eficaces contra frecuencias comprendidas entre 70 y $200 \mathrm{MHz}$; tenían unas dimensiones 180x5 $\mathrm{cm}$, e iban dispuestos en paquetes de 60 , los cuales pesaban $822 \mathrm{~g}$.

\footnotetext{
${ }^{576}$ Aunque podía estar en posiciones fijas, nació como móvil y desplegable, de forma que tanto las antenas como la cabina de los operadores, se montaban, junto con el grupo electrógeno y otros accesorios, en remolques sobre ruedas. También era fácilmente desplegable mediante avión, como se demostró durante la invasión de Noruega por Alemania. Von Kroge, Harry. GEMA: Birthplace of German radar and Sonar, op. cit., pág. 93.

${ }^{577}$ Brown, Louis. A Radar history of World War II, op. cit., págs. 296-299.

${ }^{578}$ Brown, Louis. A Radar history of World War II, op. cit., págs. 291y 292.
} 
Los "mandrel" eran generadores de "ruido" de radiofrecuencia, es decir, el ancho de banda de las frecuencias de perturbador era superior al de las frecuencias del radar, por lo que éste siempre quedaba afectado en mayor o menor medida; entrarían en servicio en octubre de 1942, siendo más tarde modificados y usados también por los norteamericanos.

Las anticontramedidas electrónicas alemanas consistieron, inicialmente, en variar la longitud de las ondas emitidas en $10 \mathrm{~cm}$ por arriba y por abajo, y, a partir de 1944, en los equipos "Wismar" (cambio de frecuencias), "Taunus" (filtros), y "Laus" (filtros doppler). Posteriormente se aplicó la variación continua de la frecuencia de emisión $^{579}$.

El radar Würzburg (FuG 39T/C; FuG 39T/D; FuSE 62 A, B, C y D; y FuMO 213 en la Kriegsmarine) era un radar de tiro antiaéreo y de conducción de la caza nocturna; fue diseñado por el ingeniero Pederzani, entre otros. En mayo de 1940 una batería antiaérea derribó con su ayuda un bombardero inglés en Essen-Frintoo.

Para estos cometidos se había utilizado un emisor que trabajaba entre los 500 y $600 \mathrm{MHz}$, y una antena parabólica giratoria en orientación y situación; estas características eran tan esencialmente distintas de las del Freya y de los radares sajones, que a los ingleses les era tan difícil conocerlas que optaron por dar un golpe de mano y capturar uno o, al menos, sus piezas principales. La acción tuvo lugar la noche del 27 al 28 de marzo de 1942 con el lanzamiento en paracaídas de un comando inglés de 119 hombres, desde una docena de aviones Whitley, cerca de St. Bruneval (El Havre) ${ }^{580}$, el cual anuló a los centinelas y a las defensas imprescindibles y se retiró a un submarino que le esperaba en la cercana costa, con varias piezas del radar (el receptor, el amplificador, el modulador, el transmisor y la antena, más un operador alemán), al precio de 19 bajas. La dotación de un Freya próximo supo repeler a sus atacantes.

El alcance del Würzburg era de $40 \mathrm{~km}$. Se calcula que en los días del desembarco en Normandía el ritmo de producción era de 100 al mes, estando en funcionamiento unos 2.000. Frente a este radar los aliados utilizaron el "window" del

579 Bauer, Arthur O., Deckname “Würzburg”: Ein Beitrag zur Erhellung der Geschichte des geheimnisumwittertren deutschen Radargeräts, 1937-1945, op. cit., págs. 74 y ss. (Taunus), págs. 48 y ss. (Laus). Para el Wismar, vid. Brown, Louis. A Radar history of World War II, op. cit., pág. 286 (Wismar).

${ }^{580}$ Brown, Louis. A Radar history of World War II, op. cit., pág. 230. 
tipo denominado M, eficaz contra frecuencias comprendidas entre 350 y $600 \mathrm{MHz}$; con unas dimensiones de $25 \times 0^{\prime} 55 \mathrm{~cm}$, se empleaba en paquetes de 800 , que pesaban $270 \mathrm{~g}$.

Las anticontramedidas empleadas por los alemanes, consistentes inicialmente en ampliar la banda de frecuencias de emisión, a partir de 1944 fueron los ya mencionados dispositivos Taunus, Laus y Wismar citados al hablar del Freya, y los Würzlaus (doppler) y Nürenberg (doppler), aumentándose posteriormente la frecuencia de emisión a ondas centimétricas ${ }^{581}$. Había otro modelo, el Würzburg Riese (FuG 65), derivado del radar arriba citado, que pesaba $12 \mathrm{Tm}$, tenía una antena de $7 \mathrm{~m}$ de diámetro, y un alcance de $75 \mathrm{~km}$, y del que estaban desplegados unos 1.000 el día del desembarco aliado en Normandía, el cual no hay que confundir con el que, como veremos, vino a España.

En julio de 1939 un trimotor Junkers Ju 52 probó un aparato, desarrollado por “Telefunken" por cuenta de Departamento Técnico de la Luftwaffe; se trataba de un radioaltímetro (Lichtenstein $B$ ) perfeccionado que no obtuvo el beneplácito oficial. Cuando, a comienzos de 1940 la Luftwaffe encargó a las industrias alemanas un radar aerotransportado para equipar a sus cazas nocturnos, Telefunken desempaquetó el proyecto citado y, tras no pocas dificultades de los científicos Muth y Runge para convencer a pilotos y diseñadores de aviones de que las antenas exteriores del radar eran más ventajosas al binomio piloto-avión que seguir siendo muy veloz pero ciego, el teniente Ludwig Becker, volvió a ser el primer cazador nocturno que derribó un avión enemigo gracias al radar Lichtenstein BC ó A 1 (FuG 202) ${ }^{582}$.

Con su Messerschmitt Bf 110 provisto en el morro de cuatro mástiles, en cuyo extremo una " $X$ " sujetaba otros tantos dipolos verticales (uno en cada tope final), despegó el 9 de agosto de 1941 de Holanda, abatiendo un bombardero inglés a primeras horas del día 10. El FuG 202 tenía una frecuencia de emisión de $490 \mathrm{MHz}$ (70 cm de longitud de onda), una potencia de 1 '5 $\mathrm{Kw}$, un alcance de $4 / 5 \mathrm{~km}$, y un sector de observación de $30^{\circ}$; la presentación de la información (orientación, situación y distancia) se hacía mediante tres tubos de rayos catódicos. Una mejora, consistente en ampliar el sector de exploración a $120^{\circ}$, mediante la instalación de antenas en las alas, se denominó Lichtenstein $B C / S$. Las únicas interferencias que los afectaban inicialmente

\footnotetext{
${ }^{581}$ Brown, Louis. A Radar history of World War II, op. cit., págs. 297 (Würzlaus) y 299 (Nürnberg).

${ }^{582}$ Brown, Louis. A Radar history of World War II, op. cit., pág. 287.
} 
eran los "Window"; entre junio y octubre de 1943 los ingleses pusieron en servicio los perturbadors Ground Grocer y Serrate, ambos aerotransportados en cazas Beaufighters y Mosquitos.

En mayo de 1942 un Junkers Ju 88 R-I desertó a Inglaterra, perdiéndose entonces el secreto que rodeaba a este tipo de radar. En verano de 1943 apareció el modelo FuG 212 Lichtenstein C-1 (frecuencias de 420 a $480 \mathrm{MHz}$ y con las mismas antenas que el FuG 202), y en septiembre de ese mismo año el FuG 220 ó Lichtenstein $S N 2$, uno de cuyos primeros aparatos pasó a manos inglesas cuando un $J u$ - $88-G 1$ aterrizó en la isla el 13 de julio de $1944^{583}$. También hubo versiones navales de los Lichtenstein $B / C$, fundamentalmente utilizadas por lanchas rápidas (FuMO 71) y submarinos (FuMO 72).

\section{V.8.4.- Radares para España}

En el marco del programa de armamento, la dotación en lo que respecta a los modernos medios de detección y localización alemanes no fue precisamente generosa, aunque hay que hacer constar que España iba a ser el único país en recibir aparatos de radar de entre todos los "amigos" del III Reich.

Las tres ramas del Ejército Español estaban interesadas en adquirir los modernísimos medios de localización de que disponían los alemanes, y que al parecer estaban dispuestos a entregar a España en el marco de las negociaciones en curso.

Por parte del Ejército de Tierra, se envió a la Comisión Extraordinaria para el Material de Guerra una petición que incluía 12 radiolocalizadores de largo alcance para costa, 48 radiotelémetros de costa y seis Lichtenstein de barco (sic), de los cuales, únicamente estos últimos, serían concedidos. Respecto a las peticiones de este material presentadas por el Ejército del Aire y transmitidas por el general Martínez de Campos, Presidente de la Comisión Extraordinaria para Material de Guerra, a sus homólogos en Berlín, figuraban las siguientes partidas: $n^{\circ}$ 14: seis Freyer (sic); $n^{\circ}$ 15: seis Würzburg 39 TD; $\mathrm{n}^{\mathrm{o}}$ 16: seis Lichtenstein $\mathrm{S}$ (concedidos para el Ejército de Tierra) y $\mathrm{n}^{\mathrm{o}}$ 18: seis Lichtenstein de a bordo para aviones de caza.

\footnotetext{
${ }^{583}$ Brown, Louis. A Radar history of World War II, op. cit., pág. 319.
} 
Dichas partidas fueron aceptadas por Alemania, figurando las mismas en el Anexo no 1 "Petición E.A." de la carta enviada por el Generalmajor Becker el 29 de abril de 1943 a Martínez de Campos ${ }^{584}$, siendo aceptadas, posteriormente por España.

En el anexo 3 del citado documento se citaba, así mismo, el material para la protección de vuelo que Alemania concedía a España y que ésta deseaba adquirir, que no eran sino otros veinte radiolocalizadores Freya completos y otros tantos radiotelémetros Würzburg 39 TD, lo que nos da un total de 26 aparatos de cada modelo. Esta ampliación del material radar se realizó teniendo en cuenta la carta confidencial del general Krahmer, fechada en Madrid el 8 de abril de 1943, ampliación a la relación general ofrecida en Berlín el 27 de marzo anterior.

Desgraciadamente, el 5 de mayo, en una reunión de los componentes de la Comisión del Ejército del Aire con el general Becker, éste les comunicó la imposibilidad de enviar las seis emisoras Lichtenstein para instalar en aviones de caza, todo ello motivado en las necesidades propias de este material. Dicha resolución fue comunicada oficialmente dos semanas más tarde, el 18 de mayo, mediante una nota $(\mathrm{Nr}$ 4705/43) remitida por el Alto Mando de las Fuerzas Armadas (Sección de Economía Militar), y firmada por el propio Becker ${ }^{585}$.

En el ámbito de la Marina española, los medios de detección y localización figuraban como prioritarios y por ello, en escrito a la Comisión Extraordinaria para Material de Guerra de fecha 27 de marzo de 1943, la Armada solicitaba la inclusión en la petición general de armamento y material, dieciocho radiotelémetros, de los cuales catorce serían para destructores, tres para los cruceros y uno para la Escuela de Tiro.

Pese a que el Agregado Naval consiguió a última hora, que un radiotelémetro formase parte del "Programa Bär" para la Marina española (integrado en la denominada partida 31a), lo cierto es que la mala suerte se cebó en esta adquisición pues aunque venía en el último tren con material del "Programa Bär"que llegó a la frontera española, (el $\left.n^{\circ} 26\right)$, el vagón en el que venía embalado no se llegaría a recibir, pues fue destruido por los maquis. El hecho cierto es que la Marina no se benefició de ningún

\footnotetext{
${ }^{584}$ Informes y documentación diversa sobre Alemania de los viajes del general Martínez de Campos. AGMAV. Caja 24.711. Fondo del antiguo Ministerio del Ejército.

${ }^{585}$ Informes y documentación diversa sobre Alemania de los viajes del general Martínez de Campos. AGMAV. Caja 24.711. Fondo del antiguo Ministerio del Ejército.
} 
radiotelémetro alemán y habían de pasar varios años hasta que pudiera disponer de radares para sus buques.

Como podemos leer en las memorias del Agregado Naval español en Berlín durante toda la guerra, capitán de fragata Manuel Espinosa Rodríguez:

"Con respecto al radar -aquellos Radiolocators ingleses o Funkmässgeräte alemanes-, en Berlín conseguí una vez que un teniente de navío germano nos diera tres conferencias a un grupo de militares españoles de las tres armas (Ejércitos) sobre radares alemanes. Meses después consideré un éxito el conseguir que un radar, del tipo que llevaban los cruceros acorazados de Hitler en su lucha para evitar la llegada de convoyes aliados al puerto ruso de Murmansk, fuera enviado a nuestra Marina. Habría de montarse en el crucero Canarias. Pero tuvimos mala suerte. Al vagón del tren que lo transportaba le cayó una bomba aliada cuando corría por Francia y lo destrozó" $" 586$.

Las inquietudes de Martínez de Campos se resumen estupendamente en uno de los párrafos de la carta remitida el 29 de abril de 1943 al Jefe del Departamento de Economía de Guerra del OKW, general Becker ${ }^{587}$ :

“...Desea mi gobierno, llegar a un acuerdo definitivo, por conducto mío o de las Comisiones españolas que se hallan a mis órdenes, sobre asuntos que fueron tratados en la última reunión habida en marzo con V.S., y muy especialmente en cuanto se refiere a medios de radiolocalización que interesan a nuestro ejército, a nuestra marina y a nuestra aviación. Por tanto ruego encarecidamente a V.S., me haga llegar una contestación concreta sobre las peticiones que están pendientes..."

Al hilo de las conversaciones sobre material de guerra, Martínez de Campos gestionó también con Becker la presencia en Alemania de dos equipos de jefes y oficiales, uno del Ejército de Tierra y otro de Aviación, para recibir un curso de radiolocalización: por parte del Ejército de tierra, se propuso un equipo de seis jefes y oficiales y cinco especialistas; y por el del Aire, seis técnicos. Los jefes, oficiales y especialistas de Tierra (arma de Artillería) fueron los especificados en la Tabla V-O:

\footnotetext{
${ }^{586}$ Espinosa Rodríguez, Manuel. Aventuras y desventuras de un oficial de Marina (1902-1987), Editora Naval, Madrid, 1992, pág. 480.

${ }^{587}$ Informes y documentación diversa sobre Alemania de los viajes del general Martínez de Campos. AGMAV. Caja 24.711. Fondo del antiguo Ministerio del Ejército.
} 
TABLA V-O

ESPECIALISTAS COMISIONADOS A ALEMANIA

\begin{tabular}{|c|c|}
\hline JEFES Y OFICIALES & ESPECIALISTAS \\
\hline $\begin{array}{l}\text { Comandante D. Carlos Parallé de Vicente, } \\
\text { del Alto Estado Mayor }\end{array}$ & $\begin{array}{l}\text { Ajustador D. Enrique Conesa } \\
\text { Ferreros, del Regimiento no } 72 \text {. }\end{array}$ \\
\hline $\begin{array}{l}\text { Capitán D. Felipe Jesús Perrino Morera, } \\
\text { del Regimiento } n^{\circ} 1\end{array}$ & $\begin{array}{l}\text { Ajustador D. Obdulio Madrid } \\
\text { Sacristán, del Regimiento n }{ }^{\circ} 73 \text {. }\end{array}$ \\
\hline $\begin{array}{l}\text { Comandante D. Andrés Breijo Méndez, de } \\
\text { Regimiento } n^{\circ} 2\end{array}$ & $\begin{array}{l}\text { Ajustador D. José Bueno Muñoz, } \\
\text { del Regimiento } n^{\circ} 71 \text {. }\end{array}$ \\
\hline $\begin{array}{l}\text { Capitán D. Benito Pico Yorquera, del } \\
\text { Regimiento } n^{\circ} 3\end{array}$ & $\begin{array}{l}\text { Electricista D. Francisco González } \\
\text { Fernández, del Regimiento no } 6 .\end{array}$ \\
\hline $\begin{array}{l}\text { Capitán D. Jesús Campo Vallejo, del } \\
\text { Regimiento } \mathrm{n}^{\circ} 6\end{array}$ & $\begin{array}{l}\text { Electricista D. Nicolás Torres } \\
\text { Martínez, del Regimiento } \mathrm{n}^{\mathrm{o}} 75\end{array}$ \\
\hline
\end{tabular}

Fuente: AGMAV. Caja 24.711. Fondo del antiguo Ministerio del Ejército.

La Comisión recogió apuntes y realizó memorias respecto a los Würzburg, ya que el gobierno alemán no permitió que los documentos originales fueran traídos a España. En cambio, no puso ninguna pega para que trajera los del tipo Freya.

Entre julio y septiembre de 1943 viajó a Alemania una comisión militar española, compuesta por un coronel, seis jefes y 13 oficiales de artillería, acompañados de cinco intérpretes, donde conocieron los detalles de los radares Freya y Würzburg, así como la estación de radiolocalización de Saint Germain, las centrales de información de Caen y Paris, y la de alarma de Paris. Teniendo en cuenta las posibilidades de los nuevos materiales importados en el marco del "Programa Bär", el Regimiento de Artillería $n^{\circ} 71$ de Madrid, en colaboración con la Escuela de Aplicación y Tiro de Artillería, organizó un puesto de mando de defensa aérea similar a los utilizados en Alemania (mesas Seeburg), con la particularidad de que en España, además de las variaciones que imponía la tecnología disponible, la información se volcaba en un tablero vertical transparente.

\section{V.8.5.- Las recepciones de material}

Los Lichtenstein S FuG 213 fueron los primeros radares recibidos; llegaron en el "Sofortprogramm", y correspondían a tres localizadores de buques (Schiffssuchgeräte) Lichtenstein S de la partida 18, recibidos el 20 de julio en la estación de Canfranc en un 
vagón $\mathrm{G}$ de $5 \mathrm{Tm}$ del Tren $\mathrm{n}^{\mathrm{o}}$ 11 $^{588}$. Con estos radares, que a continuación describiremos, hubo ya en origen ciertos malentendidos y problemas. La Embajada alemana en Madrid, en carta fechada el 20 de abril, hizo llegar al Ministerio de Asuntos Exteriores una lista en la que se comentaba que sería posible suministrar en un plazo de tres semanas desde que se diera la orden de envío, de tres radares Lichtenstein $\mathrm{S}$ para el Ejército del Aire ${ }^{589}$. Por el contrario, en el documento final de las negociaciones económicas del "Programa Bär" se realiza la observación de que estos aparatos eran para el Ejército de Tierra. Y tanto fue así que, tras su llegada, fueron reexpedidos al Polígono de Experiencias "Costilla", del Ejército de Tierra sito en la provincia de Cádiz. Posteriormente, fueron entregados al Ejército del Aire, al que se le facturaron, tal y como se hacía constar en el escrito $\mathrm{n}^{\circ} 4731-0$ de 16 de diciembre del coronel jefe de la sección $4^{\text {a }}$ del EMCE dirigido al Subsecretario del Ministerio del Ejército ${ }^{590}$.

El radar denominado Lichtenstein S FuG 213 fue desarrollado a partir de 1942 por la empresa Telefunken como detector de barcos. No fue hasta 1943 cuando se comenzó a probar montado sobre aviones, en el borde anterior de ambos planos, aunque realmente no fueron muchos los aviones a los que se les instaló. Su alcance máximo para detectar objetivos navales se situaba en unos $60 \mathrm{~km}$. El precio pactado para cada uno de los seis Lichtenstein S solicitados y aceptados en el Programa ascendía a 114.000 marcos. Este se discutió en la reunión del día 23 de junio de 1943 celebrada por las subcomisiones técnicas hispano-alemanas reunidas en Madrid y coincidió con el exigido por los alemanes, al no haber contraoferta española por carecerse en España de datos sobre este material. Para convencer definitivamente a los españoles sobre la conveniencia de este precio, los alemanes dijeron que se trataba de modernísimos aparatos que acababan de salir poco tiempo antes y que era la primera vez que Alemania se decidía a exportarlo como excepción a España, y que debía tratarse como algo secreto.

Por lo que respecta a los otros tres Lichtenstein $\mathrm{S}$ formaban parte de la partida $\mathrm{n}^{\mathrm{o}}$ 38 del denominado Restprogramm o $2^{\circ}$ cupo del Programa Bär, pero lo cierto es que

\footnotetext{
${ }^{588}$ Factura no 46.810. Facturas del transporte del Programa Bär. (1943-1944). AGMAV. Caja 24.710. Fondo del antiguo Ministerio del Ejército.

${ }^{589}$ AMAE. AR. Sig. R-2065-5.

590 Documentación diversa del "Programa Bär". Datos generales, cuentas, distribuciones y correspondencia con el Agregado Militar. (1943-1947). AGMAV. Caja 24.707. Fondo del antiguo Ministerio del Ejército
} 
dicho material nunca llegó a España. Venían consignados en el Tren $n^{0} 25$ del Restprogramm, tren gafado desde el origen, que fue interceptado en Francia y jamás fue recibido por el Ejército español. La información sobre este suceso consta, entre otros muchos documentos, en un oficio remitido por la $4^{\text {a }}$ Sección del Estado Mayor Central del Ejército (EMCE) a la $2^{\text {a }}$ Sección del mismo Organismo y fechado en Madrid el 9 de septiembre de $1944^{591}$. El tren $n^{\circ} 25$, cargado con material para el Ejército de Tierra excepto estos radares, material que transportaban los cinco vagones del citado tren, salió de Dijon con destino a Port-Bou. En el trayecto, y por motivos no aclarados, tuvo varias paradas no justificadas, y terminó por ser bombardeado por la aviación aliada, dándose por perdida toda la carga que transportaban.

Respecto a los radiotelémetros Würzburg adquiridos en el "Programa Bär", eran del modelo FuG 39 TD y en principio venían consignados al Ejército del Aire. El precio pactado para este tipo de radiotelémetros en las reuniones de Madrid entre las subcomisiones militares hispano-alemanas fue de 125.000 marcos por unidad, habiendo rebajado el precio solicitado por los alemanes al inicio de las conversaciones, que ascendía a 324.000 marcos.

A los seis radares de este tipo solicitados inicialmente por el Ejército del Aire, se unieron otros veinte más, cuya entrega fue aceptada por los alemanes. Pero lo cierto es que solo llegarían a España diez Würzburg, todos ellos integrados en la partida 37 del $2^{\circ}$ cupo del "Bär" 592 . Los aparatos llegaron en el tren no 4, que salió de la estación de Perl el 7 de octubre de 1943, siendo recibidos en la estación de destino, Canfranc (Pepe, $\mathrm{n}^{\circ}$ 3) tres días más tarde, el día 10. Como aspecto curioso hemos de comentar que en una carta enviada por el teniente coronel Romero de Arcos, Agregado Militar Adjunto en Berlín $^{593}$, al coronel Aguirre, jefe de la $4^{\text {a }}$ Sección del EMCE, aquel le comunicaba que en el tren $n^{\circ} 4$ iban diez aparatos Würzburg y sólo las llaves de cuatro de ellos pues los otros seis radares se habían entregado a la empresa de transportes "Schenker" en

\footnotetext{
${ }^{591}$ Documentación diversa del "Programa Bär". Id. AGMAV. Caja 24.707. Fondo del antiguo Ministerio del Ejército.

592 Así se hace constar en el Libro Mayor de la Comisión Extraordinaria de Compras de Material de Guerra. AGMAV. Caja 24.712. Fondo del antiguo Ministerio del Ejército.

${ }^{593}$ El teniente coronel D. Alfonso Romero de Arcos pertenecía al Arma de Infantería y antes de su ascenso y su ulterior comisión de servicio en la Agregaduría Militar en Berlín, había estado destinado en la Escuela de Aplicación y Tiro de Infantería y perteneció a la Comisión de Adquisición de Material de Guerra. Documentación diversa del Programa Bär. (1943-1947). AGMAV. Caja 24.707. Fondo del antiguo Ministerio del Ejército.
} 
vagones cerrados y precintados, suponiendo que sus llaves irían en el interior de los vagones, junto a los aparatos.

Curiosamente, todos los radares de este tipo fueron enviados a la Maestranza de Artillería de Madrid, a la cual llegaron el día 15 de octubre de 1943, donde serían almacenados junto a cuatro cajas de lámparas, una de motores eléctricos y diez de transformadores. No deja de resultar paradójico el escrito de la $4^{a}$ Sección del EMCE, fechado el 13 de enero de 1944, en el que se decía textualmente ${ }^{594}$ :

“...10 radiolocalizadores (Sic) Würzburg. Sin acta de Industria y Material. (No está comprendido en el Programa Bär)...”

Lo cierto es que, al venir consignados en el Programa del Ejército del Aire y pasar más tarde a Tierra nueve de ellos, como luego veremos, hubo cierta falta de coordinación entre los diferentes estamentos encargados del material de guerra que originaron los cruces de información. El resto, hasta los 26 concedidos, nunca llegarían a España pues, como ya hemos dicho anteriormente, la invasión de Francia por los aliados cercenó las vías de comunicación por la que llegaba el material.

Desde octubre de 1943, y de acuerdo con los informes emitidos por el teniente coronel Parallé, se gestionaba en Alemania la adquisición de otro radiotelémetro, en este caso un Würzburg Modelo A, que se emplearía en una futura escuela que el Ejército de Tierra pensaba organizar, para enseñanza de este tipo de material. Este aparato, se decía en los informes de la época, debería tener características análogas al utilizado en el Regimiento de Experiencias Fliegerharst, en la ciudad de Köthen. Ocho meses después, el 10 de junio de 1944, el Agregado Militar en Berlín, Carlos Marín de Bernardo, enviaba un telegrama al coronel Jesús Aguirre, de la $2^{\text {a }}$ Sección del EMCE en los siguientes términos:

"Concedido para Ejército un radiolocalizador (Sic) Wuerzburg (Sic) dime con urgencia si todavía interesa su adquisición ${ }^{595, "}$.

Tres días después, una vez el Ministro del Ejército dio su aprobación, se cursaron las órdenes oportunas para que el Agregado Militar procediera a adquirir el citado radar pero como en otros muchos casos, toda esta operación quedó cercenada al

\footnotetext{
594 Documentación diversa del "Programa Bär". Datos generales, cuentas, distribuciones y correspondencia con el Agregado Militar. (1943-1947). AGMAV. Caja 24.707. Fondo del antiguo Ministerio del Ejército.

${ }^{595}$ Documentación varia sobre el "Programa Bär". AGMAV. Caja 24.714. Fondo del antiguo Ministerio del Ejército.
} 
cerrarse las vías de comunicación terrestres por la frontera francesa. La última referencia al mismo la encontramos en un documento del EMCE fechado el 10 de octubre de 1944, en el que la $4^{a}$ Sección comunicaba al general jefe, entre otras cosas, que no se había firmado todavía contrato referente al "radiotelémetro modelo Würzburg que el mando alemán ofreció aparte del Programa y fue aceptado por S.E. el Ministro”.

Así como en los dos modelos de radares analizados hasta aquí no existe ninguna duda en cuanto a su modelo exacto, en lo que se refiere al radiolocalizador Freya hay que decir que en ningún documento, de los muchos consultados, consta dato alguno que nos permita determinar con certeza el modelo de los concedidos a España. La única referencia que pudiera darnos una pista es la que existe en la documentación conservada en el Archivo del Ministerio de Asuntos Exteriores ${ }^{596}$ en la que se notifican los resultados de las negociaciones celebradas entre las subcomisiones técnicas. Es ahí, cuando se refieren a los Freya (erroneamente denominados Freyer), citando que eran de $8 \mathrm{Kw}$, y el precio unitario acordado para cada una de las 26 unidades aceptadas, ascendía a 260.000 marcos.

La observación detenida de una serie de fotografías que se conservan en el Servicio Fotográfico y Cartográfico del Ejército del Aire nos llevó a determinar con exactitud el modelo del Freya español: se trataba de un DeTe II Fu.M.G. Flum 40 G $(g B)$, en correcta denominación alemana. Es decir, un modelo de radiolocalizador -ya que no daba la orientación precisa ni la altura de vuelo (Flum)- puesto en servicio en 1940 (40), construido por la empresa "GEMA" (G), con una frecuencia de radiación comprendida entre los 335 y los $430 \mathrm{Mhz}$ (g), y móvil (B). Su alcance máximo era de 150 km y el mínimo de 20, y su precisión era de 1 grado en dirección y 100 metros en distancia (datos del "Manual de Empleo"). 597

\footnotetext{
${ }^{596}$ AMAE AR. Sig. R-2065-5.

${ }^{597}$ Las características principales correspondientes al mismo eran las siguientes:

Estaba compuesto por varios elementos, dispuestos para su transporte sobre carrillos o remolques, a saber - Cabina giratoria, sobre un afuste cruciforme similar al de la famosa pieza antiaérea de 88/56, a la que se acoplaban carrillos similares en forma y disposición a los del cañón.

-Antena o "somier/colchón" (llamada así coloquialmente, dado el aspecto de su entramado metálico), compuesta de dos agrupaciones de seis dipolos de onda completa polarizados y alimentados verticalmente, siendo la superior la correspondiente a la recepción y la inferior a la emisión, cada una de las cuales medía 6’2x2'5 m; siendo las dimensiones del conjunto de 6,2 $\mathrm{m}$ de ancho por $6 \mathrm{~m}$ de alto.

Las antenas se montaban sobre unos brazos articulados en la parte superior de la cabina, los cuales, para el funcionamiento del radar, giraban elevándose, colocando las antenas por encima de la cabina. En esta posición el radar tenía una altura máxima de 8’23 m. El conjunto de los dos “somieres" iba, para el
} 
Si seguimos manejando la documentación conservada en el citado Archivo ${ }^{598}$, nos encontramos con un documento de mucho interés: una carta enviada por el Secretario General Técnico del Consejo Ordenador de Minerales Especiales de Interés Militar (COMEIM), y dirigida al Director General de Política Económica (del Ministerio de Asuntos Exteriores). El asunto principal de dicha misiva es la restitución de metales no férricos a Alemania con motivo de los envíos de material de guerra que este país venía realizando. Adjuntas a la comunicación figuran cuatro relaciones con la expresión del material militar ya recibido en España en fecha 21 de abril de 1944. Pues bien, en la relación $n^{0} 3$, correspondiente al Ejército del Aire, se dan, entre otras, las siguientes cifras:

\section{TABLA V-P \\ RELACIÓN No 3}

\begin{tabular}{|l|l|l|}
\hline & Recibido & Falta \\
\hline GEMA & & \\
\hline 26 equipos Freya & 26 & 0 \\
\hline TELEFUNKEN & & \\
\hline 26 equipos Würzburg & 6 & 20 \\
\hline 6 equipos Lichtenstein & 6 & 0 \\
\hline
\end{tabular}

Fuente: AMAE R-2066-3.

Este documento, en lo que a equipos de radar se refiere, no es en absoluto fiable en ninguna de sus cifras. Ya hemos afirmado antes que la cifra real de Lichtenstein

transporte, sobre un voluminoso "carrillo de antena" cubierto por una lona. Sobre otra plataforma de dos ejes, denominada "carrillo de máquinas (A-2)", iban los "transformadores de tensión" y los "reguladores a válvulas", además de los tambores de los cables de conexión entre el grupo electrógeno y el radar, dentro de un contenedor especial.

-Grupo electrógeno sobre remolque de dos ruedas. Junto con el equipo de máquinas proporcionaba una corriente de 380 voltios a 50 amperios, de 2'8 kw.

Todos estos datos están tomados de la traducción española de un manual alemán sobre el "RadioLocalizador Freya, Aparato DeTe II, Fu.M.G. (Flum) 40 g (y b)", que se conservaba -hasta su desaparición- en el Archivo-Biblioteca del Polígono de Experiencias de Carabanchel (Madrid) APEC. Relativamente bien encuadernado, aunque mal impreso, las hoja mecanografiadas del mismo iban acompañadas de numerosas fotografías originales alemanas, en las que figuraba impreso en ese idioma el pié de las mismas, junto con la traducción española rotulada en perfecta "redondilla".

El conjunto de la traducción, compuesto por tres gruesos cuadernos (carpetas de tiras), con tapas de cartón, el escudo oficial español impreso y la leyenda "Ministerio del Ejército-Dirección General de Industria y Material. Marzo 1942", sin duda era el anteproyecto del correspondiente "Reglamento" que, aparentemente, o no se llegó a editar o se ha perdido.

${ }^{598}$ AMAE AR. Sig. R-2066-3. 
recibidos fue de tres y no seis, como el documento afirma. Por lo que respecta a los Würzburg, en la fecha de la carta, 21 de abril de 1944, hacía ya más de siete meses que se habían recibido los 10 radares en España, luego la cifra de seis es un claro y manifiesto error por defecto. Por último, para enredar todavía más todo este asunto, ¡da como recibidos los 26 equipos de radiolocalización Freya!, cuando, como ahora veremos, no se recibió más que uno de toda la partida.

En oficio $\mathrm{n}^{\circ}$ 4439-A A/B, fechado en Madrid el 13 de enero de 1944, el coronel D. Jesús Aguirre, jefe de la $4^{\mathrm{a}}$ Sección del EMCE, comunicaba al coronel Díaz Gómez, de la DGIM del Ministerio del Ejército, el envío de las llaves del aparato Freya que, en palabras textuales:

“...está a punto de llegar a la Maestranza de esta Plaza...,"599.

Y en efecto, lo cierto en lo que atañe a los radiolocalizadores Freya es que, en el tren $n^{\circ} 18$ del "Restprogramm”, y asignado a la partida numerada como 36 , fue recibido en la estación de Port-Bou (Bibi, $n^{\circ}$ 5) el 9 de enero de 1944 un único y solitario radar de vigilancia Freya. Se trataba del aparato con número de serie 51.140. fabricado en Alemania por la empresa “AEG”.

\section{V.8.6.- Tierra versus Aire. El destino de los radares}

Aunque en octubre de 1943, el teniente coronel Marín de Bernardo, Agregado Militar en Berlín, recibía una comunicación del EMCE en el sentido de que se había llegado a un acuerdo con el Ministerio del Aire, en virtud del cual los seis Lichtenstein (tres recibidos y tres por llegar) pasaran a su propiedad y, en cambio, los 26 Freya y los 26 Würzburg quedarían para el Ejército de Tierra, el Agregado Aéreo en Berlín, teniente coronel José Pazó Montes, no recibió, al parecer, información en este sentido, sucediéndose durante unos meses diversos malentendidos entre los citados Agregados.

Una carta fechada en Berlín el 10 de marzo de 1944, enviada por el Agregado Militar Adjunto en la capital de Reich, teniente coronel Alfonso Romero de Arcos, al coronel jefe de la $4^{\text {a }}$ Sección del EMCE nos puso sobre la pista del lio monumental que se generó en los Ministerios del Ejército y del Aire, con motivo de la recepción de las

599 Documentación diversa del "Programa Bär". Datos generales, cuentas, distribuciones y correspondencia con el Agregado Militar. (1943-1947). AGMAV. Caja 24.707. Fondo del antiguo Ministerio del Ejército. 
partidas de material radiolocalización del Programa Bär ${ }^{600}$. En dicho documento, el teniente coronel decía textualmente:

“... Es necesario se aclare de una manera oficial al Agregado Aéreo que los radiolocalizadores Freya y Würzburg son para el Ejército y somos nosotros quienes hemos de pagarlos. Esto viene a cuento de que al comunicarle a Ageka que esos aparatos eran para Ejército y debía pasar las facturas de su importe para la firma de su conformidad al Agregado Militar, resultó que la factura de los 10 aparatos Würzburg, ya enviados, había firmado ya la conformidad el Agregado Aéreo y que incluso este Ministerio había girado dinero para pago de su importe. Igualmente, la factura del único Freya enviado hasta ahora, aunque sin firmar, estaba extendida a nombre del Ministerio del Aire. He hablado con el Agregado Aéreo, Teniente Coronel Salas, y éste me ha dicho que sí sabía que los aparatos Lichtenstein pasaban aviación pero que no creía hubiera nada sobre los aparatos Würzburg y Freya que seguirían destinados al Ministerio del Aire, que los había pedido, tenía personal instruido para su manejo e, incluso, tenían pensado ampliar el pedido. Como esto no se compagina con lo que comunicabais en la nota $n^{\circ} 4971-\mathrm{L}$ de 25 de octubre por la que parecía existente un acuerdo con el Ministerio del Aire para la cesión de estos aparatos a Ejército y la idea de organizar una Escuela para el adiestramiento del personal que los haya de servir, con la consiguiente adquisición de material de enseñanza ya en tramitación, he decidido dejar, de momento, todo tal como está, hasta que tu me contestes aclarando el asunto y sobre todo, hasta que por el Ministerio del Aire se le aclare también a su Agregado aquí cual ha de ser el verdadero destino de estos aparatos y quien ha de ser el que los ha de pagar..."

Seis días más tarde, Romero de Arcos comunicaba a Aguirre lo siguiente ${ }^{601}$ :

“... Como sabes, en el Programa Bär figuran 26 Freya y 26 Würzburg que son los que están en litigio para tu información y para caso de que el Ejército se quede con ellos y tenga que pagarlos te diré que los primeros son a 260.000 marcos con un total de 6.760 .000 marcos y los segundos son a 125.000 marcos con un total de 3.250.000 marcos. En total son 10.010.000 marcos que habrá que tener previsto de donde se pagan pues ya ves que no se trata de un grano de anís..."

El problema, lejos de solucionarse de inmediato, parece que tomó tintes de no evolucionar pues el 5 de abril, otra carta cruzada entre los mismos mandos militares en Madrid y Berlín hacía la siguiente mención:

“...Para tu información te diré que el otro día el Agregado Aéreo ha recibido un telegrama de su Jefe de E.M. que dice: "Todos

\footnotetext{
${ }^{600}$ AGMAV. Caja 24.707. Fondo del antiguo Ministerio del Ejército.

${ }^{601}$ AGMAV. Caja 24.715. Fondo del antiguo Ministerio del Ejército.
} 
los radiolocalizadores pertenecen a este ejército y deben ser pagados de nuestros presupuestos sin atender otras indicaciones". Como ves la cosa sigue no estando clara..."

Que la cosa no estaba clara, es obvio, pero la facilidad de resolución de esta, llamémosle "desagradable coincidencia de necesidades" de moderno material de radiolocalización no fue sencilla. La semana siguiente, otra misiva cruzada entre nuestros conocidos jefes militares, ponía de manifiesto lo siguiente:

“...Conviene - decía Romero de Arcos-, me digas algo sobre la resolución adoptada sobre los radiolocalizadores (...) Por otro lado me han anunciado, me pedirán por escrito que en lo sucesivo se remitan todos los radiolocalizadores por la estación $\mathrm{n}^{\mathrm{o}} 5$ bajo el indicativo $\mathrm{LA}^{602}$, que es el correspondiente al Ministerio del Aire. Instrucciones de ese Ministerio que evitasen posibles rozamientos o desacuerdos aquí, me serían muy útiles y agradables. Mi opinión particularísima sobre este problema es que así como los aparatos de gran radio podían tener aplicación para aviación, para establecer la red de observación, los de corto radio de acción le serían completamente inútiles para su servicio y tendrían mejor aplicación en servicio de las baterías antiaéreas. Pero en fin, Parallé sabe de esto más que yo y puede informaros y daros argumentos más sólidos..."

El 3 de agosto de 1944 el Ministro del Ejército dirigió al del Aire el siguiente oficio reservado $^{603}$ :

"En el programa Bär, de adquisición de material en Alemania, figura la de los siguientes aparatos radiolocalizadores y radiotelémetros:

- 6 modelo Lichtenstein

- 26 modelo Freya, y

- 26 modelo Würzburg.

Los del primer modelo figuraban en el programa del Ejército de Tierra y los de los otros en el de ese Ejército del Aire.

En virtud de petición del E.M. de V.E. perfectamente fundamentada en la aplicación de los aparatos modelo Lichtenstein, se acordó entre ambos Ministerios ceder a ese Ejército los tres llegados, cuya entrega fue realizada, y los tres que aún habían de recibirse, estableciéndose las correspondientes compensaciones económicas. En las comunicaciones cruzadas a tal respecto se reconocía explícitamente la aplicación más clara para éste Ejército tenían los modelos Würzburg.

\footnotetext{
602 "LA" significaba, en lenguaje clave del "Programa Bär": Mercancía remitida por Luftwaffe con destino a Aviación Española.

${ }^{603}$ Índice General del Instituto de Historia y Cultura Aeronáutica (IHCA) nº 100. AHEA Sig. A-7015
} 
En efecto: como se desprende de los estudios realizados, los aparatos en cuestión pueden dividirse en dos grupos:

-Los de gran alcance y poca precisión, y

-Los de pequeño alcance y gran precisión.

A los primeros puede llamárseles radiolocalizadores, ya que no proporcionan más que la distancia y el ángulo azimutal. No sirven para el tiro de la A.A.A., ya que no dan la altura de vuelo ó ángulo de situación del objetivo, dato que, en cambio, proporcionan los segundos, verdaderos radiotelémetros.

Entre los primeros figuran los modelos Freya y Würzburg Gigante -éste último no adquirido-, con sus 200 y $80 \mathrm{~km}$ respectivamente. Entre los segundos figuran los Würzburg adquiridos, con sus $40 \mathrm{~km}$ de alcance.

De las características anteriores se desprende la aplicación concreta de todos los modelos.

Los dos primeros -Freya y Würzburg Gigante- son propios para establecer las redes de acecho y vigilancia. Los segundos Würzburg adquiridos- son indispensables para la A.A.A. El tiro con estas baterías es, fundamentalmente, un problema de telemetría, ya que se trata de blancos en movimiento. De nada serviría en las baterías adquiridas, alguna de las cuales van a ser instaladas en la defensa de aeródromos, el estar provistas, como lo están, de las Direcciones más modernas, si no se determinan de un modo exacto las coordenadas del objetivo actual, porque las del objetivo futuro que da la Dirección de Tiro serían falsas si lo son también las primeras. A lo anterior puede añadirse que, como las acciones aéreas se desarrollan en gran medida durante la noche ó sin visibilidad y con alturas de vuelo de 8 ó 9.000 metros, es lo cierto que nada puede esperarse del proyector ni de la telemetría óptica. El empleo del radiotelémetro es el único que hace posible su actuación.

Las circunstancias anteriores, que justifican la absoluta necesidad del radiotelémetro Würzburg en la A.A.A., son las que me inducen a proponer a V.E. la cesión a este Ejército, mediante las compensaciones económicas necesarias, de los 26 aparatos modelo Würzburg contratados, quedando a cargo de ese Ministerio los 26 Freya y 6 Lichtenstein del mismo programa."

En el mismo expediente anterior encontramos el borrador de la respuesta que dirigió el Ministro del Aire al de Tierra, siendo, sin duda, el original del escrito que se firmara muy similar, o idéntico, al mismo, como más adelante podremos comprobar. Entresacamos los párrafos más significativos del mismo.

"Todos los radares (citados en su escrito) figuraban en el programa del Ministerio del Aire. Independientemente figuraban también otros de modelo Lichtenstein que, según la primera información alemana, correspondían a localización de barcos. Por ello 
se adjudicaron al programa del Ejército de Tierra; pero sin anular los radiotelémetros a instalar en avión, que seguían figurando en los solicitados por parte del Ejército del Aire (...)

Según los datos que obran en el Ministerio del Aire, (...) tanto los estudios realizados por su personal, como también la información de técnicos especialistas venidos para el montaje de dichos aparatos, su clasificación se ajusta al escrito de V.E. con las aclaraciones siguientes:

El Würzburg tipo 39 TD, que es el actualmente recibido, es el único que actualmente se construye en Alemania para toda clase de servicios (...); resultaba menor su alcance que el (del) Gigante para la Aviación de Caza, pero mucho mayor que el necesario para la Artillería Antiaérea (...) Esta consideración hizo que, aunque el Ministerio del Aire había solicitado los Würzburg mayores posibles desde luego sin precisar el tipo-Alemania decidiera el envío de los 39 TD por considerar que eran los más eficaces para el plan del Ejército del Aire (...)

Independientemente de las razones que la Artillería Antiaérea tenga para necesitar los radiotelémetros en las direcciones de tiro, la Aviación de Caza necesita indispensablemente dichos radiotelémetros. Como el escrito de V.E. señala, los radiolocalizadores Freya no dan más que la distancia y el ángulo azimutal; con estos datos, y particularmente de noche o con visibilidad defectuosa, no es posible resolver el problema de interceptación de la caza (...) Por esto Alemania emplea los radiolocalizadores por parejas, un buscador Freya y otro de precisión (...) tipo Würzburg. Y esta es la forma en que, precisamente, han sido pedidos los actuales 26 Freya y 26 Würzburg. Por otra parte, su utilización más eficaz para el territorio español ha sido hecha según indicaciones de los propios técnicos alemanes; y las gestiones se llevaron por parte del Ministerio del Aire, sin que éste conozca las razones por las que la Artillería Antiaérea no pidió el material que correspondiera a sus propias baterías.

Como desgraciadamente no hay por ahora en España, según las noticias de este Ministerio, el mismo número de Freyas y de Würzburg, propongo a V. E. el siguiente plan:

-Que se entreguen al Ministerio del Aire todos los Freya que se hayan recibido y el mismo número de Würzburg. Esta entrega convendrá (hacerla) con la mayor urgencia para aprovechar el personal técnico que actualmente se encuentra en espera del material.

-Que queden para las baterías antiaéreas el resto de los Würzburg. Esta entrega deberá considerarse a título provisional para ser compensada por (una) nueva adquisición de otros tantos Würzburg, si en alguna ocasión lo permiten las circunstancias..."

Aquella propuesta, sin duda, fue aprobada por el Ejército de Tierra, quizás suponiendo que era muy difícil que se pudieran conseguir más radares de la colapsada Alemania, pasando al Ejército del Aire un radar de cada tipo, los cuales son los que 
aparecen en las fotografías conservadas en el Centro Fotográfico y Cartográfico del Ejército del Aire, tomadas, probablemente, en los terrenos de la Escuela de Transmisiones del Ejército del Aire, en Cuatro Vientos. Con ellos se formó la primera y embrionaria "Red de Alerta Radar", la cual actuó durante el último año del conflicto mundial, además de servir de escuela a los primeros radaristas del Ejército del Aire.

Concretamente, como constatación de lo anterior, diremos que existe un oficio ${ }^{604}$ de la Dirección de Protección de Vuelo, de fecha 30 de junio de 1944, en el que interesaba del E.M. del Aire la correspondiente autorización para "colocar la primera pareja de radiolocalizadores para la defensa de Madrid”. En esencia, el mismo decía:

"Para la instalación de la (...) defensa de Madrid, que a la vez servirían de escuela para adiestramiento del personal de todas las demás instalaciones, se ha procedido a una exploración técnica, teniendo en cuenta las condiciones siguientes: alojamiento fácil (...), acceso (...), suministro de energía eléctrica (...), zona de vuelos frecuentes (...), buena recepción, etc. Un lugar muy adecuado dentro de dichas condiciones es las proximidades del Aeródromo de Alcalá de Henares, exactamente al Sur del terreno de despegue y fuera de la pista.

Ruego a V. E. (...) se autorice el correspondiente transporte de energía y estudiar la instalación de los primeros radiolocalizadores que nos sean entregados..."

Acompañaba el escrito un anexo en el que figuraban los siguientes extremos, además de dos croquis, uno de situación y otro con el "Diagrama de Ángulos de Cubrimiento" (zonas vistas y ocultas a la señal radar). En el croquis de situación aparecen reseñados dos puntos, con una " $F$ " y una "W", que suponemos representan, respectivamente, los asentamientos de los radares Freya y Würzburg.

A esta petición contestó el Estado Mayor, afirmativamente, el 7 de julio siguiente. En los informes a los que nos referiremos más adelante ${ }^{605}$, se dice textualmente:

“...En julio de 1944 se eligieron los emplazamientos de tres estaciones de radiolocalización que cubrían ampliamente el Sector de Madrid. Se encontraban a una distancia media de Madrid de $70 \mathrm{~km}$ en línea recta, estando situadas al Este, Oeste y Sur de la citada población. El emplazamiento Este se encontraba en Valbueno, provincia de Guadalajara, el Oeste en Valmojado (Madrid) y el Sur en

\footnotetext{
${ }^{604}$ Escrito de la Dirección General de Protección de Vuelo no 838. AHEA. Sig. A-9877.

${ }^{605}$ Escrito de la Dirección General de Protección de Vuelo no ${ }^{114}$. AHEA. Sig. A-10021.
} 
Yepes (Toledo). Dichos puntos fueron reconocidos previamente desde el aire y, con posterioridad, se hizo otro reconocimiento minucioso del terreno, procediendo a sacar gráficos de ángulo de movimiento, una vez situados exactamente los emplazamientos de (los) Freya y Würzburg (...) De todos estos emplazamientos el que reunía condiciones óptimas era el situado en las cercanías de Yepes (...) el ángulo de búsqueda abarcaba los $360^{\circ}(\ldots)$ "

Todo lo anterior nos da un visión bastante aproximada a cómo se previó la instalación de la primera red de alerta radar española durante la Segunda Guerra Mundial.

Entre los expedientes inventariados en el Archivo Histórico del Ejército del Aire, sito en Villaviciosa de Odón ${ }^{606}$, aunque no localizado, figura uno de 1944 reseñado como "Destino al Grupo de Instrucción del personal especializado en Alemania para radiolocalización". De no haberse perdido este expediente hubiera sido una fuente valiosísima para completar los datos de la historia española durante la Segunda Guerra Mundial, además de ampliar el conocimiento del empleo del radar por el Ejército del Aire, en sus vertientes tanto civil como militar.

Si nos hemos detenido con más detalle en este asunto de los radares del "Programa Bär" creemos que está justificado por varios motivos, todos de indudable peso. Por una parte, la importancia del material tratado, al ser un arma absolutamente novedosa, cuyos primeros frutos los estaba cosechando en los campos de batalla de la guerra mundial. En segundo lugar hay que constatar que en 1943 Alemania no había exportado la tecnología radar a ninguno de los países con los que mantenía un flujo habitual de mercancías bélicas, ni siquiera a sus aliados italianos, rumanos, búlgaros o húngaros que combatían, hombro con hombro, en los distintos frentes de la Segunda Guerra Mundial... El caso español es realmente excepcional, pese a la pequeña cantidad de material recibido.

\footnotetext{
${ }^{606}$ AHEA. Índice General 100, Exp. A-936.
} 


\section{Capítulo 6}

\section{EL PROGRAMA “BÄR”. DESARROLLO E IMPLICACIONES MILITARES. MATERIAL PARA LA ARMADA Y EL EJÉRCITO DEL AIRE}

\section{VI.1.- MATERIAL ALEMÁN PARA LA ARMADA}

El 10 de diciembre de 1942, la Embajada alemana en Madrid remitía un oficio al Ministerio de Asuntos Exteriores en el que comunicaba que el gobierno alemán había tenido conocimiento de la lista de peticiones de armamento que deseaba recibir el gobierno español. Por ello, dicha embajada proponía iniciar enseguida negociaciones verbales sobre este asunto, proponiendo que dichas conversaciones se celebraran en Berlín y que para este fin, fuera enviada a la capital germana una comisión -no muy numerosa- de oficiales españoles expertos en estas materias. El hecho de elegir Berlín como lugar de las negociaciones atendía a la realidad de que allí se disponía de todos los medios de información necesarios para facilitar y acelerar dichas negociaciones.

Esta comisión, presidida por un oficial de la Armada -el capitán de navío D. Santiago Antón Rozas-, fue enviada a Berlín a finales de año y mantuvo conversaciones con sus homónimos alemanes, presentando las listas de material solicitado e iniciando tímidas negociaciones con las autoridades del Reich. Además del capitán de navío Antón, la Armada envió desde España al teniente coronel de Artillería D. Lorenzo Pallarés, a los que se unió en Berlín el Agregado Naval, capitán de fragata Espinosa ${ }^{607}$. El hecho cierto es que durante más de tres meses, la Delegación española vivió en Berlín un auténtico toma y daca de dilaciones, esperas y viajes -más o menos "turísticos"-, pues los responsables teutones no acababan de tener claro el uso que los españoles iban dar al material solicitado, y retrasaban ad aeternum la negociación, esperando una respuesta que consideraran satisfactoria por parte de las autoridades españolas.

Tras una reunión celebrada a su llegada a Berlín en el Ministerio de Asuntos Exteriores alemán, tuvieron lugar otras dos en la central de distribución de armamentos

\footnotetext{
607 Carta reservada del Agregado Naval en Berlín al Ministro de Marina. 22-1-1943. AFNFF. Leg. 27.444 .
} 
del Reich, donde los españoles fueron recibidos por su presidente, el general de Infantería Thomas, quien les expresó los deseos del Gobierno alemán de proveer a España del armamento defensivo que más necesitara en esos momentos.

VI.1.1.-El material para la Armada en las negociaciones previas del "Programa Bär". La Comisión “Antón”.

El material genérico, todavía sin concretar cantidades, que reclamaba el entonces Ministerio de Marina en las listas presentadas por la Comisión “Antón”, se reducía a tres categorías: por una parte, material de artillería y dirección de tiro; por otra, minas y torpedos; y por último, material óptico. Con más detalle se muestra en la tabla siguiente.

\section{TABLA VI-A}

\section{MATERIAL RECLAMADO POR LA MARINA. “COMISIÓN ANTÓN"}

\begin{tabular}{|l|l|l|}
\hline $\mathbf{N}^{\mathbf{l}}$ & Material & Especialidad \\
\hline $\mathbf{1}$ & Equipos dobles de $10,5 \mathrm{~cm}$ (Antiaéreos) & Artillería \\
\hline $\mathbf{2}$ & Equipos sencillos de $10,5 \mathrm{~cm}$. & Artillería \\
\hline $\mathbf{3}$ & Equipos dobles de $8,8 \mathrm{~cm}$. (antiaéreos) & Artillería \\
\hline $\mathbf{4}$ & Equipos semiautomáticos de $3,7 \mathrm{~cm}$. & Artillería \\
\hline $\mathbf{5}$ & Equipos de ametralladoras de $3,7 \mathrm{~cm}$. & Artillería \\
\hline $\mathbf{6}$ & Equipos de ametralladoras de $2 \mathrm{~cm}$. & Artillería \\
\hline $\mathbf{7}$ & Direcciones de tiro para cañones de $10,5 \mathrm{~cm}$. & Artillería \\
\hline $\mathbf{8}$ & Direcciones de tiro para cañones de $12 \mathrm{~cm}$. & Artillería \\
\hline $\mathbf{9}$ & Direcciones de lanzamiento de torpedos & Torpedos y minas \\
\hline $\mathbf{1 0}$ & Minas submarinas tipo EMD & Torpedos y minas \\
\hline $\mathbf{1 1}$ & Torpedos G-7 & Torpedos y minas \\
\hline $\mathbf{1 2}$ & Torpedos eléctricos & Torpedos y minas \\
\hline $\mathbf{1 3}$ & Cargas de profundidad & Torpedos y minas \\
\hline $\mathbf{1 4}$ & Equipos de cineteodolitos Askania & Óptica \\
\hline $\mathbf{1 5}$ & Anteojos de observación y tijera & Óptica \\
\hline $\mathbf{1 6}$ & Telémetros Zeiss y Georg & Óptica \\
\hline $\mathbf{1 7}$ & Vidrio óptico Zeiss & \\
\hline
\end{tabular}

Fuente: AMAE. Leg. R-2066-2 
Más tarde, la Dirección de Construcciones e Industrias Navales Militares (DCINM) amplió la lista de necesidades ${ }^{608}$, solicitando el material de acero necesario para la construcción de cuatro cascos de submarinos tipo "G", con un peso total de unas 1.200 toneladas, motores diesel de 1.500 HP, motores eléctricos de 375 HP., periscopios, aparatos de navegación y otros aparatos especiales para los mismos. Para completar los talleres de las factorías que tenía a su cargo, el Consejo apuntaba la necesidad imperiosa de adquirir una gran cantidad de máquinas-herramientas, dedicadas a la construcción de buques de guerra, tales como tornos horizontales y verticales, mandrinadoras universales, cepillos variados, fresadoras, escoplos, limadoras, taladros, radiales fijos y portátiles, rectificadoras, máquinas de tallar engranajes, máquinas de equilibrar motores de turbinas, tornos de precisión, hornos, máquinas de moldear, y en general, todo lo referente a grandes talleres de construcción de máquinas alternativas, turbinas y motores diesel. Así mismo, se consideraba la compra de todo tipo de herramental para la construcción de cascos de buques de cualquier tonelaje, como planeadoras de chapa, sierras circulares, prensas hidráulicas, avellanadoras, punzones, etc...

Para terminar las obras en los submarinos tipo "D", se solicitaban a Alemania tres periscopios, aparatos de navegación, elementos de aire comprimido y otros aparatos especiales. Para la fábrica de Artillería de La Carraca sería preciso adquirir una instalación para el torneado cónico de elementos de cañones hasta $20 \mathrm{~cm}$, un laboratorio químico metalográfico y espectrográfico y taller de pruebas mecánicas, así como diversa maquinaria para completar los talleres de embutición, montajes, cañones, proyectiles, etc...

Por último, se especulaba con la posibilidad de adquirir tres catapultas Heinkel con destino a los tres cruceros, diversos grupos electrógenos, bombas, chigres, aparatos de gobierno, equipos de radio, sondadores, escuchas y aparatos de navegación para los buques en construcción por el Consejo, cuatro hidroaviones Heinkel He 114 para los cruceros (uno de ellos sería de respeto) y varios equipos motobombas de la casa AEG para ampliar la casa de bombas del dique seco de Cartagena.

\footnotetext{
${ }^{608}$ Nuevos pedidos necesarios. Ministerio de Marina. Dirección de Construcciones e Industrias Navales Militares. Documento anejo al Convenio Comercial de 16 de diciembre de 1942. AMAE. AR. Sig. R2066-2.
} 
El Agregado Naval, capitán de fragata Espinosa, manifestaba en carta remitida al Ministro de Marina el 22 de enero de 1943, su escepticismo en cuanto a la posibilidad de suministro del material solicitado por la Marina española, afirmando que por noticias reservadas particulares tenía conocimiento de que las peticiones de la Armada eran las que más dificultades encontraban. Finalizaba la misiva con sendas frases a cual más demostrativa de la pasividad alemana al respecto ${ }^{609}$ :

“... En el día de ayer la Comisión fue a visitar un polígono de tiro a unos $45 \mathrm{~km}$ de Berlín donde les enseñaron nuevos métodos de combate contra tanques. Por ahora no se sabe cuando tendrá lugar la próxima reunión."

El 21 de febrero de 1943, y tras dos meses de dilaciones en la negociación de armamentos, el gobierno español sustituyó al capitán de navío Antón por el general de división Carlos Martínez de Campos y Serrano quien, como ya hemos visto, daría un impulso decisivo a las negociaciones militares del "Programa "Bär".

El general acudió a Berlín el 10 de marzo, dispuesto a sentarse con sus homónimos alemanes y alcanzar un acuerdo definitivo al asunto del armamento. La primera reunión se produjo el día 15, poniendo Martínez de Campos encima de la mesa las peticiones concretas del material militar requerido por las tres ramas del Ejército español. La lista de Marina era la más amplia, pues parte del material estaba ya en vías de contratación por el Ministerio y la subcomisión de la Marina de Guerra en Berlín. Se trataba, en esencia, de ametralladoras y cañones antiaéreos de diferentes calibres -tanto para montar en buques como para la defensa de bases navales-, cañones de superficie para buques, proyectiles para los mismos, lanchas rápidas torpederas, motores para diversos buques, aparatos de dirección de tiro para artillería y torpedos, minas, cargas de profundidad, telémetros, anteojos, aparatos de radio etc... ${ }^{610}$

Tras una serie de reuniones -que se prolongarían en el tiempo otros dos meses y que requerirían de un segundo viaje de Martínez de Campos en Berlín- el 29 de abril el general presidente de la Comisión remitía al general Becker, jefe del Departamento de Economía de Guerra alemán, una carta con las partidas de material bélico ofrecidas por

\footnotetext{
${ }^{609}$ Carta reservada del Agregado Naval en Berlín al Ministro de Marina. 22-1-1943. AFNFF. Leg. 27.444 .

${ }^{610}$ Para analizar con detalle la lista completa de material solicitado por la Marina, ver Anexo X.
} 
el Reich que el gobierno español aceptaba así como la disposición de que se cumplieran los plazos de entrega propuestos por las comisiones alemanas.

En la misiva, Martínez de Campos insistía en la necesidad de que Alemania vendiera a España diverso material de radiolocalización; ampliaba, en sendos anexos, el material militar solicitado por Aviación y Marina y comunicaba la composición de las comisiones de los tres Ejército presentes en Berlín para proceder al estudio sistemático y detallado de los precios del material.

La comisión negociadora de Marina estaba compuesta por el capitán de fragata Manuel Espinosa Rodríguez, Agregado Naval en Berlín, el teniente de navío Agustín Miralles de Imperial y Díaz, Adjunto al Agregado Naval, el comandante de Intendencia Edmundo Núñez Limón, el teniente coronel de Artillería de la Armada Lorenzo Pallarés Cacha y el ingeniero naval civil D. Andrés Barcala Moreno (estos dos últimos, estaban en la Comisión de manera eventual)

Los encargos de la citadas comisiones, asignados a sus respectivos jefes, eran tres: firmar los contratos del material autorizado por el OKW con las sociedades designadas por el citado organismo, recibir el material cedido directamente de gobierno a gobierno y proceder a las ampliaciones o nuevas peticiones que España considerase necesario realizar.

Por otra parte, se dejaba para más adelante el nombramiento de varios equipos de jefes, oficiales y suboficiales especialistas de la Armada que habrían de efectuar prácticas concertadas verbalmente con los organismos competentes alemanes, aunque ya por esas fechas y desde octubre del año anterior, venía desarrollando su actividad una comisión de marinos españoles -integrada en la Kriegsmarine y vistiendo los uniformes propios de la marina germana- en la zona del Mar Báltico y el Golfo de Finlandia, a bordo de buques de la armada alemana. Dicha Comisión estuvo al mando del capitán de navío D. Pedro Fernández Martín y fue relevada en marzo de 1943 por otra similar al mando del capitán de corbeta D. Federico Fernández de la Puente ${ }^{611}$. Ambas comisiones se componían de once miembros, un jefe de expedición, cuatro oficiales del Cuerpo

\footnotetext{
${ }^{611}$ Forzados por la necesidad de contar con dotaciones adecuadamente formadas y en el contexto de la cooperación técnica con la Kriegsmarine desde 1939, la Marina alemana autorizó el envío de marinos españoles al Reich para realizar cursos y prácticas encuadrados en sus unidades de guerra. Alfonso Escuadra es el autor español que más profundamente ha estudiado este aspecto de las Comisiones Navales en la Kriegsmarine entre 1942 y 1943. Escuadra Sánchez, Alfonso. Españoles en la Kriegsmarine. Misiones en el Báltico (1942-1943). Galland Books, Valladolid, 2011.
} 
General de la Armada, dos oficiales del Cuerpo de Máquinas y otros cuatro suboficiales mecánicos. El adiestramiento de estos marinos españoles se estaba realizando en un escenario de guerra real: habían embarcado en barcos que realizaban sus servicios en el Báltico oriental, en la denominada "vanguardia del dispositivo naval alemán", encuadrados en el denominado "Führer der Minensuchsuchverbände Ost", a las órdenes de almirante Kurt Böhmer ${ }^{612}$. Como afirma Alfonso Escuadra:

“...La mayoría lo hizo en flotillas de dragaminas, lanchas minadoras, patrulleros y cazasubmarinos, aunque al igual que había ocurrido con la segunda comisión, hubo quien también formó parte de la dotación de grandes unidades de la flota, como el crucero ligero "Emdem" o el crucero pesado "Admiral Scheer", ahora destinados a misiones de adiestramiento en el Báltico Oriental." 613

\section{VIA.2.-Los suministros de material}

El 20 de abril una comunicación de la embajada alemana en Madrid, dirigida al Ministro de Asuntos Exteriores abría las puertas al suministro inmediato de cierta parte del material militar acordado, pese a que los técnicos de ambos países, encargados de discutir los precios de los materiales, todavía no se habían sentado en la mesa de negociación. La Marina de Guerra española fue la menos afortunada en estas primeras entregas, logrando una pequeña parte del material solicitado. La comisión de Marina manifestó su deseo de enviar la parte asignada vía Irún.

En esta primera entrega de material militar alemán encuadrado en el "Programa Bär", con la denominación oficial de "Sofortprogramm”, se entregaron a la Armada cuatro piezas antiaéreas de $3,7 \mathrm{~cm}$ SK C/30 en montaje doble C/30 con estabilizador giroscópico, 8.000 proyectiles para las mismas, una decena de piezas antiaéreas de $2 \mathrm{~cm}$ Flak 38 en montaje C/30, 20.000 proyectiles de $2 \mathrm{~cm}, 16$ piezas antiaéreas de 3,7 cm SK $\mathrm{C} / 30$ en montaje $\mathrm{C} / 39$ para submarino, 32.000 proyectiles para las mismas, 38 torpedos Whitehead-Wymouth ${ }^{614}, 500$ minas EMC y 100 cargas de profundidad $\mathrm{F}^{615}$.

\footnotetext{
${ }^{612}$ Escuadra Sánchez, Alfonso, Españoles en la Kriegsmarine, op. cit., pág. 294.

${ }^{613}$ Escuadra Sánchez, Alfonso, Españoles en la Kriegsmarine, op. cit, pág. 295.

${ }^{614}$ Al final, los negociadores de la Armada decidieron prescindir de su adquisición, pues se trataba de torpedos procedentes de botín de guerra y su precio era el triple de los G-7a, adquiridos anteriormente.

${ }^{615} \mathrm{Su}$ denominación alemana era Wasser Bombe (WA-BO) y el modelo era el "F", de ahí el acrónimo utilizado en la documentación: WBF.
} 
La llegada de este material se produjo en los meses de junio y julio de 1943 en diversos trenes recibidos por la frontera de Irún. El material y las correspondientes partidas asignadas a la Marina española por los responsables de la Comisión Extraordinaria para el Material de Guerra, vienen recogidos en la tabla adjunta.

\section{TABLA VI-B}

"PROGRAMA BÄR" MARINA. ("SOFORTPROGRAM")

\begin{tabular}{|l|l|l|}
\hline Partida & Material & Cantidad \\
\hline 1 & Flak de $3,7 \mathrm{~cm}$ SK C/30 en montaje doble estabilizado & 4 \\
\hline 2 & Flak de $3,7 \mathrm{~cm}$ SK C/30 en montaje C/39 de submarino & 16 \\
\hline 3 & Flak 38 de $2 \mathrm{~cm}$ en montaje C/30 & 10 \\
\hline 4 & Cañones de repuesto de $3,7 \mathrm{~cm}$ & varios \\
\hline 5 & Proyectiles explosivos de $2 \mathrm{~cm}$ & 20.000 \\
\hline 6 & Proyectiles explosivos de $3,7 \mathrm{~cm}$ & $48.000^{616}$ \\
\hline 7 & Minas tipo EMC & 500 \\
\hline 8 & Cargas de profundidad WBF & 100 \\
\hline
\end{tabular}

Elaboración propia. Fuente: AMAE R-2065-5

\section{VI.1.3.-Negociaciones en España. Los precios a debate}

Quizás el aspecto más curioso y jamás tratado en la poca literatura que el "Programa Bär" ha generado en el transcurso de los años, sea el debate mantenido por los negociadores españoles y alemanes en las jornadas en las que se intentaba llegar a acuerdos con respecto a un tema capital en las negociaciones: alcanzar unos precios que dejaran satisfechos a ambos países. Hemos comentado anteriormente que las propuestas alemanas -país vendedor- estaban tan infladas como su propia economía de guerra, intentando por todos los medios que los precios que pagaran las autoridades españolas compensaran ampliamente el desbalance de las cuentas germanas con la menor cantidad

\footnotetext{
${ }^{616}$ Pese a que estaba previsto haber recibido 40.000 proyectiles de $3,7 \mathrm{~cm}$ para los cañones dobles y sencillos llegados a España en esta primera entrega, lo cierto es que en los envíos desde Alemania se incorporaron 8.000 proyectiles más de los inicialmente previstos, alcanzando los 48.000, modificándose, de esta manera, el coste presupuestado en el "Sofortprogramm" para la Marina española, como se analizará en el capítulo siguiente.
} 
de material posible, pues sólo de esta manera podrían alcanzar cotas interesantes de contrapartidas españolas sin romper los pactos alcanzados con el Acuerdo Comercial de diciembre de 1942.

España, por otra parte, habría de intentar por todos los medios que los precios del material militar se adecuaran a los que en ese momento regían en el mercado internacional del armamento, pues sólo así tendrían la seguridad de que las negociaciones eran ventajosas para una economía francamente descompuesta, como la española, destrozada por la Guerra Civil y castigada muy severamente por la Segunda Guerra Mundial.

El material asignado a la Marina en esta primera fase del programa fue valorado por los alemanes según se muestra en la Tabla VI-C, y como también puede observarse en la misma, los precios solicitados triplicaban los normales de estas armas, de cuya validez daban muestra las ofertas recibidas en España sólo un año antes, firmadas por las casas constructoras germanas.

\section{TABLA VI-C}

"PROGRAMA BÄR" MARINA. "SOFORTPROGRAMM". VALORACIÓN ALEMANA Y PRECIOS ACORDADOS

\begin{tabular}{|l|l|l|l|}
\hline Material & Precio alemán & Precio acordado & Precio total \\
\hline $\begin{array}{l}\text { Flak de 3,7 cm SK C/30 en montaje } \\
\text { doble estabilizado }\end{array}$ & $442.200,00$ & 154.400 & 617.600 \\
\hline $\begin{array}{l}8.000 \text { granadas rompedoras cartucho 40 } \\
\text { 10 Flak de 2 cm en montaje de } \\
\text { submarino }\end{array}$ & $98.000,00$ & 28.200 & 263.200 \\
\hline $\begin{array}{l}20.000 \text { granadas rompedoras luminosas } \\
\text { para submarino }\end{array}$ & 29,05 & & 282.000 \\
\hline 32.000 disparos de 3,7 cm & $174.600,00$ & 60.000 & 172.600 \\
\hline 38 torpedos Whitehead-Wymouth & $87.500,00$ & 25.000 & 960.000 \\
\hline 500 minas EMC & $11.895,00$ & 3.000 & 1.052 .800 \\
\hline 100 cargas de profundidad & $2.800,00$ & 1.000 & No se adquirieron \\
\hline & & Total & 1.500 .000 \\
\hline
\end{tabular}

*Todas las cantidades vienen expresadas en marcos. Fuente: AMAE AR. Sig. 2066-4.

Las subcomisiones de técnicos militares para la revisión de los precios del armamento, en sus reuniones celebradas en Madrid a lo largo de los meses de junio y 
julio de 1943 dejaron claro que la valoración española era la más acertada y próxima a la realidad, pese a que los alemanes insistieron en que se tuvieran en cuenta las circustancias extraordinarias por las que estaba pasando su país, para así conseguir una valoración superior.

En un momento de las reuniones, el representante del Ministerio de Marina afirmó de manera categórica que en el aspecto puramente militar las circunstancias difíciles de la guerra no podían influir en la diferencia de precios, sino en la determinación sobre la entrega del material, pero una vez acordada la entrega, el precio debía ser el mismo.

Este fue, en esencia el comportamiento habitual de los representantes militares españoles - no sólo de Marina- en las reuniones con los militares alemanes: no ceder un ápice en lo referente a valoración real del material asignado en el "Programa Bär", y ajustar al máximo el precio en pro de los intereses de España.

De esta manera, los precios se fueron adaptando, de manera general, salvo algunos casos concretos, a las previsiones españolas, dando por sentado lo inflados que los negociadores germanos habían propuesto los citados precios. Un caso concreto en el que podemos pararnos es en el de las seis lanchas rápidas torpederas cuya adquisición se había negociado enmarcada en el "Programa Bär". Para su valoración, los técnicos españoles tuvieron en cuenta las diferentes piezas que las componían -casco, motores, armamento, accesorios...-, llegando a la conclusión que su precio no debía ser superior al millón de marcos por cada una. Como quiera que por cada lancha Alemania pedía cinco millones de marcos, los negociadores hispanos no tuvieron más remedio que hacer constar su malestar y manifestar que por el precio que Alemania había fijado para una lancha rápida, en España en aquellas fechas se podría fabricar un submarino.

Las negociaciones sobre los precios finalizaron con el acuerdo entre ambas subcomisiones -española y alemana-, rebajando los precios inicialmente solicitados y dando paso de esta manera al desarrollo de la segunda fase del "Programa Bär" -el "Restprogramm-. Todo el material recibido ya en el "Sofortprogramm" se valoró en 4.948.200 marcos frente a la petición germana que ascendía a 19.523.900 marcos.

El material pendiente de recepción, que puede ser consultado en el Anexo X bis, estaba formado por una veintena de motores diesel, radiogoniómetros y periscopios para submarinos, un cineteodolitode la fábrica "Askania", emisoras de radio de la casa "Lorenz" y receptores “Telefunken”, cañones y ametralladoras de diversos calibres y sus municiones, seis lanchas rápidas torpederas, minas, cargas de profundidad, 
telémetros, anteojos y alguna partida aprobada en el último momento como estaciones para carga de acumuladores, 800-900 toneladas de acero para los cuerpos de los submarinos Tipo VIIC, una docena de direcciones de tiro y un radiotelémetro.

El valor de todo este material alcazaba los 70.805.293 marcos, aunque como veremos a continuación, solo llegaría una parte de lo que restaba.

\section{VI.1.4.-Material recibido en el "Restprogramm"}

El primero de los trenes del "Restprogramm" en los que llegó material para la Armada fue el $n^{\circ} 8$, en el que venían consignadas una partida de minas EMC de las 500 que restaban para esta continuación del Programa. Poco después, en el tren $n^{\circ} 10$ se recibieron los 32 telémetros (“Goerz" y “Zeiss"), los 20 anteojos así como el resto de minas EMC, hasta completar las previstas. En ese mismo tren vendría una partida de cañones antiaéreos sencillos de $37 \mathrm{~mm}$ y un centenar de cargas de profundidad.

Poco a poco y en diferentes trenes fueron llegando más partidas de las contempladas en el Programa de la Armada, hasta el tren $\mathrm{n}^{\circ} 26$, último de los recibidos en la frontera. En la Tabla VI-D se recoge todo el material efectivamente recibido en España con destino a la Marina, enmarcado en el "Restprogramm". Baste aquí decir que además de las seis lanchas rápidas torpederas, el vidrio óptico y el cineteodolito “Askania", el grueso del material recibido lo componían piezas de artillería de $2 \mathrm{~cm}, 3,7$ cm y $10,5 \mathrm{~cm}$ y sus municiones, así como las cargas de profundidad y las minas EMC. Ninguno de los motores para submarino, ni los periscopios, ni siquiera el acero especial para los mismos ni los radiogoniómetros, se llegaron a recibir de Alemania, a lo que habría que sumar las direcciones de tiro, las válvulas, las emisoras y receptores y un solitario radiotelémetro para destructores que el Agregado naval en Berlín -capitán de fragata Espinosa- había conseguido incorporar al Programa. Nada de esto llegó a formar parte de la Armada Española. 
TABLA VI-D

MATERIAL DEL “RESTPROGRAMM" DE MARINA RECIBIDO EN ESPAÑA

\begin{tabular}{|l|l|}
\hline Partida & Material \\
\hline 8 & 1 instalación de cineteodolito “Askania" sin cable acorazado para gran distancia \\
\hline 16 & 32 Flak de 3,7 cm SK C/30 en montaje doble estabilizado \\
\hline 17 & 142.000 granadas rompedoras cartucho 40 \\
\hline 18 & 22 Flak de 2 cm cuádruples para buque \\
\hline 19 & 176.000 granadas rompedoras luminosas \\
\hline 20 & 30 Flak de 2 cm en montaje de submarino \\
\hline 21 & 60.000 granadas rompedoras luminosas \\
\hline 22 & 12 Flak de 10,5 cm C/32 en cureña C/52 para torpederos \\
\hline 23 & $9.900^{617}$ disparos de 10,5 cm de diversos tipos \\
\hline 24 & 6 lanchas rápidas tipo grande \\
\hline 25 & 20 anteojos de observación 20 x 80 \\
\hline 26 & 35 Flak de 3,7 cm C/30 en cureña C/39 de submarino para buque \\
\hline 27 & 57.500 granadas rompedoras mod 40 \\
\hline 31 & 500 minas EMC sin anclaje, la mitad con 300 m de cable y la otra mitad con 350 m de cable. \\
\hline 32 & $100^{618}$ cargas de profundidad F \\
\hline 33 & 12 telémetros "Goerz" de 2 m de base \\
\hline 34 & 20 telémetros “Zeiss" de 1,25 m de base \\
\hline 3.000 kg de vidrio óptico \\
\hline 35
\end{tabular}

Fuente: Elaboración propia. Anexo XIV

\section{VI.1.4.1.-Las lanchas torpederas}

Las seis lanchas rápidas torpederas $\mathrm{S} / 38$ que incluía el denominado "Restprogramm" fueron, junto a los aviones Messerschmitt Bf 109 F, los Junkers Ju 88 y parte de los equipos pesado de transmisiones de aviación, los únicos materiales del "Programa Bär" que alcanzaron España por sus propios medios. En el caso de las embarcaciones se programaron sendas entregas de las mismas, realizadas ambas en la ciudad portuaria francesa de Burdeos: la primera tuvo lugar el 30 de julio de 1943 -se

\footnotetext{
${ }^{617}$ Pese a que en las cuentas desde Alemania se enviaron 11.400 proyectiles de este calibre, 1.500 se perdieron en un vagón del tren 26 que nunca llegó a España. La diferencia de valor de estos 1.500 proyectiles, 344.104 marcos, sería cubierta por el seguro contratado por la Armada.

${ }^{618} \mathrm{Al}$ igual que en el caso de los proyectiles, desde Alemania se enviaron otras 200 cargas de profundidad, 100 de las cuales se perdieron en el mismo vagón que los proyectiles de $10,5 \mathrm{~cm}$. El seguro cubrió la pérdida, que en este caso eran 100.000 marcos.
} 
entregarían dos lanchas- ${ }^{619}$ y la segunda y última, el 28 de agosto, recibiendo los españoles las cuatro restantes ${ }^{620}$.

Las seis lanchas formaban parte de la Kriegsmarine germana, donde prestaban servicio integradas en diversas flotillas. Su casco era de construcción mixta, en madera y aleación de aluminio y su armamento principal eran dos tubos lanzatorpedos situados a proa -a babor y estribor-, aunque también llevaban dos varaderos situados en popa para lanzar cargas de profundidad del modelo WBF y dos cañones de $20 \mathrm{~mm} \mathrm{C} / 30$, en afustes sencillos, ubicados a proa y a popa. Además, estas lanchas disponían de sendos aparatos productores de cortinas de humo y una instalación desmontable para el fondeo de minas. Como se aprecia, eran embarcaciones versátiles, polivalentes, rápidas y muy modernas.

Dos de las lanchas eran veteranas del conflicto mundial (S 73 y S 78), habiendo actuado con la $6^{\mathrm{a}}$ y $4^{\mathrm{a}}$ Flotilla de Schnellboote, respectivamente, tomando parte en operaciones desde mediados de 1942, tanto en Noruega como en Holanda y Francia. El resto eran prácticamente nuevas, con menos de 150 horas de funcionamiento y con escasos tres meses desde su fabricación ${ }^{621}$.

\footnotetext{
619 "Al día siguiente (30 de julio de 1943), en presencia de todos ellos, el Konteradmiral Heinrich Wagner, Comandante del Arsenal de Burdeos hizo entrega oficial de las lanchas a la Armada Española, representada en aquella ocasión por el capitán de fragata Espinosa. Durante la sencilla ceremonia unos marinos alemanes arriaron la Reichskriegsflagge para que los españoles procedieran a izar la bandera bicolor. A continuación el capitán de fragata Urzáiz, en calidad de Jefe del Grupo de Lanchas Rápidas, hizo entrega del mando de ambas unidades a los alféreces de navío García de Quesada y Gómez Suarez..." Escuadra Sánchez, Alfonso. Españoles en la Kriegsmarine, op. cit., pág. 231.

620 "Durante el día 27 se procedió a recibir de las dotaciones alemanas los diversos cargos de cada lancha y el 28, en un solemne acto presidido por nuestro Agregado Naval y el jefe de los Servicios de la Marina alemana en Burdeos, se verificó la entrega de las mismas a España. Las recibió nuestro Agregado Naval. Se arrió la bandera alemana y se izó la nuestra con toda solemnidad y después se procedió a la entrega del mando de las lanchas a sus comandantes respectivos." Escuadra Sánchez, Alfonso. Españoles en la Kriegsmarine, op. cit., pág. 235.

${ }^{621}$ Coello Lillo, Juan Luis, Buques de la Armada española. Los años de la postguerra, op. cit., pág. 218.
} 
TABLA VI-E

\section{LANCHAS TORPEDERAS S-38 RECIBIDAS EN ESPAÑA}

\begin{tabular}{|l|l|l|l|}
\hline $\begin{array}{l}\text { Denominación } \\
\text { alemana }\end{array}$ & Entrada en servicio & $\begin{array}{l}\text { Denominación } \\
\text { española }\end{array}$ & Comandante (Teniente de navío) \\
\hline S-73 & Primavera de 1942 & LT-23 & Isidoro González-Adalid Rodríguez \\
\hline S-78 & Idem. & LT-24 & Fernando Moreno Reina \\
\hline S-124 & 15 de abril 1943 & LT-21 & José García de Quesada \\
\hline S-125 & 16 de mayo de 1943 & LT-25 & Jaime Gómez-Pablos Duarte \\
\hline S-126 & 12 de junio de 1943 & LT-26 & Ricardo Jara Serantes \\
\hline S-134 & Finales mayo 1943 & LT-22 & Alfonso Gómez Suárez \\
\hline
\end{tabular}

Fuente. Elaboración propia. Escuadra Sánchez, Alfonso. Españoles en la Kriegsmarine. Misiones en el Báltico (1942-1943). Todos los comandantes de las lanchas eran tenientes de navío, empleo equivalente a capitán.

En noviembre de 1943, en el denominado Tren n 10 del "Restprogramm", entre otro material para la Marina española, llegaron a Irún media docena de motores diesel Daimler-Benz MB 501 de cuatro tiempos, 20 cilindros en V y arranque por aire. Se trataba de motores de reserva para las seis lanchas torpederas anteriores.

Estas lanchas se utilizaron hasta el final de la Segunda Guerra Mundial en aguas del Estrecho, como bien afirma Coello:

“...en defensa de la neutralidad seguida por el Gobierno español durante la etapa final de la Segunda Guerra Mundial.,

Serían dadas de baja en la Armada entre 1956 y 1957.

\section{VI.1.4.2.- Artillería para la Marina española}

El grueso del material recibido en el marco del "Programa Bär" para la Armada fueron piezas de artillería. Como se puede analizar en la tabla VI-F, fueron 161 los cañones navales de diferentes modelos y calibres que llegaron a España. Los mayores fueron los 10,5 cm C/32 en montaje C/52 para torpederos de "Rheinmetall-Borsig", destinados a ser la artillería principal de los denominados en España "destructores tipo Audaz”, que no eran sino una versión construida en nuestro país de los torpederos

\footnotetext{
${ }^{622}$ Coello Lillo, Juan Luis, Buques de la Armada española. Los años de la postguerra, op. cit., pág. 219.
} 
franceses clase "Le Fier", alguno de los cuales fueron capturados en proceso de construcción por los alemanes tras la caida de Francia.

Obviamente, con los doce cañones recibidos fue imposible armar los nueve buques de la serie, pues cada uno de ellos llevaba tres de estas piezas, dispuestas todas ellas a popa, en la línea de crujía. Eran cañones bivalentes pues podían utilizarse tanto para tiro de superficie como para fuego antiaéreo. Al final, la Marina los utilizó para armar provisionalmente los cañoneros clase "Pizarro" ${ }^{623}$ hasta que se ultimó su artillería principal, y entonces pasaron a los cuatro primeros destructores de la clase "Audaz".

Los 36 cañones Flak de 3,7 cm SK C/30 en montaje doble estabilizado recibidos (de los 42 previstos), eran idénticos a los 26 que se habían recibido entre 1942 y 1943 , adquiridos estos últimos directamente en Alemania por la Marina española y con los que se dotó de antiaérea secundaria a los cruceros. En el caso de los adquiridos en el seno del "Programa Bär" estaba previsto que sirvieran para artillar los buques de las clases "Pizarro" y "Audaz", en el primer caso cuatro piezas dobles cada uno de los ocho buques previstos, y en el segundo, dos piezas dobles cada una de las unidades que componían la serie.

Pero el número de cañones recibidos tampoco fue capaz de cubrir las expectativas de la Armada para completar con estas armas antiaéreas todos los buques previstos. Con los 26 montajes inicialmente recibidos se pudo mejorar la antiaérea secundaria de los cruceros "Canarias", "Galicia", "Miguel de Cervantes" y "Méndez Núñez”, convertido este último en crucero antiaéreo, a razón de cuatro montajes en el "Canarias", ocho en los "Galicia" y "Miguel de Cervantes" y otros cinco previstos (cuatro reales) en el "Méndez Núñez". Con los 36 montajes recibidos en el "Programa Bär" se logró artillar los cañoneros "Pizarro" los minadores "Eolo" y "Tritón", así como los destructores "Audaz", aunque en alguno de estos últimos se tuvieron que emplear montajes sencillos debido a la carencia de piezas dobles.

Por lo que respecta a los 22 montajes cuádruples de $2 \mathrm{~cm}$ (denominados en Alemania "Vierling") recibidos en el "Restprogramm" fueron emplazados a razón de cinco piezas en cada uno de los cruceros modernizados "Galicia" y "Miguel de Cervantes", cuatro en el crucero antiaéreo "Méndez Núñez" y dos cada una de las cuatro primeras unidades de cañoneros “Audaz”. El montaje estaba fabricado por la

\footnotetext{
${ }^{623}$ Fue posible emplear estos cañones para armar los primeros "Pizarro" debido al retraso y a las dificultades experimentadas en el alistamiento de los destructores "Audaz". Coello Lillo, Juan Luis, Buques de la Armada española. Los años de la postguerra, op. cit., pág. 181.
} 
casa Reinmetall-Borsig, aunque los cuatro cañones con los que estaba dotado eran de la firma Mauser. Podía batir blancos aéreos y terrestres y su dotación era de nueve sirvientes.

Sería muy prolijo detallar a que unidades de la Marina española fueron a parar los 51 cañones sencillos de 3,7 cm C/30 y los 40 de $2 \mathrm{~cm} \mathrm{C/30,} \mathrm{ambos} \mathrm{en} \mathrm{el} \mathrm{llamado}$ montaje "de submarino" para buque, que se recibieron en el marco del "Programa Bär". Baste señalar que además de los recibidos de Alemania, en los Talleres de Artillería de San Fernando (Cádiz) se fabricaron un centenar de piezas de 3,7 cm antiaéreas para la Armada de idéntica factura que las teutonas-denominadas "Bazán- RB”, con destino a unidades menores. Como se apuntó en el primer capítulo de este trabajo, la Armada había adquirido la patente para fabricar estos cañones en España.

"Eran unos buenos cañones -en palabras del vicealmirante de la Armada Española Jorge García Parreño y Kaden-, con velocidad inicial y precisión en el tiro. Pero en unos años en los que ya había magníficas ametralladoras antiaéreas de $40 \mathrm{~mm}$, poco tenían que hacer."

Todos los dragaminas, corbetas, guardacostas, remolcadores, guardapescas, patrulleros, transportes, etc... montaron bien cañones sencillos de $3,7 \mathrm{~cm}$, bien cañones de $2 \mathrm{~cm}$, o bien ambos tipos de piezas, que estuvieron en servicio hasta mediados de la década de los cincuenta del siglo XX, cuando comenzó a llegar material de origen norteamericano, que relegó a misiones secundarias a las pocas piezas de origen alemán que todavía pervivían en nuestra Marina ${ }^{625}$.

Por lo que respecta a la munición para la artillería, se recibieron 9.900 proyectiles de 10,5 $\mathrm{cm}$-lo que suponían 825 disparos por cañón recibido-; 248.300 proyectiles de $3,7 \mathrm{~cm}$-un total de 2.020 disparos por cada cañón recibido- y 256.000 cartuchos de $2 \mathrm{~cm}-2.000$ disparos por cada cañón recibido-. Parte de la munición contratada nunca se llegó a recibir.

\footnotetext{
${ }^{624}$ García Parreño y Kaden, Jorge, Las armas navales españolas, op. cit., pág. 273.

${ }^{625}$ Muchos cañones de 3,7 cm sencillos pasaron a cometidos menos guerreros, constituyendo las baterías de salvas de arsenales e instalaciones navales.
} 


\section{TABLA VI-F}

ARTILLERÍA NAVAL OBTENIDA EN EL "PROGRAMA BÄR"

\begin{tabular}{|c|c|c|c|c|c|}
\hline Modelo & Sofortprogramm & Tren $\mathbf{n}^{\circ}$ & Restprogramm & Tren $\mathbf{n}^{0}$ & Total \\
\hline $\begin{array}{l}\text { Flak de } 10,5 \mathrm{~cm} C / 32 \text { en cureña } \\
\mathrm{C} / 52 \text { para torpederos }\end{array}$ & & & 12 & $21,23,24$ & 12 \\
\hline $\begin{array}{l}\text { Flak de } 3,7 \mathrm{~cm} \text { SK } \mathrm{C} / 30 \text { en } \\
\text { montaje doble estabilizado }\end{array}$ & 4 & 7 & 32 & 17,21 y 24 & 36 \\
\hline $\begin{array}{l}\text { Flak de } 3,7 \mathrm{~cm} C / 30 \text { en cureña } \\
\mathrm{C} / 39 \text { de submarino para buque }\end{array}$ & 16 & 7 & 35 & $10,21,23,24$ & 51 \\
\hline $\begin{array}{l}\text { Flak de } 2 \mathrm{~cm} \text { cuádruples para } \\
\text { buque }\end{array}$ & & 7 & 22 & $17,21,24$ & 22 \\
\hline $\begin{array}{l}\text { Flak de } 2 \mathrm{~cm} \text { en montaje de } \\
\text { submarino }\end{array}$ & 10 & & 30 & 17 y 21 & 40 \\
\hline TOTAL & 30 & & 131 & & 161 \\
\hline
\end{tabular}

Fuente: Elaboración propia. Anexos XIII y XIV.

\section{VI.1.4.3.- Otros materiales}

Todas las minas EMC contratadas en el programa se llegaron a recibir, la mitad en el denominado "Sofortprogramm" y la otra mitad en el "Restprogramm". En cambio sólo 200 cargas de profundidad WBF de las 2.000 contratadas llegaron a suelo español: 100 en el "Sofortprogramm" y otras 100 en el "Restprogramm" 626 . También llegarían a España una veintena de anteojos, $3.200 \mathrm{~kg}$ de vidrio óptico y el cineteodolito $^{627}$ encargado a Askania.

Nada más de lo encargado a Alemania en este programa de armamento llegaría a suelo español, pese a los esfuerzos de las autoridades navales españolas, que intentaron continuar recibiendo mercancías en la zona franca de un país neutral con frontera con Alemania: Suiza ${ }^{628}$. El 6 de octubre de 1944, desde el Estado Mayor de la Armada se propuso al agregado comercial de la Embajada germana en Madrid que los contratos firmados en el seno del "Programa Bär" podrían continuar en vigor si las empresas

\footnotetext{
${ }^{626}$ Si bien es cierto que los alemanes enviaron 100 cargas de profundidad más de las aquí consignadas en total 300-, estas venían en uno de los vagones perdidos del tren $\mathrm{n}^{\mathrm{o}} 26$, junto al radiotelémetro y a diversa munición de $10,5 \mathrm{~cm}$.

${ }^{627}$ El cineteodolito era un aparato óptico que servía para hacer un seguimiento preciso de objetos en vuelo y suministrar datos de posición y trayectoria. Entre otras aplicaciones se empleaban para medir la velocidad inicial de los proyectiles al salir de la boca de fuego que los disparaba.

${ }^{628}$ APFE. Embajada en España en Berlín. Agregado Naval. Telegrama recibido nº 601. Ref. 11285/5462.
} 
suministradoras aceptaban la condición de que el pago se efectuara contra la recepción del material en Suiza.

El 9 de noviembre de 1944 el Almirante Jefe del Estado Mayor de la Armada remitía un telegrama ${ }^{629}$ al Agregado Naval en Berlín en el que ordenaba que se comunicara a la empresa Schenker que a partir de esa fecha cesara en la recepción de material correspondiente al "Programa Bär". Ese mismo día, el capitán de fragata Espinosa recibía otro telegrama ${ }^{630}$ de Madrid en el que se decía que comunicara al mando de la Kriegsmarine que quedaba sin efecto la ejecución del "Programa Bär", cesando por tanto la entrega de cualquier tipo de material pendiente de ser suministrado, en particular las armas y municiones listas para su entrega y que el almirantazgo germano había manifestado el deseo de disponer de ellas.

\section{VI.2.- MATERIAL PARA EL EJÉRCITO DEL AIRE}

El "Programa Bär" para el Ejército del Aire fue, quizás, el más modesto de las tres ramas de las Fuerzas Armadas españolas, tanto en los modelos solicitados como en la cantidad prevista, probablemente debido a que era la rama de las fuerzas armadas españolas que más contratos había firmado con los alemanes desde 1939 para adquisición de material y licencias de fabricación hasta ese momento. En la primera lista conocida de armamento solicitado por el Ejército de Aire, que consta como anexo 2 al acuerdo sobre suministro de metales no férricos y sus aleaciones ${ }^{631}$, aparece el siguiente ${ }^{632}$ :

"Aviones M-109 G (Sic) (Caza); aviones de transporte Ju 52 G 10 e2; aviones de bombardeo He $111 \mathrm{H}-6$, repuestos; piezas antiaéreas de $37 \mathrm{~mm}$, camiones remolque para las piezas antiaéreas; municiones para todo el material, incluso ametralladoras de avión 7,92 mm; grupos radio de campaña $1,5 \mathrm{kw}$ onda larga y corta; grupos de radio de pequeña potencia $(100 \mathrm{w})$; camiones meteorológicos completos y grupos móviles de alumbrado de campo."

\footnotetext{
${ }^{629}$ APFE. Embajada en España en Berlín. Agregado Naval. Telegrama recibido no ${ }^{\circ} 618$, Ref. 11299/5575.

${ }^{630}$ APFE. Embajada en España en Berlín. Agregado Naval. Telegrama recibido no ${ }^{\circ} 619$. Ref. 11298/5568.

${ }^{631}$ AMAE. AR. Sig. R-2066-2.

632 La lista era una primera aproximación a lo que cada Ministerio desea le sea suministrado. No se hablaba de cantidades.
} 


\section{VI.2.1.- Comisión de compras en Berlín}

La Comisión Extraordinaria para Material de Guerra que llegó a la capital del Reich a mediados de enero de 1943, permaneció el primer mes casi sin actividad real ${ }^{633}$, aunque a partir de mediados de febrero, tras el nombramiento como presidente del general Martinez de Campos ${ }^{634}$, se fueron acercando posiciones y se presentaron una serie de relaciones de material que se deseaba adquirir. En un primer listado fechado en Berlín el 15 de marzo de 1943, el Ejército del Aire solicitaba genéricamente el siguiente material:

Por lo que se refiere a aviones de caza, material para localización y protección de vuelo, se requerían 250 aviones con sus repuestos correspondientes, 800 estaciones de radio de onda corta de 40 a 60 w, 250 grupos electrógenos, ocho equipos de radio pesados (sobre camión) de onda corta y larga de 1,5 Kw, 15 equipos de radio pesados de onda corta y larga de $100 \mathrm{w}$, ocho remolques gonio (E-383N), tres camiones meteorológicos completos, cuatro equipos móviles para aterrizaje sin visibilidad, una docena de radiolocalizadores, 6.000 .000 de cartuchos de 7,92 mm y 500.000 cartuchos de $20 \mathrm{~mm}$.

Como material antiaéreo se solicitaron 400 ametralladoras de $37 \mathrm{~mm}$ en montaje terrestre móvil con 2.500 disparos por pieza y 20 baterías completas de $88 \mathrm{~mm}$-con cuatro cañones cada una, dirección de tiro, proyectores y localizadores- con 500 disparos por pieza. También se necesitaban tractores para las piezas antiaéreas pesadas, a razón de seis por batería, sumando un total de 120 vehículos.

También se incluyeron en el pedido 150 aviones de bombardeo con los repuestos correspondientes, 15 grupos electrógenos "Still", 20 alimentadores rectificadores para estaciones FuG-3 y 2.000.000 de cartuchos de diversos tipos y calibre 12,70 o similar para dichos aviones.

Por último, serían necesarios -según los españoles- 75 aparatos de caza nocturna y 45 aviones de transporte, todos ellos con sus repuestos, así como seis equipos de radiolocalización de abordo.

\footnotetext{
${ }^{633}$ Ruhl Klaus -Jörg. Franco, Falange y III Reich. España durante la II Guerra Mundial, op. cit., pág. 226.

634 Exactamente el 21 de febrero de 1943, después de una reunión en El Pardo entre Franco y los Ministros Militares. García Pérez, Rafael. Franquismo y III Reich, op. cit., pág. 385.
} 
Haciendo uso de la figura del "recorte" en tiempos difíciles -que eran los que realmente se vivían en Alemania en 1943-, devolvieron la petición española disminuída en las partidas más importantes, que no eran otras que las de material volante. El 28 de marzo salió para España una lista considerada "definitiva", la cual tras intensos estudios, fue aprobada con diversas modificaciones e incluso eliminaciones por parte de las autoridades militares españolas. ${ }^{635}$

En una atenta carta enviada por el general Martinez de Campos al Generalmajor Becker, Jefe del Departamento de Economía de Guerra alemán, y fechada en Berlín el 29 de abril de 1943, se le comunicaban a éste las partidas aceptadas por España, los plazos de entrega del material, así como otros aspectos relacionados con el asunto.

La Comisión del Ejército del Aire encargada de firmar los contratos, recibir el material y proceder, en su caso, a las ampliaciones o nuevas peticiones estaba formada por los tenientes coroneles José Pazó Montes (jefe) y Ángel Salas Larrazábal y los comandantes Enrique Cárdenas Rodríguez y Álvaro Soriano Muñoz

Así mismo se solicitaba autorización para el envío de los distintos equipos que habían de efectuar las prácticas concertadas verbalmente con las autoridades alemanas, que por lo que respecta al Ejército del Aire eran uno de pilotos de caza, formado por 12 jefes u oficiales; otro de bombardeo, con 18 jefes u oficiales y 22 especialistas; un equipo de reparación Messerschmit, con dos jefes de sección y ocho obreros; un equipo de reparación bombarderos, formado por un maestro de taller, dos jefes de sección y diez obreros; un equipo de reparación de radiolocalizadores dotado de seis técnicos, y un equipo de reparación de radiofaros direccionales "Elecktra" y radiogoniómetros “Adcock" de onda corta y larga, del que formarían parte seis técnicos (dos por aparato).

La lista de material que los alemanes estaban dispuestos a entregar y que fue aceptada por España era, en esencia, la siguiente:

\section{-Aviones}

15 aviones de caza Me 109 F4 y 10 aviones de bombardeo Ju 88 A4, con utensilios y repuestos para una escuadrilla de cada modelo.

\footnotetext{
${ }^{635}$ AMAE. AR. Sig. R-2066-4.
} 


\section{-Artillería antiaérea}

20 baterías de artillería antiaérea pesada de $8,8 \mathrm{~cm}$, de cuatro cañones cada una. No se aprobó la entrega de munición para estas piezas ${ }^{636}$.

\section{-Munición para los aviones ${ }^{637}$}

Cuatro millones de proyectiles de 7,92 $\mathrm{mm}$ para los aviones de seis modelos, repartidos de la siguiente manera: 1.000 .000 de disparos sS; 1.000 .000 de disparos SmK; 500.000 disparos SmK oL.; 500.000 disparos SmK oL Mess.; 500.000 disparos PmK, y 500.000 disparos PmK Mess..

\section{-Material de transmisiones ${ }^{638}$}

Cuatro equipos de radio móviles completos de onda corta y 1,5 Kw y otros cuatro equipos de onda larga de la misma potencia; 15 equipos móviles ligeros FuG 10 de $100 \mathrm{w}$ (onda corta/onda larga); 50 teléfonos de campaña mecanizados, tipo 33 y 100 equipos de radio ligeros de onda corta VR $27 b .{ }^{639}$

\section{-Material de protección de vuelo}

Ocho equipos gonio de remolque $(\mathrm{E}-383 \mathrm{M})$; cuatro radiofaros fijos de aterrizaje; cuatro equipos de aterrizaje sin visibilidad (UKW); 26 radiolocalizadores "Freya" completos y 26 radiotelémetros "Würzburg" completos.

También se aprobó la adquisición de 15 grupos electrógenos "Still", con remolque tipo A2 y otros 100 grupos electrógenos con alternador de 100/150 V (EMG). De la lista original presentada por Alemania, las autoridades españolas eliminaron los diez cazas franceses Dewoitine, procedentes de botín de guerra, que no interesaban al Ejército del Aire.

\footnotetext{
${ }^{636}$ La disposición alemana en este sentido era la de entregar un grupo pesado al trimestre (compuesto por tres baterías de $88 \mathrm{~mm}$ ). Antes de terminar las negociaciones, y por mediación del Agregado Aéreo en la Embajada alemana en Madrid, general Kramer, el mariscal Goering accedió al envio de dos grupos móviles y uno estacionario, todos de $88 \mathrm{~mm}$, al trimestre. Todos estos grupos pasarían al Ejército de Tierra.

${ }^{637}$ En un principio se aceptaron los cuatro millones de cartuchos ofrecidos por los alemanes. Pero en una nota al margen que figuraba en la carta enviada por Martinez Campos a Becker, se hacía constar que por el momento solo se enviaran la cuarta parte de dichos cartuchos, el resto, al entregar los aviones pedidos.

${ }^{638}$ Esta lista fue ampliada posteriormente, ofreciéndose diversos equipos de radio de abordo así como emisoras de onda corta y larga.

${ }^{639} \mathrm{La}$ entrega de este material fue retrasada debido a los bombardeos.
} 


\section{VI.2.2.- Llegan a España los materiales}

A partir de finales de mayo de 1943 comenzaría a llegar el material militar del "Programa Bär", en concreto el denominado "Sofortprogramm", en el cual el Ejército del Aire recibió lo siguiente ${ }^{640}$ :

15 cazas Me 109 F4; 10 bombarderos Ju 88 A4; 15 Grupos electrógenos Still; 1.000.000 de disparos para ametralladoras de avión de calibre 7,92, de seis diferentes modelos (sS, SmK, SmK oL, SmK oL Mess, PmK y PmK Mess); cuatro radiofaros de aterrizaje; tres aparatos para localización de barcos Liechtenstein; 50 teléfonos de campaña mod. 33 ("Siemens-Halske"); 15 equipos de repuestos y accesorios para los Bf 109; cuatro equipos de radio pesados motorizados de onda corta; otros cuatro equipos de radio similares a los anteriores pero de onda larga; 15 equipos de radio ligeros motorizados de onda corta FuG y ocho equipos radiogoniométricos E-383 M.

Las tres baterías de cañones antiaéreos de $88 \mathrm{~mm}$, así como doce cañones Oerlikon de $20 \mathrm{~mm}$ que en principio estaban asignados al Ejército del Aire, junto a sus telémetros y proyectores, pasaron a engrosar las partidas de armamento destinadas al Ministerio del Ejército, ya que en España la artillería antiaérea era misión del Ejército de Tierra y no de la Aviación, como ocurría en Alemania.

${ }^{640}$ AMAE. AR. Sig. R-2065-5. 


\section{TABLA VI-G}

\section{"SOFORTPROGRAMM" AIRE. PRECIOS ACORDADOS}

\begin{tabular}{|c|c|c|}
\hline Material & Precio unitario acordado & Precio total \\
\hline $\begin{array}{l}15 \text { cazas Messerschmitt Bf } 109 \text { F-4 } \\
\text { con } 9 \text { equipos de repuestos y } \\
\text { accesorios para los cazas }\end{array}$ & $216.483,3$ & $\begin{array}{l}3.247 .249,5 \text { (Rebajado } \\
\text { finalmente a: } 2.827 .830)\end{array}$ \\
\hline $\begin{array}{l}10 \text { bombarderos Junkers Ju } 88 \text { A-4 } \\
\text { con } 9 \text { equipos de repuestos y } \\
\text { accesorios para los bombarderos }\end{array}$ & 690.000 & 6.900 .000 \\
\hline 1.000 .000 de proyectiles de $7,92 \mathrm{~mm}$ & - & 179.125 \\
\hline 4 radiofaros de aterrizaje & 56.500 & 226.000 \\
\hline 3 radiotelémetros Liechtenstein & 30.000 & 90.000 \\
\hline 50 teléfonos de campaña mod. 33 & 120 & 6.000 \\
\hline 8 equipos de radio motorizados & 211.140 & 1.689 .120 \\
\hline $\begin{array}{l}15 \text { equipos de radio ligeros FüG } 10 \\
\text { motorizados }\end{array}$ & 28.600 & 429.000 \\
\hline 8 radiogoniómetros E-383M & 18.200 & 145.600 \\
\hline \multirow[t]{2}{*}{15 Grupos electrógenos EMS-I "Still" } & 16.000 & 240.000 \\
\hline & Total & 12.732 .675 \\
\hline
\end{tabular}

Todas las cantidades vienen expresadas en marcos. Fuente: AMAE R. 2066-4.

Una vez se hubieron solucionado los problemas económicos, y el trabajo de las subcomisiones técnicas para determinar el precio del material hubo finalizado, comenzó a recibirse el denominado "Restprogramm", que debería comprender todo lo que faltaba del armamento del "Programa Bär" concertado con Alemania.

Enmarcadas en este segundo contingente, llegaron las siguientes partidas:

Un radiolocalizador Freya, diez radiotelémetros Würzburg, 22 temporizadores para señalización radio "Pintsch"; 12 radioemisoras de onda corta AS-59 "Telefunken"; 40 radioemisoras de a bordo FuG 10 "Lorenz"; 20 radioemisoras de a bordo FuG 7 AP 1 "Telefunken"; 100 radioemisoras de a bordo Fu BL 1 y 50 grupos electrógenos E.M.2 w 220 .

Una pequeña parte del material destinado al Ejército del Aire, al igual que ocurrió con el destinado a la Armada o el Ejército de Tierra, no llegaría nunca a manos españolas. La liberación de Francia y la consiguiente retirada alemana, cortó de raíz las lineas terrestres de suministros, lineas utilizadas para el transporte del material de guerra contratado en el "Programa Bär". Quizás lo más importante de este material perdido 
fueran 16 radiotelémetros Würzburg, 25 radiolocalizadores Freya, tres Liechtenstein que restaban de los seis solicitados, 45 radioemisoras FuG 10 de a bordo y 50 grupos electrógenos E.M.2 w 220.

\section{TABLA VI-H}

\section{“RESTPROGRAMM" AIRE. MATERIAL RECIBIDO}

\begin{tabular}{|c|c|c|}
\hline Material & Precio unitario acordado & Precio total \\
\hline $\begin{array}{l}12 \text { radioemisoras AS } 59 \text { (onda corta) } \\
\text { Telefunken }\end{array}$ & 14.000 & 168.000 \\
\hline $\begin{array}{l}85 \text { radioemisoras FuG } \mathrm{X} \text { de a bordo } \\
\text { (onda corta y larga) (solo llegaron } 40 \\
\text { pero hubo que pagar las } 85 \text { contratadas y } \\
\text { reclamar a Schenker las } 45 \text { perdidas) }\end{array}$ & 17.400 & $\begin{array}{l}1.479 .000 \text { (reclamación a } \\
\text { Schenker de } 783.000)\end{array}$ \\
\hline 50 grupos electrógenos E.M. 4 W 220 & 2.220 & 111.000 \\
\hline $100 \mathrm{Fu}$ BL 1 Aparato de a bordo & 5.000 & 500.000 \\
\hline $\begin{array}{l}22 \text { temporizadores para señalización } \\
\text { radio "Pintsch" }\end{array}$ & 2.230 & 49.060 \\
\hline 20 radioemisoras FuG VII aF1 & 5.000 & 100.000 \\
\hline $\begin{array}{l}3 \text { radiotelémetros Liechtenstein }(\mathrm{Se} \\
\text { perdieron en el tren } 25 \text {, pero hubo que } \\
\text { pagarlos y reclamar a Schenker) }\end{array}$ & 30.000 & $\begin{array}{l}90.000 \text { (reclamación a } \\
\text { Schenker de 90.000) }\end{array}$ \\
\hline 1 Radiolocalizador "Freya" & 260.000 & 260.000 \\
\hline \multirow[t]{2}{*}{10 radiotelémetros "Würzburg""641 } & 125.000 & $\begin{array}{l}1.250 .000 \text { (reclamación a } \\
\text { Tierra de } 1.125 .000)\end{array}$ \\
\hline & Total & 4.007.060 (Real: 2.009.060) \\
\hline
\end{tabular}

Todas las cantidades vienen expresadas en marcos. Fuente: AMAE AR. Sig. R. 2066-4

Analicemos con más detalle todo este material recibido en el Ejército del Aire.

\section{VI.2.3.- Material de vuelo y munición para el mismo}

Por lo que respecta a los aviones Messerschmitt Bf 109 F-4, después de ser aceptada la entrega de quince de ellos por parte alemana, su precio se discutió en la reunión celebrada el 28 de junio de 1943 entre las subcomisiones de técnicos militares hispano-alemanes para la revisión de los precios del armamento del "Programa Bär". En dicha reunión, y a requrimiento del representante del Ministerio del Aire Español, los

${ }^{641}$ De estos 10 aparatos, nueve de ellos pasaron al Ejército de Tierra. Aire reclamaría posteriormente 1.125.000 marcos a este Ejército. 
técnicos alemanes aclararon que se trataba de una partida de 15 aviones completos y además, todos los accesorios correspondientes a nueve aparatos, que eran los que constituían una escuadrilla.

El precio solicitado era de 690.000 marcos por avión, incluyendo los accesorios, al cual, los españoles se opusieron rotundamente, pues según ellos, los últimos Meserschmitt ofrecidos, según una oferta alemana fechada en agosto de 1942, lo habían sido a tan sólo 198.000 marcos cada uno, reconociendo que únicamente iba incluído el valor del aparato y no el de los accesorios.

Según los alemanes, el equipo de accesorios lo constituían: un patín de cola; palas sueltas de la hélice; alerones, timones; tren de aterrizaje (patas, ruedas y neumáticos); además de otros elementos de menor entidad.

Los técnicos españoles manifestaron a sus homólogos germanos que los aparatos recibidos no eran nuevos ${ }^{642}$, aunque estaban en buen estado, constando en las cartillas un número variado de horas de vuelo por lo que instaron a reducir el precio solicitado por Alemania, a todas luces exagerado, y aplicar además una rebaja en función de las horas de vuelo de cada avión. El porcentaje pactado fue de un 1\% de descuento sobre el precio final consensuado, por cada diez horas de vuelo que figuraran anotadas en sus cartillas. Al finalizar las reuniones de las subcomisiones técnicas el precio final pactado entre ambos países fué de 203.940 marcos por avión, al que habría que aplicar la rebaja correspondiente.

-Dos aviones con $10 \mathrm{~h}$ de vuelo: $(2 \times 203.940) \times 0.99=$ 403.802

-Dos aviones con $50 \mathrm{~h}$ de vuelo: $(2 \times 203.940) \times 0.95=$ 387.486

-Cinco aviones con $60 \mathrm{~h}$ de vuelo: $(5 \times 203.940) \times 0.94=$ 958.518

-Un avión con 75 h de vuelo: $(1 \times 203.940)$ x $0.925=$ 188.644

-Tres aviones con $110 \mathrm{~h}$ de vuelo: $(3 \times 203.940) \times 0,89=$ 544.519

-Dos aviones ( $\mathrm{n}^{\mathrm{o}}$ de horas de vuelo: desconocido): 2 x $203.940=407.880$

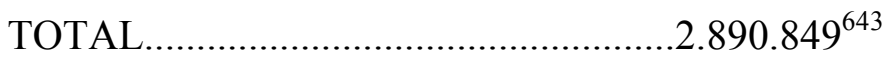

\footnotetext{
${ }^{642}$ En efecto, los aparatos habían estado en servicio con la Luftwaffe según se desprendía de las libretas de vuelo. Informe confidencial sobre el estado del material. Sección de fabricación. Dirección General de Industria y Material. Ministerio del Aire. AMAE. AR. Sig. R-2065-5.

${ }^{643}$ Estas horas de vuelo fueron una aproximación para aplicar la rebaja en el precio y no se correspondían, en general, con la realidad particular de cada avión. Las cantidades son en marcos.
} 
Los repuestos para la escuadrilla de Bf 109 F-4 fueron tasados en un total de 356.400 marcos, suponiendo por tanto, los cazas con sus repuestos, un desembolso global de 3.247.249 marcos.

Pero al final, se debió llegar a algún tipo de acuerdo con "Messerschmitt AG" por el que la cifra total adeudada, que consta en la contabilidad final del "Programa Bär" referente a los aviones Bf 109 F-4 suministrados fue de $2.827 .830 \operatorname{marcos}^{644}$, incluyendo aquí tanto los aparatos como los repuestos correspondientes a una escuadrilla de nueve aviones. Es posible que la empresa germana se aviniera a realizar el descuento por la pérdida de uno de los aparatos, que se estrelló en el vuelo a España desde el aeródromo francés de Villacoubley, aunque esto no deja de ser una suposición.

El 17 de mayo de 1943 fueron entregados los quince Bf $109 \mathrm{~F}-4^{645}$ a los pilotos españoles en el citado aerodromo, quienes salieron ese mismo dia en dirección a Toulouse, a donde llegaron después de una breve escala en Chateauroux. Dos dias después, el diecinueve de mayo, salieron de Toulouse tomando tierra en esa misma jornada en el aerodromo de Reus, donde permanecieron otros dos dias. El dia 21 llegaron a Barajas, y por fin, el 22, aterrizaron en su destino final, Morón de la Frontera. Como hemos apuntado, sólo llegarían catorce aparatos ya que uno de ellos se perdió por accidente en el periplo Villacoubley-Morón ${ }^{646}$.

Por otra parte, los alemanes consintieron la entrega de diez aparatos de bombardeo Junkers Ju 88 A-4. El precio de los mismos se discutió en la reunión mantenida por la subcomisión de técnicos militares del dia 1 de julio de 1943, manifestando los alemanes que no era posible la aceptación del precio propuesto por los españoles, ya que éste se basaba en una oferta de Heinkel 111, y según su parecer no era

\footnotetext{
${ }^{644}$ Correspondencia del Agregado Aéreo en Berlín. AHEA. A-11035. Documento en alemán fechado el 24 de octubre de 1944. En esos momentos esta cantidad todavía figuraba en los listados como no pagada. En la factura remitida por Messerschmit figuraba como precio unitario 198.000 marcos por avión.

${ }^{645}$ Se trataba de los aviones con los números de serie siguientes: 5.789, 7.327, 7.341, 7.486, 7.539, 8.172, $8.205,8.328,10.062,12.638,12.906,13.106,13.110,13.210$ y 13.329 . Cada aparato llevaba un motor DB 601 E, dos ametralladoras MG 17, un cañón MG 151 y dos aparatos de radio, un FuG VII y un FuG 25. Estos datos constan en la factura remitida por "Messerschmitt A.G." al Ministerio del Aire español el 19 de enero de 1944. Correspondencia del Agregado Aéreo en Berlín. AHEA. A-11035.

${ }^{646}$ Aunque en todos los documentos consultados, incluyendo la factura citada anteriormente, figura que los Bf 109 eran de la versión F-4, después de las investigaciones realizadas por mi buen amigo Jose Luis Gonzalez Serrano, hay que concluir que este extremo no debió de ser así, y por lo menos cinco de los aparatos, -a juzgar por algunos aspectos externos así como los Werk Nummer correspondientes a los mismos- pertenecían a la serie F-2. La investigación está abierta.
} 
posible una comparación entre ambos aparatos. A estos efectos señalaron que el Ju 88 A-4 tenía más movilidad y más fuerza que el He $111^{647}$, tratándose además se trataba de una combinación de caza y bombardero.

El representante del Ministerio del Aire español manifestó que el precio ofrecido por España se basaba en la oferta hecha por Alemania en diciembre de 1942 y que en realidad el aparato era el mismo ${ }^{648}$. En dicha oferta el Heinkel He 111 se trataba de un aparato con las más modernas instalaciones de aviación, como por ejemplo radiogoniómetros, aparatos de puntería óptica, transmisión de mandos automático, instalaciones de visibilidad, depósito de bombas y ametralladoras, instalación de altura etc..., y sin embargo el precio solicitado fue de 498.000 marcos. Estuvo de acuerdo con las variaciones de las características de un avión y de otro, pero creía, sin embargo, que dada la calidad de ambos aviones el precio no podría variar ostensiblemente. El precio, según su apreciación, no podría subir de 500.000 marcos.

Los alemanes apostillaron que, aún después de escuchar los razonamientos españoles, los aparatos no eran similares, y por consiguiente su precio tampoco podía serlo. Se trataba del avión más caro que construía la aviación alemana.

En cualquier caso, despues de arduas negociaciones, se llegó por fin a un acuerdo en el precio de estos aparatos, fijándolo en 600.000 marcos cada uno, aproximándose mucho más a la posición española que a la alemana.

Los repuestos para una escuadrilla de nueve aparatos de esta clase fue tasada en 900.000 marcos, suponiendo, por tanto, los diez aviones con los repuestos, un precio total de 6.900 .000 marcos.

Los aviones fueron entregados por el IV KG 76 en Toulouse el dia 30 de noviembre de 1943, después de un intensivo entrenamiento de las tripulaciones españolas, llegando en vuelo los diez aparatos sin novedad a Albacete ese mismo día. Al mando de la escuadrilla el teniente coronel Manuel Lapuente de Miguel.

\footnotetext{
${ }^{647}$ En una de las reuniones celebradas en Berlín entre el Presidente de la Comisión española general Martinez de Campos y el general alemán Becker, se trató el asunto del posible cambio de los Ju 88 A4 por He 111, aviones que preferían los militares españoles. El coronel alemán Beutler indicó a Martinez de Campos que no era posible el cambio de los Ju 88 por los He 111 porque estos aviones hacían falta para Africa.

${ }^{648}$ Obviamente el aparato no era el mismo.
} 
Las municiones recibidas para los aviones, 1.000 .000 de cartuchos, constituían la partida n 17 del "Sofortprogramm" y llegaron a España el 16 de junio en el denominado tren $\mathrm{n}^{\mathrm{o}} 4$, a la estación de Port Bou, clasificándose en los siguientes tipos:

250.000 proyectiles de 7,92 s.S.; 250.000 proyectiles de 7,92 SmK; 125.000 proyectiles de 7,92 SmK o.L.; 125.000 proyectiles de 7,92 SmK o.L. Mess; 125.000 proyectiles de 7,92 PmK y 125.000 proyectiles de 7,92 PmK Mess.

Su coste total se evaluó en 179.125 marcos. Los técnicos militares alemanes aceptaron el precio propuesto por los españoles para todas estas partidas.

\section{VI.2.4.- Equipos de radio y localización}

Por lo que respecta a los equipos móviles pesados, cada uno de ellos venía repartido en tres camiones y un remolque: un camión para el equipo transmisor, otro para el receptor y un tercero para la antena, llevando en el remolque el grupo electrógeno. Se trataba de un material contenido en camiones especiales dotados de cajas cerradas, especialmente diseñadas para transportarlos y operar con los soldados dentro de los mismos vehículos. Todo el material radio era de la empresa "Telefunken". Se trataba de unos potentísimos equipos de 1.500 watios de potencia de salida, aptos para las comunicaciones entre cuarteles generales, cuepos de ejército o estados mayores de los ejércitos ${ }^{649}$.

Los equipos receptores: eran una mezcla de aparatos nuevos con otros muy usados y los camiones eran de tipo Mercedes, fabricados entre 1941 y 1942, presentando un aspecto muy digno y con poco uso. Se puede decir que venían en muy buen estado.

Los equipos emisores eran aparatos en buen estado pero muy usados. Los camiones, de tipo Krupp, en cambio, eran muy antiguos y presentaban, en general, mal aspecto. La pintura descuidada, ruedas muy gastadas, aletas y estribos dañados, y faltaban cortinillas, lonas y algunos útiles como gatos y herramientas. Los motores también estaban bastante usados.

Los equipos de antenas se notaban también muy usados, y el estado de los camiones porta-antena era lamentable.

\footnotetext{
649 German Radio Communication Equipment. US War Department Technical Manual, TME 11-227.
} June, 1944, pag. 14. 
En las conversaciones entre las comisiones económicas de ambos países, se decidió, después de muchas horas de discusión, valorar cada uno de los equipos de onda corta en 227.700 marcos, frente a los 860.000 marcos que solicitaban los alemanes. De la misma forma, los equipos de onda larga fueron valorados en 269.100 marcos cada uno, frente al 1.020.000 marcos solicitados por la Delegación germana. En total, los ocho equipos de radio móviles fueron valorados en 1.986.200 marcos.

Hubo una revisión posterior de los precios de estos equipos de radio pues en la contabilidad final del material del Ejército del Aire recibido en el marco del "Programa Bär" consta como precio pagado por los ocho equipos citados un montante de 1.689.120 marcos, una cifra inferior a la previamente pactada en casi $300.000 \operatorname{marcos}^{650}$.

Al analizar la factura emitida por Telefunken ${ }^{651}$ por estos ocho equipos encontramos la solución. La propia casa, después de las protestas por el estado en que llegó el material a España, reconsideró el precio de los ocho equipos aplicando al precio conjunto pactado en Madrid una rebaja del 15\%. En efecto, el 15\% de 1.987 .200 marcos son 298.080 marcos, que restados a la cantidad inicial nos proporcionan la cifra contenida en la contabilidad final del "Programa Bär" del Ejército del Aire.

Los equipos móviles ligeros eran los mismos aparatos FuG 10 que llevaban los aviones pero montados en remolques ligeros, fácilmente transportables.

Pese a que la subcomisión alemana solicitaba 88.000 marcos por cada uno de estos equipos FuG 10 de la casa Lorenz, los españoles consiguieron que fueran valorados finalmente en 17.400 marcos cada uno, rebajando considerablemente la oferta alemana con la que se iniciaron las negociaciones. El importe total de la partida de quince equipos se fijó, por tanto, en 261.000 marcos alemanes.

Pero posteriormente, el 10 de agosto de 1944, los negociadores germanos consiguieron elevar el precio de estos equipos móviles, aduciendo que no se trataba solamente de los equipos de radio, sino que se debería valorar también el remolque en el que iban los mismos, quedando la cifra final contemplada en la contabilidad del

\footnotetext{
650 Así ocurrió. En un documento entregado al Agregado Aéreo español por representantes del Ministerio del Aire alemán el 26 de octubre de 1944, consta esa cantidad de 1.689.120 marcos como pagada por los ocho equipos móviles. Correspondencia del Agregado Aéreo en Berlín. AHEA. A-11035.

${ }^{651}$ Esta factura consta en la documentación y correspondencia del Agregado Aéreo en Berlín. AHEA. A11035.
} 
"Programa Bär" del Ministerio del Aire, en 429.000 marcos -28.600 marcos por cada equipo FuG 10-.

Se adquirieron también equipos de a bordo de los modelos FuG $7^{652}$ y FuG $10^{653}$ para montar en aeronaves, radioemisoras AS 59 de onda corta ${ }^{654}$, aparatos de a bordo Fu $B L 1^{655}$ y teléfonos de campaña mod 33.

Referente a los radiolocalizadores y radiotelémetros no haremos más que una somera mención, por haber sido tratados ampliamente de manera conjunta en el capítulo anterior, al estudiar el material del Ejército de Tierra.

Los radiolocalizadores Liechtenstein SFuG 213 fabricados por "Telefunken", eran unos modernos aparatos de radar para ser embarcados en los propios aviones. Por su reciente incorporación a la Luftwaffe resultaban desconocidos en España pues nunca habían sido exportados por Alemania. Su precio de 114.000 marcos fue aceptado por los negociadores hispanos, ya que no tenían elementos de juicio para regatear ni para saber a ciencia cierta su precio real de mercado ${ }^{656}$. Curiosamente, con posterioridad, los propios alemanes rebajarían esta cifra, dejando el precio de cada aparato en 30.000 marcos, por lo que los seis incluidos en el programa alcanzarían un valor de 180.000 marcos. Pese a todo, únicamente se recibirían tres unidades.

\footnotetext{
${ }^{652}$ El FuG 7 fue el equipo de radio estandar en los aviones monoplaza (sobre todo el Bf 109) desde el comienzo de la Segunda Guerra Mundial hasta 1943. Desde ese año fue sustituido por el FuG 16Z, aunque se siguió empleando en algunos aparatos de la Luftwaffe como el Ju 87 "Stuka". German Radio Communication Equipment, op. cit., pág. 38.

${ }^{653}$ El FuG 10 fue el equipo más utilizado en los aviones polimotores -cazas y bombarderos- de primera línea, incluyendo también algunos hidroaviones. Podía emitir y recibir en onda corta y larga para lo que disponía de dos transmisores y dos receptores. En los últimos modelos, los receptores de onda corta disponían de un identificador amigo-enemigo. German Radio Communication Equipment, op. cit., pág. 40.

${ }^{654}$ Se trataba de equipos transmisores fabricados por Telefunken entre 1939 y 1940, con 200 watios de potencia de salida. En el transcurso de la guerra, también fueron fabricadas en Francia por SFR, en su factoría de Levallois-Perret, cerca de París. http://www.nonstopsystems.com/radio/hellschreiber-mil-txrx.htm.

${ }^{655}$ Los FuG. BL 1 eran equipos complementarios de a bordo para aterrizaje sin visibilidad.

${ }^{656}$ Como ya se ha explicado en el capítulo anterior, el asunto de los radiotelémetros y radiolocalizadores estuvo rodeado de problemas. Todos los Freya y los Würzburg contratados en el "Programa Bär" eran para el Ejército del Aire, -para dirigir con ellos a la aviación de caza-, lo mismo que los "Liechtenstein", que eran aparatos para montar en los propios aviones. Recibido el material, se llegó a un acuerdo interministerial entre Aire y Tierra para repartírselos.
} 
De los 26 equipos de radiolocalización Würzburg Mod 39 TD contratados solamente llegaron diez, pagando el Ejército del Aire 125.000 marcos por unidad. Más tarde se llegaría a un acuerdo con Ejército de Tierra para entregar nueve de ellos para la artillería antiaérea. Sólo uno del grupo de 26 Freya contemplados el el "Bär" llegó a España; sería empleado junto a un Würzburg en la Unidad de Protección de Vuelo del Ejército del Aire.

\section{VI.2.6.- Material para la protección de vuelo y otros equipos}

Cada uno de los cuatro radiofaros de aterrizaje adquiridos fue valorado por la comisión alemana en 56.500 marcos, realizando los españoles una contraoferta de 26.500 marcos por unidad, basándose en el precio de aparatos idénticos adquiridos hacía poco menos de un año. Al final se llegaría a un acuerdo, incrementándose algo la oferta española, pactándose un precio por radiofaro de 35.000 marcos. Inexplicablemente, el precio final recogido en las cuentas generales del Ejército del Aire en el "Programa Bär" es el inicialmente solicitado por los alemanes, 56.500 marcos por cada aparato ${ }^{657}$.

Los radiogoniómetros venían sobre remolques de cuatro ruedas, en general en buen estado de conservación, aunque no eran nuevos. Alemania solicitó 70.000 marcos por cada uno, cifra a todas luces exagerada pues en enero de 1943 se habían adquirido nueve aparatos semejantes al precio de 9.500 marcos. El precio final aceptado por ambas comisiones fue de 18.200 marcos.

Para terminar, los grupos electrógenos modelo EMS I "Still” (partida n ${ }^{0}$ 5), eran el material que, en apariencia, estaba en mejor estado, considerándolo como nuevo. Aún así los técnicos alemanes, después de breve deliberación, aceptaron el precio de la oferta española cifrada en 16.000 marcos por unidad, descartando los 30.963 solicitados por ellos al inicio de las negociaciones. En cualquier caso hay que comentar que en la partida de los quince recibidos los había de dos tipos diferentes: unos sobre chasis de cuatro ruedas y otros sobre chasis de dos ruedas.

Los generadores EM.4 "Still” se habían solicitado para para dar corriente a los 100 equipos de radio VR. 27b de onda corta solicitados en el Programa. Sólo se

\footnotetext{
${ }^{657}$ Correspondencia del Agregado Aéreo en Berlín. 5841g/G/44 vW/Pr, con fecha 24-10-1944. AHEA. A-11035.
} 
recibirían 50 aparatos, los otros cincuenta sucumbirían en el denominado Tren $\mathrm{n}^{\mathrm{o}} 27$, que fue bombardeado en su trayecto hacia España, y las radioemisoras jamás se recibirían.

El material obtenido por el Ejército del Aire español en el marco del "Programa Bär" fue más bien discreto, y sin duda, menor en cantidad que sus homólogos de Tierra y Marina. $\mathrm{Y}$ es que todas las baterías antiaéreas, tanto pesadas como ligeras, que en principio pertenecían a Aire, pasaron al programa del Ejército de Tierra; al igual que la mayor parte de los radiotelémetros Würzburg, y muchos de ellos así como todos los Freya -excepto uno- nunca se llegarían a recibir. Tampoco llegarían algunos equipos de radio y la mitad de los grupos electrógenos ligeros contratados.

En cualquier caso hay que decir que la Aviación española había adquirido numeroso material bélico y licencias de fabricación al margen del programa, mediante los famosos "Acuerdos Marco" -Rahmenwertrage- con empresas germanas desde 1939.

Respecto a los militares españoles que deberían acudir a Alemania para instrucción, el OKW germano consideró que el personal de maestranza que habría de practicar las reparaciones de los Junkers Ju 88 se podría sustituir por los especialistas de tierra de las escuadrillas. Además, el alto mando de la Wehrmacht redujo a seis los técnicos del Ejército del Aire que deberían acudir al Reich a practicar con los radiolocalizadores, radiofaros y radiogoniómetros "Adcock". 


\section{Capítulo 7}

\section{LAS CUENTAS GENERALES DEL "PROGRAMA BÄR"}

Como hemos visto, las negociaciones hispano-alemanas llevadas a cabo entre 1942 y 1943 dieron como resultado más importante la firma del denominado "Programa Bär", cuya vertiente militar ya hemos analizado. Nos disponemos ahora a estudiar como se desarrolló el aspecto económico del programa, principal escollo para las aspiraciones alemanas de disponer de crédito suficiente para financiar sus importaciones en España, debido en gran medida a la labor estricta y eficiente de los militares españoles que valorararon y justipreciaron el material bélico germano.

Las reuniones celebradas en Madrid de la denominada Subcomisión TécnicoMilitar para el estudio de la valoración del material de guerra adquirido en el marco del "Programa Bär" ${ }^{658}$, dieron comienzo el 15 de junio de 1943, y se prolongaron durante un mes entero, finalizando el 17 de julio. El resultado definitivo de las mismas fue un gran fiasco para los intereses germanos: estos habían valorado el material solicitado por España en 625.525.828 marcos, precio que se vería mermado tras las negociaciones económicas entre las citadas subcomisiones en casi dos terceras partes de esta cantidad. El precio acordado para todo el armamento, al final de las negociaciones, sería de 216.508.793 marcos, muy lejos, evidentemente, de la cifra solicitada en primera instancia por los alemanes.

Hay que decir que si se hubiera cumplido a rajatabla el desarrollo del Programa, habría llegado a España material militar para los tres ejércitos por valor de esos 216.508.793 marcos. Pero resulta conocido, y hemos tenido ocasión de analizarlo en capítulos anteriores, que los acontecimientos bélicos ocurridos en Francia a partir de junio de 1944, con el desembarco aliado en la región de Normandía, dieron al traste la posibilidad de comunicación por vía terrestre entre Alemania y España, por lo que el "Programa Bär" de armamento -al igual que ocurrió con el de maquinaria- nunca llegaría a completarse.

\footnotetext{
${ }^{658}$ En estas reuniones participaron por parte española, el teniente coronel de artillería José Salgado Muro; el teniente coronel de armas navales, Lorenzo Pallarés Cacha, el comandante de intendencia, Antonio González de Guzman y el coronel ingeniero aeronáutico, Antonio Núñez Rodríguez. AMAE. AR. Sig. R2066/6.
} 
La primera fase de dicho programa, la que hemos denominado "Sofortprogramm", cuyos transportes de mercancías tuvieron lugar entre mayo y junio de 1943, pudo llevarse a efecto satisfactoriamente, casi en su totalidad. Lo cierto es que algunas partidas - muy pocas- de lo concedido al Ejército de Tierra y a Aviación, quedaron fuera de este primer envío masivo de material militar y pasaron a engrosar el contingente de la segunda fase -la que hemos denominado insistentemente "Restprogramm"-. En cambio, lo presupuestado para la Marina española en el primer envío superó las previsiones iniciales, llegando algún material adicional que no estaba contemplado para esta fase, lo que provocó un incremento en la cifra acordada en las conversaciones de Madrid para la Armada. Solo así se explican las pequeñas desviaciones en las cifras reales del "Sofortprogramm", que pueden verse reflejadas en la primera parte de la Tabla VII-N, situada al final de este capítulo a modo de resumen y recapitulación.

Las verdaderas dificultades de ejecución y los problemas derivados del transporte terrestre por una Francia cada vez más peligrosa, se manifestaron en el transcurso de la segunda fase del "Programa Bär", la que hemos venido denominando "Restprogramm". Entre septiembre de 1943 y junio de 1944 las expediciones se produjeron con cierta regularidad, aunque en ningún caso se cumplieron los plazos previstos en las conversaciones hispano-germanas celebradas en Berlín en la primavera de 1943. En esta segunda fase saldrían de Alemania y alcanzarían la frontera española con normalidad un total de 24 trenes con armamento y material para los tres ejércitos. Otros cuatro trenes pertenecientes a esta segunda fase, los numerados desde el 25 hasta el 28, sufrieron todo tipo de incidencias en su periplo por Alemania y Francia, lo que provocó que una buena parte del material que transportaban se perdiera o incluso volviera a las estaciones de origen en mejor o peor estado.

Todos estos inconvenientes en el normal desarrollo de los transportes, unidos a ciertos cambios -o llamémosle correcciones- en la valoración de algunos materiales, unas veces al alza y otras a la baja, por parte de las autoridades germanas, o incluso el rechazo de algunas partidas o la solicitud de que formaran parte del Programa otras que no se habían discutido en las conversaciones de Madrid, produjeron distorsiones en las cifras originales del "Programa Bär", distorsiones que nos proponemos analizar desde su vertiente económica, con el estudio y la comparativa entre los presupuestado en las reuniones Madrid en julio de 1943 y lo que al final "pudo llevarse a cabo" de este envío 
masivo de armas de guerra de la Alemania hitleriana a la España franquista de mediados de los años cuarenta.

Como primera aproximación a las valoraciones económicas del armamento alemán del "Programa Bär" deberemos tener presentes los precios solicitados por Alemania al iniciarse las conversaciones de Madrid en junio de 1943 y los acordados entre ambas delegaciones al finalizar las dicusiones, en julio de 1943. Dicha comparativa se puede ver en la tabla mostrada a continuación.

\section{TABLA VII-A}

“PROGRAMA BÄR”. NEGOCIACIONES ECONÓMICAS DE MADRID

\begin{tabular}{|c|c|c|c|c|c|c|c|c|}
\hline & \multicolumn{2}{|c|}{ Ejército de Tierra } & \multicolumn{2}{|c|}{ Marina } & \multicolumn{2}{|c|}{ Ejército del Aire } & \multirow{2}{*}{$\begin{array}{c}\text { Total } \\
\text { solicitado }\end{array}$} & \multirow{2}{*}{$\begin{array}{c}\text { Total } \\
\text { acordado }\end{array}$} \\
\hline & Solicitado & Acordado & Solicitado & Acordado & Solicitado & Acordado & & \\
\hline $\begin{array}{l}\text { 1' Expedición } \\
\text { "Sofortprogramm" }\end{array}$ & 45.845 .086 & 21.073 .100 & 19.343 .900 & 4.948 .200 & 50.057 .954 & 13.268425 & 115.246 .940 & 39.289.725 \\
\hline $\begin{array}{l}2^{a} \text { Expedición } \\
\text { "Restprogramm" }\end{array}$ & 138.221 .873 & 90.929 .350 & 218.117 .385 & 70.805 .293 & 153.939 .630 & 15.484 .435 & 510.278 .888 & 177.219 .078 \\
\hline Total solicitado & 184.066 .959 & & 237.461 .285 & & 203.997.584 & & 625.525 .828 & \\
\hline Total acordado & & 112.002 .450 & & 75.753 .493 & & 28.752 .860 & & 216.508 .793 \\
\hline \% disminución & & $39,16 \%$ & & $69,10 \%$ & & $85,91 \%$ & & $65,39 \%$ \\
\hline
\end{tabular}

Fuente: Elaboración propia. AMAE R-2066, Leg. 4. (Todas las cantidades en marcos)

Para el pago de los suministros bélicos del "Programa Bär", siguiendo las instrucciones de los ministerios militares, del ministerio de Asuntos Exteriores y del Instituto Español de Moneda Extranjera (IEME), se llegó al acuerdo que se haría mediante ingreso en dicho Instituto del contravalor en pesetas de las cantidades que correspondieran en cada caso a cada uno de los tres ministerios implicados: Tierra, Marina o Aire. Las instrucciones recibidas por el IEME para el pago a los alemanes fueron las de abrir un crédito a AGEKA por las cantidades depositadas, del cual dispondría por sumas parciales contra la presentación de facturas o contratos que llevaran la autorización o el visto bueno del Agregado Mililitar correspondiente. Esta forma de pago se estimó como las más rápida y práctica, obteniendo la aprobación por parte del Agregado Comercial alemán de la Embajada germana en Madrid.

En el caso de que los contratos no tuvieran como contraparte a la AGEKA, sino que se hubieran firmado con una casa comercial o fábrica alemana, el Agregado Militar 
correspondiente tendría que indicar a dicha empresa alemana que se pusiera de acuerdo con AGEKA para que ésta le hiciera efectivo el importe de su factura o facturas ${ }^{659}$.

Analicemos separadamente lo ocurrido con cada uno de los tres beneficiarios del Programa, pues su desarrollo fue diferente y con vicisitudes propias.

\section{VII.1.- LAS CUENTAS DEL EJÉRCITO DE TIERRA}

Entre el mes de julio y el de diciembre del año 1943 se realizaron dos aportaciones económicas para ir haciendo frente a los pagos del material enviado hasta entonces, correspondiente al Ejército de Tierra. La primera de ellas fue de 21.073.100 marcos, muy aproximada al valor del material recibido en el "Sofortprogramm", y la segunda, de 27.280.320, cercana también al material recibido hasta finales de diciembre de ese año y encuadrada en la segunda fase del Programa. De esta manera, el 31 de diciembre, el Ministerio del Ejército había aportado ya 48.353 .420 marcos.

Iniciado ya el año 1944, y concretamente el 26 de enero, el Ministerio del Ejército realizó una tercera consignación de crédito por valor de 40.000 .000 de marcos, con lo cual, la cifra total de crédito abierto a la AGEKA alemana por parte del Ejército de Tierra español ascendía ya en esa fecha a la cifra de 88.353.420 marcos

Los pagos autorizados por el Agregado Militar en Berlín hasta el mes de mayo de 1944 supusieron 86.690.726 marcos, incluyendo en esta cifra el total del material recibido en el "Sofortprogramm", recogido en las 13 facturas que generó esta primera fase (por valor de 20.718.340 marcos, Tabla VII-B), y el comprendido entre las facturas 1 y 72 del denominado "Restprogramm" (cuyo valor ascendía a 65.972.386 marcos) El saldo disponible a favor de España sobre el crédito inicial era entonces de 1.662.694 marcos.

\footnotetext{
${ }^{659}$ Carta remitida por el coronel José Salgado Muro al Agregado Militar español, coronel Carlos Marín de Bernardo, el 8 de octubre de 1943, con las instrucciones para el pago del material comprendido en el "Programa Bär". En esta misma misiva el coronel Salgado informa a Marín de Bernardo que "...Por lo que se refiere a Marina y Aire, aún cuando los Agregados Militares en esa (Embajada) recibirán instrucciones de sus Ministerios, en el Instituto de Moneda me indican, propondrán seguir la misma tramitación y forma de pago que nosotros..." En cambio, todo lo referente al "Programa BärMaquinaria”, Salgado afirma: “... escribo con frecuencia a Villegas, dándole instrucciones, por no molestarle a Vd. con más discos de los que ya tiene, y porque esa cuestión la llevará más directamente la Dirección de Industria y Material, siguiendo instrucciones del Sr. Ministro y con arreglo a las relaciones que obran en su poder..." AGMAV. Caja 24.706. Fondo del antiguo Ministerio del Ejército.
} 
TABLA VII-B

"SOFORTPROGRAMM" TIERRA. FACTURAS RECIBIDAS

\begin{tabular}{|l|l|l|r|}
\hline $\mathbf{N}^{\mathbf{0}}$ & Núm. factura & Clase de material & Importe (en marcos) \\
\hline 1 & 1177 & 3 baterías de 8,8 cm Flak & 1.482 .410 \\
\hline 2 & $179 / 81989$ & Tres direcciones de tiro, telémetros, et... & 501.880 \\
\hline 3 & $571012 / 1$ & 3 juegos de instalaciones eléctricas UTG 37 & 265.710 \\
\hline 4 & $97566 / \mathrm{Wi}$ & 100 motocicletas pesadas BMW R-750 & 259.400 \\
\hline 5 & Sin núm. & 10.000 granadas de mano fumígenas & 43.100 \\
\hline 6 & 814 & 400 motocicletas tipo medio & 593.840 \\
\hline 7 & Sin núm. & 10.000 brocales de fusil & 1.520 .000 \\
\hline 8 & NBM 727 & 50.000 minas antitanque & 2.750 .000 \\
\hline 9 & 812 & 1.000 fusiles lanzagranadas & 1.100 .000 \\
\hline 10 & 813 & 100 cañones de 12.2 cm y 3.000 proyectiles & 11.710 .000 \\
\hline 11 & 811 & 12 piezas de 2 cm Flak Oerlikon Flak 28 & 356.400 \\
\hline 12 & KS 761128 & 4 proyectores de 60 cm & 116.400 \\
\hline 13 & $197 / 84277 / 1$ & Cuatro telémetros de 1 m de base R-36. & 19.200 \\
\hline & & TOTAL & $\mathbf{2 0 . 7 1 8 . 3 4 0}$ \\
\hline
\end{tabular}

Elaboración propia. "Pago del material contratado en Alemania" Cuarta Sección del EMCE. 17 de diciembre de 1943. Caja 24708, carpeta 2 .

Notas:

-Las facturas 1, 2 y 3 corresponden al Grupo antiaéreo pesado fijo, emplazado en Algeciras. Su coste pactado en Madrid fue 2.250 .000 , igual al aquí consignado

-El precio unitario pactado en Madrid de las primeras 100 motos, fue de $2.230 \mathrm{RM}$ y el de las 650 restantes, de 2.650. La AGEKA estableció un precio medio unitario de $2.594 \mathrm{RM}$, que se aplica aquí y se aplicará al segundo cupo.

-El precio unitario de las granadas fumígenas fue rebajado, de 4,5 RM por unidad a 4,31 RM por cada granada de mano.

-Las facturas 11, 12 y 13 corresponden al Grupo antiaéreo ligero. La suma de las tres importa una cantidad de 492.000 RM, idéntico al acordado en Madrid.

-Del primer cupo de Ejército de Tierra sólo quedaban por abonar: 6 equipos repetidores de baja frecuencia, 20 teletipógrafos y 3 radiotelémetros "Litchtestein". Los dos primeros llegaron en el "Restprogramm” y el tercero pasó al Ejército del Aire, luego tendría que pagarlo este Ejército.

El 19 de junio de 1944, el Ministerio del Ejército pondría a disposición del IEME un cuarto y último pago a cuenta del "Programa Bär", para abonar en la cuenta abierta a AGEKA, por valor de 14.000 .000 de marcos.

Dos meses y medio más tarde, el 31 de agosto de 1944, el Director General de Industria y Material del Ministerio del Ejército, remitía al ministro un informe detallado de la situación financiera del "Programa Bär" del Ejército de Tierra hasta ese momento ${ }^{660}$. Para la realización del documento no se tuvo en cuenta ni el tren $\mathrm{n}^{\mathrm{o}} 25$, del que se desconocía su paradero, ni el nº 26, del que sólo se sabía que había llegado a la frontera, no sabiendo nada de su contenido y valoración. Tampoco se tuvieron en

660 "Liquidación del Plan de Adquisiciones con destino al Ejército hasta el tren $\mathrm{n}^{\mathrm{o}} 24$ inclusive". AGMAV. Caja 24.708. Fondo del antiguo Ministerio del Ejército. 
consideración para redactar el informe los trenes $n^{\circ} 27$ y 28, pues ninguno de ellos había salido todavía de Alemania, por lo que se ignoraba también su contenido y la valoración del mismo.

Hay que aclarar que este informe, por precipitado, contenía información no contrastada y cifras que no se correspondían con la realidad, como meses más tarde se comprobó en informes posteriores. Si lo traemos aquí es por la sencilla razón de que era la primera vez que se intentaban cuadrar las cuentas generadas por el conjunto de las partidas adquiridas en el seno del "Programa Bär" de manera sistemática y desde un organismo oficial directamente implicado en su desarrollo. Las dificultades en las comunicaciones de la época (teléfonos, valija diplomática, correo...), agravadas si cabe por los bombardeos continuos de la capital del Tercer Reich - con los consiguientes trastornos sufridos en la Embajada de España- y los retrasos permanentes en los transportes por vía terrestre, unido todo ello a las necesidades germanas de armamento y la dilación en constituirse trenes cargados con material que justificaran un viaje tan largo, provocaron un verdadero caos administrativo que repercutió negativamente en la comprensión económica y organizativa del Programa.

Según el informe, todo el material recibido en España, tanto el correspondiente al "Sofortprogramm" como el recibido hasta el tren $n^{\circ} 24$ del "Restprogramm" -último recogido en el informe-, se valoraba en ese momento en 92.017.517,51 marcos, aunque las facturas recibidas a fecha 31 de agosto de 1944 solo recogían un importe conjunto de 87.461.695,11 marcos, por lo que se deduce que muchas de ellas todavía no habían sido remitidas desde Berlín, por parte del Agregado Militar.

Hemos detallado ya, que mediante cuatro transferencias realizadas al IEME en diferentes fechas de los años 1943 y 1944, se había puesto a disposición de AGEKA un montante total de 102.353.420 marcos, cuyo desglose se justifica en la tabla siguiente.

\section{TABLA VII-C}

\section{PAGOS AUTORIZADOS A AGEKA (31-8-1944)}

\begin{tabular}{|l|l|r|}
\hline Pago & \multicolumn{1}{|c|}{ Fecha } & \multicolumn{1}{c|}{ Cantidad } \\
\hline 1 & $6-10-1943$ & 21.073 .100 \\
\hline 2 & $12-11-1943$ & 27.280 .320 \\
\hline 3 & $26-1-1944$ & 40.000 .000 \\
\hline 4 & $19-6-1944$ & 14.000 .000 \\
\hline & TOTAL & $\mathbf{1 0 2 . 3 5 3 . 4 2 0}$ \\
\hline
\end{tabular}


Fuente: "Liquidación del Plan de Adquisiciones con destino al Ejército hasta el tren n 24 inclusive". AGMAV. Caja 24.708. Cantidades en marcos

Por tanto, a 31 de agosto de 1944, y a falta de contabilizar el material correspondiente al Ejército de Tierra que venía en los trenes 25 y 26, el saldo a favor del Estado español en poder de AGEKA ascendía a la diferencia entre lo consignado a ésta y el valor de las mercancías supuestamente recibidas en territorio español: 10.347.289,15 marcos.

Dos meses después de este primer informe, en octubre de 1944, la cuarta sección del EMCE presentó al general jefe del organismo un estado de cuentas mucho más realista y madurado de la evolución financiera de la parte del "Programa Bär" correspondiente al Ejército de Tierra, que en líneas generales, era el siguiente ${ }^{661}$ :

Una gran parte del material del "Programa Bär" que había sido recibido en nuestro país estaba ya abonado contra la cuenta de clearing. Se trataba de todo aquel que disponía de factura comprobada y firmada por el Agregado Militar en Berlín, y en estas fechas su valor era 88.792.701 marcos. La diferencia entre el dinero consignado a AGEKA y el realmente pagado por el material recibido en España era, según los datos del Agregado Militar en Berlín, de 13.560.719 marcos a favor de España ${ }^{662}$.

Por contra había cierto material que, pese a estar ya en España, no se había pagado al no haberse presentado las facturas correspondientes por parte alemana. Este material pertenecía a las partidas numeradas como 32, 49, 50, 73 y 66, y su importe ascendía a 1.883.240 marcos. (Ver Anexo XV-A)

Otra parte del material había salido ya de Alemania, aunque no se había recibido en España por problemas en el transporte (destrucción o captura de los vagones en los que viajaba, en territorio francés). Aquí estaba todo el cargamento que transportaba el denominado "Tren $n^{\circ} 25$ ", el cual no había sido asegurado contra el riesgo de guerra y

\footnotetext{
${ }^{661}$ Estado Mayor Central del Ejército. Sección Cuarta. No 4598-K. A/M Cuenta para S.E. "Estado actual de las entregas y pagos del material correspondiente al Programa Bär. AGMAV. Caja 24.707. Fondo del antiguo Ministerio del Ejército.

${ }^{662}$ Es muy curioso constatar que en agosto, el saldo a favor de España fuera de 10.347.289,15 marcos, pero dos meses mas tarde -y siempre según el Agregado Militar en Berlín- dicho saldo había pasado a ser de 13.560.719,15 marcos. Esto podría interpretarse como un error o un absurdo contable, pero tiene su explicación. Sabemos que en la valoración llevada a cabo en agosto, se tuvo en cuenta el precio de todo el material recibido hasta el tren $n^{\circ} 24$, se hubiera recibido o no la factura acreditativa del proveedor alemán. Es evidente que en la valoración de octubre, realizada por el coronel Marín de Bernardo, éste tuvo en cuenta únicamente el material entregado del que se había presentado la correspondiente factura, por eso existe esta aparente divergencia en las cifras.
} 
que al parecer fue destruido por el "Maquisard" en Francia, en el trayecto de Dijon a Port-Bou. El armamento que transportaba este tren se tuvo que considerar -a efectos de la contabilidad- como material entregado, y las discusiones sobre el mismo habrían de tener lugar entre el gobierno español y la casa transportista Schenker, pues según el Agregado Militar en Berlín, tenía motivos para pensar que la no llegada a España de este material tuvo como causa la negligencia de los encargados del transporte. Dicho tren transportaba granadas de fusil contracarro, correspondientes a las partidas 45, $46 \mathrm{y}$ 47, así como 200 ruedas de repuesto para las motocicletas BMW R 75, cuyo valor era de 939.000 marcos. (Ver Anexo XV-B)

Si sumamos las dos cantidades anteriores, obtendremos el valor total del armamento recibido en España y todavía no pagado en octubre de 1944. Éste era, por tanto, 2.822.240 marcos, cantidad que habría que restar del depósito en ROWAK anteriormente citado para conocer el saldo real a favor del Ejército español en poder del los alemanes. Esta cifra alcanzaba los 10.738.479 marcos.

\section{TABLA VII-D}

“PROGRAMA BÄR" (TIERRA). ESTADO DEL MISMO EN OCTUBRE DE 1944

\begin{tabular}{|l|l|}
\hline Concepto & Valor \\
\hline Depositado en AGEKA por el Ministerio del Ejército & 102.353 .420 \\
\hline Material recibido y pagado por el Ministerio del Ejército & $(88.792 .701)$ \\
\hline Material recibido y no pagado por el Ministerio del Ejército & $(1.883 .240)$ \\
\hline Material que viajaba en el Tren no 25 (considerado como recibido) & $(939.000)$ \\
\hline Saldo real a favor del Ministerio del Ejército español & $\mathbf{1 0 . 7 3 8 . 4 7 9}$ \\
\hline $\begin{array}{l}\text { Material no recibido pero entregado a Schenker en Alemania (Trenes 27 y 28). } \\
\text { Este material estaba cubierto por el seguro. }\end{array}$ & 4.997 .747 \\
\hline
\end{tabular}

Elaboración propia con datos anteriormente expuestos.

Además hay que contemplar el hecho de que existía otra parte del material que se encontraba todavía en Alemania, bien entregado ya por las casas fabricantes a la empresa de transportes "Schenker", o bien sin entregar todavía por las empresas germanas por no disponer de él. 
Por lo que respecta al material entregado ya a Schenker y dispuesto para su envío a España, se formaron sendos trenes -los numerados 27 y 28 - con material del "Programa" y con los últimos fonolocalizadores Tepas Belge de los contratados en un programa específico de adquisición de fonos, al margen del "Bär". Dichos convoyes llegaron a salir de la estación de Perl, aunque ambos fueron bombardeados en el trayecto y su material resultó muy dañado. En el Anexo XV-B se detalla de manera pormenorizada y valorada el material que transportaban ambos trenes y que nunca fue recibido en España.

Pese a esta desgracia -si podemos calificarla como tal-, una pequeña parte del material contenido en el tren $n^{\circ} 27$ volvió intacto a las fábricas de origen; en concreto se trataba de las 48 ametralladoras antiaéreas de $20 \mathrm{~mm}$ Flak 28 Oerlikon y de cuatro aparatos de transmisiones WT-40. Es evidente que el material que resultó destruido total o parcialmente en los bombardeos de los trenes $n^{\circ} 27$ y 28, repercutió en el Estado español y hubo que considerar su pago, pues las casas fabricantes se lo habían entregado ya a la empresa de transportes Schenker para su envío a España, por lo que según los contratos firmados al efecto, era como si estuviera ya en poder del Estado español. Alemania, en cambio, asumió como no entregados los objetos que en los citados bombardeos de los trenes no habían resultado dañados -las ametralladoras Oerlikon y los aparatos MEK-3- incorporándolos a su parque de material y no reclamando su coste a España. El OKW aceptó quedarse con las ametralladoras y los equipos de transmisiones para su empleo en unidades del Heer. En cualquier caso, todo el material transportado en estos dos trenes estaba asegurado contra el riesgo de guerra, por lo que la compañía de seguros pagaría a España la cantidad correspondiente al armamento perdido en el viaje. La cantidad adeudada en este caso por el material de estos dos trenes, sin tener en cuenta ni el devuelto en buenas condiciones al OKW ni los fonolocalizadores Tepas Belge -que como ya hemos citado no pertenecían al "Programa Bär”- ascendía a 4.997.747 marcos, cantidad que debería cubrir el seguro, pero que España tendría abonar a las fábricas germanas suministradoras.

Para finalizar, hay que considerar que una parte del material contratado, nunca saldría de Alemania con destino a España. En este caso, según contrato, no habría que pagarlo. La valoración de este material alcanzó los 14.687 .843 marcos y su detalle puede verse en el Anexo XV-C. 
Dos meses más tarde, a punto de finalizar 1944, las cuentas habían tenido unas relativas alteraciones pues ya todo el material presente en España estaba pagado, ascendiendo éste a 90.475.940,85 marcos, y el que no se había entregado a España se había cancelado con arreglo a la propuesta del OKW recibida por el coronel Marín de Bernardo en la Agregaduría Militar de Berlín el 7 de octubre de $1944^{663}$.

Quedaba en litigio, todavía, el material que venía en el tren $n^{\circ} 25$, por valor de 939.000 marcos, así como el correspondiente a los trenes $\mathrm{n}^{\mathrm{o}} 27$ y 28 que había resultado destruido por los bombardeos a los citados trenes, cuyo importe ascendía a 4.997.747 $\operatorname{marcos}^{664}$. El material contenido estos dos trenes tenía cuatro procedencias: las fábricas "Zeiss", "Krupp" y "Siemens", y la propia AGEKA. De las cuatro, solamente había presentado facturas Siemens por un importe de 985.100. marcos, con una inusitada prisa por cobrar esa cantidad. El resto, con AGEKA a la cabeza, estuvieron dispuestos a no cobrar su parte y esperar a la resolución del seguro, que tardaría, como mínimo, tres meses.

Como resumen hemos de afirmar que a finales de 1944 Alemania había suministrado material del "Programa Bär" al Ejército de Tierra por valor de 96.412.687 marcos ${ }^{665}$, cantidad de la cual estaban ya pagados 90.475 .940 marcos, adeudando en ese momento 5.936.747 marcos. Para analizar el conjunto del programa para el Ejército de Tierra deberemos incluir el "Programa Bär" de maquinaria ${ }^{666}$, pues fue pagado con

\footnotetext{
${ }^{663}$ Dicha nota decía lo siguiente: "Conforme a su escrito del 27-9-1944 se manifiesta el OKW completamente de acuerdo con que se interrumpa el resto de la entrega de material de guerra previsto en el "Programa Bär", teniendo en cuenta el desarrollo de las condiciones de transporte.

Por lo tanto el $\mathrm{OKW}$, atendiendo a la sugerencia española, no prepara por el momento más material para el envío y quedará con aquel que ha pasado a ser propiedad española, pero que actualmente todavía disponible dentro del territorio del Reich. Esto no afecta al derecho de la parte española, derivada de los contratos, a una entrega posterior del correspondiente material.

Por lo demás el $\mathrm{OKW}$ ha tomado nota del deseo que existe por parte española de transportar algún material de transmisiones por vía aérea a España. El OKW está dispuesto a apoyar este deseo o corresponder a él en tanto que existan adecuadas posibilidades de transporte o que la parte española pueda ponerlass a disposición a este fin.
}

Firmado Radtke."

AGMAV. Caja 24.707. Fondo del antiguo Ministerio del Ejército.

${ }^{664}$ Hay que considerar que en este tren viajaban también los fonolocalizadores Tepas-Belge, que no pertenecían al "Programa Bär", cuyo importe era de 486.000 marcos. Si tuviéramos en cuenta esta cantidad, el importe adeudado por material suministrado y no pagado total sería 5.483 .747 marcos.

${ }^{665}$ Esta cantidad es la suma del valor del material que realmente fue recibido en España (90.475.940) más el material que transportaba el Tren $\mathrm{n}^{\circ} 25$, que se perdió en Francia, aunque el coste de su mercancía hubo de asumirlo España ya que no iba asegurada frente a riesgos de guerra (939.000), más el material de los trenes 27 y 28, destruido en Alemania cuando circulaba en dichos convoys (4.997.747).

${ }^{666}$ Del "Programa Bär" de maquinaria sólo se recibieron dos tornos universales de la casa Stenzel por un valor de 68.496 marcos, que se pagaron con el crédito para material en la AGEKA. Carta del Agregado 
créditos concedidos para el de armamento. En la Tabla VII-E se recoge el estado de pagos y deudas correspondientes al "Programa Bär" a finales de 1944, teniendo en cuenta que la deuda generada por los fonos Tepas ya fue estudiada en el Capítulo I.

\section{TABLA VII-E}

\section{“PROGRAMA BÄR” (TIERRA). RESUMEN DE PAGOS}

\begin{tabular}{|l|r|r|r|r|}
\hline \multicolumn{1}{|c|}{ Material } & Suministrado pagado & Suministrado no pagado & No suministrado & Total del Programa \\
\hline $\begin{array}{l}\text { “Bär" } \\
\text { armamento }\end{array}$ & 90.475 .940 & 5.936 .747 & 14.687 .843 & $\mathbf{1 1 1 . 1 0 0 . 5 3 0}$ \\
\hline $\begin{array}{l}\text { "Bär" } \\
\text { maquinaria }\end{array}$ & 68.496 & - & & $\mathbf{6 8 . 4 9 6}$ \\
\hline Total & $\mathbf{9 0 . 5 4 4 . 4 3 6}$ & & & $\mathbf{1 1 1 . 1 6 9 . 0 2 4}$ \\
\hline
\end{tabular}

Fuente: Aclaraciones a los números resúmenes del "Programa Bär”. AGMAV Caja 24.707.

En los anexos XV-D, XV-E y XV-F se pueden encontrar todas las facturas autorizadas por el Ejército de Tierra correspondientes al "Restprogramm", numeradas, con su importe y el número de tren en el que se recibió el citado material.

Además del propio coste del material suministrado por Alemania, hay que tener en cuenta los gastos en los que incurrió el Ejército de Tierra en el transporte y en el seguro de todo lo enviado hasta la Península. Para hacer frente a estos gastos, se habían consignado hasta el 31 de agosto de 1944 un total de 2.073.644,23 marcos (equivalentes a 9.000.000 de pesetas), poniendo dicha cantidad a disposición del Agregado Militar en cuatro giros sucesivos, el 4 de agosto y el 23 de septiembre de 1943, y el 29 de enero y el 24 de junio de 1944. Hasta la fecha anteriormente citada solo se habían recibido en la Dirección General de Industria y Material las facturas correspondientes al "Sofortprogramm", que ascendían a 483.078,35 marcos. Había, pues, un remanente para hacer frente a las facturas de Schenker del "Restprogramm" de 1.590.565,9 marcos.

En el Anexo XVIII constan los pagos correspondientes a los gastos de transporte facturados por Schenker al Ejército de Tierra.

Militar Adjunto en Berlín al coronel Jesús Aguirre, jefe de la $4^{\text {a }}$ Sección del EMCE de 1 de diciembre de 1944. AGMAV. Caja 24.704. Fondo del antiguo Ministerio del Ejército. 


\section{VII.2.- LAS CUENTAS DE LA ARMADA}

El valor total del material recibido por la Marina española desde Alemania en el marco del del "Programa Bär" ascendió a 43.816.919 marcos, de los cuales 5.237.720 correspondían a lo recibido el el "Sofortprogramm" y el resto a lo que llegó en el "Restprogramm". Hay que decir que esta cifra corresponde a lo que realmente llegó a España, aunque lo entregado por Alemania sea algo superior, pues se produjeron diversas pérdidas de material en varios envíos -al igual que sucediera con el Ejército de Tierra-, como tendremos ocasión de examinar a continuación.

\section{TABLA VII-G}

“SOFORTPROGRAMM" MARINA. MATERIAL RECIBIDO VALORADO

\begin{tabular}{|l|l|l|}
\hline Material & Precio unitario & Precio total \\
\hline 4 Flak de 3,7 cm SK C/30 en montaje doble estabilizado & 154.400 & 617.600 \\
\hline 48.800 granadas rompedoras cartucho 40 & 32,90 & 1.605 .520 \\
\hline 10 Flak de 2 cm en montaje de submarino & 28.200 & 282.000 \\
\hline 20.000 granadas rompedoras luminosas & 8,63 & 172.600 \\
\hline 16 Flak de 3,7 cm C/30 en cureña C/39 para submarino & 60.000 & 960.000 \\
\hline 500 minas EMC & 3.000 & 1.500 .000 \\
\hline 100 cargas de profundidad & 1.000 & 100.000 \\
\hline & Total & $\mathbf{5 . 2 3 7 . 7 2 0}$ \\
\hline Fuente: Elaboración propia. Anexo XIII. Trenes recibidos del “Sofortprogramm” &
\end{tabular}

Existió una una ligera discrepancia con respecto a los datos negociados en Madrid por las Subcomisiones Técnicas. En lugar de recibirse 8.000 proyectiles para los cañones de $3,7 \mathrm{~cm}$ en afuste doble y 32.000 proyectiles para los mismos cañones en afuste sencillo, lo que daría un total de 40.000 disparos de este calibre recibidos en el "Sofortprogramm", llegaron a Irún en el tren n 7 de esta primera parte del "Programa Bär" un total de 48.800 proyectiles de $37 \mathrm{~mm}$, con el consiguiente incremento del valor de lo transportado para la Marina española. Frente a los 4.948.200 marcos inicialmente presupuestados -según el valor del material naval que se iba a enviar en el "Sofortprogramm"-, lo que realmente se recibió en España estaba valorado en 5.237.720 marcos. El resto del material realmente recibido en la frontera de Irún por la Marina española, integrado en el "Restprogramm" viene recogido y valorado en la siguiente tabla. 


\section{TABLA VII-H}

\section{“RESTPROGRAMM" (MARINA). MATERIAL RECIBIDO VALORADO}

\begin{tabular}{|c|c|c|}
\hline Material & Precio unitario & Precio total \\
\hline $\begin{array}{l}1 \text { instalación de cineteodolito "Askania" sin cable acorazado } \\
\text { para gran distancia }\end{array}$ & 187.145 & 187.145 \\
\hline 32 Flak de 3,7 cm SK C/30 en montaje doble estabilizado & 154.400 & 4.940 .800 \\
\hline 142.000 granadas rompedoras cartucho 40 & 32,90 & 4.671 .800 \\
\hline 22 Flak de $2 \mathrm{~cm}$ cuádruples para buque & 125.000 & 2.750 .000 \\
\hline 176.000 granadas rompedoras luminosas & 8,63 & 1.518 .880 \\
\hline 30 Flak de $2 \mathrm{~cm}$ en montaje de submarino & 28.200 & 846.000 \\
\hline 60.000 granadas rompedoras luminosas & 8,63 & 517.800 \\
\hline 12 Flak de $10,5 \mathrm{~cm} \mathrm{C} / 32$ en cureña $\mathrm{C} / 52$ para torpederos & 230.000 & 2.760 .000 \\
\hline $9.900^{667}$ disparos de $10,5 \mathrm{~cm}$ de diversos tipos & 2.271 .090 (total) & 2.271 .090 \\
\hline 6 lanchas rápidas tipo grande & 2.000 .000 & 12.000 .000 \\
\hline 20 anteojos de observación 20 × 80 & 4.500 & 90.000 \\
\hline $\begin{array}{l}35 \text { Flak de } 3,7 \mathrm{~cm} \mathrm{C} / 30 \text { en cureña } \mathrm{C} / 39 \text { de submarino para } \\
\text { buque }\end{array}$ & 60.000 & 2.100 .000 \\
\hline 57.500 granadas rompedoras mod 40 & 32,9 & 1.891 .750 \\
\hline $\begin{array}{l}500 \text { minas EMC sin anclaje, la mitad con } 300 \mathrm{~m} \text { de cable y la } \\
\text { otra mitad con } 350 \mathrm{~m} \text { de cable. }\end{array}$ & 3.000 & 1.500 .000 \\
\hline $100^{668}$ cargas de profundidad $\mathrm{F}$ & 1.000 & 100.000 \\
\hline 12 telémetros "Goerz" de $2 \mathrm{~m}$ de base & 13.000 & 156.000 \\
\hline 20 telémetros "Zeiss" de $1,25 \mathrm{~m}$ de base & 5.720 & 114.400 \\
\hline \multirow[t]{2}{*}{$3.000 \mathrm{~kg}$ de vidrio óptico } & $20 / \mathrm{kg}$ & 64.333 \\
\hline & Total & 38.479 .998 \\
\hline
\end{tabular}

Fuente: Elaboración propia. Anexo XIV. Trenes recibidos en el "Restprogramm"

En esta cantidad de 38.479.998 marcos no se tienen en cuenta los 680.944 marcos que la Armada Española reclamó al seguro, debido a que el último tren recibido con armamento del "Programa Bär" (el no 26), faltaba diverso material ${ }^{669}$, que se perdió

${ }^{667}$ Pese a que según las cuentas alemanas se enviaron 11.400 proyectiles de este calibre, 1.500 se perdieron en tres vagones del tren 26 que nunca llegaron a España. La diferencia de valor de estos 1.500 proyectiles, 344.104 marcos, sería cubierta por el seguro contratado por la Armada.

668 Al igual que en el caso de los proyectiles, desde Alemania se enviaron otras 100 cargas de profundidad, que se perdieron en los mismos vagones que los proyectiles de 10,5 cm. El seguro cubrió la pérdida, que en este caso eran 100.000 marcos.

${ }^{669}$ En concreto eran los vagones denominados "Kassel 26748" (perdido en Toul), "Karlsruhe 71082" (desaparecido en Montelimar) y "Posen 4481" (desaparecido en Moisson). Telegrama enviado por el Agregado naval en Berlín al Almirante Jefe del Estado Mayor de la Armada en 30 de agosto de 1944. APFE. Embajada en España en Berlín. Agregado Naval. Telegrama transmitido nº 656. 
en varios vagones, en concreto 1.500 proyectiles de $10,5 \mathrm{~cm}$ con diferentes tipos de espoleta, 100 cargas de profundidad y un radiotelémetro para destructores que, con muchísimo esfuerzo, el Agregado Naval en Berlín había conseguido a última hora tras duras negociaciones con los mandos de la Kriegsmarine. El desglose del citado material viene recogido en la siguiente tabla.

\section{TABLA VII-I}

"RESTPROGRAMM" (MARINA). MATERIAL DEL TREN N' 26 QUE NO LLEGÓ A RECIBIRSE EN ESPAÑA.

\begin{tabular}{|l|l|}
\hline Material & Coste \\
\hline 296 proyectiles explosivos de $10,5 \mathrm{~cm}$ (espoleta a tiempos) & $6.997,44$ marcos \\
\hline 504 proyectiles explosivos de $10,5 \mathrm{~cm}$ (espoleta de ojiva) & $10.830,96$ marcos \\
\hline 700 proyectiles de $10,5 \mathrm{~cm}($ espoleta de ejercicio) & 163.100 marcos \\
\hline 100 cargas de profundidad WBF & 100.000 marcos \\
\hline 1 radiotelémetro & 239.560 marcos \\
\hline TOTAL & $\mathbf{6 8 0 . 9 4 4 ~ m a r c o s}$ \\
\hline
\end{tabular}

Fuente: Elaboración propia. Telegrama recibido en la Agregaduría Naval de Berlín en 3-11-1944. APFE

Al igual que hemos hecho al estudiar el Ejército de Tierra, este material hay que considerarlo como entregado a España, pese a haberse perdido por el camino. Por eso, habrá que incluirlo en la cifra final del "Restprogramm" de Marina, quien reclamaría al seguro el pago de dicha cantidad. Por tanto podemos afirmar que el coste total del “Programa Bär” para la Armada ascendió a 44.398.662 marcos.

El 2 de noviembre de 1944 el Agregado Naval en Berlín transmitía un telegrama $^{670}$ a Madrid, dirigido al Almirante Jefe de Estado Mayor de la Armada, en el que le comunicaba que AGEKA recordaba que las facturas adeudadas del material suministrado a la Marina española en el marco del "Programa Bär" ascendía en ese momento a 27.873.654, 11 marcos. Como la citada AGEKA tenía noticia de que en breve recibiría del Ministerio de Marina la cantidad de 24.695.838,91 marcos, aquella quería saber la distribución de dicha cantidad entre las casas proveedoras.

\footnotetext{
${ }^{670}$ APFE. Embajada en España en Berlín. Agregado Naval. Telegrama transmitido no 821.
} 
Pero lo cierto era que en aquel momento, como se encargaron de recordar desde el EMA al Agregado en Berlín, la deuda real con Alemania por el suministro a España en el marco del "Programa Bär", ascendía a 28.141.211,15 marcos, habiéndose abonado por parte del IEME a la Embajada Alemana en Madrid un total de 24.711.835,95 marcos. Los 3.429.375,29 restantes habían sido anticipados por parte del Ministerio de Marina español a diferentes empresas alemanas por cuenta de otro material al margen del "Programa Bär", material que todavía no habían entregado en noviembre de $1944^{671}$. El almirante Jefe del EMA recordaba a Espinosa que dichas empresas deberían devolver o reintegrar esos anticipos para poder terminar de pagar la cantidad restante del “Programa Bär”. El Ministerio de Marina se había reunido con el agregado comercial de la Embajada alemana en Madrid para llegar a este acuerdo, y en esa misma reunión éste se comprometió en transmitir el citado acuerdo a los centros competentes de la capital alemana $^{672}$.

Para la Marina de Guerra el transporte y seguro del material recibido en el "Sofortprogramm", ascendió a 133.980,30 marcos ${ }^{673}$; un 2,557\% del valor total del material transportado. Nos ha sido imposible encontrar las cifras pagadas por la Armada en el transporte y seguro del "Restprogramm", aunque es probable que rondasen el millón de marcos, si tenemos en cuenta que el valor de lo transportado en esta segunda parte del "Programa Bär" fue ocho veces mayor que lo enviado en la primera.

\section{VII.3.- LAS CUENTAS DEL EJÉRCITO DEL AIRE}

En una carta certificada remitida por el Ministerio del Aire alemán al Agregado Aéreo español, teniente coronel Ángel Salas Larrazábal ${ }^{674}$ en 24 de octubre de $1944^{675}$,

\footnotetext{
${ }^{671}$ Dicho material, empresas y cantidades a devolver eran, en esencia, los siguientes: Rheinmetall por cañones de 8,8 cm: 990.465 marcos; Daimler-Benz, por 13 motores de lanchas rápidas, 1.458.104,02; Deutsche Werke, por torpedos, 10.669,28 marcos; Askania, por aparatos de instrucción de comandantes y timoneles de submarinos, 455.520 marcos; Zeiss, por dos contratos de telémetros y estereotelémetros, 508.850 marcos y Friedrich Dekel, de Munich, por una máquina de grabar, 5.766, 9marcos. APFE. Embajada en España en Berlín. Agregado Naval. Telegrama recibido n $11346 / 6180$.

${ }^{672}$ APFE. Embajada en España en Berlín. Agregado Naval. Telegrama recibido no 11288/5524.

${ }^{673}$ Según desglose de cantidades pagadas en concepto de gastos de transporte y seguro del "Programa Bär". 26 de enero de 1944. AGMAV. Caja 24.713. Fondo del antiguo Ministerio del Ejército.

${ }^{674}$ El relevo del teniente coronel José Pazó por el del mismo empleo, Ángel Salas Larrazábal -que hasta entonces actuaba como Agregado Adjunto- se había producido a mediados de febrero de 1944, tras cuatro años y siete meses de misión ininterrumpida en Alemania. Pazó Giménez de la Espada, Alejandro. El vuelo de José Pazó. La trayectoria de un ingeniero aeronáutico y aviador militar en el siglo XX. Edición particular no venal, Valladolid, 2012, pág. 136.
} 
se señalan con detalle los diversos materiales servidos a la Aviación militar española en el transcurso del "Programa Bär", con indicación de las cantidades adeudadas y pagadas por el mismo.

\section{TABLA VII-J}

\section{“PROGRAMA BÄR" (AIRE). MATERIAL RECIBIDO VALORADO, PAGADO Y ADEUDADO (OCTUBRE DE 1944).}

\begin{tabular}{|c|c|c|c|c|c|}
\hline Cantidad & Concepto & Empresa & Precio & Pagado & Adeudado \\
\hline \multicolumn{6}{|c|}{ AVIONES Y SUS REPUESTOS } \\
\hline 15 & Me 109 F-4 & Messerschmitt & 2.827 .830 & - & 2.827 .830 \\
\hline 10 & Ju 88 A-4 & Junkers & 6.900 .000 & 6.900 .000 & - \\
\hline \multicolumn{6}{|c|}{ MUNICIÓN DE AVIÓN } \\
\hline 1.000 .000 & Proyectiles 7,92 & $\mathrm{DM}$ & 179.125 & 179.125 & - \\
\hline \multicolumn{6}{|c|}{ EQUIPOS PARA LA PROTECCIÓN DE VUELO } \\
\hline 4 & Radiofaros de aterrizaje de $120 \mathrm{w}$ & Lorenz & 226.000 & 226.000 & - \\
\hline 8 & Radiogoniómetros de navegación & Telefunken & 145.600 & 145.600 & - \\
\hline 22 & $\begin{array}{l}\text { Temporizadores Morse para } \\
\text { radiofaros }\end{array}$ & Pintsch & 49.060 & - & 49.060 \\
\hline \multicolumn{6}{|c|}{ EQUIPOS DE RADIO Y LOCALIZACIÓN } \\
\hline 8 & $\begin{array}{l}\text { Equipos móviles de radio ( } 4 \text { onda } \\
\text { corta y } 4 \text { onda larga) }\end{array}$ & Telefunken & 1.689 .120 & 1.689 .120 & - \\
\hline 15 & FuG 10 ligeros móviles & Lorenz & 429.000 & - & 429.000 \\
\hline 12 & $\begin{array}{l}\text { Radioemisoras AS } 59 \text { (onda } \\
\text { corta) }\end{array}$ & Telefunken & 168.000 & 168.000 & - \\
\hline 50 & Teléfonos de campaña mod 33 & $\begin{array}{l}\text { Siemmens \& } \\
\text { Halske }\end{array}$ & 6.000 & 6.000 & - \\
\hline 20 & Radioemisoras FuG VII aF1 & Telefunken & 100.000 & 100.000 & - \\
\hline 85 & $\begin{array}{l}\text { Radioemisoras FuG } 10 \text { de a } \\
\text { bordo (onda corta y larga) }\end{array}$ & Lorenz & 1.479 .000 & 696.000 & 783.000 \\
\hline 100 & Fu BL 1 Aparato de a bordo & Lorenz & 500.000 & 500.000 & - \\
\hline 6 & $\begin{array}{l}\text { Radiotelémetros SFuG } 213 \\
\text { "Liechtenstein" }\end{array}$ & Telefunken & 180.000 & 180.000 & - \\
\hline 1 & Radiotelémetro "Freya" & Gema & 260.000 & 260.000 & \\
\hline 10 & Radiotelémetros 39 "Wurzburg" & Telefunken & 1.250 .000 & 1.250 .000 & - \\
\hline
\end{tabular}

${ }^{675}$ Se trata de un documento fundamental para el estudio económico de la adquisición de material del "Programa Bär" por parte del Ejército del Aire. Su referencia es: 5841g/G/44 vW/Pr, con fecha 24-101944. Correspondencia del Agregado Aéreo en Berlín. AHEA. A-11035.

${ }^{676}$ De las 85 FuG 10 contratadas sólo llegarían 40. Las otras 45 radioemisoras venían en el fatídico tren $\mathrm{n}^{\circ}$ 25, que fué interceptado en Francia y nunca llegó a su destino. De todas formas hubo que pagarlas, procediendo el Estado Español a reclamar a la casa de transportes Schenker las cantidades adeudadas. 


\begin{tabular}{l|l|l|l|l|l}
\hline \multicolumn{2}{l}{ GRUPOS ELECTRÓGENOS } & & & & \\
\hline 15 & Grupo electrógeno EMS I & Still & 240.000 & 240.000 & - \\
\hline 100 & $\begin{array}{l}\text { Grupos electrógenos E.M. 4 W } \\
220 .\end{array}$ & Still & 232.000 & 232.000 & - \\
\hline 50 & Carretes de cable y conexiones & Still & $6.537,50$ & - & $6.537,50$ \\
\hline & Totales & & $\mathbf{1 6 . 8 6 7 . 2 7 2 , 5 0}$ & $\mathbf{1 2 . 7 7 1 . 8 4 5}$ & $\mathbf{4 . 0 9 5 . 4 2 7 , 5 0}$ \\
\hline
\end{tabular}

Fuente: Escrito del Ministerio del Aire alemán 5841g/G/44 vW/Pr, con fecha 24-10-1944. AHEA. A-11035.

De esta manera sabemos que el importe total del "Programa Bär" del Ejército del Aire ascendió a 16.867.272,50 $\operatorname{marcos}^{677}$, y que en esa fecha -24 de octubre de 1944- se había pagado con abono en el clearing hispano-alemán, un total de 12.771 .845 marcos, quedando como saldo pendiente en esa misma fecha la cifra de 4.095.427,50 marcos. La partida más importante de las todavía no pagadas eran los 15 cazas Messerschmitt Bf 109, a los que había que añadir 15 equipos de radio móviles ligeros de la casa Lorenz, 22 temporizadores para radiofaros de la casa Pintsch así como las 85 emisoras FuG 10 de a bordo de la casa Lorenz, de las cuales 45 se habían perdido en el tren $\mathrm{n}^{\mathrm{o}} 25$. Otra deuda todavía no saldada eran 50 carretes de cable y las correspondientes conexiones, enviadas para los 50 grupos electrógenos E.M. 2 que llegaron en el tren $n^{\circ} 6$ del "Restprogramm". En cualquier caso, hubo que reclamar al seguro el valor de los 50 grupos electrógenos E.M. 2 perdidos en el Tren $n^{\circ}$ 27, y que ascendía a 116.000 marcos.

Y pese a todo, de los 10 radiotelémetros Würzburg Mod. 39 recibidos, nueve de los mismos pasarían a ser propiedad del Ejército de Tierra que los integró en los Regimientos de Artillería Antiaérea para la adquisición de blancos aéreos, con lo que el valor final del material del Ejército del Aire se reduciría aún más. En concreto, el valor de esos nueve radares Würzburg ascendía a 1.125.000 marcos, con lo que la cifra real definitiva de material alemán para el Ejército del Aire quedaría reducida a 15.626.272,5 marcos ${ }^{678}$. Esta última cantidad sería abonada por el Ejército de Tierra.

Al igual que ocurriera en el Ejército de Tierra, todo el material perdido en el fatídico Tren $\mathrm{n}^{\mathrm{o}}$ 25, que quedó en Francia a merced de los "maquisard", al no venir cubierto por un seguro para riesgos derivados de la guerra, hubo que pagarlo íntegro, recurriendo a denunciar a la empresa de transportes -"Schenker"- para que respondiera

\footnotetext{
${ }^{677}$ Hay que tener en cuenta que todos los grupos antiaéreos pasaron al Ejército de Tierra, por lo que su coste se imputó también a este ejército. De esta manera se entiende que de un montante total de 27.717.660 marcos se pase al que estamos tratando de 16.867.272,50 marcos.

${ }^{678}$ Aunque esa deuda habría de compensarla con el Ejército de Tierra, no con la AGEKA.
} 
de la falta del deber de custodia del citado tren, debido a las razones ya expuestas en el epígrafe anterior. Para analizar los detalles, la valoración y la consideración de estos materiales se puede consultar los Anexos XVI-A y XVI-B.

El 8 de febrero de 1944 el Ministerio del Aire había hecho un ingreso en el IEME de 57.584.964,5 pesetas, como contravalor de 13.268.425 marcos, cantidad que sería comunicada a ROWAK en Berlín para abonar importes adeudados del "Programa Bär". De esta manera, quizás un poco tarde si tenemos en cuenta lo realizado por el Ejército de Tierra, el Ministerio del Aire ponía a disposición de Alemania las divisas necesarias para financiar las importaciones, tan necesarias en ese momento.

Ya terminando el año 1944, el Agregado Aéreo en Berlín remitía un telegrama al general Jefe del EMA, con fecha 2 de noviembre, en el que le comunicaba que la deuda por el material suministrado en el "Programa Bär" era aproximadamente 4.100.000 marcos, rogándole que pusiera esta cantidad a disposición de ROWAK para hacer frente al pago. Ese mismo mes se contestaba al teniente coronel Salas desde el Ministerio de Asuntos Exteriores confirmando que la DGIM estaba comprobando los ajustes de material recibido y no pagado, así como el pagado y no recibido, para de esta manera organizar los pagos y reducirlos a lo estrictamente recibido.

Un mes más tarde, se reclamaban a "Schenker" 783.000 marcos, que era el valor de los 45 equipos de radio de a bordo FuG 10 perdidos en el tren $n^{\circ} 25$ del "Restprogramm", denunciando por negligencia en el transporte a la empresa consignataria del mismo. De la misma manera se hacía lo propio con el material radar "Lichtenstein" perdido en el mismo tren, cuyo valor alcanzaba los 90.000 marcos.

En lo que respecta al transporte del material y el seguro, para el primer cupo del "Programa Bär", el Ejército del Aire pagó seis facturas el 7 de diciembre de 1943 por un importe de 17.123,30 marcos, detallando los pagos en la tabla siguiente. 
TABLA VII-K

“SOFORTPROGRAMM" (AIRE). PAGOS DE TRANSPORTES Y SEGUROS.

\begin{tabular}{|l|l|l|}
\hline Concepto & Factura $\mathbf{n}^{\mathbf{0}}$ & Cantidad en RM \\
\hline Transporte & 46.873 & 862,50 \\
\hline Transporte & 46.879 & 575,00 \\
\hline Transporte & 46.880 & 695,75 \\
\hline Transporte & 46.889 & $8.625,00$ \\
\hline Transporte & 46.890 & $4.350,00$ \\
\hline Seguro & 35.095 & $2.105,05$ \\
\hline & Total & $\mathbf{1 7 . 1 2 3 , 3 0}$ \\
\hline
\end{tabular}

Fuente: AHEA. Correspondencia Agregado Aéreo. A-11035

Hasta el tren $n^{\circ} 13$ del "Restprogramm", los gastos de trasporte y seguro del Ejército del Aire ascendieron a 32.749,50 marcos, con el desglose indicado a continuación:

TABLA VII-L

“RESTPROGRAMM" (AIRE). PAGOS DE TRANSPORTES Y SEGUROS.

\begin{tabular}{|l|l|l|}
\hline Concepto & Factura $^{\mathbf{0}}$ & Cantidad en RM \\
\hline Transporte & 55.886 & $19.725,00$ \\
\hline Transporte & 55.729 & $6.775,00$ \\
\hline Transporte & 55.167 & $2.993,00$ \\
\hline Seguro & 49.834 & $3.256,50$ \\
\hline & Total & $\mathbf{3 2 . 7 4 9 , 5 0}$ \\
\hline
\end{tabular}

Fuente: AHEA. Correspondencia Agregado Aéreo. A-11035

Sólo quedarían, por tanto, sin contabilizar, los gastos correspondientes al porte y seguro de 22 temporizadores de radioseñalización de la casa "Pintsch", recibidos en el tren $n^{\circ}$ 16; el radiolocalizador Freya FuMG (Flum) 41G de la casa "GEMA", recibido en España con el tren $\mathrm{n}^{\mathrm{o}}$ 18; 12 estaciones de radio de onda corta AS 59, de “Telefunken”, recibidas en el tren $n^{\circ} 22$ y los repuestos para una escuadrilla de Junkers 
Ju 88, recibidos en Irún en enero de 1944 en dos vagones que no formaban un tren especial del "Programa Bär".

También estaba pendiente de pago al Ejército de Tierra el seguro y transporte de los radares "Lichtenstein", ya que inicialmente ocurrió el malentendido de que éstos aparatos estaban destinados a la artillería de $\operatorname{costa}^{679}$ y dichos gastos los había satisfecho el Ministerio del Ejército con su presupuesto.

\section{VII.4.- CUENTAS GENERALES EN MAYO DE 1945}

A raíz del hallazgo de un documento ${ }^{680}$ de la Dirección General de Industria y Material del Ministerio del Ejército, conocemos la situación de los créditos y deudas del Ejército de Tierra español con Alemania el 3 de mayo de 1945, pocos días antes de que se consumara la derrota del Tercer Reich en todos los frentes de batalla. En dicho documento se aclara que el dinero está depositado en Alemania para el "Programa Bär" así como para las adquisiciones de la denominada "Comisión de Compras" del Ministerio y de las Fábricas Militares dependientes del mismo. Así mismo se recoge la única deuda que todavía estaba reconocida por el Ejército de Tierra en estas fechas, y que no era otra que unos cañones navales artillados en las Islas Canarias en 1941, servidos por la Kriegsmarine y cuya factura circuló de departamento en departamento, como tuvimos ocasión de estudiar en el Capítulo I.

\footnotetext{
${ }^{679}$ Hay que hacer constar que Tierra pagó en concepto de gastos de transporte 684 marcos por los tres radares recibidos en el "Sofortprogramm" cantidad que suponía el 2 por mil del valor de la mercancía, ascendiendo el seguro a 124,15 marcos. Como quiera que el precio de estos radares fue rebajado por Alemania y sólo hubo que contabilizar 90.000 marcos por los tres Lichtenstein, la cantidad a abonar por este material debería haber sido 180 marcos en lugar de los 684. Por tanto, el Ejército de Tierra reclamaría a "Schenker" la diferencia, 504 marcos, cargando al Ejército del Aire los 180 marcos de portes más los 124,15 de seguro: 304,15 marcos.

${ }^{680}$ Este resumen complementa lo afirmado al finalizar el Capítulo I, respecto a las cuentas correspondientes al material contratado directamente por los diversos organismos del Ministerio del Ejército. En este caso se añade el dinero depositado en ROWAK a cuenta del material no suministrado del "Programa Bär". Resumen de la situación de créditos y deudas con Alemania. DGIM del Ministerio del Ejército. AGMAV. Caja 24.704. Fondo del antiguo Ministerio del Ejército.
} 


\section{TABLA VII-M}

\section{EJÉRCITO DE TIERRA. CRÉDITOS Y DEUDAS CON ALEMANIA. MAYO 45}

\begin{tabular}{|l|l|l|}
\hline Concepto & Deudas de España & Créditos de España \\
\hline $\begin{array}{l}\text { Depósitos en Alemania para el } \\
\text { "Programa Bär" }\end{array}$ & 10.608 .982 marcos \\
\hline $\begin{array}{l}\text { Depósitos de la Comisión de } \\
\text { Compras de la DGIyM para } \\
\text { diversos contratos }\end{array}$ & $957.829,67$ marcos \\
\hline $\begin{array}{l}\text { Depósitos de diversas Fábricas } \\
\text { Militares a las fábricas }\end{array}$ & & $213.907,59$ marcos \\
\hline $\begin{array}{l}\text { Anticipado a la Comisión de } \\
\text { productoras por las } \\
\text { Compras con arreglo a las } \\
\text { cláusulas de diversos contratos }\end{array}$ & & $4.421 .460,1$ marcos \\
\hline $\begin{array}{l}\text { Suman los créditos } \\
\text { Baterías de Canarias }\end{array}$ & $5.628 .914,7$ marcos & $\mathbf{1 6 . 2 0 2 . 1 8 0}$ marcos \\
\hline Diferencia & & \\
\hline
\end{tabular}

Fuente: AGMAV. Caja 24.704

Desgraciadamente, no hemos encontrado nada similar para las otras dos ramas del Ejército español -la Marina y el Ejército del Aire-, aunque parecería lógico pensar que lo mismo que ocurrió con Tierra, pasara también en los otros dos casos: los créditos depositados en ROWAK o en las propias casas germanas tanto por material adquirido en el seno del "Programa Bär" como por adquisiciones directas de ambos Ejércitos, fueran favorables a España, pues mucho material contratado y pagado no pudo alcanzar la península a partir de julio-agosto de 1944.

Parece, por tanto, bastante factible la cifra de 39.907.834 marcos, ofrecida por Rafael García Pérez ${ }^{681}$ como material de guerra germano no suministrado a España, contenida en un memorándum entregado a la delegación aliada en Madrid, el 12 de febrero de $1947^{682}$, en el que se hacía referencia a situación de los créditos españoles con Alemania al terminar la Segunda Guerra Mundial. Pese a que García Pérez afirma que los suministros “...procedían del antiguo Programa Bär”, ésto, como acabamos de ver, no es totalmente cierto, sino que una buena parte procedía de programas de compras de las DGIM de los tres ministerios militares.

\footnotetext{
${ }^{681}$ García Pérez, Rafael, Franquismo y Tercer Reich, op. cit., pág. 563.

${ }^{682}$ AMAE. AR. Sig. R-5472-2.
} 
García Pérez duda de la existencia de una deuda tan abultada al final de la Segunda Guerra Mundial y para afianzar su aserto pone de manifiesto la incapacidad de los negociadores españoles a la hora de aportar pruebas documentales sobre las partidas pagadas pendientes de suministro. Esta opinión creemos que choca con la afirmación posterior de este mismo autor en la que afirma textualmente ${ }^{683}$ :

"La naturaleza esencialmente política de este programa de suministro de armamentos a gran escala, impulsó a los aliados a adoptar una posición de firmeza ante la cual carecieron de argumentos los negociadores españoles."

En efecto, considerando la existencia de una cuentas perfectamente claras, como en el caso que acabamos de exponer del Ejército de Tierra, con las que se podía demostrar fehacientemente la entrega a cuenta a diversos organismos y empresas germanas de cantidades de dinero suficientemente importantes, la realidad de no reconocer estos créditos por parte de la Comisión de Control Aliada, iba más allá de la mera cuestión económica. El componente político-económico que dio origen al programa de armamentos, la supremacía militar aliada en Europa, la inestabilidad del régimen franquista en esas circunstancias y la poca capacidad de maniobra de unos negociadores españoles en franca inferioridad dieron al traste con una reclamación, en nuestra opinión justa y adecuada a la realidad económica.

En la siguiente tabla recogemos las cifras reales del "Programa Bär" una vez finalizada su vigencia, comparándolas con las pactadas en las reuniones de Madrid y analizando el porcentaje de cumplimiento así como las desviaciones producidas. Introducimos también, la pequeña cantidad pagada por el casi "nonato" "Programa Bär" Maquinaria, para tener una visión completa de los pagos realizados en el marco de todo el Programa.

${ }^{683}$ García Pérez, Rafael, Franquismo y Tercer Reich, op. cit., pág. 564. 


\section{TABLA VII-N}

\section{"PROGRAMA BÄR". RESULTADOS REALES Y PORCENTAJES DE}

CUMPLIMIENTO

\begin{tabular}{|c|c|c|c|c|}
\hline $1^{\text {a }}$ Expedición & & Acordado en Madrid & Realmente pagado & $\%$ de cumplimiento \\
\hline & Ejército de Tierra & 21.073 .100 & 20.718 .340 & $98,32 \%$ \\
\hline & Armada & 4.948 .200 & 5.237 .720 & $105,85 \%$ \\
\hline & Ejército del Aire & 13.268 .425 & 12.732 .675 & $95,32 \%$ \\
\hline $\mathbf{A}$ & Total & 39.289 .725 & 38.688 .735 & $98,47 \%$ \\
\hline \multicolumn{5}{|l|}{$\begin{array}{l}\text { 2ªxpedición } \\
\text { "Restprogramm" }\end{array}$} \\
\hline & Ejército de Tierra & 90.929 .350 & 75.694 .347 & $83,24 \%$ \\
\hline & Armada & 70.805 .293 & 39.160 .942 & $55,31 \%$ \\
\hline & Ejército del Aire & 15.484 .435 & 4.220 .597 & $27,26 \%$ \\
\hline B & Total & 177.219.078 & 119.175 .087 & $67,25 \%$ \\
\hline \multicolumn{5}{|l|}{$\begin{array}{c}\text { "Programa Bär" } \\
\text { completo }\end{array}$} \\
\hline & Ejército de Tierra & 112.002 .450 & 96.412 .687 & $86,08 \%$ \\
\hline & Armada & 75.753 .493 & 44.398 .662 & $58,60 \%$ \\
\hline & Ejército del Aire & 28.752 .860 & 16.953 .272 & $58,96 \%$ \\
\hline $\mathbf{A}+\mathbf{B}$ & Total general & 216.508 .793 & 157.863 .822 & $72,91 \%$ \\
\hline $\begin{array}{c}\text { "Programa Bär" } \\
\text { maquinaria }\end{array}$ & & & 68.496 & \\
\hline TOTAL PAGADO & & & 157.932 .318 & \\
\hline
\end{tabular}

Fuente: Elaboración propia. AMAE R-2066, Leg. 4. (Todas las cantidades en marcos) 


\section{Capítulo 8}

\section{EL CANTO DEL CISNE. LOS PROGRAMAS "ANKARA" Y "ELTZE" DE 1944 Y LAS EXPEDICIONES DE MATERIAL MILITAR ALEMÁN POR VÍA AÉREA}

\section{VIII.1.- LOS PROGRAMAS “ANKARA" Y "ELTZE"}

A principios de $1944^{684}$ las autoridades españolas y alemanas comenzaron a hablar de una ampliación del programa de armamentos en curso de suministro, el "Programa Bär". Dicha ampliación tendría una nueva denominación en clave, y esta sería "Programa Ankara"685.

Previamente a cualquier denominación específica, un documento interno de la Cuarta Sección del EMCE ${ }^{686}$ comunicaba al Agregado Militar en Berlín, Carlos Marín de Bernardo, la adquisición de nuevo material militar en Alemania como ampliación del programa en curso de suministro: el "Programa Bär". Como consecuencia de las peticiones de material militar, comprendidas en diversas notas y telegramas cifrados enviados a la Embajada alemana en Madrid entre diciembre de 1943 y febrero de 1944, el embajador teutón entregó al ministro Jordana una nota el 28 de febrero en la que se aceptaba suministrar al Ejército español diverso material militar. Dicha nota está resumida en la Tabla VIII-A. Este material fue aceptado por el Ministro del Ejército, con la reserva que las condiciones de suministro del mismo fueran las mismas que regían en el "Programa Bär"687.

\footnotetext{
${ }^{684}$ Las primeras referencias a la ampliación del "Programa Bär" corresponden a las notas de la 4 a Sección no 4384-P de 30 de diciembre de 1943 y 4192-A de 7 de enero de 1944 así como los telegramas cifrados de la Agregaduría Militar en Berlín de fechas 15 de enero y de 12 de febrero de 1944. AGMAV. Caja 24.713. Fondo del antiguo Ministerio del Ejército.

${ }^{685}$ El nombre clave de "Ankara" no empezó a utilizarse hasta la primavera de ese mismo año, cuando ya se cerraron las cantidades y los materiales a entregar. Ver AGMAV. Caja 20.903. Fondo del antiguo Ministerio del Ejército.

${ }^{686}$ Sección Cuarta. N ${ }^{\circ}$ 4484-D A/M. Nota para el teniente coronel Marín de Bernardo. Embajada de España. AGMAV. Caja 24.713. Fondo del antiguo Ministerio del Ejército.

${ }^{687}$ Hay un aspecto muy interesante en esta nota al Agregado Militar español en Berlín a la que estamos haciendo referencia. En el punto $n^{0}$, el general jefe de la citada Sección comentaba al Agregado en Berlín: “...No solamente en previsión de que no puedan conseguirse estos nuevos grupos de tipo móvil sino con vistas a los tres fijos ya en España, es necesario obtener los planos de material de 88/56 fijos en
} 


\section{TABLA VIII-A}

\section{"PROGRAMA ANKARA". MATERIAL APROBADO POR EL EMBAJADOR ALEMÁN}

\begin{tabular}{|c|c|}
\hline Ejército de Tierra & Ejército del Aire \\
\hline $\begin{array}{l}\cdot \mathbf{1}^{\mathbf{0}} \text { Transmisiones: } \\
-7.000 \text { válvulas K.L. }{ }^{688} \\
-75 \text { aparatos de radio de } 15 \text { vatios y } 100 \text { de } 100 \text { vatios }^{689} \\
-100 \text { teletipógrafos Siemens } \\
-1.000 \text { kilómetros de cable multipar (Feldfernkabel) }\end{array}$ & $\begin{array}{l}\mathbf{5}^{\circ} \text { Material de vuelo } \\
-25 \text { aviones de bombardeo } \\
\text { Junkers Ju } 88 \\
-100 \text { aviones de caza } \\
\text { Messerschmitt Bf } 109 \mathrm{G}\end{array}$ \\
\hline $\begin{array}{l}-2^{\mathbf{O}} \text { Carros de combate } \\
\text {-33 carros Panzerkampfwagen Ausf. IV con su dotación de municiones y sus } \\
\text { carros de mando }\end{array}$ & \\
\hline $\begin{array}{l}\cdot 3^{\mathbf{0}} \text { Motocicletas } \\
-100 \text { extra-pesadas Zundapp-Werke K.S. } 750 \text { cc con side-car y diferencial tipo } \\
\text { B.W.-40 } \\
\text {-100 ligeras de } 200-250 \text { cc para enseñanza }\end{array}$ & \\
\hline $\begin{array}{l}\text {-4 Material antiaéreo } \\
-25 \text { grupos antiaéreos de } 88 / 56 \text { y } 25 \text { baterías de cañones de } 20 \mathrm{~mm} \text {, proyectores } \\
\text { de } 60 \mathrm{~cm} \text {, respetos y accesorios, el máyor número posible de ellos, móviles. } \\
\text {-Munición para estos grupos y para los recibidos en el "Programa Bär" a razón } \\
\text { de } 1.000 \text { disparos de } 88 / 56 \mathrm{~mm}(30 \% \text { perforantes }) \text { y } 2.400 \text { disparos de } 20 \mathrm{~mm} \\
\text { Oerlikon que acompañen a éstos. } \\
-25 \text { grupos de proyectores de } 240 \mathrm{~cm} \text { a razón de uno por cada grupo de } \\
\text { cañones. }\end{array}$ & \\
\hline
\end{tabular}

Fuente: AGMAV. Caja 24.713

la parte del montaje que se diferencia del móvil a fin de poder estudiar algún dispositivo que permita trasladar estos grupos al menos en las ocasiones más necesarias." Desconocemos si estos planos se llegaron a conseguir, pero lo cierto que es años más tarde, en España los cañones Flak de 88/56 en montaje fijo recibidos en el marco del "Programa Bär" fueron transformados en móviles. Sección Cuarta. No 4484-D A/M. Nota para el teniente coronel Marín de Bernardo. Embajada de España. AGMAV. Caja 24.713. Fondo del antiguo Ministerio del Ejército.

${ }^{688}$ No estaban comprendidas en la oferta de válvulas las 7.000 del modelo K.F.3 y 3.000 del modelo K.B.C.1, que en su momento habían sido solicitadas. Según la $4^{a}$ Sección del EMCE, dichas válvulas eran necesarias y debía seguir gestionándose su adquisición en Alemania para ser incluidas en el nuevo Programa. Sección Cuarta. No 4484-D A/M. Nota para el teniente coronel Marín de Bernardo. Embajada de España. AGMAV. Caja 24.713. Fondo del antiguo Ministerio del Ejército.

${ }^{689}$ Tampoco se había tenido en cuenta la solicitud de 1.000 estaciones de radio de 2 vatios, hecha por las autoridades españolas. Al igual que en el caso anterior, debía seguir gestionándose su adquisición. Sección Cuarta. No 4484-D A/M. Nota para el teniente coronel Marín de Bernardo. Embajada de España. AGMAV. Caja 24.713. Fondo del antiguo Ministerio del Ejército.

${ }^{690}$ Este capítulo $5^{\circ}$ correspondía al Ministerio del Aire, por lo que en toda la documentación del Ejército de Tierra se prescinde del mismo. Dicho capítulo comprendía 25 aviones de bombardeo Ju 88 y 100 aviones de caza Me 109G. Nota fechada el 28 de febrero de 1944 en la que se señalan los plazos de entrega negociados para el nuevo material que supone la ampliación del "Programa Bär". AGMAV. Caja 24.713. Fondo del antiguo Ministerio del Ejército. 
En otro documento posterior del Estado Mayor Central del Ejército ${ }^{691}$, fechado el 4 de abril de 1944 y remitido por la $4^{\text {a }}$ Sección del mismo a la $2^{\text {a }}$ Sección Información- a efectos de comunicación al Agregado Militar alemán en Madrid, Generalmajor Hans Doerr ${ }^{692}$, además de la relación de material solicitado al gobierno alemán por el Agregado Militar español, aparecía otra que recogía el ofrecido a España por el director de la AGEKA, señor Eltze. Dicha relación tenía dos únicos capítulos en los que se englobaban los materiales ofrecidos por el director de la AGEKA. Este programa debe considerarse como una ampliación del anteriormente aprobado por la Embajada alemana en Madrid.

\section{TABLA VIII-B}

\section{MATERIAL OFRECIDO POR EL SR. ELTZE ${ }^{693}$}

\section{-Carros de combate}

-67 carros Panzerkampfwagen Ausf. IV $V^{694}$

\section{-Cañones}

-60 cañones de infantería de $75 \mathrm{~mm}$ Rheinmetall

-Un cañón de 150/52 Rheinmetal

-Un cañón de 210 mm Skoda

Fuente: AGMAV. Caja 24.713

El 11 de abril de 1944 se volvía a relacionar dicho material de guerra, aunque desaparecían los 60 cañones de infantería de 7,5 cm Rheinmetall ofrecidos por Eltze ${ }^{695}$

691 "Nota para la $2^{\text {a }}$ Sección de este Estado Mayor. Casa. Sección 4 ${ }^{\text {a }}$ N $^{\mathrm{o}}$ 4577-E A./J." AGMAV Caja 24.705-1. Fondo del antiguo Ministerio del Ejército.

692 Generalmajor Hans Doerr (14-9-1897 Wilhelmshaven; 16-9-1960, Rosenheim) Fue promovido a alférez de artillería en 1915, combatiendo durante la Primera Guerra Mundial. Pasó al retiro en 1919, reintegrándose al Reichwehr en 1924, donde ascendió y desarrolló diferentes comisiones y destinos hasta el inicio del conflicto mundial. Durante el transcurso del mismo desempeñó diferentes cometidos, destacando como oficial de enlace con el $2^{\circ}$ Ejército italiano y con el $4^{\circ}$ Ejército rumano, así como jefe de estado mayor del XVII Cuerpo de Ejército alemán. Fue nombrado Agregado Militar en la Embajada alemana en Madrid el 10 de agosto de 1943, cargo que desempeñaría hasta el mismo día de la rendición, el 10 de mayo de 1945. http://www.geocities.com/ orion47/WEHRMACHT/HEER/ Generalmajor/DOERR_HANS.html.

${ }^{693}$ Sección cuarta. N ${ }^{\circ}$ 4513-D A/M. Nota para el teniente coronel Marín de Bernardo fechada el 11 de marzo de 1944. Embajada de España. Berlín. AGMAV Caja. 24.713. Fondo del antiguo Ministerio del Ejército.

${ }^{694}$ Con los 67 carros ofrecidos por Eltze unidos a los 33 aprobados anteriormente por la Embajada en Madrid, se pretendía organizar tres batallones homogeneos, a tres compañías de 10 carros por batallón, más uno de mando. $4^{\mathrm{a}}$ Sección. № 4707-E A/M 10 de abril de 1944. Nota remitida al Agregado Militar en Berlín. AGMAV Caja 24.705-1. Fondo del antiguo Ministerio del Ejército.

${ }^{695}$ El caos administrativo generado en esas fechas en la documentación de los diversos ministerios españoles implicados en estas adquisiciones es palmaria. En una carta reservada del ministro del Ejército, Carlos Asensio, al de Exteriores, Jordana, fechada el 9 de junio de 1944 se puede leer que se acepta el 
$\mathrm{y}$, en cambio, se hablaba de la adquisición de la patente para fabricar en España el cañón de Infantería de 7,5 cm L/12. Dos meses más tarde, el 8 de junio, el general Subsecretario del Ministerio del Ejército daba traslado al Director de la DGIM del citado documento.

Un mes y medio más tarde, el 26 de mayo, el coronel Jesús Aguirre, de la sección cuarta del EMCE, remitía una nota informativa ${ }^{696}$ al general jefe del citado órgano del ejército español, y en ella le daba cuenta -entre otros asuntos- del nombre clave que tendrá la ampliación del "Programa Bär": su nombre sería "Ankara". De la misma manera hacía especial hincapié en el estado de ánimo de los responsables alemanes tras conocer la posición española con los Aliados por esas fechas:

"La ampliación del programa "Bär" se llamará programa "Ankara". En su tramitación es donde más se notan los reflejos que la marcha de la política española produce en las autoridades alemanas.

Antes de la firma del tratado con los Aliados todo eran facilidades. Una vez firmado, y como primer destello, se comunicó a nuestro Agregado que ni aún la parte común de los programas "Bär" y "Ankara" habrían forzosamente de tener precios iguales, aunque esto no quería decir que, necesariamente, y en todos los casos, fueran mayores..."

Es muy interesante constatar, como lo hacía el coronel Aguirre en esta nota, que las autoridades alemanas pensaban, que en España se empleaba mucho tiempo en resolver asuntos que el Agregado Militar presentaba ante ellas con gran urgencia y que, en ocasiones, esta circunstancia restaba eficacia a las gestiones. Por este motivo, Aguirre apremiaba al general jefe del EMCE - previendo acontecimientos bélicos en Francia-:

"La Sección considera un deber presentar ante V.E. la impresión que dentro, claro es, de la conveniencia nacional, deberían acelerarse todos los trámites conducentes a obtener la decisión de adquisición del material que convenga, no perdiendo de vista la circunstancia de que llegue el momento en el que las adquisiciones de esta fuente lleguen a ser imposibles..."

ofrecimiento de Eltze sobre la base de que se desplacen a España técnicos alemanes o a Alemania la Comisión española, a efectos de valorar el material de $75 \mathrm{~mm}$ Rheinmetall. Un material que dos meses antes había desaparecido de las listas. AGMAV. Caja 24.713. Fondo del antiguo Ministerio del Ejército.

${ }^{696}$ Sección cuarta. N ${ }^{\circ}$ 4624-G A./J. Secreto. Nota informativa para S.E. Asunto: Envíos de armamento desde Alemania. AGMAV. Caja 24.713. Fondo del antiguo Ministerio del Ejército. 
También estaba previsto incluir en este nuevo programa de armamento, el asunto de las baterías de costa recibidas en Canarias en 1941 (Baterías del "Programa Isabela"), facturadas a la Marina española y luego transferida dicha factura al Ejército de Tierra.

El 16 de junio de 1944 el Secretario General del Ministerio del Ejército remitía una interesantísima carta al Director General de Industria y Material referente a los envíos de armamento y material desde Alemania ${ }^{697}$. Entre otros asuntos, afirmaba:

"Informaciones recogidas por nuestro Agregado Militar en Alemania, respecto a este asunto, señalan algunos puntos de vista de excepcional interés, que han sido sometidos por este E.M. a la consideración de S.E. el Ministro. De entre ellos se destaca uno que por la repercusión que puede tener en las futuras negociaciones relacionadas con el programa "Ankara" ha dispuesto dicha autoridad se comunique a V.E. La situación especial en que con relación a los bombardeos se encuentra el país alemán y las zonas ocupadas, exigen negociaciones rápidas si el material ha de obtenerse, ya que lo que es posible en un momento puede dejar de serlo en plazo corto..."

Era evidente que la situación en Francia una semana después del desembarco de Normandía, era caótica, previendo el español el posible cierre de las fronteras de Irún y Port-Bou de manera inminente, hecho que conllevaría la paralización de los transportes por tierra entre Alemania y España. De la misma manera, se estaba produciendo una situación límite en muchas ciudades germanas, debido a los bombardeos anglonorteamericanos. Citaba el Secretario General del Ministerio del Ejército un caso que acababa de ocurrir, se trataba de un posible y próximo contrato a celebrar por el Ministerio para adquirir vehículos todo-terreno a la casa "Steyr", contrato fallido debido a que uno de los bombardeos alcanzó las instalaciones de la fábrica, donde ardieron esos vehículos en construcción, junto a otros muchos elementos.

En esta misiva aclaraba un aspecto muy importante de este nuevo programa de armamento, en el sentido de considerar el programa denominado "Ankara" exclusivamente por el material gestionado por el Agregado Militar en Berlín, sin incluir en el mismo la oferta realizada por el señor Eltze, que llevaría un camino paralelo, aunque no coincidente.

El ministro del Ejército español ordenó que se activaran con la máxima urgencia los trámites administrativos necesarios para llegar a la aceptación del "Programa Ankara", del ofrecimiento de Eltze, así como de la adquisición de determinada

${ }^{697}$ AGMAV. Caja 24.708. Fondo del antiguo Ministerio del Ejército. 
maquinaria, con el fin de no demorar los envíos y salvar en lo posible el cierre previsto de los pasos fronterizos con Francia si los negros presagios de ocupación aliada del territorio continental francés se hacían realidad, como así ocurrió.

La Embajada de España en Berlín comunicó al gobierno alemán ${ }^{698}$ que España aceptaba la entrega del material de guerra contenido en el nuevo "Programa Ankara" el 14 de julio de 1944, advirtiendo que se aceptaban los mismos precios que se acordaron en el "Programa Bär" para el material común. Para el que no estaba incluido en el "Bär", o las modificaciones que pudiera hacer el gobierno alemán en los precios, el embajador reservaba la conformidad española una vez los técnicos hicieran las comprobaciones correspondientes. .

Es interesante constatar que los precios de casi todo el material del "Programa Ankara" se conocieron esos mismas días de julio de 1944, coincidiendo plenamente con los del material análogo adquirido hasta ese momento ${ }^{699}$.

\section{VIII.2.-EXPEDICIONES A ESPAÑA POR VÍA AÉREA}

Es muy complejo hacer un seguimiento de todos los envíos de material militar, comprendidos o no en el denominado "Programa Bär", que llegaron a España por vía aérea. En primer lugar porque la documentación obtenida es ciertamente fragmentaria y cuando se refiere a estos envíos, en la mayoría de las ocasiones cita un determinado número de bultos o paquetes o, incluso, cajones, y su peso correspondiente, obviando el contenido de los mismos. Además, muchos de los envíos realizados por esta vía, correspondientes a material para las Fuerzas Armadas españolas, no eran material negociado en el "Programa Bär", sino que había sido contratado directamente por algún organismo de los ministerios militares con diversas empresas alemanas o con AGEKA, pero al margen del citado programa de adquisición de armamentos.

Por la propia naturaleza del medio empleado para el transporte, los paquetes debían ser pequeños, por lo que el material también debía tener unas dimensiones muy

\footnotetext{
${ }^{698}$ Nota verbal de la Embajada de España en Berlín remitida al Ministerio de Asuntos Exteriores alemán el 14 de julio de 1944. AGMAV. Caja 24.713. Fondo del antiguo Ministerio del Ejército.

${ }^{699}$ Nota informativa para S.E. Asunto: Precios del material del Progrma "Ankara". EMCE, Sección Cuarta $\mathrm{n}^{\circ}$ 4540-I A/M. Fechada el 12 de julio de 1944. De todo el material que componía el Programa, únicamente se desconocían los precios de las estaciones de radio de 2 watios y de los proyectores de luz de $240 \mathrm{~cm}$, aunque esas partidas “... no será posible conseguirlas al menos por ahora..." según afirmaba el coronel jefe de la Sección, Jesús Aguirre. AGMAV. Caja 24.713. Fondo del antiguo Ministerio del Ejército.
} 
limitadas, y esto marcaba, sin duda, la clase de envíos que los miembros de la Agregaduría Militar española en Berlín podían contratar con la compañía aérea del Tercer Reich.

La mayor parte de los objetos transportados por avión correspondían a material sanitario, de transmisiones, algún repuesto, bibliografía técnica sobre el material adquirido y planos de patentes compradas en Alemania durante ese período, así como algunos envíos particulares de miembros de la Embajada española en Berlín.

El 14 de diciembre de 1944, el teniente coronel Romero de Arcos, Agregado Militar Adjunto en Berlín, remitía una carta -como hacía todas las semanas-dirigida al coronel Jesús Aguirre, jefe de la $4^{a}$ Sección del Estado Mayor del Ejército en la que entre otras cosas decía ${ }^{700}$ :

“...El transporte por vía aérea parece que, al fin, va tomando forma de realidad y por ello es momento de que organicemos y acordemos su modalidad.

Independientemente de los detalles de cupo y forma de realizarlos en Berlín, que todavía hay que puntualizar con el Ministerio de Economía alemán, tenemos ya el conocimiento oficial de su posibilidad..."

Debido al poco volumen de los envíos se eliminó a la empresa de transportes Schenker de la ejecución de los mismos por esta vía.

Como era habitual, las empresas entregaban el material en fábrica o almacén y debían ser pagadas contra la presentación de documentos de facturación y salida de sus almacenes. Aunque se intentó hacer la recepción en Barcelona ("Telefunken" estaba dispuesta, no así "Siemens"), pagando España la prima de seguro de las mercancías, esto no fue posible y la recepción de los materiales se realizaba en la propia Embajada española, con la obligación de pago a partir de la recepción del material. Continuaba Romero de Arcos:

“...Incluiremos en estos transportes el material sanitario que está comprando Perial para el Parque Central de Sanidad y todo otro que tenga interés para el Ministerio del Ejército..."

Requería Romero, a continuación, una respuesta rápida a lo que estaba proponiendo, con autorización -si era el caso- para asumir riesgos a la hora de adquirir el material -que probablemente sería el último, por la marcha de los acontecimientos-.

\footnotetext{
${ }^{700}$ Carta mecanografiada del teniente coronel Alfonso Romero de Arcos al coronel Jesús Aguirre, fechada en Berlín el 14 de diciembre de 1944. AGMAV. Caja 24.714. Fondo del antiguo Ministerio del Ejército.
} 
“...Esto hay que tomarlo así -continuaba Romero- y pagarlo caso de que nos interesen estos materiales, de otro modo no conseguiremos se nos entregue ni una vulgar lámpara de luz eléctrica. Como ves, dadas las modalidades de estas entregas de material, se hace necesario conceder a Marín un margen de confianza para disponer estos pagos y eximirle de la responsabilidad de recibir un material que tiene orden de adquirir y no tiene posibilidad de asegurar contra todo riesgo (...) en una posible destrucción por bombardeo..."

Finalizaba su extensa carta el teniente coronel Romero de Arcos con unas palabras en defensa de su jefe, el Agregado Militar en Berlín, coronel Marín de Bernardo, que destilaban cierta ironía:

“...Aclarando estas cosas todos quedamos tranquilos, pues si la tal destrucción acaeciese (Dios no lo quiera) y siguieran en esa sustentando la teoría de que los argumentos de Siemens no convencen, veo a Marín a descuento hasta que sea el más ancianito de los generales del Ejército español.”

En cualquier caso, según un documento del Estado Mayor Central del Ejército fechado en Madrid el 10 de octubre de $1944^{701}$, el material del "Programa Bär" que podría ser enviado por vía aérea, siguiendo instrucciones del ministro del Ejército, sería el correspondiente a las partidas numeradas $65,66,68,74$ y 79, con el fin de completar el material de esas mismas partidas que ya había llegado a España ${ }^{702}$. Dichas partidas correspondían a material de transmisiones, en concreto: 16 aparatos de localización por el sonido Tfb1 y ocho Tfb2 (partida 65), cuatro aparatos MEK-8 y doce MEK-3 (partida 66), 110 auriculares amplificadores de escucha (partida 68), 100 estaciones de radio de 15 vatios SE-469 a (partida 74) y 12.770 válvulas de radio (partida 79).

Casi en las mismas fechas, el 13 de octubre, el Agregado Naval en Berlín, capitán de fragata Espinosa, enviaba un telegrama dirigido al Almirante Jefe de Estado Mayor de la Armada pidiendo autorización para remitir vía aérea sesenta kilogramos de planos y documentos de la casa "Rheinmetall" con destino al Consejo Ordenador de Construcciones Navales Militares. El aparato sería un hidroavión Dornier Do 24T de los adquiridos por el Ejército del Aire para salvamento marítimo, saldría la semana

\footnotetext{
${ }^{701}$ AGMAV. Caja 24.707. Fondo del antiguo Ministerio del Ejército. Cuenta para S.E. Asunto: Estado actual de las entregas y pagos del material correspondiente al "Programa Bär" (Sección Cuarta, n 4598$\mathrm{K})$.

702 De una de las partidas citadas - la numerada como 79, que comprendía válvulas de radio- no había llegado en la fecha de emisión del documento citado ni una sola de las mismas.
} 
siguiente llevando esa carga para el Ministerio de Marina español ${ }^{703}$. Obviamente, se le contestó autorizando la operación desde el EMA ${ }^{704}$.

Por valija diplomática fue enviado en distintas fechas entre septiembre y noviembre de 1944, diverso material con destino al Parque Central de Sanidad. Se recibieron los siguientes pedidos: dos aparatos "Tranfusex", un cistoscopio "Wolf", un gastroscopio "Wolf" y diverso instrumental de cirugía de ojos. Para el coronel médico Alberto Blanco, se recibió de Alemania por esta misma vía un libro: el "Tratado de enclavijamiento medular de huesos" (Boehler) ${ }^{705}$.

También en noviembre, en concreto el día 16, amerizaba en Pollensa un hidroavión Dornier Do 24T para el Ejército del Aire, que llevaba 60 kilogramos de planos y documentos de "Rheinmetall" con destino al Consejo Ordenador de Construcciones Navales Militares. Todavía quedaban en la Embajada española en Berlín otro centenar de kilos de planos, en espera de ocasión para ser trasladados a España $^{706}$.

El 12 de diciembre amerizaba en Pollensa otro hidro con material para la Armada. En este caso se trataba de un cajón de $51 \mathrm{~kg}$ conteniendo planos y cinco paquetes con diferente documentación ${ }^{707}$.

Otro envío para Marina, consistente en doce rollos de documentación y planos saldría en avión de Lufthansa el día 20 de diciembre y otro con once rollos más partiría días después. El precio que cobraba la compañía aérea germana por estos envíos, que podían tener un peso máximo de 60 kilogramos eran de 4,30 marcos por kilo enviado ${ }^{708}$.

En una carta ${ }^{709}$ fechada el 14 de enero de 1945, el Agregado Militar adjunto en Berlín, Alfonso Romero de Arcos, remitía al coronel Jesús Aguirre unas notas de lo que

\footnotetext{
703 APFE. Embajada en España en Berlín. Agregado Naval. Telegrama transmitido no 762 de 17 de noviembre de 1944.

${ }^{704}$ APFE. Embajada en España en Berlín. Agregado Naval. Telegrama recibido Ref. 11263/5024 de 1944.

705 AGMAV. Caja 24.705. Fondo del antiguo Ministerio del Ejército. Carpeta 3. Documentación sobre compra de material y transporte, 1944-1945.

${ }^{706}$ APFE. Embajada en España en Berlín. Agregado Naval. Telegrama transmitido no 878 de 1944.

${ }^{707}$ APFE. Embajada en España en Berlín. Agregado Naval. Telegrama recibido. Ref.12525/6285 de 1944.

708 APFE. Embajada en España en Berlín. Agregado Naval. Telegramas transmitidos no 935 y 940 de 1944.

${ }^{709}$ Carta fechada en Berlín el 13 de enero de 1945. Sucede un hecho muy curioso y que podía inducir a error, pues el teniente coronel Romero de Arcos comete un fallo muy habitual a principios de cada año, como es fechar la carta en el día y el mes correcto, aunque el año, por la querencia hasta ese momento, lo
} 
había conseguido ante las autoridades berlinesas por lo que al transporte por vía aérea se refiere. Decía así:

"En mi próxima carta te daré una explicación más amplia sobre la forma como se ha podido organizar los transportes por avión. Ahora solo te indico lo más importante: cada vez que agotemos un cupo concedido para transporte es necesario solicitar otro, en principio lo acordado son $600 \mathrm{~kg}$ mensuales, el pago se hace en el momento de la facturación, el precio 4,30 marcos por kilogramo hasta Barcelona. Reuno en la Embajada el material, no solo del "Programa Bär" sino todo lo que interesa al Ministerio. Se envía al aeródromo según posibilidades de transporte; cuando se agotan los $600 \mathrm{~kg}$, como te digo, se solicita otro contingente; naturalmente esto lo haremos antes de que se agote totalmente. Los paquetes van con una etiqueta como la que te adjunto, con un sello en tinta del Agregado Militar y un número grande. Los pesos que figuran en la relación son completamente aproximados pues carecemos de báscula y no me fío mucho de los que nos dan las casas...."

En los primeros días de enero de 1945 las autoridades alemanas autorizaban un contingente de unos 400 kilogramos mensuales para que el Agregado Naval español remitiera mercancía por vía aérea. El precio era el fijado días antes, 4,30 marcos por kilo, las dimensiones máximas autorizadas eran de $1,80 \times 1,80 \times 2,40$ metros y el pago podría realizarse indistintamente tanto en Berlín como en Madrid ${ }^{710}$. De la misma manera, el Consorcio de Compañías Aseguradoras del Reich contra los riesgos de guerra hicieron una oferta para asegurar las mercancías a enviar, cuya prima era del $2 \%$ para el transporte y el almacenaje previo del material en Berlín. Como gran parte del material enviado correspondía a planos y dibujos del contrato de Marina con Rheinmetall, y éstos no podían ser valorados a efectos del seguro, el Estado Mayor de la Armada urgió al Agregado Naval adoptar las medidas precisas para minimizar los riesgos que podía correr este material, como evitar entregas prematuras de "Rheimetall" con relación a la salida de los aviones de Berlín, o almacenajes prolongados en la Embajada, debido a los bombardeos permanentes a que estaba sujeta la capital alemana $^{711}$.

pone equivocado, en este caso, 1944. Por el contenido de la carta se deduce muy facilmente que dicha misiva está redactada en 1945, año en el que estaban gestionando los envíos en avión. AGMAV. Caja 24.707 .

${ }^{710}$ APFE. Embajada en España en Berlín. Agregado Naval. Telegrama transmitido no 15 de 1945.

${ }^{711}$ APFE. Embajada en España en Berlín. Agregado Naval. Telegrama recibido no $11409 / 150$ de enero de 1945. 
Otro avión de Lufthansa partió de Berlín el 13 de enero con 13 rollos conteniendo tablas de instrucción de Rheimetall con destino al Consejo Ordenador de Construcciones Navales Militares. El peso de dicho material era de 135 kilogramos $^{712}$.

A primeros de febrero de 1945, el general jefe del Estado Mayor Central del Ejército comunicaba a la Subsecretaría del Ministerio del Ejército que acababa de llegar a Barcelona la primera expedición aérea procedente de Berlín, de material del "Programa Bär" y de los pedidos de material sanitario realizados por el coronel Gómez Ulla $^{713}$.

En efecto, con fecha 15 de enero de 1945 había salido de Berlín un avión de Lufthansa con 389 kilos de material, la mayor parte sanitario, por el que se pagó a la compañía aérea germana la cantidad de $1.673,10 \operatorname{marcos}^{714}$.

El 26 de febrero de 1945 llegaba a Barcelona un avión de Lufthansa ${ }^{715}$ con 440 kilogramos de cristal óptico con destino al Taller de Precisión de Artillería, material que fue remitido a la Maestranza de Artillería de Barcelona, desde donde se enviaría a Madrid, al citado establecimiento artillero.

Un mes más tarde, el 22 de marzo de 1945, el agregado militar en Berlín, coronel Marín de Bernardo indicaba por carta al coronel Aguirre ${ }^{716}$ :

“... Para el transporte por avión encontramos bastantes facilidades por lo cual seguirá el envío regular de todo lo que nos vayan mandando las Casas. Con el envío que sale en el avión de hoy se nos queda la Embajada limpia de material. Y para no perder la oportunidad enviaremos algunas cosas particulares que esperó

\footnotetext{
712 APFE. Embajada en España en Berlín. Agregado Naval. Telegrama transmitido $n^{\text {o }} 37$ de enero de 1945.

${ }^{713}$ AGMAV. Caja 24.707. Fondo del antiguo Ministerio del Ejército. Carpeta 8. Transporte avión.

${ }^{714}$ Esta expedición se componía de los siguientes elementos:

-Para Sanidad: Cuatro microscopios, dos "Weka" colorímetros, pirofán, un cistoscopio "Wolf", un litotritor "Wolf" con óptica, una pantalla de rayos X para odontología, ocho aparatos transfusores "Tranfusex" y gafas de prueba, un aparato de anestesia "Kirschner" con accesorios, un soplete de soldadura oxídrica con accesorios y dos equipos de radio Telefunken, todo ello con un peso aproximado de 230 kilos.

-Para la Jefatura de Transmisiones: 30 válvulas de radio RS 384, con un peso aproximado de 127 kilos.

-Para la Dirección General de Industria y Material: 11 tapacubos para Pak de 7,5 cm, con un peso de 34 kilos. Este material correspondía, inequívocamente, al "Programa Bär". AGMAV. Caja 20.903. Fondo del antiguo Ministerio del Ejército. Ministerio del Ejército. Subsecretaría.

${ }^{715}$ AGM de Ávila. Caja 24.707. Fondo del antiguo Ministerio del Ejército. Carpeta Material de Artillería. E.M.C.E. Sección $3^{\mathrm{a}}$, División $4^{\mathrm{a}}$. Material topográfico y de observación.

${ }^{716}$ AGMAV. Caja 24.707. Fondo del antiguo Ministerio del Ejército. Carpeta 8. Transporte avión.
} 
enviarás a su destino como ya lo has hecho en análogas ocasiones.

Esta es la única forma que tenemos aquí de salvar algunos objetos valiosos y de impedir que los disfruten los comisarios soviéticos..."

En una nota del Agregado Militar español en Berlín para el EMCE, de fecha 15 de abril de 1945, Marín de Bernardo relacionaba los pagos efectuados por la legación española a Lufthansa en concepto de transporte por avión de material militar. El total de las cinco expediciones que relaciona Marín -todas ellas de marzo de 1945- sumaba 7.221,20 marcos. A esta cantidad habría que añadir 1.830, 40 marcos en concepto de transporte aéreo para destinatarios particulares. Eran en total 34 bultos enviados respectivamente en diferentes fechas ${ }^{717}$.

El 12 de abril se recibieron en vuelo desde Alemania, 609 kilogramos, que correspondían a cuatro cajones con material de transmisiones "Telefunken", cuatro aparatos de radio para el Centro de Transmisiones del Ejército y un cajón y cuatro cartones con diverso material radio. En definitiva, hasta el 18 de abril, se habían recibido por vía aérea un total de ocho expediciones de material de transmisiones. ${ }^{718}$.

El último vuelo germano con destino a España, transportando material militar se recibió la primera semana de mayo, y logró poner en nuestro país diversos elementos adquiridos por la Jefatura de Ingenieros ${ }^{719}$. Este envío era ajeno al "Programa Bär".

Los envíos por vía aérea no dejan de ser una pequeña anécdota en el conjunto de programas de adquisición de material militar de los tres ejércitos en el transcurso de la Segunda Guerra Mundial. Pero es la huella inequívoca de la necesidad española de hacerse con un material imposible de obtener de otra manera y en otros mercados, debido al conflicto mundial y al estigma que suponía entre los aliados el que España, en el último decenio, hubiera estado tan ligada al ya derrotado Reich hitleriano.

\footnotetext{
717 -Bultos 1-11: expedición el 8 de marzo de 1945. Destinos: particulares y Centro de Transmisiones del Ejército. -Bultos 12-14: expedición el 9 de marzo de 1945. Destino: Centro de Transmisiones del Ejército. -Bultos 18 y 20: expedición el 14 de marzo de 1945. Destino: Centro de Transmisiones del Ejército. Bultos 15, 16, 17 y 19: expedición el 14 de marzo de 1945. Destino oficial no confirmado. -Bultos 21 a 34: expedición el 14 de marzo de 1945. Destino: Centro de Transmisiones del Ejército. AGMAV. Caja 24.705. Fondo del antiguo Ministerio del Ejército. Carpeta 3. Documentación sobre compra de material y transporte, 1944-45.

${ }^{718}$ AGMAV. Caja 24.704. Fondo del antiguo Ministerio del Ejército. Esta expedición, la 8a , había logrado traer en vuelo 30 válvulas RS-384.

${ }^{719}$ AGMAV. Caja 24.707. Fondo del antiguo Ministerio del Ejército. Se trataba de diverso material de transmisiones: 17 receptores Ae 1.076, cuatro receptores Telefunken, varios teleescritores Hell y 16 adaptadores.
} 


\section{CONCLUSIONES}

El decenio que transcurre entre los años 1936 y 1945 fue clave en las relaciones económicas entre España y Alemania. En primer lugar la Guerra Civil española y, sin solución de continuidad, la Segunda Guerra Mundial, provocaron una situación realmente compleja, no exenta de provisionalidad y de intereses perentorios y urgentes que fueron sorteados de distinta manera, según avanzaban los conflictos y los propios intereses de ambos países, aunque a menudo era Alemania la que marcaba el devenir de la relación, dado su carácter de potencia continental, económica y militar. A medida que pasaban los años y el conflicto mundial se iba tornando en contra de las armas teutonas, el papel de España en las relaciones bilaterales tomó un auge que en otras condiciones hubiera sido impensable.

Si en julio 1936 España no significaba apenas nada en el contexto del comercio exterior alemán, a raíz de su participación en el conflicto español las autoridades germanas vieron la posibilidad de incorporar a su órbita la economía española con todos los recursos naturales que generaba. La empresa "HISMA Ltda.", creada al albur de la guerra española con el objeto de actuar a favor de los sublevados como una auténtica cámara de compensación en los acuerdos de "clearing", se convirtió al finalizar la contienda en el consorcio Sofindus, un auténtico holding de empresas de inversión, con participación en numerosos negocios industriales en territorio español.

Antes, incluso, de finalizar la Guerra Civil, y tras evaluar y comparar las aportaciones de italianos y germanos a los esfuerzos de guerra, las autoridades del bando nacional se decantaron por Alemania como pieza clave y garante de la futura reconstrucción de España, pues veían clara la supremacía militar y el florecimiento económico del Tercer Reich en el contexto europeo: un nuevo orden en el que España y el régimen que saldría vencedor de la guerra civil- quería tener su lugar de preeminencia.

Pese a los esfuerzos económicos realizados por los sublevados durante la guerra española, los suministros bélicos, tanto del material enviado como del personal encuadrado en las unidades expedicionarias italiana y teutona, supusieron un montante tan elevado que no hubo más remedio que recurrir al crédito. Italia evaluó su aportación 
en 1939 y consintió una rebaja global -un corte de casi el 40\%- y el pago de la deuda generada durante el conflicto a un plazo de 27 años y medio, condiciones satisfactorias para los intereses españoles del momento. Alemania, a través de "HISMA Ltda.", tardó más en cerrar sus cuentas con el nuevo Estado español, no terminando antes de finales de mayo de 1940, tras numerosas reuniones celebradas entre comisiones mixtas de ambos países para determinar las cantidades adeudadas. En este caso ni hubo rebaja global, ni período de carencia, ni siquiera un plazo tan amplio como el ofrecido por Italia para pagar la deuda. Quedó pendiente sine díe un remanente de deuda compuesta, básicamente, por los gastos de personal de la Legión Cóndor y varias reclamaciones por daños a nacionales alemanes durante el conflicto.

Una buena parte del material militar aportado por Alemania al esfuerzo de guerra de los sublevados - sobre todo en el apartado aeronáutico, aunque también en el terrestre- era de última generación, habiendo salido directamente de las fábricas germanas en dirección a nuestro país, para ser evaluado en condiciones reales de combate en suelo español. Modelos tan emblemáticos en la historia de la aviación militar como el Junkers Ju 87 "Stuka”, el Messerschmitt Bf 109 o el Heinkel He 111; o de los carros de combate como el Panzerkampfwagen I, amén de las modernas piezas de artillería de 10,5 y $15 \mathrm{~cm}$, se estrenaron y probaron su valor militar en España, dando pie a sus diseñadores a contrastar sus defectos y sus virtudes en base a su comportamiento en combate, acometiendo las modificaciones que los hicieran más adecuados a la realidad del campo de batalla moderno.

Muchos de estos modernos materiales alemanes, junto a los aportados al conflicto por los italianos - menos tecnológicos y más devaluados por su uso y desgaste-, quedaron en España y constituyeron la base de los Ejércitos de Tierra, Mar y Aire españoles durante más de un decenio. Esto, en cualquier otro momento de la historia, en cualquier otra circunstancia que no hubiera sido la que aconteció aquel año de 1939, hubiera sido suficiente para que el Ejército español estuviera dotado y equipado con un material, sino mejor, sí a la altura de cualquiera de los países europeos de su entorno. El hándicap era evidente y terrible: el país estaba devastado por una cruenta guerra civil, y harían falta años y mucho esfuerzo para alcanzar las cotas económicas de 1936. La ventaja militar frente a los países vecinos también era clara: España disponía de un ejército en pie de guerra de más de un millón de hombres con experiencia en combate y completamente motivado. 
La dependencia tecnológica de Alemania fue una realidad desde el mismo momento en que los responsables militares españoles, finalizada la guerra civil, decidieron diseñar un potente ejército con el apoyo del III Reich. Se negociaron adquisiciones de patentes de los más modernos aviones, buques, cañones, fusiles, ametralladoras y un sinfín de equipos alemanes para desarrollar una industria bélica nacional incipiente - con largos años de tradición y buen hacer, eso sí-, aunque lastrada por el estado calamitoso del conjunto de la industria española tras la devastación ocurrida en la contienda.

Pero no habían pasado todavía seis meses desde el final de la guerra española, cuando en ese fatídico año de 1939 daba comienzo el más grande enfrentamiento bélico que ha padecido la humanidad en toda su historia: la que luego sería conocida como Segunda Guerra Mundial. Alemania, que en teoría iba a ser el motor de la reconstrucción de la industria española, el modelo en que inspirar los nuevos ejércitos españoles de la postguerra, se embarcaba en una guerra de proporciones desconocidas entonces, que le impediría -o por lo pronto ralentizaría, por razones obvias- atender las demandas de material bélico de otros países que no compartían con ella el campo de batalla en el conflicto bélico que comenzaba.

Pese a la situación creada a partir del 1 de septiembre de 1939 con la invasión de Polonia por la Wehrmacht, las victoriosas campañas del ejército alemán en los meses siguientes no dieron al traste con las expectativas españolas de adquirir suministros bélicos -sobre todo repuestos para el material en servicio- o licencias de fabricación, ni siquiera con las comisiones de las tres ramas de las Fuerzas Armadas que a menudo viajaban a Alemania para visitar fábricas de armamento o de diferentes equipos de aplicación militar, con el fin de estudiar y analizar, bien su adquisición, bien su fabricación por la industria nacional.

En el otro platillo de la balanza hay que poner el hecho de que la maquinaria bélica germana movilizaba cantidades ingentes de materias primas para su correcto funcionamiento, además de productos de consumo como aceite, naranjas, pieles, etc..., productos que España estaba en disposición de enviar y que hacían viable un despegue de la actividad exportadora, así como un desfase -lento pero constante- de la cuenta de "clearing" entre ambos países, con un balance claro a favor de España.

Las adquisiciones de material bélico en Alemania -repuestos, licencias, etc...siguieron produciéndose en 1940 y 1941, teniendo en cuenta que cada uno de los tres 
ministerios militares, a través de sus respectivas Direcciones Generales de Armamento y Material, así como las Fábricas Militares, las Maestranzas Aéreas y el denominado Consejo Ordenador de las Construcciones Navales Militares, realizaban independientemente y sin planes conjuntos, pedidos de lo que consideraban necesario para su mejor funcionamiento. Todo se llevaba a cabo en el seno de diferentes acuerdos marco -Rahmenvertrage, en alemán- llevados a cabo por los organismos implicados con la industria germana a través, normalmente, de la AGEKA, consorcio oficial del Tercer Reich para la exportación de material militar de cualquier tipo.

Los más beneficiados por estos acuerdos fueron, sin lugar a dudas, el Ejército del Aire y la Marina, que consiguieron firmar diversos contratos para producir en España aviones y buques de patente alemana, así como piezas de artillería y munición diversa, amén de adquirir directamente diversos modelos de aeronaves, repuestos y material de artillería naval y torpedos.

En los tres años que transcurrieron entre el 1 de septiembre de 1939 y el 31 de agosto de 1942, la cuenta compensadora del comercio exterior entre ambos países tuvo una tremenda caída que perjudicaba a España -exportadora neta- y beneficiaba los intereses alemanes y su economía de guerra, que veían como se mantenía el flujo de materias primas básicas para su industria y para el sostenimiento de su capacidad militar en todos los frentes, sin tener que compensar a España de ninguna forma por mor de esta situación ciertamente anómala. Este desequilibrio en el "clearing" a favor de Alemania no tenía justificación alguna desde el punto de vista del nuevo ministro de Asuntos Exteriores español, general Gómez Jordana, recién incorporado al Palacio de Santa Cruz en sustitución del defenestrado Serrano Súñer, el 3 de septiembre de 1942.

En poco más de tres meses desde que tomó posesión como ministro de Exteriores, el conde de Jordana dio un vuelco a la política exterior desarrollada por el equipo de Serrano -contemporizador y pro-germano- en las relaciones con el Tercer Reich. Amén de sustituir a sus más directos colaboradores en el ministerio, cambió a los responsables de las embajadas en Roma y Berlín, gestionando y supervisando con mano de hierro las negociaciones comerciales en curso con Alemania, fijando posturas coherentes con los intereses españoles y marcando claramente los límites que, bajo ningún concepto, podían ser sobrepasados en las reuniones con las comisiones teutonas. No hay que olvidar que Jordana no era político, sino militar de la vieja escuela, 
fogueado en las guerras de Cuba y Marruecos, con un concepto de la disciplina y de entrega a su patria fuera de toda duda.

De esta manera, y con la mirada puesta en no continuar por la senda de la financiación gratuita y sin control a la Alemania hitleriana, Jordana dio un impulso a las negociaciones para llegar a la firma definitiva de un tratado comercial con el Reich, un tratado que debería reglamentar las operaciones bilaterales entre ambos países y poner coto al imparable crecimiento del descubierto exterior acumulado en los últimos años. El tira y afloja entre los negociadores germanos y españoles fue tremendo, mezclándose cuestiones políticas, diplomáticas y comerciales en cada una de las reuniones celebradas en Madrid.

El revulsivo a todo el problema planteado por la financiación incontrolada del déficit comercial exterior germano, vino de la mano del armamento; un armamento por el que los tres ministerios militares españoles suspiraban desde hacía años; un armamento que vendría a tapar muchos agujeros en las plantillas de los ejércitos españoles, cuyo material había quedado obsoleto con los avances espectaculares ocurridos en el transcurso de la guerra mundial, y era ya, en muchos casos, venerable chatarra de finales del siglo XIX o de principios del XX.

Un armamento, en fin, que cumpliría la doble función de paliar los desequilibrios comerciales del Tercer Reich con la España de Franco y servir a los propios militares para cubrir -en la medida de lo posible- la carencia de materiales de última generación y el desfase tecnológico que había propiciado el desarrollo de la guerra mundial, que había cerrado las puertas a la modernización efectiva del ejército español. Ambas funciones iban a ser valoradas por un ministro de Exteriores militar, en una Europa en guerra, con los Aliados desembarcando en el norte de África y con la lupa puesta en el papel que representaba España y su política comercial, con los países del Eje.

En este contexto de guerra mundial, negociaciones comerciales, concesiones políticas y tacto fino en las relaciones diplomáticas entre España y Alemania, nació el que a partir de ese momento - diciembre de 1942- sería conocido como "Programa de Armamentos" o utilizando el nombre clave que se emplearía para su desarrollo, "Programa Bär" - oso en lengua germana-, el más ambicioso proyecto de adquisición de material militar de la primera mitad del siglo XX. 
Hasta la fecha no se ha puesto en valor la realidad que supuso para la defensa de España -situada en el epicentro de un conflicto de proporciones nunca vistas hasta entonces- ese programa armamentístico, pues el mismo nunca ha sido objeto de un estudio sosegado, profundo y minucioso; un análisis que determinara de manera independiente e individualizada los efectos que produjeron en el estamento militar español de los años cuarenta, esas adquisiciones -casi inesperadas, aunque largamente solicitadas- de material de guerra moderno.

Si bien las cantidades adquiridas de ciertos elementos necesarios para cubrir las plantillas de material, fueron en algunas ocasiones exiguas -caso de los carros de combate o los aviones-, en otros superaron con creces las expectativas españolas planteadas por las comisiones negociadoras en Berlín -caso de la artillería de campaña, las motocicletas, las minas contracarro o los cañones antitanque-, rechazando, incluso, en algunos casos, ciertas armas que se podían fabricar, sin problemas en nuestro paíssubfusiles o cañones de $50 \mathrm{~mm}-$. También es cierto que algunas de las peticiones españolas no se vieron satisfechas por las autoridades alemanas -caso concreto de los medios de tracción (camiones pesados) o proyectores antiaéreos de gran calibre-, suministros que la producción teutona no era capaz de fabricar ni para su propio consumo, en una Wehrmacht a menudo sobrevalorada y supuestamente mecanizada, pese a que la realidad cotidiana del famoso ejército alemán fuese mucho más cercana a lo que representaría un ejército hipomóvil con un fuerte déficit de medios de transporte mecánico en todos los frentes.

Solo analizando la estructura del Ejército de Tierra español, de la Marina o del Ejército del Aire a finales del año 1942, comprenderemos el porqué de la composición del material contratado en el "Programa Bär".

El desfase tecnológico español impedía disponer de carros de combate modernos, manteniendo en servicio los modelos más básicos procedentes de la guerra civil, superados tanto en protección como en potencia de fuego y movilidad. La petición española chocó frontalmente con la realidad germana de principios de 1943. En el mismo momento en que el general Paulus se rendía a los soviéticos en Stalingrado y poco después del desembarco aliado en el norte de África, lo que no sobraba a la industria bélica germana era, precisamente, carros de combate, por lo que la entrega de un grupo acorazado completamente nuevo -recién salido de fábrica-, compuesto por 32 vehículos blindados (22 carros Panzer IV y 10 cañones de asalto) podría considerarse un 
éxito relativo de los negociadores españoles. La familiarización con estos blindados modernos (potente cañón de $75 \mathrm{~mm}$, motor Maybach de casi $300 \mathrm{CV}$, cinco tripulantes, y un blindaje de hasta $80 \mathrm{~mm}$, potenciado con faldones (Schürzen) en los laterales del casco y de la torre para evitar la munición de carga hueca y con pasta antimagnética (Zimmerit) para evitar las minas magnéticas) fue un enorme adelanto y sirvió para formar una fuerza acorazada capaz de adaptarse a los nuevos tiempos que marcaban los adelantos técnicos. No se cubrían las plantillas, evidentemente, pero se plantaba una semilla para el desarrollo futuro del arma acorazada.

La motorización del ejército español, al igual que ocurría en otros aspectos, era deficiente, manteniéndose en servicio motocicletas, coches y camiones importados durante la pasada guerra civil. En cualquier caso, las plantillas estaban cubiertas excepto en lo que respecta a las motocicletas, vehículos rápidos muy apropiados para exploración, y si estaban armadas, también para la explotación del éxito de la ofensiva, misiones ambas fundamentales del Arma de Caballería. En este caso también puede considerarse un rotundo éxito la adquisición de 750 motos pesadas BMW R-75 con carro lateral -el famoso side-car, en terminología sajona-, recién salidas de fábrica, y armadas la mitad de ellas con la ubicua y excelente ametralladora MG 34, una de las mejores armas de la historia. De esta manera se consiguieron 325 parejas de motos -con una de ellas armada y la otra cargada con munición para la ametralladora-, en las que podían trasladarse hasta seis hombres - dos en cada moto y uno en el side-car-. Como complemento, se adquirieron otras 400 motos ligeras de varias marcas, en este caso de segunda mano, aptas para misiones de exploración. Hasta la llegada masiva de los famosos "jeeps" norteamericanos, estas más de mil motos germanas fueron la espina dorsal de la Caballería española.

Quizás el mayor éxito del presidente de la Comisión española que negoció en Berlín el "Programa Bär", el general Martínez de Campos, fuera conseguir convencer a los teutones que en lugar de dos grupos de artillería de campaña de mediano calibre que ofrecían -24 cañones soviéticos de $122 \mathrm{~mm}$ capturados en el frente del Este tras la Operación "Barbarroja"-; España necesitaba, por lo menos, seis veces más: 12 grupos completos para dotar a los Cuerpos de Ejército peninsulares y del Protectorado, de potencia de fuego suficiente y moderna, de manera inminente. Y lo consiguió, y no sólo llegaron 150 cañones potentes y robustos, sino también munición para ellos y todos los 
accesorios y herramientas necesarios para su mantenimiento y puesta en servicio inmediata.

Si, como ya hemos apuntado, las existencias de carros de combate en España eran francamente pobres, lo mismo se podría afirmar de los medios modernos para luchar contra ellos. Todo lo que había en nuestro país procedía, de alguna manera, de los excedentes de la guerra española; se trataba de pequeños cañones cuyos calibres habían quedado francamente escasos para combatir contra las corazas de los modernos carros rusos, alemanes o norteamericanos. Y en este asunto sí se puede decir que en el "Programa Bär" se cerró el círculo: al margen de los 300 cañones que se recibieron -de los que la mitad eran franceses, ligeros, botín de guerra y de dudosa eficacia, y la otra mitad germanos, pesados, de última generación y de efectos letales para los carros de combate-, también se tuvo en cuenta la lucha de los zapadores y de los propios infantes contra los monstruos de acero. Para los zapadores se adquirieron minas "de plato" pesadas y ligeras, así como una partida de minas magnéticas, que se adherían a la chapa de los carros y producían la deflagración con efectos terribles en la dotación. Todas estas minas eran modernas, eficaces y probadas en combate, sobre todo en la URSS. Para los soldados de infantería se adquirieron granadas de humo para cegar a los carros, fusiles antitanque especiales y brocales, unas bocachas especiales que transformaban los fusiles y carabinas Mauser, en verdaderas armas para luchar contra los carros de combate. También se adquirieron unas granadas especiales para ser empleadas con estos fusiles.

Además, para que los cañones alemanes procedentes de la guerra -Pak 36 de 37 mm, de dotación en el ejército español- pudieran ser más eficaces, prolongando así su vida activa, se adquirió un tipo de proyectil especial de carga hueca, de avancarga y que a poca distancia podía poner fuera de combate a cualquier carro moderno. Por último, debido a la experiencia alcanzada por los alemanes en transformar piezas de campaña francesas Schneider Mod. 97 -capturadas en las campañas polaca y del oeste- en verdaderas armas para la lucha contra los tanques, el OKW ofreció a España modificar 200 cañones procedentes de la pasada guerra civil y adaptarlos a un afuste alemán: el de los Pak 38, cañones contracarro de $50 \mathrm{~mm}$ ya poco operativos en 1943. España aceptaría, aunque reduciría su número a 50 piezas, para lo que se procedió al envío de dos de ellas a Alemania para que se hicieran pruebas. Al final, los técnicos alemanes fueron incapaces de adaptarlas, devolviendo ambos cañones y frustrando la operación. 
Las necesidades de la artillería se cerraban con la potenciación de la débil defensa antiaérea del ejército español. Pese a que se había adquirido la patente para construir en España el probado cañón Flak de $88 \mathrm{~mm}$, las expectativas más optimistas afirmaban que las primeras piezas podían salir de la fábrica de Trubia entorno a 194647 , por lo que urgía completar las unidades con material moderno hasta que la variante hispana estuviera desarrollada y en servicio. Treinta baterías -120 cañones- serían suficientes para jubilar las viejas piezas procedentes de la Guerra Civil española y completar una mínima red de defensa activa moderna y potente del territorio nacional, incluyendo Canarias, Baleares y el Protectorado marroquí. Las baterías pesadas vendrían acompañadas de sus correspondientes direcciones de tiro modernas, grupos electrógenos y sistemas electro-mecánicos que permitieran emplear con éxito la puntería centralizada que ofrecían los directores de tiro. Además, se negoció el envío de fonolocalizadores RRH, que complementarían a las 30 nuevas baterías como a las ya existentes en España, mejorando su eficacia al poder determinar por el sonido independientemente de las condiciones climáticas o del momento del día o de la nochela presencia de aviones y sus coordenadas. Los alemanes, en cambio, no consintieron el envío de proyectores pesados de luz -complemento básico a los fonos-para iluminar los blancos aéreos. Las necesidades propias ante las campañas de bombardeo que sufría el territorio del Reich a partir de esas fechas, puede que pesaran mucho en esta decisión.

Como complemento de las baterías antiaéreas pesadas se negoció el envío de 14 baterías ligeras de cañones Oerlikon de $20 \mathrm{~mm}-168$ piezas-, armas de origen suizo que Alemania había adquirido a finales de los años veinte y había incorporado a su parque armamentístico con el nombre de Flak 28. Dichos cañones llegarían acompañados de sus correspondientes telémetros para el cálculo de distancias y -en este caso sí- de proyectores de luz ligeros AEG, de calibre $60 \mathrm{~cm}$.

Al margen del "Programa Bär", pero con la mirada puesta en dotar de medios de detección a los grupos antiaéreos de la artillería costera y de los regimientos de artillería para cuerpo de ejército, se adquirieron otros fonolocalizadores de origen belga y de calidad inferior a los alemanes; era lo único disponible en el mercado de armamento en esos momentos. La operación se realizó a través de la AGEKA, empresa estatal germana para la exportación de material militar, que también funcionaba en los países ocupados, enviando los aparatos en varios trenes de los fletados para el material del programa. 
Pese a que en las reuniones preparatorias del "Programa Bär", los alemanes quisieron incorporar a los listados de material exportable: morteros de infantería, lanzallamas, fusiles y subfusiles así como algún otro tipo de piezas artilleras, la Comisión española renunció a su compra debido a que en las fábricas españolas se podían producir esos materiales y su adquisición sólo podría acarrear problemas logísticos de municionamiento, reparaciones y conservación, además de multiplicar calibres o modelos en servicio.

Dos últimos aspectos de las adquisiciones son muy de resaltar; por una parte la llegada a España de un arma que estaba revolucionando los campos de batalla de la Segunda Guerra Mundial y que marcaría las guerras futuras, nos referimos al radar; y por otra, la compra de diverso material de transmisiones, del que el ejército era deficitario ya desde antes de la Guerra Civil.

Las restricciones germanas sobre un material revolucionario y novedoso -que ellos denominaban radiolocalizador o radiotelémetro, según su alcance - eran evidentes, y en el transcurso del conflicto no habían compartido esas máquinas con ninguno de sus aliados. Tras numerosos "tira y afloja", en las reuniones de Berlín las autoridades germanas accedieron vender una partida de radares con destino al Ejército del Aire español: serían 27 radiotelémetros Würzburg de corto alcance, y otros tantos radiolocalizadores Freya de largo alcance, además de seis aparatos Lichtenstein para montar en aviones militares. La Marina, después de un trabajo ímprobo de su Agregado en Berlín, también obtuvo la cesión de uno para montar en el crucero "Canarias", buque insignia de la Flota. El discurrir de los transportes ferroviarios en conjunción con los acontecimientos en Francia tras el desembarco de Normandía provocó que esas generosas cifras quedaran reducidas a la llegada a España de un único y solitario Freya, diez Würzburg y tres Lichtenstein, cuyos avatares en nuestro país son dignos de un trabajo más profundo. El de la Armada nunca llegaría debido a un ataque del maquis al tren que lo transportaba.

Entre el material de transmisiones se negoció la compra de equipos de radio (transmisores y receptores) de varios modelos, tipos y procedencias; válvulas, equipos de telefonía, teletipógrafos mecánicos, radiogoniómetros, equipos repetidores, cable telefónico de campaña, etc...

La Marina española ya había tenido ocasión, en los años precedentes, de satisfacer ciertas necesidades de reconstrucción y modernización de la flota, 
adquiriendo patentes de construcción de buques y piezas artilleras, e importando cañones, ametralladoras, munición, cargas de profundidad y torpedos. Una vez iniciadas las negociaciones que desembocaron en el "Programa Bär", la Armada agrupó sus peticiones, considerando solicitar a Alemania, material de artillería, torpedos y minas, óptica, material para la construcción de los submarinos tipo "G”, máquinasherramientas para la construcción naval en general, lanchas torpederas, aparatos de dirección de tiro y equipos de radio.

Pese a que las peticiones presentadas por la Armada Española -y aceptadas por los alemanes- eran las más amplias de los tres ejércitos, al final no iba a ser la más beneficiada, debido a que una buena parte de los materiales pactados, o bien se cayeron de las listas por la imposibilidad germana de suministrarlos o bien no pudieron llegar a España con motivo de las dificultades y el posterior cierre de las comunicaciones por vía terrestre de Francia tras el desembarco de Normandía.

Lo cierto es que el "Programa Bär" supuso para Marina la recepción de 160 piezas de artillería antiaérea de 20, 37 y $105 \mathrm{~mm}$ de calibres, con su munición correspondiente, una treintena de telémetros ligeros, seis lanchas rápidas torpederas, un millar de minas navales tipo EMC, 200 cargas de profundidad, 20 anteojos, tres toneladas de vidrio óptico y un cineteodolito "Askania", aparato este último que se emplea para hacer un seguimiento preciso de objetos en vuelo y suministrar datos de posición y trayectoria.

Las piezas de artillería vinieron muy bien para intentar completar la dotación antiaérea de calibres ligeros y medios, a muchos de los buques en servicio, una asignatura pendiente en la Armada hasta ese momento. Las lanchas torpederas del tipo Schnellboote $S 38$ (S-Boote), pese a ser material ya usado por la Kriegsmarine, dieron un magnífico resultado en su misión y permanecieron en el Estrecho de Gibraltar hasta su baja, a mediados de los años cincuenta. Las 1.000 minas EMC fueron bien recibidas y las pocas cargas de profundidad que llegaron (de las 2.000 contratadas), dejaron un poso amargo en la Armada, cuyo balance de este programa de armamentos no fue todo lo determinante que se pretendía. Quizás la asignatura pendiente fue el famoso radar que, pese al esfuerzo del Agregado Naval por conseguirlo, nunca llegaría a la frontera española debido a los acontecimientos en Francia del verano de 1944.

Por lo que se refiere a la Aviación, el "Programa Bär" era el menos ambicioso de los tres ejércitos, pues en los años precedentes fue, quizás, quien que más contratos 
firmó con su homónima alemana, la Luftwaffe y con las empresas constructoras germanas. En cualquier caso, los deseos españoles de obtener aviones de los últimos modelos en servicio - de caza, transporte y bombardeo- se vio poco recompensada con el envío -casi testimonial- de sendas escuadrillas de caza y bombardeo, que pese a ser modelos modernos y empleados por Alemania en todos los frentes, eran muy poca cosa para el Ejército del Aire, necesitado de material moderno hasta que la industria nacional pudiera entregar los aviones que estaban en producción. Junto a los aparatos se entregaría munición para los mismos así como repuestos suficientes para las unidades encargadas.

Además del material de vuelo descrito, el programa de armamentos facilitó la entrega de 35 equipos de radio diversos - motorizados y fijos-, así como otros 60 para emplear a bordo, en los aviones; un centenar de equipos de aterrizaje sin visibilidad; medio centenar de teléfonos de campaña, 65 grupos electrógenos de diversos modelos; ocho radiogoniómetros de campaña y cuatro radiofaros de aterrizaje. Como elementos "estrella", para este ejército llegaron once radares, cuyas vicisitudes con el Ejército del Aire no pasaron de la mera especulación de su empleo en la red de alerta, pasando la mayoría de ellos al Ejército de Tierra, que los asignaría a las unidades antiaéreas más importantes para facilitar la adquisición de blancos aéreos.

Al igual que ocurriera con los otros dos ejércitos, la aviación no pudo completar el "Programa Bär" debido a la imposibilidad de tránsito de los transportes por la Francia recién liberada por los Aliados, tras el desembarco en las costas normandas, en junio de 1944.

Por último, el cuarto brazo del "Programa Bär" -y quizás el más ambicioso de todos-, el de la maquinaria para dotar a las industrias y fábricas del Ejército de Tierra de los elementos necesarios para su modernización y mejora, con vistas a la fabricación de nuevos materiales bélicos, quedó prácticamente olvidado, no recibiéndose en España más que un elemento auxiliar -en concreto dos tornos de la casa Stenzel- cuyo valor no llegaba a los 70.000 marcos. Los plazos para la entrega de esta maquinaria, mucho más largos que los del armamento, impidieron su desarrollo y lastraron durante unos años la capacidad de la industria militar nacional, que no pudo modernizarse al ritmo que se preveía.

Los no natos programas "Ankara" y "Eltze", directos sucesores del "Bär", no llegaron a plantearse más que el los documentos de los negociadores, de los estados 
mayores y de las embajadas berlinesa y madrileña, pasando a mejor vida antes, incluso, de iniciarse su desarrollo. Los motivos fueron los mismos que dieron al traste con la finalización del "Programa Bär", el corte de las comunicaciones terrestres con Alemania.

Desde entonces, sólo quedó abierta una vía, la aérea, para transportar a España material de origen militar; una vía que sería utilizada mucho más de lo que se cree, aunque los elementos eran siempre pequeños paquetes, bibliografía, lámparas para equipos de radio o material quirúrgico. El último avión con envíos militares procedente del Tercer Reich aterrizaba en Barcelona la primera semana de mayo de 1945, cuando Hitler era ya historia.

En resumen, las relaciones militares entre España y Alemania durante la Segunda Guerra Mundial fueron lo suficientemente importantes como para no pasarlas por alto y contextualizarlas en su justo término: no llegaron a ser lo que los españoles esperaban, debido a la marcha de la guerra -contraria a los intereses germanos-, ni lo que los alemanes hubieran deseado, forzados estos últimos a entregas masivas de armamento, fruto de la necesidad de disponer de materias primas a toda costa.

Pese a ello, desde 1939 y hasta finales de 1942, España adquirió numerosas patentes para fabricar todo tipo de armas para los tres ejércitos -buques, aeronaves, artillería, fusiles ametralladores, etc...-, obtuvo repuestos y herramientas para una buena parte del material militar presente en las diferentes unidades -procedente todo él de la Guerra Civil-, compró armas, material de guerra, instrumental médico, equipos de radio y telefonía, maquinaria diversa para fábricas de armas, astilleros y maestranzas aéreas, etc... mediante acuerdos entre diferentes organismos de cada uno de los ministerios militares españoles y las industrias de armamento germanas. Todo este comercio de material bélico se producía, ya desde los tiempos de la Guerra Civil, con el eufemístico y poco llamativo nombre de "Suministros Especiales".

Una vez firmado el Acuerdo Comercial con Alemania, en diciembre de 1942, las tornas cambiaron para ambos países: Alemania se comprometía a mantener un descubierto máximo en la cuenta de clearing con España; cualquier desviación al alza, el Tercer Reich habría de compensarla con armamento y maquinaria para la industria bélica española, naciendo así el denominado "Programa Bär". Tras arduas negociaciones, militares -en Berlín- primero y económicas -en Madrid- después, se alcanzó un acuerdo que sería firmado en San Sebastián en agosto de 1943, 
complementario o, si se quiere, ampliatorio, del rubricado en diciembre del año anterior. Mientras tanto, desde mayo de 1943 estaban llegando a la frontera española diferentes convoyes ferroviarios cargados de material bélico para las fuerzas armadas, envíos realizados desde Alemania con una logística compleja y algo sinuosa, forzada, sin lugar a dudas, por la marcha de la guerra y las disponibilidades germanas de ese tipo de suministros.

Durante más de un año las estaciones de Irún, en el Pirineo vasco, Canfranc, en el Pirineo aragonés, y Port Bou, en el Pirineo catalán, fueron testigos de la recepción de 40 trenes con más de mil vagones, cargados con la friolera de 10.000 toneladas de armamento y material bélico contemplado en el "Programa Bär". Este material, tras su descarga, sería organizado y remitido a todos los rincones de España y el Protectorado, potenciando así las unidades militares existentes, en el momento más crítico del conflicto bélico mundial. Todo esto sin contar los aviones y las lanchas torpederas, que llegaron por sus propios medios, vía aérea y marítima, respectivamente.

Pese a que en 1944 se organizaron otros programas de entrega de armamento, que se solaparían con el "Bär" y lo completarían, todos quedaron en papel mojado tras el desembarco de Normandía y el ulterior corte de las comunicaciones terrestres con Alemania por territorio francés.

Es muy difícil llegar a valorar en su justa medida la importancia que tuvo para España la recepción de todo este armamento en aquellos tiempos convulsos, en pleno conflicto mundial, con los Aliados en el norte de África y desembarcando en la costa atlántica francesa. El concepto de "oportunidad" se mezcla aquí con el de "necesidad", y aunque resulte obvio que España jamás hubiera podido enfrentarse con garantías de éxito a los anglo-norteamericanos, éstos tampoco habrían estado en condiciones de distraer un solo hombre ni una sola máquina del objetivo principal: derrotar al Tercer Reich. 
ANEXOS 


\section{ANEXO I}

\section{Acuerdo comercial entre España y Alemania (16-12-}

1942)

"El Gobierno español y el Gobierno del Reich, animados del deseo común de encauzar y fomentar el comercio hispano-alemán y teniendo presentes las actuales circunstancias, han convenido reglamentar el intercambio comercial entre sus dos países durante el período de tiempo comprendido entre el 1 de diciembre de 1942 y el 30 de noviembre de 1943, con un trato de excepción durante los tres primeros meses del mencionado período, con arreglo a las siguientes bases:

1.

Ambos Gobiernos aceptan como base del presente Acuerdo el equilibrio en el valor del intercambio hispano-alemán. Se reservan asimismo la facultad de concertar nuevos arreglos para ampliar o modificar el presente, en el caso de que a consecuencia de suministros adiccionales que incrementasen el volumen del intercambio comercial actualmente previsto, se produjera una nueva situación.

2.

El Gobierno español, en vista de la excepcional situación actual, se compromete a facilitar durante el período comprendido entre el $1^{\circ}$ de diciembre de 1942 y el 28 de febrero de 1943, la exportación efectiva a Alemania de mercancías españolas dentro del margen de las indicadas en la lista adjunta, habilitando los fondos necesarios hasta el contravalor de 100 millones de R.M., para el pago a los exportadores españoles.

Del mismo modo España facilitará la exportación de naranjas a Alemania, adelantando, con carácter excepcional, 30 millones de R.M. como suplemento a la cifra anterior.

3.

Ambos gobiernos prevén durante dicho período de $1^{\circ}$ de diciembre de 1942 a 28 de febrero de 1943 el ingreso de pagos por valor de R.M. 60 millones, resultante de una importación efectiva en España de mercancías o productos alemanes.

4.

Ambos gobiernos convienen, si antes no se hubiera acordado otro procedimiento, según el artículo $1^{\circ}$, en armonizar las adquisiciones alemanas en el mercado español y los envíos alemanes a España, de modo que al comenzar el segundo trimestre de vigencia del presente Acuerdo, se disminuya gradualmente el desequilibrio a que diese lugar el artículo $2^{\circ}$ y se llegue en 30 de noviembre de 1943 a la cifra de R.M. 70 millones, máxima de descubierto, sin otra financiación que la convenida en los artículos anteriores.

Hecho en Madrid, en doble ejemplar en español y alemán, para que ambos textos hagan fe, el 16 de diciembre de 1942.

Por el Gobierno del Reich, Por el Gobierno de España" 


\section{ANEXO II}

\section{-Plan de suministros alemanes desde 1-12-42 al 30-11-43}

\section{Suministro de material de guerra}

\section{-a) Contratos firmados (en marcos)}

\begin{tabular}{|c|c|c|c|c|}
\hline Núm. & Concepto & Valor total & Pagado & $\begin{array}{l}\text { Resta en los } \\
\text { próx. } 12 \text { meses }\end{array}$ \\
\hline 1 у 2 & $\begin{array}{l}12 \text { cañones de } 8,8 \mathrm{~cm} \text { para submarino con } \\
\text { munición }+3 \text { id. } \text { Id. Id. Id. }(\mathrm{M})\end{array}$ & 4.952 .325 & 2.640 .950 & 2.311 .375 \\
\hline $\begin{array}{l}3,4 y \\
5\end{array}$ & $\begin{array}{l}26 \text { piezas antiaéreas en cureña doble de } 3,7 \mathrm{~cm} .+ \\
26.000 \text { granadas rompedoras de } 3,7 \mathrm{~cm}+26.000 \\
\text { granadas rompedoras para ejercicio de } 3,7 \mathrm{~cm}(\mathrm{M})\end{array}$ & 5.642 .000 & 4.764 .000 & 878.000 \\
\hline 6 & 52.000 granadas rompedoras de $3,7 \mathrm{~cm}(\mathrm{M})$ & 1.710 .000 & 1.710 .000 & -------------- \\
\hline 7 & 26 transformadores para antiaéreos de 3,7 cm (M) & 299.850 & 188.200 & 111.650 \\
\hline 8 & $\begin{array}{l}60.000 \text { munición diversa de } 3,7 \mathrm{~cm} \text { (anticarro y } \\
\text { antiaérea) (ET) }\end{array}$ & 1.506 .000 & ---------- & 1.506 .000 \\
\hline 9 & Diversos espejos para reflectores (M) & 297.000 & ----------- & 297.000 \\
\hline 10 & 80 torpedos con accesorios $(\mathrm{M})$ & 3.444 .000 & 2.856 .400 & 587.600 \\
\hline $\begin{array}{l}11 \mathrm{y} \\
12\end{array}$ & $\begin{array}{l}250 \text { ametralladoras pesadas de } 15 \mathrm{~mm}+3.250 .000 \\
\text { proyectiles de } 15 \mathrm{~mm}(\mathrm{ET})\end{array}$ & 30.300 .000 & 13.500 .000 & 16.800 .000 \\
\hline 13 & $\begin{array}{l}40 \text { motores de lanchas rápidas con piezas de } \\
\text { repuesto }(\mathrm{M})\end{array}$ & 12.400 .000 & 4.133 .333 & 8.266 .667 \\
\hline 14 & 459 minas con accesorios $(\mathrm{M})$ & 1.193 .869 & 1.193 .869 & --------------- \\
\hline
\end{tabular}

Todo este material estaba ya contratado antes del 31 de julio de 1942

Fuente: AMAE. AR. Sig. R-2066-2

\section{-b) Contratos por firmar (en marcos)}

\begin{tabular}{|l|l|l|l|l|}
\hline Núm. & \multicolumn{1}{|c|}{ Concepto } & Valor total & Pagado & $\begin{array}{l}\text { Ingreso en los prox. } \\
\mathbf{1 2} \text { meses }\end{array}$ \\
\hline 15$)$ & $\begin{array}{l}\text { 6 cañones antiaéreos dobles de } 10,5 \mathrm{~cm} \text { con } \\
\text { munición }(\mathrm{M})\end{array}$ & 9.000 .000 & --------- & 4.500 .000 \\
\hline 16$)$ & 32 telémetros (M) & 890.300 & -------- & 890.300 \\
\hline 17$)$ & 10 torpedos (M) & 400.000 & -------- & 400.000 \\
\hline 18$)$ & 5.000 ametralladoras ligeras Z.B. 26 (ET) & 7.020 .000 & -------- & 7.020 .000 \\
\hline 19$)$ & 1.000 ametralladoras pesadas Z.B. 37 (ET) & 5.720 .000 & --------- & 5.720 .000 \\
\hline 20$)$ & 1.500 .000 cartuchos PLV (ET) & 12.820 .000 & -------- & 12.820 .000 \\
\hline
\end{tabular}




\begin{tabular}{|l|l|l|l|l|}
\hline 21$)$ & 250.000 cartuchos de $15 \mathrm{~mm} \mathrm{P}(\mathrm{ET})$ & 1.365 .000 & -------- & 1.365 .000 \\
\hline 22$)$ & Un modelo de cañón de $15 \mathrm{~cm}(\mathrm{ET})$ & 265.000 & -------- & 265.000 \\
\hline
\end{tabular}

Fuente: AMAE. AR. Sig. R-2066-2

\section{Licencias para fabricación de material de guerra}

-a) Contratos firmados:

\begin{tabular}{|l|l|l|l|l|}
\hline $\mathbf{N}^{\mathbf{1}}$ & \multicolumn{1}{|c|}{ Concepto } & Valor total & Pagado & $\begin{array}{l}\text { Ingreso en los próx. } \\
\mathbf{1 2} \text { meses }\end{array}$ \\
\hline 23 & Cañones antiaéreos automáticos de 3,7 cm (M) & 400.000 & ---------- & 400.000 \\
\hline 24 & Cureña pivot (M) & 200.000 & ---------- & 200.000 \\
\hline 25 & Cureña de pedestal (M) & 170.000 & ---------- & 170.000 \\
\hline 26 & Plataformas triangulares (M) & 40.000 & ---------- & 40.000 \\
\hline 27 & Chasis (M) & 60.000 & ---------- & 60.000 \\
\hline 28 & Munición de 3,7 cm (M) & 200.000 & ---------- & 200.000 \\
\hline 29 & Lanchas rápidas (M) & 400.000 & ----------- & 400.000 \\
\hline 30 & Minas (M) & 500.000 & 150.000 & 350.000 \\
\hline
\end{tabular}

Todas estas licencias estaban ya contratadas antes del 31 de julio de 1942

Fuente: AMAE. AR. Sig. R-2066-2

\section{b) Contratos por firmar:}

\begin{tabular}{|l|l|l|l|l|}
\hline Núm & \multicolumn{1}{|c|}{ Concepto } & Valor total & Pagado & $\begin{array}{l}\text { Ingreso en los } \\
\text { próx. 12 meses }\end{array}$ \\
\hline 31 & $\begin{array}{l}\text { Fabricación de ametralladoras ligeras Z.B. 26 y } \\
\text { Z.B. 30 de 7,92 mm (ET) }\end{array}$ & 800.000 & - -------- & 800.000 \\
\hline 32 & $\begin{array}{l}\text { Fabricación de ametralladoras pesadas Z.B. 37 de } \\
7,92 \text { mm (ET) }\end{array}$ & 1.600 .000 & ---------- & 1.600 .000 \\
\hline 33 & $\begin{array}{l}\text { Fabricación de ametralladoras pesadas Z.B. 60 de } \\
15 \text { mm (ET) }\end{array}$ & 800.000 & - --------- & 800.000 \\
\hline 35 & $\begin{array}{l}\text { Fabricación de municiones de 15 mm (PLV, PL, } \\
\text { P, N, y C) (ET) }\end{array}$ & 500.000 & ----------- & 500.000 \\
\hline 36 & Fabricación de cañones antiaéreos de 88/56 mm & 3.000 .000 & $-----------~$ & 3.000 .000 \\
\hline 37 & $\begin{array}{l}\text { Fabricación de cañones antiaéreos dobles de 10,5 } \\
\text { cm (M) }\end{array}$ & 5.200 .000 & - ----------- & 5.200 .000 \\
\hline 38 & Ayuda técnica para cañón de 15 cm (ET) & 500.000 & ----------- & 500.000 \\
\hline
\end{tabular}




\begin{tabular}{|l|l|l|l|l|}
\hline 39 & $\begin{array}{l}\text { Licencia de fabricación de proyectiles trazadores } \\
\text { S.M.K y S.M.K.L. (ET) }\end{array}$ & 500.000 & ----------- & 500.000 \\
\hline 40 & Direcciones de tiro para cañones de $10,5 \mathrm{~cm}(\mathrm{M})$ & 1.000 .000 & ----------- & 1.000 .000 \\
\hline 41 & Fabricación de torpedos (M) & 1.000 .000 & ---------- & 1.000 .000 \\
\hline
\end{tabular}

Fuente: AMAE. AR. Sig. R-2066-2

-III Suministros según convenio del 21 de julio del 42:

\begin{tabular}{|l|l|l|l|l|}
\hline Núm. & Concepto & Valor total & Pagado & $\begin{array}{l}\text { Ingreso en } \\
\text { los próx. 12 } \\
\text { meses }\end{array}$ \\
\hline 42 & Diferentes materiales & 10.000 .000 & -------- & 10.000 .000 \\
\hline
\end{tabular}

Fuente: AMAE. AR. Sig. R-2066-2

-IV Objetos "Suances”:

\begin{tabular}{|l|l|l|l|l|}
\hline Núm. & Concepto & Valor total & Pagado & $\begin{array}{l}\text { Ingreso en } \\
\text { los próx. 12 } \\
\text { meses }\end{array}$ \\
\hline 43 & Diferentes instalaciones & 40.000 .000 & -------- & 40.000 .000 \\
\hline
\end{tabular}

Fuente: AMAE. AR. Sig. R-2066-2

-V Objetos industriales según relación entregada con la primera proposición del acuerdo el día 22 de agosto de 1942

\begin{tabular}{|l|l|l|l|l|}
\hline Núm. & Concepto & Valor total & Pagado & $\begin{array}{l}\text { Ingreso en } \\
\text { los próx. 12 } \\
\text { meses }\end{array}$ \\
\hline 44 & Diferentes instalaciones & 37.175 .000 & 16.446 .000 & 20.728 .000 \\
\hline
\end{tabular}

Fuente: AMAE. AR. Sig. R-2066-2

\section{-VI Exportaciones normales:}

\begin{tabular}{|l|l|l|l|l|}
\hline Núm. & Concepto & Valor total & Pagado & $\begin{array}{l}\text { Ingreso en } \\
\text { los próx. 12 } \\
\text { meses }\end{array}$ \\
\hline 45 & & 100.000 .000 & $------------~$ & 100.000 .000 \\
\hline
\end{tabular}

Fuente: AMAE. AR. Sig. R-2066-2

\begin{tabular}{l|l|l|l|} 
TOTAL & $\mathbf{3 0 6 . 2 7 0 . 3 4 4}$ & $\mathbf{4 7 . 6 0 2 . 7 5 2}$ & $\mathbf{2 5 3 . 2 8 6 . 5 9 2}$
\end{tabular}

Fuente: AMAE. AR. Sig. R-2066-2

Nota: las letras (M) y (ET) significan que el contrato correspondía a la Marina o el Ejército de Tierra, respectivamente. 


\title{
ANEXO III
}

\section{Listados completos de peticiones españolas negociadas por el general Martínez de Campos en Berlín el 15 de abril de 1943.}

\author{
$-1^{\circ}$ Grupo.
}

a) Para el Ejército del Aire se solicitaban:

250 aviones de caza con repuestos, 800 estaciones de radio de onda corta, 250 grupos electrógenos, 23 equipos de campaña radio receptores de onda larga y corta de 100 y $1.500 \mathrm{Kw}$ sobre camión, tres camiones meteorológicos completos, cuatro equipos móviles para aterrizaje sin visibilidad, 12 equipos de radiolocalización de aviones desde el suelo, la mitad de largo alcance y la mitad de precisión, 6.000.000 de cartuchos de 7,92 mm, 500.000 cartuchos de $20 \mathrm{~mm}$, 400 ametralladoras terrestres en montaje móvil de 37 mm, 20 baterías completas (80 cañones) de cañones antiaéreos de $88 \mathrm{~mm}, 1.000 .000$ proyectiles de $37 \mathrm{~mm}$ y 40.000 proyectiles de $88 \mathrm{~mm}$.

b) Para la Marina, la lista era más amplia, pues parte del material estaba ya en vías de contratación por el Ministerio y la subcomisión de la Marina de Guerra en Berlín:

Se solicitaban 64 ametralladoras antiaéreas de $20 \mathrm{~mm}$ en montaje terrestre móvil, 40 cañones antiaéreos sencillos de $37 \mathrm{~mm}$ con montaje terrestre, diez baterías completas (40 piezas) antiaéreas de $105 \mathrm{~mm}, 160.000$ proyectiles de $20 \mathrm{~mm}, 100.000$ proyectiles de $37 \mathrm{~mm}, 32.000$ proyectiles de $105 \mathrm{~mm}, 12$ lanchas rápidas torpederas (reducidas al final de las conversaciones a seis), 12 cañones dobles antiaéreos de $105 \mathrm{~mm}$ para cañoneros (reducidos también a seis), ocho motores de 3.000 HP para cuatro cañoneros, 34 cañones sencillos antiaéreos de $105 \mathrm{~mm}$ para defensa de bases navales, 27.200 proyectiles de 105 mm para los cañones anteriores, 42 cañones antiaéreos Rheinmetall de $37 \mathrm{~mm}$ en montaje doble para buques en servicio y nuevas construcciones, 51 cañones antiaéreos de $37 \mathrm{~mm}$ en montaje sencillo para buques en servicio y nuevas construcciones, 102.000 proyectiles para los anteriores, 22 equipos de ametralladoras antiaéreas de $20 \mathrm{~mm}$ en montaje naval cuádruple para armamento 
de buques en servicio, 176.000 proyectiles para las ametralladoras cuádruples, 40 ametralladoras antiaéreas de $20 \mathrm{~mm}$ en montaje naval sencillo para armamento de buques en servicio, 80.000 proyectiles para las anteriores, dos direcciones de tiro, cada una para tres equipos antiaéreos de $105 \mathrm{~mm}$ en montaje doble para cañoneros, cuatro direcciones de tiro, cada una para cuatro cañones sencillos de $105 \mathrm{~mm}$, para cuatro cañoneros, nueve direcciones de tiro para los destructores tipo "Le Fier", cinco direcciones de lanzamiento de torpedos para submarinos, 100 torpedos G-7a con sus respetos y accesorios, 20 torpedos eléctricos, un equipo completo de regulación de torpedos eléctricos, 2.000 minas submarinas tipo EMC, un tercio con antena y el resto sin ella, 2.000 cargas de profundidad con $135 \mathrm{~kg}$ de carga, un equipo de cineteodolitos Askania, 20 anteojos de observación y tijera tipo 10x50 en montaje naval, 12 telémetros Goerz antiaéreos de $2 \mathrm{~m}$ de base, 20 telémetros Zeiss antiaéreos de 1,25 $\mathrm{m}$ de base, de escala fija, $3.600 \mathrm{~kg}$. de vidrio óptico de diversas clases, cuatro motores Diesel de $1.000 \mathrm{HP}$ para remolcadores de alta mar, 30 radiotransmisores Lorenz de o.c. de 40 watios, 18 a $100 \mathrm{~m}$ tipo S.18205/II o de tipo análogo Telefunken con grupo motor, corriente continua de 24 voltios y un generador de alterna de 110 a 220 voltios, 880 válvulas rectificadoras, 20 receptores Telefunken tipo E.437S de 12 a 200 m, 10 agujas giroscópicas Anschutz con cuatro repetidores, cinco elementos sensibles para giroscópica Anschütz, 10 radiogoniómetros Telefunken tipo $280 \mathrm{~S}$ para submarinos con instalación de cuadro especial 1000 NIX y receptor de radiogoniómetros T3 P.L.L., cuatro equipos de carga de acumuladores para Bases Navales, máquinas especiales para los talleres de artillería de La Carraca, 1.200 toneladas de material de acero para la construcción de cuatro cascos de submarinos tipo "G", ocho motores Diesel de 1.500 HP para submarinos del tipo "G", ocho motores eléctricos de 375 HP para submarinos del tipo "G", periscopios para 4 submarinos del tipo " $G$ " y cuatro hidroaviones de reconocimiento Heinkel 114 para los cruceros del tipo "Cervera" (Las gestiones dependían de las noticias a recibir del Arma aérea)

c) Para el Ejército de Tierra se solicitaba material en tres categorías diferentes.

El primero era maquinaria y material para fábricas militares, entre el que podemos destacar, electrodos de grafito para hornos eléctricos, barrenadoras 
rápidas sistema Rheinmetall, máquinas de pulir para ánimas de cañón sistema MAN, torno rápido de desbaste para tubos de $10 \mathrm{~m}$. de longitud, portacabezas, cabezas y herramientas para rayar el cañón de 8,8 cm., $100 \mathrm{~kg}$. de Widia en lengüetas y otro material diverso.

Por otro lado, se pedían casi 10 millones de cartuchos para unas ametralladoras antiaéreas de $15 \mathrm{~mm}$ que se acababan de adquirir al III Reich en el marco de una operación normal de suministro de material bélico. Y por último, en este denominado primer grupo, se solicitaba material de transmisiones, que incluia:

20 equipos dobles de alta frecuencia con accesorios, 150 amplificadores terminales para líneas telefónicas, 10 equipos repetidores de baja frecuencia, $1.000 \mathrm{~km}$ de cable múltiple de campaña, 75 teletipógrafos de campaña Siemens Hell, 40 teletipógrafos Siemens mecánicos, 150 grupos electrógenos para carga de baterías, 20 equipos de telegrafía armónica, 10.000 válvulas de radio, 25 estaciones radio de 200 vatios de onda corta, 100 estaciones de radio de 15 vatios de campaña, 50 receptores de radio especiales y 20 receptores de radio registradores.

\section{$2^{\circ}$ Grupo.}

El segundo grupo de los listados de pretensiones españolas contenía material para el Ejército del Aire y para el de Tierra. La aviación había solicitado 150 aviones de bombardeo con repuestos para los mismos, 15 grupos electrógenos Still, 20 alimentadores rectificadores para estaciones Fu-G-3 y 2.000.000 de cartuchos para las ametralladoras de los aviones.

El material solicitado por el Ejército de Tierra en este grupo condensaba muy bien las necesidades de material pesado para las unidades de Artillería y de carros de combate. Se solicitaban 75 cañones de $150 \mathrm{~mm}$ de gran alcance con todos sus elementos, seis direcciones de tiro para otras tantas batería de este calibre y 14.100 proyectiles para las piezas. También se pedían 125 piezas antitanque de calibre entre 50 y $75 \mathrm{~mm}$ con 1.000 disparos por pieza; 250 carros de combate con cañón de 45-50 mm y dos ametralladoras de 7,92 mm; 100 carros con cañón de $75 \mathrm{~mm}$ y dos ametralladoras del mismo calibre que las anteriores y 720 tractores para remolcar cañones de $150 \mathrm{~mm}$ y $88 \mathrm{~mm}$. 


\section{$3^{\circ}$ Grupo.}

Por último, el tercer grupo de peticiones contenía un listado más escueto, entre el que podemos destacar, para el Ejército del Aire, 75 aviones de caza nocturna con sus repuestos, 45 aviones de transporte con sus repuestos y seis equipos de localización de aviones utilizable en vuelo, por onda reflejada o sistema similar. El Ejército de Tierra deseaba 400 motocicletas sencillas sin carro lateral, con gran autonomía y dispositivo para montar un arma automática ligera; 750 motos con carro lateral para dos sirvientes y dispositivo para ametralladora, accesorios y piezas de repuesto para motos y motores; 400 fusiles ametralladores y 750 ametralladoras, ambos de calibre 7,92 mm como dotación de las motocicletas anteriores; 200.000 minas y una cantidad indefinida de minas de contacto.

Además de todo este material, como acabamos de decir, solicitado "de oficio" por las autoridades españolas, los comisionados alemanes ofrecieron material lanzallamas, granadas de fusil contra-carro, artillería de asalto, cañones de Infantería y granadas de humo. 


\section{ANEXO IV}

\section{Resumen general de necesidades del Ejército de Tierra.}

\section{Diciembre 1942}

Material de artillería y armamento vario

\begin{tabular}{|l|l|l|l|l|l|l|l|l|l|l|l|l|}
\hline $\begin{array}{l}\text { Material } \\
\text { artillería }\end{array}$ & $\mathbf{6 5 / 1 7}$ & $\mathbf{7 0 / 1 6}$ & $\mathbf{7 5 / 2 2}$ & $\mathbf{7 5 / 2 7}$ & $\mathbf{7 5 / 2 8}$ & $\mathbf{7 7 / 2 4}$ & $\mathbf{7 7 / 3 2}$ & $\mathbf{1 0 0 / 1 7}$ & $\mathbf{1 0 5 / 1 1}$ & $\mathbf{1 0 5 / 2 2}$ & $\mathbf{1 0 5 / 2 8}$ & $\mathbf{1 0 5 / 3 0}$ \\
\hline Plantillas & 0 & 0 & 0 & 0 & 12 & 0 & 0 & 0 & 352 & 680 & 0 & 0 \\
\hline Existencias & 306 & 213 & 32 & 490 & 291 & 119 & 68 & 195 & 458 & 322 & 99 & 68 \\
\hline Faltas & & & & & & & & & & 358 & & \\
\hline
\end{tabular}

\begin{tabular}{|l|l|l|l|l|l|l|l|l|l|l|l|}
\hline $\begin{array}{l}\text { Material } \\
\text { artillería }\end{array}$ & $\mathbf{1 4 9 / 1 2}$ & $\mathbf{1 4 9 / 3 5}$ & $\mathbf{1 4 9 / 2 4}$ & $\mathbf{1 5 0 / 2 7}$ & $\mathbf{1 5 5 / 1 3}$ & $\mathbf{2 1 0 / \mathbf { B }}$ & $\mathbf{2 6 0}$ & $\mathbf{3 0 5 / 1 7}$ & $\mathbf{1 0 5 / 5 2}$ & $\mathbf{1 0 5 / 2 8}$ & $\mathbf{1 4 9 / 3 0}$ \\
\hline Plantillas & 0 & 120 & 0 & 12 & 196 & 0 & 8 & 4 & 120 & 0 & 0 \\
\hline Existencias & 150 & 13 & 0 & 12 & 202 & 16 & 8 & 4 & 4 & 4 & 4 \\
\hline Faltas & & 107 & & & & & & & 116 & & \\
\hline
\end{tabular}

\begin{tabular}{|l|l|l|l|l|}
\hline $\begin{array}{l}\text { Material } \\
\text { artillería }\end{array}$ & $\mathbf{8 8} / \mathbf{5 6}$ AA & $\mathbf{8 8} / \mathbf{4 5}$ AA & $\mathbf{7 5 / 3 6}$ AA & G Pesado DA \\
\hline Plantillas & 264 & 0 & 0 & 12 \\
\hline Existencias & 52 & 4 & 88 & \\
\hline Faltas & 212 & & & 12 \\
\hline
\end{tabular}

\begin{tabular}{|l|l|l|l|l|l|l|l|l|l|l|}
\hline $\begin{array}{l}\text { Material } \\
\text { vario }\end{array}$ & $\begin{array}{l}\text { AAA } \\
\mathbf{1 5} \mathbf{~ m m}\end{array}$ & $\begin{array}{l}\text { AAA } \\
\mathbf{2 0} \mathbf{~ m m}\end{array}$ & $\begin{array}{l}\text { CCC } \\
\mathbf{3 7} \mathbf{~ m m}\end{array}$ & $\begin{array}{l}\text { CCC } \\
\mathbf{4 5} \mathbf{~ m m}\end{array}$ & $\begin{array}{l}\text { Fusil CC } \\
\mathbf{1 5} \mathbf{~ m m}\end{array}$ & $\begin{array}{l}\text { Cañón } \\
\text { Inf. }\end{array}$ & $\begin{array}{l}\text { Carros } \\
\text { Tipo I }\end{array}$ & $\begin{array}{l}\text { Carros } \\
\text { Tipo II }\end{array}$ & $\begin{array}{l}\text { Carros } \\
\text { Tipo III }\end{array}$ & $\begin{array}{l}\text { Mortero } \\
\mathbf{1 2 0} \mathbf{~ m m}\end{array}$ \\
\hline Plantillas & 0 & 1.437 & 0 & 1.015 & 307 & 356 & 147 & 232 & 89 & 111 \\
\hline Existencias & 250 & 341 & 436 & 248 & 0 & 0 & 144 & 138 & 0 & 48 \\
\hline Faltas & & 1.096 & & 331 & 307 & 356 & 3 & 94 & 89 & 63 \\
\hline
\end{tabular}

Fuente: AGMAV. Caja 24.711. Fondo del antiguo Ministerio del Ejército.

AA: Antiaéreo, DA: División Acorazada; AAA: Ametralladora antiaérea; CC: Contracarro; CCC: Cañón contracarro; G: Grupo; Inf.: Infantería; 


\section{ANEXO V}

\section{Material solicitado, ofrecido y aceptado por el Ejército de Tierra en las conversaciones previas al "Programa Bär"}

(En rojo, el material solicitado; en azul, el material ofrecido y en negro, lo realmente aceptado)

\begin{tabular}{|c|c|c|c|}
\hline MATERIAL & SOLICITADO & OFRECIDO & ACORDADO \\
\hline \multicolumn{4}{|l|}{ Transmisiones } \\
\hline Equipos dobles de alta frecuencia & 20 & 16 ( 8 equipos) & 12 \\
\hline Amplificadores terminales & 150 & 40 & 40 \\
\hline $\begin{array}{l}\text { Equipos repetidores de baja } \\
\text { frecuencia }\end{array}$ & 10 & 10 & 10 \\
\hline Cable múltiple & $1.000 \mathrm{~km}$ & $1.000 \mathrm{~km}$ & $1.000 \mathrm{~km}$ \\
\hline Teletipógrafos de campaña & 75 & 75 & 75 \\
\hline Teletipógrafos mecánicos & 40 & 40 & 40 \\
\hline Grupos electrógenos & 150 & No ofrecen & \\
\hline Equipos de telegrafía armónica & 20 & 20 & 20 \\
\hline Válvulas de radio & 10.000 & 12.770 & 12.770 \\
\hline Estaciones radio $200 \mathrm{w}$. Onda corta & 25 & 2 & 2 \\
\hline Estaciones radio $15 \mathrm{w}$ campaña & 100 & 100 & 100 \\
\hline Receptores radio espaciales & 50 & & \\
\hline Receptores radio registradores & 20 & No ofrecen & \\
\hline \multicolumn{4}{|l|}{ Artillería de campaña } \\
\hline $\begin{array}{l}\text { Cañones de } 15 \mathrm{~cm} \text { de gran alcance } \\
\text { con todos sus elementos }\end{array}$ & 75 & - & No ofrecen \\
\hline Direcciones de tiro para los mismos & 6 & 0 & No ofrecen \\
\hline Munición para los mismos & 188 por pieza & 0 & No ofrecen \\
\hline Cañones de $12,2 \mathrm{~cm}$ rusos & - & 24 & 150 \\
\hline Munición para los mismos & - & 15.000 & 15.000 \\
\hline \multicolumn{4}{|l|}{ Artillería antiaérea } \\
\hline Ametralladoras de 15 o $20 \mathrm{~mm}$ & 2.000 & 0 & No ofrecen \\
\hline Munición para las mismas & 2.500 por pieza & 0 & No ofrecen \\
\hline Ametralladoras de $37 \mathrm{~mm}$ & 300 & 0 & No ofrecen \\
\hline Munición para los mismos & 2.500 por pieza & 0 & No ofrecen \\
\hline Cañones de $88 \mathrm{~mm}$ & 300 & 0 & No ofrecen \\
\hline Munición para los mismos & 500 por pieza & 0 & No ofrecen \\
\hline \multicolumn{4}{|l|}{ Artillería antitanque } \\
\hline Piezas calibre $50-75 \mathrm{~mm}$ & 125 & & \\
\hline
\end{tabular}




\begin{tabular}{|c|c|c|c|}
\hline Munición para los mismos & 1.000 por pieza & & \\
\hline Cañones franceses de $25 \mathrm{~mm}$ Pak 25 & - & 150 & 150 \\
\hline Munición para los mismos & - & & \\
\hline Cañones de 50 mm Pak 38 & - & 150 & No interesan \\
\hline Munición para los mismos & - & & \\
\hline Cañones de 75 mm Pak 40 & - & 150 & 150 \\
\hline Munición para los mismos & - & & \\
\hline $\begin{array}{l}\text { Transformación de cañones de } 7,5 \mathrm{~cm} \\
\text { Mod. } 06 \text { de origen francés }\end{array}$ & - & 200 & 50 \\
\hline \multicolumn{4}{|l|}{ Cañones de infantería } \\
\hline Cañones rusos de $76,2 \mathrm{~cm}$ & - & 120 & No interesan \\
\hline \multicolumn{4}{|l|}{ Carros de combate } \\
\hline Carros con cañón de $45 / 50 \mathrm{~mm}$ & 250 & 0 & No ofrecen \\
\hline Carros con cañón de 75 mm & 100 & 20 & 20 \\
\hline $\begin{array}{l}\text { Cañones de asalto con cañón de } \\
75 \mathrm{~mm}\end{array}$ & - & 10 & 10 \\
\hline \multicolumn{4}{|l|}{ Tractores para artillería } \\
\hline Para cañón de campaña de $15 \mathrm{~cm}$ & 150 & 0 & No ofrecen \\
\hline Para cañón antiaéreo de $8,8 \mathrm{~cm}$ & 450 & 0 & No ofrecen \\
\hline \multicolumn{4}{|l|}{ Motocicletas } \\
\hline Motos sencillas sin carro & 400 & 400 & 400 \\
\hline Fusiles ametralladores & 400 & 0 & Se renunció \\
\hline Motos con carro & 750 & 750 & 750 \\
\hline Ametralladoras & 750 & 375 & Una cada dos motos \\
\hline \multicolumn{4}{|l|}{ Armas individuales contracarro } \\
\hline Fusiles & - & 1.000 & 1.000 \\
\hline Brocales & - & 10.000 & 10.000 \\
\hline Granadas & - & 250.000 & \\
\hline \multicolumn{4}{|l|}{ Granadas de humo contracarro } \\
\hline Granadas & - & 20.000 & 20.000 \\
\hline \multicolumn{4}{|l|}{ Minas } \\
\hline Minas de contacto & Interesan & 6.000 & 6.000 \\
\hline Minas anticarro francesas & & 150.000 & Se renuncia \\
\hline Minas anticarro "T" & 200.000 & 50.000 & 200.000 \\
\hline \multicolumn{4}{|l|}{ Subfusiles y ametralladoras } \\
\hline Ametralladoras MG 34 & - & 3.000 & No interesan \\
\hline Pistolas-ametralladoras & - & 1.000 & No interesan \\
\hline \multicolumn{4}{|l|}{ Morteros } \\
\hline Morteros de $81 \mathrm{~mm}$ pesados & - & 300 & No interesan \\
\hline
\end{tabular}




\begin{tabular}{|l|l|l|l|}
\hline Morteros de $81 \mathrm{~mm}$ cortos & - & 200 & No interesan \\
\hline Munición diversa & & 4.000 & \\
\hline $\begin{array}{l}\text { Granadas de rabiza de } 6,6 \mathrm{~cm} \text { para } \\
\text { cañón antitanque de } 2,5 \mathrm{~cm}\end{array}$ & - & $\begin{array}{l}15 \text { disparos por } \\
\text { cañón }\end{array}$ & \\
\hline Granadas de rabiza para Pak 37 & - & & \\
\hline $\begin{array}{l}\text { Proyectiles para ametralladora de 15 } \\
\text { mm Waffenwerke Brünn }\end{array}$ & 9.450 .000 & 15.000 .000 & No interesan \\
\hline Proyectiles de 7,92 mm & 100.000 .000 & & No pueden darlos \\
\hline Proyectiles de 7 mm & & & \\
\hline
\end{tabular}

Fuente: elaboración propia. AGMAV. Caja 24.711. Fondo del antiguo Ministerio del Ejército.

\section{ANEXO VI}

\section{"Programa Bär". Aviación.}

\begin{tabular}{|c|c|c|c|}
\hline 1 & $\begin{array}{l}15 \text { aviones de caza Bf } 109 \mathrm{~F} .4 \text { con utensilios en } \\
\text { proporción al equipo primario de una } \\
\text { escuadrilla }\end{array}$ & 15 & $\begin{array}{l}\text { 4.000.000 de disparos de } 7,92 \mathrm{~mm} \text { para } \\
\text { ametralladora (armamento de a } \\
\text { bordo) }\end{array}$ \\
\hline 2 & $\begin{array}{l}10 \text { aviones de combate } \mathrm{Ju} 88 \mathrm{~A} .4 \text { con utensilio } \\
\text { en proporción al equipo primario de una } \\
\text { escuadrilla }\end{array}$ & 16 & $\begin{array}{l}\text { Seis radiolocalizadores para su } \\
\text { instalación en los aviones }\end{array}$ \\
\hline 3 & $\begin{array}{l}\text { Grupo pesado de antiaéreos: tres baterías a } \\
\text { cuatro piezas de } 8,8 \mathrm{~cm}^{7} \text { dos baterías a } 12 \\
\text { piezas de } 2 \mathrm{~cm} \text { Oerlikon }{ }^{723} \text {. }\end{array}$ & 17 & $\begin{array}{l}\text { Munición para ametralladoras de } 15 \\
\text { mm Waffen-Werke Brünn }\end{array}$ \\
\hline
\end{tabular}

${ }^{720}$ En carta confidencial del general Krahmer, Agregado aéreo alemán en Madrid, de fecha 8 de abril de 1943 enviada al general Martínez de Campos, esta partida fue aumentada con otros 10 aviones de origen francés Dewoitine, aparatos que después de ser evaluados por los técnicos españoles, fueron desestimados y se anuló su adquisición.

${ }^{721}$ Distribuido de la siguiente manera: 1.000.000 munición SS.o.L.; 1.000.000 SMK trazadora 100/600 s.L.; 500.000 SMK o.L. acero; 500.000 SMK 0.L. latón; 500.000 BMK o.L. latón n.G. y 500.000 BMK latón. En principio sólo se pedían 1.000 .000 de cartuchos. El resto hasta los 4.000.000, cuando se entregaran los aviones solicitados.

${ }^{722}$ En este asunto, se aceptaban los 10 Junkers Ju 88 A.4 pero se expresaba una preferencia del Ministerio del Aire en el sentido de modificar los aparatos a Heinkel He 111 H6 en lugar de los Junkers, con el fin de homogeneizar el material de bombardeo presente en las unidades españolas.

${ }^{723}$ Se dejaba la puerta abierta a la adquisición de dos piezas más para las baterías de $88 \mathrm{~mm}$ (de 6 piezas en lugar de 4) así como la adquisición para las mismas de una dotación primaria de munición. Esta partida sería entregada una por trimestre hasta completar los 10 Grupos del total del Programa. Por el mismo motivo citado en la nota 20 el suministro se amplió a tres Grupos completos al trimestre, siendo aceptada por Martínez de Campos esta modificación. En cualquier caso, como se verá posteriormente, ni las baterías se constituyeron con seis piezas cada una, ni en el Programa "Bär" se llegó a negociar el envío de munición para los cañones Flak de $88 \mathrm{~mm}$.

${ }^{724} \mathrm{Su}$ distribución era la siguiente: 7.500 .000 granadas explosivas; 450.000 granadas perforantes y 1.500.000 granadas de instrucción. Considero un error absoluto integrar esta partida en el programa de "Fuerzas Aéreas", pues las ametralladoras de esta marca y calibre era una adquisición del Ejército de Tierra previa al "Programa Bär" y absolutamente independiente del mismo, ajena, por tanto, al Ejército del Aire. 


\begin{tabular}{|c|c|c|c|}
\hline 4 & $\begin{array}{l}\text { Cuatro equipos pesados de radio motorizados } \\
\text { (de onda corta) }\end{array}$ & 18 & $\begin{array}{l}\text { Cuatro equipos móviles completos con } \\
\text { emisor, receptor, alimentador, } \\
\text { generador y antena, de onda larga y } 1,5 \\
\text { Kw. }\end{array}$ \\
\hline 5 & $\begin{array}{l}\text { Cuatro equipos pesados motorizados (de onda } \\
\text { larga) }\end{array}$ & 19 & $\begin{array}{l}\text { Cuatro equipos móviles completos con } \\
\text { emisor, receptor, alimentador, } \\
\text { generador y antena, de onda corta y } 1 \\
\text { Kw. }\end{array}$ \\
\hline 6 & $\begin{array}{l}15 \text { equipos ligeros de radio FuG } 10 \\
\text { motorizados (de onda corta-onda larga) }\end{array}$ & 20 & $\begin{array}{l}15 \text { equipos móviles completos con } \\
\text { emisor, receptor, alimentador, } \\
\text { generador y antena, de onda corta y } \\
\text { larga y mediana potencia }(250 / 100 \mathrm{w}) \text {. }\end{array}$ \\
\hline 7 & $\begin{array}{l}\text { Ocho equipos motorizados de radiogoniómetros } \\
\mathrm{Z}\end{array}$ & 21 & $\begin{array}{l}\text { Ocho radiogoniómetros Adcock de } \\
\text { onda larga, móviles, para remolque o } \\
\text { camión. }\end{array}$ \\
\hline 8 & $\begin{array}{l}\text { Cuatro equipos fijos para aterrizaje sin } \\
\text { visibilidad }\end{array}$ & 22 & 20 equipos "FREYA" completos \\
\hline 9 & $\begin{array}{l}15 \text { grupos electrógenos "STILL", sobre } \\
\text { remolque especial A2 }\end{array}$ & 23 & 20 equipos "WÜRZBURG" completos \\
\hline 10 & $\begin{array}{l}100 \text { aparatos de radio VR27b ligeros (onda } \\
\text { corta) }\end{array}$ & 24 & $\begin{array}{l}100 \text { emisores potencia } 200 / 100 \mathrm{w}, \\
\text { comprendiendo la onda especial para } \\
\text { los aviones de caza, con alimentador. }\end{array}$ \\
\hline 11 & 100 grupos electrógenos EM4 o "2w220” & 25 & 100 receptores para los anteriores. \\
\hline 12 & Seis aparatos radiolocalizadores FREYER ${ }^{725}$ & 26 & 20 alimentadores para estaciones FuG3 \\
\hline 13 & $\begin{array}{l}\text { Seis aparatos radiolocalizadores } \\
\text { "WÜRZBURG" } 39 \text { T.D. }\end{array}$ & 27 & 15 grupos electrógenos "STILL" \\
\hline 14 & $\begin{array}{l}\text { Seis radiolocalizadores de barcos } \\
\text { "LICHTENSTEIN S. }{ }^{726}\end{array}$ & & \\
\hline
\end{tabular}

Nota: De la partida 18 a la 27 fueron solicitadas por Martínez de Campos en el Anexo $3^{\circ}$ de la carta citada y añadidas a las ya existentes en los ofrecimientos germanos. Fuente: elaboración propia. AGMAV. Caja 24.711. Fondo del antiguo Ministerio del Ejército.

\section{ANEXO VII}

\section{“Programa Bär”. Marina de Guerra}

\begin{tabular}{|c|c|c|c|}
\hline 1 & $\begin{array}{l}\text { Ocho motores Diesel de } 2.500 \text { Ps } \\
\text { fabricados por Burmeister und Wain para } \\
\text { cañoneros }\end{array}$ & 21 & $\begin{array}{l}20 \text { equipos de } 3,7 \mathrm{~cm} \text { Flak, con montaje de } \\
\text { campaña } \mathrm{C} / 30 \text {, incluidos repuestos, accesorios y } \\
2.000 \text { disparos por pieza para Infantería de } \\
\text { Marina. }\end{array}$ \\
\hline 2 & $\begin{array}{l}\text { Cuatro motores Diesel, cada uno de } 800 \\
\text { Ps. De la casa Schulze para remolcadores } \\
\text { de alta mar }\end{array}$ & 22 & Seis lanchas rápidas, tipo grande. \\
\hline 3 & 10 radiogoniómetros & 23 & $\begin{array}{l}20 \text { anteojos de observación y tijera de tipo } \\
10 \times 80\end{array}$ \\
\hline 4 & Ocho motores Diesel para submarino & 24 & $\begin{array}{l}51 \text { equipos de } 3,7 \mathrm{~cm} \mathrm{C} / 30 \text { en afuste de } \\
\text { submarino } C / 39 \text { para barcos }\end{array}$ \\
\hline 5 & $\begin{array}{l}\text { Ocho motores E para submarinos Tipo } \\
\text { VII C }\end{array}$ & 25 & $\begin{array}{l}\text { Cuatro direcciones de tiro, cada una para cuatro } \\
\text { equipos de cañones sencillos de } 10,5 \mathrm{~cm} \text { en } \\
\text { montaje de dos ejes para cañoneros con } \\
\text { turbinas. }\end{array}$ \\
\hline
\end{tabular}

${ }^{725}$ En realidad se denominaban "FREYA" y no "FREYER", como se afirma en el documento español.

${ }^{726}$ Se apostillaba en el citado anexo que los equipos venían destinados al Ejército de Tierra. Esto no era del todo cierto, como veremos más adelante. 


\begin{tabular}{|c|c|c|c|}
\hline 6 & $\begin{array}{l}\text { Ocho periscopios para submarinos Tipo } \\
\text { VII C }\end{array}$ & 26 & $\begin{array}{l}\text { Nueve direcciones de tiro para los destructores } \\
\text { de tipo "Le Fier" }\end{array}$ \\
\hline 7 & Un cineteodolito ASKANIA & 27 & 56 torpedos Whitehead-Wymouth \\
\hline 8 & 30 emisoras de onda corta S $18205 / \mathrm{II}$ & 28 & $\begin{array}{l}1.000 \text { minas EMC sin antenas, la mitad con } 300 \\
\mathrm{~m} \text { de anclaje y la otra mitad con } 350 \mathrm{~m} \text {. }\end{array}$ \\
\hline 9 & $\begin{array}{l}880 \text { lámparas de radio según } \\
\text { especificación }\end{array}$ & 29 & 12 telémetros Goerz de 2 metros de base \\
\hline 10 & 20 reflectores E 437S & 30 & 20 telémetros Zeiss de 1,25 metros de base \\
\hline 11 & $\begin{array}{l}\text { Cuatro estaciones de carga de } \\
\text { acumuladores }\end{array}$ & 31 & $\begin{array}{l}\text { Munición para material de artillería } \\
\text { correspondiente }\end{array}$ \\
\hline 12 & $\begin{array}{l}800-900 \text { toneladas de acero para cascos } \\
\text { de submarinos VII C }\end{array}$ & 32 & $3.000 \mathrm{~kg}$ de cristal óptico \\
\hline 13 & $\begin{array}{l}\text { Seis equipos de cañón } 10,5 \mathrm{C} / 33 \text { en } \\
\text { montaje doble } \mathrm{C} / 37 \text { completos para } \\
\text { cañoneros }\end{array}$ & 33 & $\begin{array}{l}24 \text { equipos de ametralladoras sencillas de } 20 \\
\text { mm en montaje de submarino con accesorios }{ }^{727} \text {. }\end{array}$ \\
\hline 14 & $\begin{array}{l}42 \text { equipos de cañones de } 3,7 \mathrm{~cm} \mathrm{C} / 30 \text { en } \\
\text { montaje doble con estabilizador } \\
\text { giroscópico completo para barcos }\end{array}$ & 34 & $\begin{array}{l}48.000 \text { disparos para los anteriores equipos } \\
(2.000 \text { por pieza) }\end{array}$ \\
\hline 15 & $\begin{array}{l}22 \text { equipos de ametralladoras de } 20 \mathrm{~mm} \\
\text { Mod. } 38 \text { con montaje cuádruple ( } 3 \text { ejes) } \\
\text { para barcos }\end{array}$ & 35 & $\begin{array}{l}10 \text { direcciones de tipo, cada una para cuatro } \\
\text { equipos de cañones de } 10,5 \mathrm{~cm} \text { antiaéreos en } \\
\text { montaje fijo de dos ejes, instalados en tierra } \\
\text { para defensa de bases navales. }\end{array}$ \\
\hline 16 & $\begin{array}{l}40 \text { equipos de ametralladoras de } 20 \mathrm{~mm} \\
\text { Mod. } 38 \text { con montaje C/30 ( } 24 \text { equipos } \\
\text { para submarinos, aún en estudio) }\end{array}$ & 36 & $\begin{array}{l}\text { Dos direcciones de tiro, cada una para tres } \\
\text { equipos de artillería de } 10,5 \mathrm{~cm} \text { en montaje } \\
\text { doble de } 3 \text { ejes, para cañoneros con motor } \\
\text { diesel. }\end{array}$ \\
\hline 17 & $\begin{array}{l}27 \text { equipos de cañones de } 10,5 \mathrm{~cm} \mathrm{C} / 32 \\
\text { con montaje M.P.L. para torpederos } \\
\text { C/32; siete equipos para minadores y } 16 \\
\text { para cañoneros. }\end{array}$ & 37 & $\begin{array}{l}\text { Cinco direcciones de lanzamiento de torpedos } \\
\text { para submarinos }\end{array}$ \\
\hline 18 & $\begin{array}{l}40 \text { equipos } 10,5 \text { lak incluidas } 10 \\
\text { direcciones de tiro, } 800 \text { disparos por } \\
\text { pieza, repuestos y accesorios. }\end{array}$ & 38 & $\begin{array}{l}10 \text { agujas giroscópicas "ANSCHUTZ”, con } \\
\text { siete repetidores cada una }\end{array}$ \\
\hline 19 & $\begin{array}{l}64 \text { equipos de } 2 \mathrm{~cm} \text { Flak con montaje de } \\
\text { campaña mod } 38 \text {, incluidos repuestos, } \\
\text { accesorios y } 2.000 \text { disparos por pieza. }\end{array}$ & 39 & $\begin{array}{l}\text { Cinco elementos sensibles para giróscopos } \\
\text { "ANSCHUTZ" }\end{array}$ \\
\hline 20 & $\begin{array}{l}20 \text { equipos de } 3,7 \mathrm{~cm} \text { Flak, en montaje } \\
\text { fijo simple, incluidos repuestos, } \\
\text { accesorios, } 2.000 \text { disparos por pieza para } \\
\text { puntos de apoyo en la costa. }\end{array}$ & 40 & $\begin{array}{l}\text { Cuatro hidroaviones de reconocimiento Heinkel } \\
\text { He } 114 \text { para los cruceros tipo "Cervera" }\end{array}$ \\
\hline
\end{tabular}

Nota: De la partida 33 a la 40 fueron solicitadas por Martínez de Campos en el Anexo $4^{\circ}$ de la carta citada. Este material había sido presentado a la Comisión de Armamento alemana en la reunión celebrada en enero de 1943, cuando la Comisión española la presidía el capitán de navío Antón Rozas. Fuente: elaboración propia. AGMAV. Caja 24.711. Fondo del antiguo Ministerio del Ejército.

Además, el propósito de la Marina de Guerra española era el de concertar un contrato de colaboración con la firma germana Rheinmetall-Borsig A.G. para todo el asunto de la construcción en España de diverso material de artillería naval, y profundizar en la petición de material de radiolocalización y radiotelemetría solicitado por el Agregado Naval en las reuniones celebradas en Berlín.

\footnotetext{
${ }^{727}$ Para el armamento de buques en servicio y nuevas construcciones. Esta partida había sido anulada en las conversaciones de la Comisión, junto a la siguiente, referida a munición para las ametralladoras, pero la Marina de Guerra no quería renunciar a su adquisición.
} 


\section{ANEXO VIII}

\section{“Programa Bär”. Ejército de Tierra}

\begin{tabular}{|c|c|c|c|}
\hline 1 & 10.000 brocales de fusil $^{728}$. & 17 & $\begin{array}{l}750 \text { motocicletas pesadas con carro lateral } \\
\text { nuevas. }\end{array}$ \\
\hline 2 & 1.000 fusiles lanzagranadas mod. $318^{729}$. & 18 & $\begin{array}{l}750 \text { ametralladoras de } 7,92 \mathrm{~mm} \text { a montar en } \\
\text { España }\end{array}$ \\
\hline 3 & $\begin{array}{l}150 \text { cañones contracarro de } 2,5 \mathrm{~cm} \\
\text { (franceses) con proyectiles con carga } \\
\text { hueca. }\end{array}$ & 19 & $\begin{array}{l}10 \text { equipos repetidores de baja frecuencia tipo } \\
38 \text {. }\end{array}$ \\
\hline 4 & $\begin{array}{l}150 \text { cañones contracarro de } 7,5 \mathrm{~cm} \text { Mod } \\
40 .\end{array}$ & 20 & 40 teletipógrafos mecánicos. \\
\hline 5 & 6.000 minas de contacto contracarro. & 21 & 12.770 válvulas (Transmisiones) ${ }^{731}$. \\
\hline 6 & 20.000 granadas de humo anticarro. & 22 & $\begin{array}{l}50 \text { receptores especiales, de los que } 10 \text { serían } \\
\text { para todas las ondas, tipo aparato escucha para } \\
\text { grandes distancias, empalme para corriente } \\
\text { alterna, } 120 \text { voltios; otros } 10 \text { para onda corta y } \\
\text { extra-corta, alimentación por batería y los } 30 \\
\text { restantes para ondas cortas y medias, } \\
\text { alimentación por batería. }\end{array}$ \\
\hline 7 & 100.000 minas $\mathrm{T}$ anticarro. & 23 & 1.000 kilómetros de cable múltiple \\
\hline 8 & 150 cañones rusos de $12,2 \mathrm{~cm}$ Mod. 390. & 24 & $\begin{array}{l}51 \text { equipos de } 3,7 \mathrm{~cm} \mathrm{C} / 30 \text { en afuste de } \\
\text { submarino } \mathrm{C} / 39 \text { para barcos }\end{array}$ \\
\hline 9 & $\begin{array}{l}\text { Modificación de } 50 \text { piezas de } 7,5 \mathrm{~cm} \\
\text { españolas L/36 (f) con afuste anticarro } \\
\text { Mod } 38^{732} \text {. }\end{array}$ & 25 & $\begin{array}{l}20 \text { equipos Duplex para telegrafía de alta } \\
\text { frecuencia. }\end{array}$ \\
\hline 10 & 310.000 grandas de fusil contracarro. & 26 & 620 toneladas de electrodos de grafito. \\
\hline 11 & $\begin{array}{l}4.000 \text { granadas de rabiza de } 6,6 \mathrm{~cm} \text { para } \\
\text { el cañón de } 2,5 \mathrm{~cm}(\mathrm{f}) \text { además de } \\
\text { munición normal de } 2,5 \mathrm{~cm} .\end{array}$ & 27 & $\begin{array}{l}\text { Dos barrenadoras sistema Rheinmetall para } \\
\text { perforaciones de } 6 \mathrm{~m} \text { de longitud y dispositivos } \\
\text { especiales para barrenado cónico. }\end{array}$ \\
\hline 12 & $\begin{array}{l}4.530 \text { granadas de rabiza para cañón } \\
\text { anticarro de } 3,7 \mathrm{~cm}^{733}\end{array}$ & 28 & $\begin{array}{l}\text { Máquinas de pulir para ánima de cañón (sistema } \\
\text { MAN) de } 6 \text { m de longitud y sus accesorios. }\end{array}$ \\
\hline
\end{tabular}

${ }^{728}$ Se aceptaron a condición de que sirvieran para granadas contracarros.

${ }^{729}$ También se puso la condición de que fueran útiles en la lucha contra los carros de combate.

${ }^{730}$ Se impuso la condición de que se pudiera utilizar munición española y de que se pudieran montar sobre los carros laterales. Como se verá más adelante, esta partida se redujo a la mitad pues por indicación alemana, de cada dos motocicletas con carro lateral, sólo una portaba la ametralladora, la otra llevaba más munición para apoyar a la primera.

${ }^{731}$ Este tipo de material de transmisiones fue solicitado en detalle por parte española (modelos y tipos de válvulas) en una carta dirigida por Martínez de Campos al general Becker el 25 de febrero de 1943.

${ }^{732}$ Se trata de un asunto muy curioso y absolutamente desconocido. Baste decir aquí que los alemanes se ofrecieron a modificar 200 cañones franceses de $75 \mathrm{~mm}$ Schneider en servicio en España, y convertirlos en cañones contracarro mediante la adaptación del afuste de la pieza germana de $5 \mathrm{~cm}$ Pak 38 . Sólo se enviarían a Alemania dos cañones de este modelo a los que se realizó la citada modifícación.

733 Se trataba de munición especial de mucho más poder destructor que los proyectiles normales, apta para ser empleada por los cañones contracarro germanos de 3,7 cm Pak 35/36, que habían sido entregados al ejército español durante la Guerra Civil española. Estos cañones se volvieron totalmente obsoletos en su cometido principal de luchar contra la coraza de los carros de combate nada más comenzar la Segunda Guerra Mundial y estas granadas de rabiza eran la única posibilidad de que estas piezas artilleras tuvieran 


\begin{tabular}{|l|l|l|l|}
\hline 13 & $\begin{array}{l}\text { 5.000 granadas de carga hueca de 7,5 cm } \\
\text { para anticarro 97/36 }\end{array}$ & 29 & $\begin{array}{l}\text { Cuatro portacabezas y demás herramientas para } \\
\text { rayado del tubo de cañón de 8,8 cm antiaéreo. }\end{array}$ \\
\hline 14 & $\begin{array}{l}\text { 30 carros de combate. Un grupo mixto } \\
\text { compuesto por dos compañías de carros } \\
\text { modelo IV y una compañía de cañones } \\
\text { de asalto StuG III. }\end{array}$ & 30 & $\begin{array}{l}\text { Un torno rápido de desbaste para tubos de } \\
\text { longitudes de } 10 \mathrm{~m} .\end{array}$ \\
\hline 15 & $\begin{array}{l}\text { 400 motocicletas sin carro lateral, } \\
\text { usadas, de tipo medio. }\end{array}$ & 31 & 100 kilogramos de "Widia" en lenguetas. \\
\hline 16 & $\begin{array}{l}\text { 400 fusiles ametralladores de } 7,92 \mathrm{~mm} \\
\text { para estas motos }\end{array}$ & 32 & Maquinaria para la industria de armamento. \\
\hline
\end{tabular}

Fuente: elaboración propia. AGMAV. Caja 24.711. Fondo del antiguo Ministerio del Ejército.

\section{ANEXO IX}

\section{"Programa Bär". Maquinaria}

\begin{tabular}{|c|c|c|c|}
\hline 1 & Una prensa de forjar elementos de $5.000 \mathrm{Tm}$. & 42 & $\begin{array}{l}\text { Cuatro fresadoras verticales con superficie de } \\
\text { mesa de } 1.400 \mathrm{~mm} \times 325 \mathrm{~mm} \text { dos de ellas, y } \\
1.600 \times 40 \mathrm{~mm} \text { las otras dos }\end{array}$ \\
\hline 2 & Una prensa de forjar elementos de $1.500 \mathrm{Tm}$. & 43 & Cuatro máquinas de puntear número 14 y 15 \\
\hline 3 & $\begin{array}{l}\text { Una prensa de forjar proyectiless de } 1.200 \\
\text { Tm. }\end{array}$ & 44 & $\begin{array}{l}\text { Ocho cepillos limadores con curso de } 600 \text { a } \\
900 \mathrm{~mm}\end{array}$ \\
\hline 4 & $\begin{array}{l}\text { Una prensa para laminar proyectiles de } 120 \text { a } \\
210 \mathrm{~mm} \text {. }\end{array}$ & 45 & $\begin{array}{l}16 \text { fresadoras universales con dimensiones } \\
\text { variables }\end{array}$ \\
\hline 5 & $\begin{array}{l}\text { Una instalación de tres estampas de caída con } \\
\text { mazas de } 4,2 \text { y } 1 \text { toneladas. }\end{array}$ & 46 & $\begin{array}{l}\text { Ocho tornos rápidos de } 1,5 \text { metros entre } \\
\text { puntos (universales) }\end{array}$ \\
\hline 6 & $\begin{array}{l}\text { Una instalación de tres estampas de caída con } \\
\text { mazas de } 3,2 \text { y } 1 \text { toneladas. }\end{array}$ & 47 & $\begin{array}{l}\text { Cuatro tornos rápidos de longitud de } 700 \\
\text { entre puntos }\end{array}$ \\
\hline 7 & $\begin{array}{l}\text { Una instalación para tratamientos térmicos de } \\
\text { proyectiles de } 150 \mathrm{~mm} \text {. }\end{array}$ & 48 & $\begin{array}{l}\text { Ocho taladros diversos para Parques de } \\
\text { Artillería }\end{array}$ \\
\hline 8 & $\begin{array}{l}\text { Una instalación de forja mecánica para } 2.000 \\
\text { proyectiles de calibre } 105 \mathrm{~mm} \text { diarios. }\end{array}$ & 49 & Dos fresadoras universales \\
\hline 9 & $\begin{array}{l}\text { Una instalación de un horno eléctrico de } \\
\text { inducción de } 2 \text { a } 3 \text { toneladas. }\end{array}$ & 50 & $\begin{array}{l}\text { Cuatro tornos rápidos con longitud de } 750 \\
\text { mm. }\end{array}$ \\
\hline 10 & $\begin{array}{l}\text { Un horno eléctrico de templar, vertical, de } 10 \\
\text { metros. }\end{array}$ & 51 & Una rectificadora de roscas \\
\hline 11 & $\begin{array}{l}\text { Un horno eléctrico de templar, con cámara } \\
\text { horizontal de } 1.000 \times 500 \times 500 \mathrm{~mm} \text {. }\end{array}$ & 52 & Una máquina para grabar retículos "KESEL" \\
\hline 12 & $\begin{array}{l}\text { Un horno de sales para temple de aceros } \\
\text { rápidos de } 350 \mathrm{~mm} \text { de altura mínima por } 170 \\
\text { mm de diámetro. }\end{array}$ & 53 & $\begin{array}{l}\text { Una máquina de tallar piñones cónicos } \\
\text { "RAPID" }\end{array}$ \\
\hline 13 & Cuatro tornos de desbaste de 10 metros & 54 & Una máquina de tallar roscas cortas "GROB” \\
\hline 14 & Dos tornos universales de 10 metros & 55 & Una máquina de rectificar perfiles "LOEWE" \\
\hline
\end{tabular}

algo de eficacia en la guerra moderna. Martínez de Campos solicitó 15 granadas por cada uno de los cañones que todavía sobrevivían después de la guerra de España, que eran exactamente 302.

${ }^{734}$ Era munición para los 50 cañones españoles (modelo francés) Schneider de 7,5 mm que, en teoría, se iban a modificar en Alemania para convertirlos en anticarro, de ahí la denominación 97/38 (97 por el modelo francés y 38 por el modelo de afuste alemán que iban a recibir).

${ }^{735}$ Se montarían sobre las mismas en España. Esta partida se aceptó, condicionada a que dichos fusiles ametralladores pudieran utilizar la munición española y se resolviera por parte alemana, el montaje sobre las motocicletas. Se verá más adelante que dicho problema no fue solucionado y se desechó su adquisición. 


\begin{tabular}{|c|c|c|c|}
\hline 15 & $\begin{array}{l}\text { Dos barrenadoras de alto rendimiento de } 10 \\
\text { metros }\end{array}$ & 56 & $\begin{array}{l}\text { Una máquina para ensayos mecánicos "UPD } \\
35 \text { MOHR" }\end{array}$ \\
\hline 16 & $\begin{array}{l}\text { Cuatro tornos paralelos de } 5 \text { metros entre } \\
\text { puntos y } 350 \mathrm{~mm} \text { de altura }\end{array}$ & 57 & $\begin{array}{l}\text { Un horno de cementar en baño de sales } \\
\text { "UDO" }\end{array}$ \\
\hline 17 & $\begin{array}{l}\text { Tres máquinas de pulimentar ánimas de } \\
\text { cañón de } 6 \text { metros }\end{array}$ & 58 & $\begin{array}{l}\text { Una instalación completa de maquinaria } \\
\text { apropiada para un taller de herramientas de } \\
\text { cartuchería para una producción diaria de } \\
800.000 \text { cartuchos de } 7 \text { ó } 7,92 \mathrm{~mm} \text {. }\end{array}$ \\
\hline 18 & $\begin{array}{l}\text { Cuatro tornos de desbaste para calibres entre } \\
37 \text { y } 45 \mathrm{~mm} \text {. }\end{array}$ & 59 & $\begin{array}{l}\text { Una instalación para fabricar } 200 \mathrm{~kg} \text { de } \\
\text { Pentaeritrita (explosivo) en } 8 \text { horas, partiendo } \\
\text { de alcohol etílico y formol }\end{array}$ \\
\hline 19 & $\begin{array}{l}\text { Cuatro barrenadoras para calibres entre } 37 \text { y } \\
45 \mathrm{~mm} \text {. }\end{array}$ & 60 & $\begin{array}{l}\text { Una instalación de nitración para la } \\
\text { fabricación continua de } 150 \mathrm{~kg} \text { de T4 o } 300 \\
\text { kg de Pentrita en } 8 \text { horas }\end{array}$ \\
\hline 20 & $\begin{array}{l}\text { Dos máquinas de rayar para calibres entre } 37 \\
\text { y } 45 \mathrm{~mm} \text {. }\end{array}$ & 61 & $\begin{array}{l}\text { Una instalación para producir } 1.200 \mathrm{~kg} \text { de } \\
\text { Centralita I, partiendo de Etilanilina y } \\
\text { Fósgeno, en jornada ordinaria }\end{array}$ \\
\hline 21 & $\begin{array}{l}\text { Dos máquinas de pulimentar para calibres } \\
\text { entre } 37 \text { y } 45 \mathrm{~mm} \text {. }\end{array}$ & 62 & $\begin{array}{l}\text { Una instalación completa para producir } 25 \\
\text { Tm de Oleum en jornada ordinaria. }\end{array}$ \\
\hline 22 & $\begin{array}{l}\text { Tres tornos rápidos para conclusión de tubos } \\
\text { de calibre entre } 37 \text { y } 45 \mathrm{~mm} \text {. }\end{array}$ & 63 & $\begin{array}{l}\text { Una instalación para producir } 20 \mathrm{Tm} \text { de } \\
\text { Nítrico, en jornada ordinaria, partiendo de } \\
\text { amoniaco. }\end{array}$ \\
\hline 23 & Una máquina de barrenar hasta $30 \mathrm{~mm}$. & 64 & $\begin{array}{l}\text { Una instalación completa de cdesnitrificación } \\
\text { y concentración de Ácido Nítrico para } 6 \mathrm{Tm} \\
\text { diarias de mezcla usada, en jornada ordinaria. }\end{array}$ \\
\hline 24 & $\begin{array}{l}\text { Una máquina de rayar con dos herramientas } \\
\text { de hasta } 25 \mathrm{~mm} \text {. }\end{array}$ & 65 & $\begin{array}{l}\text { Dos aparatos para concentración de Ácido } \\
\text { Sulfúrico procedente de } 6 \mathrm{Tm} \text { diarias de } \\
\text { mezcla usada. }\end{array}$ \\
\hline 25 & $\begin{array}{l}\text { Tres tornos rápidos de } 3.500 \text { de longitud } \\
\text { entre puntos. }\end{array}$ & 66 & $\begin{array}{l}\text { Dos bombas de acero especial para servicio } \\
\text { de los aparatos anteriores. }\end{array}$ \\
\hline 26 & $\begin{array}{l}\text { Tres fresadoras universales para armas de } 20 \\
\mathrm{~mm} \text {. }\end{array}$ & 67 & $\begin{array}{l}\text { Diez autoclaves para taller de preparación de } \\
\text { algodón }\end{array}$ \\
\hline 27 & $\begin{array}{l}\text { Una máquina de proyección verificadora de } \\
\text { plantillas para ametralladoras de } 20 \mathrm{~mm} \text {. }\end{array}$ & 68 & Cuatro trituradoras de trapos. \\
\hline 28 & $\begin{array}{llll}\text { Una rectificadora de } & \text { perfiles } & \text { para } \\
\text { ametralladoras de } 20 \mathrm{~mm} . & & \end{array}$ & 69 & 24 turbinas de nitración de algodón. \\
\hline 29 & $\begin{array}{l}12 \text { tornos para proyectiles de } 30,5 \text { a } 38,1 \mathrm{~cm} \\
\text { (grandes calibres) }\end{array}$ & 70 & $\begin{array}{l}\text { Ocho autoclaves de acero inatacables de } \\
2.750 \text { litros para nitroalgodón }\end{array}$ \\
\hline 30 & $\begin{array}{l}\text { Cuatro tornos paralelos de } 1,5 \mathrm{~m} \text { de longitud } \\
\text { y altura de puntos } 150 \mathrm{~mm} .\end{array}$ & 71 & 20 autoclaves de hierro para nitroalgodón. \\
\hline 31 & $\begin{array}{l}\text { Una instalación de tornos automáticos para } \\
8,8 \mathrm{~cm} \text { con rendimiento de } 1.000 \text { proyectiles } \\
\text { diarios }\end{array}$ & 72 & Diez turbinas para deshidratación. \\
\hline 32 & $\begin{array}{l}\text { Tres tornos revolver con dispositivo para } \\
\text { roscar y plato de } 625 \mathrm{~mm} \text { a } 550 \mathrm{~mm} \text {, con } \\
\text { longitudes de } 700 \mathrm{a} 900 \mathrm{~mm} \text {. }\end{array}$ & 73 & 16 laminadores previos para pólvora. \\
\hline 33 & $\begin{array}{l}\text { Dos máquinas para roscar proyectiles con } \\
\text { husillo fresa. }\end{array}$ & 74 & Dos guillotinas. \\
\hline 34 & $\begin{array}{l}\text { Dos instalaciones completas para una } \\
\text { producción diaria de } 1.000 \text { proyectiles cada } \\
\text { una, para calibres de } 37 \text { a } 50 \mathrm{~mm}\end{array}$ & 75 & $\begin{array}{l}20 \text { prensas para moldeo de pólvoras N.S.D., } \\
\text { con capacidad de } 8 \mathrm{Tm} \text { en jornada ordinaria }\end{array}$ \\
\hline 35 & $\begin{array}{l}\text { Dos instalaciones completas de } 6.000 \\
\text { cartuchos diarios cada una, para calibre de } 20 \\
\text { mm. (con vainas de acero) }\end{array}$ & 76 & Diez bombas para las prensas anteriores \\
\hline 36 & Una instalación de cargas para calibre $20 \mathrm{~mm}$ & 77 & 10 acumuladores hidráulicos \\
\hline 37 & $\begin{array}{l}\text { Dos instalaciones de reutilización de vainas } \\
\text { de } 20 \mathrm{~mm} \text {. }\end{array}$ & 78 & $\begin{array}{l}\text { Material de precisión para laboratorio y } \\
\text { pruebas de pólvoras. }\end{array}$ \\
\hline 38 & $\begin{array}{l}\text { Tres mandrinadoras con superficie de mesa } \\
1.100 \times 900 \mathrm{~mm}\end{array}$ & 79 & Maquinaria para cajas de fusil. \\
\hline
\end{tabular}




\begin{tabular}{|l|l|c|l|}
\hline 39 & $\begin{array}{l}\text { Un torno vertical para tornear en diámetro de } \\
1.050 \mathrm{~mm}\end{array}$ & 80 & $\begin{array}{l}\text { Maquinaria para laboratorios (a especificar } \\
\text { con posterioridad) }\end{array}$ \\
\hline 40 & $\begin{array}{l}\text { Dos máquinas de rectificar universales, con } \\
\text { dispositivo para interiores }\end{array}$ & 81 & Maquinaria para la Escuela Politécnica. \\
\hline 41 & Dos taladros radiales de $900 \mathrm{~mm}$ de curso & & \multicolumn{2}{|l|}{} \\
\hline
\end{tabular}

Fuente: elaboración propia. AGMAV. Caja 24.711. Fondo del antiguo Ministerio del Ejército.

\section{ANEXO X}

\section{“Programa Bär". Marina. Material solicitado por la Comisión "Martínez de Campos".}

\begin{tabular}{|c|c|c|c|}
\hline 1 & $\begin{array}{l}64 \text { ametralladoras antiaéreas en montaje } \\
\text { terrestre móvil, de } 20 \mathrm{~mm}\end{array}$ & 24 & 20 torpedos eléctricos \\
\hline 2 & $\begin{array}{l}40 \text { cañones antiaéreos sencillos con montaje } \\
\text { terrestre, de } 37 \mathrm{~mm}\end{array}$ & 25 & $\begin{array}{l}1 \text { equipo completo de regulación de torpedos } \\
\text { eléctricos }\end{array}$ \\
\hline 3 & $\begin{array}{l}10 \text { baterías completas ( } 40 \text { piezas) antiaéreas } \\
\text { de } 105 \mathrm{~mm}\end{array}$ & 26 & $\begin{array}{l}2.000 \text { minas submarinas tipo EMC, un tercio } \\
\text { con antena y el resto sin ella }\end{array}$ \\
\hline 4 & 160.000 proyectiles de $20 \mathrm{~mm}$ & 27 & $\begin{array}{l}2.000 \text { cargas de profundidad con } 135 \mathrm{~kg} \text {. de } \\
\text { carga }\end{array}$ \\
\hline 5 & 100.000 proyectiles de $37 \mathrm{~mm}$ & 28 & 1 equipo de cineteodolitos Askania \\
\hline 6 & 32.000 proyectiles de $105 \mathrm{~mm}$ & 29 & $\begin{array}{l}20 \text { anteojos de observación y tijera tipo } 10 \times 50 \\
\text { en montaje naval }\end{array}$ \\
\hline 7 & 12 lanchas rápidas torpederas (reducidas a 6) & 30 & $\begin{array}{l}12 \text { telémetros Goerz antiaéreos de } 2 \mathrm{~m} \text {. de } \\
\text { base }\end{array}$ \\
\hline 8 & $\begin{array}{l}12 \text { cañones dobles antiaéreos de } 105 \mathrm{~mm} \text {. } \\
\text { para cañoneros (reducidos a } 6 \text { ) }\end{array}$ & 31 & $\begin{array}{l}20 \text { telémetros Zeiss antiaéreos de } 1,25 \mathrm{~m} \text {. de } \\
\text { base, de escala fija }\end{array}$ \\
\hline 9 & 8 motores de 3.000 HP para cuatro cañoneros & 32 & $3.600 \mathrm{~kg}$. de vidrio óptico de diversas clases \\
\hline 10 & $\begin{array}{l}34 \text { cañones sencillos antiaéreos de } 105 \mathrm{~mm} \\
\text { para defensa de bases navales }\end{array}$ & 33 & $\begin{array}{l}4 \text { motores Diesel de } 1.000 \text { HP. Para } \\
\text { remolcadores de alta mar }\end{array}$ \\
\hline 11 & $\begin{array}{l}27.200 \text { proyectiles de } 105 \mathrm{~mm} \text { para los } \\
\text { cañones anteriores }\end{array}$ & 34 & $\begin{array}{l}30 \text { radiotransmisores Lorenz de o.c. de } 40 \\
\text { watios, } 18 \text { a } 100 \text { m. tipo S. } 18205 / \mathrm{II} \text { o de tipo } \\
\text { análogo Telefunken con grupo motor, } \\
\text { corriente continua de } 24 \text { voltios y un } \\
\text { generador de alterna de } 110 \text { a } 220 \text { voltios }\end{array}$ \\
\hline 12 & $\begin{array}{l}42 \text { cañones antiaéreos Rheinmetall de } 37 \mathrm{~mm} \\
\text { en montaje doble para buques en servicio y } \\
\text { nuevas construcciones }\end{array}$ & 35 & 880 válvulas rectificadoras \\
\hline 13 & $\begin{array}{l}51 \text { cañones antiaéreos de } 37 \mathrm{~mm} \text { en montaje } \\
\text { sencillo para buques en servicio y nuevas } \\
\text { construcciones }\end{array}$ & 36 & $\begin{array}{l}20 \text { receptores Telefunken tipo E.437S de } 12 \text { a } \\
200 \mathrm{~m}\end{array}$ \\
\hline 14 & 102.000 proyectiles para los anteriores & 37 & $\begin{array}{l}10 \text { agujas giroscópicas Anschütz con } 4 \\
\text { repetidores }\end{array}$ \\
\hline 15 & $\begin{array}{l}22 \text { equipos de ametralladoras antiaéreas de } 20 \\
\text { mm en montaje naval cuádruple para } \\
\text { armamento de buques en servicio }\end{array}$ & 38 & $\begin{array}{l}5 \text { elementos sensibles para giroscópica } \\
\text { Anschütz }\end{array}$ \\
\hline 16 & $\begin{array}{l}176.000 \text { proyectiles para las ametralladoras } \\
\text { cuádruples }\end{array}$ & 39 & $\begin{array}{l}10 \text { radiogoniómetros Telefunken tipo } 280 \mathrm{~S} \\
\text { para submarinos con instalación de cuadro } \\
\text { especial } 1000 \text { NIX y receptor de } \\
\text { radiogoniómetros T3 P.L.L. }\end{array}$ \\
\hline 17 & $\begin{array}{l}40 \text { ametralladoras antiaéreas de } 20 \mathrm{~mm} \text { en } \\
\text { montaje naval sencillo para armamento de } \\
\text { buques en servicio }\end{array}$ & 40 & $\begin{array}{l}4 \text { equipos de carga de acumuladores para } \\
\text { Bases Navales }\end{array}$ \\
\hline 18 & 80.000 proyectiles para las anteriores & 41 & Máquinas especiales para los talleres de \\
\hline
\end{tabular}




\begin{tabular}{|c|l|c|l|}
\hline 19 & $\begin{array}{l}\text { 2 direcciones de tiro, cada una para 3 equipos } \\
\text { antiaéreos de 105 mm en montaje doble para } \\
\text { cañoneros }\end{array}$ & 42 & $\begin{array}{l}\text { artillería de La Carraca } \\
\text { construcción de 4 cascos de submarinos tipo } \\
\text { "G" }\end{array}$ \\
\hline 20 & $\begin{array}{l}\text { 4 direcciones de tiro, cada una para cuatro } \\
\text { cañones sencillos de 105 mm, para cuatro } \\
\text { cañoneros }\end{array}$ & 43 & $\begin{array}{l}8 \text { motores Diesel de 1.500 HP para } \\
\text { submarinos del tipo "G" }\end{array}$ \\
\hline 21 & $\begin{array}{l}\text { 9 direcciones de tiro para los destructores tipo } \\
\text { "Le Fier" }\end{array}$ & 44 & $\begin{array}{l}8 \text { motores eléctricos de 375 HP para } \\
\text { submarinos del tipo "G" }\end{array}$ \\
\hline 22 & $\begin{array}{l}5 \text { direcciones de lanzamiento de torpedos } \\
\text { para submarinos }\end{array}$ & 45 & Periscopios para 4 submarinos del tipo "G" \\
\hline 23 & $\begin{array}{l}100 \text { torpedos G-7a con sus respetos y } \\
\text { accesorios }\end{array}$ & 46 & $\begin{array}{l}\text { 4 hidroaviones de reconocimiento Heinkel } \\
114 \text { para los cruceros del tipo "Cervera" (Las } \\
\text { gestiones dependían de las noticias a recibir } \\
\text { del Arma aérea) }\end{array}$ \\
\hline
\end{tabular}

Fuente: elaboración propia. AGMAV. Caja 24.711. Fondo del antiguo Ministerio del Ejército.

\section{ANEXO X bis}

\section{"Programa Bär". Marina. Material aprobado para su entrega a España}

\begin{tabular}{|c|c|c|c|c|}
\hline Partida & Material & $\begin{array}{l}\text { Precio unitario } \\
\text { alemán (RM) }\end{array}$ & $\begin{array}{l}\text { Precio unitario } \\
\text { pactado (RM) }\end{array}$ & $\begin{array}{l}\text { Precio total } \\
\text { pactado }(\mathrm{RM})\end{array}$ \\
\hline 1 & ANULADO & & & \\
\hline 2 & $\begin{array}{l}4 \text { motores diesel de } 1.000 \mathrm{HP} \text { cada } \\
\text { uno, mod. Sulzer, fabricados en } \\
\text { Halberg }\end{array}$ & 391.000 & $181.244,23$ & $724.976,92$ \\
\hline 3 & $\begin{array}{l}10 \text { radiogoniómetros } 280 \mathrm{~S} \text {. Para } \\
\text { submarino con cuadro especial } 1.000 \\
\text { NIX, receptor para T } 3 \text { TLL }\end{array}$ & 72.800 & 18.300 & 183.000 \\
\hline 4 & $\begin{array}{l}8 \text { motores diesel para submarino } \\
\text { (Krupp) con empaque }\end{array}$ & $473.437,50$ & $281.936,48$ & $2.255 .491,84$ \\
\hline 5 & $\begin{array}{l}8 \text { motores para submarino (Brown } \\
\text { Boveri) empacados }\end{array}$ & 200.000 & 82.500 & 660.000 \\
\hline 6 & 4 periscopios para submarino & 363.000 & 130.000 & 520.000 \\
\hline 7 & $\begin{array}{l}4 \text { periscopios de observación } \\
\text { nocturna para submarino }\end{array}$ & 207.000 & 50.000 & 200.000 \\
\hline 8 & $\begin{array}{l}1 \text { instalación de cineteodolito } \\
\text { "Askania" sin cable acorazado para } \\
\text { gran distancia }\end{array}$ & 561.435 & 187.145 & 187.145 \\
\hline 9 & $\begin{array}{l}10 \text { emisoras de radio de onda corta } \\
\text { "Lorenz" S } 18 \text { y otras } 20 \mathrm{~S} 11 \text {, de } 40 \\
\text { watios con grupo electrógeno de } \\
\text { corriente continua } 24 \text { voltios y } \\
\text { transformador de corriente alterna. }\end{array}$ & 19.500 & 12.212 & 366.360 \\
\hline 10 & 880 lámparas de radio Lt específica & 36.840 (total) & 20.000 (total) & 20.000 \\
\hline 11 & $\begin{array}{l}20 \text { receptores Telefunken de } 6 \\
\text { círculos } 437 \mathrm{~S}\end{array}$ & 12.960 & 4.400 & 88.000 \\
\hline 12 & $\begin{array}{l}4 \text { estaciones de carga de } \\
\text { acumuladores }\end{array}$ & 500.000 & 242.500 & 970.000 \\
\hline 13 & $\begin{array}{l}900 \mathrm{Tm} \text { de acero para los cascos de } \\
\text { los submarinos Tipo VIIC }\end{array}$ & $2.222,22$ por $\mathrm{Tm}$ & 1.000 por $\mathrm{Tm}$ & 900.000 \\
\hline 14 & 6 cañones de Marina de $10,5 \mathrm{~cm}$ & 2.280 .000 & 850.000 & 5.100 .000 \\
\hline
\end{tabular}




\begin{tabular}{|c|c|c|c|c|}
\hline & $\begin{array}{l}\mathrm{L} / 33 \text { en cureña doble } \mathrm{C} / 37 \text { para } \\
\text { cañoneros }\end{array}$ & & & \\
\hline 15 & $\begin{array}{l}11.400 \text { disparos de } 10,5 \mathrm{~cm} \text { de } \\
\text { diversos tipos y } 6.000 \text { disparos de } \\
3,7 \mathrm{~cm} \text { (subcalibre) }\end{array}$ & 8.375 .400 (total) & 2.800 .000 (total) & 2.800 .000 \\
\hline 16 & $\begin{array}{l}42 \text { Flak de } 3,7 \mathrm{~cm} \mathrm{SK} \mathrm{C} / 30 \text { en } \\
\text { montaje doble estabilizado }\end{array}$ & 442.200 & 154.400 & 6.484 .800 \\
\hline 17 & $\begin{array}{l}168.000 \text { granadas rompedoras } \\
\text { cartucho } 40\end{array}$ & 98,70 & 32,90 & 5.527 .200 \\
\hline 18 & $\begin{array}{l}22 \text { Flak de } 2 \mathrm{~cm} \text { cuádruples para } \\
\text { buque }\end{array}$ & 411.250 & 125.000 & 2.750 .000 \\
\hline 19 & $\begin{array}{l}176.000 \text { granadas rompedoras } \\
\text { luminosas }\end{array}$ & 29,05 & 8,63 & 1.518 .880 \\
\hline 20 & $\begin{array}{l}64 \text { Flak de } 2 \mathrm{~cm} \text { en montaje de } \\
\text { submarino }\end{array}$ & $101.318,51$ & 28.200 & 1.804 .800 \\
\hline 21 & $\begin{array}{l}128.000 \text { granadas rompedoras } \\
\text { luminosas }\end{array}$ & 29,05 & 8,63 & 1.104 .640 \\
\hline 22 & $\begin{array}{l}34 \text { Flak de } 10,5 \mathrm{~cm} \mathrm{C} / 32 \text { en cureña } \\
\mathrm{C} / 52 \text { para torpederos }\end{array}$ & 854.000 & 230.000 & 7.820 .000 \\
\hline 23 & $\begin{array}{l}32.310 \text { disparos de } 10,5 \mathrm{~cm} \mathrm{de} \\
\text { diversos tipos y17.000 disparos de } \\
3,7 \mathrm{~cm} \text { (subcalibre) }\end{array}$ & 27.308 .610 (total) & 7.802 .000 (total) & 7.802 .000 \\
\hline 24 & 6 lanchas rápidas tipo grande & 5.000 .000 & 2.000 .000 & 12.000 .000 \\
\hline 25 & 20 anteojos de observación 20 x 80 & 13.200 & 4.500 & 90.000 \\
\hline 26 & $\begin{array}{l}51 \text { Flak de } 3,7 \mathrm{~cm} \mathrm{C} / 30 \text { en cureña } \\
\text { C739 de submarino para buque }\end{array}$ & 174.600 & 60.000 & 3.060 .000 \\
\hline 27 & $\begin{array}{l}102.000 \text { granadas rompedoras mod } \\
40\end{array}$ & 98,70 & 32,9 & 3.355 .800 \\
\hline 28 & $\begin{array}{l}4 \text { direcciones de tiro EWA para } 4 \\
\text { piezas de } 10,5 \text { de cañonero }\end{array}$ & 437.500 & 102.500 & 410.000 \\
\hline 29 & $\begin{array}{l}9 \text { direcciones de tiro para puesto de } \\
\text { mando de torpedero tipo "Le Fier" }\end{array}$ & $805.555,55$ & $191.111,11$ & 1.720 .000 \\
\hline 30 & ANULADO & & & \\
\hline 31 & $\begin{array}{l}1.000 \text { minas EMC sin anclaje, la } \\
\text { mitad con } 300 \mathrm{~m} \text { de cable y la otra } \\
\text { mitad con } 350 \mathrm{~m} \text { de cable. }\end{array}$ & 11.895 & 3.000 & 3.000 .000 \\
\hline 32 & 2.000 cargas de profundidad F & 2.800 & 1.000 & 2.000 .000 \\
\hline 33 & $\begin{array}{l}12 \text { telémetros “Goerz" de } 2 \mathrm{~m} \mathrm{de} \\
\text { base }\end{array}$ & 39.000 & 13.000 & 156.000 \\
\hline 34 & $\begin{array}{l}20 \text { telémetros "Zeiss" de } 1,25 \mathrm{~m} \text { de } \\
\text { base }\end{array}$ & 7.620 & 5.720 & 114.400 \\
\hline \multirow[t]{2}{*}{35} & $3.000 \mathrm{~kg}$ de vidrio óptico & 68 & 20 & 60.000 \\
\hline & & & TOTAL & $75.753 .493,76$ \\
\hline
\end{tabular}

Fuente: elaboración propia. AMAE. R-2065-5 y AGMAV. Caja 24.711. Fondo del antiguo Ministerio del Ejército. 


\section{ANEXO XI}

\section{“Programa Bär". Aire. Material aprobado para su entrega a}

\section{España}

\begin{tabular}{|c|c|c|c|c|c|}
\hline Cantidad & Concepto & $\begin{array}{l}\text { Precio unitario } \\
\text { solicitado por } \\
\text { Alemania }\end{array}$ & $\begin{array}{l}\text { Precio unitario } \\
\text { ofrecido por } \\
\text { España }\end{array}$ & $\begin{array}{l}\text { Precio unitario } \\
\text { pactado por la } \\
\text { subcomisión }\end{array}$ & Programa \\
\hline \multicolumn{6}{|c|}{ AVIONES Y SUS REPUESTOS } \\
\hline 15 & Me 109 F-4 & $690.000,00$ & $198.000,00$ & $203.940,00$ & Sofortp. \\
\hline 10 & Ju 88 A-4 & $2.800 .000,00$ & $500.000,00$ & $600.000,00$ & Sofortp. \\
\hline 15 & Repuestos Me 109 & ------------ & $39.600,00$ & $39.600,00$ & Sofortp. \\
\hline 10 & Repuestos Ju $88^{736}$ & ------------ & $100.000,00$ & $100.000,00$ & Sofortp. \\
\hline \multicolumn{6}{|c|}{ MUNICIÓN DE AVIÓN } \\
\hline 250.000 & Proyectiles $7,92 \mathrm{SS}$ & 0,26 & 0,1525 & 0,13 & Sofortp. \\
\hline 250.000 & Proyectiles 7,92 SMK & 0,45 & 0,1833 & 0,228 & Sofortp. \\
\hline 125.000 & Proyectiles 7,92 SMK OL & 0,33 & 0,165 & 0,165 & Sofortp. \\
\hline 125.000 & Proyectiles 7,92 SMK MESS & 0,29 & 0,162 & 0,146 & Sofortp. \\
\hline 125.000 & Proyectiles 7,92 PMK & 0,41 & 0,18 & 0,203 & Sofortp. \\
\hline 125.000 & Proyectiles 7,92 PMK MESS & 0,41 & 0,18 & 0,203 & Sofortp. \\
\hline \multicolumn{6}{|c|}{ EQUIPOS PARA LA PROTECCIÓN DE VUELO } \\
\hline 4 & $\begin{array}{l}\text { Radiofaros de aterrizaje de } 120 \\
\text { w }\end{array}$ & ¿? & 26.500 & 56.500 & Sofortp. \\
\hline 8 & $\begin{array}{l}\text { Radiogoniómetros de } \\
\text { navegación }\end{array}$ & 70.000 & 14.000 & 18.200 & Sofortp. \\
\hline 22 & $\begin{array}{l}\text { Temporizadores para } \\
\text { señalización radio "Pintsch",737 }\end{array}$ & ¿? & ¿? & 2.230 & Restp. \\
\hline \multicolumn{6}{|c|}{ EQUIPOS DE RADIO Y LOCALIZACIÓN } \\
\hline 6 & $\begin{array}{l}\text { Radiotelémetros SFuG } 213 \\
\text { "Liechtenstein" } 738\end{array}$ & 114.000 & ----------- & $\begin{array}{l}114.000 \\
\text { (reducido a } \\
30.000 \text { ) }\end{array}$ & $\begin{array}{l}3 \text { en } \\
\text { Sofortp. y } \\
3 \text { en } \\
\text { Restp. }\end{array}$ \\
\hline 26 & $\begin{array}{l}\text { Radiotelémetros "Würzburg" } \\
\text { Mod } 39 \text { TD }\end{array}$ & 125.000 & & 125.000 & Restp. \\
\hline 26 & Radiolocalizadores "Freya" & 260.000 & & 260.000 & Restp. \\
\hline
\end{tabular}

736 Llegaron el 21 de enero a la estación fronteriza de Port-Bou en los vagones SNCF 40273 y SNCF 105965, constituyendo la partida $44 \mathrm{H}$ de la lista de transportes

${ }^{737}$ Se trataba de manipuladores Morse automáticos de señales características de radio-faros. La casa Pintsch fue desmantelada después de la guerra y trasladada en bloque a la URSS, donde siguió produciendo estos mismos temporizadores. Fuente: http://www.knirim.de/a0601 mod.htm

${ }^{738}$ Como ya se ha afirmado anteriormente, esta cifra fue rebajada por los propios alemanes, quedando fijada en 30.000 marcos. 


\begin{tabular}{|c|c|c|c|c|c|}
\hline 4 & $\begin{array}{l}\text { Equipos móviles de radio } \\
\text { (Onda corta) }\end{array}$ & 860.000 & 207.000 & 227.700 & Sofortp. \\
\hline 4 & $\begin{array}{l}\text { Equipos móviles de radio } \\
\text { (Onda larga) }\end{array}$ & 1.020 .000 & 207.000 & 269.100 & Sofortp. \\
\hline 15 & FuG X ligeros móviles & 88.000 & 15.000 & 28.600 & Sofortp. \\
\hline 12 & $\begin{array}{l}\text { Radioemisoras AS } 59 \text { (onda } \\
\text { corta) Telefunken }\end{array}$ & 50.050 & ¿? & 14.000 & Restp. \\
\hline 50 & Teléfonos de campaña mod 33 & 280 & ¿? & 120 & Sofortp. \\
\hline 20 & Radioemisoras FuG VII aF1 & ¿? & ¿? & 5.000 & Restp. \\
\hline 85 & $\begin{array}{l}\text { Radioemisoras FuG X de a } \\
\text { bordo (onda corta y larga) }\end{array}$ & 54.000 & ¿? & 17.400 & Restp. \\
\hline 100 & Fu BL 1 Aparato de a bordo & & & 5.000 & Restp. \\
\hline \multicolumn{6}{|c|}{ GRUPOS ELECTRÓGENOS } \\
\hline 15 & $\begin{array}{l}\text { Grupos electrógenos EMS I } \\
\text { "Still }\end{array}$ & $30.963,60$ & 16.000 & 16.000 & Sofortp. \\
\hline 100 & $\begin{array}{l}\text { Grupos electrógenos E.M. } 4 \mathrm{~W} \\
220 \text {. }\end{array}$ & & & 2.320 & Restp. \\
\hline
\end{tabular}

Fuente: elaboración propia. AHEA.

\section{ANEXO XII}

\section{Claves para el desarrollo del Programa Bär ${ }^{740}$}

En las comunicaciones realizadas entre los distintos órganos del Ministerio del Ejército, cuando se hablase del material con destino al Ejército del Aire se pondría la letra $\mathrm{X}$, y cuando fuera el material con destino a la Marina el tratado, se pondría la Y.

Cuando se citase material del propio Ejército de Tierra habría que tener en cuenta la siguiente guía de siglas:

Cañón de $88 \mathrm{~mm}$ :

Ametralladora de $20 \mathrm{~mm}$ antiaérea: B

Brocal de fusil:

Fusil lanzagranadas:

$\mathrm{D}$

Granada de humo:

$\mathrm{E}$

Mina T:

Mina ligera:

\footnotetext{
${ }^{739}$ De las 85 FuG X contratadas sólo llegarían 40. Las otras 45 radioemisoras venían en el fatídico tren $\mathrm{n}^{\circ}$ 25, que fué interceptado en Francia y nunca llegó a su destino. De todas formas hubo que pagarlas, procediendo el Estado Español a reclamar a la casa de transportes Schenker las cantidades adeudadas.

${ }^{740}$ Estado Mayor del Ejército. Sección Cuarta. AGMAV. Caja 24.713. Fondo del antiguo Ministerio del Ejército. Carpeta "Claves y teléfonos".
} 
Cañón de 122 mm:

Proyectil de $122 \mathrm{~mm}$ :

Moto sin carro lateral:

Moto con carro lateral:

$\mathrm{K}$

Material de transmisiones:

$\mathrm{L}$

Delante de cada letra se colocararía un número, que indicaba el de los elementos -piezas, granadas, motos, etc...- que lo formaban. En el material de transmisiones, se indicaba sólo el número de bultos.

En el caso del material de 88 y $20 \mathrm{~mm}$ se pondría detrás de la A o la $\mathrm{B}$, una “m” precedida de un número que indicaría el de proyectiles que venían de las dos piezas ${ }^{741}$.

En los casos de material de 88 y 20 antiaéreo y $122 \mathrm{~mm}$, se pondría detrás de la $\mathrm{A}, \mathrm{B}$ o $\mathrm{H}$, una $\mathrm{n}$ que indicaba accesorios, y un número, que cuantificaba el de éstos, si como era de suponer llegaban separados de las piezas. Esta regla se aplicaría al caso de las motos.

En un primer momento se dispuso por orden del EMCE, que fueran cuatro las estaciones de llegada del material alemán, a saber, Irún, Canfranc, Puigcerdá y PortBou. El ritmo diario de llegada de vagones a cada estación se estableció, así mismo, en seis, excepto en Puigcerdá que se bajó a tres, cada uno con una carga máxima de 5.500 $\mathrm{kg}$, debido a las peores condiciones en cuanto a elementos de apoyo a la descarga, para hacer el trasvase de bultos de los vagones alemanes a los españoles. De hecho, debido a esto, al final se optó por desechar Puigcerdá como estación de recepción, quedando únicamente las otras tres citadas.

En cada una de las estaciones se nombró una comisión de recepción, constituida por un jefe del Ejército de Tierra del Servicio de Estado Mayor y un jefe del Servicio Militar de Ferrocarriles. Además, en las estaciones de Irún y Port-Bou hubo sendos representantes de los Ministerios de Marina (Irún) y Aire (Port-Bou), ya que por estas estaciones se esperaba la recepción del material asignado a estos dos Ejércitos.

En los citados puntos de llegada se destacaron las escoltas necesarias para vigilar y acompañar los materiales a los lugares habilitados para la apertura de los bultos y entrega de los mismos. Lo cierto fue que en las mismas estaciones las únicas maniobras

\footnotetext{
${ }^{741}$ Esta norma no tuvo efecto alguno pues en el "Programa Bär" no se incluyó munición alguna para estos dos tipos de cañones antiaéreos.
} 
que se realizaban eran las de descarga de los vagones alemanes y carga en los españoles, realizándose, acto seguido, el transporte de los materiales a los puntos designados para efectuar la entrega, que por regla general, y para el Ejército de Tierra, eran los Parques y Maestranzas de Burgos, Valladolid, Zaragoza, Barcelona y Madrid.

Todos los bultos, cajas, cajones etc... venían marcados de Alemania, bien con una "M" (Kriegsmarine), si eran para la Marina de Guerra, con una "H" (Heer), si eran para el Ejército de Tierra, o bien con una "L" (Luftwaffe) si eran para el Ejército del Aire. Además, todo el material antiaéreo, como venía destinado al Ejército de Tierra y en Alemania pertenecía a la Luftwaffe, traía las dos inscripciones "L" y "H".

Tanto para la primera como para la segunda parte del Programa ("Sofortprogramm" o "Restprogramm"), se numeraron correlativamente todas las partidas que las componían, numeración que iba a servir para identificarlas en todas las comunicaciones entre los distintos organismos de los ministerios implicados en la recepción, transporte, identificación, recuento y reconocimiento del material.

Así mismo, en las comunicaciones realizadas entre los jefes destinados en la Agregaduría Militar española en Berlín y el Estado Mayor del Ejército, se definieron una serie de parámetros fundamentales a la hora de identificar el material enviado, los tipos de medios de transporte, las estaciones de recepción, etc... De esta manera, en los documentos que se manejaban en las comunicaciones telegráficas se establecieron las siguientes reglas ${ }^{742}$ :

1.- Para la comunicación de las estaciones de recepción del material militar del "Programa Bär", estas serían señaladas en clave, bien mediante un número, bien mediante un alias. Irún sería la número 1 y su alias "Tata"; Canfranc sería identificada como número 3, y su alias "Pepe"; por último Port-Bou tendría asignado en número 5 y su alias sería "Bibi". La clase de material se identificaría por el número de la partida asignada.

2.- Los vagones en los que venía el material militar del Programa hasta las estaciones de desembarco, serían alemanes y según su tipología se les asignaba una

\footnotetext{
742 Estos datos han sido extraídos de dos documentos esenciales para entender la organización de los envíos del Programa Bär: "Notas para S.E. el general Martínez de Campos. Estado Mayor del Ejército. 4" Sección. No 4130-E A/M" y una carta particular remitida el 21 de mayo de 1943 por el Agregado Militar en Berlín, D. Carlos Marín de Bernardo, al coronel D. Jesús Aguirre, jefe de la $4^{\text {a }}$ Sección del Estado Mayor del Ejército, acompañada de cuatro anexos. AGMAV Caja 24.713. Fondo del antiguo Ministerio del Ejército. Carpeta "Correspondencia. Fronterizos"
} 
letra. De esta manera, las autoridades españolas dedicadas al trasvase del material a vagones españoles podrían saber las necesidades de los mismos para enviar el armamento a los distintos Parques o Maestranzas. Así, los vagones "Plataforma" fueron codificados con la letra "F", los vagones "Cubiertos", con la "G" y los vagones "Batea", con la letra "R".

3.- Cada uno de los materiales tenía un origen concreto en Alemania, y venía destinado bien al Ejército de Tierra, bien a la Marina o bien al Ejército del Aire. Para su correcta adscripción y entrega a su destinatario real, en cualquier documento emitido sobre un material concreto, tras la palabra "Bär" se hacía constar mediante una letra, su origen en Alemania; y mediante otra letra, su destino en España. Las letras de origen eran "H” (Heer), "L" (Luftwaffe) y "M" (Kriegsmarine) y las de destino "T" (Ejército de Tierra), "A" (Ejército del Aire) y "M" (Marina de Guerra). Así una ametralladora antiaérea de $20 \mathrm{~mm}$ Flak 28 procedía en Alemania de la Luftwaffe, pero en España iba destinada al Ejército de Tierra. En este caso, la inscripción era "Bär L-T". En cambio, una ametralladora antiaérea de $20 \mathrm{~mm}$ Flak 30 que procedía de la Kriegsmarine e iba destinada a la Marina española, su inscripción era: "Bär M-M".

4.- La llegada de las sucesivas expediciones debían ser puestas en conocimiento del EMCE con una anticipación mínima de 48 horas a la llegada a la frontera, señalando el detalle del material transportado con seguridad absoluta.

5.- La empresa encargada del transporte del material militar del "Programa Bär" sería "Schenker und Co. G.m.b.H.", en concreto su departamento de Transportes Especiales denominado "Spetra KM", por lo que en toda la documentación generada referente a cada uno de los envíos, figuraría esta palabra seguida del número identificativo del transporte concreto. Con cada expedición iba un representante de la casa "Schenker" para vigilar y garantizar la seguridad de los envíos. Iba provisto de relaciones por triplicado del material que transportaba. Dos de estas relaciones con el recibí firmado por el representante español en la frontera le eran devueltas para justificar que la entrega se había realizado correctamente.

En el caso de que algún material, bulto, caja o paquete que se recibieran en frontera aparecieran con deterioros, roturas, desperfectos debidos evidentemente a la manipulación en el transporte o señales evidentes de que habían sido forzados, la representación española levantaría acta por duplicado en presencia del representante de Schenker, en donde, bajo la firma de ambos, constaran con el mayor detalle las 
observaciones que estimaran pertinentes. Las faltas cualitativas no eran objeto del $\operatorname{acta}^{743}$. Dichos documentos firmados, servirían en su momento para las reclamaciones que procedieran por parte de las autoridades militares españolas.

Los gastos de envío que presentó "Schenker" a la Comisión española por parte de "Schenker" fueron los siguientes:

\begin{tabular}{|l|l|l|l|}
\hline Lugar de envío & Frontera de llegada & Coste en marcos \\
\hline Perl (Alemania) & Irún 1 (Material) & 31,25 por $100 \mathrm{~kg}$. \\
\hline Perl (Alemania) & Irún 1 (Munición) & 15,50 por $100 \mathrm{~kg}$. \\
\hline Perl (Alemania) & Canfranc 3 (Material) & 32,50 por $100 \mathrm{~kg}$. \\
\hline Perl (Alemania) & Canfranc 3 (Munición) & 16,00 por $100 \mathrm{~kg}$. \\
\hline Perl (Alemania) & Port-Bou 5 (Material) & 28,75 por $100 \mathrm{~kg}$. \\
\hline Perl (Alemania) & Port-Bou 5 (Munición) & 14,50 por $100 \mathrm{~kg}$. \\
\hline Incluyendo gastos de embarque, acompañamiento y entrega en frontera & \\
\hline
\end{tabular}

Fuente: Correspondencia con los alemanes durante la estancia en Berlin. AGMAV. Caja 24.711.

6.- A la salida de cada tren del punto de partida, la estación ferroviaria de Perl (pueblo situado en la región del Sarre fronteriza con Luxemburgo y Francia), la casa Schenker avisaba de la composición del convoy y del material que transportaba, así como de la llegada aproximada a la estación de destino. Estos datos serían enviados a Madrid por avión dentro de un pliego dirigido al Ministro del Aire. El envío de este pliego se anunciaba por teléfono al jefe de la $2^{\text {a }}$ Sección del Estado Mayor del Ejército. Entonces, la $4^{\text {a }}$ Sección de ese mismo Estado Mayor podría retirar en el Ministerio del Aire un sobre que a nombre del jefe de la misma iba incluido en el pliego antes citado. Debido al tiempo probable que tardaría el tren en llegar a la frontera española (normalmente 3 o 4 días), se preveía que no sería necesario tener que telegrafiar la información, pues ésta llegaría mucho más completa y clara por el procedimiento señalado.

\footnotetext{
${ }^{743}$ Se entendía por faltas cualitativas como las deducidas del estado de conservación y defectos o roturas propios del material o producidas por el deficiente embalaje.
} 
Los trenes saldrían de origen cada tres días para cada una de las tres estaciones, es decir, cada una de ellas recibiría un tren cada nueve días aproximadamente. En principio estos trenes se compondrían de entre 33 y 35 vagones alemanes ${ }^{744}$.

7.- Una vez que el material militar estuviera en los Parques y Maestranzas designadas por las autoridades españolas, se procedería a su indispensable reconocimiento y recuento. Estas labores debían ser realizadas con premura y remitir también con premura- a la Agregaduría Militar en Berlín, una copia del acta en cada caso, para poder conocer la posición española frente a las preguntas del $\mathrm{OKW}$ respecto a conformidad o reparos en relación al número y estado del material y poder ir dando por terminadas las gestiones de transporte.

A finales de octubre de 1944, el Agregado Militar en Berlín, Carlos Marín de Bernardo, tras la imposibilidad manifiesta de que ningún tren más pudiera salir de Alemania y cruzar Francia para traer material de ninguna clase, renunció a la entrega momentánea- de materiales, armas y municiones que faltaban de enviar, que no hubiesen salido ya de Alemania ${ }^{745}$.

El Almirante Jefe de Estado Mayor de la Armada, remitió a Espinosa un telegrama el 3 de noviembre de ese año, comunicándole que tras una reunión con el consejero comercial de la Embajada alemana en Madrid, se le propuso que los contratos del "Programa Bär" podrían continuar en vigor cuando las firmas suministradoras aceptaran la condición de que el pago se realizara contra la recepción del material en Suiza. $^{746}$

Pocos días más tarde, el día 6 de noviembre, contestaba el capitán de fragata Espinosa al telegrama de Madrid, puntualizando un detalle importante: suponía el Agregado Naval que el material que se quería depositar en Suiza no se trataba de

\footnotetext{
${ }^{744}$ Es evidente que esto era "la teoría". La práctica distó mucho de ser así en todos los casos, como más adelante tendremos ocasión de comprobar cuando veamos la composición de cada uno de los convoyes.

${ }^{745}$ APFE. Embajada en España en Berlín. Agregado Naval. Telegrama transmitido $\mathrm{n}^{\circ}$ 811. En este documento se preguntaba al Estado Mayor de la Armada si este mismo criterio lo iba a seguir el Ministerio de Marina español, con la salvedad de que si las circunstancias cambiaban y se ofrecían posibilidades de transporte, se estaría dispuesto a continuar con entregas mensuales.

${ }^{746}$ Con este telegrama se contestaba al remitido por Espinosa con el $\mathrm{n}^{\circ} 811$, visto en la nota anterior. Marina no se resignaba a perder lo que faltaba por entregar del "Programa Bär" y luchaba por acumular en Suiza un material que no sabía como trasladar a España con posterioridad, cuando las circunstancias fueran favorables. En cualquier caso, dicha condición se trasladó al Oberkommando der Kriegsmarine $(\mathrm{OKM})$, como era deseo del Almirante español. APFE. Embajada en España en Berlín. Agregado Naval. Telegrama recibido $\mathrm{n}^{\mathrm{O}} 11285 / 5462$.
} 
armamento pues creía (con razón) que para el paso por el país helvético no habría todavía autorización. El OKM apremiaba en conocer este aspecto pues en aquellos momentos de penuria y derrota para las armas alemanas, quería conservar a toda costa armas y municiones no suministradas a España ${ }^{747}$.

Enseguida, el Estado Mayor de la Armada ordenaba a su Agregado en Berlín comunicara a OKM que dejara sin efecto la ejecución del "Programa Bär", cesando en la entrega de todo el material de cualquier clase que por cuenta de dicho programa se hallaba pendiente de ser suministrado y dispusiera, por tanto, para su utilización, de armas y municiones listas para su entrega a la marina española. De la misma manera, debería comunicar a "Schenker" que a partir del día 9 de noviembre debía cesar en la recepción de material correspondiente al "Programa Bär". En el caso de que tuviera en su poder algún tipo de suministros entregados por alguna de las firmas germanas contratantes, debería hacerlo saber para recibir instrucciones al respecto ${ }^{748}$.

\footnotetext{
${ }^{747}$ Se trataba de la contestación al telegrama analizado en la nota anterior. APFE. Embajada en España en Berlín. Agregado Naval. Telegrama transmitido $n^{\circ} 533$.

748 APFE. Embajada en España en Berlín. Agregado Naval. Telegramas recibidos Ref. 11298/5568, $11299 / 5575$ y $11305 / 5695$
} 


\section{ANEXO XIII}

\section{Programa Inmediato ("Sofortprogramm")}

\section{A.- Partidas ${ }^{749}$ que componían el "Sofortprogramm"}

(Las partidas de Marina se señalan con fondo azul claro, las del Ejército del Aire, con fondo azul oscuro y las del Ejército de Tierra, con fondo marrón)

\begin{tabular}{|c|c|c|c|}
\hline PARTIDA & MATERIAL & EJÉRCITO & NOTAS \\
\hline 1 & $\begin{array}{l}4 \text { cañones de } 3,7 \mathrm{~cm} \text { SK C/30 en afuste doble } \\
\text { estabilizado } \mathrm{C} / 30\end{array}$ & Marina & Suministra Rheinmetall \\
\hline 2 & $\begin{array}{l}16 \text { cañones } 3,7 \mathrm{~cm} \text { SK C } 30 \text { en afuste } \mathrm{C} / 39 \text { de } \\
\text { submarino }\end{array}$ & Marina & Suministra Rheinmetall \\
\hline 3 & 10 Flak 38 de $2 \mathrm{~cm}$ en montaje $\mathrm{C} / 30$ & Marina & Suministra Rheinmetall \\
\hline 4 & cañones de repuesto de $3,7 \mathrm{~cm}$ & Marina & Suministra Rheinmetall \\
\hline 5 & 20.000 proyectiles de $2 \mathrm{~cm}$ & Marina & Suministra Rheinmetall \\
\hline 6 & 48.800 proyectiles de $3,7 \mathrm{~cm}$ & Marina & Suministra Rheinmetall \\
\hline 7 & 500 minas EMC m & Marina & Suministra Ageka GmbH \\
\hline 8 & 100 cargas de profundidad WBF & Marina & Suministra Ageka GmbH \\
\hline $\mathrm{s} / \mathrm{n}$ & 15 aviones de caza Bf.109 F-4 & Aire & $\begin{array}{l}\text { Suministra } \\
\text { Messerschmitt AG. } \\
\text { Llegaron en vuelo }\end{array}$ \\
\hline $\mathrm{s} / \mathrm{n}$ & 10 aviones de bombardeo Ju $88 \mathrm{Z}-4$ & Aire & $\begin{array}{l}\text { Suministra Junkers AG. } \\
\text { Llegaron en vuelo }\end{array}$ \\
\hline 9 & $\begin{array}{l}\text { Repuestos para una escuadrilla de caza. } \\
\text { Dotaciones. }\end{array}$ & Aire & $\begin{array}{l}\text { Suministra } \\
\text { Messerschmitt AG. }\end{array}$ \\
\hline 10 & 12 cañones antiaéreos de $88 / 56 \mathrm{~mm}$ & $\begin{array}{l}\text { Aire (pasaron } \\
\text { a Tierra) }\end{array}$ & $\begin{array}{l}\text { Suministan Fried Krupp } \\
\text { AG. }\end{array}$ \\
\hline 11 & 3 direcciones de tiro Mod. 40 completas & $\begin{array}{l}\text { Aire (pasaron } \\
\text { a Tierra) }\end{array}$ & Suministra Carl Zeiss \\
\hline 12 & 12 cañones antiaéreos de $20 \mathrm{~mm}$ & $\begin{array}{l}\text { Aire (pasaron } \\
\text { a Tierra) }\end{array}$ & Suministra Ageka GmbH \\
\hline 13 & 4 proyectores de $60 \mathrm{~cm}$ Siemens & $\begin{array}{l}\text { Aire (pasaron } \\
\text { a Tierra) }\end{array}$ & $\begin{array}{l}\text { Suministra Siemens } \\
\text { Schuckert }\end{array}$ \\
\hline 14 & 4 telémetros $\mathrm{R} 36$ de $1 \mathrm{~m}$ de base $\mathrm{y}$ & Aire (pasaron & Suministra Carl Zeiss \\
\hline
\end{tabular}

\footnotetext{
${ }^{749}$ La referencia a "partidas" está hecha en función a las que, posteriormente, se constituyeron cuando los materiales fueron saliendo de Alemania con destino a España.
} 


\begin{tabular}{|c|c|c|c|}
\hline & herramientas & a Tierra) & \\
\hline 15 & 4 radiofaros de aterrizaje de 120 watios & Aire & Suministra Lorenz AG \\
\hline 16 & 15 grupos electrógenos Still & Aire & Suministra Hans Still \\
\hline 17 & 1.000.000 de cartuchos de 7,92 & Aire & $\begin{array}{l}\text { Suministra Deutsche } \\
\text { Waffen und } \\
\text { Munitionsfabriken }\end{array}$ \\
\hline 18 & 3 localizadores de buques Liechtenstein & Aire & $\begin{array}{l}\text { Suministra Telefunken. } \\
\text { Hubo cierta confusión } \\
\text { con esta partida, } \\
\text { disputándosela Tierra y } \\
\text { Aire. Era de Aire. }\end{array}$ \\
\hline 19 & 50 teléfonos de campaña 33 & Aire & $\begin{array}{l}\text { Suministra Telefunken. } \\
\text { No estaban incluidos en } \\
\text { el "Sofort Programm" }\end{array}$ \\
\hline 20 & 10.000 brocales & Tierra & $\begin{array}{l}\text { Suministra Th. } \\
\text { Bergmann and Co. }\end{array}$ \\
\hline 21 & 1.000 fusiles lanzagranadas & Tierra & Suministra Ageka GmbH \\
\hline 22 & 10.000 granadas de mano fumígenas & Tierra & Suministra J. Riedel \\
\hline 23 & 46.000 minas $\mathrm{T}-42$ & Tierra & Suministra R. Rinker \\
\hline 24 & 4.000 minas ligeras & Tierra & Suministra R. Rinker \\
\hline 25 & 100 cañones de $122 / 46 \mathrm{~mm}$ & Tierra & Suministra Ageka GmbH \\
\hline 26 & 3.000 proyectiles de $122 \mathrm{~mm}$ & Tierra & Suministra Ageka GmbH \\
\hline 27 & 400 motocicletas sin carro lateral & Tierra & $\begin{array}{l}\text { Suministra Ageka } \\
\text { GmbH. Se desecharon } \\
103 \text {, pero luego } \\
\text { mandaron otras tantas. }\end{array}$ \\
\hline 28 & 100 motocicletas con carro lateral & Tierra & Suministra BMW \\
\hline 29 & $\begin{array}{l}6 \text { equipos repetidores de alta frecuencia } \\
\text { (multiamplificadores) }\end{array}$ & Tierra & $\begin{array}{l}\text { Anulada del } \\
\text { "Sofortprogramm" }\end{array}$ \\
\hline 30 & 20 teletipógrafos mecánicos & Tierra & $\begin{array}{l}\text { Anulada del } \\
\text { "Sofortprogramm" }\end{array}$ \\
\hline 31 & $\begin{array}{l}6 \text { aparatos Malsi y } 6 \text { UTG } 37 \text { para baterías } \\
88 / 56\end{array}$ & $\begin{array}{l}\text { Aire (pasaron } \\
\text { a Tierra) }\end{array}$ & $\begin{array}{l}\text { Suministra Siemens } \\
\text { Incorporados al } \\
\text { "Sofortprogramm" }\end{array}$ \\
\hline $\mathrm{s} / \mathrm{n}$ & $\begin{array}{l}4 \text { equipos pesados de radio (móviles) de onda } \\
\text { larga }\end{array}$ & Aviación & $\begin{array}{l}\text { Suministra Telefunken. } \\
\text { Llegaron antes de }\end{array}$ \\
\hline
\end{tabular}

${ }^{750}$ Las cuatro partidas que figuran en el cuadro a continuación como "sin número" son de material de transmisiones del Ejército del Aire encargado en el "Sofort Programm", pero que no se transportó a España de forma convencional en los trenes habilitados al efecto. Por lo visto, si hacemos caso al acta de 


\begin{tabular}{|l|l|l|l|}
\hline & & & $\begin{array}{l}\text { iniciarse el } \\
\text { "Sofortprogramm" }\end{array}$ \\
\hline $\mathrm{s} / \mathrm{n}$ & $\begin{array}{l}4 \text { equipos pesados de radio (móviles) de onda } \\
\text { corta }\end{array}$ & Aviación & $\begin{array}{l}\text { Suministra Telefunken. } \\
\text { Llegaron antes de } \\
\text { iniciarse el } \\
\text { "Sofortprogramm" }\end{array}$ \\
\hline $\mathrm{s} / \mathrm{n}$ & 15 equipos ligeros de radio FuG X & Aviación & $\begin{array}{l}\text { Suministra C. Lorenz } \\
\text { AG. Llegaron antes de } \\
\text { iniciarse el } \\
\text { "Sofortprogramm" }\end{array}$ \\
\hline $\mathrm{s} / \mathrm{n}$ & 8 equipos radiogoniómétricos de navegación & Aviación & $\begin{array}{l}\text { Suministra Telefunken. } \\
\text { Llegaron antes de } \\
\text { iniciarse el }\end{array}$ \\
\hline
\end{tabular}

En azul claro, las pertenecientes a Marina, en azul oscuro, las del Ejército del Aire y en negro, las pertenecientes al Ejército de Tierra. Fuente: Elaboración propia. AGMAV. Cajas 24.707, 24.708 y 24.714.

\title{
B.- Trenes del "Sofortprogramm" 751
}

\section{TREN No 1}

-Fecha de llegada: 31-mayo de 1943

-Estación de llegada: 5 (Bibi)

-Peso total aproximado: 15 toneladas por vagón

• 38 vagones G, cuatro de protección y un furgón. Partidas 23 y 24 completas ${ }^{752}$.

\begin{abstract}
las negociaciones mantenidas en el seno de la subcomisión técnico-militar del día 25 de junio de 1943, “...cuando el general Martínez de Campos mostró los deseos del suministro rápido de 4 equipos de radio, se dieron las órdenes oportunas por el Ministerio del Aire y se supo que dichas estaciones habian salido ya para Hendaya, pero procedentes de la fábrica de Alemania..." Se sabe, por las citadas Actas que el material estaba muy usado y que, evidentemente no procedía de fábrica, sino de unidades de la Luftwaffe, probablemente, acantonadas en el sur de Francia, cerca de la frontera con España. AMAE. AR. Sig. R2066-5.
\end{abstract}

En un informe sin fecha sobre el estado del material del Ministerio del Aire AMAE. Leg. R-2065-5, emitido probablemente para aportar a los militares españoles presentes en la subcomisión técnico-militar, se dice sobre el material radio recibido: "Todos los elementos recibidos están usados, aunque en muy diferente grado. Algunos de ellos tienen la instalación completa con material nuevo. Son de tipos y años de fabricación muy diferentes, tanto las instalaciones como el material de transporte. De este último, parte está en muy buen estado y remozado interiormente; parte, en cambio, está en estado de muy avanzado uso." El conjunto de cada Grupo Móvil consistía en un camión emisor, otro receptor y otro porta-antena, además de un grupo electrógeno para suministrar corriente a los equipos. Desconozco la forma en la que llegaron estos materiales a España; pudo ser por vía ferroviaria, previa a la constitución de los convoyes del "Sofort Programm" o pudo ser por su propios medios, ya que se trataba de vehículos de motor y pudieron traspasar la frontera si la unidad de la Luftwaffe que los entregó, estuviera próxima a la frontera. Hoy por hoy, es todo un misterio.

${ }^{751}$ Para la elaboración de este apartado de llegada, carga e incidencias de cada uno de los trenes del "Sofortprogramm" se han revisado todas las carpetas contenidas en la caja 24.713 del Archivo General Militar de Ávila. 
-Partida 23: 46.090 minas T-42

-Partida 24: 4.040 minas ligeras antitanque

-Spetra/KM-53041/Kr/Co.- Salida de Perl: 27 de mayo

-Transporte $\mathrm{n}^{\mathrm{o}} 6630573$.

•38 vagones “G": 28.433, 95.984, 2.697, 18.935, 11.327, 17.066, 1.728, 23.829,

$34.911,1.750,4.537,66.619,7.341,31.265,52.928,80.245,37.693,22.776$,

$94,416,48.856,53.116,19.969,66.650,97.684,90.243,78.139,88.077,40.418$,

78.982, 11.918, 97.017, 40.637, 26.892, 66.302, 60.136, 22.101, 3.892, 95.464.

\section{TREN No 2}

•Fecha de llegada: 3-junio de 1943

-Estación de llegada: 1 (Tata)

-Peso total aproximado: 75 toneladas

-23 vagones G. Partida 7 (incompleta)

-Partida 7: 143 minas EMC. y 58 cajas (Marina)

-Spetra/KM-53042/Kr/Co.- Salida de Perl: 29 de mayo

•23 vagones “G": 24.273, 15.601, 22.402, 9.537, 4.279, 5.775, 11.023, 36.714,

18.895, 19.203, 36.692, 7.094, 3.631, 13.722, 32.098, 13.190, 7.879, 33.794,

$35.704,15.270,39.206,8.039$ y 38.595 .

\section{TREN No 2a}

-Fecha de llegada: 4-junio de 1943

-Estación de llegada: 1 (Tata)

-Peso total aproximado: 100 toneladas

-29 vagones G. Partida 7 (incompleta)

-Partida 7: 197 minas EMC y 123 cajas. (Marina)

-Spetra/KM-53042/Kr/Co.- Salida de Perl: ¿30 mayo?

\footnotetext{
${ }^{752}$ El tren llegó a las 13,00 horas a Port-Bou y se terminó de descargar el día 1 a las 04,00 horas. Entre los días 2 y 3 de junio, todas las minas fueron remitidas al Parque de Villaverde (Madrid), saliendo para sus destinos los días 3 y 4 de junio. AGMAV. Caja 24.706. Fondo del antiguo Ministerio del Ejército.
} 
•29 vagones “G": 18.913, 41.263, 25.837, 10.579, 17.492, 45.226, 17.206,

$19.135,45.290,42.985,43.042$, 34.669, 32.670, 15.646, 35.598, 16.988, 5.177,

$43.009,42.846,25.322,43.028,14.532,22.329,45.184,14.391,21.080,16.860$,

23.875 y 18.754 .

\section{TREN N 3}

-Fecha de llegada: 4-junio de 1943

-Estación de llegada: 3 (Pepe)

-Peso total aproximado: 293 toneladas

-36 vagones R y 1 vagón G. Partida 25 (incompleta)

-Partida 25: 36 cañones de campaña de 122/46 con accesorios y artificios.

-Spetra/KM-53043/Ha/Co.- Salida de Perl: 31 de mayo

•36 vagones “R”: 74.112, 80.890, 23.749, 76.242, 76.927, 78.967, 66.091, $31.955,63.031,85245,46.501,39.162,67.791,85.515,10.233,23.297,16.915$, 75.670, 36.358, 693.763, 1.653, 26.536, 40.316, 91.306, 80.644, 74.401, 47.906, $85.771,3.593,10.999,74.838,38.368,62.151,23.994,62.181,46.965$.

•1 vagones “G”: 6.342 .

\section{TREN No $4^{753}$}

-Fecha de llegada: 16-junio de 1943

-Estación de llegada: 5 (Bibi)

-Peso total aproximado: 230 Toneladas

\footnotetext{
${ }^{753}$ El tren no 4 llegó, a decir del coronel Aguirre, de la $4^{\text {a }}$ Sección del EMCE, "muy liado con cosas para Aire". Se dejaron por el camino, debido al descarrilamiento de varios vagones, una pieza completa de 122 $\mathrm{mm}$, así como tres tubos de 88/56 y una dirección de tiro "Modelo 40". Por lo visto, el conductor del tren venía con unas copas de más. Carta del coronel Jesús Aguirre al Agregado Militar en Berlín de 19 de junio de 1943. AGMAV. Caja 24.707. El vagón 441.782, que transportaba una dirección de tiro modelo 40, llegó el día 20 de junio de 1943 a Port Bou. Ocho días más tarde, el 28 de junio, llegaría el vagón 91.927, con los tres tubos de cañón antiaéreo de 88/56 que faltaban, con desperfectos obserbables en las guías de resbalamiento, consecuencia de golpes en el transporte debido a un accidente ferroviario. El día 27 había llegado el vagón 95.941 llevando un resto de la partida 16 (generadores Still) para el Ejército del Aire.
} 
-28 vagones R y 9 vagones G. Partidas: 9, 10, 12, 13, 14, 15, 16, 17 y 19; además de las 11 y 25 (incompletas)

-Partida 9: accesorios para 15 equipos de vuelo. Dotaciones. (Aire)

-Partida 15: cuatro radiofaros de aterrizaje de $120 \mathrm{~W}$ fijos. (Aire)

-Partida 19: 50 teléfonos de campaña $\bmod 33^{754}$ (Aire)

-Partida 14: cuatro telémetros de $1 \mathrm{~m}$ R-36 y herramientas para maestro armero.

-Partida 16: 15 grupos electrógenos Still en carrillos especiales A.2

(Aire)

-Partida 13: cuatro proyectores antiaéreos de $60 \mathrm{~cm}$ con sus remolques y grupos electrógenos.

-Partida 17: 1.000.000 de cartuchos de 7,92 mm para ametralladora de avión. (Aire)

-Partida 25: 12 piezas rusas de 12,2 $\mathrm{cm}$ y accesorios.

-Partida 12: 12 Flak 28 de $2 \mathrm{~cm}$ con accesorios

-Partida 10: 12 piezas de $8,8 \mathrm{~cm}$ Flak en montaje fijo.

-Partida 11: 1 dirección de tiro Modelo 40.

-Spetra/KM-53044/Ha/Dö.- Salida de Perl: 12 de junio

•28 vagones “ $R$ ": 95.941, 1.513, 473.267, 96.226, 92.226, 92.809, 91.077, $52.479,24.020,18.375,21.236,41.139,12.653,68.745,31.055,597.727$, $77.567,35.136,3.382,39.808,501,28.542,39.346,23.261,49.365,77.615$, 91.927 y 441.782

•9 vagones “G”: 79.567, 27.387, 38.645, 26.546, 21.690, 78. 760, 38.370, 12.133 y 66.174 .

\section{TREN No $5^{755}$}

•Fecha de llegada: 9-junio de 1943

\footnotetext{
${ }^{754}$ No correspondían al "Sofortprogramm", sino al "Restprogramm". Su envío se aceleró, probablemente, por estar disponibles.

${ }^{755}$ Este tren, que debía haber estado compuesto por 41 vagones $-40 \mathrm{R}$ y uno G-, sólo trajo 33 vagones pues ocho de ellos quedaron en la propia estación de origen por el mucho peso que transportaba (más de 600 toneladas, incluyendo el peso de los propios vagones). De estos 33 vagones, dos quedaron en tránsito por avería. Pese a que la fecha de llegada estaba prevista para el día 11, el convoy llegó a España dos días antes, el 9 de junio.
} 
-Estación de llegada: 1 (Tata)

-Peso total aproximado: 256 toneladas

•32 vagones $\mathrm{R}$ y 1 vagón $\mathrm{G}$. Partida 25 incompleta.

-Partida 25: 32 piezas rusas de 12,2 $\mathrm{cm}$ con accesorios.

-Spetra/KM-53045/Ha/Dö.- Salida de Perl: 6 de junio

•32 vagones " $R$ ": 440.038, 2.923, 463.719, 10.630, 95.724, 46.764, 92.199,

92.153, 462.369, 2.146, 778, 1.317, 477.104, 272, 472.237, 2.393, 96.046,

$95.446,1.682$, 95.589, 3.049, 51.405, 83.499, 26.579, 26.545, 41.102, 40.559,

34.292, 40.546, 38.036, 129, 470.189.

•1 vagón “G”: 41.588 .

\section{TREN No $\mathbf{N a}^{756}$}

-Fecha de llegada: 16-junio de 1943

-Estación de llegada: 1 (Tata)

-Peso total aproximado: 63 toneladas

-8 vagones R. Partida 25 incompleta

-Partida 25: 8 piezas rusas de 12,2 $\mathrm{cm}$ con accesorios.

-Spetra/KM-53045/Hz/Le.- Salida de Perl: 11 de junio

-Envío especial

•8 vagones “ $R$ ”: 426.001, 94.470, 51.222, 47.370, 24.914, 844.832, 90.617 y

94.261.

\footnotetext{
${ }^{756}$ Dos vagones de estos ocho, quedaron en tránsito por causa de una avería. Dichos vagones llegarían más tarde.
} 


\section{Carta fechada en Berlín el 10 de junio de $1943^{757}$}

"Querido Jesús:

Te mando la nota correspondiente al tren $n^{\circ} 6$, que ya hoy se ha comunicado por teléfono. Te aclararé que el peso total del tren son 165 toneladas que van repartidas desigualmente en los vagones por la calidad del material que conceden ya que unos son de municiones y otros de motos. (...)

El tren $n^{\circ} 5$ con 41 vagones y que debió llegar el día 13, es el mismo que llegó el día 9 con 31 vagones. Parece ser que el mucho peso, más de 600 toneladas, les obligó en el último momento a segregar 8 vagones que se enviarán en partida cerrada, es decir independientemente y como complemento al tren $n^{\circ} 5$ del que formó parte. Los otros dos vagones deben haberse quedado en tránsito por avería...

Y sin más por hoy, un abrazo de tu buen amigo: Lasheras

Fdo: Coronel de Ingenieros Carlos Marín de Bernardo

Agregado Militar en Berlín

\section{TREN No 6}

-Fecha de llegada: 13-junio de 1943

-Estación de llegada: 3 (Pepe)

-Peso total aproximado: 165 toneladas

•38 vagones G. Partidas 26 y 27 (incompleta).

-Partida 27: 297 motocicletas ligeras (24 vagones).

-Partida 26: 3.000 proyectiles de 122/46

-Spetra/KM-53040/Ha/Co.- Salida de Perl: 10 de junio

•38 vagones “G”: 74.112, 80.890, 23.749, 76.242, 76.927, 78.967, 66.091, $31.955,63.031,85.245,46.501,39.162$, 67.791, 85.515, 10.233, 23.297, 16.915, 75.670, 36.358, 693.763, 1.653, 26.536, 40.316, 91.306, 80.644, 74.401, 47.906, $85.771,3.593,10.999,74.838,38.368,62.151,23.994,62.181$ y 46.965. (Faltan datos referentes a 2 vagones)

\footnotetext{
${ }^{757}$ Embajada de España en Berlín. Carta remitida el 10 de junio de 1943 al coronel jefe del la 4 ${ }^{a}$ Sección del EMCE, Jesús Aguirre. AGMAV. Caja 24.707. Fondo del antiguo Ministerio del Ejército.
} 


\section{TREN No $7^{758}$}

-Fecha de llegada: 15-junio de 1943

-Estación de llegada: 1 (Tata)

-Peso total aproximado: 367,3 toneladas

-22 vagones $\mathrm{G}$ y 6 vagones $\mathrm{R}$. Partidas $1,2,3,4,5,6,7$ (incompleta) y 8.

-Partida 1: cuatro cañones de 3,7 cm SK C30 en afuste doble estabilizado. (Marina)

-Partida 2: 16 cañones 3,7 cm SK C/30 en afuste C/39 de submarino.

(Marina)

-Partida 3: 10 Flak 38 de $2 \mathrm{~cm}$ en montaje C/30. (Marina)

-Partida 4: cañones de repuesto de 3,7 cm. (Marina)

-Partida 5: 20.000 cartuchos de $2 \mathrm{~cm}$. (incompleta). (Marina)

-Partida 6: 48.800 cartuchos de 3,7 cm. (incompleta). (Marina)

-Partida 7: 160 minas EMC m. (Marina)

-Partida 8: 100 cargas de profundidad WBF. (Marina)

-Spetra/KM-53046/Ha/Co.- Salida de Perl: 13 de junio

•22 vagones “G”: 11.042, 31.475, 22.421, 34.000, 96.343, 36.313, 33.722,

15.992, 50.352, 21.025, 27.178, 66.803, 13.689, 31.008, 103, 9.994, 41.554,

$26.896,9.515,9.790,24.714,50.802$

•6 vagones “ $R$ ”: 52.081, 3018, 61.340, 18.333, 86.675, 70.335.

\section{TREN 7a}

-Fecha de llegada: 2-julio de 1943

-Estación de llegada: 1 (Tata)

-Peso total aproximado: 77,5 toneladas

\footnotetext{
${ }^{758}$ Como expedición complementaria de este tren, que en principio se formó con 33 vagones, llegarán más tarde cinco vagones $\mathrm{G}$ segregados en la estación de partida por rebasar el tren completo las 600 toneladas de peso total. Esta expedición llevará el nombre de tren 7 a y conducirá material de las partidas 5 y 6. Los cañones de 3,7 cm de ambos modelos venían en los seis vagones R. Las minas, en 15 vagones G; la munición de 2 y $3,7 \mathrm{~cm}$, en cuatro vagones G; las cargas de profundidad, en un vagón $\mathrm{G}$ y las ametralladoras de $2 \mathrm{~cm}$, en otro vagón $\mathrm{G}$.
} 
- 5 vagones $\mathrm{G}$ segregados del tren anterior. Partidas 5 y 6 .

-Partidas 5 y 6: munición de 2 y 3,7 cm. (incompletas).

-Spetra/KM-53046/Hz/Co.- Salida de Perl: 24 de junio

•5 vagones “G”: 13.408, 23.103, 28.038, 13.911 y 83.648.

\section{TREN No 8}

-Fecha de llegada: 20-junio de 1943

-Estación de llegada: 3 (Pepe)

-Peso total aproximado: 165,9 toneladas

-20 vagones G y 12 vagones $R$. Partidas 21, 22, 25 (incompleta) y 28.

-Partida 21: 1.000 fusiles lanzagranadas

-Partida 22: 10.000 granadas de mano fumígenas

-Partida 25: 12 cañones de $122 \mathrm{~mm}$

-Partida 28: 100 motocicletas BMW R-75

-Spetra/KM-53047/Ha/Co.- Salida de Perl: 17 de junio

•20 vagones “G”: 52.664, 36.495, 13.502, 10.629, 64.663, 17.591, 45.860,

20.841, 23.314, 30.397, 82.961, 71.716, 47.463, 61.789, 85.591, 45.538, 81.274,

83.304, 34.793, 79.003 .

•12 vagones “R": $33.330,83.507,83.725,41.602,90.157,41.817,83.620$,

$6.847,83.651,83.435,80.516$ y 4.152

\section{TREN No 8 a}

-Fecha de llegada: 1-julio de 1943

-Estación de llegada: 3 (Pepe)

-Peso total aproximado: 3 toneladas

-1 vagones G. Partida 15 (incompleta)

-Partida 25: Accesorios para cañones de $122 \mathrm{~mm}$ : anteojos, brújulas, gemelos, goniómetros, etc... en 13 cajones ${ }^{759}$

\footnotetext{
${ }^{759}$ Se trataba este material de 211 gemelos prismáticos completos, 59 reglas de cálculo, 25 escuadras de nivel, 25 portaplanos, 268 brújulas, 9 llaves de pitones pequeñas, 25 cuentasegundos, 68 coordinatógrafos, 43 anteojos de antena con sus trípodes, 25 mesas plegables con reglas, sectores planos y fundas, 9 mesas de dibujo de madera, 9 reglas de doble escala (1/100.000 y 1/50.000), 9 sectores planos
} 
-Spetra/KM-53047/Ha/Co.- Salida de Perl: 24 de junio

-1 vagón “G”: 20.048

\section{TREN No 9}

-Fecha de llegada: 2 de julio de 1943

-Estación de llegada: 5 (Bibi)

-Peso total aproximado: 45 toneladas

-2 vagones G y 1 vagón $\mathrm{R}$. Resto de la Partida 11 y dos bultos correspondientes a las partidas 9 y 12 .

-Partida $11^{760}$ : dos direcciones de tiro modelo 40 con telémetros de $4 \mathrm{~m}$ $\mathrm{y}$ accesorios.

-Spetra/KM-53044/2-Ha/Co.- Salida de Perl: 29 de junio

•2 vagones “G”: 25.460 y 8.775.

•1 vagón "R": 36.656.

\section{TREN No 10}

-Fecha de llegada: 18 de julio de 1943

-Estación de llegada: 5 (Bibi)

-Peso total aproximado: 0,8 toneladas

-Un vagón G. Partida 31

-Partida 31: seis aparatos calculadores "Malsi" para dos grupos de 88 mm y seis juegos de transmisores (UTG 37) para dos grupos de $88 \mathrm{~mm}$.

-Spetra/KM-53048-Ha/Co.- Salida de Perl: 14 de julio

•1 vagón "G": 310.565

1/25.000, 34 juegos de dibujo completos y 34 estuches portaplanos. Todo este material se recibió en 13 empaques de madera perfectamente precintados. Acta de la Junta Facultativa del Parque de Zaragoza de 6 de julio de 1943. AGMAV. Caja 24.704. Fondo del antiguo Ministerio del Ejército.

${ }^{760}$ En realidad una dirección de tiro modelo 40 debía haber llegado en el tren $\mathrm{n}^{\circ} 4$, aunque hemos visto que el vagón en el que venía se retrasó, llegando varios días más tarde. En este tren se enviaron las otras dos direcciones de tiro que faltaban para completar el grupo de 88/56 mm recibido en el "Sofortprogramm". 


\section{TREN N 11}

-Feha de llegada: 20-julio de 1943

-Estación de llegada: 3 (Pepe)

-Peso total aproximado: 32,5 toneladas

-13 vagones G. Partidas 18,20 y resto de la 27

-Partida 18: tres radiolocalizadores “Lichtenstein" (Aire)

-Partida 20: 10.000 brocales de fusil

-Partida $27^{761}$ : 103 motos sin carro

-Spetra/KM-53049/Ha/Co.- Salida de Perl: 17 de julio

•13 vagones “G": 4.910, 75.853, 39.957, 37.342, 14.174, 3.913, 13.813, 17.944,

$111.427,9.435,271.930,136.980,33.736$.

\section{TREN No 12: No pertenecía al "Programa Bär"}

-Fecha de llegada: 14-agosto de 1943

-Estación de llegada: 5 (Bibi)

-Peso total aproximado: 95 Toneladas

•35 vagones R. Partida Fonos "Tepas” (fuera del Programa Bär).

-Partida fuera de programa: 35 fonolocalizadores "Tepas"

-Spetra/KM-53050/1/Ha/Dö.- Salida de Perl el 11 de agosto

•35 vagones “ $R$ ”: 41.608, 83.352, 82.197, 50.076, 80.543, 36.928, 77.739,

$25.532,80.419,26.075,921,15.530,20.787,38.253,19.218,841.668,16.681$, $44.068,4.389,4.388,45.140,75.853,3.501,9.488,60.364,83.708,626.655$, $41.652,17.982,16.711,30.534,91.488,20.279,30.359$ у 625.561 .

\footnotetext{
${ }^{761}$ En las relaciones de facturas alemanas adjudican a esta partida un supuesto tren $n^{\circ} 20$, que jamás existió en el "Sofortprogramm".
} 


\section{Carta fechada en Berlín el 12 de agosto de $1943^{762}$}

"Mi querido coronel y amigo:

Te adjunto nota relativa al tren $n^{\circ} 12$ que lleva 35 de los 71 fonolocalizadores "Tepas-Belge". Dentro de unos días y por la misma estación te enviaré otro tren con el resto de los "Tepas" y las partidas 29 y 30 de la primera relación o cupo.

Como ves, todo lo posible está conseguido y no se podrá enviar ni un clavo más si no se firman contratos. Esto no debiera retrasarse, creo yo, al menos por causa nuestra, pues cada vez se hará más difícil conseguir elementos que si en un día pudieron prescindir de ellos, quizás en el presente o en el futuro no ocurra así, especialmente en maquinaria. (...)

Fdo. Teniente coronel de Infantería Alfonso Romero de Arcos

Agregado Militar adjunto en Berlín”

\section{TREN No 13: No pertenecía al "Programa Bär"}

-Fecha de llegada: 21-agosto de 1943

-Estación de llegada: 1 (Pepe)

-Peso total aproximado: 98 Toneladas

•36 vagones R. Partida Fonos “Tepas” (fuera de Programa Bär)

-Partida fuera de programa: 36 fonolocalizadores "Tepas"

-Spetra/KM-53050/2/Ha/Dö.- Salida de Perl el 17 de agosto

•36 vagones "R": $61.407,40.510,18.503,33.119,64.839,86.768,86.835$,

$153.529,36.893,80.265,74.085,51.871,37.465,38.951,1.692,15.897,23.587$,

80.395, 457.106, 17.002, 735, 30.704, 27.781, 35.967, 36.484, 24.867, 49.798,

$597,27.679,60.151,44.031,35.828,2.677,17.146,95.592$ у 473.370.

El "Sofort Programm" comprendía 397 vagones de diversos tipos, y fue completado entre el 31 de mayo y el 20 de julio de $1943^{763}$.

\footnotetext{
${ }^{762}$ Embajada de España en Berlín. Agregado Militar. 12 de agosto de 1943. Carta remitida al coronel Jesús Aguirre, de la $4^{\circ}$ Sección del EMCE. AGMAV. Caja 24.707. Fondo del antiguo Ministerio del Ejército.

${ }^{763}$ AMAE. AR. Sig. R-2066-4.
} 


\section{C.- Resumen de trenes, vagones y pesos transportados en el "Sofortprogramm", con sus estaciones de destino.}

\begin{tabular}{|c|c|c|c|c|}
\hline Tren / Nºvagones & Estación "Tata" (n 1) & Estación "Pepe" (n+ 3) & Estación "Bibi" (n 5) & Peso (aprox.) \\
\hline$N^{\circ} 1 / 38$ vagones & & & 38 vagones $G$ & $500 \mathrm{Tm}$ \\
\hline$N^{\circ} 2 / 23$ vagones & 23 vagones $G$ & & & $75 \mathrm{Tm}$ \\
\hline $\mathrm{N}^{\mathrm{o}} 2 \mathrm{a} / 29$ vagones & 29 vagones $G$ & & & $100 \mathrm{Tm}$ \\
\hline$N^{\circ} 3 / 37$ vagones & & $\begin{array}{l}36 \text { vagones } R \text { y } \\
1 \text { vagón } G\end{array}$ & & $293 \mathrm{Tm}$ \\
\hline$N^{\circ} 4 / 37$ vagones & & & $\begin{array}{l}28 \text { vagones } R \text { y } \\
9 \text { vagones } G\end{array}$ & $230 \mathrm{Tm}$ \\
\hline$N^{0} 5 / 33$ vagones & $\begin{array}{l}32 \text { vagones } R \text { y } \\
1 \text { vagón } G\end{array}$ & & & $256 \mathrm{Tm}$ \\
\hline $\mathrm{N}^{\circ} 5 \mathrm{a} / 8$ vagones & 8 vagones $\mathrm{R}$ & & & $63 \mathrm{Tm}$ \\
\hline$N^{\circ} 6 / 38$ vagones & & 38 vagones $\mathrm{G}$ & & $165 \mathrm{Tm}$ \\
\hline $\mathrm{N}^{\circ} 7 / 28$ vagones & $\begin{array}{l}22 \text { vagones } G \text { y } \\
6 \text { vagones } R\end{array}$ & & & $367 \mathrm{Tm}$ \\
\hline $\mathrm{N}^{\mathrm{o}} 7 \mathrm{a} / 5$ vagones & 5 vagones $G$ & & & $78 \mathrm{Tm}$ \\
\hline$N^{o} 8 / 32$ vagones & & $\begin{array}{l}20 \text { vagones } \mathrm{G} y \\
12 \text { vagones } \mathrm{R}\end{array}$ & & $166 \mathrm{Tm}$ \\
\hline $\mathrm{N}^{\circ} 8 \mathrm{a} / 1$ vagón & & 1 vagón $\mathrm{G}$ & & $3 \mathrm{Tm}$ \\
\hline$N^{\circ} 9 / 3$ vagones & & & $\begin{array}{l}2 \text { vagones } G \text { y } \\
1 \text { vagón } R\end{array}$ & $45 \mathrm{Tm}$ \\
\hline $\mathrm{N}^{\circ} 10 / 1$ vagón & & & 1 vagón $\mathrm{G}$ & $1 \mathrm{Tm}$ \\
\hline $\mathrm{N}^{\mathrm{o}} 11 / 13$ vagones & & 13 vagones $G$ & & $32 \mathrm{Tm}$ \\
\hline 326 vagones & $\begin{array}{l}126 \text { vagones } \\
(80 \mathrm{G} \text { y } 46 \mathrm{R})\end{array}$ & $\begin{array}{l}121 \text { vagones } \\
\text { (73 G y } 48 \mathrm{R})\end{array}$ & $\begin{array}{l}79 \text { vagones } \\
(50 \mathrm{G} \text { y } 29 \mathrm{R})\end{array}$ & \\
\hline$\%$ vagones & $38,65 \%$ & $37,12 \%$ & $24,23 \%$ & \\
\hline CARGA & 939 Tm $(39,60 \%)$ & $656 \operatorname{Tm}(27,67 \%)$ & $776 \operatorname{Tm}(32,73 \%)$ & $2.371 \mathrm{Tm}$ \\
\hline
\end{tabular}

Fuente: Elaboración propia. 


\section{D.- Trenes ajenos al "Sofortprogramm" que transportaron los fonolocalizadores "Tepas" en las mismas fechas}

\begin{tabular}{|c|c|c|c|c|}
\hline Tren / $\mathbf{N}^{0}$ vagones & Estación "Tata" (n 1) & Estación "Pepe" (n 3) & Estación "Bibi" (n 5) & Peso (aprox.) \\
\hline$N^{0} 12 / 35$ “ & & & 35 vagones $R$ & $95 \mathrm{Tm}$ \\
\hline$N^{0} 13 / 36$ “ & 36 vagones $R$ & & & $98 \mathrm{Tm}$ \\
\hline
\end{tabular}

Fuente: Elaboración propia.

\section{E.- Coste de las partidas del "Sofortprogramm" (en marcos)}

(Las partidas de Marina se señalan con fondo azul claro, las del Ejército del Aire, con fondo azul oscuro y las del Ejército de Tierra, con fondo marrón)

\begin{tabular}{|c|c|c|}
\hline PARTIDA & MATERIAL & COSTE \\
\hline 1 & 4 cañones de $3,7 \mathrm{~cm} \mathrm{SK} \mathrm{C/30} \mathrm{en} \mathrm{afuste} \mathrm{doble} \mathrm{C/30} \mathrm{(154.400/ud.)}$ & 617.600 \\
\hline 2 & 16 cañones $3,7 \mathrm{~cm}$ SK C30 en afuste C/39 de subm. (60.000/ud) & 960.000 \\
\hline 3 & 10 Flak 38 de $2 \mathrm{~cm}$ en montaje C/30 (28.200/ud) & 282.000 \\
\hline 4 & cañones de repuesto de $3,7 \mathrm{~cm}$ & Incluido partida 1 \\
\hline 5 & 20.000 proyectiles de $2 \mathrm{~cm}(8,63 / \mathrm{ud})$ & 172.600 \\
\hline 6 & 48.800 proyectiles de $3,7 \mathrm{~cm}(32,90 / \mathrm{ud})$ & 1.605 .520 \\
\hline 7 & 500 minas EMC m $(3.000 / u d)$ & 1.500 .000 \\
\hline \multirow[t]{2}{*}{8} & 100 cargas de profundidad WBF (1.000/ud) & 100.000 \\
\hline & SUMA MATERIAL DE MARINA & 5.237 .720 \\
\hline $\mathrm{s} / \mathrm{n}$ & $\begin{array}{l}8 \text { equipos pesados de radio (móviles), cuatro de onda larga y } \\
\text { cuatro de onda corta }\end{array}$ & 1.689 .120 \\
\hline $\mathrm{s} / \mathrm{n}$ & 15 equipos ligeros de radio FuG 10 móviles & $429.000^{764}$ \\
\hline $\mathrm{s} / \mathrm{n}$ & 8 equipos radiogoniómétricos de navegación & 145.600 \\
\hline $\mathrm{s} / \mathrm{n}$ & 15 aviones de caza $\mathrm{Bf} 109 \mathrm{~F}-4$ & $2.827 .830^{765}$ \\
\hline
\end{tabular}

\footnotetext{
${ }^{764}$ En la negociación final, los equipos móviles terrestres FuG 10 fueron valorados en 28.600 marcos, frente a los 17.400 que logró la delegación española, por lo que la cifra global pasó de 261.000 a 429.000 marcos. AHEA. Leg. 11035 Sección 2, 3 y $15^{\text {a }}$ División, pág. 748

${ }^{765}$ Pese a que el precio pactado en las reuniones de la Subcomisión era de 3.415 .500 de marcos por toda la partida (243.540 marcos por avión con repuestos), se especificó que habría que reducir el precio de los aviones en un $1 \%$ por cada hora de vuelo de los aparatos que pasara de 10 horas. El precio final aprobado por Alemania fue de 2.827 .830 para toda la partida. En octubre de 1944 aparece esta cifra como total adeudado a Messerschmitt AG por los 15 aparatos con sus repuestos correspondientes. Todavía no se había pagado en esa fecha. AHEA. Leg. 11035 Sección 2, 3 y $15^{\text {a }}$ División, pág. 748
} 


\begin{tabular}{|c|c|c|}
\hline $\mathrm{s} / \mathrm{n}$ & $\begin{array}{l}10 \text { aviones de bombardeo Ju } 88 \mathrm{Z}-4 \text { (incluye el valor de los } \\
\text { repuestos) }\end{array}$ & 6.900 .000 \\
\hline 15 & 4 radiofaros de aterrizaje de 120 watios & $226.000^{766}$ \\
\hline 16 & 15 grupos electrógenos Still & 240.000 \\
\hline 17 & 1.000 .000 de cartuchos de 7,92 & 179.125 \\
\hline 18 & 3 localizadores de buques Liechtenstein & $90.000^{767}$ \\
\hline \multirow[t]{2}{*}{19} & 50 teléfonos de campaña 33 & 6.000 \\
\hline & SUMA MATERIAL DE AVIACIÓN & 12.732.675 \\
\hline 10 & 12 cañones antiaéreos de $88 / 56$ mm & 1.482 .410 \\
\hline 11 & 3 direcciones de tiro Mod. 40 completas & 501.880 \\
\hline 12 & 12 cañones antiaéreos de $20 \mathrm{~mm}$ & 356.400 \\
\hline 13 & 4 proyectores de $60 \mathrm{~cm}$ Siemens & 116.400 \\
\hline 14 & 4 telémetros R 36 de $1 \mathrm{~m}$ de base y herramientas & 19.200 \\
\hline 20 & 10.000 brocales & 1.520 .000 \\
\hline 21 & 1.000 fusiles lanzagranadas & 1.100 .000 \\
\hline 22 & 10.000 granadas de mano fumígenas & 43.100 \\
\hline 23 & 46.000 minas T-42 & 2.750 .000 \\
\hline 24 & 4.000 minas ligeras & Incluido en anterior \\
\hline 25 & 100 cañones de $122 / 46 \mathrm{~mm}$ & 11.200 .000 \\
\hline 26 & 3.000 proyectiles de $122 \mathrm{~mm}$ & 510.000 \\
\hline 27 & 400 motocicletas sin carro lateral & 593.840 \\
\hline 28 & 100 motocicletas con carro lateral $^{768}$ & 259.400 \\
\hline
\end{tabular}

${ }^{766} \mathrm{Se}$ intentó modificar la valoración de la última propuesta debido a que los equipos enviados eran de 120 watios en lugar de 500 watios, que fueron los que se pidieron. La oferta española era de 140.000 marcos en lugar de los 226.000 solicitados. Pero al final, en la contabilidad del Ejército del Aire siguen figurando los 226.000 como pagados por estos radiofaros AHEA. Leg. 11035 Sección 2, 3 y $15^{\text {a }}$ División, pág. 937 y 748.

${ }^{767}$ Pese a que se habían solicitado en un primer momento 342.000 marcos, el precio real cobrado por los alemanes fue de 90.000 por los tres radares, según consta en la valoración final del "Programa Bär" del Ejército del Aire. AHEA. Leg. 11035 Sección 2, 3 y 15ª División, pág. 748

${ }^{768}$ Aunque ya se ha comentado en el capítulo 5, como se pactaron dos precios diferentes para las motos del "Sofortprogramm" y las del "Restprogramm", se utilizó un precio medio unitario para valorar las motos BMW R75: 2.594 marcos. Por esta razón el importe de esta primera factura -259.400 marcosdifería del concertado para estas 100 motocicletas. 


\begin{tabular}{|l|l|r|}
\hline 29 & 6 equipos repetidores de alta frecuencia (multiamplificadores) & $\begin{array}{r}\text { No recibidos. Pasaron } \\
\text { al "Restprogramm"- }\end{array}$ \\
\hline 30 & 20 teletipógrafos mecánicos & $\begin{array}{r}\text { No recibidos. Pasaron } \\
\text { al "Restprogramm"- }\end{array}$ \\
\hline 31 & 6 aparatos Malsi y 6 UTG 37 para baterías 88/56 & 265.710 \\
\hline & SUMA MATERIAL DE TIERRA & $\mathbf{2 0 . 7 1 8 . 3 4 0}$ \\
\hline & TOTAL & $\mathbf{3 8 . 6 8 8 . 7 3 5}$ \\
\hline
\end{tabular}

En azul claro, las pertenecientes a Marina, en azul oscuro, las del Ejército del Aire y en negro, las pertenecientes al Ejército de Tierra. Fuente: Elaboración propia.

\section{ANEXO XIV}

\section{Programa Restante (“Restprogramm”)}

\section{A.- Partidas que componían esta fase del Programa}

(Las partidas de Marina se señalan con fondo color azul claro, las del Ejército del Aire, con fondo azul oscuro y las del Ejército de Tierra, con fondo marrón)

(En tipografía roja, se señala el material que no llegó a España; en azul, el que llegó sólo una parte, y en negra, el que llegó todo lo previsto en el Programa)

\begin{tabular}{|c|l|l|l|l|}
\hline PARTIDA & \multicolumn{1}{|c|}{ MATERIAL } & \multicolumn{1}{|c|}{ EJÉRCITO } & TRENES & \multicolumn{1}{|c|}{ NOTAS } \\
\hline $\mathbf{1}$ & ANULADA & Marina & & No llegaron \\
\hline $\mathbf{2}$ & $\begin{array}{l}\text { 10 radiogoniómetros 280 } \\
\text { S para submarinos, con } \\
\text { cuadro especial 1000 } \\
\text { NIX, Receptor para T3 } \\
\text { TLL }\end{array}$ & Marina & & \\
\hline $\mathbf{3}$ & $\begin{array}{l}\text { 8 motores F para } \\
\text { submarinos (Brown- } \\
\text { Boveri) con empaque }\end{array}$ & Marina & No llegaron $^{770}$ \\
\hline
\end{tabular}

\footnotetext{
${ }^{769}$ Correspondían tres de ellos a los necesarios para montar en los tres submarinos españoles tipo D y los otros siete, para los tipo G que se fabricarían en España, incluyendo uno de reserva. La casa Telefunken, fabricante de los mismos, comunicó al Agregado Naval español, capitán de fragata Espinosa, a finales del mes de octubre de 1944, que tres de ellos, correspondientes a los tipo D, junto a los diez aparatos transformadores de tensión, estaban listos para ser enviados. Así mismo, interesó del oficial español para saber si los otros siete gonios comprendidos en la partida 1 del Programa Bär, todavía interesaban al Ministerio de Marina. APFE. Embajada en España en Berlín. Agregado Naval. Telegrama transmitido $n^{\circ}$ 812.

${ }^{770}$ El 19 de octubre de 1944 la agencia de transportes Schenker había recibido la orden del Agregado Naval en Berlín de recoger los motores Brown-Boveri que se encontraban en Friburgo para ser transportados a Suiza. El capitán de fragata Espinosa escribió al Estado Mayor de la Armada que comunicaría la llegada de estos motores al citado país. APFE. Embajada en España en Berlín. Agregado Naval. Telegrama transmitido $\mathrm{n}^{\circ} 774$
} 


\begin{tabular}{|c|c|c|c|c|}
\hline 4 & $\begin{array}{l}4 \text { periscopios verticales } \\
\text { de observación para } \\
\text { submarinos }\end{array}$ & Marina & & No llegaron \\
\hline 5 & $\begin{array}{l}4 \text { periscopios de mira } \\
\text { nocturna para } \\
\text { submarinos }\end{array}$ & Marina & & No llegó ninguno \\
\hline 6 & $\begin{array}{l}1 \text { instalación de } \\
\text { cineteodolito (Askania) } \\
\text { sin cable acorazado para } \\
\text { gran distancia }\end{array}$ & Marina & 23 y 26 & Llegó \\
\hline 7 & $\begin{array}{l}30 \text { emisoras de radio de } \\
\text { onda corta (Lorenz) S } 18 \\
20 \mathrm{SII} 40 \mathrm{~W}, 18-100 \mathrm{~m} \\
\text { con grupo electrógeno, } \\
\text { corriente continua } 24 \\
\text { voltios y transformador } \\
\text { de corriente alterna }\end{array}$ & Marina & & No llegó ninguna \\
\hline 8 & $\begin{array}{l}880 \text { válvulas de radio Lt } \\
\text { según especificaciónn }\end{array}$ & Marina & & No llegó ninguna \\
\hline 9 & $\begin{array}{l}20 \text { receptores de onda } \\
\text { corta (Telefunken) de } 6 \\
\text { círculos F-437 S }\end{array}$ & Marina & & $\begin{array}{l}\text { Fueron destruidos en el } \\
\text { tren 27. No llegó } \\
\text { ninguno } 771\end{array}$ \\
\hline 10 & ANULADA & Marina & & \\
\hline 11 & $\begin{array}{l}800-900 \text { toneladas de } \\
\text { material de acero para } \\
\text { cascos de submarinos } \\
\text { tipo G }\end{array}$ & Marina & & No llegó ninguno \\
\hline 12 & $\begin{array}{l}6 \text { cañones de marina de } \\
10,5 \mathrm{~cm} \text { SK C/35 en } \\
\text { cureña doble } C / 37 \text { para } \\
\text { cañoneros }\end{array}$ & Marina & & No llegó ninguno \\
\hline 13 & $\begin{array}{l}17.400 \text { proyectiles de } \\
\text { varios tipos para cañón } \\
\text { de } 10,5 \mathrm{~cm}\end{array}$ & Marina & & No llegaron \\
\hline 14 & $\begin{array}{l}38 \text { cañones antiaéreos de } \\
3,7 \mathrm{~cm} \mathrm{S.K.} \mathrm{en} \mathrm{montaje} \\
\text { doble }\end{array}$ & Marina & 17,21 y 24 & Llegaron 32 piezas \\
\hline 15 & $\begin{array}{l}\text { 160.000 proyectiles mod. } \\
\text { 40/L4,1 Lh37 para piezas } \\
\text { de } 3,7 \mathrm{~cm}\end{array}$ & Marina & $17,20,23$ y 26 & Llegaron 142.000 \\
\hline 16 & 22 piezas de $2 \mathrm{~cm}$ Flak & Marina & 17,21 y 24 & Llegaron todas \\
\hline
\end{tabular}

${ }^{771}$ Fueron destruidos los 20 receptores en Francia, mientras se realizaba el transporte en el tren 27. La casa Telefunken comunicó al Agregado Naval español si todavía interesaba la entrega, para preparar otros 20 aparatos. APFE. Embajada en España en Berlín. Agregado Naval. Telegrama transmitido n 812. 


\begin{tabular}{|c|c|c|c|c|}
\hline & 38 en montaje cuádruple & & & \\
\hline 17 & $\begin{array}{l}176.000 \text { proyectiles } \\
\text { explosivos de } 2 \mathrm{~cm} \text { con } \\
\text { traza roja para Flak } \\
\text { cuádruple }\end{array}$ & Marina & 20 y 26 & Llegaron todos \\
\hline 18 & $\begin{array}{l}40 \text { piezas de } 2 \mathrm{~cm} \text { Flak } \\
38 \text { en montaje de } \\
\text { candelero }\end{array}$ & Marina & 17 y 21 & Llegaron 30 piezas \\
\hline 19 & $\begin{array}{l}80.000 \text { proyectiles de } 2 \\
\text { cm Flak } 38\end{array}$ & Marina & 20 y 26 & Llegaron 60.000 \\
\hline 20 & $\begin{array}{l}34 \text { cañones de } 10,5 \mathrm{~cm} \\
\text { SK C/32 en montaje } \\
\text { C/32 para torpederos }\end{array}$ & Marina & 21,23 y 24 & Llegaron 12 piezas \\
\hline 21 & $\begin{array}{l}34.010 \text { proyectiles de } \\
\text { varios tipos para cañón } \\
\text { de } 10,5 \mathrm{~cm} \mathrm{SK} \mathrm{C/32}\end{array}$ & Marina & 23 y 26 & Llegaron 11.400 \\
\hline 22 & $\begin{array}{l}20 \text { anteojos de } \\
\text { observación de } 10 \text { × } 80\end{array}$ & Marina & 10 & Llegaron todos \\
\hline 23 & $\begin{array}{l}35 \text { cañones antiaéreos de } \\
3,7 \mathrm{~cm} \text { SK C/30 en } \\
\text { afuste de submarino }\end{array}$ & Marina & $10,21,23$ y 24 & Llegaron todos \\
\hline 24 & $\begin{array}{l}70.000 \text { proyectiles } \\
\text { explosivos para piezas de } \\
3,7 \mathrm{~cm} \text { en montaje para } \\
\text { submarinos }\end{array}$ & Marina & $17,20,23$ y 26 & Llegaron 57.500 \\
\hline $\mathbf{s} / \mathbf{n}$ & $\begin{array}{l}6 \text { lanchas rápidas tipo } \\
\text { grande }\end{array}$ & Marina & & $\begin{array}{l}\text { Llegaron todas por vía } \\
\text { marítima }\end{array}$ \\
\hline 25 & $\begin{array}{l}4 \text { direcciones de tiro } \\
\text { EWA, para cada } 4 \text { piezas } \\
\text { antiaéreas de } 10,5 \mathrm{~cm} \text { de } \\
\text { cañonero con turbina }\end{array}$ & Marina & & No llegó ninguna \\
\hline 26 & $\begin{array}{l}9 \text { direcciones de tiro para } \\
\text { puesto de mando de } \\
\text { torpedero tipo "Le Fier" }\end{array}$ & Marina & & No llegó ninguna \\
\hline 27 & 500 minas EMC & Marina & 8 y 10 & Llegaron todas \\
\hline 28 & $\begin{array}{l}1.900 \text { cargas de } \\
\text { profundidad W.B.F. }\end{array}$ & Marina & 10,24 y 26 & Llegaron $300^{772}$ \\
\hline
\end{tabular}

${ }^{772}$ De estas 300 cargas de profundidad W.B.F., 100 fueron recibidas en el tren $\mathrm{n}^{\circ} 10$, otras 100 en el $\mathrm{n}^{\circ}$ $24 \mathrm{y}$ otras cien en el tren $\mathrm{n}^{\circ} 26$. Parece ser que estas últimas nunca se recibieron, pues la empresa Schenker las extravió. Así consta en diversos telegramas del Estado Mayor de la Armada dirigidos al Agregado Naval en Berlín, para que reclame a la empresa de transportes el importe cobrado por dicho transporte, y a la Ageka, suministradora del material, el importe de las cargas, que ascendía a 100.000 RM. APFE. Embajada en España en Berlín. Agregado Naval. Telegramas recibidos $n^{\circ}$ 11276/5292, $11286 / 5463,11297 / 5567,11325 / 6175$ y $11356 / 6216$ y telegramas transmitidos $\mathrm{n}^{\mathrm{o}} 808$. 


\begin{tabular}{|c|c|c|c|c|}
\hline 29 & $\begin{array}{l}12 \text { Telémetros de } 2 \mathrm{~m} \\
\text { Goertz }\end{array}$ & Marina & 10 & Llegaron todos \\
\hline 30 & $\begin{array}{l}20 \text { Telémetros de } 1,25 \mathrm{~m} \\
\text { Zeiss }\end{array}$ & Marina & 10 & Llegaron todos \\
\hline 31 & $\begin{array}{l}3.200 \mathrm{Kg} \text { de vidrio } \\
\text { óptico }\end{array}$ & Marina & 26 & Llegaron $3.216,66 \mathrm{Kg}$ \\
\hline $31 \mathrm{a}$ & $\begin{array}{l}1 \text { radiotelémetro con } \\
\text { instalación para } \\
\text { destructores }\end{array}$ & Marina & 26 & No llegó ${ }^{773}$ \\
\hline $31 b$ & $\begin{array}{l}6 \text { motores de reserva MB } \\
501 \text { para lanchas rápidas }\end{array}$ & Marina & 10 & Llegaron todos \\
\hline 32 & $\begin{array}{l}108 \text { cañones antiaéros } \\
\text { Flak } 36 \text { y } 27 \text { direcciones } \\
\text { de tiro Modelo } 40\end{array}$ & $\begin{array}{l}\text { Aire-(pasaron a } \\
\text { Tierra) }\end{array}$ & $7,16,18$ y 22 & $\begin{array}{l}\text { Llegaron } 84 \text { cañones y } \\
21 \text { direcciones de tiro }\end{array}$ \\
\hline 33 & $\begin{array}{l}156 \text { cañones antiaéreos } \\
\text { de } 2 \mathrm{~cm} \text { Flak } 28 \\
\text { Oerlikon con } 40 \\
\text { proyectores y } 30 \\
\text { telémetros de } 1 \mathrm{~m}\end{array}$ & $\begin{array}{l}\text { Aire-(pasaron a } \\
\text { Tierra) }\end{array}$ & $\begin{array}{l}3,6,16,18 \\
22,27 \text { y } 28\end{array}$ & $\begin{array}{l}\text { Llegaron } 108 \text { cañones } \\
\text { de } 2 \mathrm{~cm} \text { Flak } 28,44 \\
\text { telémetros de } 1 \mathrm{~m} \text { y } 16 \\
\text { proyectores. } \\
\text { Otras } 48 \\
\text { ametralladoras, ocho } \\
\text { telémetros y ocho } \\
\text { proyectores viajaban } \\
\text { en los trenes } 27 \text { y } 28 \text {. } \\
\text { Las ametralladoras } \\
\text { fueron devueltas a } \\
\text { Alemania y los } \\
\text { telémetros y } \\
\text { proyectores fueron } \\
\text { destruidos en Francia }\end{array}$ \\
\hline 34 & $\begin{array}{l}100 \text { radioemisoras VR } \\
27 \mathrm{~b} \text { (onda corta) })^{774}\end{array}$ & Aire & & No llegaron \\
\hline 35 & $\begin{array}{l}100 \text { equipos electro- } \\
\text { generadores EM-4 }\end{array}$ & Aire & 6 y 27 & $\begin{array}{l}\text { Llegaron } 50 \text {. Los otros } \\
50 \text { venían en el tren n } \\
27 \text {, que nunca llegó a } \\
\text { España }\end{array}$ \\
\hline 36 & $\begin{array}{l}26 \text { radiolocalizadores } \\
\text { Freya }\end{array}$ & Aire & 18 & Llegó 1 ejemplar \\
\hline 37 & $\begin{array}{l}26 \text { radiolocalizadores } \\
\text { Würzburg } 39 \text { TD }\end{array}$ & $\begin{array}{l}\text { Aire-(9 de ellos } \\
\text { pasaron a Tierra) }\end{array}$ & 4 & $\begin{array}{l}\text { Llegaron } 10 \\
\text { ejemplares }\end{array}$ \\
\hline 38 & $\begin{array}{l}3 \text { localizadores S Fu } \\
\text { G213 "Lichtenstein" }\end{array}$ & Aire & 25 y 28 & $\begin{array}{l}\text { Los Lichtenstein se } \\
\text { perdieron en el tren } n^{\circ} \\
25 . \text { Un cajón con }\end{array}$ \\
\hline
\end{tabular}

${ }^{773}$ Parece que estaba previsto recibirlo en el tren $n^{\circ} 26$, pero fue extraviado y lo cierto es que nunca se recibió. Su precio, 239.560 RM fue reclamado por el Estado Mayor de la Armada a ROWAK. APFE. Embajada en España en Berlín. Agregado Naval. Telegrama recibido nº 11356/6216.

${ }^{774}$ Eran de la casa Philips, holandesa, similares a las alemanas FuG3. 


\begin{tabular}{|c|c|c|c|c|}
\hline & & & & $\begin{array}{l}\text { respetos para estos } \\
\text { localizadores venía en } \\
\text { el tren } n^{\circ} 28 .\end{array}$ \\
\hline 39 & $\begin{array}{l}6 \text { radiogoniómetros para } \\
\text { instalación en aviones }\end{array}$ & Aire & & $\begin{array}{l}\text { Anulada por ser los } \\
\text { mismos Lichtenstein } \\
\text { de la partida anterior }\end{array}$ \\
\hline 40 & $\begin{array}{l}12 \text { estaciones de radio de } \\
\text { onda corta AS } 59 \\
\text { (Telefunken) }\end{array}$ & Aire & 22 & Llegaron todas \\
\hline 41 & $\begin{array}{l}22 \text { temporizadores para } \\
\text { señalización radio } \\
\text { Morsen (Pintsch) }\end{array}$ & Aire & 16 & Llegaron todos \\
\hline 42 & $\begin{array}{l}50 \text { teléfonos de campaña } \\
\text { Mod. } 33\end{array}$ & Aire & & $\begin{array}{l}\text { Llegaron en el } \\
\text { "Sofortprogramm" }\end{array}$ \\
\hline 43 & $\begin{array}{l}85 \text { radioemisoras Fu G } \\
10 \text { (Lorenz) de onda } \\
\text { corta y larga para } \\
\text { instalación a bordo }{ }^{775}\end{array}$ & Aire & 6,12 y 25 & $\begin{array}{l}\text { Llegaron } 40 \text {. Otras } 45 \\
\text { FuG } 10 \text { y } 63 \text { válvulas } \\
\text { se perdieron en el tren } \\
\mathrm{n}^{\circ} 25 .\end{array}$ \\
\hline 44 & $\begin{array}{l}20 \text { Fu.G.7 a.F } 1 \text { aparato } \\
\text { de a bordo con material } \\
\text { de montaje y cables }\end{array}$ & Aire & 6 & Llegaron todos \\
\hline $44 a$ & $\begin{array}{l}27 \text { fonolocalizadores } \\
\text { RRH }\end{array}$ & $\begin{array}{l}\text { Aire-(pasaron a } \\
\text { Tierra) }\end{array}$ & 6 & Llegaron todos \\
\hline $44 b$ & $\begin{array}{l}27 \text { fonolocalizadores } \\
\text { RRH }\end{array}$ & $\begin{array}{l}\text { Aire-(pasaron a } \\
\text { Tierra) }\end{array}$ & $12,16,18$ y 22 & Llegaron todos \\
\hline $44 c$ & $\begin{array}{l}15 \text { radioemisoras de } 100 \\
\text { watios (Lorenz) de onda } \\
\text { larga. Instalación de } \\
\text { tierra }\end{array}$ & Aire & & No llegaron \\
\hline 44d & 100 goniómetros GV & Aire & & $\begin{array}{l}\text { Anulados a petición } \\
\text { española }\end{array}$ \\
\hline $44 \mathrm{e}$ & $\begin{array}{l}100 \text { aparatos de abordo } \\
\text { Fu BL1 }\end{array}$ & Aire & 12 & Llegaron todos \\
\hline 44 f y $44 g$ & $\begin{array}{l}16+5 \text { goniómetros } \\
\text { Adcock }\end{array}$ & Aire & & No llegaron \\
\hline $44 h$ & $\begin{array}{l}\text { Repuestos para } 9 \text { equipos } \\
\text { de vuelo. Bombarderos. } \\
\text { Dotaciones. }\end{array}$ & Aire & $\mathbf{s} / \mathbf{n}$ & $\begin{array}{l}\text { Correspondían al } \\
\text { "Sofortprogramm". } \\
\text { Llegaron todos. } \\
\text { Recibidos en Port Bou }\end{array}$ \\
\hline
\end{tabular}

$\overline{775}$ En la relación española se habían soicitado $100 \mathrm{FuG}$ 10, aunque los alemanes sólo concedieron 85 de estas estaciones

${ }^{776}$ Se trataba de las partidas numeradas por Ageka como 62B y 62C. La 62 B consistía en ocho goniómetros fijos y otros ocho móviles, todos ellos de la casa Telefunken. La partida $62 \mathrm{C}$ comprendía cinco goniómetros de la casa Lorenz. AHEA. Correspondencia del Agregado Aéreo en Berlín. A-11035. 


\begin{tabular}{|c|c|c|c|c|}
\hline & & & & $\begin{array}{l}\text { en dos vagones el } 21 \\
\text { de enero de 1944. Tren } \\
\text { ajeno al Programa }\end{array}$ \\
\hline 45 & $\begin{array}{l}110.000 \text { granadas contra } \\
\text { carros de } 6,6 \mathrm{~cm} \text { para } \\
\text { fusil especial }\end{array}$ & Tierra & $\begin{array}{l}3,24,25,27 y \\
28\end{array}$ & $\begin{array}{l}\text { Llegaron } 49.000 \text {. } \\
14.000 \text { se perdieron en } \\
\text { el tren } n^{\circ} 25 \\
\text { Otras } 44.000 \text { granadas } \\
\text { venían en el tren } 27 \text { y } \\
\text { fueron destruidas en } \\
\text { Francia. }\end{array}$ \\
\hline 46 & $\begin{array}{l}200.000 \text { granadas contra } \\
\text { carros de } 6,6 \mathrm{~cm} \text { para } \\
\text { fusil ordinario }\end{array}$ & Tierra & 24,25 y 28 & $\begin{array}{l}\text { Llegaron } 20.000 \text {. } \\
20.000 \text { se perdieron en } \\
\text { el tren } n^{\circ} 25 \\
\text { Otras } 96.000 \text { granadas } \\
\text { (correspondientes a } \\
\text { ésta y a la anterior } \\
\text { partida) venían en el } \\
\text { tren } 28 \text { y fueron } \\
\text { destruidas en Francia. }\end{array}$ \\
\hline 47 & $\begin{array}{l}110.000 \text { cartuchos de } \\
\text { proyección para fusil } \\
\text { lanzagranadas }\end{array}$ & Tierra & $\begin{array}{l}3,24,25,27 y \\
28\end{array}$ & $\begin{array}{l}\text { Llegaron } 29.000 \text {. } \\
14.000 \text { se perdieron en } \\
\text { el tren } n^{\circ} 25 \\
\text { Otros } 45.000 \text { venían en } \\
\text { los trenes } 27 \text { y } 28 \text { y } \\
\text { fueron destruidas en } \\
\text { Francia. }\end{array}$ \\
\hline 48 & $\begin{array}{l}150 \text { cañones contra } \\
\text { carros de } 2,5 \mathrm{~cm} \\
\text { (franceses) }\end{array}$ & Tierra & 5 & Llegaron todos \\
\hline 49 & $\begin{array}{l}30.000 \text { proyectiles } \\
\text { perforantes de } 2,5 \mathrm{~cm} \\
\text { mod. } 114\end{array}$ & Tierra & 5 y 21 & $\begin{array}{l}\text { Aumentada a } 48.760 \\
\text { proyectiles. Llegaron } \\
\text { todos }\end{array}$ \\
\hline 50 & $\begin{array}{l}30.000 \text { proyectiles } \\
\text { perforantes trazadoras de } \\
2,5 \mathrm{~cm} \text { mod. } 115\end{array}$ & Tierra & 21 & $\begin{array}{l}\text { Cambiada por } 11.240 \\
\text { trazadores, del mod. } \\
115(4.320) \text { y } 116 \\
(6.920) . \text { Llegaron } \\
\text { todos }\end{array}$ \\
\hline 51 & $\begin{array}{l}\text { 4.000 Proyectiles } \\
\text { perforantes explosivos } \\
\text { para brocal (de } 6,6 \mathrm{~cm} \\
\text { francesas) }\end{array}$ & Tierra & 5 & Llegaron todos \\
\hline 52 & $\begin{array}{l}150 \text { cañones contracarro } \\
\text { de } 7,5 \mathrm{~cm} \text { Pak } 40 \mathrm{con} \\
\text { accesorios }\end{array}$ & Tierra & 13,19 y 21 & Llegaron todos \\
\hline 53 & $\begin{array}{l}45.000 \text { proyectiles } \\
\text { rompedores HL/C } 38 \text { y } \\
\text { Mod. } 34 \text { para cañón }\end{array}$ & Tierra & 15 y 24 & $\begin{array}{l}22.500 \text { del modelo } 38 \\
\text { HLC y } 22.500 \text { del } \\
\text { modelo } 34 . \text { Llegaron }\end{array}$ \\
\hline
\end{tabular}




\begin{tabular}{|c|c|c|c|c|}
\hline & $\begin{array}{l}\text { contracarro de } 7,5 \mathrm{~cm} \\
\text { Pak } 40\end{array}$ & & & todos \\
\hline 54 & $\begin{array}{l}6.000 \text { minas magnéticas } \\
\text { H } 3\end{array}$ & Tierra & 7 & Llegaron todas \\
\hline 55 & $\begin{array}{l}10.000 \text { granadas de mano } \\
\text { fumígenas }\end{array}$ & Tierra & 3 & Llegaron todas \\
\hline 56 & 50.000 minas $\mathrm{T}-42$ & Tierra & 11 & Llegaron todas \\
\hline 57 & $\begin{array}{l}50 \text { cañones de } 12.2 \mathrm{~cm} \\
\mathrm{~L} / 46390 / 2(\mathrm{r})\end{array}$ & Tierra & 1,4 y 23 & Llegaron todos \\
\hline 58 & $\begin{array}{l}12.000 \text { granadas } \\
\text { rompedoras de } 12,2 \mathrm{~cm}\end{array}$ & Tierra & 2 & Llegaron todas \\
\hline 59 & $\begin{array}{l}20 \text { carros de combate } \\
\text { Panzer IV L/48 Ausf. H } \\
\text { con doble dotación de } \\
\text { municiones } \\
\text { Se amplió con otros dos } \\
\text { carros más en versión de } \\
\text { mando }\end{array}$ & Tierra & 17 & $\begin{array}{l}\text { Llegaron los } 20 \text { carros } \\
\text { de línea. } \\
\text { Los carros de mando } \\
\text { nunca se recibieron }\end{array}$ \\
\hline 60 & $\begin{array}{l}10 \text { cañones de asalto } \\
\text { StuG III G }\end{array}$ & Tierra & 14 & $\begin{array}{l}\text { Llegaron los } 10 \\
\text { cañones de asalto }\end{array}$ \\
\hline 61 & $\begin{array}{l}4.000 \text { proyectiles de } 7,5 \\
\text { cm rompedores mod. } 34 \\
\text { y } 6.000 \text { perforantes mod. } \\
39 \text {, para carros de } \\
\text { combate. } 63.840 \\
\text { proyectiles perforantes y } \\
\text { otros } 63.840 \text { rompedores } \\
\text { para ametralladora. } 20 \\
\text { cargas explosivas Z- } 72 \text { y } \\
\text { otras } 20 \text { Z- } 85\end{array}$ & Tierra & 19 y 21 & $\begin{array}{l}\text { Se trataba de dos } \\
\text { dotaciones de } \\
\text { munición para carros } \\
\text { de combate Llegaron } \\
\text { todos los proyectiles. } \\
\text { Las dotaciones de } \\
\text { munición para los } \\
\text { carros de mando } \\
\text { venían en el tren } 28 \text { y } \\
\text { fueron destruidas en } \\
\text { Francia. }\end{array}$ \\
\hline 62 & $\begin{array}{l}2.500 \text { proyectiles de } 7,5 \\
\text { cm rompedores mod. } 34 \text {, } \\
\text { y } 2.500 \text { perforantes mod. } \\
39 \text { para cañones de } \\
\text { asalto. } 31.920 \text { proyectiles } \\
\text { perforantes y otros } \\
31.920 \text { rompedores para } \\
\text { ametralladora. } 10 \text { cargas } \\
\text { explosivas Z-72 y otras } \\
10 \text { Z-85. } 21.260 \\
\text { cartuchos de varios tipos } \\
\text { para subfusil MP } 40 .\end{array}$ & Tierra & 19 y 21 & $\begin{array}{l}\text { Se trataba de dos } \\
\text { dotaciones de } \\
\text { munición para cañones } \\
\text { de asalto. } \\
\text { Llegaron todos los } \\
\text { proyectiles de } 75 \mathrm{~mm} \\
\text { y } 15.600 \text { de } \\
\text { ametralladora de cada } \\
\text { modelo }\end{array}$ \\
\hline 63 & $\begin{array}{l}375 \text { ametralladoras MG } \\
34\end{array}$ & & 15,19 y 21 & Llegaron todas \\
\hline 64 & $\begin{array}{l}650 \text { motocicletas con } \\
\text { carro lateral (BMW) }\end{array}$ & Tierra & $3,6,9,12$ y 25 & $\begin{array}{l}\text { Llegaron todas. Se } \\
\text { perdieron en el tren }\end{array}$ \\
\hline
\end{tabular}




\begin{tabular}{|c|c|c|c|c|}
\hline & & & & $\begin{array}{l}\mathrm{n}^{0} 25,200 \text { ruedas de } \\
\text { repuesto }\end{array}$ \\
\hline 65 & $\begin{array}{l}16 \text { aparatos de } \\
\text { localización por el } \\
\text { sonido Tfb } 1 \text { y ocho Tfb } \\
2 \text { de alta frecuencia. } \\
20 \text { puentes (compra } \\
\text { supletoria) (Siemens) }\end{array}$ & Tierra & 24 y 27 & $\begin{array}{l}\text { No llegó ningún Tfb } 1 \\
\text { y Tfb } 2.8 \mathrm{Tfb} 1 \text { y } 2 \\
\text { Tfb } 2 \text { fueron } \\
\text { destruidos en el tren } 27 \\
\text { en Francia } \\
\text { Llegaron los } 20 \\
\text { puentes }\end{array}$ \\
\hline 66 & $\begin{array}{l}6 \text { aparatos de telefonía } \\
\text { MEK- } 8 \text { y } 12 \text { de la misma } \\
\text { clase MEK } 3 \text { (AEG) }\end{array}$ & Tierra & $19,23,26$ y 27 & $\begin{array}{l}\text { Llegaron } 4 \text { MEK-8 y } 2 \\
\text { MEK-3. } \\
\text { Otros cuatro MEK } 3 \\
\text { viajaban en el tren } 27 \text { y } \\
\text { fueron devueltos a } \\
\text { Alemania. }\end{array}$ \\
\hline 67 & $\begin{array}{l}40 \text { amplificadores } \\
\text { terminales para batería } \\
\text { (Siemens) }\end{array}$ & Tierra & 27 & $\begin{array}{l}\text { No llegó nada. Fueron } \\
\text { destruidos en Francia.. } \\
\text { Venían en el tren } 27\end{array}$ \\
\hline 68 & $\begin{array}{l}110 \text { auriculares } \\
\text { amplificadores de } \\
\text { escucha (Siemens) }\end{array}$ & Tierra & & No llegó nada \\
\hline 69 & $\begin{array}{l}10 \text { equipos repetidores } \\
\text { de baja frecuencia de } 3 \\
\text { canales con accesorios }\end{array}$ & & 4 y 19 & Llegaron todos \\
\hline 70 & $\begin{array}{l}1.000 \text { kilómetros de } \\
\text { cable telefónico } \\
\text { reforzado para } \\
\text { conducción a gran } \\
\text { distancia Feldernkabel } \\
\text { (FFK)y accesorios } \\
\text { (Siemens) }\end{array}$ & Tierra & 27 y 28 & $\begin{array}{l}\text { No llegó nada. Los } \\
\text { primeros } 150 \mathrm{~km} \\
\text { venían en los trenes } 27 \\
\text { y } 28, \text { y fueron } \\
\text { destruidos en Francia }\end{array}$ \\
\hline 71 & $\begin{array}{l}75 \text { teletipógrafos de } \\
\text { campaña }\end{array}$ & Tierra & 21 y 28 & $\begin{array}{l}\text { Llegaron } 60 . \\
\text { Los otros } 15 \text { venían en } \\
\text { el tren } 28 \text { y resultaron } \\
\text { destruidos en Francia. }\end{array}$ \\
\hline 72 & $\begin{array}{l}40 \text { teletipógrafos } \\
\text { mecánicos y } 40 \text { aparatos } \\
\text { amplificadores } \\
\text { (Siemmens) }\end{array}$ & Tierra & 4,19 y 21 & $\begin{array}{l}\text { Llegaron } 20 \\
\text { teletipógrafos y } 20 \\
\text { amplificadores }\end{array}$ \\
\hline 73 & $\begin{array}{l}40 \text { aparatos terminales } \\
\text { WT- } 40 \text { de } 6 \text { canales } \\
\text { (eran } 20 \text { equipos de } \\
\text { telegrafía armónica) }\end{array}$ & Tierra & 19,26 y 28 & $\begin{array}{l}\text { Llegaron } 4 \text { WT- } 40 . \\
\text { Una caja de accesorios } \\
\text { venía en el tren } 28 \text { fue } \\
\text { destruida en Francia. }\end{array}$ \\
\hline 74 & $\begin{array}{l}100 \text { estaciones de radio } \\
\text { de } 15 \text { watios SE. } 469 \text { a } \\
\text { (Telefunken) }\end{array}$ & Tierra & 7,19 y 26 & Llegaron 50 \\
\hline
\end{tabular}




\begin{tabular}{|c|c|c|c|c|}
\hline 75 & $\begin{array}{l}10 \text { receptores de radio } \\
\text { Tipo } 860 \mathrm{BS} \text { o R } 15 / 36 \\
\text { (f) de onda corta (Ageka) }\end{array}$ & Tierra & 7 & Llegaron todos \\
\hline 76 & $\begin{array}{l}10 \text { receptores de radio de } \\
\text { onda corta y extracorta y } \\
\text { batería de } 12 \text { voltios }\end{array}$ & Tierra & & No llegó nada \\
\hline 77 & $\begin{array}{l}40 \text { receptores de mochila } \\
\text { de onda corta (Lorenz) }\end{array}$ & Tierra & 7 & Llegaron todos \\
\hline 78 & $\begin{array}{l}10 \text { radiogoniómetros de } \\
\text { onda media y larga } \\
\text { Funkpeiler A/B }\end{array}$ & Tierra & 7 & Llegaron todos \\
\hline 79 & 12.770 válvulas de radio & Tierra & & No llegó nada \\
\hline 80 & $\begin{array}{l}2 \text { estaciones radio } \\
\text { transmisoras-receptoras } \\
\text { de } 200 \text { watios AS-1008 } \\
\text { (Telefunken) }\end{array}$ & Tierra & 7 & Llegaron todas \\
\hline 81 & $\begin{array}{l}10 \text { transmisoras de radio } \\
\text { onda corta de } 1 \mathrm{Kw}\end{array}$ & Tierra & 7 & Llegaron todas \\
\hline 82 & $\begin{array}{l}4.500 \text { proyectiles de } \\
\text { rabiza "Stiel" para Pak } \\
35 / 36 \text { de } 3,7 \mathrm{~cm}\end{array}$ & Tierra & 23 & Llegaron todos \\
\hline 83 & $\begin{array}{l}45.381 \text { proyectiles para } \\
\text { cañón contra carro de } 2,5 \\
\text { cm (f) mod. } 118 \text { y } 4.619 \\
\text { mod. } 117\end{array}$ & Tierra & & No llegó nada \\
\hline 84 & $\begin{array}{l}10.000 \text { proyectiles } \\
\text { perforantes para cañón } \\
\text { contracarro de } 7,5 \mathrm{~cm} \\
\text { Pak } 40\end{array}$ & Tierra & 15,19 y 21 & Llegaron todos \\
\hline $\mathbf{s} / \mathbf{n}$ & $\begin{array}{l}2 \text { cañones de campaña de } \\
7,5 \mathrm{~cm} \text { españoles } \\
\text { transformados }\end{array}$ & Tierra & 23 & Llegaron \\
\hline $\begin{array}{l}\text { Fuera de } \\
\text { Programa }\end{array}$ & $\begin{array}{l}\text { Fonolocalizadores Tepas } \\
\text { Belge }\end{array}$ & Tierra & & $\begin{array}{l}\text { Llegaron } \\
\text { Otros } 16 \text { que venían en } \\
\text { los trenes } 27 \text { y } 28 \\
\text { fueron destruidos en } \\
\text { Francia }\end{array}$ \\
\hline
\end{tabular}

Fuente: Elaboración propia. AGMAV. Cajas 24.707, 24.708 y 24.714. 


\section{B.- Trenes del "Restprogramm"}

\section{TREN No 1}

-Fecha de llegada: 26-septiembre de 1943

-Estación de llegada: 3 (Pepe)

-Peso total aproximado: 300 toneladas

-33 vagones $\mathrm{R}$ y un vagón $\mathrm{G}$. Partida 57.

-Partida 57 (incompleta): 33 piezas rusas de 12,2 cm y accesorios.

(Partida Ageka: 77)

-Spetra/KM-53051/Ha./Co.- Salida de Perl: 22-9-1943

•33 vagones “ $R$ ”: 91.112, 632.522, 87.190, 4.333, 3.815, 337.593, 685.413,

$92.109,96.265,206,4.743,43.755,90.105,31.590,96.623,44.390,12.601$,

70.934, 50.901, 70.890, 37.566, 75.160, 42.876, 36.515, 30.524, 23.264, 66.116,

$32.941,44.788,26.534,27.824,77.599$ у 85.431 .

•1 vagón "G": 6.630

\section{TREN No 2}

-Fecha de llegada: 24-septiembre de 1943

-Estación de llegada: 1 (Tata)

-Peso total aproximado: 480 toneladas

-32 vagones $\mathrm{G}^{777}$. Partida 58

-Partida 58 (completa): 12.000 proyectiles de $12,2 \mathrm{~cm}^{778}$. (Partida

Ageka: 78)

-Spetra/KM-53052/Ha./Co.- Salida de Perl: sobre el 21 de septiembre

\footnotetext{
${ }^{777}$ En principio, había preparados 32 vagones "G" para conformar este tren. El enorme peso del convoy hizo que diez de ellos fueran retenidos y se incorporaran al tren $\mathrm{n}^{\circ} 5$, donde los tendremos en cuenta.

778 Por dificultades de última hora este tren solo transportó 22 vagones. Los otros 10 fueron con el tren $\mathrm{n}^{\mathrm{o}}$ 5, que llegó a Irún el 13 de octubre de 1943. El problema real para retrasar estos vagones fue el enorme peso del tren con los 32 vagones. De los diez vagones retrasados que salieron con el tren $n^{\circ} 5$, uno quedó en Francia retenido y los otros nueve, fueron enviados al Parque de Artillería de Valladolid, donde se estaban reuniendo todos los proyectiles de esta clase.
} 
•22 vagones “G": 78.611, 95.751, 6.776, 51.301, 12.504, 15.847, 95.129, 49.027, 93.356, 35.930, 153.637, 60.162, 30.727, 57.285, 3.187, 76.307, 34.115, $21.668,11.719,95.397,32.573,12.238$.

\section{TREN No 3}

-Fecha de llegada: 2-octubre de 1943

-Estación de llegada: 5 (Bibi)

-Peso total aproximado: 158,5 toneladas

•23 vagones G y 17 vagones $R$. Partidas 33, 45, 47, 55 y 64

-Partida 33: 72 Flak 28 Oerlikon de $2 \mathrm{~cm}$ y 24 proyectores de $60 \mathrm{~cm}$. (Partida Ageka: 39)

-Partida 45: 40.000 granadas para fusil lanzagranadas especial (con banda reforzada) con sus cartuchos de proyección. (Partida Ageka: 65)

-Partida 47: 20.000 cartuchos de proyección mod 318 para granada contra carro. (Partida Ageka: 67)

-Partida 55: 10.000 granadas de mano fumígenas. (Partida Ageka: 75)

-Partida 64: 100 motos pesadas BMW con sidecar. (Partida Ageka: 85)

-Spetra/KM-53053/Ha./Co.- Salida de Perl: 28 de septiembre de 1943

•23 vagones “G”: 257.087, 130.662, 653, 79.304, 7.552, 40.062, 81.758, $33.430,80.043,90.239$, 40.106, 83.705, 41.222, 90,116, 41.425, 81.038, 80.691, $33.206,81.298,40.038,162.902$ y 38.886 .

•17 vagones “R”: 1.728, 96.296, 47.172, 60.054, 18.447, 15.056, 91.637, $94.876,70.096,31.729,40.195,43.809,76.277,74.904,28.137,15.297$ y 69.810 .

\section{TREN No 4}

-Fecha de llegada: 10-octubre de 1943

-Estación de llegada: 3 (Pepe)

-Peso total aproximado: 182 toneladas

- 27 vagones R y cuatro vagones G. Partidas 37, 57, 69 y 72 (incompletas)

-Partida 37: 10 radiolocalizadores "Würzburg" 39 T.D. (Aire) 
-Partida 57: 17 piezas rusas de 12,2 cm K 390/2 con accesorios. (Partida Ageka: 77)

-Partida 69: 6 equipos repetidores baja frecuencia. (Partida Ageka: 91)

-Partida 72: 3 inscriptores de cinta (Teletipógrafos mecánicos). (Partida Ageka: 94)

-Spetra/KM-53054/Ha./Co.- Salida de Perl: 7 de octubre

•26 vagones "R" ${ }^{\text {"779 }: ~ 72.871, ~ 65.378, ~ 74.965, ~ 78.276, ~ 19.987, ~ 41.261, ~ 84.879, ~}$

67.536, 40.374, 35.169, 21.563, 687, 77.594, 87.531, 50.397, 14.462, 46.941,

$45.154,42.332$, 19.976, 47.386, 91.126, 730, 463.530, 65.802 у 1.723 .

•4 vagones "G": 5.635, 90.832, 724 y 3.757.

\section{TREN N 5}

-Fecha de llegada: 13 de octubre 1943

-Estación de llegada: 1 (Tata)

-Peso total aproximado: 252 toneladas

- 12 vagones $R$ y cuatro vagones $G$ (más otros 10 vagones $G$ que no pudieron ir con el tren $\mathrm{n}^{\mathrm{o}} 2$ ). Partidas 48 y 51 completas y 49 incompleta $^{780}$.

-Partida 48: 150 cañones contracarro de 2,5 cm (f). (Partida Ageka: 68)

-Partida 49: 23.000 G.P de 25 mm mod. 114 f. (Partida Ageka: 69)

-Partida 51: 4.000 G.P. 6,6. (Partida Ageka: 71)

-Spetra/KM-53055/Ha./Co.- Salida de Perl: 5 de octubre

•12 vagones “R": $74.769,82.984,27.028,12.887,15.976,91.826,18.350$, $83.035,47.683,24.478,152.318$ y 1.365 .

•14 vagones “G”: 72.317, 61.931, 97.537, 12.465, 16.131, 60.597, 139.314, $12.940,40.842,20.064,4.456,37.610,3.093$ у 95.129

\footnotetext{
${ }^{779}$ Al parecer, según informaciones del Agregado Militar Adjunto en carta remitida al coronel Jesús Aguirre el 8 de octubre de 1943, este tren llevaba 27 vagones R en lugar de 26. Desconocemos el número de este vagón adicional.

${ }^{780}$ Llegaron con este tren nueve vagones con disparos de 122/46, que fueron remitidos a Valladolid para reunirse con el resto de disparos. El décimo vagón quedó detenido en París (Francia) junto a otro más de este mismo tren que transportaba 12 cañones contracarro de $25 \mathrm{~mm}$. Tanto cañones de $25 \mathrm{~mm}$ como disparos para los mismos (partidas 51 y 42) quedaron en Irún guardados en 28 vagones cerrados y precintados con guardia militar, a la espera de resultados de las gestiones de cambio llevadas a cabo en Berlín por el Agregado militar. Como dichas gestiones de cambio no dieron resultado, dichos vagones fueron remitidos a la Maestranza de Artillería de Burgos.
} 


\section{TREN No 6}

-Fecha de llegada: 14 de octubre 1943

-Estación de llegada: 5 (Bibi)

-Peso total aproximado: 187 toneladas

• 14 vagones $\mathrm{R}$ y 29 vagones $\mathrm{G}$. Partidas 33, 35, 43, 44, 44a, 44b y 64

-Partida 33: 24 telémetros Em 1m R 36. (Partida Ageka: 39)

-Partida 35: 50 E.M.4 (Elektro Maschinensätze 2 W 220) (Aire)

-Partida 43: 30 Fu.G.10 onda larga, equipos de abordo (Lorenz) (Aire)

-Partida 44: 20 Fu.G.7 a.F.1m (Aire)

-Partida 44a ${ }^{\mathbf{7 8 1}}$ : 24 Fonos RRH. (Electroacustic) (Partida Ageka: 38a)

-Partida 44b: 3 fonos RRH. (Electroacustic) (Partida Ageka: 38b)

-Partida 64: 150 motocicletas BMW con sidecar. (Partida Ageka: 85)

-Spetra/KM-53056/Ha./Co.- Salida de Perl: 11 de octubre

•14 vagones “ $R$ ": 4.279, 83.590, 39.511, 18.390, 32.957, 76.226, 24.533, 8.740, $45.543,2.274,244,72.692,36.970$ у 75.876 .

•29 vagones “G”: 39.640, 38.525, 20.520, 19.114, 84.243, 4.836, 80.065, 7.634, $84.197,41.709,40.063,40.685,32.934,80.045,40.699,225.402$, 40.522, 225.361, 93.058, 1.710.509, 5.359, 2.277, 4.307, 83.226, 41.806, 34.675, $82.277,82.052$ y 8.519 .

\section{TREN N 7}

-Fecha de llegada: 28 de octubre 1943

-Estación de llegada: 3 (Pepe)

-Peso total aproximado: 358 toneladas

-11 vagones G y 26 vagones $R$. Partidas $32,54,74,75,77,78,80$ y 81

\footnotetext{
${ }^{781}$ Los fonolocalizadores RRH de la partida, la "44 a" estaban pensados para complementar las baterías antiaéreas existentes en España para las que no se disponía de estos medios de localización. En la terminología germana del programa se las conocía como ("für die alten Condorbatterien") En cambio, los incluidos en la partida " 44 b", eran para las baterías de $88 / 56 \mathrm{~mm}$ adquiridas en el propio "Programa Bär".
} 
-Partida 32: 24 Flak 8,8 cm (12 piezas en montaje fijo y 12 móviles), seis direcciones de tiro mod.40 y seis equipos y máquinas de transmisión mod. 37. (Partida Ageka 38)

-Partida 54: 6.000 minas magnéticas H-3. (Partida Ageka 74)

-Partida 74: 50 estaciones de radio de 15 watios. (Partida Ageka 96)

-Partida 75: 10 receptores de radio Tip. 860 BS. (Partida Ageka 97)

-Partida 77: 40 receptores de mochila; onda corta. (Partida Ageka 99).

-Partida 78: 10 radiogoniómetros Peiler A. (Partida Ageka 100)

-Partida 80: dos estaciones de radio de 200 vatios. (Partida Ageka 102)

-Partida 81: 10 emisoras de 1 kilovatio. (Partida Ageka 103)

-Spetra/KM-53057/Ha./Co.- Salida de Perl: 25 de octubre

•11 vagones “G": 36.810, 20.007, 82.107, 37.188, 5.750, 4.895, 87.394, 26.556, $93.595,357.171$ у 22.430 .

•26 vagones “ $R$ ": 41.130, 1.111, 49.410, 34.971, 39.326, 52.755, 38.956, 19.072, 67.043, 75.904, 72.000, 18.714, 77.624, 45.924, 46.865, 92.086, $463.613,60.747,27.347,32.372,95.131,33.411,76.805,46.780,85.103$ у 15.618 .

\section{TREN No 8}

-Fecha de llegada: 21 de octubre 1943

-Estación de llegada: 1 (Tata)

-Peso total aproximado: 332 toneladas

-29 vagones G. Partida 27.

-Partida 27: 300 minas E.M.C. (Marina)

-Spetra/KM-53058/Ha./Dö.- Salida de Perl: 17 de octubre

•29 vagones “G": 1.993, 7.380, 4.954, 69.235, 10.286, 39.832, 20.108, 18.210, $12.955,202.243,2.468,27.980,23.304,17.658,1.258,88.259,8.855,84.138$, $17.857,38.841,759,23.653,47.294,95.274,22.272,78.611,52.944,32.513$ y 320.640 


\section{TREN No 9}

-Fecha de llegada: 22 de octubre 1943

-Estación de llegada: 5 (Bibi)

-Peso total aproximado: 90 toneladas

-33 vagones G. Partida 64.

-Partida 64: 200 motocicletas BMW con sidecar. (Partida Ageka: 85)

-Spetra/KM-53059/Ha./Co.- Salida de Perl: 19 de octubre

•33 vagones “G”: $33.198,6.404,32.959,33.316,8.116,5.362,5.176,6.824$, $33.871,80.293,8.309,5.712,3.356,32.176,6.027,119.886,223.248,225.169$, 223.713, 223.180, 81.783, 80.493, 80.568, 6.206, 33.996, 6.094, 5.469, 80.159, $83.585,223.826,33.196,83.583,223.686$.

\section{TREN N ${ }^{0} 10$}

-Fecha de llegada: 1 de noviembre 1943

-Estación de llegada: 1 (Tata)

-Peso total aproximado: 291 toneladas

-5 vagones R, 2 vagones OM y 22 vagones G. Partidas 22, 23, 27, 28, 29, 30 y $31 b$.

-Partida 22: 20 Prismáticos de 10x80 (Marina)

-Partida 23: 10 cañones 3,7 cm SK C/30 en afuste de submarino.

(Marina). (Partida Ageka 26)

-Partida 27: 200 minas E.M.C. (Marina)

-Partida 28: 100 cargas de profundidad W.B.F. (Marina). (Partida Ageka 32)

-Partida 29: 12 telémetros de 2 m (Goerz). (Marina)

-Partida 30: 20 telémetros de 1,25 m (Zeiss). (Marina)

-Partida 31b: 6 motores de reserva MB 501 para Schnellboote.

(Marina)

-Spetra/KM-53060/Ha./Co.- Salida de Perl: 29 de octubre

•5 vagones “R”: 43.614, 86.681, 49.467, 80.282 y 63.725 .

•2 vagones “OM”: 46.314 y 4.147. 
•22 vagones “G": 99.714, 40.023, 2.246, 40.249, 11.160, 98.338, 23.181, 296.490, 6.094, 320.034, 272.826, 260.530, 155.429, 37.433, 268.490, 12.573, $264.979,290.245,22.435,182.895,149.067$ y 156.326 .

\section{TREN No 11}

-Fecha de llegada: 2 de noviembre 1943

-Estación de llegada: 5 (Bibi)

-Peso total aproximado: 507 toneladas

-36 vagones G. Partida 56. (Partida Ageka: 76)

-Partida 56: 50.000 minas modelo T. (Partida Ageka: 76)

-Spetra/KM-53061/Ha./Co.- Salida de Perl: 30-10-1943

•36 vagones “G”: 98.701, 59.827, 69.254, 94.110, 23.198, 29.665, 36.399, 3.286, 3.285, 43.261, 77.070, 69.795, 182.344, 8.805, 94.782, 18.414, 4.386, 93.649, 97.701, 70.500, 17.191, 11.801, 84.951, 40.987, 66.310, 43.997, 85.508, $11.768,17.662,28.247,63.641,20.560,40.185,6.775,61.412$ у 73.533.

\section{TREN No 12}

-Fecha de llegada: 8 de noviembre 1943

-Estación de llegada: 5 (Bibi)

-Peso total aproximado: 117 toneladas

33 vagones G y 4 vagones R. Partidas 43, 44b, 44c y 64.

-Partida 43: 10 instalaciones de abordo Fu.G. 10. (Partida Ageka 59)

(Aire)

-Partida 44b: 6 Fonos RRH con remolque. (Partida Ageka: 38a)

-Partida 44c: 100 aparatos de a bordo Fu. BL. (Partida Ageka: 59)

(Aire)

-Partida 64: 200 motos pesadas con carro lateral. (Partida Ageka: 85) •Spetra/KM-53062/Ha./Co.- Salida de Perl:5-11-1943

•33 vagones “G”: 16.312, 84.220, 6.576, 83.050, 1.850, 91.261, 78.083, $223.712,83.448,41.459,34.456,84.060,5.734,5.558,80.694,223.077,80.226$, 
4.521, 319.374, 92.530, 41.479, 34.840, 229.388, 41.451, 223.206, 79.613,

$90.135,83.289,33.739,91.268,81.913,5.638$ у 225.354 .

•4 vagones “ $R$ ": 34-420, 4.718, 64.909 y 71.120.

\section{TREN N ${ }^{0} 13$}

-Fecha de llegada: 20 de noviembre 1943

-Estación de llegada: 3 (Pepe)

-Peso total aproximado: 115 toneladas

-19 vagones especiales. Partida 52.

-Partida 52: 75 cañones contracarros de 75 mm Pak-40 con accesorios. (Partida Ageka 72)

-Spetra/KM-53063/Ha./Fi.- Salida de Perl: 16-11-1943

•19 vagones “Especiales": 80.236, 83.395, 40.227, 81.770, 91.254, 40.026,

$41.272,90.323,40.627,41.724,80.231,83.366,78.058,90.116,81.869$ y

78.041

\section{TREN No 14}

-Fecha de llegada: 15 de noviembre 1943

-Estación de llegada: 1 (Tata)

-Peso total aproximado: 222 toneladas

•10 vagones FFM (especiales) y 1 vagón G. Partida 60.

-Partida 60: 10 piezas de asalto StuG III con dos dotaciones de municiones (excluidas las del cañón). (Partida Ageka 80)

-Spetra/KM-53064/Ha./Co.- Salida de Perl: 12-11-1943

•10 vagones “FFM": 1.325, 8.128, 13.326, 9.372, 13.314, 9.602, 19.543, 3.067, 21.011 y 13.248 ,

•1 vagón “G”: 33.731 . 


\section{TREN N $\mathbf{N}^{0} 15$}

-Fecha de llegada: 22 de noviembre 1943

-Estación de llegada: 3 (Pepe) $)^{782}$

-Peso total aproximado: 357 toneladas

- 25 vagones G. Partidas 53, 63 y 84.

-Partida 53: 22.500 granadas rompedoras para c.c.c. de 75 mm Pak-40. (Partida Ageka 73)

-Partida 63: 200 ametralladoras M.G. 34. (Partida Ageka 84)

-Partida 84: 4.000 granadas perforantes para c.c.c. de 75 mm Pak-40. (Partida Ageka 73a)

-Spetra/KM-53065/Ha./Fi.- Salida de Perl: 19-11-1943

•25 vagones “G”: 2.658, 45.287, 372.900, 79.642, 181.986, 66.297, 71.089, 20.090, 216.583, 32.207, 120.314, 43.198, 18.366, 8.474, 11.594, 362.590, $184.081,267.498,11.055,24.017,13.209,57.546,85.676,17.998$ y 20.395 .

\section{TREN N 16}

-Fecha de llegada: 16 de diciembre 1943

-Estación de llegada: 5 (Bibi)

-Peso total aproximado: 105 toneladas

- 12 vagones $R$ y tres vagones $G$. Partidas $32,33,41$ y 44b.

-Partida 32: 12 Flak de 8,8 cm (en montaje fijo), tres direcciones de tiro mod.40 con tres telémetros y tres equipos y máquinas de transmisión mod. 37. (Partida Ageka 38)

\footnotetext{
${ }^{782}$ Fue el último tren que entró por la estación $n^{\text {o }} 3$ (Pepe), debido a que la afluencia de material disponible para enviar había disminuido y el ritmo era, por tanto, más lento. Como el material había de distribuirse entre la tres estaciones, esto obligaba a que, al tardar más en completar trenes, parte de ellos estaban expuestos varios días a bombardeos y los vagones inmovilizados, eran necesarios para realizar otros transportes. Fue por ello que la casa Schenker, adjudicataria del transporte, propuso al Agregado militar suprimir una estación y como Marina deseaba recibir su material por la estación $\mathrm{n}^{\mathrm{o}} 1$ (Irún) y Aviación por la $n^{\circ} 5$ (Port-Bou), se decidió suprimir la $n^{\circ} 3$. Así consta en una carta fechada en Berlín el 12 de noviembre de 1943, remitida por el $2^{\circ}$ Agregado Militar (Alfonso Romero de Arcos) al coronel jefe

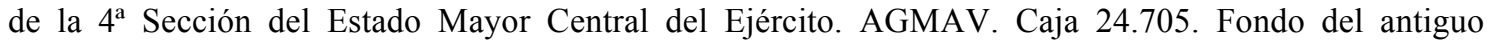
Ministerio del Ejército. "Transporte de Mercancías entre Alemania y España (1943-1944)"
} 
-Partida 33: 12 Flak 28 de $2 \mathrm{~cm}$ Oerlikon, cuatro proyectores de $60 \mathrm{~cm}$ y 20 telémetros de $1 \mathrm{~m}$ R-36. (Partida Ageka 39)

-Partida 41: 22 temporizadores de radio señalización. (Aire) (Partida Ageka s/n)

-Partida 44b: seis fonos RRH. (Partida Ageka 38a)

-Spetra/KM-53066/Ha./Fi.- Salida de Perl: 11 ó 12 -12-1943

•12 vagones “R": 3.033, 86.698, 27.601, 47.708, 4.725, 28.782, 4.403, 22.334, $41.028,15.509$ у 60.932 .

•3 vagones “G”: 80.294, 196.898 y 42.764 .

\section{TREN No $17^{783}$}

-Fecha de llegada: 3 de diciembre 1943

-Estación de llegada: 1 (Tata)

-Peso total aproximado: 723 toneladas

-9 vagones G, 11 vagones R y 20 FFM (especiales). Partidas 14, 15, 16, 18, 24 y 59.

-Partida 14: 16 piezas de 3,7 cm S.K. doppellafette. (Marina). (Partida Ageka 16)

-Partida 15: 16.000 proyectiles mod. $40 \mathrm{~L} / 4,1 \mathrm{Lh} 37$ para piezas de 3,7 cm en montaje doble C/30 (Marina). (Partida Ageka 17)

-Partida 16: 8 piezas de $2 \mathrm{~cm}$ Flak 38 Vierling. (Marina). (Partida Ageka 18)

-Partida 18: 20 piezas de $2 \mathrm{~cm}$ Flak 38 en candelero. (Marina). (Partida Ageka 22)

-Partida 24: 20.000 proyectiles para piezas de 3,7 $\mathrm{cm}$ en montaje de submarino. (Marina). (Partida Ageka 27)

-Partida 59: 20 carros de combate mod. IV L/48 con doble dotación de municiones. (Partida Ageka 79)

-Spetra/KM-53067/Ha./Fi.- Salida de Perl: 29 ó 30-12-1943

•9 vagones “G”: 15.609, 76.290, 23.327, 13.722, 9.553, 30.463, 77.613, 18.445 y 241.813 .

\footnotetext{
${ }^{783}$ En el tren n ${ }^{\text {o }} 17$ sólo fueron 38 vagones de los 40 que componían en citado tren. Dos de ellos se retrasaron y fueron por separado.
} 
•11 vagones "R": 3.808, 45.018, 49.721, 43.807, 82.175, 85.187, 93.249, $38.067,354,33867$ y 45.101.

•20 vagones "FFM": 3.495, 12.679, 23.020, 1.193, 22.624, 9.992, 14.364,

8.153, 6.606, 8.997, 9.613, 20.310, 5.434, 20.905, 3.010, 12.139, 15.071, $20.630,5.067$ y 6.264 .

\section{Carta fechada en Berlín el 9 de diciembre de $1943^{784}$}

"Mi querido coronel:

Con esta carta te mando unas cuantas cosas que te iré relacionando a continuación.

1.- Una copia más decente del aviso del tren $\mathrm{n}^{\mathrm{o}} 17$ (...)

5.- Una colección de notas en que van ligeramente reseñadas las facturas que se han autorizado para que sean pagadas por la AGEKA, a cuenta del crédito que le habéis abierto para pago de material.

Yo había querido mandarte las traducciones completas de estas facturas, y ya estaban hechas, pero esto ha sido una de las cosas que se han quemado.

Y hablando de la quema, te diré que también se han quemado los contratos que teníamos firmados y todos los antecedentes y notas de Guiloche sobre material de transmisiones. Todo lo tenía en un armario en la oficina con otras cosas mías, la mayor parte alimenticias: café, leche condensada, etc... y todo quedó en la hoguerita. (...)

Hoy que tengo más tiempo te voy a contar algo de las aventuras pasadas los últimos días y del estado actual de la vida por aquí.

Yo aguanté el primer bombardeo en el sótano de mi casa en Berlín, que también ha ardido totalmente, $\mathrm{y}$, chico, la verdad, no me daba tiempo a respirar; poco después se hizo físicamente más dificil porque crujía la casa y las paredes al desconcharse llenaron el sótano de un polvo que casi no se veía; los que tenían careta (máscara antigás) se la pusieron y los que no la teníamos tosíamos. La nota cómica la dio una pobre mujer que no sabiendo que ponerse metió la cabeza dentro de un cubo y a modo de casco le llegaba a descansar en los hombros y lo sujetaba con las manos. Cuando la cosa parecía que amainaba, salí al patio un poco por curiosidad y otro poco para respirar, y vi que ardía el tejado de la casa; traté de convencer a los vecinos de que debíamos subir y apagar aquello pero como todavía caían algunas bombas, no lo consideró oportuno el hombre del casco

\footnotetext{
${ }^{784}$ Embajada de España en Berlín. Carta remitida el 9 de diciembre de 1943 al coronel jefe del la $4^{\text {a }}$ Sección del EMCE. AGMAV. Caja 24.707. Fondo del antiguo Ministerio del Ejército.
} 
(Jefe de la casa para estos casos, y que se le conoce porque lleva casco). Poco después parece que le convencieron y subimos un comandante de aviación alemán, otro hombre con careta y yo, después apareció una mujer. Con los cubos de agua y una bomba, apagamos dos focos en el tejado pero el tercero necesitaba una bomba de bomberos de verdad; aquí tosí más que en el sótano, el humo hace más daño que el polvo.

Bajamos nuevamente al sótano y al fin tuvimos que salir por el de la casa de al lado: yo me había quemado un poco el cogote y todo el traje, el mejorcito que tenía, también quemado por los goterones de alquitrán, brea o chapapote, que fundidos se desprendían del cartón con que tienen la manía de cubrir los tejados.

Por cierto que ahora se me ocurre sería muy instructivo para los arquitectos interesados en la defensa pasiva, hacer una visita a Berlín, y estudiar los efectos sobre los diferentes tipos de construcción. Tienen un amplio campo donde hacer observaciones. (...)

Cuando salí a la calle, por la casa de al lado, había cesado la alarma, pero el espectáculo era imponente; ríete de Nerón y de la película "San Francisco", manzanas enteras ardían al mismo tiempo, un viento huracanado llevaba las chispas, muchas de ellas del tamaño de naranja, en nubes, de acera a acera, pero que no queman, pues como son gordas, tropiezan con el cuerpo o dan en la cabeza y caen al suelo y no ha pasado nada. Las calles, sabes, son anchas, pues bien, algunas era imposible seguirlas, las llamas de ambos lados se cruzaban y en algunos sitios te volqueaban. Yo volví a entrar en mi casa desde la calle, subí al piso, las puertas y las ventanas y los quicios en el suelo, y las persianas y las cortinas ardían, tomé mis cosas en una maleta y un saco y volví a salir como un mozo de estación, un bulto delante y otro detrás unidos por el cinturón y de esa guisa, y parándome de asombro y cansancio, de cuando en cuando, contemplaba lo grandioso del espectáculo que parecía imposible. Como a un kilómetro de la mía, encontré sin quemar una casa conocida y dejé el equipaje, eran las dos de la madrugada y no había comido.

Me fui a buscar un sitio donde pudiera dormir un poco, la casa conocida, si bien no se había quemado, no tenía ni cristales ni persianas, y hacía un frío del demonio. Con igual panorama llegué al Eden Hotel, también había sido tocado y el quinto piso ardía el llamas, pero en lo que era el bar había butacas vacías ya que mucha gente había marchado a buscar otros sitios más saludables. Me encontré allí a Castro, el teniente coronel médico, y decididos a dormir un poco subimos al tercer piso y yo me acondicioné en la habitación de Pumarola, éste había salido hacia la representación de la División, que estaba entera pero con mucho humo, no obstante las circunstancias, el alojamiento me pareció expléndido. Dormí tres horas, me comí una onza de chocolate y fui a la oficina, que ya sabía por Castro, había ardido a primera hora, para ver si se había salvado alguien. 


Me encontré entonces a Marín y juntos llegamos, no quedaban
más que las paredes y en el jardín los papeles que llenaban dos autos.
Trabajando hicimos una rampa con los escombros y a las tres de la
tarde sacamos los coches como en el circo, convoy, carrera de
obstáculos, cables, escombros, más escombros, contramarchas,
rodeos, etc, etc, y por fin nos vimos en la carretera, de milagro no me
perdí siete veces, al fin, a las seis y media llegué al pueblo donde vive
Marín, de noche y preguntando, porque hasta tuve reventón y cambio
de rueda y en casa de Espinosa me lavé y cené caliente, ya me había
olvidado de estos menesteres porque, claro, tampoco al mediodía
habíamos comido. (...)
Ya se va reestableciendo todo pero con las dificultades
naturales y eso que esta gente ha hecho verdaderos milagros. Si me
faltaba alguna razón más para admirar este pueblo la he adquirido
ahora plenamente: si son grandes en sus victorias, he podido apreciar
que lo son mucho más en sus desgracias. No he visto ni lloros, ni
protestas, ni palabras inútiles, ni multitudes alocadas, más que
resignación, es un estoicismo al que no creí se pudiera llegar; aprietan
los dientes y se ponen a trabajar desde el primer instante como si
hubiera sido un terremoto y no fuera a volver a repetirse.
No obstante, yo para ir a la oficina tardo dos horas en ir y dos
en volver, e igual les pasa a las mecanógrafas y demás personal y esto
con tres cambios de tren y esperas a veces de más de 20 minutos.
Luego el trabajo sin máquinas, sin casi papel, sin un sitio seguro
donde dejar las cosas de un día para otro, se hace cada vez más penoso
y menos lucido.
Yo tengo varias comunicaciones preparadas para AGEKA y
OKW pero como son en alemán debe hacérmelas una de las chicas
alemanas que estos días no está pues la pobre ha perdido su casa y a
sus padres en el sótano de ella. En fin, muchas dificultades pero ya ves
que se hace lo que se puede. (...)
Yabes te quiere.
Fada más, un abrazo de tu buen amigo y subordinado que
Militar adjunto en Berlín"

\section{TREN N ${ }^{0} 18$}

-Fecha de llegada: 10 de enero 1944

-Estación de llegada: 5 (Bibi)

-Peso total aproximado: 280 toneladas

-30 vagones R y 5 vagones G. Partidas 32, 33, 36 y 44b (incompletas). 
-Partida 32: 24 piezas Flak de 8,8 cm móviles, tres direcciones de tiro mod.40 y seis equipos y máquinas de transmisión mod. 37. (Partida Ageka 38)

-Partida 33: 24 piezas Flak 28 de $2 \mathrm{~cm}$ y 8 proyectores de $60 \mathrm{~cm}$.

(Partida Ageka 39)

-Partida 36: un radiolocalizador FREYA FuMG (Flum) $41 \mathrm{G}$ (cB) Nr. 5140 Hersteller “AEG”. (Aire) (Partida Ageka 49)

-Partida 44b: tres fonos RRH con accesorios. (Partida Ageka 38a) -Spetra/KM-53068/Ha./Fi.- Salida de Perl: 5 de enero de 1944 •30 vagones “ $R$ ”: 8.517, 46.177, 19.689, 5.225, 29.922, 27.933, 92.371, 10.423, 4.776, 83.974, 196.057, 49.382, 60.597, 43.290, 68.102, 92.247, 462.716, 1.348, 509, 31.060, 11.085, 153.587, 2.881, 5.198, 12.058, 73.008, 4.359, 6.307, 629.683 у 682.455 .

•5 vagones “G”: 30.891, 154.015, 22.960, 261.519 y 9.862.

\section{TREN sin número}

-Fecha de llegada: 21 de enero 1944

-Estación de llegada: 5 (Bibi)

-Peso total aproximado: 20 toneladas

-2 vagones G. Partida 44h

-Partida 44h: repuestos y accesorios para 10 Junkers Ju 88. (Aire)

(Partida Ageka 37)

-Spetra/KM-103001/Ha./Fi.- Salida de Perl: 18 de enero de 1944

•2 vagones “G”: 40.273 y 105.965

\section{TREN No 19}

-Fecha de llegada: 2 de febrero 1944

-Estación de llegada: 1 (Tata)

-Peso total aproximado: 275 toneladas

-32 vagones G. Partidas 74, 72, 69, 61, 62, 52, 63, 84, 66, 72 у 73. 
-Partida 52: 50 cañones contracarro de 7,5 cm Pak 40. (Partida Ageka 72)

-Partidas 61 y 62: 2.400 disparos de 7,5 $\mathrm{cm}$ mod.34, 3.600 disparos de 7,5 cm mod.39, 63.840 cartuchos SmK para MG-34, 63.840 disparos trazadores para M.G.-34, 20 cargas Z-72 y 20 cargas Z-85. (Para carros de combate). (Partida Ageka 81a y b)

-Partida 63 ${ }^{785}: 100$ ametralladoras M.G. 34. (Partida Ageka 84)

-Partida 66: 2 aparatos MEK-8. (Partida Ageka 88)

-Partida 69: 4 equipos repetidores de baja frecuencia. (Partida Ageka 91)

-Partida 72: 4 teletipógrafos mecánicos y 20 aparatos amplificadores.

(Partida Ageka 94)

-Partida 73: 4 aparatos terminales WT-40. (Partida Ageka 95)

-Partida 74: 50 estaciones de radio de 15 Watios. (Partida Ageka 96)

-Partida 84: 4.000 disparos de 7,5 cm para cañón contracarro Pak 40. (Partida Ageka 73a)

-Spetra/KM-103000/Ha./Fi.- Salida de Perl: 29-1-1944

•32 vagones “G": 854, 20.025, 7.104.518, 93.549, 69.006, 92.839, 59.808,

272.248, 91.407, 121.488, 1.133.589, 364.455, 42.431, 1.024.850, 172.449,

1.010.332, 41.393, 41.306, 41.790, 83.589, 157.740, 80.318, 233.798, 78.057, $83.387,38.086,41.405,40.106,23.447,40.687,223.564$ y 41.315.

\section{TREN No 20}

-Fecha de llegada: 11 de febrero 1944

-Estación de llegada: 1 (Tata)

-Peso total aproximado: 350 toneladas

-21 vagones G. Partidas 15, 24, 19 y 17

-Partida 15: 96.000 disparos de 3,7 cm. Granadas rompedoras. (Marina) (Partida Ageka 17)

\footnotetext{
${ }^{785}$ De las cien ametralladoras MG 34, sólo se recibieron 50 ejemplares en este tren. Las otras cincuenta vendrían en el tren $n^{\circ} 20$, pocs días después. Nota para el teniente coronel Romero de Arcos de 8 de marzo de 1944, enviada por el coronel Jesús Aguirre, jefe de la 4ª Sección del E.M.C.E. AGMAV. Caja 24.705 "Transporte de Mercancías entre Alemania y España (1943-1944)”. Fondo del antiguo Ministerio del Ejército.
} 
-Partida 17: 64.000 disparos de 2 cm Flak 38 (Mont. cuádruple)

(Marina) (Partida Ageka 19)

-Partida 19: 40.000 disparos de 2 cm Flak 38 (Mont. candelero)

(Marina) (Partida Ageka 21)

-Partida 24: 8.000 disparos de 3,7 cm. Id. (Marina) (Partida Ageka 27) -Spetra/KM-103001/Ha./Fi.- Salida de Perl: 8-2-1944

•21 vagones “G”: 30.790, 12.684, 49.253, 92.660, 78.065, 59.212, 35.750, $15.510,7.508,21.935,30.277,79.727,46.757,4.123,92.750,51.689,72.725$, $7.903,19.460,72.523$ у 44.866 .

\section{Carta fechada en Berlín el 18 de febrero de $1944^{786}$}

"Mi querido coronel:

Como verás ya estoy otra vez aquí, en el frente de Berlín, cada vez más roto y menos agradable, no solo para la vida sino para mi trabajo que se dificulta con la perturbación en tranvías, metros y teléfonos, haciendo algunas veces casi imposible los contactos con los organismos con quienes trato.

El otro día precisamente para aclarar que clase de material llevaba el tren $\mathrm{n}^{\circ} 19$ empleé toda la mañana para llegar a Schenker y eso que usé toda clase de medios de transporte; claro es que fue al día siguiente del último bombardeo, es decir, el miércoles, y los rotos en las redes fueron los suficientes para tener que estudiar lo tuyo si quieres ir de un lado a otro en Berlín.

En fin, ya seguimos y vamos a lo que interesa: (...)

Y nada más por hoy, un abrazo de tu buen amigo y compañero que sabes te quiere:

Fdo. Teniente coronel de Infantería Alfonso Romero de Arcos.

Agregado Militar adjunto en Berlín”

\footnotetext{
${ }^{786}$ Embajada de España en Berlín. Agregado Militar. 18 de febrero de 1944. Carta remitida al coronel Jesús Aguirre, de la 4a Sección del EMCE. AGMAV. Caja 24.707. Fondo del antiguo Ministerio del Ejército.
} 


\section{TREN N 21}

-Fecha de llegada: 11 de marzo 1944

-Estación de llegada: 1 (Tata)

-Peso total aproximado: 420 toneladas

•14 vagones R y 25 vagones G. Partidas 14, 16, 18, 20, 23, 49, 50, 52, 61, 62, $63,71,72$ y 84 .

-Partida 14: 12 piezas de 3,7 cm SK C30 con afuste doble. (Marina)

(Partida Ageka 16)

-Partida 16: 6 piezas de $2 \mathrm{~cm}$ Flak con afuste cuádruple. (Marina)

(Partida Ageka 18)

-Partida 18: 10 piezas de $2 \mathrm{~cm}$ Flak con afuste de candelero. (Marina)

(Partida Ageka 22)

-Partida 20: 3 piezas de 10,5 cm SK C32. (Marina) (Partida Ageka 20)

-Partida 23: 11 piezas de 3,7 cm SK C30 con afuste de submarino.

(Marina) (Partida Ageka 26)

-Partida 49: 25.760 proyectiles perforantes mod 114, para contracarro de 25 mm. (Partida Ageka 69)

-Partida 50: 4.320 proyectiles mod. 115 y $6.920 \mathrm{id}$ mod. 116, para contracarro de $25 \mathrm{~mm}$. (Partida Ageka 70)

-Partida 52: 25 cañones c.c.c. de 7,5 cm Pak 40. (Partida Ageka 72)

-Partida 61: 1.600 granadas rompedoras mod. 34 y 2.400 perforantes mod.39. (Para carros de combate) (Partida Ageka 81a)

-Partida 62: 2.500 granadas perforantes mod. 39, 2.500

granadarompedoras mod. 34, 16.620 cartuchos perforantes para ametralladora y 16.620 cartuchos trazadores para ametralladora. (Para cañones de asalto) (Partida Ageka 81b)

-Partida 63: 75 ametralladoras MG 34. (Partida Ageka 84)

-Partida 71: 60 teletipógrafos de campaña. (Partida Ageka 93)

-Partida 72: 13 teletipógrafos mecánicos. (Partida Ageka 94)

-Partida 84: 2.000 granadas perforantes para cañón contracarro de 7,5 cm. (Partida Ageka 73a)

•Spetra/KM-103002/Ha./Fi.- Salida de Perl: 8-3-1944 
•14 vagones “R": 299, 31.280, 11.046, 11.128, 3.894, 62.904, 82.915, 11.135,

$42.428,14.041,77.693,49.725,67.850$ y 50.776 .

•25 vagones “G”: 13.766, 78.113, 41.351, 41.651, 41.773, 223.702, 78.074,

78.012, 83.752, 55.882, 309.180, 28.707, 39.741, 28.771, 11.340, 17.963,

$17.168,16.378,17.991,3.008,71.247,174.229,260.200,175.843$ у 172.596 .

\section{Carta fechada en Berlín el 10 de marzo de $1944^{787}$}

"Mi querido coronel:

Con nueva semana nueva carta y después de tres días de bombardeo diurno, pues parece que ahora se han propuesto estropearnos las comidas de mediodía. Anteayer con un día magnífico de sol y con una cara tan dura como hermoso el día se pasearon por Berlín y nos dejaron sin comer hasta las cuatro de la tarde, no obstante parece ser que les costó bastante caro el paseito; ayer igual numerito y ya no comí hasta que regresé a casa a las siete y media en que tomé un bocadillo en espera de la hora de la cena. Antes eran solo las noches y ahora parece que no vamos a poder estar tranquilos ni durante el día. Y vamos a lo que interesa:

Te mando nota correspondiente al tren $\mathrm{n}^{\circ} 21(\ldots)$

Y nada más por hoy, un abrazo de tu buen amigo y compañero.

Fdo. Teniente coronel de Infantería Alfonso Romero de Arcos.

Agregado Militar adjunto en Berlín”

\section{TREN No 22}

-Fecha de llegada: 4 de abril 1944

-Estación de llegada: 5 (Bibi)

-Peso total aproximado: 225 toneladas

- 26 vagones $R$ y tres vagones $G$. Partidas 32,33 , 40 y 44 b.

-Partida 32: 24 Flak de 8,8 cm, 12 en montaje fijo y 12 móviles; seis direcciones de tiro mod. 40 , seis telémetros y seis equipos y máquinas de transmisión mod. 37. (Partida Ageka 38)

\footnotetext{
${ }^{787}$ Embajada de España en Berlín. Agregado Militar. 10 de marzo de 1944. Carta remitida al coronel Jesús Aguirre. AGMAV. Caja 24.707. Fondo del antiguo Ministerio del Ejército.
} 
-Partida 33: ocho proyectores de $60 \mathrm{~cm}$. (Partida Ageka 39)

-Partida 40: 12 estaciones de radio (onda corta). (Aire) (Partida Ageka 56)

-Partida 44b: 12 fonolocalizadores RRH con ocho remolques mod. 51.

(Partida Ageka 38a)

-Spetra/KM-103003/Kn./Mz.- Salida de Perl: 1-4-1944

•26 vagones “R": 3.417, 9.826, 37.770, 1.341, 76.415, 32.468, 62.784, 85.850, 5.841, 18.295, 44.195, 92.579, 19.290, 6.116, 32.548, 80.495, 451, 13.715,

$13.927,14.696,44.262,10.089,3.993,12.543,212.833$ у 262.606

•3 vagones “G”: $7.840,37.456$ y 31.783

\section{TREN No 23}

-Fecha de llegada: 21 de abril 1944

-Estación de llegada: 1 (Tata)

-Peso total aproximado: 330 toneladas

•8 vagones R y 19 vagones $G$. Partidas $6,15,20,21,23,24,57,66$ y 82

-Partida 6: 1 Cineteodolito. (Marina) (Partida Ageka 8)

-Partida 15: 14.000 proyectiles de 3,7 cm Sprgtr. Patr. L/4,1 Lh37 y

16.000 proyectiles de 3,7 cm Sprgr. Patr. L/4,1 Lh37, (Marina) (Partida Ageka 17)

-Partida 20: 6 piezas de 10,5 cm SK C32. (Marina) (Partida Ageka 22)

-Partida 21: 1.600 proyectiles de 10,5 cm Sprgtr. Patr. 32L/4,4 Lh31

m.Zt.Z.S/30.; 800 proyectiles de 10,5 cm Sprgtr. Patr. 32L/4,4 Lh31 m.

Kz 28; 300 proyectiles 10,5 cm Üb. Sprenggr. Patr. 32L/4,4 Lh31m

Zt.Z.S/30 y 150 proyectiles 10,5 cm Lg Patr. 32 L/4,0 mit Z.Z. S/60 n.A.

(Marina) (Partida Ageka 27)

-Partida 23: 7 piezas de 3,7 cm SK C30 (montaje C39 de submar.)

(Marina) (Partida Ageka 26)

-Partida 24: 1.500 proyectiles de 3,7 cm Abk. Patr. L/2,5 mit Kz32, (Marina) (Partida Ageka 23) 
-Partida 57 ${ }^{788}$ : 2 tubos para cañón de $122 \mathrm{~mm}$; 1 seguro de inercia y una reja de anclaje. (Partida Ageka 77)

-Partida 66: 2 MEK-8 y 2 MEK-3. (Partida Ageka 88)

-Partida 82: 4.500 granadas de rabiza para Pak de 3,7 cm. (Partida Ageka 93). (Partida Ageka 104)

-Partida s/n: 2 cañones de campaña de 7,5 cm españoles. (Partida Ageka $\mathrm{s} / \mathrm{n})$

-Spetra/KM-103004/Ha./Fi.- Salida de Perl: 17-4-1944

•8 vagones “ $R$ ": 44.562, 66.055, 61.215, 75.903, 69.268, 73.611, $71.480 \mathrm{y}$

32.516 .

•19 vagones “G”: $3.920,174.002,63.868,25.459,373.672,1.000 .609,27.671$, 23.297, 24.858, 32.078, 45.649, 22.942, 91.905, 14.473, 1.315, 81.943, 24.768, 60.907 y 7.956 .

${ }^{788}$ Habían llegado dos tubos inútiles. Se trataba del n $n^{\circ} 202$, por impacto, y el 488, por erosión interna. Los tubos nuevos recibidos en este tren fueron remitidos a la Maestranza de Artillería de Zaragoza, donde estaban almacenados los inútiles para su devolución a Alemania. Llegaron como mercancía de la Wehrmacht enviados desde Berlín-Spandau. AGMAV. Caja 24.704. Fondo del antiguo Ministerio del Ejército. 


\section{Carta fechada en Berlín el 9 de mayo de $1944^{789}$}

"Mi querido coronel:

Te mando por el teniente Horica de esta oficina la nota del tren $\mathrm{n}^{\mathrm{o}} 24$ pues creo que es el medio más rápido y te llega a tiempo en tus necesarias previsiones.

Ya se han vuelto a acordar de nosotros y el domingo por la mañana y ayer lunes a la misma hora (a las 10'45) nos han dado unas pasadas de consideración que recordaron a las de noviembre.

Otra vez la oficina de la Embajada nos la han estropeado y como es natural las puertas, ventanas y enlucido de las paredes y techos se han ido a freir espárragos pues una de las bombas tocó a cinco metros de una de las fachadas y otra por la parte de atrás y otra no hizo explosión.

Claro está que en estas condiciones no se puede llamar por teléfono y desde aquí, Strausberg, donde hoy estoy, no tenemos comunicación con España, ni hoy por teléfono con Berlín. (...)

Y nada más por hoy, un abrazo de tu buen amigo y subordinado que te quiere.

Fdo. Alfonso Romero de Arcos"

\section{TREN N ${ }^{0} 24$}

-Fecha de llegada: 15 de mayo 1944

-Estación de llegada: 1 (Tata)

-Peso total aproximado: 383 toneladas

-10 vagones R y 19 vagones G. Partidas 14, 16, 20, 23, 28, 45, 46, 47, 53 y 65.

-Partida 14: 4 piezas de 3,7 cm SK C30 en afuste doble. (Marina)

(Partida Ageka 16)

-Partida 16: 8 piezas de 2 cm Flak 38 en afuste cuádruple. (Marina)

(Partida Ageka 18)

-Partida 20: 3 piezas de 10,5 cm SK C32. (M) (Partida Ageka 22)

\footnotetext{
${ }^{789}$ Embajada de España en Berlín. Agregado Militar. 9 de mayo de 1944. Carta remitida al coronel Jesús Aguirre. AGMAV. Caja 24.707. Fondo del antiguo Ministerio del Ejército.
} 
-Partida 23: 7 piezas de 3,7 cm SK C30 montaje C39 de submarino. (Marina) (Partida Ageka 26)

-Partida 28: 100 cargas de profundidad (WBF). (Marina) (Partida Ageka 32)

-Partida 45: 9.000 granadas antitanque para fusil especial. (Partida Ageka 65)

-Partida 46: 20.000 granadas antitanque para fusil ordinario. (Partida Ageka 66)

-Partida 47: 9.000 cartuchos de proyección para granada antitanque. (Partida Ageka 67)

-Partida 53: 22.500 proyectiles HL/C 38 (carga hueca) para Pak 40 de 7,5 cm. (Partida Ageka 73)

-Partida 65: 20 puentes para los aparatos de esta partida (Tfb 1). (Partida Ageka 87)

-Spetra/KM-103005/Kn./Fi.- Salida de Perl: 8-5-1944

•19 vagones “G”: 1.717.320, 40.134, 35.506, 9.786, 14.492, 91.875, 534, 6.409, 13.693, 6.812, 21.776, 33.118, 46.758, 20.625, 4.249, 208.627, 242.531, 257.648 y 170.508 .

•10 vagones “R": 46.082, 36.263, 42.856, 26.179, 3.174, 48.516, 43.371, $81.232,93.828$ y 29.865 .

\section{TREN No 25: Nunca llegó a España, pues fue bombardeado en Dijon}

-Fecha de llegada: Prevista el 10 de junio de 1944.

-Estación de llegada: 5 (Bibi)

-Peso total aproximado: 34 toneladas

-4 vagones G. Partidas 38, 43, 45, 46, 47 y 64.

-Partida 38: 3 aparatos FuG 213 (Lichtenstein S). (Aire)

-Partida 43: 45 FuG 10 y 63 válvulas. (Aire) (Partida Ageka 59)

-Partida 45: 14.000 granadas contra carros para fusil especial. (Partida Ageka 65)

-Partida 46: 20.000 granadas contra carro para fusil ordinario. (Partida Ageka 66) 
-Partida 47: 14.000 cartuchos de proyección para granada contra carros.

(Partida Ageka 67)

-Partida 64: 200 ruedas de repuesto para motos. (Partida Ageka 85)

-Spetra/KM-103006/Kn./Fi.- Salida de Perl: 30-5-1944

•4 vagones “G”: 2.641, 65.650, 36.796 y 80.022.

Precio total del cargamento de este tren: 2.064.000 Reichmarks.

\section{TREN No 26: De su composición original, tres vagones se retrasaron y cayeron en manos de los maquis}

-Fecha de llegada: 18 de junio 1944

-Estación de llegada: 1 (Tata)

-Peso total aproximado: 490 toneladas

•36 vagones G. Partidas 6, 15, 17, 19, 21, 24, 28, 31, 31a, 66, 73 y 74.

-Partida 6: 5 cajas de accesorios ópticos para la instalación del cineteodolito. (Marina) (Partida Ageka 8)

-Partida 15: 24.000 granadas explosivas de 3,7 cm 40/L/4,1 Lh37.

(Marina) (Partida Ageka 17)

-Partida 17: 112.000 granadas explosivas de $2 \mathrm{~cm}$ con traza roja para

Flak cuádruple. (Marina) ) (Partida Ageka 19)

-Partida 19: 20.000 granadas explosivas de $2 \mathrm{~cm}$ con traza roja para Flak montaje candelero. (Marina) ) (Partida Ageka 21)

-Partida 21 ${ }^{790}$ : 4.800 granadas explosivas de 10,5 cm 32 L/4,4 Lh31 con espoleta a tiempo $\mathrm{S} / 30 ; 2.400$ granadas explosivas de $10,5 \mathrm{~cm} 32 \mathrm{~L} / 4,4$

Lh31 m.Kz. 28; 900 granadas explosivas de instrucción 32 L/4,4 Lh31 con espoleta a tiempo $\mathrm{S} / 30 ; 450$ granadas $\mathrm{Lg}$. $10,5 \mathrm{~cm}$ con espoleta a tiempo S/30; 4.500 granadas Abk. de 3,7 cm L/2,5 con Kz32. (Marina) (Partida Ageka 27)

-Partida 24: 28.000 granadas explosivas de 3,7 cm 40 L/4,1 Lh37 para cañón sobre afuste de submarino. (Marina) (Partida Ageka 23)

\footnotetext{
${ }^{790}$ Tres vagones, conteniendo 1.500 proyectiles de $10,5 \mathrm{~cm}$ para la Marina, las 100 cargas de profundidad de la Partida 28 y el radiotelémetro de la Partida 31a, cayeron en manos de los maquis en territorio francés y nunca llegaron a su destino. Dichos vagones quedaron retenidos en otras tantas estaciones francesas.
} 
-Partida 28: 100 cargas de profundidad W.B.F. (Marina) (Partida Ageka 32)

-Partida 31: 38 cajas con 1.738,1 kg de cristal óptico y 34 cajas con $1.478,56 \mathrm{~kg}$ de cristal óptico. (Marina)

-Partida 31a: un radiotelémetro con instalación para destructores.

(Marina)

-Partida 66: 2 juegos de aparatos MEK-8. (Partida Ageka 88)

-Partida 73: 4 estaciones terminales WT-40 con 6 canales. (Partida Ageka 95)

-Partida 74: complementos y accesorios de las estaciones de 15 watios. (Partida Ageka 96)

-Spetra/KM-103007/Kn./Fi.- Salida de Perl: ¿?

-36 vagones "G": Desconocidos

\section{TREN No 27: Salió de Alemania pero nunca llegó a España}

-33 vagones. Partidas 35, 33, 45, 47, 65, 66 y 70 (incompletas), 67 completa y Tepas (No era del "Programa Bär”) (incompleta)

-Partida 35: 50 equipos electro-generadores EM-4 (Aire)

-Partida 33: 48 ametralladoras de $2 \mathrm{~cm}$ Flak 28, 8 telémetros de $1 \mathrm{~m}$ y 8 proyectores de $60 \mathrm{~cm}$ (Partida Ageka 39)

-Partida 45: 44.000 proyectiles para fusil lanzagranadas especial. . (Partida Ageka 65)

-Partida 47: 14.000 cartuchos de proyección para las granadas anteriores (Partida Ageka 67)

-Partida 65: 8 aparatos TFb-1 y 2 aparatos TFb-2. (Partida Ageka 87)

-Partida 66: 4 MEK 3. (Partida Ageka 88)

-Partida 67: 40 amplificadores (Partida Ageka 89)

-Partida 70: 50 km de Feldernkabel. (Partida Ageka 92)

-Tepas Belge: 16 fonolocalizadores “Tepas” (Fuera del Programa Bär) -Spetra/KM-103008/Kn./Fi.- Salida de Perl: ¿?

•33 vagones: $86.349,203.955,16.163,14.964,9.459,19.556,18.883,52.702$,

914.195, 618, 52.715, 52.718, 52.704, 52.701, 52.712, 52.645, 52.700, 52.699, 


\section{Carta fechada en Berlín el 30 de agosto de $1944^{791}$}

\section{“Querido Jesús:}

Hoy tengo una multitud de asuntos que comunicarte, todos ellos de una cierta importancia, y no exentos de complicación, pues las cosas están poniéndose de tal manera que, si dentro de poco no estamos todos los aquí presentes camino de Siberia con destino a una fábrica de embutidos en calidad de materia prima, vamos a tener asuntos interesantes que ventilar. Por de pronto y para abrir boca, ahí te largo los siguientes líos organizados.

\section{(...)}

\section{Tren 25 (q.e.p.d)}

Este tren constaba de cinco tristes vagones. Tristes por la soledad en que viajaban, y tristes por el triste fin que les ha cabido en suerte. Estos vagones llegaron a Dijon; después de larga e infructuosa espera, decidió el Begleiter de la casa Schenker marcharse a Port Bou a pasarse unos días comiendo bien y sin marcas de racionamiento. Cuando después de múltiples peripecias regresó a Dijon el bien nutrido y poco celoso funcionario de Schenker, los vagones habían sido destruidos por los "maquisards", aunque él aseguró que habían sido destruidos por la aviación aliada, para evitarse así el pago del seguro, ya que este tren no habíamos cubierto el riesgo de guerra. Nosotros sostenemos que se han perdido por abandono de Schenker. (...) te tendré minuciosamente al tanto de la marcha de este pleito en embrión, y procuraré que el feto no se desarrolle.

\section{Vagones del tren 26 fallecidos en acción de guerra}

De este tren se quedaron rezagados 5 vagones (cifra fatídica). Poco después continuaron viaje dos, que llegaron felizmente a su destino. Los otros tres han sucumbido en manos de los "maquisards". Este asunto está claro, pues este tren iba cubierto contra todo riesgo. Un poco caro fue el seguro pero para algo va a servir el gasto. Por otra parte, el material era de Marina, por lo cual queda liquidado por mi parte el asunto.

\section{(...)}

\section{Material recibido y no enviado a España}

Este es también un asunto muy bonito, de los que más amenidad nos va a proporcionar. Según el contrato tipo, elaborado minuciosamente por la Comisión Martínez de Campos, con el

\footnotetext{
791 Embajada de España en Berlín. Agregado Militar. 30 de agosto de 1944. Carta de cuatro folios remitida al coronel Jesús Aguirre. AGMAV. Caja 24.707. Fondo del antiguo Ministerio del Ejército.
} 


asesoramiento de valiosos representantes de las ramas administrativas
del Ejército y de la Armada, y que recibió la confirmación y demás
sacramentos de todos los ministros, el material del "Programa Bär"
pasa a ser propiedad del estado español en cuanto la casa Schenker, en
representación del mismo, se hace cargo de él. (...) Como quiera que
que ya no se puede pensar ni remotamente en enviar este material a
España, han decidido las autoridades militares alemanas que vuelva
todo él a los depósitos y fábricas de procedencia, quedando de
propiedad del Estado español.
Este material queda en una situación un tanto aventurada, pues
no creo que sea pecar de pesimista el considerar que los alemanes van
a perder la guerra, en cuyo caso no habría ni que pensar (opinión
personal mía) en que los aliados nos dejaran disponer de él. Como con
arreglo a los contratos tenemos que pagar todos estos trastos a los dos
meses de efectuada la recepción por Schenker, habríamos perdido
unos cuantos millones.
(...)
Y no te sigo escribiendo, pues con esto que te ha largado vas
ya bien servido, y porque son casi las doce de la noche y me voy a
meter en el catre a echar una siestecilla hasta la una y media que
tendré que salir a recibir la amable visita de los ingleses.
Recibe un fuerte abrazo de tu buen amigo y compañero.
Fdo. Coronel de Ingenieros Carlos Marín de Bernardo
Lasheras.

\section{TREN No 28: Salió de Alemania pero nunca llegó a España}

• 10 vagones. Partidas 45, 46, 47, 61, 66, 70, 71 y 73 (incompletas) y s/n para la Marina

-Partida 45 y 46: 96.000 proyectiles para fusil lanzagranadas. (Partidas Ageka 65 y 66)

-Partida 47: 31.000 cartuchos de proyección para las granadas anteriores. (Partida Ageka 67)

-Partida 61: Dos dotaciones de municiones para carro de combate. (Partida Ageka 81a)

-Partida 70: $100 \mathrm{~km}$ de feldfernkabel. (Partida Ageka 92)

-Partida 71: 15 teletipógrafos de campaña. (Partida Ageka 93)

-Partida 73: Una caja de accesorios. (Partida Ageka 95) 
-Partida s/n: 4 máquinas Tiefenruder $\mathrm{f}$ para timones de profundidad.

(para el Consejo Ordenador, no era del "Programa Bär") (Marina)

-Spetra/KM-103008/Kn./Fi.- Salida de Perl: ¿?

•10 vagones: $92.899,1.699,122.462,13.759,26.983,6.355,13.318,182.872$,

$126.531,51.875$.

\section{Carta fechada en Berlín el 14 de diciembre de $1944^{792}$}

"Mi querido coronel:

Como casi todas las semanas hoy te escribo, siempre hay algo nuevo que decirte o preguntarte; no me refiero al enfermo, que recupera fuerzas por días, ni a la sonrisa de sus familiares que vuelven a tener confianza en su vitalidad, ni a mi conocido optimismo que espera siempre, y ahora creo en breve plazo, reacciones insospechadas si las realidades responden a las promesas. (...)

Recibe un fuerte abrazo de tu amigo y compañero. Lasheras.

Fdo. Coronel de Ingenieros Carlos Marín de Bernardo

Agregado Militar en Berlín”

\section{C.- Resumen de trenes, vagones y pesos transportados en el "Restprogramm con detalle de las estaciones de destino}

\begin{tabular}{|c|c|c|c|c|}
\hline Tren / N ${ }^{\mathbf{o}}$ vagones & Estación "Tata" (n 1) & Estación "Pepe" ( $\left.\mathrm{N}^{0} 3\right)$ & Estación "Bibi" (N 5) & Peso (aprox) \\
\hline $\mathrm{N}^{\mathrm{o}} 1 / 34$ vagones & & $\begin{array}{l}33 \text { vagones } R \text { y } \\
1 \text { vagón } G\end{array}$ & & $300 \mathrm{Tm}$ \\
\hline$N^{0} 2 / 32$ & 32 vagones $\mathrm{G}$ & & & $480 \mathrm{Tm}$ \\
\hline $\mathrm{N}^{\circ} 3 / 40$ “ & & & $\begin{array}{l}17 \text { vagones } R \text { y } \\
23 \text { vagones } G\end{array}$ & $158 \mathrm{Tm}$ \\
\hline$N^{0} 4 / 31$ “ & & $\begin{array}{l}27 \text { vagones } R \text { y } \\
4 \text { vagones } G\end{array}$ & & $182 \mathrm{Tm}$ \\
\hline$N^{0} 5 / 16$ “ & $\begin{array}{l}12 \text { vagones } R \text { y } \\
4 \text { vagones } G\end{array}$ & & & $252 \mathrm{Tm}$ \\
\hline
\end{tabular}

\footnotetext{
${ }^{792}$ Embajada de España en Berlín. Agregado Militar. 14 de diciembre de 1944. Carta remitida al coronel Jesús Aguirre. AGMAV. Caja 24.707. Fondo del antiguo Ministerio del Ejército.
} 


\begin{tabular}{|c|c|c|c|c|c|}
\hline$N^{\circ} 6 / 43$ & “ & & & $\begin{array}{l}14 \text { vagones } R \text { y } \\
29 \text { vagones } G\end{array}$ & $187 \mathrm{Tm}$ \\
\hline$N^{\circ} 7 / 37$ & “ & & $\begin{array}{l}26 \text { vagones } R \text { y } \\
11 \text { vagones } G\end{array}$ & & $358 \mathrm{Tm}$ \\
\hline $\mathrm{N}^{0} 8 / 29$ & “ & 29 vagones $\mathrm{G}$ & & & $332 \mathrm{Tm}$ \\
\hline $\mathrm{N}^{\circ} 9 / 33$ & “ & & & 33 vagones $G$ & $90 \mathrm{Tm}$ \\
\hline$N^{\circ} 10 / 29$ “ & “ & $\begin{array}{l}5 \text { vagones } \mathrm{R}, \\
22 \text { vagones } \mathrm{G} \text { y } \\
2 \text { vagones } \mathrm{OM}\end{array}$ & & & $291 \mathrm{Tm}$ \\
\hline $\mathrm{N}^{\mathrm{o}} 11 / 36$ & “ & & & 36 vagones $\mathrm{G}$ & $507 \mathrm{Tm}$ \\
\hline $\mathrm{N}^{\mathrm{o}} 12 / 37$ & “ & & & $\begin{array}{l}4 \text { vagones } R \text { y } \\
33 \text { vagones } G\end{array}$ & $117 \mathrm{Tm}$ \\
\hline $\mathrm{N}^{\mathrm{o}} 13 / 19$ & “ & & 19 vagones especiales & & $115 \mathrm{Tm}$ \\
\hline $\mathrm{N}^{\mathrm{o}} 14 / 11$ & “ & $\begin{array}{l}10 \text { vagones FFM y } 1 \\
\text { vagón } G\end{array}$ & & & $222 \mathrm{Tm}$ \\
\hline $\mathrm{N}^{\mathrm{o}} 15 / 25$ & “ & & 25 vagones $\mathrm{G}$ & & $357 \mathrm{Tm}$ \\
\hline $\mathrm{N}^{\mathrm{o}} 16 / 15$ & “ & & & $\begin{array}{l}12 \text { vagones } R \text { y } \\
3 \text { vagones } G\end{array}$ & $105 \mathrm{Tm}$ \\
\hline$N^{0} 17 / 40$ & “ & $\begin{array}{l}11 \text { vagones } R \\
9 \text { vagones } G \text { y } \\
20 \text { vagones } F F M\end{array}$ & & & $723 \mathrm{Tm}$ \\
\hline$N^{o} 18 / 35$ & “ & & & $\begin{array}{l}30 \text { vagones } R \text { y } \\
5 \text { vagones } G\end{array}$ & $280 \mathrm{Tm}$ \\
\hline $\mathrm{S} / \mathrm{n} / 2$ & & & & 2 vagones $G$ & $20 \mathrm{Tm}$ \\
\hline$N^{0} 19 / 32$ “ & “ & 32 vagones $\mathrm{G}$ & & & $275 \mathrm{Tm}$ \\
\hline$N^{\circ} 20 / 21$ “ & “ & 21 vagones $G$ & & & $350 \mathrm{Tm}$ \\
\hline $\mathrm{N}^{\mathrm{o}} 21 / 39$ “ & “ & $\begin{array}{l}14 \text { vagones } R \\
25 \text { vagones } G\end{array}$ & & & $420 \mathrm{Tm}$ \\
\hline $\mathrm{N}^{\mathrm{o}} 22 / 29$ “ & “ & & & $\begin{array}{l}26 \text { vagones } R \text { y } \\
3 \text { vagones } G\end{array}$ & 225 \\
\hline$N^{\circ} 23 / 27$ “ & “ & $\begin{array}{l}8 \text { vagones } R \\
19 \text { vagones } G\end{array}$ & & & $330 \mathrm{Tm}$ \\
\hline$N^{0} 24 / 29$ ، & “ & $\begin{array}{l}10 \text { vagones } R \\
19 \text { vagones } G\end{array}$ & & & $383 \mathrm{Tm}$ \\
\hline
\end{tabular}




\begin{tabular}{|c|c|c|c|c|}
\hline $\mathrm{N}^{\circ} 25 / 4$ “ & & & 4 vagones $G$ & $34 \mathrm{Tm}$ \\
\hline$N^{\circ} 26 / 36$ “ & 36 vagones $\mathrm{G}$ & & & $490 \mathrm{Tm}$ \\
\hline $\mathrm{N}^{\circ} 27 / 34$ “ & 33 vagones $\mathrm{G}^{793}$ & & & $156 \mathrm{Tm}$ \\
\hline $\mathrm{N}^{\circ} 28 / 11$ “ & 10 vagones $G$ & & & $109 \mathrm{Tm}$ \\
\hline $\begin{array}{l}\text { Salieron para } \\
\text { España } \\
804 \text { vagones }\end{array}$ & $\begin{array}{l}384 \text { vagones } \\
(249 \mathrm{G}, 60 \mathrm{R}, 2 \mathrm{OM} \text { y } \\
30 \mathrm{FFM})\end{array}$ & $\begin{array}{l}146 \text { vagones } \\
\text { (41 G, } 86 \mathrm{R} \mathrm{y} \\
19 \text { especiales) }\end{array}$ & $\begin{array}{l}274 \text { vagones } \\
(171 \mathrm{G} \text { y } 103 \mathrm{R})\end{array}$ & $7.848 \mathrm{Tm}$ \\
\hline $\begin{array}{l}\text { No llegaron a } \\
\text { España } \\
50 \text { vagones }\end{array}$ & $\begin{array}{l}3 \text { vagones } G \text { del tren } \\
n^{\circ} 26 \text { (Perdidos en } \\
\text { Francia) y } 43 \text { vagones } \\
\text { G de los trenes } 27 \text { y } 28\end{array}$ & & $\begin{array}{l}4 \text { vagones } G \text { del tren } \\
n^{0} 25 \text { (Perdidos en } \\
\text { Francia) }\end{array}$ & $339 \mathrm{Tm}^{794}$ \\
\hline $\begin{array}{l}\text { Alcanzaron } \\
\text { España } \\
754 \text { vagones }\end{array}$ & $\begin{array}{l}338 \text { vagones } \\
(246 \mathrm{G}, 60 \mathrm{R}, 2 \mathrm{OM} \text { y } \\
30 \mathrm{FFM})\end{array}$ & $\begin{array}{l}146 \text { vagones } \\
\text { (41 G, } 86 \mathrm{R} \text { y } \\
19 \text { especiales) }\end{array}$ & $\begin{array}{l}270 \text { vagones } \\
(167 \mathrm{G} \text { y } 103 \mathrm{R})\end{array}$ & $7.509 \mathrm{Tm}$ \\
\hline$\%$ vagones & $44,83 \%$ & $19,36 \%$ & $35,81 \%$ & \\
\hline Carga & $\begin{array}{l}4.508 \mathrm{Tm} \\
(60,04 \%)\end{array}$ & $\begin{array}{l}1.312 \mathbf{T m} \\
(17,47 \%)\end{array}$ & $\begin{array}{l}1.689 \text { Tm } \\
(22,49 \%)\end{array}$ & $7.509 \mathrm{Tm}$ \\
\hline
\end{tabular}

Fuente: Elaboración propia. Anexos XIII y XIV.

${ }^{793}$ Se incluyen en esta cantidad los correspondiente al transporte de los fonolocalizadores Tepas Belge ( 15 vagones $\mathrm{G}$ ), cuyo peso era de 48 toneladas.

${ }^{794}$ Corresponde al peso del material cargado en el tren $\mathrm{n}^{\mathrm{o}} 25$ (34 Tm), al de los trenes $\mathrm{n}^{\mathrm{o}} 27$ y $28(156 \mathrm{y}$ 109 toneladas, respectivamente) y a una aproximación de los tres vagones perdidos del Tren $\mathrm{n}^{\mathrm{o}} 26$ (40 $\mathrm{Tm})$, cifra ésta última calculada como un porcentaje del peso total del tren. 


\section{ANEXO XV}

\section{"Restprogramm" del Ejército de Tierra}

\section{A. Material recibido y no pagado (octubre 1944)}

\begin{tabular}{|l|l|l|l|}
\hline \multicolumn{1}{|c|}{ Partida } & \multicolumn{1}{|c|}{ Material } & \multicolumn{1}{c|}{$\mathbf{N}^{\mathbf{0}}$ tren } & \multicolumn{1}{c|}{ Importe (RM) } \\
\hline 32 & Cañones de $88 / 56$ & 22 & 1.003 .760 \\
\hline 49 & Proyectiles de $25 \mathrm{~mm}$ & 21 & 386.400 \\
\hline 50 & Proyectiles de $25 \mathrm{~mm}$ & 21 & 191.080 \\
\hline 73 & Transmisiones & 26 & 102.000 \\
\hline 66 & Transmisiones & 26 & 200.000 (Aprox) \\
\hline & & Total & $\mathbf{1 . 8 8 3 . 2 4 0}$ \\
\hline
\end{tabular}

Fuente: Estado actual de las entregas y pagos del material correspondiente al Programa Bär. AGMAV Caja 24.707

\section{B. Material enviado a España y no recibido. (Enviado en los trenes $\mathbf{n}^{0}$}

25, 27 y 28)

\begin{tabular}{|c|c|c|}
\hline PARTIDA & MATERIAL & PRECIO \\
\hline & TREN N ${ }^{\circ} 25$ & \\
\hline $45^{*}$ & 14.000 granadas contracarro de fusil & 378.000 \\
\hline $46^{*}$ & 20.000 granadas contracarro de fusil & 540.000 \\
\hline $47 *$ & 14.000 cartuchos de proyección para las granadas & 21.000 \\
\hline \multirow[t]{3}{*}{$64 *$} & 200 ruedas de repuesto para motocicletas & Sin valorar \\
\hline & TOTAL Tren $n^{0} 25$ & 939.000 \\
\hline & TREN N 27 & \\
\hline $67 * * *$ & 40 amplificadores & 9.800 \\
\hline $45 * * *$ & 44.000 granadas de fusil & 1.188 .000 \\
\hline $47 * * *$ & 14.000 cartuchos de proyección & 21.000 \\
\hline $70 * * *$ & $50 \mathrm{~km}$ de cable de campaña & 194.750 \\
\hline $66 * *$ & 4 aparatos M.E.-3 & Sin valorar \\
\hline $65 * * *$ & 8 aparatos T.F. b-1 & 72.000 \\
\hline $65 * * *$ & 2 aparatos T.F. b-2 & 18.000 \\
\hline $33 * *$ & 48 ametralladoras Flak 28 de $20 \mathrm{~mm}$ & Sin valorar \\
\hline $33 * * *$ & 8 proyectores de $60 \mathrm{~cm}$ & 232.800 \\
\hline \multirow[t]{2}{*}{$33 * * *$} & 8 telémetros de $1 \mathrm{~m}$ de base $\mathrm{R} 36$ & 38.400 \\
\hline & TOTAL Tren $n^{0} 27^{795}$ & 1.774.750 \\
\hline
\end{tabular}

\footnotetext{
${ }^{795}$ Hay que tener en cuenta que en el tren $n^{\circ} 27$ venía una partida destinada al Ejército del Aire: 50 grupos electrógenos que también se perdieron.
} 


\begin{tabular}{|c|c|c|}
\hline & TREN N 28 & \\
\hline $46^{* * *}$ & 96.000 granadas de fusil & 2.592 .000 \\
\hline $47^{* * *}$ & 31.000 cartuchos de proyección & 46.500 \\
\hline $61 * * *$ & $\begin{array}{l}2 \text { dotaciones de municiones para carros de mando ( } 400 \text { granadas de } \\
7,5 \mathrm{~cm} \text { Sprgr. Patronen, } 600 \text { granadas de 7,5 cm Pzgr. Patronen y } \\
6.384 \text { proyectiles de } 7,92 \mathrm{~mm} \text { ) }\end{array}$ & 126.747 \\
\hline $70^{* * *}$ & $100 \mathrm{~km}$ de cable de campaña & 389.500 \\
\hline $71^{* * *}$ & 15 teletipógrafos de campaña & 68.250 \\
\hline \multirow[t]{4}{*}{$73 * * *$} & 1 caja de accesorios & $\mathrm{s} / \mathrm{c}$ \\
\hline & TOTAL Tren $\mathrm{n}^{0} \mathbf{2 8}^{796}$ & 3.222.997 \\
\hline & TOTAL material “Bär" Trenes 27 y 28 & 4.997 .747 \\
\hline & TOTAL material "Bär" Trenes 25, 27 y 28 & 5.936 .747 \\
\hline \multirow[t]{2}{*}{$\mathrm{s} / \mathrm{n}^{* * *}$} & $\begin{array}{l}16 \text { fonolocalizadores TEPAS-BELGE (Venían en el tren n }{ }^{\circ} 27 \\
\text { aunque no eran del "Programa Bär") }\end{array}$ & 486.000 \\
\hline & TOTAL general, incluyendo Tepas & 6.422.747 \\
\hline
\end{tabular}

Fuente: elaboración propia. EMCE. "Resumen estado en que se encuentra el desarrollo del Programa Bär ( $\left.2^{\circ} \mathrm{Cupo}\right)$. Diciembre 1944”, y "Aclaraciones a los números resúmenes. Comisión extraordinaria para material de guerra. Diciembre de 1944". AGMAV. Caja 24.707. Fondo del antiguo Ministerio del Ejército. Todas las cantidades, en marcos.

* Material del Tren $n^{\circ} 25$. Se considera perdido, pues este tren (con cinco vagones) parece ser que fue bombardeado en Francia y no se supo más de el.

** Material correspondiente al Tren $\mathrm{n}^{\circ} 27$. Este material volvió intacto a las fábricas y el gobierno alemán se hizo cargo de él, por lo cual su valor no lo sumamos para calcular los totales, sino que pasa al epígrafe "Material que no pudo ser enviado a España", estudiado en el Anexo XVI. Vienen señaladas en tipografía roja.

*** Material contenido en los Trenes $n^{\circ} 27$ y 28. Este material fue destruido y según contrato, hubo que pagarlo, aunque al estar asegurado, no se consideraría pérdida.

\section{Material que no pudo ser enviado a España}

\begin{tabular}{|l|l|l|}
\hline PARTIDA & MATERIAL & PRECIO \\
\hline $33^{797}$ & 48 ametralladoras Flak 28 de $20 \mathrm{~mm}$ & 1.425 .600 \\
\hline 32 & 6 baterías de $88 / 56 \mathrm{~mm}$ (24 cañones) & 2.964 .820 \\
\hline 32 & 6 direcciones de tiro modelo 40 & 1.003 .760 \\
\hline 32 & 6 instalaciones eléctricas para $88 / 56$ & 531.420 \\
\hline 45 & 22.000 granadas de fusil & 594.000 \\
\hline 46 & 45.000 granadas de fusil & 1.215 .000 \\
\hline 47 & 22.000 cartuchos de proyección & 33.000 \\
\hline
\end{tabular}

\footnotetext{
${ }^{796}$ En este tren $n^{\text {o }} 28$ venían también materiales para el Ejército del Aire (varias piezas de los radares "Lichtenstein") y para la Armada, concretamente, para el Consejo Ordenador de Construcciones Navales Militares (cuatro máquinas Tiefenruder f).

${ }^{797}$ Se enviaron en el Tren $\mathrm{n}^{\circ} 27$ y resultaron intactas tras un bombardeo aliado. Fueron asumidas por el OKW e incorporadas al Heer. La AGEKA y el Ministerio del Ejército español las consideró como "material no entregado del Programa Bär".
} 


\begin{tabular}{|l|l|l|}
\hline 59 & 2 carros de combate (mando) & 538.068 \\
\hline 65 & 8 aparatos TFb-1 & 72.000 \\
\hline 65 & 6 aparatos TF b-2 & 54.000 \\
\hline $66^{798}$ & 10 aparatos MEK-3 y accesorios & 964.240 \\
\hline 68 & 110 auriculares amplificadores & 22.000 \\
\hline 70 & 850 km de cable de campaña & 3.310 .750 \\
\hline 72 & 20 teletipógrafos y 20 (veinte) amplificadores & 144.000 \\
\hline 73 & 32 aparatos WT-40 & 816.000 \\
\hline 76 & 10 receptores de onda corta y extracorta & 148.000 \\
\hline 79 & 12.770 válvulas de radio & 255.400 \\
\hline 37 & 1 radiolocalizador Würzburg 799 & 125.000 \\
\hline s/n & 45.381 granadas para Pak 25 f (mod. 118) & 408.429 \\
\hline s/n & 4.619 granadas para Pak 25 f (mod. 119) & 62.357 \\
\hline & TOTAL & $\mathbf{1 4 . 6 8 7 . 8 4 3}$ \\
\hline
\end{tabular}

Fuente: elaboración propia. EMCE. Resumen estado en que se encuentra el desarrollo del Programa Bär ( $2^{\circ}$ Cupo). Diciembre 1944. AGMAV. Caja 24.707. Fondo del antiguo Ministerio del Ejército Todas las cantidades, en marcos.

\section{D._Facturas autorizadas a AGEKA para su pago (hasta el 30-12-1943)}

\begin{tabular}{|c|c|c|c|}
\hline Núm. orden & Núm. factura & Casa suministradora y clase de material & $\begin{array}{l}\text { Importe (en RM) y no } \\
\text { de tren }\end{array}$ \\
\hline 1 & 861 & $\begin{array}{l}\text { AGEKA ( } 72 \text { Flak } 28 \text { Oerlikon con telémetros y } \\
\text { proyectores) }\end{array}$ & $2.138 .400(5)$ \\
\hline 2 & 862 & AGEKA (150 cañones antitanque (f) de $25 \mathrm{~mm}$ ) & $3.150 .000(5)$ \\
\hline 3 & 863 & $\begin{array}{l}\text { AGEKA ( } 23.000 \text { granadas perforantes } 114 \text { para } \\
\text { antitanque de } 25 \mathrm{~mm}(\mathrm{f}))\end{array}$ & $345.000(5)$ \\
\hline 4 & 864 & $\begin{array}{l}\text { AGEKA ( } 4.000 \text { granadas perforantes para brocal } \\
\text { de } 6,6 \mathrm{~cm} \text { de antitanque de } 25 \mathrm{~mm}(\mathrm{f}))\end{array}$ & $272.000(5)$ \\
\hline 5 & 865 & AGEKA (50 cañones de $12,2 \mathrm{~cm})$ & $5.600 .000(1$ y 4$)$ \\
\hline 6 & 866 & AGEKA (12.000 disparos de $12,2 \mathrm{~cm})$ & $2.040 .000(2)$ \\
\hline 7 & 867 & $\begin{array}{l}\text { AGEKA ( } 40.000 \text { granadas contracarros para fusil } \\
\text { y } 20.000 \text { cartuchos de proyección } 318)^{*}\end{array}$ & $1.110 .000(3)$ \\
\hline 8 & $97575 / \mathrm{Wi}$ & B.M.W. (250 motos pesadas con carro lateral) & $648.500(3$ y 6$)$ \\
\hline 9 & NBN 845 & Richard Rinker (50.000 minas antitanque $\mathrm{T}$ 42) & $2.750 .000(11)$ \\
\hline
\end{tabular}

\footnotetext{
798 Cuatro de estos aparatos viajaban en un vagón del Tren $\mathrm{n}^{\mathrm{0}} 27$ y al igual que las ametralladoras, resultaron intactas tras el bombardeo de dicho convoy. Tuvieron la misma consideración que las citadas ametralladoras a efectos del estudio del "Programa Bär" por parte de las autoridades españolas y alemanas.

799 Se refiere a un aparato radiotelémetro Würzburg que el mando alemán ofreció al margen del "Programa Bär" y que fue aceptado por el Ministro del Ejército. Era un modelo más antiguo que los recibidos en el Programa de Aire (y que pasarían a Tierra), y se emplearía en misiones de escuela.
} 


\begin{tabular}{|l|l|l|r|}
\hline 10 & $97599 / \mathrm{Wi}$ & B.M.W. (200 motos pesadas con carro lateral) & 518.800 (9) \\
\hline 11 & Z 1723 & Rheinmetall (200 ametralladoras MG 34) & 476.000 (15) \\
\hline 12 & Z 1721 & Rheinmetall (75 cañones contracarro Pak 40) & 3.150 .000 (13) \\
\hline 13 & $41 / 102$ & Siemens-Halske (6 equipos repetidores b. Frec.) & $121.140^{* *}$ (4) \\
\hline 14 & 1193 & Fried Krupp (6 baterías de 88/56)*** & 2.964 .820 (7) \\
\hline 15 & $97600 / \mathrm{Wi}$ & B.M.W. (200 motos pesadas con carro lateral) & 518.800 (12) \\
\hline 16 & $2711 / 81989 / 2$ & Carl Zeiss (6 direcciones de tiro “Modelo 40”) & 1.003 .760 (7) \\
\hline 17 & $119-51 / 150818$ & Fried Krupp (20 carros de combate Pz.IV) & 5.260 .000 (17) \\
\hline 18 & 434 & Electroacustic (39 fonolocalizadores RRH) & 2.161 .770 (6, 12 y 16) \\
\hline & & TOTAL & $\mathbf{3 4 . 2 2 8 . 9 9 0}$ \\
\hline
\end{tabular}

* El precio de las 40.000 granadas fue de 1.080.000 RM y el de los cartuchos de proyección, 30.000 RM.

**Esta factura se componía de dos partes: una de 95.040 RM (6 equipos repetidores a 15.840 RM por unidad y no a 17.600 RM como fueron contratados). El precio de 15.840 RM es la media aritmética entre los 17.600 del primer lote y los 13.200 del segundo, para 6 y 4 aparatos respectivamente. Los 26.100 RM restantes corresponden a accesorios no previstos en el contrato, aunque necesarios.

*** La diferencia con el precio pactado en las conversaciones de Madrid corresponde a las direcciones de tiro y a las instalaciones eléctricas.

Fuente: Comisión Extraordinaria para Material de Guerra. "Programa Bär”. (Segundo cupo). AGMAV. Caja 24.708. Fondo del antiguo Ministerio del Ejército.

\section{E.- Facturas autorizadas a AGEKA para su pago (hasta mayo de 1944)}

\begin{tabular}{|c|c|c|c|}
\hline Núm. orden & Núm. factura & Casa suministradora y clase de material & Importe ( $\mathrm{n}^{0}$ tren) \\
\hline 19 & Sche/R-2711 & Rheinmetall (22.500 granadas rompedoras $75 \mathrm{~mm}$. Pak 40) & $2.182 .500(\mathbf{1 5})$ \\
\hline 20 & 200047 & Siemens (3 teletipógrafos mecánicos) & $13.500(4)$ \\
\hline 21 & $\mathrm{IV} / 35 / 1578$ & Köln-Rottweil (6.000 cargas adhesivas H-3) & $432.000(7)$ \\
\hline 22 & 1194 & Fried Krupp ( 3 baterías fijas de $88 / 56$ ) & $1.482 .410(\mathbf{1 6})$ \\
\hline 23 & $193-41$ & Telefunken ( 2 estaciones de radio de 200 vatios AS.1008) & $59.700(7)$ \\
\hline 24 & $193-42$ & Telefunken (10 aparatos radio onda corta de 1 kilovatio) & $1.520 .000(7)$ \\
\hline 25 & $40-12$ & Daimler-Benz (10 cañones de asalto StuG III) & $2.400 .000(14)$ \\
\hline 26 & $193-43$ & Telefunken ( 50 estaciones radio de 15 vatios SE. 409) & $660.000(7)$ \\
\hline 27 & Sche/R-2753 & Rheinmetall (4.000 granadas perforantes para Pak 40*) & $578.000(\mathbf{1 5})$ \\
\hline 28 & $2810 / 84277 / 2$ & Carl Zeiss (24 telémetros de 1 m R.36) & $115.000(6)$ \\
\hline 29 & KS $761128 / 1$ & Siemens-Schuckert (24 proyectores de $60 \mathrm{~cm}$ ) & $698.400(3)$ \\
\hline 30 & $41 / 243 \mathrm{Kd}$ & $\begin{array}{l}\text { Siemens-Halske ( } 4 \text { equipos repetidores de baja frecuencia, } 3 \\
\text { canales y } 4 \text { series de accesorios**) }\end{array}$ & 80.760 (19) \\
\hline 31 & $22 / 70602 \mathrm{~T}$ & Siemens (4 teletipógrafos mecánicos) & $18.000(19)$ \\
\hline 32 & 1210 & Fried Krupp ( 6 baterías de $88 / 56 \mathrm{~mm}$ ) & $2.964 .820(\mathbf{1 8})$ \\
\hline 33 & 1213 & $\begin{array}{l}\text { Fried Krupp (Primer envío de las } 2 \text { dotaciones de } \\
\text { municiones para carros de combate) }\end{array}$ & $778.552,30(19)$ \\
\hline 34 & 1072 & Electroacustic (3 fonolocalizadores RRH) & $166.290(\mathbf{1 8})$ \\
\hline
\end{tabular}




\begin{tabular}{|c|c|c|c|}
\hline 35 & 907 & AGEKA (36 ametralladoras Flak 28 Oerlikon) & $1.069 .200(\mathbf{1 6}$ y 18) \\
\hline 36 & $18616 / 6 b$ & Lorenz (10 radiogoniómetros) & $143.000(7)$ \\
\hline 37 & KS $761128 / 3$ & Siemens-Schuckert (12 proyectores de $60 \mathrm{~cm})$ & $349.200(\mathbf{1 6}$ y 18) \\
\hline 38 & 930 & AGEKA (10 receptores de radio, toda onda) & $27.000(7)$ \\
\hline 39 & $281 / 84277 / 3$ & Carl Zeiss (20 telémetros de 1 m. EM.36) & $96.000(\mathbf{1 6})$ \\
\hline 40 & Sche/R $21 \mathrm{~B}$ & Rheinmetall (100 ametralladoras MG 34 y soportes) & $238.000(\mathbf{1 9})$ \\
\hline 41 & Sche/R 20 B & Rheinmetall (4.000 granadas perforantes de $75 \mathrm{~mm}$ Pak 40) & $578.000(\mathbf{1 9})$ \\
\hline 42 & Sche/R 18 B & Rheinmetall ( 25 cañones antitanque de 75 mm Pak 40) & $1.050 .000(19)$ \\
\hline 43 & Sche/R 19 B & Rheinmetall ( 25 cañones antitanque de $75 \mathrm{~mm}$ Pak 40) & $1.050 .000(19)$ \\
\hline 44 & 200167 & Siemens (20 amplificadores***) & 106.000 (19) \\
\hline 45 & 0193-61 & Telefunken (40 receptores E 454Bs $* * * *$ ) & $228.000(7)$ \\
\hline 46 & 100.001 & AEG (2 aparatos ME. 8 de alta frecuencia) & 246.180 (19) \\
\hline & & TOTAL & $19.330 .712,30$ \\
\hline
\end{tabular}

Fuente: Comisión Extraordinaria para Material de Guerra. "Programa Bär”. (Segundo cupo). AGMAV. Caja 24.708. Fondo del antiguo Ministerio del Ejército. Todas las cantidades, en marcos.

*Precio acordado con AGEKA, pues estos proyectiles fueron encargados con posterioridad a las reuniones de las subcomisiones técnico-militares de Madrid.

** Debe tenerse en cuenta que el precio pagado por estos cuatro equipos, al igual que ocurrió con los otros seis, fue de 15.840. El resto corresponde a accesorios no previstos en el precio original.

*** Los 20 primeros se pagaron a 5.300 RM por unidad. Para los otros 20 del contrato, se acordó bajar el precio a 2.700 TM por cada uno.

****Se habían contratado con la casa Lorenz por $5.600 \mathrm{RM}$ el aparato tipo mochila, pero, por causa de la guerra, ésta no pudo suministrarlos. Al final los envió Telefunken, pero 100 RM por unidad más caros que los de la casa Lorenz.

\section{F.- Facturas autorizadas a AGEKA para su pago (hasta octubre de 1944)}

\begin{tabular}{|c|l|l|r|}
\hline Núm. orden & Núm. factura & Clase de material & Importe (en marcos) \\
\hline 47 & $571-012 / 2$ & Siemens (3 instalaciones eléctricas para 88/56) & $265.710(7)$ \\
\hline 48 & $571-012 / 3$ & Siemens (3 instalaciones eléctricas para 88/56) & $265.710(7)$ \\
\hline 49 & $571-012 / 4$ & Siemens (3 instalaciones eléctricas para 88/56) & $265.710(\mathbf{1 6 )}$ \\
\hline 50 & $281 / 801989 / 3$ & Carl Zeiss (6 direcciones de tiro para 88/56) & $1.003 .760(\mathbf{1 6} \mathbf{y ~ 1 8 )}$ \\
\hline 51 & $22 / 602187$ & Siemens-Halske (4 aparatos terminales WT-40) & $102.000(\mathbf{1 9})$ \\
\hline 52 & $571-012 / 5$ & Siemens (3 instalaciones eléctricas para 88/56) & $265.710(\mathbf{1 8})$ \\
\hline 53 & $571-012 / 5$ & Siemens (3 instalaciones eléctricas para 88/56) & $265.710(\mathbf{1 8 )}$ \\
\hline 54 & 1559 & Electroacustic (12 fonolocalizadores RRH fijos) & $602.760^{800}(\mathbf{2 2})$ \\
\hline 55 & Z-1723-R 103/II & Rheinmetall (75 ametralladoras MG 34 y soportes) & $178.500(\mathbf{2 1 )}$ \\
\hline
\end{tabular}

${ }^{800}$ Estos 12 fonos recibidos en el tren $\mathrm{n}^{\mathrm{o}} 22$ fueron rebajados de precio con respecto al resto de los recibidos (15 en total). De los 55.430 marcos por unidad que costaban los primeros se rebajaron hasta 50.230 marcos por cada uno de ellos, debido a que estos últimos venían destinados a los grupos fijos de $88 / 56 \mathrm{~mm}$, por lo que no disponían de elementos de transporte. En efecto, si sumamos las tres baterías de $88 / 56 \mathrm{~mm}$ en montaje fijo que se recibieron en el "Sofortprogramm" (Grupo de Algeciras) y las 9 recibidas en el "Restprogramm", corresponden a los 12 fonos fijos recibidos en el tren antes indicado. 


\begin{tabular}{|c|c|c|c|}
\hline 56 & $1248-51 / 150817$ & $\begin{array}{l}\text { Fried Krupp (municiones para carros de combate y } \\
\text { cañones de asalto) }\end{array}$ & $1.118 .526,15(\mathbf{1 4}$ y 21) \\
\hline 57 & Z-1721-R 110 & Rheinmetall ( 25 cañones antitanque de 75 mm Pak 40) & $1.050 .000(21)$ \\
\hline 58 & $22 / 70043$ & Siemens-Halske (3 teletipógrafos mecánicos) & $13.500(\mathbf{2 1})$ \\
\hline 59 & $22 / 70396$ & Siemens-Halske (1 teletipógrafo mecánico) & $4.500(21)$ \\
\hline 60 & $22 / 70733$ & Siemens-Halske (1 teletipógrafo mecánico) & $4.500(21)$ \\
\hline 61 & $22 / 70768$ & Siemens-Halske (60 teletipógrafos de campaña) & $273.000(\mathbf{2 1})$ \\
\hline 62 & $22 / 70876$ & Siemens-Halske ( 1 teletipógrafo mecánico) & $4.500(21)$ \\
\hline 63 & $22 / 70876$ & Siemens-Halske ( 1 teletipógrafo mecánico) & $4.500(21)$ \\
\hline 64 & $22 / 70980$ & Siemens-Halske (6 teletipógrafos mecánicos) & $27.000(21)$ \\
\hline 65 & $193-70$ & Telefunken (50 estaciones radio 15 w SE 409) & $660.000(19)$ \\
\hline 66 & Z-1722-R 132 & $\begin{array}{l}\text { Rheinmetall ( } 2.000 \text { granadas perforantes de } 75 \mathrm{~mm} \\
\text { para Pak 40) }\end{array}$ & $289.000(\mathbf{2 1})$ \\
\hline 67 & 1251 & Fried Krupp ( 6 baterías de $88 / 56 \mathrm{~mm}$ ) & $2.964 .820(\mathbf{2 2})$ \\
\hline 68 & $571-012 / 8$ & Siemens ( 3 instalaciones eléctricas para 88/56) & $265.710(22)$ \\
\hline 69 & $42 / 521409$ & Siemens (20 puentes para aparatos alta frecuencia)* & $30.000(\mathbf{2 4})$ \\
\hline 70 & 100.002 & AEG (2 aparatos ME.3 de alta frecuencia) & $147.960(\mathbf{2 3})$ \\
\hline 71 & 100.003 & AEG (2 aparatos ME. 8 de alta frecuencia) & $246.180(\mathbf{2 3})$ \\
\hline 72 & Z-1722-R 195/IIc & $\begin{array}{l}\text { Rheinmetall ( } 22.500 \text { granadas rompedoras } 38 \mathrm{HL} \text { de } \\
\text { carga hueca para } 75 \mathrm{~mm} \text { para Pak } 40)\end{array}$ & $2.092 .500(\mathbf{2 4})$ \\
\hline 73 & Z-1747-R 202 & $\begin{array}{l}\text { Rheinmetall ( } 4.500 \text { granadas con rabiza para Pak de } \\
37 \mathrm{~mm})\end{array}$ & $760.500(\mathbf{2 3})$ \\
\hline 74 & $\mathrm{~s} / \mathrm{n}$ & J.D. Riedel (10.000 granadas de mano fumígenas) & $43.100(3)$ \\
\hline 75 & 1260 & $\begin{array}{l}\text { Fried Krupp (municiones de pistola para cañones de } \\
\text { asalto)** }\end{array}$ & $4.282,40(\mathbf{1 4})$ \\
\hline 76 & 1134 & $\begin{array}{l}\text { AGEKA ( } 29.000 \text { granadas contracarro para fusil y } \\
9.000 \text { cartuchos de proyección) }\end{array}$ & $796.500(\mathbf{2 4})$ \\
\hline 77 & KS $761128 / 4$ & Siemens-Schuckert $(8$ proyectores de $60 \mathrm{~cm})$ & $232.800(\mathbf{2 2})$ \\
\hline 78 & $571-012 / 6$ & Siemens ( 3 instalaciones eléctricas para 88/56) & $265.710(22)$ \\
\hline 79 & 1215 & $\begin{array}{l}\text { AGEKA ( } 25.760 \text { granadas perforantes } 114 \text { y } 11.240 \\
\text { granadas perforantes } 115 \text { y } 116 \text { para Pak } 2,5\end{array}$ & $577.480(21)$ \\
\hline 80 & 200396 & Siemens-Halske (4 centrales terminales WT. 40) & $102.000(\mathbf{2 6})$ \\
\hline \multirow[t]{3}{*}{81} & $410 / 81989 / 4$ & Carl Zeiss (6 direcciones de tiro para Flak de $88 / 56$ ) & $1.003 .760(22)$ \\
\hline & & TOTAL & $16.197 .898,55$ \\
\hline & & Suma de todas las partidas (1-13 Sofort y 1-81 Rest) & $90.475 .940,85$ \\
\hline $\begin{array}{l}\text { Fuera de } \\
\text { Programa }\end{array}$ & 839 & AGEKA (71 fonolocalizadores Tepas-Belge V-20)*** & 2.556 .000 \\
\hline
\end{tabular}




\section{ANEXO XVI}

\section{“Restprogramm" del Ejército del Aire}

\section{A. Material enviado a España y no recibido. (Enviado en los trenes $\mathbf{n}^{0}$}

\section{5,27 y 28)}

\begin{tabular}{|c|c|c|}
\hline PARTIDA & MATERIAL & PRECIO \\
\hline \multicolumn{3}{|l|}{ TREN No 25} \\
\hline $38^{*}$ & 3 radiotelémetros "Lichtenstein" & 90.000 \\
\hline \multirow[t]{2}{*}{$43 *$} & 45 radioemisoras $\mathrm{FuG} 10$ & 783.000 \\
\hline & TOTAL Tren $\mathbf{n}^{0} 25$ & 873.000 \\
\hline \multicolumn{3}{|l|}{ TREN No 27} \\
\hline \multirow[t]{2}{*}{$35 * *$} & 50 grupos electrógenos EM-4 & 116.000 \\
\hline & TOTAL Tren $\mathbf{n}^{0} 27$ & 116.000 \\
\hline \multicolumn{3}{|l|}{ TREN No 28} \\
\hline \multirow[t]{4}{*}{$46^{* *}$} & Varios accesorios para radiotelémetros "Lichtenstein" & Sin valorar \\
\hline & TOTAL Tren $n^{0} 28$ & Sin valorar \\
\hline & TOTAL material “Bär” Trenes 27 y 28 & 116.000 \\
\hline & TOTAL material "Bär" Trenes 25, 27 y 28 & 989.000 \\
\hline
\end{tabular}

Elaboración propia. Fuente: EMCE. "Resumen estado en que se encuentra el desarrollo del Programa Bär $\left(2^{\circ} \mathrm{Cupo}\right)$. Diciembre 1944", y “Aclaraciones a los números resúmenes. Comisión extraordinaria para material de guerra. Diciembre de 1944”. AGMAV. Caja 24.707. Todas las cantidades, en marcos.

* Material del Tren $\mathrm{n}^{\circ} 25$. Se considera perdido, pues este tren (con cinco vagones) parece ser que fue bombardeado en Francia y no se supo más de el.

** Material contenido en los Trenes $n^{\circ} 27$ y 28 . Este material fue destruido y según contrato, hubo que pagarlo, aunque al estar asegurado, no se consideraría pérdida.

\section{B. Material que pasó al Ejército de Tierra}

\begin{tabular}{|l|l|l|}
\hline PARTIDA & MATERIAL & PRECIO \\
\hline 37 & 9 radiotelémetros "Würzburg” & 1.125 .000 \\
\hline & TOTAL & $\mathbf{1 . 1 2 5 . 0 0 0}$ \\
\hline
\end{tabular}

Elaboración propia. 


\section{ANEXO XVII}

\section{“Restprogramm" de la Armada}

\section{A. Material enviado a España y no recibido. (Enviado en los trenes $\mathbf{n}^{\mathbf{0}}$}

26 y 28)

\begin{tabular}{|c|c|c|}
\hline PARTIDA & MATERIAL & PRECIO \\
\hline \multicolumn{3}{|l|}{ TREN No 26} \\
\hline $31 \mathrm{a}$ & 1 radiotelémetro para destructores & 239.560 \\
\hline 28 & 100 cargas de profundidad W.B.F. & 100.000 \\
\hline \multirow[t]{2}{*}{21} & $\begin{array}{l}1.500 \text { proyectiles de } 10,5 \mathrm{~cm} 32 \mathrm{~L} / 4,4 \mathrm{Lh} 31 \text { con espoleta a tiempo } \\
\mathrm{S} / 30\end{array}$ & 341.384 \\
\hline & TOTAL Tren $n^{\circ} 26$ & 680.944 \\
\hline \multicolumn{3}{|l|}{ TREN No 28} \\
\hline \multirow[t]{3}{*}{$\begin{array}{l}\text { s/n. No era } \\
\text { "Programa Bär". } \\
\text { Destinado al } \\
\text { Consejo } \\
\text { Ordenador }\end{array}$} & 4 máquinas “Tiefenruder f” para timones de profundidad. & Sin valorar \\
\hline & TOTAL Tren $n^{0} 28$ & Sin valorar \\
\hline & TOTAL material “Bär” Trenes 26 y 28 & 680.944 \\
\hline
\end{tabular}

Elaboración propia. Fuente: Telegrama recibido en la Agregaduría Naval de Berlín en 3-11-1944. APFE. Todas las cantidades, en marcos. 


\section{ANEXO XVIII}

\section{Pagos del transporte del material del "Programa Bär" 801}

Se han rastreado un total de siete créditos habilitados para pagar a Schenker los portes del Programa Bär (En marcos):

1.-(Tierra) Crédito $\mathrm{n}^{\circ} 11.441$ de 30 de agosto de 1943 por : $\quad 650.000,00$

2.-(Tierra) Crédito ${ }^{\circ} 11.506$ de 9 de noviembre de 1943 por: $\quad 75.000,00$

3.-(Tierra) Crédito $\mathrm{n}^{\mathrm{o}} 11593$ de 10 de febrero de 1944 por: $\quad 657.400,00$

4.-(Marina) Crédito n 11.692 de 17 de julio de 1944 por: $\quad$ 133.980,30

5.-(Tierra) Crédito $\mathrm{n}^{0} 11.693$ de 19 de julio de 1944 por: $\quad$ 691.244,23

6.-(D.G. Industria) Crédito $n^{\circ} 11.694$ de 19 de julio de 1944 por: $65.462,00$

7.-(Aire) Crédito $\mathrm{n}^{\circ} 11.716$ de 20 de septiembre de 1944 : $\quad 17.931,45$

TOTAL:

2.291.017,98

Depositado en ROWAK para pagar transportes a Schenker (en marcos):

1.-Pagado a ROWAK el 7 de diciembre de 1943 para hacer frente a los transportes de "Sofortprogramm":

-De Aire:

$17.123,30$

-De Marina:

133.980,30

-De Tierra:

483.886,50

-Pagado por error:

$9.000,00$

TOTAL 1

643.990,10

2.-Pagado a ROWAK el 15 de noviembre de 1943 para hacer frente al transporte de los fonos TEPAS (Ejército):

$65.462,00$

3.-Pagado a cuenta a ROWAK el 7 de junio de 1944:

672.947,90

4.-Pagado a cuenta a ROWAK el 24 de agosto de 1944:

600.000,00

5.-Pagado a cuenta a ROWAK el 8 de noviembre de 1944:

300.000,00

TOTAL GENERAL:

2.282.400,00

801 "Libro Mayor de la Comisión Extraordinaria de Compras de Material de Guerra". AGMAV. Caja 24.711. 


\section{ANEXO XIX}

\section{Desglose de todo el material del Ejército de Tierra recibido en el "Programa Bär" con su precio unitario}

\begin{tabular}{|c|c|c|c|}
\hline Material & Precio unitario & Material & Precio unitario \\
\hline Cañones rusos de $12,2 \mathrm{~cm}$ & 112.000 & $\begin{array}{l}\text { Equipos repetidores de baja } \\
\text { frecuencia }\end{array}$ & 15.840 \\
\hline Proyectiles de $12,2 \mathrm{~cm}$ & 170 & $\begin{array}{l}\text { Accesorios equipos repetidores } \\
\text { de baja frecuencia }\end{array}$ & 4.350 \\
\hline Batería completa de 88/56 Flak 36 & 750.000 & Ametralladora Flak 28 Oerlikon & 29.700 \\
\hline Batería de 20/70 Flak 28 Oerlikon & 492.000 & Radiogoniómetros & 14.300 \\
\hline Cañones antitanque de $25 \mathrm{~mm}$ & 21.000 & Receptor de radio toda onda & 2.700 \\
\hline Minas antitanque "T" & 55 & Ametralladoras MG 34 & 2.380 \\
\hline Cargas adhesivas " $\mathrm{H}$ " & 72 & Cañón antitanque Pak 40 & 42.000 \\
\hline Motos sin carro & 1.440 & Receptores E.454B Telefunken & 5.700 \\
\hline Motos con carro lateral & 2.594 & $\begin{array}{l}\text { Carros de combate Panzer IV } \\
\text { Ausf. H }\end{array}$ & 263.000 \\
\hline Fonolocalizadores RRH móvil & 55.430 & Fonolocalizadores RRH fijo & 50.230 \\
\hline Granada rompedora de $75 \mathrm{~mm} \mathrm{Pak} *$ & 95 & Aparatos ME. 3 alta frecuencia & $92.683,33$ \\
\hline Teletipógrafos mecánicos & 4.500 & Aparatos ME. 8 alta frecuencia & 123.090 \\
\hline Estaciones radio de 200 vatios & 29.850 & $\begin{array}{l}\text { Granada perforante de } 75 \mathrm{~mm} \\
\text { Pak** }^{* *}\end{array}$ & 144,5 \\
\hline Aparatos radio onda corta $1 \mathrm{Kv}$ & 152.000 & Telémetros de $1 \mathrm{~m} \mathrm{R.36}$ & 4.800 \\
\hline Cañones de asalto & 240.000 & Proyectores AEG de $60 \mathrm{~cm}$ & 29.100 \\
\hline Estaciones radio 15 vatios & 13.200 & & \\
\hline
\end{tabular}

*Las primeras 22.500 granadas, se pagaron a 97 RM. Las otras 22.500, a 93 RM

** Precio acordado con AGEKA, pues estos proyectiles fueron encargados con posterioridad a las reuniones de las subcomisiones técnico-militares de Madrid.

Elaboración propia. Fuente. AMAE. AR. Sig. 2066-4. Los precios en marcos 


\section{ANEXO XX}

\section{Desglose de todo el material de la Armada recibido en el "Programa Bär" con su precio unitario}

\begin{tabular}{|c|c|c|c|}
\hline Material & Precio unitario & Pagado & Recibido \\
\hline Flak de $3,7 \mathrm{~cm}$ SK C/30 en montaje doble estabilizado & 154.400 & 5.558 .400 & 36 \\
\hline Flak de $3,7 \mathrm{~cm}$ SK C/30 en montaje $\mathrm{C} / 39$ de submarino & 60.000 & 3.060 .000 & 51 \\
\hline Flak 38 de $2 \mathrm{~cm}$ en montaje $\mathrm{C} / 30$ & 28.200 & 1.128 .000 & 40 \\
\hline Flak 38 de 2 cm "Vierling" & 125.000 & 2.750 .000 & 22 \\
\hline Proyectiles explosivos de $2 \mathrm{~cm}$ & 8,63 & 2.209 .280 & 256.000 \\
\hline Proyectiles explosivos de $3,7 \mathrm{~cm}$ & 32,90 & 8.169 .070 & 248.300 \\
\hline Minas tipo EMC & 3.000 & 3.000 .000 & 1.000 \\
\hline Cargas de profundidad WBF & 1.000 & 200.000 & 200 \\
\hline Instalación de cineteodolito "Askania" & 187.145 & 187.145 & 1 \\
\hline Flak de $10,5 \mathrm{~cm} \mathrm{C} / 32$ en cureña $\mathrm{C} / 52$ para torpederos & 230.000 & 2.760 .000 & 12 \\
\hline Proyectiles de $10,5 \mathrm{~cm}$ de diversos tipos & varios & 2.271 .090 & 9.900 \\
\hline Lanchas rápidas tipo grande $\mathrm{S} / 38$ & 2.000 .000 & 12.000 .000 & 6 \\
\hline Telémetros "Goerz" de 2 metros de base & 13.000 & 156.000 & 12 \\
\hline Telémetros "Zeiss" de 1,25 metros de base & 5.720 & 114.400 & 20 \\
\hline Vidrio óptico & $20 / \mathrm{kg}$ & 64.333 & $3.200 \mathrm{~kg}$ \\
\hline Anteojos & 4.500 & 90.000 & 20 \\
\hline Total & & 43.717.718 & \\
\hline
\end{tabular}

Elaboración propia. Fuente: AMAE. AR. Sig. 2066-4 y Anexos XIII y XIV. Los precios en marcos. 


\section{ANEXO XXI}

\section{Desglose de todo el material del Ejército del Aire recibido en el "Programa Bär" con su precio unitario}

\begin{tabular}{|c|c|c|c|}
\hline Material & Precio unitario & Pagado & Recibido \\
\hline 15 aviones Messerschmitt $\mathrm{Bf} 109$ con repuestos & 188.522 & 2.827 .830 & 15 \\
\hline 10 aviones Junkers Ju 88 con repuestos & 690.000 & 6.900 .000 & 10 \\
\hline 4 equipos pesados móviles de onda larga y 4 de onda corta & 211.140 & 1.689 .120 & 8 \\
\hline 15 equipos ligeros móviles de onda larga y corta & 28.600 & 429.000 & 15 \\
\hline 8 equipos radiogoniométricos de navegación & 18.200 & 145.600 & 8 \\
\hline 4 radiofaros de aterrizaje de 120 watios & 56.500 & 226.000 & 4 \\
\hline 15 grupos electrógenos Still & 16.000 & 240.000 & 15 \\
\hline 100 equipos electrogeneradores EM4 (Llegaron solo 50) & $2.385,37$ & 238.537 & 50 \\
\hline 1 radar Freya & 260.000 & 260.000 & 1 \\
\hline 10 radares Würzburg & 125.000 & 1.250 .000 & 10 \\
\hline 3 radares de a bordo Lichtenstein & 30.000 & 90.000 & 3 \\
\hline 3 radares idem anteriores (Perdidos en tren 25 ) & 30.000 & 90.000 & 0 \\
\hline 1.000 .000 de proyectiles de $7,92 \mathrm{~mm}$. Munición de a bordo. & 0,179 & 179.125 & 1.000 .000 \\
\hline 12 radioemisoras de onda corta & 14.000 & 168.000 & 12 \\
\hline 22 aparatos Morse para radiofaros & 2.230 & 49.060 & 22 \\
\hline 50 equipos de radio Modelo 33 & 120 & 6.000 & 50 \\
\hline 85 equipos de radio FuG 10 de a bordo (perdidos 45 en tren 25 ) & 17.400 & 1.479 .000 & 40 \\
\hline 20 equipos FuG 7 A F1 & 5.000 & 100.000 & 20 \\
\hline 100 equipos $\mathrm{Fu} \mathrm{B} 1$ de a bordo & 5.000 & 500.000 & 100 \\
\hline Total & & 16.867 .272 & \\
\hline
\end{tabular}

Fuente: AHEA. Leg. 11035 Sección 2, 3 y $15^{\text {a }}$ División, pág. 748. Precios en marcos. 


\section{ANEXO XXII}

\section{Presupuestos españoles 1940-1945 (En pesetas)}

\begin{tabular}{|l|l|l|l|}
\hline Año & Estado (E) & Ministerios militares (D) & \%D/E \\
\hline $\mathbf{1 9 4 0}$ & $7.161 .222 .337,29$ & $1.959 .198 .237,90$ & 27,36 \\
\hline $\mathbf{1 9 4 1}$ & $8.318 .801 .213,11$ & $1.839 .059 .381,65$ & 22,11 \\
\hline $\mathbf{1 9 4 2}$ & $7.880 .194 .669,28$ & $1.908 .569 .938,16$ & 24,22 \\
\hline $\mathbf{1 9 4 3}$ & $9.456 .475 .296,41$ & $2.524 .525 .830,54$ & 26,70 \\
\hline $\mathbf{1 9 4 4}$ & $13.292 .690 .130,06$ & $4.067 .236 .103,32$ & 30,60 \\
\hline $\mathbf{1 9 4 5}$ & $13.235 .065 .791,53$ & $5.341 .440 .582,74$ & 40,36 \\
\hline & & \%medio & $\mathbf{2 8 , 5 6}$ \\
\hline
\end{tabular}

Fuente: Coello Lillo, Juan Luis, op. cit., pág. 295 


\section{FUENTES}

\section{ARCHIVOS}

-Archivo de la Fábrica de Artillería de Trubia, AFAT. (Trubia-Asturias)

•Archivo de la Fundación Nacional "Francisco Franco", AFNFF. (Madrid).

-Archivo General de la Administración, AGA. (Alcalá de Henares-Madrid).

-Archivo General Militar de Ávila, AGMAV. (Ávila).

-Archivo General Militar de Madrid, AGMM. (Madrid).

-Archivo General Militar de Segovia, AGMAS. (Segovia).

-Archivo Histórico del Ejército del Aire, AHEA. (Villaviciosa de OdónMadrid).

-Archivo Histórico Nacional, AHN. (Madrid).

-Archivo Intermedio del Cuartel General del Ejército del Aire, AICGEA. (Madrid).

-Archivo del Ministerio de Asuntos Exteriores, AMAE. (Madrid).

-Archivo del Polígono de Experiencias de Carabanchel, APEC. (Madrid).

-Archivo privado de la familia Espinosa, APFE, (Ibiza-Islas Baleares).

-Archivo privado del general José Varela Iglesias, APGJVI. (Cádiz).

-Servicio Histórico del Cuartel General de la Armada, SHEMA. (Madrid).

\section{FUENTES HEMEROGRÁFICAS}

-Diario "La Vanguardia"

-Diario "ABC" 


\section{FUENTES DE INTERNET}

•http://www.archives.gov/research/holocaust/finding-aid/military/rg-226-

3g.html.

•http://www.spartacus.schoolnet.co.uk/GERschacht.htm.

•http://www.dornier24.com/

•http://en.wikipedia.org/wiki/Otto_Schniewind

•http://www.geocities.com/ orion47/WEHRMACHT/KRIEGSMARINE/Vizead mirals/SIEMENS_LEOPOLD.html

•http://www.geocities.com/ orion47/WEHRMACHT/KRIEGSMARINE/Admir

als/FUCHS WERNER.html

•http://www.navweaps.com/Weapons/WNGER_59-45_skc16.htm

•http://www.navweaps.com/Weapons/WNGER 59-40 skc96.htm

•www.galegos.es

•http://www.euskomedia.org/aunamendi/45407

•www.lenntech.es/periodica/elementos/w.htm

-caceresnatural.blogspot.com.es/2010/01/minerales-de-caceres-ambligonita.html

-www.asturnatura.com

•http://es.wikipedia.org/wiki/Mica

•www.gemselect.com/spanish/gem-info/beryl/beryl-info.php

-www.forocartagena.com

•http://www.geocities.com/ orion47/WEHRMACHT/LUFTWAFFE/Generalleu tnant/KRAHMER_ECKARD.html

•http://www.geocities.com/ orion47/WEHRMACHT/KRIEGSMARINE/Vizead mirals/BUERKNER_LEOPOLD.html

•www2gravestone.com/general/becker-Wilhelm

•http://www.geocities.com/ orion47/WEHRMACHT/HEER/Generalmajor/BEU TLER OTTO.html

•www.logistics.dbschenker.es/log-es-es/start/compania/historia_html

•www.vonbibra.net/Waltershausen.html

-http://forum.axishistory.com/viewtopic.php?f=45\&p=1420456

•http://www.netherlandsnavy.nl/Torpedoes.html

•http://www.quarry.nildram.co.uk/apib.html

•http://www.jaegerplatoon.net/AT_GUNS1.htm 
•http://sturmvogel.orbat.com/GermWeapProd.html

•http://www.wehrmacht-awards.com/forums/showthread.php? $p=5726556$

•http://tetraclorurodetitanio.blogspot.com.es/2011/06/tetracloruro-de-titanio.html

•http://es.wikipedia.org/wiki/Tetracloruro_de_silicio

•http://www.cdvandt.org/Wirecomm99.pdf

http://www.wehrmacht awards.com/forums/showthread.php?t= 305265

•http://www.nonstopsystems.com/radio/hellschreiber-mil-tx-rx.htm

•http://www.knirim.de/a0601mod.htm

-http://www.geocities.com/ orion47/WEHRMACHT/HEER/Generalmajor/DOE

RR_HANS.html

•http://www.surplusrifleforum.com/viewtopic.php?p=558184

\section{MEMORIAS Y DOCUMENTOS}

•"Memoria de la Comisión de Artillería Antiaérea. Julio a septiembre de 1943." Documento mecanografiado perteneciente a la Escuela de Aplicación y Tiro de Artillería.

-"Memoria sobre el estudio de la artillería de asalto y la artillería acorazada", desarrollada por la Comisión Militar en Alemania (1-9-1943 al 15-10-1943). Documento mecanografiado de 119 páginas. Archivo del Polígono de Experiencias de Carabanchel.

-Documentos inéditos para la historia del Generalísimo Franco. Tomos II-1 y II-2. Madrid, Azor, Colección de Estudios Contemporáneos. Fundación Nacional Francisco Franco, 1992.

-Documentos inéditos para la historia del Generalísimo Franco. Tomo IV. Azor. Colección de Estudios Contemporáneos. Fundación Nacional Francisco Franco, Burgos, 1994

\section{MANUALES TÉCNICOS}

-La ametralladora Z.B. 37 de dotación en los Escuadrones de Ametralladoras de las Brigadas de Caballería. Escuela de Aplicación de Caballería y Equitación del Ejército. F-4. Septiembre de 1944. 
- Carnet del instructor. Motocicleta pesada B.M.W. de $750 \mathrm{~cm} 3$, con carro lateral tipo R.75. Descripción del vehículo e instrucciones para su manejo. Editorial Gran Capitán, Madrid sin fecha.

•Manual R-7. Cañón contra carros calibre 25 mm" Hotchkiss-Puteaux Mod. 37$S A L$.

-Radio-Localizador Freya, Aparato DeTe II, Fu.M.G. (Flum) 40 g (y b).

•US. War Department Technical. Manual. TME 11-227, June 1944

-Reichsminister der Luftfahrt und Oberbefehlshaber der Lutwaffe

Trägerfrequenzfernsprechgerät. 23-1-1942, nº 507/42

•US Army. Directory of German Radar Equipment, TME11-219, 1945

-US War Department Technical. German Radio Communication Equipment. Manual, TME 11-227. June, 1944.

\section{BIBLIOGRAFÍA}

-Arévalo Molina, Jacinto: "Minas en la Guerra Civil Española"; Memorial de Ingenieros $n^{\circ}$ 58, Madrid (Hoyo de Manzanares), 1998.

-Arráez Cerdá, J. y Sales Lluch, J.M., "Una unidad muy especial: la Escuadrilla de Sondeos Meteorológicos”. Revista Española de Historia Militar n 3, (mayo 2000).

•Ávila Cruz, Gonzalo, "Historia de los Do 24 en el Ejército del Aire”, Revista "Fuerza Aérea" n 60, Año VII, Vol. 6

•Bauer, Arthur O., Deckname "Würzburg": Ein Beitrag zur Erhellung der Geschichte des geheimnisumwittertren deutschen Radargeräts, 1937-1945, Verlag Historischer Technikerliteratur, Herten (Nordrhein-Westflen), sin fecha.

-Bekker, Cajus, Augen durch Nacht und Nebel: die Radarstory, Gerhard Stalling Verlag, Oldenburg/Hamburg, 1964. 
-Bishop, Chris. La Enciclopedia de las armas de la Guerra Mundial. Londres, Barnes \& Noble Books, 1998.

-Bonilla, Miguel. Apuntes para la Escuela de los Ayudantes de Artificiero; Servicio de Recuperación de Material de Guerra, Región Centro, 1940.

•Brown, Louis. A Radar history of World War II, Iop, Bristol, 1999.

-Caballero Jurado, Carlos y Molina Franco, Lucas. Panzer IV. El "puño” de la Wehrmacht. Quirón Ediciones, Valladolid, 2006.

-Catalán Vidal, Jordi. La economía española y la Segunda Guerra Mundial. Barcelona, Editorial Ariel, 1995.

-Coello Lillo, Juan Luis. Buques de la Armada Española. Los años de la postguerra. Aldaba Ediciones, Madrid, 1995.

-Díaz Benitez, Juan José, "Colaboración hispano-alemana para la defensa de Canarias: el viaje del capitán de fragata Krauss". Boletín Millares Carlo n ${ }^{\circ} 21$, 2002.

—, "La planificación militar española y la no beligerancia durante la II Guerra Mundial: el caso de Canarias". Comunicación presentada por el autor en el IV Congreso de Historia de la Defensa. "Fuerzas Armadas y políticas de defensa durante el franquismo". Madrid, 3-5 de noviembre de 2009, Instituto Universitario General Gutiérrez Mellado, UNED.

-Doussinague Teixidor, José María, España tenía razón. (1939-1945), EspasaCalpe SA, Madrid, 1949.

-Escuadra Sánchez, Alfonso. Españoles en la Kriegsmarine. Misiones en el Báltico (1942-1943). Galland Books, Valladolid, 2011.

-Espinosa Rodríguez, Manuel. Aventuras y desventuras de un oficial de Marina (1902-1987), Editora Naval, Madrid, 1992.

•Fernández-Coppel Larrinaga, Jorge. La Escuadrilla Azul. La Esfera de los Libros, Madrid 2008.

-Franco Bahamonde, Francisco: Comentarios al Reglamento de Grandes Unidades. Partes principales y análisis. Cuartel General del Generalísimo. Imprenta Aldecoa, Burgos, 1938. 
-Gander, Terry y Chamberlain, Peter. Weapons of the Third Reich: An Encyclopedic Survey of All Small Arms, Artillery and Special Weapons of the German Land Forces 1939-1945. Doubleday, Nueva York, 1979

- García Argüelles, Amador. Historia de la Artillería en Tenerife. El Regimiento Mixto de Artillería $n^{\circ}$ 93. Gráficas Tenerife, Santa Cruz de Tenerife, 1982.

-García-Parreño y Kaden, Jorge. Las armas navales españolas. E.N. Bazán, edición no comercial, Madrid, 1982.

-García Pérez, Rafael, "El proyecto continental del Tercer Reich”, Revista de Estudios Políticos nº 87, enero-marzo 1995, pág. 275.

-García Pérez, Rafael. Franquismo y Tercer Reich. Las relaciones económicas hispano-alemanas durante la Segunda Guerra Mundial. Madrid, Centro de Estudios Constitucionales, 1994.

•Gmeline, Patrick de. La "Flak": 1935-1945. La DCA allemende, Editions Heimdal, París, 1994

•Gómez Vizcaíno, Juan Lorenzo, "La defensa de costa de las islas Canarias". Revista Española de Historia Militar nº 24, junio 2002.

-González-Llanos Caruncho, José María. El Decenio. La construcción naval militar en la factoría de Ferrol. 1936-1946, Quirón Ediciones, Valladolid, 2006.

•González López, Óscar. Fallschirmajäger sobre el Gran Sasso. AF Editores, Valladolid, 2007.

•González Serrano, José Luis. "Notas sobre el 13 Regimiento y los Ju 88". Revista Aeroplano. Publicación de Historia Aeronáutica. Año 1996. nº14.

-Herrera Alonso, Emilio. "Un hidro Blohn un Voss Bv 133C-1, tres años en la Ría de Bilbao". Revista Aeroplano no 8 (1996).

•Hommes, Hans Peter, Das Wehrmachtsgespann BMW $R$ 75. Dokumente, Zeichnungen und Fotos, edición del autor, D-41363 Jüchen (Alemania) 1999.

•Jentz, Thomas L., Doyle, Hilary L. Germany's Panzers in World War Two. From Pz I to Tigre II. Pensilvania, Schiffer Military History Publishing, 2001.

-Junceda Avello, Enrique, "Semblanza de D. Carlos Marín de Bernardo". Boletín de Letras del Real Instituto de Estudios Asturianos no 169 (2007). 
-Kleinfeld, Gerald R.; Tambs, Lewis A., La división española de Hitler. La División Azul en Rusia, Editorial San Martín, Madrid, 1983.

-Laureau, Patrick. Condor. The Luftwaffe in Spain. 1936-1939. Hikoki Publications, Ottringham-East Yorkside (Great Britain), 2000.

-Leitz, Christian. Economic Relations between Nazi Germany and Franco's Spain (1936-1945). Great Britain, Clarendon Press-Oxford, 1996.

-Leitz, Christian; Durnthorn, David J., Spain in an International Context, 19361959, Berghahn Books, New York, 1999.

-Martinez de Campos, Carlos, Duque de Latorre. Ayer. 1931-1953, Instituto de Estudios Políticos, Madrid, 1970.

-Manrique García, José Ma; Molina Franco, Lucas; Mortera Pérez, Artemio. Historia de la Artillería antiaérea española. (Volumen I). Quirón Ediciones, Valladolid, 1998.

—, La Brunete. 60 años de historia. Valladolid, Quirón Ediciones, 2003.

_, Las armas de la Guerra Civil española. La Esfera de los libros, Madrid, 2006.

—, El cañón alemán de 88 mm, Galland Books, Valladolid, 2008.

-Manrique García, J. Ma y Molina Franco, Lucas, "El primer radar español de alerta y control”. Revista Española de Historia Militar $n^{\circ} 49 / 50$, Valladolid, julio-agosto 2004.

-Martínez Ruiz, Elena. El sector exterior durante la autarquía. Una reconstrucción de las balanzas de pagos de España (1940-1958). Edición revisada. Servicio de Estudios del Banco de España. Estudio no 43, Madrid, 2003.

—, "Guerra comercial y comercio de guerra: las relaciones económicas exteriores durante la Guerra Civil." Universidad de Barcelona. http://www.ucm.es/info/historia/ortega/6-05.pdf.

-Mata Duaso, Josep, Atlas ilustrado de motores en guerra. Guerra Civil española, Susaeta Ediciones, Madrid, 2011. 
-Mazarrasa Coll, Javier de. Blindados en España. $2^{a}$ parte: la dificil postguerra, 1939-1960. Valladolid, Quirón Ediciones, 1994.

—, Carro de combate Verdeja. Barcelona, Carbonell editor, 1988.

-Ministerio del Ejército. Dirección General de Industria y Material, Catálogo T0-4-1 Armamento y material (Tomo I), Imprenta del Polígono de Experiencias de Carabanchel, 1973, mat. 122/46.

-Molina Franco, Lucas. El legendario cañón antiaéreo de 88 mm. Su historia y evolución en el Ejército español. Quirón Ediciones, Valladolid, 1996.

—, El legado de Sigfrido. La ayuda militar alemana al Ejército y la Marina en la Guerra Civil española (1936-1939). Valladolid, AF Editores, 2005.

-Molina Franco, Lucas; Manrique García, José Ma . Antiaéreos improvisados en la Guerra Civil española. Galland Books, Valladolid, 2007.

—, Cuadernos de la Guerra Civil española. La Agrupación de Infantería de Ametralladoras Antiaéreas. Galland Books, Valladolid, 2012.

—, Legión Cóndor. La historia olvidada. Quirón Ediciones, Valladolid, 2000.

—, "Los carros de la División Acorazada", Revista Española de Historia Militar $\mathrm{n}^{\circ} 40$, (octubre de 2003), pág. 207 y ss.

-Moreno Juliá, Xavier, La División Azul. Sangre española en Rusia (19411945), Crítica, Barcelona 2004.

-Mortera Pérez, Artemio. La fábrica de Trubia. Dos siglos de tecnología artillera, Fundación Alvargonzález, Gijón, 2005.

—, "Kanone Rheinmetall K.18 de 15 cm.”. Revista Española de Historia Militar $\mathrm{n}^{\circ}$ 125. Valladolid, 2012.

-Müller, Werner. Sound Locators, fire control systems and searchlights of the german heavy Flak units. (1939-1945), Schiffer Publishing military/aviation history. Pensilvania, 1998.

—, Ground Radar Systems of the Luftwaffe: 1939-1945, Schiffer Publishing, Pensilvania, 1998.

•O'Donnell Torroba, César, "Misión en Alemania”. Revista Ares Enyalius n 3, julio-agosto de 2008. 
-Pazó Giménez de la Espada, Alejandro. El vuelo de José Pazó. La trayectoria de un ingeniero aeronáutico y aviador militar en el siglo $X X$. Edición particular no venal, Valladolid, 2012.

-Pérez San Emeterio, Carlos y otros. Enciclopedia de la Aviación Militar España. Vol.I. Quirón Ediciones, Valladolid, 2000.

-Permuy López, Rafael Ángel; O’Donnell Torroba, César. As de Picas. La Escuadrilla de Hidros de la Legión Cóndor en la Guerra Civil española (19361939), Galland Books, Valladolid, 2008.

•Platón, Miguel. Hablan los militares. Testimonios para la historia (1939-1996). Madrid, Planeta, 2001.

-Reitsch, Hanna. Volar fue mi vida. Memorias de la piloto de pruebas de la Luftwaffe. Niseos, Buenos Aires, 2008.

-Riess, Karl; Ring, Hans. Legion Condor. 1936-1939. Eine illustrierte Dokumentation. Dieter Hoffmann Verlag, Mainz, 1980.

•Ruhl, Klaus-Jörg. Franco, Falange y III Reich. España durante la II Guerra Mundial. Madrid, AKAL, 1986.

-Salgado Rodríguez, Juan Carlos. Focke Wulf 200 Condor. Perfiles aeronáuticos I, Quirón Ediciones, Valladolid, 2002.

-Salas Larrazábal, Jesús. De la tela al titanio. El ayer y el hoy de la actividad aeronáutica en España, Espasa-Calpe, Madrid, 1983.

__, "Bücker Bü 133C Jungmeister". Enciclopedia de la Aviación Militar española. Quirón Ediciones, Valladolid, 2000

-Salas Larrazabal, Jesús y González Serrano, José Luis. "Bücker Bü 131 Jungmann”. Enciclopedia de la Aviación Militar Española, Quirón Ediciones, Valladolid, 2000.

-Sanz-Francés San Baldomero, Emilio, Entre la antorcha y la esvástica. Franco ante la encrucijada de la Segunda Guerra Mundial, Editorial Actas, Madrid, 2009.

-Trenkle F., Bordfunkgerate der Deutschen Luftwaffe 1935-45, Motorbuch Verlag, 1979. 
-Tulliu, Steve y Schmalberger, Thomas. En buenos términos con la seguridad. Diccionario sobre control de armamentos, desarme y aumento de confianza. UNIDIR, Naciones Unidas, Ginebra, 2003

-U.S. War Department. Handbook on German Military Forces. Louisiana State University Press, Louisiana Paperback edition, 1995.

-Viñas, Angel, Guerra, dinero, dictadura: ayuda fascista y autarquía en la España de Franco. Barcelona. Crítica, 1984.

-Von Kroge, Harry. GEMA: Birthplace of German radar and Sonar, Institute of Physics Publising (IoP), Bristol and Philadelphia, 2000.

-VV.AA. Al pie de los cañones. La artillería española, Tabapress, Madrid, 1994.

-VV.AA. Aviones militares españoles. Ministerio de Defensa. Secretaría General Técnica, Madrid, 1986

-VV.AA. Germany and the Second World War. Volume V/II. Organization and mobilization in the german sphere of power. War administration, Economy and manpower resources. 1942-1944/5. Oxford University Press, 2003.

-VV.AA. La solidaridad de los pueblos con la República española. Academia de Ciencias de la URSS. Editorial Progreso, Moscú, 1974

-VV. AA. "Spanish Schnellbomber. Ju 88s with Spanish Air Force", Revista Flypast no 182, septiembre 1996.

-Whealey, Robert H. Hitler and Spain. The nazi Role in the Spanish Civil War. 1936-1939. Lexington, Kentucky, The University Press of Kentucky, 1989. 